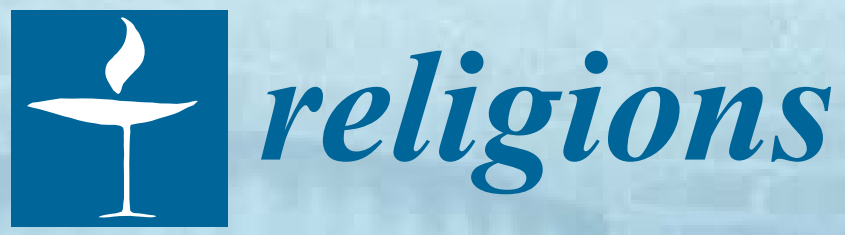

\title{
Religion, Welfare and Social Service Provision Common Ground
}

Edited by Jay Poole and Bob Wineburg Printed Edition of the Special Issue Published in Religions 


\section{Religion, Welfare and Social Service Provision}





\section{Religion, Welfare and Social Service Provision}

\section{Common Ground}

Special Issue Editors

Jay Poole

Bob Wineburg 
Special Issue Editors

Jay Poole

Bob Wineburg

University of North Carolina Greensboro

University of North Carolina Greensboro

USA

USA

\section{Editorial Office}

MDPI

St. Alban-Anlage 66

4052 Basel, Switzerland

This is a reprint of articles from the Special Issue published online in the open access journal Religions (ISSN 2077-1444) from 2016 to 2019 (available at: https:/ / www.mdpi.com/journal/religions/special_ issues/religion-welfare-socialserviceprovision)

For citation purposes, cite each article independently as indicated on the article page online and as indicated below:

LastName, A.A.; LastName, B.B.; LastName, C.C. Article Title. Journal Name Year, Article Number, Page Range.

ISBN 978-3-03897-760-5 (Pbk)

ISBN 978-3-03897-761-2 (PDF)

Cover image courtesy of unsplash.com user bamagal.

(c) 2019 by the authors. Articles in this book are Open Access and distributed under the Creative Commons Attribution (CC BY) license, which allows users to download, copy and build upon published articles, as long as the author and publisher are properly credited, which ensures maximum dissemination and a wider impact of our publications.

The book as a whole is distributed by MDPI under the terms and conditions of the Creative Commons license CC BY-NC-ND. 


\section{Contents}

About the Special Issue Editors $\ldots \ldots \ldots \ldots \ldots \ldots \ldots$ vii

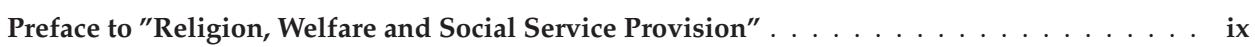

Robert Wineburg

Introduction of the Special Issue "Religion, Welfare and Social Service Provision:

Common Ground"

Reprinted from: Religions 2019, 10, 143, doi:10.3390/rel10030143 . . . . . . . . . . . . . 1

\section{Edward Queen}

History, Hysteria, and Hype: Government Contracting with Faith-Based Social Service

Agencies

Reprinted from: Religions 2017, 8, 22, doi:10.3390/rel8020022 . . . . . . . . . . . . . . . 4

\section{F. Ellen Netting and Mary Katherine O'Connor}

The Intersectionality of Religion and Social Welfare: Historical Development of Richmond's Nonprofit Health and Human Services

Reprinted from: Religions 2016, 7, 13, doi:10.3390/rel7010013 . . . . . . . . . . . . . . 33

\section{Carl Milofsky and Brandn Green}

Re-Building Coal Country: A Church/University Partnership

Reprinted from: Religions 2016, 7,75, doi:10.3390/rel7060075 . . . . . . . . . . . . . 48

\section{David Campbell}

Small Faith-Related Organizations as Partners in Local Social Service Networks

Reprinted from: Religions 2016, 7, 57, doi:10.3390/rel7050057 . . . . . . . . . . . . . . . 6

Jay Poole, John Rife, Wayne Moore and Fran Pearson

The Congregational Social Work Education Initiative: Toward a Vision for Community Health through Religious Tradition and Philanthropy

Reprinted from: Religions 2016, 7, 62, doi:10.3390/rel7060062 . . . . . . . . . . . . . 77

\section{Jo Anne Schneider}

Envisioning Religiously Diverse Partnership Systems among Government, Faith Communities and FBOs

Reprinted from: Religions 2016, 7, 105, doi:10.3390/rel7080105

\section{Ian Bedford}

Maintaining the Connection: Strategic Approaches to Keeping the Link between Initiating

Congregations and Their Social Service Off-Spring

Reprinted from: Religions 2016, 7, 111, doi:10.3390/rel7090111

\section{Daniel Rhodes}

The Dual Role a Buddhist Monk Played in the American South: The Balance between Heritage and Citizenship in the Refugee Community

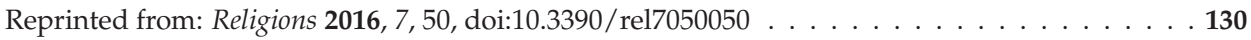

\section{Helen Harris, Gaynor Yancey and Dennis Myers}

Social Work Field Education in and with Congregations and Religiously-Affiliated

Organizations in a Christian Context

Reprinted from: Religions 2016, 7, 52, doi:10.3390/rel7050052 . . . . . . . . . . . . . . 145 
Terry A. Wolfer, Dennis R. Myers, Edward C. Polson and Betsy Bevis

Baby Boomers as Congregational Volunteers in Community Ministry

Reprinted from: Religions 2017, 8, 66, doi:10.3390/rel8040066

\section{Mark Chaves and Alison J. Eagle}

Congregations and Social Services: An Update from the Third Wave of the National

Congregations Study

Reprinted from: Religions 2016, 7, 55, doi:10.3390/rel7050055 . . . . . . . . . . . . . . . 177

\section{Rebecca Sager and Keith Bentele}

Coopting the State: The Conservative Evangelical Movement and State-Level

Institutionalization, Passage, and Diffusion of Faith-Based Initiatives

Reprinted from: Religions 2016, 7, 71, doi:10.3390/rel7060071 . . . . . . . . . . . . . . 186

\section{Brad R. Fulton}

Trends in Addressing Social Needs: A Longitudinal Study of Congregation-Based Service Provision and Political Participation

Reprinted from: Religions 2016, 7, 51, doi:10.3390/rel7050051 . . . . . . . . . . . . . . . . 212

Dan Heist and Ram A. Cnaan

Faith-Based International Development Work: A Review

Reprinted from: Religions 2016, 7, 19, doi:10.3390/rel7030019

\section{Ramya Ramanath}

Unpacking Donor Retention: Individual Monetary Giving to U.S.-Based Christian

Faith-Related, International Nongovernmental Organizations

Reprinted from: Religions 2016, 7, 133, doi:10.3390/rel7110133

\section{Jay Poole}

Postscript of Special Issue "Religion, Welfare and Social Service Provision: Common Ground" Reprinted from: Religions 2019, 10, 138, doi:10.3390/rel10030138 . . . . . . . . . . . . . . 263 


\section{About the Special Issue Editors}

Jay Poole, Dr., is currently a Professor in the Department of Social Work in the School of Health and Human Sciences at the University of North Carolina at Greensboro. Dr. Poole received his Ph.D. in 2009, specializing in cultural studies. Dr. Poole is a member of the inaugural class of the Joint Master of Social Work program and was graduated in 1999 with his Master of Social Work degree. Dr. Poole also holds the Bachelor of Arts in Psychology with a minor is Sociology and an Associate of Arts degree. Dr. Poole's research interests are in the area of community health services and identity studies. Dr. Poole's recent work can be found in Religions, the Journal of Sexuality and Culture as well as Social Work and Christianity: An International Journal. Dr. Poole is a former member of the Oxford Roundtable, where he presented his work on the faith-based initiative in community mental health to an audience of international scholars. Dr. Poole has made numerous national and international presentations regarding his research. Dr. Poole was awarded the Mary Francis Stone award for exemplary teaching in 2007 and the School of Health and Human Sciences award for community engaged scholarship in 2016.

Bob Wineburg (MSW Syracuse University; Ph.D. University of Pittsburgh) is the Jefferson Pilot Excellence Professor of Social Work at the University of North Carolina Greensboro. He is the author or coauthor of 4 books and has written many scholarly and popular articles on his specialty: the contributions the religious community makes to public life. His 1992-1995 Lilly Endowment grant enabled him to be the first social scientist to document how government agencies and the nonprofit sector in one community, Greensboro, NC plan for, implement, and evaluate the use of resources from the religious community as a natural part of their resource development process. Other researchers have since verified that this case examination of planned grassroots community partnerships is indeed a national and perhaps an international phenomenon. 



\section{Preface to "Religion, Welfare and Social Service Provision"}

For the last two decades from 30,000 feet, the average person and the distant scholar would think that religion's contribution to public life has been embodied by a shadow boxing of sorts between the right and left. Such a broad stroke does make for good news, debate, and discussion, but does not capture the thousands, if not hundreds of thousands partnerships among religious communities, government, nonprofits, to fill the gaps mostly created by a world-wide shrinking of the "welfare state" and aimed at the "public good." We are calling for papers that capture how houses of worship at the ground level, are increasingly "houses of service." Papers in this Special Issue will be focused on building a better understanding of the intersection of general welfare policy, religion, and religion and service as it takes shape in the voluntary actions of the religious community.

The overall focus is on assembling, in one volume, perhaps the first set of what may become seminal articles that cross "disciplinary boundaries" and address what is on the ground at the intersection of religion, public health, social work, human services, theology, nonprofit management, medicine, community psychology, theology, and other theoretical and especially professional service fields by defining and exploring how and why partnerships work or don't work in reality. A broad and long term goal of the volume would be to begin developing scholarship that better shapes best practices where the intersection of religion, welfare, and social service provision converge.

Jay Poole, Bob Wineburg Special Issue Editors 

Editorial

\title{
Introduction of the Special Issue "Religion, Welfare and Social Service Provision: Common Ground"
}

\author{
Robert Wineburg \\ Jefferson Pilot Excellence Professor, Department of Social Work, The University of North Carolina at Greensboro, \\ 1400 Spring Garden St, Greensboro, NC 27412, USA; bobwineburg@gmail.com
}

Received: 19 February 2019; Accepted: 25 February 2019; Published: 27 February 2019

In the early 1980s, when I was a young assistant professor teaching welfare policy, the Reagan administration's severe cuts to social services left many of the most needy Americans fending for themselves. Into the breach stepped community organizations across the country, an overwhelming number of which were churches and other faith-based entities.

While providing guidance to local organizations trying to serve those in need of immediate assistance in the Greensboro, NC area, I found myself wondering, in meeting after meeting, why we never studied congregations and their community-serving efforts in my social work program. And so, like any eager young scholar would, I started to look into who was studying the interplay between religion, welfare and social service.

What I found, in short, was very little.

Why was there this rapid outpouring of community help in the wake of the federal government's drastic cuts to social services? Was it a short-term response, or had the Reagan cuts exposed a more deep-rooted system of congregational support for those most in need?

I knew there must be other scholars looking into these questions, but back then, when a reference librarian was the closest thing we had to JSTOR, it required more than a little elbow grease to figure out what academic inquiry was taking place.

One of the first leads I found was a doctoral dissertation in 1982 on the Salvation Army contracting with the government to deliver social services. The scholar who wrote that dissertation, Ellen Netting, co-authored the second chapter in this volume. Another early lead was Diana Garland, an Evangelical Christian scholar at the Southern Baptist Theological Seminary who was studying church-based social service. Her proteges at the Diana Garland School of Social Work at Baylor University co-authored the ninth chapter and, along with Terry Wolfer, the tenth chapter.

One by one, the dots started to connect. And so it went over the course of the 1980s. From my perch in Greensboro, I spent untold hours on microfiche hunting down news stories about congregational efforts to help communities buffer the impact of the Reagan cuts. Two small case studies and a survey of Greensboro's congregations later, I knew that a new area of study was being born.

Today, as evidenced by the works in this volume, scholars from a wide range of disciplines are examining how faith-based entities are involved in the development and implementation of social services, and more broadly how religion impacts social policy and services. The research assembled here delves deeply into the meaning of the millions of partnerships forged among religious communities, government agencies and nonprofits to address human needs for the common good and to fill holes in services created by natural and political disasters and a worldwide shrinking of the "welfare state."

This volume begins with Edward Queen's history of government contracting with faith-based organizations to deliver social services, from colonial times up through President George W. Bush's controversial Faith-Based Initiative. Queen examines the interplay between voluntary organizational development and governmental partnering with religious institutions, with a particular focus on how the Supreme Court has historically viewed such contracts. 
Ellen Netting and Katherine O'Connor follow with a community-level example of Queen's overview. Their rich and thorough examination of the development of Richmond, VA's nonprofit sector provides a window into the complexity of religion's interplay with secular service development.

The next four chapters are community case studies from around the United States that reflect a simple yet all-important theme that runs through the growing body of literature on faith-based social service: People make partnerships work because they want a better community.

Carl Milofsky and Brandn Green dig into the dynamics of an unlikely institutional partnership in northeastern Pennsylvania's anthracite coal region, where a liberal arts university and a local Catholic church overcame a negative community self-image to build a successful model for service-learning projects.

Across the country in California, David Campbell takes a longitudinal view of faith-based welfare-to-work programs, demonstrating that local planning and network development are crucial to religious organizations surviving and thriving in larger community systems.

Next, the co-editor of this volume, Jay Poole, along with John Rife, Wayne Moore and Fran Pearson, traces the evolution of a Jewish philanthropic family's century-long influence on health and social services in Greensboro, from innovative mill-town services to foundational support for the world's first congregational-university social service internship program.

Jo Anne Schneider rounds out this section with a comprehensive analytical model for understanding how faith communities organize social, health, senior and education services, grounding in hard data her analysis of what goes into building and sustaining personal and organizational social capital.

The two chapters that follow tackle the controversial but undeniable fact that those who make faith a part of their social service often serve unabashedly in the name of religion.

Ian Bedford traces his Australian church's struggle to keep religious principles central to its service provision as it grew into a community provider, laying out a framework for how to keep the faith when congregations move services into the public square.

A world away, Daniel Rhodes walks a similar path, examining how his Buddhist temple in North Carolina has used faith traditions to integrate Vietnamese refugees into American life, all while struggling to maintain their distant cultural and religious identity.

The second half of this volume begins with scholarship that testifies to the enduring intellectual impact of Diana Garland. The School of Social Work at Baylor University that bears her name provides a trio of authors each for the ninth and tenth chapters.

Helen Harris, Gaynor Yancey and Dennis Myers offer a framework for conceptualizing social work field training with congregations and religiously-affiliated organizations.

Then, Terry Wolfer, along with Dennis Myers, Edward Polson and Betsy Bevis, uses service-learning concepts to analyze volunteerism among Protestant baby boomers.

They are followed by another influential scholar whose footprint is apparent throughout this volume, Mark Chaves. Along with Alison Eagle, he presents the third iteration of his National Congregations Study, the definitive demographic work on congregational social service activity in the United States.

Chaves's report, in turn, is followed by chapters from two of his former doctoral students.

Rebecca Sager, along with Keith Bentele, tackles the development of state-level religiously driven social services by analyzing the politics behind the passing of faith-based legislation.

Brad Fulton, meanwhile, examines a national increase among congregations in service provision against a corresponding decrease in political participation.

The final two chapters look beyond America's borders, to the role and practice of United States-based religious organizations in international social and economic development.

Ram Cnaan, whose groundbreaking data collection decades ago engendered a paradigm shift in the understanding of faith-based social service, lays out, together with Daniel Heist, a big-picture view of service provision abroad by American religious organizations. 
Ramya Ramanath rounds out this volume by analyzing the fundraising operations of Christian international nongovernmental organizations, focusing on keys to bolstering donor retention and furthering organizational development.

The insights on these pages, though varying in focus and scope, are all aimed at building a better understanding of the intersection of religion, welfare policy and social service. With much work still to be done in the field, this volume is offered as a foundation for scholarship on the subject-so that the students of tomorrow have an easier time making sense of all this than I did 40 years ago.

Conflicts of Interest: The authors declare no conflict of interest.

(C) 2019 by the author. Licensee MDPI, Basel, Switzerland. This article is an open access article distributed under the terms and conditions of the Creative Commons Attribution (CC BY) license (http:/ / creativecommons.org/licenses/by/4.0/). 
Article

\title{
History, Hysteria, and Hype: Government Contracting with Faith-Based Social Service Agencies
}

\author{
Edward Queen \\ Center for Ethics, Emory University, GA 30322, USA; equeen@emory.edu; Tel.: +1-404-519-9243 \\ Academic Editor: Robert Wineburg \\ Received: 23 March 2016; Accepted: 20 January 2017; Published: 10 February 2017
}

\begin{abstract}
In light of the adoption of the Charitable Choice Provision of the Welfare Reform Bill and the creation of White House Offices on faith based initiatives this article examines the history of government contracting with faith-based organizations to deliver human and social services with a particular focus on how the U. S. Supreme Court has viewed the legal status of such contracts.
\end{abstract}

Keywords: Charitable Choice; faith-based; church-state; contracting

In 1996 when the Personal Responsibility and Work Opportunity Reconciliation Act (PRWORA) was adopted by Congress and signed into law by the then President Clinton, it contained within it a provision that raised little attention at the time, but has since received immense public focus and even led to the establishment of a White House office. Section 104 of PRWORA of 1996, the so-called "Charitable Choice" provision, has moved from insignificance to importance. Virtually ignored in the leading history of the welfare reform bill, this provision—or more precisely its policy implications and the efforts to adopt similar provisions in federal funding bills-became the centerpiece of much of President George W. Bush's domestic policy, capped off by the creation of the White House Office of Faith-Based and Community Initiatives (now the Office of Faith-Based and Neighborhood Partnerships).

While the departure of the office's first director, John Dilullio, after only seven months in office and the terrorist attacks on the World Trade Towers and the Pentagon on 11 September 2001, removed both the momentum and the focus of the policy, it remained an important part of the Bush administration's domestic agenda and was continued under President Obama. Although the White House Office constricted following Dilullio's announced departure and the administrative exile of many of the most ideological proponents of the policy, the impetus remains. In late January of 1991, President Bush ordered the creation of a Center for Faith-Based and Community Initiatives in five executive departments-Health and Human Services, Housing and Urban Development, Justice, Education, and Labor [1]. In his executive order, the president stated that the purpose of the centers would be "to coordinate department efforts to eliminate regulatory, contracting, and other programmatic obstacles to the participation of faith-based and other community organizations in the provision of social services." [1]. While there was some shift in emphasis under President Barack Obama, including the office's name change, in many ways President Obama extended the work in other directions. This included a program focused on college students, the Interfaith and Community Service Campus Challenge, and, perhaps more importantly, the establishment of the Office of Religion and Global Affairs in the Department of State and the appointment of Shaun Casey as the Special Representative for Religion and Global Affairs.

During the Bush administration, perhaps his most important related appointments was that of Carl Esbeck to the position of director of the faith-based center at the Department of Justice. Mr. Esbeck, on leave from his position as professor of law at the University of Missouri, served as a key advisor to then Senator, and later Attorney General, John Ashcroft in drafting the language for what became the Charitable Choice provision. In his position at the Department of Justice, Mr. Esbeck aggressively 
promoted the view that the Charitable Choice provision and its successor provisions were, in essence, simply changes in procurement rules. These changes, he argued, were designed to allow faith-based human and social service agencies that previously might have been excluded from participating in governmental contracting to enter the system, assuming they had the capacity to do so [2].

The White House Office of Faith-Based and Community Initiatives promoted a similar view. Two of the main goals of the Office, according to its web page, were to:

- Identify and act to remedy statutory, regulatory, and bureaucratic barriers that stand in the way of effective faith-based and community social programs;

- Ensure that, consistent with the law, faith-based programs have equal opportunity to compete for federal funding and other support [3].

The incorporation of the Charitable Choice provision into PRWORA in the Welfare and the creation of the Office of Faith-Based and Community Initiatives into the White House was accompanied by hysteria across the political spectrum, from those who claimed it would solve all the problems of the welfare system to those who viewed it as the beginning of theocracy ${ }^{1}$. This article elides that discussion and instead seeks to place the Charitable Choice provision into a much ignored history, or perhaps histories, namely the way governments in the United States-from local to federal-have used faith-based organizations (FBOs) for the provision and delivery of social and human services and how the courts have interpreted the constitutionality of such contracts in light of the establishment clause ${ }^{2}$.

\section{The History of Government Contracting with Faith-Based Organizations}

A major reason for the poor quality of the public discourse surrounding Charitable Choice and the wider issue of Faith-Based initiatives is that there exists little knowledge of the topic of contracting with FBOs for the delivery of service and a lack of familiarity with the legal and practical issues involved. An additional source of confusion involves the absence of clarity in defining a faith-based organization. While there has been some notable and significant work on clarifying such understandings ${ }^{3}$, for this paper the following issues are core to determining whether an entity ought to be considered a faith-based organization or not:

(1) Does the organization understand its reason for existence or its undertaking activities as motivated or structured by religious beliefs (particularly as articulated in pertinent documents)?; or

(2) Would a reasonable and neutral outside observer describe the organization and its work as being religiously motivated or structured ${ }^{4}$ ?

To a great extent, with some exceptions to be noted, the Federal Government did little contracting - either directly or indirectly-for the provision of human and social services until the 1950s and 1960s. Given the absence of federal involvement, there emerged few challenges based on the United States Constitution. Although state and local governments regularly used religious or

1 For a discussion of the "success" of faith-based organization in the delivery of such services, see [4].

2 Constitution of the United States, Amendment I. "Congress shall make no law respecting an establishment of religion..." For a general history of establishment clause jurisprudence see the following classic study, although somewhat dated [5]. For a more contemporary discussion see [6].

3 For one of the most successful attempts to bring clarity to defining faith-based organizations see [7]. This article is valuable in helping researchers understand the differences between and among such organizations, the distinctions it draws are less relevant for legal analyses because the categories are bright lines that the courts increasingly are reluctant to observe. See note 4 below.

4 While one might find these characterizations too vague, it is important to recognize that even in judicial decisions there is no clearly drawn line. As the Ninth Circuit stated in Spencer v. World Vision "each case must turn on its own facts. All significant religious and secular characteristics must be weighed to determine whether" an organizations character is religious. Spencer v. World Vision, Inc., 619 F. 3d 1109, 1112. 
faith-based agencies to deliver human and social services, until the U.S. Supreme Court, in its decision in Everson v. Board of Education of Ewing Township ${ }^{5}$, formally declared that the Establishment Clause was incorporated into the rights protected by the Fourteenth Amendment and, thereby, applicable to the States, such state practices did not give rise to federal constitutional questions ${ }^{6}$. Finally, until the second half of the twentieth century the monies expended on these issues were relatively small (again with some very specific exceptions). Only with the growth of the welfare state did the issue of government contracting with religious-based providers of service become an issue of major importance ${ }^{7}$.

Despite the need to be cautious about drawing conclusions from activities undertaken in dramatically different legal and social situations, it remains important to be reminded that such contracting is not a new phenomenon. The federal government, as well as state and local governments, have paid religious organizations to provide much needed social and human services and have occasionally worked closely in such partnerships through the payment of subsidies, coordination of efforts, and government provision of certain advantages to these organizations.

\section{The Beginnings}

A history of such partnerships highlights the fact that many of the boundaries currently taken for granted have not been as immutable or as long-lived as one might suspect ${ }^{8}$. To understand the phenomenon more clearly, we must first look at the history of government contracting for the delivery of human and social services, paying particularly close attention to the partnerships between government and faith-based organizations.

The history of government funding of services provided by private organizations, especially private eleemosynary organizations, is a long one ${ }^{9}$. In reviewing this history in light of the policies of the Reagan administration, Lester Salamon wrote, "Government support of voluntary organizations has roots deep in American history. Well before the American Revolution, for example, colonial governments had established a tradition of assistance to private educational institutions, and the tradition persisted into the nineteenth century" $[10,11]$.

This may first strike one as strange, because few would think that nothing could be clearer than the boundary between the state government and private higher education, especially for schools of higher education established for specific religious purposes. Nearly all would agree that Harvard University holds a preeminent place among the private institutions of higher learning in the United States. Established in 1636 with its primary mission the education of ministers for the Congregational Churches of New England, Harvard's identity as both a private institution and (at least initially) a religious one cannot be denied.

Yet the connection between Harvard University and the state of Massachusetts was both intimate and long-lived. The state of Massachusetts enacted a special tax for the support of the school and paid part of the president's salary. Until after the Civil War, the state legislature also appointed the university's board of directors. In Connecticut, Yale University, which had been established in response to Harvard's perceived theological liberalism, received similar support [12].

5 Everson v. Board of Education of Ewing Township, 330 U.S. 1 (1947).

6 Challenges could have been made on the basis of the state constitutions and most states have religion clauses in their constitutions similar to those in Amendment I of the U.S. Constitution while several have language that is much more strictly separationist.

7 For a discussion of the growth of government contracting with nonprofit organizations see [8].

8 For lawyers' love of boundaries, see [9].

9 This paper uses the phrases, charitable organizations, charities, nonprofits, and similar terms interchangeably, largely ignoring what may be certain specific differences that may be of interest to specialist scholars. Part of the reason for this is to guarantee some variety in the writing, but often the sources themselves use different terms to describe the same sets of organizations. Roughly speaking, all of the terms used can be understood to include any organization that could be recognized as a 501(c)(3) tax-exempt, tax-deductible organization under the Internal Revenue Code. The paper also uses the terms, religious organization, faith-based organization, faith-based service provider, religious charities, and so forth as synonyms. All of these terms are to be understood to include any organization described in the preceding paragraph that views religion and religious beliefs to underlie its reason for existence. 
Colleges and universities were not the only places where governments provided support to private, often faith-based, organizations that delivered services. State governments provided financial support to private hospitals, as well as orphanages and poor houses, many of which were religious in nature. For example, in 1806 the New York Orphan Asylum, a decidedly Protestant organization, established an orphanage, which, by decade's end, received state monies to support over 200 orphans [13].

With the growth of major urban areas in the late nineteenth century, public expenditure for services increased to such an extent that by the "last quarter of the century, subsidies became the prevailing method for financing most voluntary institutions." [14]. In the medical field, an 1889 survey of seventeen major hospitals revealed that $12 \%-13 \%$ of their income came from government sources and a 1904 Census Bureau survey estimated that governments provided eight percent of all hospital income nationwide, a figure exceeded in many states [10].

Given that the overwhelming number of private hospitals at that time had been established under the auspices of religious organizations a large portion of this money went to hospitals founded on religious principles. The first Supreme Court case addressing the issue of government contracting with a religiously affiliated provider involved a hospital founded and operated by a religious order, a fact that gave the Supreme Court no pause in allowing the federal subsidies ${ }^{10}$.

Medical treatment was not the only or even the primary place where state and local governments contracted with private non-profit organizations to provide services. The area of poor relief in general was a major locale where government monies were given to private organizations for the delivery of services.

In New York City, an 1880s study of 200 private orphanages found that these organizations received twice as much of their funding from government support as they received from legacies, donations, and private contributions ([10], p. 101). For all social services in that city, the amount the local government paid to reimburse private benevolent institutions for the care of prisoners and paupers grew faster than did total city expenditures for those purposes.

New York City's expenditures for social services increased from less than $\$ 10,000$ in 1850 (the equivalent of nearly $\$ 300,000$ in 2016) to over $\$ 3$ million (over $\$ 82$ million in 2016) by 1898 . This means that between 1850 and 1898 city expenditures for the care of the poor, indigent, and prisoners increased from a mere $2 \%$ of the city's budget to $57 \%$ of the budget. ([10], p. 101 ; [15]). While impossible to separate out what percentage of these monies actually went to religious organizations, an examination of the funding of orphanages can be illustrative. Most orphanages during that time were established along religious lines and served orphans of a particular faith. In fact, they were subsidized by New York and other cities for doing exactly that. That both the state government and others recognized this fact is illustrated by the 1863 act of the New York legislature to charter the Roman Catholic Protectory to receive truant, vagrant, and delinquent children whose parents or guardians had requested the courts to commit them to a Catholic establishment rather than to the House of Refuge or other predominantly Protestant institutions [16].

In the provision of poor relief more generally, we know that the Salvation Army was a recipient of city funds, as were many other religious providers in New York [17]. The New York Association for Improving the Condition of the Poor (a predominantly Protestant organization), the Society of St. Vincent De Paul, and the United Hebrew Charities were among the private charities that received monies derived from New York City's excise taxes on alcohol and tobacco ([16], p. 184). By the beginning of the twentieth century, the use of private non-profit organizations for the provision of services to the orphaned, the sick, and the destitute was widespread throughout the United States. A 1901 federal survey of governmental subsidies of private charities found that "except possibly two territories and four western states, there is probably not a state in the union where some aid is not given

$10 \quad$ Bradfield v. Roberts 175 U.S. 291 (1899). 
[to religious organizations] either by state or by counties and cities." ([10], p. 101; [15], p. 360). While the Constitutions of some states prevented government monies from going to religious organizations, cities still found them appropriate providers, as did many other states ${ }^{11}$.

Even in states where the constitution seemingly forbade the payment of government monies to "sectarian" institutions, this limitation often was evaded through numerous subterfuges. Many ostensibly non-sectarian institutions were completely Protestant in ethos and practice. Catholics and Jews, in order to protect their religious rights, felt compelled to compete equally for government monies in order to prevent their co-religionists from being either under-served or from falling into the clutches of an alien religion ${ }^{12}$. Additionally, states often found ways around such limitations. A 1917 decision by the Illinois State Supreme Court rejected the claim that county payments to a sectarian institution for care of the poor violated that state's constitutional ban on aid to such organizations. The court reasoned that if the county paid the institution less than the actual cost of care, this could hardly be called aid to a sectarian organization, and so would not be a violation of the constitution [19].

Amos Warner, in his influential and oft reprinted study of private benevolent institutions in the late-nineteenth century United States, actually attributed much of the growth of governmental subsidies to private eleemosynary institutions to the influence of religious institutions. He claimed that, "The growth and persistence of the subsidy system, particularly in caring for dependent children, is closely connected with the desire of different churches to control their education in morals and religion." ([18], p. 407). Warner pointed out that 45\% of all orphanages and children's homes in the United States were under express religious control and that "a considerable percentage of those nominally non-sectarian are, in fact, strongly under sectarian influence." ([18], p. 407). He noted that, "Many institutions having no trace of sectarianism in charter, constitution, or by-laws are yet administered in the interests of a sect," and that while the willingness of an institution to admit individuals of all denominations often was used to advertise its non-sectarian nature, he noted that such a fact was "frequently less an evidence of non-sectarianism than of a tendency to make proselytes." ([18], p. 408) ${ }^{13}$.

Although the above demonstrates that state and local governments did not necessarily shy away from working with private benevolent organizations, including religious organizations, in providing care for those in need, it tells us little about the role of the federal government. To some extent this does not surprise, because, as noted previously, the federal government's role in such provision was minimal until the advent of the New Deal. While the federal government's relations with the Native American peoples might be informative in this regard, the distinctive context of that work and the

11 Particularly following the Civil War numerous states adopted what were popularly known as Blaine Amendments. They were named after James G. Blaine a U.S. representative from the Maine who introduced a U.S. Constitutional amendment to prohibit the use of governmental monies for "shall ever be under the control of any religious sect; nor shall any money so raised or lands so devoted be divided between religious sects or denominations." While the amendment passed overwhelmingly in the U.S. House of Representatives, it fell four votes short in the U.S. Senate. This led to the amendment of many state constitutions to adopt some variation of the above language. By the 1970 s 38 of the 50 states had some version of the amendment in their state constitutions. Since that time, however, there have been concerted attempts to repeal the amendments, beginning with Louisiana in 1974.

12 "In States where a constitutional limitation forbids the voting of public money to 'sectarian' institutions, members of the Protestant denominations often seek to have this clause so interpreted as to exclude the institutions offered by the Roman Catholic orders, while charitable enterprises in which they are themselves interested are nominally unsectarian. The Catholics not infrequently try to evade the constitution limitation by disingenuous subterfuges; and the Protestants...encourage such a course by their own eagerness to secure public money for the private institutions in which they are themselves interested" [18].

13 This point needs to be taken most seriously. In the nineteenth century "sectarian" often was used in a very specific sense to denote religions or denominations and their affiliated organizations that solely were operated for their members. This definition or understanding excluded many organizations that a neutral observer would have considered religious. These organizations, such as the New York Orphan Asylum mentioned above and seemingly non-sectarian were established by Protestant Christians and the ethos and training were decidedly Protestant in ethos. Since they were not denominated as Protestant, were comprised of Protestants of various denominations, and did not limit their services (although did limit their hiring) to Protestants, they claimed to be "non-sectarian." Catholic and Jews found such claims unconvincing. 
unique Constitutional issues involved make such an examination too sui generis to be useful ${ }^{14}$. In one location, however-Washington, D.C.- the role of the federal government in funding social services was central, since Congress itself functioned as D.C.'s city council.

\section{Congress, Washington, D.C. and Bradfield v. Roberts}

By the late nineteenth century, the provision of poor relief and indigent services in Washington, D.C. reflected that of most other cities in the northeast. An examination of the city's budget for that period found that not only was Congress, which functioned as D.C.'s city council and established its budget, willing to compensate private charities for the services they provided to the District's poor, but that Congress also provided funds to pay for the construction of the buildings used by these organizations.

By the last decade of the nineteenth century about half the public funds allocated by Congress for poor aid within the District of Columbia went to private charities and these charities also absorbed over $60 \%$ of the funds granted for construction of charitable facilities between 1880 and 1892 ([18], p. 337). These institutions included numerous private charitable institutions "avowedly under sectarian management" ([18], p. 401).

This funding led to the first case (and the only one before the 1980s) heard by the United States Supreme Court regarding the constitutionality of providing federal funds to religious social service providers ${ }^{15}$. The suit, Bradfield $v$. Roberts, challenged Congress's appropriation of federal funds for capital improvements for a church-related hospital in the District of Columbia.

Although decided on fairly narrow grounds, the facts surrounding the case are illuminating. In April of 1864 Congress incorporated Providence Hospital in Washington, D.C. The act of incorporation gave the corporation "full power and all rights of opening and keeping a hospital in the city of Washington for the care of such sick and invalid persons as may place themselves under treatment and care of said corporation"16. The Sisters of Charity of Emmitsburg, Maryland held the title to Providence Hospital. Its founding directors were all members of that order and held their positions as a self-perpetuating board of directors.

Three years later in April 1867, Congress appropriated \$30,000 (\$462,463 in 2016 dollars) for the construction of two isolation buildings to be operated as part of local hospitals, one of which was to be located at Providence Hospital. The appropriation was subject to two-thirds of the isolation building being for "the use of such poor patients as shall be sent there by the Commissioners of the District...." In return the hospitals were to be paid $\$ 250$ per annum (pro rata) (\$3,854 in 2016 dollars) "for such a time as such patient may be in the hospital, subject to Annual Appropriations of Congress" 17 .

Complainant objected to the appropriation on the grounds that the contract between the hospital and the federal government was "unauthorized by law" and:

involved a principle and a precedent for the appropriation of the funds of the United States for the use and support of religious societies, contrary to the article of the Constitution which declares that Congress shall make no law respecting a religious establishment, and also a precedent for giving to religious societies a legal agency in carrying into effect a public and civil duty which would, if once established, speedily obliterate the essential distinction between civil and religious functions ${ }^{18}$.

The opinion, issued by Mr. Justice Peckham, did not even reach the facts alleged. The Court looked at the act of incorporation and found it to be an appropriate legal document creating a private

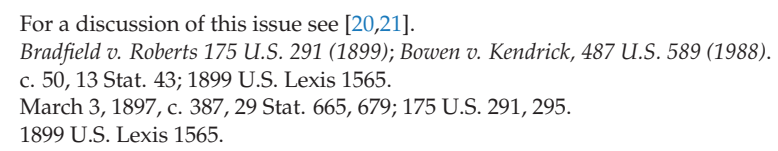


corporation. "[T]he fact that its members...are members of a...sisterhood of the Roman Catholic Church, and the further fact that the hospital is conducted under the auspices of said church, are wholly immaterial..."19

He continued:

That the influence of any particular church may be powerful over the members of a non-sectarian and secular corporation, incorporated for a certain defined purpose and with clearly stated powers, is surely not sufficient to convert such a corporation into a religious or sectarian body. That fact does not alter the legal character of the corporation... ${ }^{20}$

For the Court, the legal status of the corporation was determinative. Congress had the right and power to charter such a corporation, the corporation had not violated the charter in its operation, and Congress had the right to make the appropriations it made and to authorize the Commissioners of the District to enter into the service contract. The case was dismissed for failure to state a cause of action.

The case is almost as interesting for what was not decided as for what was. The Court left aside the question of whether such appropriations would be valid if an organization were, by its charter, an explicitly religious organization. Even if such an appropriation were invalid, the Court said, such is not the case here. One simply has a private corporation, albeit perhaps run by a religious order and operating under the patronage of a denomination, whose operations and management are governed by the document of incorporation and the laws of the land.

At a minimum, what the court allowed in the case was the use of federal funds by organizations designed to provide legitimate secular health services. Who provided that service and from what motivation and impetus was and remained irrelevant.

In Bradfield we see clearly that by the end of the nineteenth century, even in an arena solely under federal jurisdiction and subject to Constitutional limitations, there had developed a formal process by which governments, including the federal government, worked with religious organizations to provide much needed human and social services. Such a formal process as contracting for services was not the only way that the national government worked with religious organizations in the provision of services, however. With the establishment of the Sanitary Commission during the Civil War (as well as the competing commissions organized upon more explicit sectarian lines), there developed strong relationships between the national government and religious organizations in the delivery of a wide variety of services.

\section{The Civil War and Its Aftermath}

The Civil War brought about a major expansion in the power and reach of the national government in the United States. It saw not only the creation of a massive national army and expansion of the navy, but also huge contracts for war materiel as well as the introduction of the income tax. All greatly increased the power of the national government.

During the war, maintaining the health and morale of the troops presented a major challenge to its successful prosecution. Disease, stress, and loneliness all took their toll with disease far outstripping the battlefield as a major source of casualties. To address these problems, many organizations, including religious denominations, undertook numerous activities to aid the soldiers of both armies. While these undertakings did not primarily, or even necessarily, involve the expenditure of government funds to pay for the delivery of services by a faith-based organization, they readily involved a working relationship, often involving government efforts to accommodate or facilitate the work of the religious organizations, work which served military needs and, often, governmental policy. 
While these organizations undertook a wide variety of activities, three predominated. These were medical and nursing care; the maintenance of morals, morale, and sanitation; and services provided to the freedmen. In all of these activities, expressly religious organizations and organizations with a marked religious component were active. Even the United States Sanitary Commission, which, despite its name, was a private entity and nominally non-sectarian, had a prominent Unitarian minister, the Reverend Henry W. Bellows, as its chairman and formal representation from a variety of religious leaders on its board.

In the provision of nursing volunteers, perhaps the most important and, for many the most memorable, were women Roman Catholic religious. Of the estimated 3200 women who served as volunteer nurses during the war, at least 600 were Roman Catholic nuns. The latter, although looked upon with suspicion by some reformers such as Dorothea Dix, were widely admired by the soldiers and the medical corps ([16], p. 73) $)^{21}$.

In the provision of services to maintain the morals and morale of the soldiers, religious organizations often were in the forefront. The United States Christian Commission, whose members and activities often found themselves at odds with the Sanitary Commission, distributed religious tracts and Bibles to soldiers, conducted religious services, and undertook what today we would call counseling. It also took an active role in collecting and distributing medical supplies, clothing, food, and other items of personal need among the soldiers. Additionally, like so many volunteers in the war zone, its members, often clergy on leave from their pulpits, served as nurses and orderlies in the hospitals ([16], p. 76). Supported by the YMCA, numerous industrialists, and individual congregations, particularly those of an evangelical bent, the Christian Commission received access to the battlefields and to the military camps and hospitals in undertaking its work.

Organized in November of 1861 during a meeting of YMCA representatives, the Christian Commission's mission was to promote "the spiritual good of the soldiers in the army, and incidentally their intellectual improvement and social and physical comfort." ([16], p. 57). Its General Secretary, the Methodist minister William Boardman, declared it to be the first agency ever to minister both to soldiers' physical and spiritual needs and was particularly well-placed to do so ([16], p. 57).

Its board members included four bishops (two Methodists and two Episcopalians). One of the Methodist bishops, Matthew Simpson—reported to be President Lincoln's favorite preacher-was a close personal friend of both Secretary of War Edwin Stanton and Treasury Secretary Salmon P. Chase. Another commissioner, the Reverend Herman Dyer, had been a college-mate of Secretary Stanton. The Speaker of the House, Schuyler Colfax, also served on the Commission's board. The Christian Commission's annual meetings were held in the hall of the House of Representatives and attended by the President, the Chief Justice, various cabinet secretaries, Senators and Representatives, and senior members of the Army and Navy ([16], p. 58).

In the field, the Christian Commission had ready access to the troops, both in camp and in the hospitals. In the camps, the Christian Commission delivered food, clothing, and wholesome reading materials. Many of the Christian Commission's members saw the physical aid and support to individuals as the means of demonstrating the essence of true Christianity. Soldiers, one field member wrote,

could not oppose a Christianity that manifested such concern for their bodily comfort. Farina, oranges, lemons, onions, pickles, comfort-bags, shirts, towels given and distributed in the name of Jesus, though designed for the body, gave strength to the soul. To the quickened senses of a wounded soldier parched with fever, far from home and friends,

21 The elaborate habits of some of the religious orders gave rise to stories of soldiers awakening from unconsciousness and upon seeing a woman with a headpiece that looked like wings first believed he was being tended by an angel and on his way to heaven. Undoubtedly he would have been quickly disabused of this perception by both viewing and hearing the ongoings in the hospital ward. 
an onion was a stronger argument for the religion which bestowed it than the subtle reasoning of Renan, and a pickle sharper than the keenest logic of Colenso! [22]

In the field hospitals, the Christian Commission members served as nurses, aides, and orderlies. They provided bandages and other medical supplies along with food and comfort. To accomplish such tasks they required access to the troops' encampments and support from the military and the federal government. The result was a working partnership between the Christian Commission and the federal government. The Christian Commission provided goods and services beyond those provided by the military and in support of it. In return the military gave the Christian Commission access to the troops and assistance in logistics, security, and transportation. While the government provided no reimbursement to the Christian Commission, or for those of any of the other numerous soldiers' aid societies whether religious or secular, the military and the government did provide many other types of aid and a quasi-formal recognition. As the war progressed, these partnerships expanded to include assistance to the refugees it created and to support of the freedmen both during and after the war.

The numbers of refugees, contrabands (enslaved persons liberated during the Union advance), and, later, freedmen presented the Union Army and the federal government with numerous challenges. The responsibility to care for these individuals had devolved upon them and they had to find ways to do so. A wide variety of methods were employed. (General Ben Butler, the military governor of New Orleans, hired the unemployed to clean the city streets for example.) The most common method of dealing with these groups was indirect, through reliance upon private associations, mostly religious.

In no area was this more expansive than in the provision of aid to the freedmen. This work began in September 1861 when the American Missionary Society sent a group to work with freed slaves housed near Fort Monroe in South Carolina. It expanded greatly the following year when General Sherman issued an official request for aid to the abandoned and refugee slaves he was protecting at Port Royal, South Carolina. This work continued through the war and with its end became formalized with the creation of the Freedmen's Bureau under the direction of Major General Oliver Otis Howard. A man of staunch piety and referred to as the "Christian Soldier", Howard was committed to educating and aiding the recently freed slaves. A circular issued over his name in 1865 (although drafted by Lyman Abott his assistant and a minister) stated that the Bureau's policy would be to work with private organizations. "The utmost facility will be afforded to benevolent and religious organizations in the maintenance of good schools for refugees and freedmen until a system of free schools can be supported by recognized local governments" ([16], p. 126).

To achieve this end, the Bureau was to cooperate with,

private benevolent associations of citizens to aid the freedmen, and with agents and teachers, duly accredited and appointed by them...hire or provide by lease buildings for purposes of education whenever such associations shall, without cost to the government, provide suitable teachers and means of instruction and...furnish such protection as may be required for safe conduct of such schools ([16], p. 128).

In practice, the Bureau expanded its mandate significantly. Typically, after an association began constructing a school building, the Bureau would then provide the money necessary to complete it, under the auspices of repairs. After the building was complete, the Bureau would then lease the building from the association on the basis of \$10.00 (\$258.00 in 2016 dollars) per month paid for each teacher instructing at least thirty students. The result was that the Bureau effectively subsidized the agencies in hiring and supporting teachers by renting from them buildings the Bureau effectively had paid for. In this way the Bureau paid nearly $\$ 6$ million (equivalent to over $\$ 84$ million today) to private benevolent organizations, mostly the American Missionary Association (AMA) and the American Freedmen's Union Commission (AFUC), for educational work among the freedmen.

Both of those organizations had express religious commitments. The AMA demanded a fervent piety of its teachers and felt that it would be "suicidal to subject our missionaries and teachers (both in one) to any body of men not of a religious character; and we cannot separate the educational from 
the religious element" ([16], pp. 129, 133). While less expressly sectarian, the AFUC required that its teachers demonstrate a genuine spirit of love for God and man and, like the AMA, refused to hire Roman Catholics ([16], pp. 129, 133).

In addition to providing funds and access to camps and military areas where the freedmen were held, the military also provided security for these schools in order to protect the teachers and administrators from the hostile and often marauding locals. The sheer size and expanse of this work set the stage for the use of religious organizations to provided services the government desires.

The Spanish-American War and World War I saw similar partnerships between faith-based organizations and the U.S. military in the provision of support services, including medical care to soldiers, sailors, and marines. During both wars the YMCA, and, during Word War I, the newly created organizations such as the National Catholic War Conference and the National Jewish Welfare Board provided religious, social, and recreational services to the troops, and were highly visible in the conflict zones. Just as in the Civil War these organizations were aided in their access to and work with the troops, and were provided with assistance in logistics and given access to the highest level of governmental and military authorities.

While the long-term consequences of these organizations would be highly important-the National Catholic Welfare Board would, post-war, become the National Catholic Welfare Board and eventually, through several name changes, today's United States Conference of Catholic Bishops-the short-lived nature of both wars did not result in major changes in the historic relationship between religious organizations and the federal governments, with one possible exception. World War I saw the emergence of formal organizations working with the federal government that extended beyond the Protestant majority. This shift would have notable consequences down the road.

\section{The Development of the Welfare State}

The depression of 1929 saw economic events overwhelming the social service delivery system in all sectors of American society. The ability of state and local governments, as well as private nonprofit organizations, to address the immense need proved woefully inadequate. Attempts by President Herbert Hoover to call upon the voluntary spirit of Americans to provide help to those in need failed amidst the wide-scale economic meltdown. Similar efforts by President Franklin Roosevelt to establish a coherent public-private partnership to revive the American economy, collapsed amidst court decisions and the lack of private monies.

The result led to a major expansion in the level of services and activities directly funded and provided by the federal government through President Roosevelt's New Deal policies. Although the New Deal shifted the traditional way of delivering services, with the federal government preferring to deliver them through local governmental agencies instead of private organizations, the expansion of perceived governmental responsibility led, after the war, to a massive expansion of federal funds in supplying various social needs and services, from health-care to education.

The 1950s and 1960s firmly established and entrenched the current patterns of governmental funding. All levels of government in the United States-local, state, and federal—to greater or lesser degrees, pay for the delivery of social service by nonprofits through the use of four forms of support.

These are:

(1) Purchase-of-service contracts, in which the government contracts with an organization to provide a specific service for which the organization receives funds in a lump sum;

(2) Fees-for-services, in which government acts as the payee for the delivery of particular services whether it be health care, job training, etc.;

(3) Direct support through grants, in-kind contributions, low-interest loans or loan guarantees, including construction grants to hospitals under the Hill-Burton act, commodity distribution to homeless shelters and food pantries; and 
(4) Indirect support through grants or vouchers to individuals who then "purchase" services-education, drug-treatment, or housing to name a few options-from approved providers.

This expansion of governmental support, especially federal support, for many services led to conflicts within many religious organizations. The Southern Baptist Convention opposed governmental support to its institutions and many of the various state conventions found themselves facing being forced to allow hospitals and colleges to become independent of state convention control as the leaders of those institutions desired to participate in the growing governmental largesse. Baylor Medical Center and Wake Forest University were among those Southern Baptist institutions that spun themselves off as independent institutions in order to receive federal dollars [23].

The President Lyndon Johnson's War on Poverty and the social policies of President Richard Nixon's administration made even greater use of private non-profits for the delivery of governmental-funded social services. Using non-profits served the goals of both political liberals and political conservatives. It got services to those in need without creating an even larger federal (or state) bureaucracy.

One result was a massive increase in the use of private non-profit service providers. While, as we have demonstrated above, this was nothing new, the sheer growth of federal funding for these services produced a change in kind, not only in degree. The growth of this "contracting regime"- to use the phrase devised by Steven Rathgeb Smith and Michael Lipsky—was so immense that by the mid 1970s the leading non-profit providers of human and social services received major percentages of their support through some form of governmental funding [8]. By the beginning of the Reagan administration " $40 \%$ of the funds spent by federal, state, and local governments in the United States for...human service activities" went to nonprofit organizations [24].

Unsurprisingly, a large percentage of these dollars went to religious social service providers. The magnitude of this can be seen by the fact that by the close of the 20th century the seven largest religious social service agencies were serving over 60 million people annually ${ }^{22}$. For many of these organizations governmental monies dwarf all other sources of funding. In 2015, 62\% of Catholic Charities USA's funding came from government sources and Lutheran Social Services of America received over $45 \%$ of its support from government funding. Even organizations that, for religious or structural reasons, are cautious about accepting governmental monies still received significant amounts from the government. These include World Vision 19.5\%, Habitat for Humanity, 9.8\% and the Salvation Army $8.4 \%[26]^{23}$.

While several studies demonstrate the near-universal fact that religious social-service providers of every size receive significant amounts of governmental monies one example is illustrative. Stephen Monsma in examining government funding of nonprofit agencies found that of 137 child service agencies that identified themselves as religious, $51 \%$ reported receiving over $40 \%$ of their income from public funds and only $18 \%$ reported taking no governmental monies at all [27]. While the amounts today may be larger, the use of religious organizations to deliver social services is nothing new and is consistent with the long-standing American pattern, but what have the courts had to say about it?

\section{The Supreme Court and the Establishment Clause}

As suggested in the discussion of the Bradfield case, the delivery of governmental monies to faith-based organizations by governments in order to deliver human and social services potentially

22 This amount, based on self-reporting by the Salvation Army, Catholic Charities USA, the Evangelical Lutheran Church of American, and Lutheran Church-Missouri Synod, the YMCA, the YWCA, and the International Union of Gospel Missions, is reported in [25].

23 Since Lutheran Services of America also includes a large number of hospitals a significant proportion of its overall funding comes from fees for service. These amounts were not included in the percentages. Since this list only focuses on the largest charities many smaller agencies with significant governmental funding are not included here. 
implicates the establishment clause of the First Amendment to the Constitution. One challenge in clarifying the legal issues is that much of the jurisprudence is embedded in cases dealing with schools, hospitals, and employment. Determining both the current state of establishment clause jurisprudence and its direction for government contracting with faith-based organizations often requires one to look far afield ${ }^{24}$.

For example, the activities of a religious service provider in hiring only members of its own faith, while perfectly constitutional and statutorily legal, could become invalid if a court were to determine that the religious organization's acceptance of state funds made it "state-actor." As such, it would be forbidden to discriminate under the religion clauses of the First Amendment, or the Court might simply conclude that such religious discrimination is forbidden in instances where governmental funds are directly involved.

It is unlikely that the Court would make a sweeping generalization that turned all recipients of governmental monies into state actors. There are numerous related, narrower questions that courts have to address when governmental monies are placed in the hands of faith-based organizations to deliver human and social services.

An analysis of legal issues surrounding governmental funding of faith-based human social service agencies begins with the religion clauses of the First Amendment to the United States Constitution. This amendment states that, "Congress shall make no law respecting an establishment of religion, or prohibiting the free exercise thereof..." ${ }^{25}$. Although originally applying only to actions by the federal government, as were the entire first ten amendments, both religion clauses have been interpreted by the Supreme Court as incorporated into those rights protected against infringement by the states under the due process clause of the Fourteenth Amendment. Although the Court expressly made this statement in Murdock v. Pennsylvania ${ }^{26}$, the Supreme Court's decision in Everson v. Board of Education ${ }^{27}$ is generally considered the case that formally incorporated the establishment clause into the due process clause of the Fourteenth Amendment, just as Cantwell v. Connecticut expressly incorporated free exercise clause into the Fourteenth Amendment ${ }^{28}$.

While neither of these clauses, particularly free exercise, has been viewed as absolute ${ }^{29}$, both traditionally have been given broad interpretations by the Supreme Court ${ }^{30}$. The breadth of the protections provided to religious practice often appeared broader than it was since many of the leading Supreme Court cases seemingly decided on "free exercise" grounds actually were decided on other Constitutional principles, including free speech and the rights of parents to raise their children ${ }^{31}$.

24 The remainder of this article focuses solely on establishment clause cases. It does not address the current status of "free exercise" cases that have emerged since the Supreme Court's decisions in Employment Division, Department of Human Resources of Oregon v. Smith, 494 U.S. 872 (1990), Church of the Lukumi Babalu Aye, Inc. v. Hialeah, 508 U.S. 520 (1993), City of Boerne v. Flores, 521 U.S. 507 (1997). It also does not address issues raised by the Religious Freedom Restoration Act (1993) 42 U.S.C. ch. 21B or the Religious Land Use and Institutionalized Persons Act (2000) 42 U.S.C. ch. 21C. These both have potential implications for government contracting, however, depending on the legal implications of Burwell v. Hobby Lobby, 573 U.S. _ (2014). Here it is important to note that the Supreme Court's decision in the Hobby Lobby case was decided on a statutory interpretation of the Religious Freedom Restoration Act, not on a Constitutional basis.

26 Murdock v. Pennsylvania, 319 U.S. 105 (1943) at 108

27 Everson v. Board of Education, 330 U.S. 1 (1947).

28 Cantwell v. Connecticut, 330 U.S. 1 (1947).

29 For a stinging (and mostly wrong-headed) view of this see, [28].

30 There have been a few decisions that some may read as glaring exceptions to this. Many would point to the Mormon polygamy decisions as most representative. Reynolds v. United States, 98 U.S. 145 (1879). The predominant view that such deference was the norm lay behind the collective shock that greeted the Court's decision in Smith v. Oregon where, in terms of neutrally valid laws at least, Justice Scalia stated expressly that such deference not only was not the law, it was not even the norm. "We have never held that an individual's religious beliefs excuse him from compliance with an otherwise valid law prohibiting conduct that the State is free to regulate." Employment Division v. Smith, 484 U.S. 872 (1990), at 878-79.

31 Pierce v. Society of Sisters 268 U.S. 510 (1925), Wisconsin v. Yoder, 406 U.S. 205 (1971). 
The nature of these complexities is such that the jurisprudence in the so-called "church-state" arena has been somewhat murky ${ }^{32}$ and has only become murkier in the past four decades ${ }^{33}$. The murkiness has been created by the difficulty of applying fairly complex judicial tests to what often are very fact-specific situations and the Court's increasing willingness to distinguish between a statute's facial constitutionality (unconstitutional by its very nature) and its constitutionality as applied ${ }^{34}$.

The United States Supreme Court's Establishment Clause jurisprudence has been dominated by a three-part test articulated in Lemon v. Kurtzman, the so-called "Lemon test":

Every analysis in this area must begin with consideration of the cumulative criteria developed by the Court over many years. Three such tests may be gleaned from our cases. First, the statute must have a secular legislative purpose; second, its principal or primary effect must be one that neither advances nor inhibits religion; finally, the statute must not foster "an excessive government entanglement with religion." 35

In its later decisions the Court has tended to merge the last prong of the test, the "excessive entanglement" prong into the primary effect prong. As Madame Justice O'Connor wrote in her 1997 majority decision in Agostini v. Felton,

We have considered entanglement both in the course of assessing whether an aid program has an impermissible effect of advancing religion and as a factor separate and apart from "effect." Regardless of how we have characterized the issue, however, the factors we use to assess whether an entanglement is 'excessive' are similar to the factors we use to examine 'effect'...Thus, it is simplest to recognize why entanglement is significant and treat it-as we did in Walz-as an aspect of the inquiry into a statute's effects ${ }^{36}$.

If Agostini is the ruling decision, a two-prong test is administered. The first prong involves determining whether the statute being challenged has a legitimate secular purpose. In making this determination, the Court has tended to be very fact specific, carefully examining the legislative record and the expressed rationale for the law. This analysis extends far beyond a simple "rational basis" review. The Court does not base its findings on whether the law could have a legitimate secular purpose, but on whether the law as proposed and supported has as its main, if not overwhelmingly predominant, rationale some secular governmental purpose. If there is no legitimate secular purpose or the purpose of the statute was designed to further religion in some way, then a law is unconstitutional ${ }^{37}$. In instances where a government, in attempting to realize some legitimate secular purpose, provides

32 "Candor compels acknowledgment, moreover, that we can only dimly perceive the lines of demarcation in this extraordinarily sensitive area of constitutional law. The language of the Religion Clauses of the First Amendment is at best opaque, particularly when compared with other portions of the Amendment. Its authors did not simply prohibit the establishment of a state church or a state religion, an area history shows they regarded as very important and fraught with great dangers. Instead they commanded that there should be "no law respecting an establishment of religion." A law may be one "respecting" the forbidden objective while falling short of its total realization. A law "respecting" the proscribed result, that is, the establishment of religion, is not always easily identifiable as one violative of the Clause. A given law might not establish a state religion but nevertheless be one "respecting" that end in the sense of being a step that could lead to such establishment and hence offend the First Amendment. In the absence of precisely stated constitutional prohibitions, we must draw lines with reference to the three main evils against which the Establishment Clause was intended to afford protection: "sponsorship, financial support, and active involvement of the sovereign in religious activity." Lemon v. Kurtzman, 403 U.S. 602 (1971) at 612.

33 While on the one hand the Court appears to be inclined to allow certain activities that earlier Courts had deemed violative of the Establishment Clause, see for example the decision of Agostini v. Felton overruling Aguillar v. Felton, 473 U.S. 402 (1985). Despite this the Court does seem to be willing to allow the government greater authority to regulate the religious activities of individuals, the Smith case and religious organizations City of Boerne v. Flores as long as the regulations serve a legitimate governmental interest and are not specifically directed at religion or a particular religion. See Church of Lukumi Babalu Aye v. City of Hialeah, 508 U.S. 520 (1993).

34 See for example, Mitchell v. Helms, 530 U.S. 793 (2000).

35 Lemon v. Kurtzman, 403 U.S. 602 (1971) 612-613. Citations omitted.

36 Agostini v. Felton, 521 U.S. 203 (1997), at 232-33

37 See for example, Edwards v. Aguillar, 482 U.S. 578 (1987). For a discussion of how this is applied in light of a free-exercise challenge see the decision in Church of Lukumi Bablu Aye v. City of Hialeah. 
funds to all organizations that adequately serve that purpose without regard to religion, however, "then it is fair to say that any aid going to a religious recipient only has the effect of furthering that secular purpose" 38 .

The nature of the organization receiving the funds and the structure of its beliefs seemingly have no bearing on determining whether the statute has a legitimate secular purpose. Additionally, the Court has stated that the fact that an organization receives governmental monies does not mean that the organization becomes part of the government. Merely receiving governmental monies does not turn an organization into a state actor for Constitutional purposes.

In distinguishing between indoctrination that is attributable to the State and indoctrination that is not, we have consistently turned to the principle of neutrality, upholding aid that is offered to a broad range of groups or persons without regard to their religion. If the religious, irreligious, and areligious are all alike eligible for governmental aid, no one would conclude that any indoctrination that any particular recipient conducts has been done at the behest of the government...If the government is offering assistance to recipients who provide, so to speak, a wide range of indoctrination, the government itself is not thought responsible for any particular indoctrination ${ }^{39}$.

While the potential implications of this statement will be discussed below, for now it is sufficient to recognize that the mere fact that a recipient of governmental funds to deliver a social service may also engage in religious teaching, by itself, does not necessarily implicate the Establishment Clause. If the government casts its net widely in providing funds to effect a legitimate, secular purpose, the sheer breadth of the net cast is sufficient to remove any taint of religious indoctrination by the government.

If the Court determines that the statute does have a legitimate, secular purpose, the Court moves to the next prong of the test. In this prong the Court seeks to determine whether the statute's primary or principal effect advances or inhibits religion. The Court makes such a determination by examining:

the character and purposes of the institutions that are benefitted, the nature of the aid that the State provides, and the resulting relationship between the government and the religious authority. Similarly we have assessed a law's effect by examining the character of the institutions benefitted (e.g., whether the religious institutions were 'predominantly religious') and the nature of the aid that the State provided (e.g., whether it was neutral and nonideological $)^{40}$.

The Court looks to determine the extent to which the aid "is allocated on the basis of neutral secular, criteria that neither favor nor disfavor religion, and is made available to both religious and secular beneficiaries on a nondiscriminatory basis" ${ }^{41}$. In other words, the manner in which the funds find their way to a particular organization must be made on a basis completely separate from the religious character of the institution. Additionally, the program itself must not provide an incentive for the ultimate recipient of the services (in the case of Charitable Choice, the individual eligible for the services) to choose a religious provider over a secular provider. If an eligible individual would receive the particular services regardless of where she or he sought them then such an incentive does not appear to be created. An incentive to seek out religious indoctrination,

is not present, however, where the aid is allocated on the basis of neutral, secular criteria that neither favor nor disfavor religion, and is made available to both religious and secular beneficiaries on a nondiscriminatory basis. Under such circumstances, the aid is less likely to have the effect of advancing religion ${ }^{42}$.

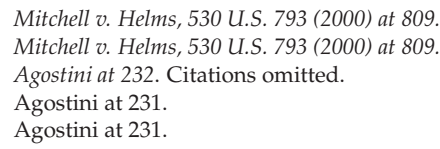


A major component in determining whether neutrality has been met is whether funds flow to a religious organization "only as a result of the genuinely independent and private choices of individuals" 43 . The Court views the aggregated private choices of individuals in choosing providers as a defense against governmental preference of one religion over another or of religious organizations over non-religious ones. Individual choice breaks the causal link between the government and the religious organization that may be the recipient of governmental monies. If the organization receives the money because of the choices of individuals it is wrong to impute any portion of the organization's religious content to the state. Even in those instances where the money flows directly to the institution in return for the delivery of a particular service, the Court, after its decision in Agostini and even more forcefully in its later decision Mitchell v. Helms (see below), is inclined to see the funds as reaching the organizations only "as a consequence of private decisionmaking" 44 .

In emphasizing the role of private choice, the Court in Mitchell seemingly rejects the previous distinctions it had made between direct and indirect aid ${ }^{45}$. Citing Agostini, the Court stated that, "[W]e have departed from the rule relied on in Ball that all government aid that directly assists [a religious organization] is invalid" 46 . By replacing the indirect/direct aid distinction with the categories of private choice and neutrality, the Court stated that it saw no difference between monies going directly to a religious organization as a result of private choices and neutral criteria and "the government issuing a paycheck to one of its employees knowing that the employee would direct the funds to a religious institution." 47 . In both instances, the Court declared, "Any money that ultimately went to religious institutions did so only as a result of genuinely independent and private choices of individuals" 48 .

Where an individual is entitled to receive a service and the provider is paid only to the extent it delivers the service to that individual, the recipient's act of choosing one provider (even if the provider is paid directly by the government) makes the funds flowing to the organization a matter of the eligible individual's choice. In such instances, the plurality in Mitchell stated that (for an educational context), "we see little difference in loaning science kits to students who then bring the kits to school, as opposed to loaning the science kits to the schools directly"49.

The Court takes a fairly functional approach to its understanding of private choice. Private choice is not only expressed when an individual who is directly given money or its equivalent chooses to purchase a service from a particular provider. For the Court, it is sufficient that an individual entitled to a particular service has a group of providers from which to choose, even if the money for that provision flows directly to the provider. If the provider is a religious organization, if it were chosen by a government to provide the services on bases unrelated to its religious character the establishment clause is not implicated.

If the statute itself meets the criteria laid out in both prongs of the Agostini test, the statute is facially valid. A court must then, if the facts of the case so dictate, look to see whether the statute as applied in a particular situation violates the second prong of the test $\mathrm{t}^{50}$.

While the Supreme Court has not expressly stated what the distinction is between such analyses ${ }^{51}$, it has recognized such a distinction in numerous cases. In at least one case, the Supreme Court, while finding the challenged statute to be constitutionally valid "on its face" and "as applied" to the named

\footnotetext{
Agostini at 226

Agostini, at 222. Mitchell, at 830 .

This distinction between direct and indirect aid was expressly made in School Dist. of Grand Rapids v. Ball 473 U.S. 373 (1985).

Mitchell at 816, citing to Agostini at 225.

Mitchell 817.

Mitchell 817

Mitchell at 831 , citing to Walker at $1468, n .18$

"There is, then, precedent in this area of constitutional law for distinguishing between the validity of the statute on its face and its validity in particular applications." Bowen v. Kendrick, 487 U.S. 589 (1988) at 602.

51 Bowen v. Kendrick, 487 U.S. 589 (1988) at 602.
} 
defendants, stated that, "[I]ndividual projects can be properly evaluated if and when challenges arise with respect to particular recipients and some evidence is then presented to show that the institution does in fact possess characteristics that make a grant of aid to the institution constitutionally impermissible" ${ }^{\prime \prime 2}$.

The "as applied" analysis requires that a court first determine whether or not the statute is facially valid, that is constitutional as it is written. If the Court determines that the statute is not facially valid, then the analysis stops, and the statute is unconstitutional. If the statute, however, is found to be constitutional on its face, a court must then determine whether in the particular instance and in terms of the particular defendants the statute is being applied in a constitutional manner.

This latter component is of particular import, particularly for issues emerging from the application of the Charitable Choice Provision. For reasons discussed below, most of the provisions of the Charitable Choice Provision probably would meet all facial challenges. The possibilities for significant violations of the both the Establishment and Free Exercise Clauses in terms of how the various contractors deliver their services are great, however.

Not only do the contractors serve vulnerable populations who often fear the loss of their services, but also new faith-based contractors entering the governmental system often lack the sophistication necessary to distinguish between activities that are allowable and those that are not ${ }^{53}$. Additionally, political factors that encourage greater use of religious service providers may increase the possibilities of constitutional violations. Political considerations create at least the possibility for bias in favor of such providers and open the door for a lack of oversight and accountability ${ }^{54}$.

Such was the result in the first case to reach trial involving a contract to religious service provider involving Temporary Assistance to Needy Families (TANF) funds under the welfare reform bill. Although analyzed in detail below, the decision of the federal district court declared that the manner in which the funds were distributed and the use to which they were put violated the establishment clause. The court in Gaylor v. McCallum did not address the issue (and indeed the plaintiffs did not raise the question) of the constitutionality of the Charitable Choice Provision. This did not, however, prevent the judge from determining that where there is inadequate attention paid to the use of governmental funds and no "effective means of guaranteeing that the state aid derived from public funds will be used exclusively for secular, neutral, and nonideological purposes, it is clear...that direct aid in whatever form is invalid"55. Obviously whether there exist such effective guarantees will be case specific and can only be determined in the various applications of the statute to particular defendants.

52 Bowen, at 601, citing to Tilton v. Richardson, 403 U.S. 672 (1971) at 682.

53 In Indiana for example of the nine faith-based contractors in the initial year of the state's implementation of the Charitable Choice provision only one had previously held a contract from the state. Personal communication to the author.

54 This was one of the issues that emerged in the case the Freedom From Religion Foundation brought against the state of Wisconsin in Freedom From Religion Foundation, Inc. v. McCallum, 179 F. Supp. 2 d 950 (W.D. Wis. 2002). In its decision the federal district court separated two different claims raised against the state of Wisconsin. In its initial decision the district court declared a state contract with an explicitly religious work readiness program, Faith Works, unconstitutional because the contract provided "unrestricted, direct funding of an organization that engages in religious indoctrination" at 954 (emphasis added) rather than indirect funding that followed and individual and was paid to Faith Works as a result of individual choice. It separated out the additional claim against the state's funding of Faith Works' drug and alcohol rehabilitation programming for prisoners because it needed further determination of the role of choice in the program. The district later rejected plaintiff's claim. On appeal, the federal appeals court rejected the Freedom from Religion Foundation's claim that such favoritism was built into the statute and declared nothing suggested otherwise. "There is no evidence that in recommending Faith Works a parole officer will be influenced by his own religious beliefs. His end is secular, the rehabilitation of a criminal, though the means include religion when the offender chooses Faith Works." The appeals court continued by emphasizing the role of choice in individuals' ability to select a service for which they are legally eligible." "Because the Supreme Court will not allow a public agency to force religion on people even if the agency honestly and indeed correctly believes that it is the best way of achieving a secular end that is within government's constitutional authority to promote, Lee v. Weisman, 505 U.S. 577, 587-89, 112 S. Ct. 2649, 120 L. Ed. 2 d 467 (1992), the state may not require offenders to enroll in Faith Works even if it is the best halfway house in Milwaukee for any or even all offenders. Kerr v. Farrey, 95 F.3d 472, 479-80 (7th Cir. 1996). The choice must be private, to provide insulating material between government and religion. It is private; it is the offender's choice." Freedom from Religion Foundation, Inc., et al., Plaintiffs-appellants, v. Scott Mccallum, et al., Defendants-appellees, and Faith Works Milwaukee, Inc., Intervening Defendant-appellee, 324 F.3d 880 (7th Cir. 2003).

55 Nyquist, 413 U.S. at 780 
While this case, Gaylor v. McCallum, expressly involved the question of a government contract with a religious provider, historically most of the cases decided by the Supreme Court that addressed the issue of governmental monies to religious organizations involved public schools. In fact, the United States Supreme Court has only heard two cases in its history dealing with governmental contracts with religious-based providers of social services, Bradfield v. Roberts, decided in 1899, and Bowen v. Kendrick, decided in 1988. The absence of such cases, given both the tremendous furor over governmental funding to religious schools and the immense amounts of funds that historically have flowed to faith-based providers of social and human services, remains somewhat surprising. While the explanation is not clear and one could attribute it to everything from the secularization of religious services, to strict governmental regulations, or to indifference, the fact remains that government contracting with faith-based providers of human and social services has engendered very little litigation of significance.

\subsection{Bradfield v. Roberts}

As discussed above, the case of Bradfield $v$. Roberts involved a contract let for the construction of an isolation wing in a hospital run by a Roman Catholic religious order and for reimbursement of the hospital for the costs (or a portion thereof) of its care for indigents. The hospital was located in Washington, D.C., and the contracting body was the United States Congress acting in its capacity as the District's legislative body.

Although charted as a private corporation, the hospital was wholly owned and controlled by the Sisters of Charity of Emmitsburg, Maryland. Its board of directors was comprised solely of members of the order and was self-perpetuating.

The Court described the case's history this way:

The plaintiff sued for an injunction barring the treasurer of the United States from paying the monies owed to the hospital under the contract. The plaintiff's contention being that the agreement if carried out would result in an appropriation by Congress of money to a religious society, thereby violating the constitutional provision which forbids Congress from passing any law respecting an establishment of religion ${ }^{56}$.

In its opinion the Court did not address the hospital's religious character. It simply looked at the hospital's articles of incorporation. The articles of incorporation simply showed the creation of a private corporation with appropriate rules and regulations that was designed to function as a hospital and which, as far as the record showed, did just that.

The Court expressly rejected the contention that the composition of its board, the nature of its governance, or its religious auspices could "change the legal character of the corporation or render it on that account a religious or sectarian body"57. The Court continued, even assuming that the plaintiff's contentions regarding the hospital were true, they would not,

in the least change the legal character of the hospital, or make a religious corporation out of a purely secular one as constituted by the law of its being. [Namely the articles of incorporation.] Whether the individuals who compose the corporation under its charter happen to be all Roman Catholic, or all Methodists, or all Presbyterians, or Unitarians, or members of any other religious organization, or of no organization at all, is of no consequence with reference to the law of its incorporation, nor can the religious beliefs upon religious matters of the various incorporators be inquired into. Nor is it material that the hospital may be conducted under the auspices of the Roman Catholic Church...The meaning of the allegation is that the Church exercises great and perhaps controlling influence over

56 Bradfield v. Roberts at 295.

57 Bradfield at 298. 
the management of the hospital. It must, however, be managed pursuant to the law of its being. That the influence of any particular church may be powerful over the members of a non-sectarian and secular corporation, incorporated for a certain defined purpose and with clearly stated powers, is surely not sufficient to convert such a corporation into a religious or sectarian body ${ }^{58}$.

Since the hospital as an incorporated entity was the creation of the State, and in this case the U.S. Congress, its existence and ultimate supervision and control were the sole responsibility "of the Government which created it" ${ }^{\prime \prime 5}$.

The Court concluded its discussion of the hospital's nature by rejecting summarily that the hospital could be anything different from what its articles of incorporation made it to be and by emphasizing the inappropriateness of any review of the religious views of those who comprised the corporation. "In respect then of its creation, organization, management and ownership of property it is an ordinary private corporation whose rights are determinable by the law of the land, and the religious opinions of whose members are not subjects of inquiry" ${ }^{\prime 60}$.

The Court ended its opinion by stating that Congress had the authority to act in the manner it did. It was within its powers to appropriate funds for the purpose of aiding the indigent ill and to authorize the Commissioners of the District of Columbia "to enter into a contract with the trustees of an incorporated hospital for the purposes mentioned in the agreement..."61

The Court in Bradfield took a formalistic approach to the question of (federal) government contracting with an organization that many could have viewed as religious in its nature. By starting with the assumption that the entity, the hospital, came into existence only through the articles of incorporation, the Court concluded that as an organization the hospital could only be what (and legally was only what) the articles made it. "All that can be said of the corporation itself is that it has been incorporated by an act of Congress, and for its legal powers and duties that act must be exclusively referred to." ${ }^{\prime 62}$. Anything outside of the four-corners of the articles of incorporation was beyond the Court's purview. If the statute of incorporation were itself violated in any way, then Congress had the power to correct any such abuses. That issue, however was completely separable from whether Congress (acting though the Commissioners) could contract with this hospital.

One interesting element of the decision is that in two separate places the Court stated that an inquiry into the religious beliefs of those who comprised the corporation would be inappropriate. Although not elaborated, the statements are fairly emphatic and stand in direct contrast to many later decisions where the religious nature and make-up of the organization proved determinative to the outcome of the case. Interestingly, although often ignored, Bradfield remains good law and was cited approvingly by the Court in its other case involving governmental contracting with religious social service providers.

\subsection{Bowen v. Kendrick}

Despite the admonitions in Bradfield, the religious nature of the organization did play a role in the other United States Supreme Court decision looking at governmental contracting with religious organizations. This case, Bowen v. Kendrick 487 U.S. $589(1988)^{63}$, involved a challenge to the Adolescent Family Life Act (AFLA) 24 U.S.C. Sect. 300z et seq. Adopted by Congress in 1981, the statute was designed to address the problems seemingly created by pregnancy and childbirth among unmarried adolescents. AFLA authorized the Secretary of Health and Human Services to contract with public

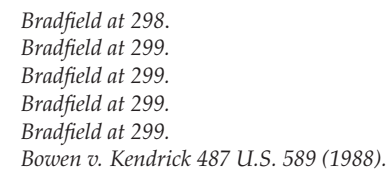


and nonprofit organizations to provide services and to undertake research in the areas of adolescent premarital sex and pregnancy. Among the specific areas targeted were the promotion of self-discipline and adoption of unwanted infants, the development of new means of delivering services to adolescents, as well as improving the means of communicating to adolescents the consequences of adolescent premarital sexual relations.

AFLA viewed the problem of adolescent premarital sexuality and its consequences as a serious and complex one, requiring the involvement of family, friends, and community organizations, including religious organizations as well as other charitable and voluntary associations ${ }^{64}$. It, therefore, required all applicants for funding to state how they would involve such organizations, including religious ones, in the provision of services ${ }^{65}$.

The statute also limited the services that could be provided by those eventually awarded contracts. Recipients could not provide family planning services unless there were no other providers of such services in the community (although they could make referrals) ${ }^{66}$. Organizations receiving funds under AFLA also were forbidden from providing abortion services or providing abortion counseling or referrals, except in response to a specific inquiry from the adolescent or her parents ${ }^{67}$.

In 1983 a suit was filed requesting declaratory and injunctive relief arguing that AFLA violated the Religion Clauses of the First Amendment both on its face and as applied. The District Court in a motion for summary judgment agreed with the plaintiffs, finding the statute invalid on its face and as applied "insofar as religious organizations are involved in carrying out the programs and purposes of the Act"68.

On appeal, the Supreme Court in its decision held that the Act was constitutional on its face but remanded it to the District Court for a factual determination as to whether it was valid as applied. In determining whether AFLA ran afoul of the Establishment Clause, the Court used the unmodified Lemon Test ${ }^{69}$. The Court began by asking whether the statute served a legitimate secular purpose and determined that reducing adolescent sexual activity and out-of-wedlock pregnancies were legitimate secular goals. Additionally, the Court stated that Congress' considered decision that a multi-faceted approach using community-based resources, including religious organizations, would be more successful in dealing with the problems also was an appropriate secular purpose. The Court then proceeded to reject expressly the contention that "Congress' 'actual purpose' in passing AFLA was one of 'endorsing religion'"'70.

That the purposes and goals of AFLA might coincide with the views and teachings of certain religious organizations did not bring AFLA into conflict with the Establishment Clause, a position the Court has held since at least $1890^{71}$. The Court concluded that it saw "no reason to conclude that AFLA served impermissible religious purposes simply because some of the goals of the statute coincide with the beliefs of certain religious organizations ${ }^{72}$. In so stating, the Court pointed to its decision in McGowan v. Maryland.

The "Establishment" Clause does not ban federal or state regulation of conduct whose reason or effect merely happens to coincide or harmonize with the tenets of some or all religions. In many instances, the Congress or state legislatures conclude that the general

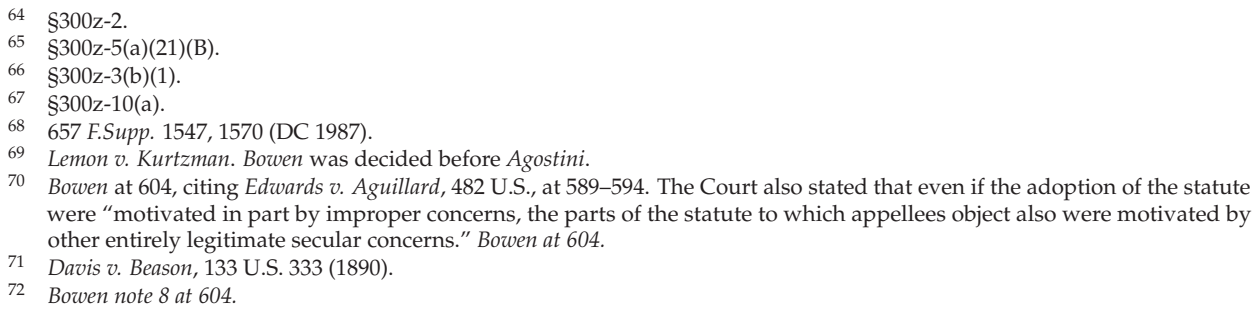


welfare of society, wholly apart from any religious considerations, demands such regulation. Thus, for temporal purposes, murder is illegal. And the fact that this agrees with the dictates of the Judaeo-Christian religions while it may disagree with others does not invalidate the regulation. So too with the questions of adultery and polygamy. The same could be said of theft, fraud, etc., because those offenses were also proscribed in the Decalogue ${ }^{73}$.

After a review of AFLA's statutory scheme, the Court concluded that there were two bases upon which one might conclude that AFLA were unconstitutional on its face. The first of these was that AFLA was unconstitutional because it expressly recognized "'that religious organizations have a role to play' in addressing the problems of teenage sexuality"74. Under this claim, even if no religious organizations received any funding, AFLA would be "invalid under the Establishment Clause because...it expressly enlists the involvement of religiously affiliated organizations in the federally subsidized programs, it endorses religious solutions to the problems addressed by the ACT, or it creates symbolic ties between church and state" ${ }^{\prime 75}$.

The Court dismissed this contention. Although AFLA mentions religious organizations in four places, speaking of the need for a variety of service providers to address the problem and requiring grantees to state how they will incorporate religious organizations into the services they will provide, the Court declared that, "these provisions of the statute reflect at most Congress' considered judgment that religious organizations can help solve the problem to which the AFLA is addressed"76.

The decision goes on to state that the Supreme Court has never said that Congress was prevented from "making such a judgment or from recognizing the important part that religion or religious organizations may play in resolving certain secular problems"77. Congress is free to make such determinations, especially in dealing with problems where the solutions involve family ties and family values. In such situations it is "sensible for Congress to recognize that religious organizations" have a role to play ${ }^{78}$. If such Congressional recognition has "any effect of advancing religion, the effect is at most 'incidental and remote'"79.

Although AFLA requires grantees to discuss how they would integrate religious organizations into their service provision, this requirement has a broader context. It also requires grantees to discuss how they integrate numerous types of organizations, including "charitable organizations, voluntary associations, and other groups in the private sector" into this work ${ }^{80}$.

The broad reach established by this provision, the Court concluded, reflected its successful "maintenance of 'a course of neutrality among religions, and between religion and nonreligion." 81 . This neutrality, neither favoring or disfavoring religion, meant that the requirement that religious providers be included was not an exception for religion, but merely a provision that maintained a balance between various organizations of all religious stripes and non-religious that might be able to aid the government in solving a serious secular problem.

The second basis the Court saw for challenging AFLA was that it allowed "religious institutions to participate as recipients of federal funds" ${ }^{82}$. In rejecting such an overarching challenge, the Court reviewed the history of its decisions (mostly involving religiously-affiliated private schools) where it had allowed religious institutions to receive such funds ${ }^{83}$. Additionally, the Court expressly noted that

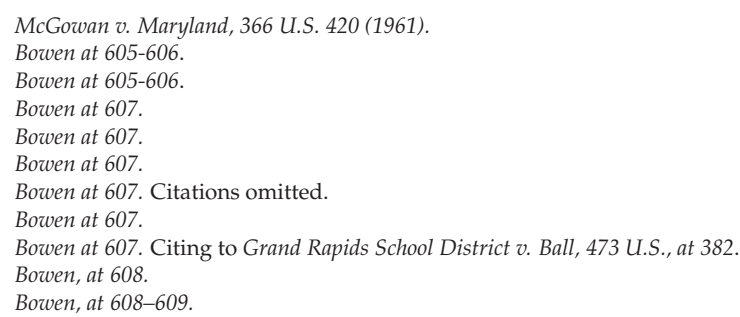


it had "never held that religious institutions are disabled by the First Amendment from participating in publicly sponsored social welfare programs" 84 . Citing Bradfield v. Roberts approvingly, the Court stated that, "the giving of federal aid to the hospital was entirely consistent with the Establishment Clause, and the fact that the hospital was religiously affiliated was 'wholly immaterial"'85. The Court in Bowen continued:

The propriety of this holding, and the long history of cooperation and interdependency between governments and charitable or religious organizations is reflected in the legislative history of the AFLA. (Charitable organizations with religious affiliations historically have provided social services with the support of their communities and without controversy ${ }^{86}$.

The one possible exception to this approval of providing funds to religious organizations to meet governmental purposes has involved monies flowing to "pervasively sectarian" organizations. The Court has understood pervasively sectarian organizations to be those in which religion is so predominant that it is impossible (or nearly so) to separate the religious component from any of the organization's undertakings ${ }^{87}$. The concern is that when an organization is pervasively sectarian, where religion consciously and intentionally pervades every element of the organization's activities, even governmental monies directed toward and used for "specific secular purposes, may nonetheless advance the pervasively sectarian institution's 'religious mission'" ${ }^{\prime \prime}$.

The "pervasively sectarian" factor has traditionally dominated the Court's deliberations in cases related to governmental monies flowing to religiously affiliated schools. This has been true because historically religious schools not only reflect the teachings of particular traditions, but instruct in those teachings, and are dominated by members of the particular faith; they primarily exist to create a uniform religious environment that pervades the organization and everything that it does.

Unlike the Court's rejection of an inquiry into religious beliefs in Bradfield, the pervasively sectarian standard historically began with "a consideration of the nature of the institutions in which the [governmentally funded] programs operate" ${ }^{\prime 89}$. If the institutions in question are pervasively sectarian, the next step involves the determination whether and to what degree the challenged statute or program directs funds to those institutions.

Where the statute in question has (as was the case of AFLA) "facially neutral grant requirements" and a wide spectrum of potential grant recipients, including many religious ones which would not be considered pervasively sectarian, then, the decision stated, there is no basis for challenging the statute on its face. The mere possibility that "grants may go to religious institutions that can be considered "pervasively sectarian'" is not "sufficient to conclude that no grants whatsoever can be given under the statute to religious organizations" $" 90$

In such an instance, the Court will uphold the statute on its face and as applied to religious organizations that are not pervasively sectarian. It will, however, leave open the question of "the consequences that would ensue if they allowed federal aid to go to institutions that were in fact pervasively sectarian" ${ }^{\prime 91}$. This means that in examining a statute as applied, the Court looks at the specific context, including a detailed analysis of the religious nature of the organization receiving the funds. This is a far cry from the formalistic standard of Bradfield.

In continuing to apply the "effects" prong of Lemon to AFLA, the Court also analyzed two elements particularly relevant to Charitable Choice. These are the role of religious organizations in

84 Bowen, at 609.

55 Bowen, at 609.

86 Bowen, at 609 .

87 See Hunt, 413 U.S. 734 at 743. "Aid may be normally thought to have a primary effect of advancing religion when it flows to an institution in which religion pervasive that a substantial portion of its functions are subsumed in the religious mission." 88 Bowen at 610.

89 Grand Rapids School District v. Ball, 473 U.S. 373 (1985) at 384.

90 Bowen at 611.

91 Bowen at 611 
providing educational and counseling services and, more specifically, "teaching by religious grant recipients on matters fundamental to religious doctrine" ${ }^{\prime \prime 2}$.

In rejecting the claim that any funds that support teaching by religious organizations renders the statute unconstitutional, the Court began by declaring what was not allowable. Any situation resulting in "government financed or government-sponsored indoctrination into the beliefs of a particular religious faith" 93 or leading to "an unacceptable risk that government funding would be used to 'advance the religious mission' of the religious institution receiving aid"94 is prohibited by the Establishment Clause. The Court rejected the District Court's presumption that religious organizations would not follow their statutory and constitutional duties in delivering the services. The Court expressly stated just the opposite. "In contrast, when the aid is to flow to religiously affiliated institutions that were not pervasively sectarian, as in Roemer, we refused to presume that it would be used in a way that would have the primary effect of advancing religion"95. The mere fact that under some circumstances there might be some inappropriate uses of the funds is an insufficient reason for the Court to declare a statute facially invalid ${ }^{96}$.

The Court also rejected the claim that AFLA's authorization of grantees to teach about matters that are central to many religious traditions rendered the statute unconstitutional. In matters of such importance as teenage sexuality, any policy decisions by Congress would coincide or conflict with some religious teachings. That fact, according to the Court, is insufficient to conclude that the act either advances or inhibits religion ${ }^{97}$. Even if the goals of AFLA were to coincide with the religious teachings of some of the grantees, this would not mean that the act crossed the line into funding religious activities "in an otherwise substantially secular setting" 98 .

AFLA, as the Court determined initially, served a legitimate secular purpose. The services it funded were designed to further that purpose. By definition, the Court concluded, such secular purposes are not "specifically religious activities," and neither are they "converted into such activities by the fact that they are carried out by organizations with religious affiliations"

Finally, the Court rejected the argument that by involving and even funding religious organizations in the delivery of services, the statute created an impermissible "symbolic link" between government and religion. While acknowledging in passing the possibility that there may be occasions where such a link might be sufficiently strong to warrant striking a statute, this instance was not one of them. Somewhat derisively the Court dismissed this part of the District Court's decision highlighting the troubling reality such a doctrine would entail.

If we were to adopt the District Court's reasoning, it could be argued that any time a government aid program provides funding to religious organizations in an area in which the organization also has an interest, an impermissible "symbolic link" could be created, no matter whether the aid was to be used solely for secular purposes. This would jeopardize government aid to religiously affiliated hospitals, for example, on the ground that patients would perceive a "symbolic link" between the hospital-part of whose religious mission might be to save lives-and whatever government entity is subsidizing the purely secular medical services provided to the patient...[I]n this litigation, whatever "symbolic link"

92 Bowen at 612. Citations and internal quotation marks omitted.

93 Bowen at 611. Citing to Grand Rapids at 385.

94 Bowen at 611. Citing to Grand Rapids at 385. Citing to Meek at 370.

95 Bowen, at 612.

96 "It has not been the Court's practice, in considering facial challenges to statutes of this kind, to strike them down in anticipation that particular applications may result in the unconstitutional use of funds." Ibid. citing to Roemer at 761.

97 Bowen, at 613.

98 Bowen, at 613. Citing to Hunt, at 743.

99 Bowen, at 613. In this phrase one can catch again the Court's difference from Bradfield. In that the decision, the functional-religious nature and structure of the organization did not change its legal character. Here the religious nature of the organizations does not alter the character of the services. 
might in fact be created by the AFLA's disbursement of funds to religious institutions is not sufficient to justify striking down the statute on its face ${ }^{100}$.

Since AFLA had a legitimate secular purpose and, in its primary effect, neither advanced nor inhibited religion the Court concluded that the statute did not violate the Establishment Clause on its face $^{101}$. It then turned to the question of whether AFLA was valid as applied.

After chiding the District Court both for its approach to assessing whether the statute violated the Establishment Clause as applied and for its over-reaching remedy, the Supreme Court remanded the case for a hearing on whether the statute had been applied in an unconstitutional manner ${ }^{102}$. In doing so, the Court offered some guidelines for the District Court to follow in making that determination as well as in crafting a remedy for any violations.

The Supreme Court stated that the District Court must determine whether government monies had been:

provided to "pervasively sectarian" religious organizations

or

used to "fund specifically religious activities in an otherwise substantially secular setting"103.

If the District Court were to determine that a grant had been given to a pervasively sectarian institution or that funds had been used for explicitly religious activities, thereby running afoul of the Establishment Clause, or if any grantee had violated the strictures or rules promulgated to ensure compliance with the Constitution, the appropriate remedy would be to withdraw the grant from the particular grantee ${ }^{104}$. It is not an appropriate remedy to declare a statute unconstitutional under such circumstances $^{105}$.

\section{The Constitutionality of the "Charitable Choice" Provision}

Bowen deserved such extensive analysis because the standards are the ones likely to be applied to all legal challenges to "Charitable Choice." Given the manner in which the provision was crafted and the purposes of the services funded by TANF monies, there is little likelihood that the statute overall would be found to be facially unconstitutional. One can draw this conclusion for the following reasons. The law serves a secular governmental purpose: the delivery of training to persons receiving TANF monies in order to prepare them for the workforce. As written, the provision simply appears to ensure

100 Bowen, at 613-614.

101 Bowen, at 617. Since this decision was written under the unmodified Lemon Test, the Court also examined the degree to which AFLA created an excessive entanglement. In just a few lines the Court rejected an entanglement claim. Since, as it had previously determined, most of the religious organizations receiving funds under AFLA would not be "pervasively sectarian" the amount of monitoring necessary to ensure compliance would be insufficient "to intrude unduly in the day-to-day operation of the religiously affiliated grantees." Bowen, at 616. Under the Agostini modification of the Lemon Test, this analysis would occur under the "primary effect" prong. There the result would have been the same.

102 Bowen, at 621.

103 Bowen, at 621 .

104 Bowen, at 621-22.

105 In an earlier part of the decision, the Court left open the possibility that statute might be so lacking in both express measures designed to ensure compliance with the Constitution and expressions of legislative intent that such compliance take place that it might be facially invalid. In fact, one could argue that a complete absence of such intent might mean the statute would fail the "secular purpose" prong of the Lemon test. The mere absence of "an express provision preventing the use of federal funds for religious purposes" is inadequate to reach that level, however. Bowen, at 614. While such a provision would be welcome and make it easier to conclude that a statute did not have the primary effect of advancing religion, it is not constitutionally required. Where, as in the case of AFLA, there is no intimation that religious uses are permitted and the legislative record itself suggested an absence of any religious intent, such facts are sufficiently adequate to conclude the statute neither had a goal other than a secular nor the goal of advancing religion. This conclusion can be buttressed by the regulations controlling the grant and the requirements placed on the grantees by the appropriate federal agencies. Ibid, at 614-15. 
that religious service providers are included in the universe of potential contractors for the delivery of those services. Religious providers are given no priority in the statute. The universe of the potential providers, both religious and non-religious, is huge. It therefore appears impossible for "pervasively sectarian" providers to dominate. Finally, the statute (unlike AFLA) contains provisions forbidding the use of funds for any express religious purposes.

If "Charitable Choice" overall seems to be valid on its face, there remains the problem of its application in specific circumstances and in the activities of certain religious or faith-based contractors. As mentioned above, the first legal challenge to contracts let under the provision to reach trial was solely as an applied challenge. The plaintiffs did not challenge the provision's constitutionality, only its application. The district court's analysis of this challenge deserves attention. It must await, however, an examination of one other issue - the plurality's decision in Mitchell v. Helms and a discussion of whether that decision has altered in major ways, the U.S. Supreme Court's Establishment Clause jurisprudence.

\section{The Strange Case of the Plurality Decision in Mitchell v. Helms ${ }^{106}$}

The plurality opinion written by Mr. Justice Thomas in Mitchell v. Helms presents some powerful challenges to an analysis of the current status of Establishment Clause jurisprudence. In many ways the decision clarifies and explains how to apply the modified Lemon Test as articulated in Agostini v. Felton. Additionally, by expressly declaring that the decisions rendered in Meek v. Pittenger ${ }^{107}$ and Wolman $v$. Walter ${ }^{108}$ to be no longer good law ${ }^{109}$, the Supreme Court removed what many had viewed as serious conflicts between those decisions and the Court's later decisions in Agostini and Zobrest v. Catalina Foothills School Dist ${ }^{110}$, as well as dicta (passing statements in a written decision with no precedential weight) -in Board of Ed. of Kiryas Joel Village School Dist. v. Grumet ${ }^{111}$.

Mitchell v. Helms involved a challenge to Chapter 2 of the Education Consolidation and Improvement Act of $1981^{112}$. The act provided federal funds to local agencies for programs assisting elementary and secondary school children. Among the activities allowed under Chapter 2 of the statute was the purchase "of instructional and educational materials, including library services and materials (including media materials), assessments, reference materials, computer hardware and software for instructional use, and other curricular materials"113.

These materials were to be provided to both public and nonprofit, private schools. The monies provided to any private schools were to be allocated on a basis equal to those allocated to public schools, on a per capita basis. The funds used for materials provided to private schools were to be allocated in such a way that they only supplemented the private schools' budgets and did not "supplant funds from non-Federal sources"114.

Numerous restrictions were placed on how the materials supplied to the private schools could be used. First, all the materials and equipment had to be "secular, neutral, and non-ideological"115. Additionally, the schools themselves never took title to the materials. They remained titled to the local education agency empowered to operate the program. The latter simply loaned the materials to the schools.

The district court found the program to be unconstitutional, in having a primary effect of advancing religion. It issued a permanent injunction barring the loan of equipment to pervasively

\footnotetext{
106 Mitchell v. Helms, 530 U.S. 793 (2000).

107 Meek v. Pittenger, 421 U.S. 349 (1975).

108 Wolman v. Walter, 433 U.S. 229 (1977).

109 Mitchell, at 808.

110 Zobrest v. Catalina Foothills School District, 509 U.S. 1 (1993)

111 Board of Ed. of Kiryas Joel Village School Dist. v. Grumet, 512 U.S. 687 (1994).

112 Education Consolidation and Improvement Act of 1981, 20 U.S.C. $\$ \S 7301-7373$.

11320 U.S.C. $\S 7351(b)(2)$.

$114 \S 7371(b)$

115 §7372(a)(1).
} 
sectarian schools. The Fifth Circuit upheld the ruling of the district court on the bases of Meek and Wolman, noting that while the Supreme Court's later decisions appeared to conflict with the former decisions the Supreme Court had not explicitly over-ruled either Meek or Wolman.

While commending the Fifth Circuit for its restraint, the Supreme Court proceeded to reverse the decision and in doing so expressly overruled Meek and Wolman. The Court based its decision on the modified Lemon Test as developed in Agostini. While the overall rationale for the Court's ruling is unimportant for this discussion, several elements in the plurality's decision are potentially of the utmost importance for future discussions of federal funding to religious organizations.

That said, the fact that the opinion of Mr. Justice Thomas commanded only a plurality of the Court $^{116}$ and that the concurring opinion by Madame Justice $\mathrm{O}^{\prime}$ Connor ${ }^{117}$ disagreed in numerous places with the plurality's rationale raises questions about the applicability of the decision to future cases. With that caveat in mind, it is important to examine three elements of the decision. These are the plurality's rejection of the "pervasively sectarian" standard, the shift from examining whether the aid provided to religious organizations is direct or indirect to whether the funds flow as a result of individual choices, and, finally, the dismissal of the diversion of the aid as a constitutional problem.

The plurality opinion's express rejection of the "pervasively sectarian" standard undoubtedly has the potential for the most far-reaching impact. In a long line of cases, focusing primarily on private, religious schools, whether a recipient of governmental funds was pervasively sectarian could determine a case's outcome. Given the difficulty in the Court's view of preventing governmental support from being used to further the religious mission of pervasively sectarian institutions, the extent to which a program supplied funds to such institutions readily could be outcome determinative on both facial and as applied grounds. Indeed this was the basis for the Court's decision in both Meek and Wolman.

In rejecting the analytical category of pervasively sectarian organizations, the decision in Mitchell began by pointing to its decreasing role in the Court's decisions. By the time of the Court's decisions in Zobrest and Agostini, the decision argued, the determinative nature of this category of organizations had been diminished to nothing. Zobrest, the opinion pointed out, disregarded the fact that the funds went to a pervasively sectarian institution and focused instead on the importance of private choice and the absence of any government-funded religious content. In Agostini, according to the plurality, the majority decision "did not bother to mention that pervasively sectarian schools were at issue"118.

Beyond its declining significance in the Court's Establishment Clause jurisprudence, the plurality claimed that the "pervasively sectarian" factor should be dispensed for more substantive reasons as well. On a fundamental level, it is irrelevant. "The religious nature of a recipient should not matter to the constitutional analysis, so long as the recipient adequately furthers the government's secular purpose"119. If the government offers "permissible aid" to all who can deliver a service adequately, "the religious (including the pervasively sectarian), the areligious, and the irreligious, it is a mystery which view of religion the government has established, and thus a mystery what the constitutional violation would be"120. Under such circumstances the pervasively sectarian institution has received no special benefit and by singling out those institutions for exclusion, the result is a "special hostility" reserved "for those who take their religion seriously, who think that their religion should affect the whole of their lives, or who make the mistake of being effective in transmitting their views to children"121.

Not only is it unnecessary to inquire into the depth and nature of a recipient's religious views, it is, the plurality declared, offensive. The Court pointed out that it has been well established in

\footnotetext{
116 The opinion written by Mr. Justice Thomas was joined by Mr. Chief Justice Rehnquist, and Messrs. Justices Scalia and Kennedy.

117 Madame Justice O'Connor was joined in her opinion by Mr. Justice Breyer.

118 Mitchell, at 827.

119 Mitchell, at 827.

120 Mitchell, at 827.

121 Mitchell, at 827-28.
} 
"other contexts, that courts should refrain from trolling through a person's or institution's religious beliefs"122. Such trolling, however, is required to determine whether an institution is pervasively sectarian. Not only is this troubling on its own, but also it runs against the settled principle prohibiting "governments from discriminating in the distribution of public benefits based on religious status or sincerity"123. The government, including the courts, cannot prevent an institution, otherwise qualified, from participating in a widely available program simply because it or its members hold their religious beliefs strongly and fervently. Religion is not to be disfavored.

Finally, the Court claims that the hostility to aiding pervasively sectarian institutions "has a shameful pedigree that we do not hesitate to disavow"124. Born amidst the anti-Catholic bias of the late nineteenth century as reflected in the history of the so,-called "Blaine amendments," it was an open secret that "sectarian" was a code for "Catholic"125.

Although "sectarian" could be used for organizations established by any religious body, the Court, according to the plurality, eliminated this potential use by adopting the phrase, "pervasively sectarian." This term, according to Mr. Justice Thomas, "could be applied almost exclusively to Catholic parochial schools and which even today's dissent exemplifies chiefly by reference to such schools"126.

In concluding its discussion of the pervasively sectarian category of institutions, the opinion states that the Establishment Clause does not require the exclusion of pervasively sectarian institutions from otherwise constitutional aid programs. Additionally, other Constitutional principles forbid such exclusions. For these compelling reasons, the opinion declares, "This doctrine [no funds to pervasively sectarian institutions], born of bigotry, should be buried now"127.

If Mitchell signaled the end of the pervasively sectarian factor, it also may have reflected, a major shift in the Court's Establishment Clause jurisprudence, signifying a turn to a pure neutrality standard that gives no consideration to the nature of the institution receiving governmental monies ${ }^{128}$. Despite Mr. Justice Thomas's suggestion that the end of the pervasively sectarian standard is nothing more than a return to the positions adopted in Everson v. Board of Education and Board of Education v. Allen ${ }^{129}$ and, one might add, Bradfield as well, the rejection of the pervasively sectarian standard eliminates what many understood to be a settled legal principle.

If Mitchell signified an end to the "pervasively sectarian" factor as part of Establishment Clause jurisprudence, its rejection of the "no divertability" rule potentially constricts greatly both the number and kinds of challenges that could be brought against programs that provide governmental funds to religious institutions.

For the Court, the ability of an organization to use support-whether funds, equipment, or training-for religious purposes does not reach the Constitution. "The evidence of actual diversion and the weakness of the safeguards against actual diversion are not relevant to the constitutional inquiry, whatever relevance they may have under the statute and regulations" ${ }^{\prime 130}$.

In rejecting the "no divertability" rule the decision expressly stated that where the aid provided by the government is religious in nature it is impermissible under the Constitution. It continues, however, arguing that where the "aid is not itself unsuitable...because of religious content, and eligibility for aid

\footnotetext{
122 Mitchell, at 827-28.

123 Mitchell, at 827-28.

124 Mitchell, at 827-28. While the Court's decision in this case speaks directly to aid to schools given the fact that historically aid to schools has had to meet a higher standard than aid to other institutions, the argument should hold across the board.

125 Mitchell, at 827-28.

126 Mitchell, at 829.

127 Mitchell, at 829.

128 For a favorable discussion of the neutrality standard see [29]. For a critique see [30].

129 Board of Education v. Allen 392 U.S. 236.

130 Mitchell, at 834.
} 
is determined in a constitutionally permissible manner, any use of that aid to indoctrinate cannot be attributed to the government and is thus not of constitutional concern"131.

Finally, Mitchell (as discussed earlier), signifies an express shift from the Court's use of direct versus indirect aid as a touchstone for the constitutionality of programs that fund religious organizations. Dismissing as irrelevant formalisms the distinction between monies or materials provided to individuals who then give them to religious institutions and those given directly to the institutions on behalf of the individuals ${ }^{132}$, the Court went on to conclude that "private choice and neutrality resolve the concerns formerly addressed by the [indirect/direct aid] rule"133.

Following Mitchell, there seems to be little left of traditional Establishment Clause jurisprudence except for two elements. Government cannot directly expend funds for programs with religious content and government funds cannot intentionally be designed to further (or hinder) religious ends. Additionally, while the misallocation of the monies for religious purposes can lead to sanctions, there mere fact that the monies can be diverted to such purposes does not in and of itself render a statute unconstitutional.

\section{Conclusions}

This article sought to provide the relevant historical and legal background necessary to any informed and reasonable discussion of government contracting with faith-based organizations. The inclusion of the "Charitable Choice" provision in the 1996 welfare reform bill brought to the fore an issue that many had ignored, namely the fact of such contracting, its magnitude, and its long history. The ignorance of that history led many to view "Charitable Choice" as a novelty. While it may have been, its novelty lay not in in opening up faith-based organizations to government contracting but mostly in requiring states to allow them to participate equally.

A more important question involved the constitutionality of such contracts. What if anything were the limits?

A complicating element in the discussion was that "Charitable Choice" was adopted during a fairly unsettled time in establishment clause jurisprudence. Seemingly settled issues were being undone and clarity was lacking.

When combined with the aggressiveness of the proponents of faith-based social services, many feared that we were facing a monster of governmentally funded religious indoctrination and coercion. The monster, however, seems to be relatively meek. Despite the shifting nature of establishment clause jurisprudence, several elements seem solid. Governments may not directly fund any services that have an explicit religious content. When a government identifies a wide variety of providers from which an individual entitled to that service may choose, the fact that a particular provider may have an express religious component is irrelevant. The individual's choice is essential. In such instances the government may pay the provider directly. Finally, the government cannot act in a manner that coerces or forces an individual to use a provider with express religious content.

The biggest change seems to be that constitutional determinations now focus overwhelmingly on the element of individual choice in selecting a service and determining that the choice is real. The nature of the organization, whether or not it is "pervasively sectarian" has become irrelevant. What an organization does, not what it is, matters, along with the individual's freedom to choose what it does (and how).

131 Mitchell, at 821. This does not mean that there would be no consequences for doing so. As the Court stated in the appropriate response would be revocation of the contract. Just as fraud or misappropriation of a military contract can be corrected through non-constitutional means, so can a contract with a faith-based service provider. The mere fact that such a provider illegitimately may use the funds to promote religion is no more imputable to the government than is the theft or misappropriation of monies is imputable to the government in a military contract.

132 Mitchell, at 817.

133 Mitchell, at 816. 
While fears about the consequences of "Charitable Choice" and its offspring seem to have been unfounded, there has been a substantial positive result in the field of scholarship. Many have been led to a greater attention to the role that faith-based organizations play in the delivery of services, their place in the ecology of government contracting, and, more broadly, the role of religion and religious belief in civil society. Such explorations were overdue.

Conflicts of Interest: The authors declare no conflict of interest.

\section{References and Notes}

1. "Executive Order 13199-Establishment of White House Office of Faith-Based and Community Initiatives." Available online: http:/ / www.presidency.ucsb.edu/ws/?pid=61481 (accessed on 21 March 2016).

2. Carl Esbeck (at that time Director, Center for Law \& Religious Freedom (CLRF) Springfield, Virginia). Personal communication, 16 May 2001.

3. The web site of the White House of Faith-Based and Community Initiatives. Available online: http://www.ed.gov/offices/OIIA/pfie/whoweare/faithbased.html (accessed on 20 March 2002). This site currently is removed and there does not seem to be an archived version available.

4. Sheila Suess Kennedy, and Wofgang Bielfeld. Charitable Choice at Work: Evaluating Faith-Based Job Programs in the States. Washington: Georgetown University Press, 2006.

5. Leonard W. Levy. The Establishment Clause: Religion and the First Amendment. New York: Macmillan, 1986.

6. Kent Greenawalt. Religion and the Constitution: Vol. 2. Establishment and Fairness. Princeton: Princeton University Press, 2008.

7. Wolfgang Bielefeld, and William Suhs Cleveland. "Defining Faith-Based Organizations and Understanding Them through Research." Nonprofit and Voluntary Sector Quarterly 42 (2013): 442-67. [CrossRef]

8. Steven Rathgeb Smith, and Michael Lipsky. Non Profits for Hire: The Welfare State in the Age of Contracting. Cambridge: Harvard University Press, 1993.

9. Martha Minow. "Partners, Not Rivals: Redrawing the Lines between Public and Private, Non-Profit and Profit, and Secular and Religious." Boston University Law Review 80 (2000): 1061-94.

10. Lester M. Salamon. "Partners in Public Service: The Scope and Theory of Government Nonprofit Relations." In The Nonprofit Sector: A Research Handbook. Edited by Walter W. Powell. New Haven: Yale University Press, 1987, p. 100.

11. Lester M. Salamon, and Lester M. Salamon. Partners in Public Service: Government Nonprofit Relations in the Modern Welfare State. Baltimore: Johns Hopkins University Press, 1995.

12. John S. Whitehead. The Separation of College and State: Columbia, Dartmouth, Harvard, and Yale, 1776-1876. New Haven: Yale University Press, 1973.

13. Marvin Olasky. The Tragedy of American Compassion. Washington: Regnery Gateway, 1992, p. 14.

14. Ralph Kramer. Voluntary Agencies in the Welfare State. Berkeley: University of California Press, 1981, p. 61.

15. Frank Fetter. "The Subsidizing of Private Charities." American Journal of Sociology 7 (1901-1902): 359-85. [CrossRef]

16. Robert Bremner. The Public Good: Philanthropy and Welfare in the Civil War Era. New York: Alfred A. Knopf, 1980, p. 87.

17. Diane Winston. Red-Hot and Righteous: The Urban Religion of the Salvation Army. Cambridge: Harvard University Press, 1999, pp. 136-37 and passim.

18. Amos Warner. American Charities. New York: Thomas Y. Crowell, 1908, pp. 409, 413.

19. Bernard J. Coughlin. Church and State in Social Welfare. New York: Columbia University Press, 1965, p. 46.

20. J. Bruce Nichols. The Uneasy Alliance: Religion, Refugee Work, and U.S. Foreign Policy. New York: Oxford University Press, 1988.

21. R. Pierce Beaver. Church and State, and the American Indians. St. Louis: Concordia, 1966.

22. Charles C. Coffin. The Boys of '61 or, Four Years of Fighting. Boston: Estes and Lauriat, 1880, p. 373.

23. Edward L. Queen, II. In the South the Baptists Are the Center of Gravity: Southern Baptists and Social Change, 1930-1980. Lehi: Carlson Publishing, 1991, p. 106ff.

24. Lester Salamon. "The Marketization of Welfare: Changing Nonprofit and For-profit Roles in the American Welfare State." Social Service Review 67 (1993): 16-39. [CrossRef] 
25. John McCarthy, and Kim Castelli. Religion-Sponsored Social Service Providers: The Not-So-Independent Sector. Working Paper Series. Washington: The Aspen Institute, 1998.

26. "Forbes Magazine's 2015 list of the 50 largest U.S." Available online: http:/ /www.forbes.com/top-charities / list/\#tab:rank (accessed on 14 March 2016).

27. Stephen Monsma. When Sacred and Secular Mix: Religious Nonprofit Organizations and Public Money. Lanham: Rowman \& Littlefield, 1996, p. 68.

28. Kenneth Craycraft. The American Myth of Religious Freedom. Dallas: Spence Publishers, 1999.

29. Carl A. Esbeck. "A Constitutional Case for Governmental Cooperation with Faith-Based Social Service Providers." Emory Law Journal 46 (1997): Article 1.

30. Alan E. Brownstein. "Interpreting the Religion Clauses in Terms of Liberty, Equality, and Free Speech Values-A Critical Analysis of 'Neutrality Theory' and Charitable Choice." Notre Dame Journal of Law Ethics E Public Policy 13 (1999): Article 243.

(C) 2017 by the author; licensee MDPI, Basel, Switzerland. This article is an open access article distributed under the terms and conditions of the Creative Commons Attribution (CC BY) license (http:/ / creativecommons.org/licenses/by/4.0/). 


\title{
The Intersectionality of Religion and Social Welfare: Historical Development of Richmond's Nonprofit Health and Human Services
}

\author{
F. Ellen Netting ${ }^{1, *}$ and Mary Katherine $\mathrm{O}^{\prime}$ Connor ${ }^{2}$ \\ 1 School of Social Work, Virginia Commonwealth University, 9534 Oldhouse Drive, Richmond, VA 23238, USA \\ 2 School of Social Work, Virginia Commonwealth University, 2956 Hathaway Road, \#706, Richmond, \\ VA 23225, USA; mkoconno@vcu.edu \\ * Correspondence: enetting@vcu.edu; Tel.: +1-804-747-5477
}

Academic Editor: Robert Wineburg

Received: 27 November 2015; Accepted: 14 January 2016; Published: 21 January 2016

\begin{abstract}
Studying the intersectionality of religion and social welfare in Richmond, Virginia requires going back to the beginning of the Virginia colony. In the crucible of the colony, the religious and social welfare functions of a parish community were one and the same. However, after the Revolutionary War it was just a matter of time before the entire system was disassembled. The process of disentanglement of church and state created an identity crisis in Virginia. In the late 1700s, the emergence of charitable efforts began with leading men of Richmond who tried to address the temporary needs of travelers, followed by groups of women who discovered new roles they could play through charitable works. The new "system" became a potpourri of societies, congregations, associations, and county units attempting to provide for the social welfare of the populous. The intersectionality of religion and social welfare continued as a diverse landscape of small and large organizations and congregations performing the social welfare functions in Richmond and throughout the Commonwealth emerged. Today, to attempt to separate the church from the state in this conglomerate of agencies is neither possible nor desirable. However, understanding its' historical complexity is essential if one is to engage in contemporary practice within Richmond's health and human service system.
\end{abstract}

Keywords: faith-based; social service; history; church-state

\section{Introduction}

Over the last two decades we have been engaged in historical research about the establishment and development of Richmond, Virginia's nonprofit health and human service system. To call it a system assumes that something systematic occurred or that there was a master plan. In fact, after the American Revolution and with the disestablishment of the parish vestry system in the late 1700s [1], Richmond's charitable and public relief organizations were independently founded in response to various human needs as they arose [2]. This somewhat random proliferation of social welfare societies, associations, and asylums continued well into the next two centuries.

We began our research at the Valentine History Center archives where we located City Directories published in the 1800s and in which Richmond's societies, associations, asylums and charitable agencies were listed. We discovered that the names of board members often accompanied these lists and were surprised to find that the vast majority of these organizations had all "lady boards" in addition to male boards of corporators. Our surprise was not that women were involved in the creation and management of these organizations, but that they were running the majority of these organizations well before women had property or voting rights. We became intrigued with the "lady board" concept 
that had not appeared in the nonprofit literature and had essentially been erased from history. For a full exploration of women's roles on lady boards, we refer the reader to our earlier writings on the subject [3,4]. We were particularly interested in those health and human service organizations that had survived for over a century because we assumed that their histories would hold clues to nonprofit capacity building and sustainability. And, thus, another surprise was finding 24 centenarian health and human service type agencies that had been in continuous operation in Richmond in some form for over 100 years. It is important to recognize that in order to survive, these organizations had altered their structures (sometimes many times) to ride the waves of change. For example, clinics morphed into hospitals, some eventually becoming part of for-profit chains; orphanages diversified into family service organizations; old age homes merged into large continuing care retirement communities, and so forth. We assume that those that did not change with the times were the ones that disappeared from the social welfare landscape. We studied the 24 surviving centenarian organizations in terms of their identity construction and early cultures [5], their capacity building strategies [6], and their fundraising methods [7].

The purpose of this paper is to explore the importance of the religious community in the founding, governing, and ongoing development of the social welfare system in early Richmond. Whereas, our previous studies focused on the 24 health and human service organizations that can trace their genealogy back at least 100 years, here we also refer to a few societies, associations, asylums, and other relief agencies founded in the late 1700s and throughout the 1800s that are no longer part of Richmond's landscape. The organizations of interest for this paper and their combined story reflect the intersectionality of religion and social welfare in one southern city and has important implications for understanding and contextualizing Richmond's social welfare system today.

Our database consists of secondary references and hundreds of primary documents. Secondary sources include the works of feminist historians who have focused on Virginia [8,9] and Richmond specifically [2,10], as well as various women's societies and associations [11-14]. Several theses provide studies of Richmond agencies [15-19], along with agency histories [20-23], and histories of religious communities in Virginia [24-28].

Primary documents were located at the Valentine History Center, the Virginia Historical Society, the Richmond public library, Virginia Commonwealth University's archival collections, and in church and synagogue archives. Agency reports, newspaper clippings, minutes of boards, correspondence, and assorted documents pertaining to specific health and human service agencies were read in order to capture information on the agencies listed in Table 1 . To understand the intersectionality of religion and social welfare in Richmond, a look at the deep history of the city and of Virginia is important. This deep history including important waves of religiosity embodied in the history of the Great Awakenings gives important insights into the evolution of social welfare and human services as constructed today. 


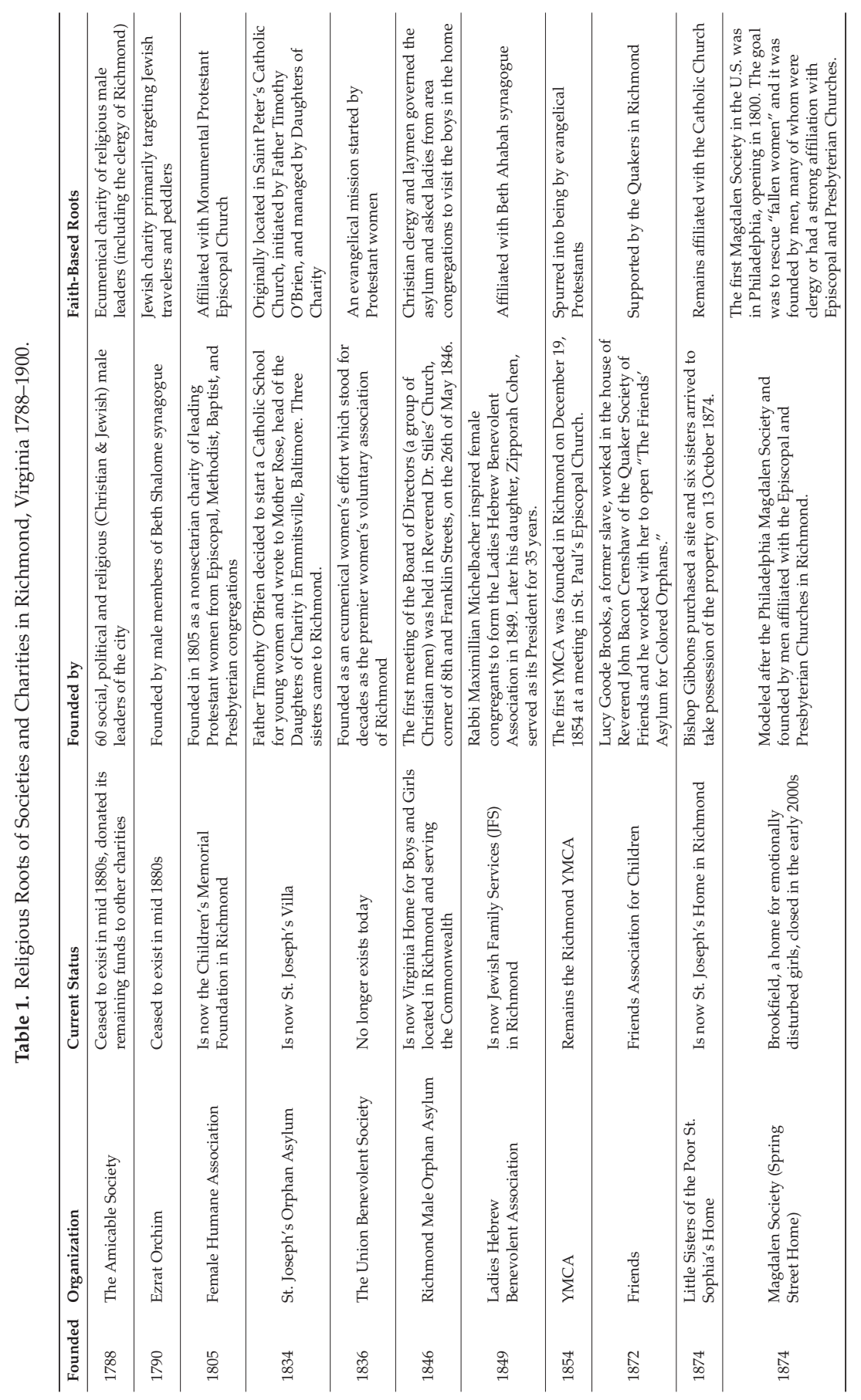




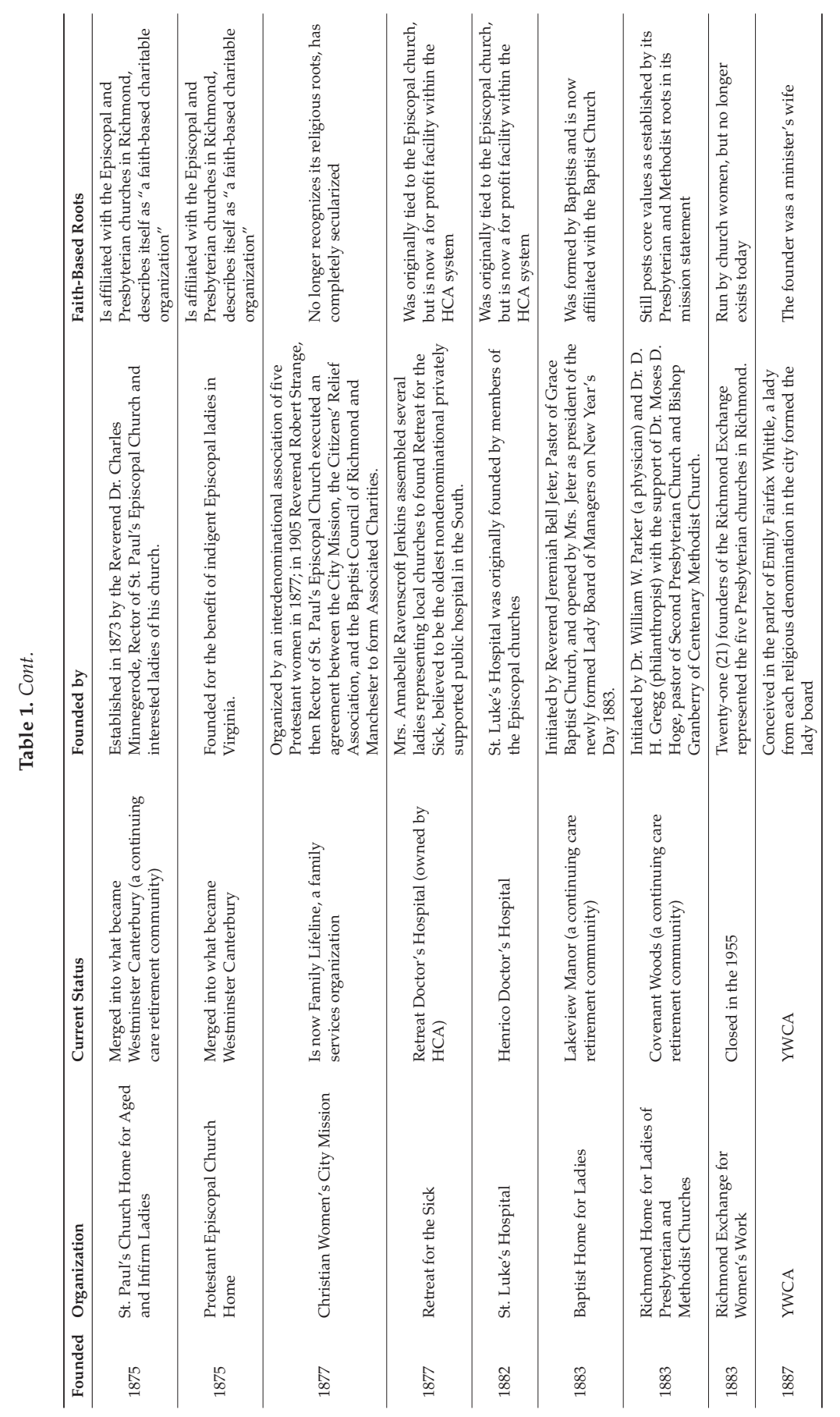


Religions 2016, 7, 13

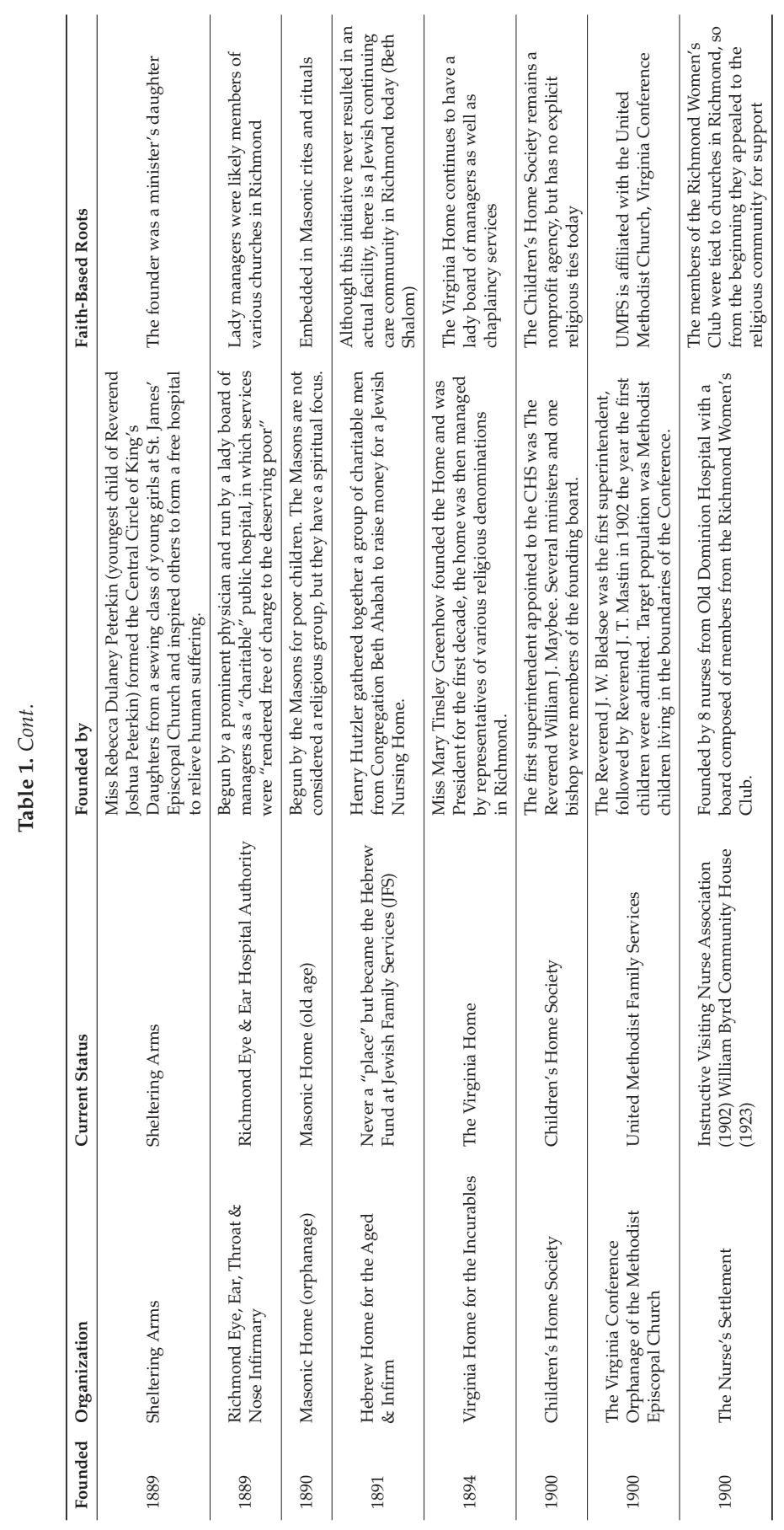




\section{Colonial Virginia as Context}

Virginia was one of the original 13 colonies, established by England and governed by the Anglican (Episcopal) Church as the church of Virginia. The colonists modeled their provision of aid after The English Poor Laws in which outdoor relief was administered through the parish vestry system. There was no separation of church and state, in that the parish was responsible for overseeing secular (e.g., road repair, caring for the poor) as well as religious functions (e.g., repairing church buildings, hiring ministers). Also borrowed from the parish system in England, were laws of settlement based on the assumption that receiving poor relief required one to reside in a geographic location (a parish) for at least one year. The expectation was that one would remain in the same community his or her entire life; would belong to a parish; and would be known by others. As a result, everyone knew who was in need of help and formalized investigations were not necessary [10].

Virginia was somewhat unique from the other colonies. “Unlike Plymouth (Separatist Puritans), Massachusetts Bay (Non-separatist Puritans), Maryland (Roman Catholics), or Pennsylvania (Quakers), Virginia was not established as a haven for any particular religious minority. Virginia's early settlers were neither trying to create a godly society in the New World nor escape religious persecution back home" [26]. As the population grew and a General Assembly was established in the early 1600s the Virginia colony was moving toward a limited amount of self-government. Several laws were enacted to "help the church carry out both its civil and religious functions" and, finally, one statute formally established the Church of England in Virginia ([26], pp. 172-73).

An uprising of the Powhatans in 1622 resulted in a third of the settlers losing their lives, including several clergy. A shortage of clergymen remained until the end of the century, thus "colonial laity began to take a larger role in church governance ... developing a system that led to lay control of Virginia's Church of England" ([26], p. 175). Colonial vestries (composed of 12 laymen within each parish) did everything from raise taxes in the form of tithes to providing for the poor. "The colonial church was not merely a religious institution, it was also the largest and most effective social welfare agency of the period" ([26], p. 181). In short, in colonial Virginia, the church and social welfare were one and the same and thus, the church (the Episcopal Church) and the state were for all practical purposes, inseparable.

It was not until the 1740s and 1750s that the established Church would face challenges from other religious groups and experience divisions within its own structure. A few Quaker groups, a group of dissenters who called themselves Presbyterians, and Separate Baptists began to engage in evangelical activities during what was later labeled the first "Great Awakening." This was the first of a series of Protestant evangelical awakenings that came in waves throughout subsequent centuries. An awakening was distinguished from a revival in which individual lives were altered. Historians would define an awakening as decades long, composed of many revivals and activities throughout Protestantism that altered the "worldview of a whole people or culture" ([27], p. ix). Itinerant Baptist ministers were harassed when they challenged Virginia society, holding members to strict moral codes and asserting that their authority came from God, not from the state church. Simultaneously, within the Anglican Church, The Great Awakening had inspired some clergy to embrace revivalism. "Although these evangelicals within the church sometimes existed uneasily with other Anglican ministers, they nonetheless led an internal revival movement that - and without their blessing-led to the creation of the separate Methodist Church in Virginia" ([26], p. 191). It is within this context that Virginia approached the American Revolution in which "the church stumbled through the war years with an identity crisis" as large numbers of displaced refugees "strained systems of charity to the limit" ([26], p. 206), but more than a mere intersection continued.

In summary, prior to the Revolutionary War, church (the Anglican Church) and state were one and the same. With a shortage of trained clergy, laity played a greater role than in European countries and Protestant evangelism engaged both clergy and laity in religious work. This set the stage for faith-based services and congregational volunteerism to emerge in the decades to come. 


\section{Antebellum Richmond (Post-Revolutionary War)}

The Revolutionary War, accompanied by an increasingly mobile and growing population, had significant consequences for Virginia's social welfare system. First, the Virginia Statute for Religious Freedom was enacted into law in 1786, disestablishing the Church of England in Virginia and guaranteeing freedom from religion to all people of all religious faiths, including Catholic, Jewish, and Protestant denominations [29]. The disestablishment of the Anglican Church meant vestrymen were no longer responsible for poor relief, and the state (overseers of the poor at the county level) inherited this responsibility. Second, a new category of the deserving poor were singled out-veterans and their widows. These persons became eligible for federal support through state pensions. Third, Richmond assumed a more prominent role in Virginia, replacing Williamsburg as the state capital [10]. And fourth, as people became more mobile, settlement requirements became increasingly difficult to maintain. As the diversification of the population increased, social welfare was less communal or personal as everyone no longer knew everyone else, but the role of the laity in leading "good works" efforts continued as you will see in later discussion.

Green describes post-Revolutionary War Richmond as a "rough and tumble frontier town" of nearly 6000 residents by 1800 . Immigrants from Germany, France, Scotland, Ireland, Spain, and Portugal had arrived in the late 1780s and 1790s to join the merchants, artisans, lawyers, bureaucrats, and politicians in the newly formed state capital ([10], p. 24). Soon a mixture of free blacks, slaves, and white laborers worked in warehouses and lived in Richmond neighborhoods. Few services were available to persons living in poverty. Now a crossroads of commerce, more and more people were traveling to and through Richmond. Some were in dire need and untethered to sources of support.

Green asserts that "the transfer of responsibility for the poor from church vestry to local government had not gone smoothly" ([10], p. 24). As Richmond struggled to address the needs of its poorest and destitute citizens, new and different religious congregations were organizing as well. In 1789 German Jews in the mercantile trades founded Beth Shalome synagogue. Other religious groups met irregularly for services in informal settings. "Quakers established a "meeting" in 1794; Roman Catholics a "mission" in 1796; and Methodists made Richmond a "station" for circuit riders in 1798 ... Baptists who had organized their biracial church in 1780, erected a frame meetinghouse in $1800 "$ "([10], pp. 29-30).

In 1788 , to provide outdoor relief to strangers traveling through Richmond the Amicable Society was formed by 60 social, political and religious male leaders of the city. This was Richmond's first known charitable organization independent from church or government formal auspices, but influenced in its approach by what had gone before them. Although the Amicable Society included both Christian and Jewish men, it "was joined in the effort to aid travelers in need by a new organization, Ezrat Orchim, founded by members of Beth Shalome synagogue in 1790" ([10], p. 30). Even though Ezrat Orchim did not specify that the recipient of aid be Jewish, it was created to address "the large number of requests for help addressed to the congregation, probably by Jewish peddlers and other travelers in financial distress. The first president, Isaiah Isaacs, distributed funds according to a constitution that spelled out how much could be given to particular applicants (distinguishing, for example between "those persons of a gentlemanly good character" and those "whose characters are unknown" and between those who had lived in Richmond for at least six months and those who had recently arrived)" ([28], p. 27). Both the Amicable Society and Ezrat Orchim provided their services to men and both survived into the mid-1800s.

From 1785-1837, Thomas (1981) documents a second "Great Awakening" of religious evangelism, "a more sweeping movement of revivals after the American Revolution which as an 'organizing process' not only gave direction to the young American nation in terms of moral values-such as the need for slavery reform-but also brought the majority of Americans into a meaningful participation in church life and benevolent activity" ([27], p. xiv). Without a state church to formalize benevolent activity through the parish system and with an increasingly involved laity, the stage was set for a proliferation of societies, associations, asylums, and charities. 


\section{The Early to Mid-1800s: Societies, Associations, Asylums, and Charities}

Recognizing the increasing need for poor relief, in 1805 the city government began building a poorhouse on its northern fringe. Simultaneously, the religious community "refused to die" and was being fueled by "rebuilding of the church in Virginia [through] women's voluntary associations" ([26], p. 220). That same year, a group of white Protestant women founded The Female Humane Association, now seen as one of the oldest continually operating charities in the nation. "An ecumenical organization composed of women from the city's Episcopal, Methodist, Baptist, and Presbyterian congregations, the association operated a nonsectarian Christian asylum for the relief and comfort of friendless girls ([30], p. 121). The history of the Female Humane Association is replete with Christian references. Although the children attended various churches of all Protestant denominations, the Association's church home was Monumental Protestant Episcopal Church. In addition to providing for basic needs and educational instruction, "the fundamental principles of religion were seriously taught" ([31], p. 11). The Constitution and Bylaws of the Association stated that the girls "shall be taught the fundamental principles of the Christian Religion, and have their health and morals diligently attended to" ([32], p. 11) (Constitution and Bylaws, 1833, p. 11). The duties of the Matron included holding "family prayers in [the] living-room, and ... [seeing] that the children go to church" ([33], p. 49).

Later, in 1845, ladies at the Female Humane Association spurred the development of the Richmond Male Orphan Asylum when a small boy came begging for food at their doorstep [30]. Frustrated that the asylum only served homeless girls, the director encouraged her husband and other benevolent male colleagues to consider establishing an orphan society for destitute boys. Annual reports, board minutes, newspaper clippings and a host of other documents reveal deep Protestant religious connections for the Asylum, including appeals to the moral responsibility of good Christian people to support the cause and noting that the boys were required to attend church on Sundays.

Green writes that "Although staid Episcopal Richmond had largely resisted the evangelical impulse at the opening of the century, by the 1830s Richmond had become an evangelical city, with a plethora of new charities and voluntary associations" ([10], p. 47]. The city directories list multiple temperance groups and various societies. Some groups focused on moral reformation in addition to charity. Methodist-based nonsectarian Dorcas Societies gave clothing to poor children, and people pooled their resources to help one another through mutual aid societies. "In the 1830s the Richmond City Mission Society supported two missionaries [to visit the poor in town]; and the City Mission Sewing-Circle of the First Baptist Church also supported a city missionary in Richmond at various times during the antebellum period" ([34], p. 271).

Whereas, most of these charities and associations targeted specific groups of people, the very evangelical Union Benevolent Society (UBS) was created in 1836 to serve the entire city. UBS viewed all of Richmond as its mission and divided the city into districts (much like the original vestries). Two visitors canvased each district and identified 111 poor families in which women were unemployed. The UBS opened a Depository of Work for 30 women, taught sewing classes to girls, and distributed food and blankets to the city's poor. A Gentlemen's Benevolent Society was created to support the women's work, but male visitors were required to be accompanied by female members of the UBS. The UBS became representative of the rise in, and acceptance of, women's evangelical activism in the city ([10], p. 49).

In the early to mid-1800s, Protestant evangelicals (both lay and clergy) embraced benevolence as a means to reform persons in need. Christian clergy in Richmond grasped the opportunity to win over the souls of the needy, establishing benevolent associations within and as extensions of their churches. For example, very vocal in promoting benevolent efforts was The Reverend Jeremiah Jeter, pastor of First Baptist Church (1836-1849) and Grace Street Baptist Church (1852-1870) and The Reverend Moses Drury Hoge who served Richmond's Second Presbyterian Church for 54 years (1845-1899). Of Drury, one writer observed that engagement in benevolent activities took an increasingly larger percentage of his time as needs increased ([34], p. 173). 
The First African Baptist Church was established in 1841 by splitting with the formerly biracial First Baptist Church. In 1848 this new church established a Poor Saints Fund to provide aid to older members of the congregation. This type practice was likely widespread among Richmond's African American Churches, but they met in secret because "members feared they would be arrested for illegal congregating" ([10], p. 48). Thus, archival records documenting the extent of aid provided in the African American community do not exist. Churches continued to provide aid to their needy congregants, leading Lebsock [8] to contend that church membership served as a type of social insurance for older or homebound black congregants.

Green asserts that a kind of "sectarian competition" between Protestants, Catholics and Jews played some role in the early 1800s ([10], p. 48). In the Protestant community it was common for clergy wives and daughters to have long-term commitments to single charitable ventures [5]. Catholics in particular feared the rise of evangelical Protestantism [25]. This led to religious groups establishing their own private asylums and charities.

In 1834 St. Joseph's Female Academy and Orphan Asylum opened to serve Catholic girls. A dream of Bishop Timothy O'Brien's, St. Joseph's was staffed by three Sisters of Charity who came to Richmond from Emmitsburg, Maryland. The asylum and school was part of St. Paul's Catholic Church, the first Catholic church in Richmond ([25], p. 67). Father O'Brien had also arranged for the sisters to provide nurses to Richmond Medical College, but this did not last. The sisters felt so oppressed by the physicians there that they left town shortly thereafter. In 1860 they would return as the Daughters of Charity to found St. Francis de Sales Infirmary in Richmond "totally under their control" ([25], p. 68).

In 1839 Jewish men in Richmond organized the "Chebrah Ahabah Yisroel" or self-help organization "to aid the needy, help the sick, and bury the dead" ([22], p. 16). In 1849 Rabbi M. J. Michelbacher created the Ladies Hebrew Benevolent Association "for the purpose of drawing into closer relationship the Jewish women of [Richmond], there being no organization at the time to care for the sick and provide funds for the poor and needy among [the women in the Jewish community]" ([35], p. 21). The women who joined this mutual aid society were mostly recent German immigrants "in the 'second wave' of Jewish immigrants to Richmond" ([22], p. 9).

Prior to the Civil War, Richmonders founded a chapter of the Young Men's Christian Association (YMCA), enthusiastically supported by evangelicals who were concerned about the spiritual and moral condition of the majority of Richmond's young men ([34], p. 172). The Young Men's Aid Society was founded by the Methodist Episcopal Church.

\section{The Post Civil War Era in Richmond}

During the Civil War Richmond's charitable sector was stretched to its limits and pressed into duty caring for wounded soldiers and victims of war. For example, the YMCA operated one of the many hospitals during the War, and any available building, including homes and churches, became temporary hospitals. Ladies' benevolent societies and associations sewed uniforms and wrapped bandages, assisting the war effort in any way possible.

During and after the Civil War, religious values and language continued to permeate charitable work in societies, associations, and asylums even if direct relationships with sponsoring churches seemed to cease. The religious and political contexts in which new organizations emerged is revealed in the city directories and other public documents of the time. For example, immediately after the Civil War, the following statement prefaced the list of "Societies" in which the writer referred to the regalia worn by "colored" society members in Richmond: "God has made the white man lower than the angels, and the African race lower than the white, and it is still the law, the universal suffrage bill to the contrary notwithstanding" ([36], p. 104). In short, racist attitudes were obvious during Richmond's Reconstruction period and were framed in religious language.

In addition to the services that existed, responding to the immense needs following the Civil War generated the creation of numerous new religiously inspired health and human service organizations. Friends Association for Colored Children was founded by a former slave, Lucy Goode Brooks. She 
worked in the house of the Reverend John Bacon Crenshaw of the Quaker Society of Friends (known for their opposition to slavery). Reverend Crenshaw worked with her to open the Friends' Asylum for Colored Orphans" in 1872.

In 1874 the Magdalen Society opened the Spring Street Home, based on the first Magdalen Society in the U.S. in Philadelphia (circa 1800). The goal was to rescue "fallen women" and it was founded by men, many of whom were clergy or had a strong affiliation with the Episcopal and Presbyterian Churches. That same year Catholic Bishop Gibbons purchased a site for the Little Sisters of the Poor to house St. Sophia's Home, an old age home. Six sisters arrived to take possession of the property in 1874 ([25], pp. 230-31). St. Paul's Church Home for Aged and Infirm Ladies was established by the Reverend Dr. Charles Minnegerode, Rector of St. Paul's Episcopal Church, along with interested ladies of the church. In 1875 the Protestant Episcopal Church Home was founded for the benefit of indigent Episcopal ladies in Virginia. In 1877 the Christian Women's City Mission was organized by an interdenominational association of five Protestant women. Later in 1905, the Reverend Robert Strange, then Rector of St. Paul's Episcopal Church, executed an agreement between the City Mission, the Citizens' Relief Association, and the Baptist Council of Richmond and Manchester to form Associated Charities (the first Charity Organization Society in Richmond).

Retreat for the Sick was organized when ladies from several local churches were mobilized to establish the oldest nondenominational privately supported public hospital in the South. Other hospitals with religious connections, including St. Luke's Hospital (1882), Richmond Eye, Ear, Throat, and Nose Infirmary (1889) became part of the health care environment. Sheltering Arms led the community in establishing its first rehab hospital. Miss Rebecca Dulaney Peterkin, the youngest child of The Reverend Joshua Peterkin, formed the Central Circle of The King's Daughters from a sewing class of young girls at St. James Episcopal Church and inspired others to form a free hospital to relieve human suffering. A board member of Sheltering Arms, Miss Mary Tinsley Greenhouse, recognized that Sheltering Arms could not meet the needs of persons with severe chronic disabling conditions created the Virginia Home for the Incurables in Richmond. This home was managed by a lady board of managers from various religious denominations and continues so today.

The rise in health care facilities after the Civil War was described in a newspaper article in 1892 as follows: "It is a distinctive feature of Christian lands that those enfeebled by age, worn by disease, orphaned, or otherwise deprived of their natural guardians and protectors, find in homes, hospitals, and asylums comforts that could never otherwise be theirs ... In such institutions Richmond is greatly blessed. We have large numbers of them and they represent in the good work done the intelligent effort and humane spirit of all the denominations and sects who have houses of worship in our city, and are in many instances the recipients of aid from the city and from individuals" ([37], unknown page). Human services of that time could not be separated from their religious precipitants. This seems to persist over time.

In 1900, three more agencies were founded-Children's Home Society, The Virginia Conference Orphanage of the Methodist Episcopal Church, and the Nurses Settlement. All three would become well established parts of Richmond's nonprofit sector, still visible today. The Reverend Joseph Thomas Mastin, first superintendent of The Virginia Conference Orphanage would be tapped as the first Secretary of the State Board of Charities and Corrections in 1908. Reverend Mastin accepted the position only after a new minister was appointed as superintendent of the orphanage and the Bishop gave his consent [38]. The Nurses Settlement changed its name to the Instructive Visiting Nurses' Association (IVNA) and would play a role in the ultimate development of the School of Social Work. The nurses would be joined by social workers who would spin off into William Byrd Community House (WBCH) in 1923 [39]. Revisiting Table 1 it should be clear from this overview that all services identified in the table and, therefore, the major, most well-established human service providers in Richmond today were either directly or indirectly begun due to religious incentives or inspiration. 


\section{Discussion}

Studying the intersectionality of religion and social welfare in Richmond requires going back to the beginning of the Virginia colony and setting a context. In the crucible of the Virginia colony, the religious and social welfare functions of a parish community were one and the same. Without a separation of church and state and with a small collection of colonists, taking care of people's needs was institutionalized into the fabric of the community through the parish system. We believe that hints of this institutionalization continue today. This is not to say that there were no problems with this approach, but it was manageable and familiar because it had accompanied the colonists to the shores of the New World.

Within this setting, Virginia did not face the same early challenges between state and religious perspectives evident in other colonies that began with the desire to escape religious persecution or to create new ways of providing for the common good. In Virginia, the social contract between its government and its citizens was so embedded in religiosity to make the State and the Church virtually inseparable. Though Virginia presented the impetus for the first amendment to the Bill of Rights via its position on First Freedoms, separation of Church and State was not as important as the freedom to practice one's religion freely. The disestablishment of the Anglican Church as the church of Virginia essentially disassembled the system of care in the state.

The Revolutionary War was jarring for the Anglican Church in Virginia. No longer being tethered to Britain brought with it a disestablishment of a parish-based system that had been in place for well over a century. Not only were new religious groups springing up within the new Commonwealth, but there was dissention within the Anglican Church over the evangelistic nature of the Second Great Awakening. The disentanglement of church and state created an identity crisis of vast proportions as all the functions of society that had been blended into one system were separated into "religious" and "secular" functions. Social welfare as a function moved to the county overseers of the poor acting as representatives of local government. A diversification of social welfare occurred as government and the new private sector struggled with how to deal with a mobile population of persons in need, but with religiously based charitable intensions as the core of service.

In Richmond, the emergence of charitable efforts began with leading men of the city who tried to address the temporary needs of travelers, followed by groups of women who discovered new roles they could play through structured charitable works. Simultaneously, as government attempted to design a poor house and women created an orphan asylum, congregations of various denominations continued to provide support to their members in need. In short, the new "system" became a potpourri of societies, congregations, associations, and county units attempting to provide for the social welfare, still with strong ties to religious thought. The intersectionality of religion and social welfare continued but in a serendipitous form. Whereas there had been a single entry point in the parish vestry system, there were now multiple entry points to access whatever might be available to serve needs. However, the agencies that emerged were still tethered to their religious communities even though they were chartered by the state and they received local government dollars in the form of subsidies. This was very similar to modern day purchase of service contracts between government and the nonprofit sector.

Of particular interest for today's understanding of the secular side of human services in Richmond is the language used in the founding legends of the earliest charities. It was frequently noted that the term "nonsectarian" or "interdenominational" were used. This language pertained to groups of Protestant agencies created by women from Episcopal, Presbyterian and Methodist congregations. Baptists tended to create their own societies and associations, while early Jewish and Catholic groups tended to serve their own. Nonsectarian organizations in Richmond were primarily Christian and incorporated Christianity into their service provision, at the same time they received charters from the General Assembly (state government) and some funding from Richmond's city government. This type of intermingling of religion and state would rarely be questioned in Richmond until the faith-based issues of the late 20th century brought them to the forefront. 
To us, Richmond's history offers a preview of the city's complexity today. There is still tension between those religious groups that believe in more evangelical approaches and those that are less prone to proselytize. Thus, proselytizing as part of service delivery versus service without question as a charitable act is still present. This tension emerged during the Second Great Awakening and often resurged with challenging times. There are agencies in Richmond that have had board members from religious congregations and generations of family members on their boards, creating a deep historical relationship with communities of faith. The mixing of public and private funds for the purpose of service has been in existence since the beginning of the colony and is still evident in the social welfare system today.

Table 1 summarizes what we learned about the beginnings of those organizations that emerged, many of which are still a vital part of Richmond's health and human system today. Some agencies maintained their religious roots. Names such as St. Joseph's Villa or Jewish Family Services attest to these continuing religious affiliations, while others such as Family Lifeline (originally the Christian Women's City Mission) and Retreat for the Sick have secularized to the point that little if any explicit memory of their religious roots remain. Still others maintain chaplaincy services (The Virginia Home or United Methodist Family Services) for their residents and clients. Many more agencies arose in the 1900s that we have not even begun to study, including those obviously rooted in religious traditions such as Commonwealth Catholic Charities or Bon Secours Health Care System. Interestingly, some agencies that were formally religious have secularized, whereas others have emerged from religious groups to declare their religious affiliations. What remains in the 21st century is a diverse landscape of small and large organizations and congregations that perform the majority of the social welfare functions in Richmond. To attempt to separate the church from the state in this network of agencies is neither possible nor desirable; however, understanding its' historical religious complexity is essential if one is to appropriately engage in contemporary practice within Richmond's health and human service system.

\section{Conclusions}

Since Colonial times there have been waves of commitment to service for those in need. This commitment has ranged from the moral imperatives and evangelism of what have been called the Great Awakenings to serve the least of our brethren to the evangelistic fervor that predicates service with the need to proselytize. This moral component to service seems well-rooted in many nonprofit human service agencies in Richmond. Some are more secularized than others, but most acknowledge their long-term religious ties in some way, such as website histories, religious sounding names, or board membership.

When considering service to the needy, there appears to be little that is new. How service is constructed and delivered may be different, but many of the same motivations appear from colonial times to the present. Thomas (1981) asserts that this question of what motivates religious people to act benevolently is as old as the second Great Awakening [27], and in our research on contemporary faith-based programs the same question can be asked today [40].

As one looks at the modern day faith-based service movement, those concerned about separation of Church and State tend to want assurance that services are sufficiently secularized by seeing that religious artifacts and practices are absent. Historically, in Richmond faith traditions and artifacts in services were unabashedly present. Through secularization they were removed or at least were not as blatantly present. But religiosity has deep cultural roots in the agencies we investigate. The organizational cultures of these agencies, even in the present, are rooted in the founding religions. One needs to know this and the religious belief systems that have been historically institutionalized in order to understand the organization, what is occurring, and how it is being evaluated. To overlook these deep cultural roots is to miss important clues about an agency. Over time, the agency may have tinkered with its artifacts; but the underlying beliefs about service and those being served only slowly change. We have found that it is not easy to identify this influence, particularly when it has 
been asserted to be absent. In long standing agencies like those in Richmond, religious beliefs have been historically infused in such a way to have become intrinsic aspects of the underlying beliefs that undergird the organizational culture.

Our work with hundred year old agencies in Richmond and our recent research into the history of religion and religious freedom in Virginia suggests networks of faith and ideology that cannot be reduced to mere intersectionality. This may be a story unique to Richmond and Virginia, but the lessons learned may have broader implications when considering social welfare and American religiosity generally. Our step further backwards into history has helped us to clarify some of the issues that were intriguing about human services at the turn of the 20th century. They may, indeed, be informative for navigating the challenges of the 21 st century.

Author Contributions: We both conceptualized the article in a series of meetings/conversations, based on our previous research and long collaboration, and located new sources of information. Ellen wrote a first draft to get us started, then we engaged in an interactive "back-and-forth" creating numerous revisions, both participating in the writing, reading and final approval of our manuscript.

Conflicts of Interest: The authors declare no conflict of interest.

\section{References}

1. Willam H. Seiler. "The Anglican parish vestry in colonial Virginia." The Journal of Southern History 22 (1956): 310-37. [CrossRef]

2. Marcus Wilson Jernegan. "The development of poor relief in colonial Virginia." Social Service Review 3 (1929): 1-18. [CrossRef]

3. F. Ellen Netting, and Mary Katherine O'Connor. "Lady boards of managers: Subjugated legacies of governance and administration." Affilia 20 (2005): 448-64. [CrossRef]

4. F. Ellen Netting, Mary Katherine O'Connor, and David P. Fauri. "A missing tradition: Women managing charitable organizations in Richmond, Virginia 1805-1900.” Social Service Review 89 (2009): 447-584. [CrossRef]

5. F. Ellen Netting, Mary Katherine O'Connor, and David P. Fauri. "Identity construction in centenarian agencies: Coherence and change." Families in Society 92 (2011): 364-71. [CrossRef]

6. F. Ellen Netting, Mary Katherine O'Connor, and David P. Fauri. "Capacity building legacies: Boards of the Richmond Male Orphan Asylum for Destitute Boys \& the Protestant Episcopal Church Home for Infirm Ladies 1870-1900." Journal of Sociology and Social Welfare 39 (2012): 111-31.

7. F. Ellen Netting, and Mary Katherine O'Connor. "Maidens fair, matrons plump, fat cats \& sugar daddies: Fundraising in a human service community." Affilia 27 (2012): 249-62.

8. Suzanne Lebsock. The Free Women of Petersburg: Status and Culture in a Southern Town, 1784-1860. New York: W.W. Norton and Company, 1984.

9. Elizabeth R. Varon. We Mean to be Counted: White Women and Politics in Antebellum Virginia. Chapel Hill: University of North Carolina Press, 1998.

10. Elna C. Green. This Business of Relief: Confronting Poverty in a Southern City, 1740-1940. Athens: The University of Georgia Press, 2003.

11. Karin J. Blair. The Clubwoman as Feminist: True Womanhood Redefined, 1868-1914. New York: Holmes and Meier Publishers, Inc., 1980.

12. Patricia C. Click. The Spirit of the Times: Amusements in Nineteenth-Century Baltimore, Norfolk, and Richmond. Charlottesville: The University Press of Virginia, 1989.

13. Kathleen Waters Sander. The Business of Charity: The Woman's Exchange Movement, 1832-1900. Urbana: University of Illinois Press, 1998.

14. Anne F. Scott. Natural Allies: Women's Associations in American History. Chicago: University of Chicago Press, 1993.

15. Sarah Elizabeth Kabler. "The Richmond Travelers' Aid Society." M.S.S.W. Thesis, School of Social Work of the College of William and Mary, Richmond Professional Institute, Richmond, VA, USA, 1935. 
16. Dorothy Overton Post. "A study of the Masonic Home of Virginia." M.S.S.W. Thesis, School of Social Work of the College of William and Mary, Richmond Professional Institute, Richmond, VA, USA, April 1948.

17. Mary Frances Shelburne. "A brief history of the Family Service Society of Richmond, Virginia." M.S.S.W. Thesis, School of Social Work of the College of William and Mary, Richmond Professional Institute, Richmond, VA, USA, 1932.

18. Drusilla Sibert. "The development of the community houses in Richmond, Virginia." M.S.S.W. Thesis, School of Social Work of the College of William and Mary, Richmond Professional Institute, Richmond, VA, USA, 1932.

19. Robert Houston Welton. "A study of the structural organization of William Byrd Community House." M.S.S.W. Thesis, School of Social Work of the College of William and Mary, Richmond Professional Institute, Richmond, VA, USA, April 1948.

20. Elna C. Green. "Gendering the city, gendering the welfare state: The Nurses' Settlement of Richmond 1900-1930." Virginia Magazine of History and Biography 113 (2005): 277-311.

21. Anne Rutherford Lower. Sheltering Arms Hospital: A Centennial History (1889-1989). Richmond: The William Byrd Press, 1989.

22. Peter K. Opper. "Like a Giant Oak" A History of the Ladies Hebrew Benevolent Association and Jewish Family Services of Richmond, Virginia, 1849-1999. Richmond: Peter K. Opper, 1999.

23. Sandra Gioia Treadway. Women of Mark: A History of the Woman's Club of Richmond, Virginia 1894-1994. Richmond: The Library of Virginia, 1995.

24. Ethel W. Born. Candlesticks: Methodist Women Putting Faith to Work in Virginia. Salem: Virginia Conference United Methodist Women and E \& C Partnership, 2004.

25. Gerald P. Fogarty. Commonwealth Catholicism: A History of the Catholic Church in Virginia. Notre Dame: University of Notre Dame Press, 2001.

26. Edward L. Bond, and Joan R. Gundersen. "The Episcopal Church in Virginia, 1607-2007." The Virginia Magazine of History and Biography 115 (2007): 163-344.

27. Arthur Dicken Thomas Jr. "The Second Great Awakening in Virginia and slavery reform, 1785-1837." Ph.D. Dissertation, Union Theological Seminary of Virginia, Richmond, VA, USA, 15 April 1981.

28. Melvin I. Urofsky. Commonwealth and Community: The Jewish Experience in Virginia. Richmond: Virginia Historical Society and Jewish Community Federation of Richmond, 1977.

29. Daniel L. Dreisbach. "A new perspective on Jefferson's views on church-state relations: The Virginia Statute for Establishing Religious Freedom in its legislative context." The American Journal of Legal History 35 (1991): 172-204. [CrossRef]

30. Susan E. Barber. "Anxious care and constant struggle: The female humane association and Richmond's white civil war orphans." In Before the New Deal. Edited by Elna C. Green. Athens: The University of Georgia Press, 1999, pp. 120-37.

31. Memorial Home for Girls (formerly Female Humane Association) 1805-1938. Richmond: Virginia Historical Society, 1938.

32. Constitution and Bylaws of the Female Humane Association of the City of Richmond. Adopted 1 April 1833. Richmond: Shepherd and Colin Printers, 1843.

33. Memorial Home for Girls. Duties of matron of Memorial Home for Girls. Richmond: Virginia Historical Society, 1926.

34. Anne C. Loveland. Southern Evangelicals and the Social Order 1800-1860. Baton Rouge: Louisiana State University, 1980.

35. Zipporah Cohen. Paper on the Ladies' Hebrew Benevolent Association since its Organization. In Read for the Council of Jewish Women at its meeting of October 1910 as part of the 1911 annual report. Box: JFS Yearbooks 1911-1974; Richmond, VA: Beth Ahabath Museum and Archives.

36. Societies. The Richmond Directory and Business Code for 1866 published by Starke \& Mills, Richmond, VA. Gary and Clemmitt, Printers. Located in the Valentine History Center archives.

37. Homes for the Sick: Where the Aged, the Poor, and the Sick Are Cared for. Richmond: Valentine Richmond History Center Archives, 1892.

38. Arthur W. James. Virginia's Social Awakening: The Contribution of Dr. Mastin and the Board of Charities and Corrections. Richmond: Garrett and Massie, Inc., 1939. 
39. F. Ellen Netting, Mary Katherine O'Connor, David P. Fauri, D. Crystal Cole, and Amy Prorock-Ernest. "Resurrecting Nannie Minor \& Orie Hatcher: Emergence of professional social work education in one southern city." Affilia 30 (2015): 259-69.

40. F. Ellen Netting, Mary Katherine O'Connor, and Gaynor Yancey. "Belief systems in faith-based human service programs." Journal of Religion and Spirituality in Social Work 25 (2006): 261-86. [CrossRef]

(C) (1)

(C) 2016 by the authors; licensee MDPI, Basel, Switzerland. This article is an open access article distributed under the terms and conditions of the Creative Commons Attribution (CC BY) license (http:/ / creativecommons.org/licenses/by/4.0/). 
Article

\title{
Re-Building Coal Country: A Church/University Partnership
}

\author{
Carl Milofsky ${ }^{1, *}$ and Brandn Green ${ }^{2}$ \\ 1 Department of Sociology and Anthropology, Bucknell University, Lewisburg, PA 17837, USA \\ 2 Independent Scholar, Washington DC 20011, USA; brandng@gmail.com \\ * Correspondence: milofsky@bucknell.edu \\ Academic Editor: Robert Wineburg \\ Received: 25 March 2016; Accepted: 24 May 2016; Published: 13 June 2016
}

\begin{abstract}
This paper describes a developing partnership between a church-based service learning center and a university initiative to build a field station in a low-income community in the anthracite coal region of Pennsylvania. It is a case study of how secular and religious institutions have been collaborating to achieve the shared goal of improving social conditions in specific communities. The theoretical focus of the paper is on how a change from a "glass is half empty" to a "glass is half full" perception of the community opens new possibilities for change. This paper concentrates on the story of one partnership as a case study demonstrating current trends in service learning both within universities and within the Catholic Church in America. Analysis centers on the basic question of why the project had symbolic power for both partners and on the institutional processes within both organizations that helped the partnership grow. We use the framework of Assets-Based Community Development (ABCD), also known as the "strengths perspective", to conceptualize the contrast.
\end{abstract}

Keywords: community-based research; service-learning; community development; interinstitutional relations; organizational case studies

\section{Introduction/Background}

The Mother Maria Kaupas Center for Service Learning is a parish ministry of the Divine Redeemer Catholic Church in Mount Carmel, PA. It is also a teaching, service, and research center anchored at Bucknell University 35 miles from Mount Carmel. In a period of eighteen months the collaboration expanded from a phase of informal conversations and informal research by the different parties to a formalized partnership with significant resource support and a number of dynamic projects sponsored and supported by the different parties. There is value in simply documenting the development of this church/university/community partnership.

But the deeper question is why the project worked. All of the parties have expressed frank surprise at the speed and ease with which the enterprise developed. There was a perception that the community was too poor, too old, and too passive to support the project well. The university, with its secular orientation, was not expected to put in the energy, expertise, and resources to give the project vitality and permanence. The local Catholic Church was emerging from a period of crisis related to population decline, the child abuse scandal involving priests, and a perception by local residents that the Diocese office, located in the state capital 75 miles away, was not interested in supporting small, poor, rural communities in the anthracite coal region.

The argument of this paper is that negative community self-image blocks local improvement and development projects, where a more positive community-self image would allow projects to be successful and make dramatic community change possible. We have experience with other towns in central Pennsylvania where very negative community self-images threatened real economic development opportunities. Necessary community infra-structure changes would not be made as a 
consequence. Derogatory comments by residents and people in surrounding towns might encourage agents of economic change to by-pass the town rather than settle, invest there, and revitalize the place. They might pass over the town, even though community development projects could be effective. We demonstrated this in another community/university partnership targeted at a highly stigmatized neighborhood that dramatically changed the area over a five-year period [1]. Similarly, we worked in Derry/Londonderry where over a ten-year period a community initiative dramatically changed the city from one with disastrous levels of conflict to a place where peace and economic growth remade the central city [2].

The concept of community self-image is part of a general discussion about the social construction of community and the notion that community is a symbolic construct shared in slightly different ways by the residents of a locale [3,4] Communities do not automatically exist in a local area. Social and economic history foster relationships and shape local culture [5]. These give some residents a strong sense of shared identity, just as it may exclude others who do not share this history and the relationships it produces [6,7]. Self-interested efforts by local institutions like churches, YMCAs, school districts, and real estate agents encourage residents to see themselves as part of a local community, to develop self-images as community members, and to act to build and support the community [8-10]. On a larger scale, efforts to develop community self-image can lead to a sense of regional identity for a place like "Chicagoland" [11], or can be linked to the attraction of professional sports teams to urban areas [12] and a subsequent improvement in community self-image.

There is an interaction between community self-image and personal well-being [13]. Part of this has to do with feelings of optimism about the place [14]. Alternatively, residents may come to feel that their neighborhood is a dangerous place. Fear of crime, which may be exaggerated, is documented to have negative effects on the health of senior citizens $[15,16]$. Contrariwise, residents who have positive feelings about their community are more likely to participate in positive community action [17].

This paper proposes that symbols can motivate a shift from negative self-images of places to positive self-images where effective community action can be taken. This is an argument made by Kretzman and McKnight [18,19] and activated by their community organizing methodology, Assets-Based Community Development (ABCD). Kretzman and McKnight argue that a simple change in framework, from a deficit perspective to one that emphasizes the abundance of local assets, can make dynamic local change projects possible. Their perspective is best known in urban planning circles, but it is congruent with a growing and widely respected perspective in social work, called the strengths approach, used both in individual psychotherapy and community interventions. In social work, the strengths perspective is contrasted with one that emphasizes pathology as the starting point for therapy and treatment [20-23].

Implicit in their approach, is the observation that progressive, effective changes could have been possible in communities if they had not held themselves back because of their deficit frame of reference. We argue that the church/university/community partnership described in the present case is an illustration of the effect a shift in frame from deficit to assets has for communities. Participants were surprised at the success of the project because they shared deficit perspectives. However, nothing magical happened in the project. The resources to build an effective project and the possibility of success were always there. Once the guiding perspective changed to one that focused on identifying and using assets that were in place, the project quickly grew through these strengths.

\section{Data}

As active members in the creation of the Mother Maria Kaupas Center collaboration with Bucknell University, we do not present our case study free from our own personal biases. To mitigate misrepresentation, we completed interviews with key actors in all of the coordinating institutions. In total, eight interviews were completed, field notes were taken, and they were used to support the grounded theory approach presented here. Participatory analysis developed the interpretation we 
offer about creating an inter-institutional collaboration between a secular university and a Catholic Church to address gaps in social welfare in a post-industrial mining community in Pennsylvania.

\section{Mount Carmel in the Context of Post-Industrialism}

Mount Carmel is a town of about 7000 people situated in a narrow valley that sits astride the anthracite coal deposits in Pennsylvania. The coal industry mostly closed down in the 1960s, leading to a 50-year period continuing to the present in which the isolated towns that drew their wealth and livelihood from the industry for nearly a century lost their economic base [24,25]. The population aged and young people moved away. Today, nearly $70 \%$ of the schoolchildren are eligible for free and reduced cost school lunches, which is an indicator of the extent of poverty in the town. Census data tell us that out of five hundred school districts in Pennsylvania, Mount Carmel is the twenty-second poorest [26].

The Catholic Church has been a core institution in the coal region since the mid-1800s. The discovery and exploitation of anthracite coal in the small towns of Pennsylvania was a central force that drove the Industrial Revolution in America. Hot-burning, clean anthracite coal, coupled with the availability of iron ore in the local hills, led to the invention of steelmaking in towns like Bethlehem While Bethlehem produced rails, the train engines and cars were built in coal region towns like Scranton. During the last half of the 19th century, large industrial cities-Pittsburgh, for example-grew from small towns to industrial centers. But industrial production continued to depend on the coal that was being mined in the small number of counties that made up the anthracite coal region, because this was the only place anthracite coal existed [24].

Labor demands in the coal region meshed with the immigration waves of the last half of the 19 th century and the social worlds of coal towns grew up around complex mixes of ethnic groups. Many of these groups were Catholic and they were forced to develop defensive, self-sustaining institutions built around their language groups and their distinctive styles of faith [5]. Economic oppression was common and led to the invention and development of the labor movement in these small mountain towns [27]. Dominant economic groups usually were Protestant. Catholic ethnic, religious, educational, and mutual aid groups grew up with a fierce sense of pride and autonomy. Social reform and resistance were central to the philosophical basis and political orientation of these groups (manifested in movements local to Mount Carmel, like the Molly Maguires [28]).

The church retained its dynamic core position and leadership role well after the coal industry began its decline in the 1950s. The church continued as a venue for enacting community. It did this partly by preserving language, rituals, and specific traditions that community members would enact each year. From this, they not only socialized each other and their children but also built strong social capital and created a sense that their ethnicity had a human reality that was fundamental to their health and vitality [29].

However, in the 1990s these systems all collapsed. Economic and population decline meant that more and more often churches had many empty pews. With increasingly impoverished communities, parishes could not generate enough income to pay the costs of having priests or keeping their buildings open and in good repair. In 2002, the Diocese in Harrisburg combined parishes, and in the case of Mount Carmel, twelve churches were consolidated into two, one of them being Divine Redeemer. The action was economically necessary and debated for nearly a decade. Members of the Holy Cross congregation argued particularly hard, claiming that the home congregation of Mother Maria Kaupas, a person in the process of beatification, should not be closed, but to no avail.

In some towns, the first step towards unification was that different services were held in one building for each of the constituent congregations. To combat this duplication, the priest who took over Divine Redeemer had the feeling that his primary responsibility was to help congregation members feel that they were part of a single congregation. To achieve this unification he removed all of the historical records and icons of the former local churches. This created a lot of anger and the majority of 
members stopped going to church. All of this created a local feeling that the Diocese in Harrisburg was uninterested in the coal region and unwilling to invest in its congregations.

\section{The Recent History of Divine Redeemer Church}

This history is important to know, partly to understand why the Sisters of St. Casimir would recognize a tie to Mount Carmel and have a desire to honor their foundress, Mother Maria Kaupas. It also is important for seeing that the Catholic Church was a core institution of the community in a town like Mount Carmel. It is not quite right to say that the church "served" the community. More accurately it was the community. In important ways, the church buildings, its associations, and its processes of ritual and worship were the means by which local residents developed a sense of place [25], a strong sense of culture and meaning, and an action framework in which to identify and act upon community issues and concerns.

For Divine Redeemer Church the Mother Maria Kaupas Center project had its beginning when, in 2013, the newly assigned priest of the church, Father Marty sought ways to follow the Pope's directive that each Parish should seek ways to celebrate the work of "people religious" from the local area. Father Marty, new to the parish, began research on local history and discovered that a large and successful order of nuns had their beginning in Mount Carmel when Mother Maria Kaupas and two other nuns began teaching in Holy Cross School in 1908. The success of Mother Maria's project reached the archbishop in Chicago who worked to have Mother Maria Kaupas and her community transferred to that city so that she and her partners could form a foundation to provide educational opportunities and pastoral care to the large Lithuanian community there. Over the following 40 years, the Sisters of St. Casimir grew significantly and started hospitals and schools. Upon her death the archbishop of Chicago began proceedings to look at the exemplary life of Mother Maria Kaupas. This ultimately led her to be nominated for beatification as an American Saint [30].

In the fall of 2014, discovering the historic role of Mother Maria Kaupas in Mt. Carmel Father Marty asked permission of Bishop Ronald Gainer, bishop of the Catholic Diocese of Harrisburg, to explore the creation of a service-learning center in the former St. Peter's Convent that once housed the Felician Sisters. At the same time, he asked Bishop Gainer's permission to contact the Sisters of Saint Casimir, which Mother Maria Kaupas had founded, to see if they would be interested in having an association with the new center. They were pleased to support the creation of the new center in Mount Carmel, in part because it would honor their foundress and her community. This support was also financial, as the Sisters provided the capital necessary for renovating the convent to serve the daily operations of the center.

In addition to his identification of a key symbol and community asset in Mother Maria Kaupas, Father Marty had social networks in, and strong and weak ties to, the Bucknell academic community, upon which he could draw as he sought to find partners for the community-based work of the parish. At Bucknell, he had been part of a dynamic partnership between the Protestant Chaplain, the Jewish Chaplain, and himself. Together, they had energized and reconceptualized the religious presence at this strongly secular private university. Their work around the September 11, 2001 tragedy had become an important part of campus life. Subsequent to his time at Bucknell, Father Marty was director of service learning programs at all Catholic Colleges in the United States, being based in Cincinnati.

When Father Marty arrived in Mount Carmel in July 2013, he inherited a situation where there was distrust of the church, low church attendance, and an aging town that no longer seemed economically viable. Father Marty had the energy, vision, and many of the skill sets necessary to engage with, and begin to remedy these problems. He followed a strategy whereby building the community that surrounds a church can be an effective vehicle for building the internal organization of a congregation $[9,31]$.

Much of what he had to confront was anger that came from specific events and also a civic belief that the town lacked the kind of effective leadership that could reverse the negative economic trend. Upon arrival, Fr. Marty began an assets-based approach, following the model of Asset-Based 
Community Development (ABCD) $[18,19]$ for overcoming anger from congregants by generating a more positive town orientation. His hope was that, by first changing perceptions and attitudes through the Mother Maria Kaupas project, he could lay a foundation for the community to work together to creatively remake the economic foundation of the town.

In addition to the economic hardships and historical trends away from congregational participation, the international crisis of Catholic priests sexually abusing children had a strong impact on dioceses within the United States, and even the community of Mount Carmel. Local residents have told Father Marty that abuse occurred with several priests. There were two highly public incidents. One priest was relieved of his duties for child sexual abuse. In another case, a local priest had invited a friend to live in his house and work in the local church. When he discovered that this individual was sexually abusing children he removed all of the former friend's possessions out of his house and threw them in the front yard. The fact that this abuse was coincident with the merger of local parishes heightened the distrust and anger felt towards the church by Mount Carmel residents.

Important as these events were personally for those affected, and in terms of the overall distrust of the church by town residents, child sexual abuse by priests was also important in terms of the way it shaped Father Marty's early religious leadership experiences. He arrived at Bucknell as a new priest at the height of the child abuse crisis and he felt during his time at the University that there was always distrust, since his role involved working with young people. Part of his pride about the time he spent at Bucknell was in the way his clergy colleagues and he were able to make these concerns irrelevant, demonstrating as they did meaningful, strong ties with students and playing such a positive, important role in campus life.

For Father Marty, the child abuse scandal was made more difficult because it was conflated with what he perceived as distrust and perhaps prejudice against Catholics. He said, for example, that he was not allowed to wear a collar on campus during his time at Bucknell. There was long-standing frustration that the Protestant and Jewish chaplains were paid as university staff but the Diocese had to pay the Catholic chaplain. This meant that he was not eligible for some benefits the other chaplains received as university employees. It also set him up for criticism by some administrators who said he worked for an outside organization and was not really part of the University program.

It is perhaps always puzzling for an outsider to hear about accounts of prejudice (a Protestant person listening to a Jewish friend talk about perceived anti-Semitic slights in campus programming is similarly hard to interpret). However, in Lewisburg (where Bucknell is located), and in Central Pennsylvania generally, anti-Catholic prejudice is historically real (for a review of anti-Catholic sentiment in Protestant communities see [32]). The largest church congregation in Lewisburg is the Catholic one, but the church building was only built in the 1950s, while most of the other local congregation buildings date to the late 19th century. There is a sign downtown marking the spot where the first Catholic meeting was held in town in the late 1700s. The Catholic building took 200 years to build because none of the local landowners, all Protestants, would sell land to the Catholics for a church.

Father Marty's formative years as a priest were colored by the two negative experiences of distrust because of child abuse and resistance from Protestants. One might take this as an idiosyncratic personal story, except that, when we were interviewing the Sisters of St. Casimir in Chicago, their leader told of her own experience of prejudice against Catholics when, in the 1990s, she was involved in her PsyD training to become a clinical psychologist at the Chicago School of Professional Psychology. She encountered situations where people made prejudiced comments about the Catholic religion even though she was right there in the room. Clearly, it hurt and offended her on one hand, but on the other hand it pushed her to develop a resolve to confront the situation openly in seminar settings. This was a school that prided itself in its openness to diversity, yet there was clearly a bias toward Catholicism (for further discussion of prejudice against Catholics in professional circles see the discussions of priest and former University of Chicago sociologist Andrew Greeley $[33,34])$. 
There is a toughness of personality that she manifests that we also see in Father Marty. He is definite and positive about the strong leadership and socializing role he can play with parishioners, including children. He has also said with pride that the Diocese has around 10 young priests. It has been successful in attracting young people to the vocation and he says it has been recognized by residents in town that the Diocese supports the region because it has been sending dynamic young priests to serve the area. For years, people thought the Diocese just sent old retreads to serve as priests in the area, but that perception is changing now.

\section{The Recent History of Bucknell University}

The partnership developed in a different way on the Bucknell University side. The Coal Region Field Station was an important development, formalizing an initiative by faculty that has slowly been developing over a decade or more. What is important is that the University for the first time has recognized and given formal support to a community research and action center. This has been possible primarily because the need and symbolic importance of the coal region has made this a project that people could visualize and its worth as a social action project was clear. Where our work in the past had struggled because it lacked a metaphor or a symbolic anchor, the Mount Carmel project had immediate broad appeal that made support institutionally possible.

Bucknell is a private liberal arts university located in rural Central Pennsylvania. It tends to be somewhat inwardly focused as an institution. Historically, it had a limited mission basis for serving or relating to the surrounding community. When a new strategic plan was created shortly after the year 2000, "building bridges" to the community was added as a strategic goal, but the University has struggled to find programmatic ways to achieve this goal. At the same time, it has a number of faculty whose research and teaching are oriented to being involved in the local community. Some of this orientation has to do with fields like sociology, psychology, and environmental studies, where internships in the community and student research projects that identify and explore community problems are an important part of the curriculum. These faculty members have also been committed to using the resources of their university to help and serve people in the communities that populate the region.

For more than thirty years, a small group of senior faculty had been working with community professionals using research skills, university resources, and the labor of student interns to support a variety of community projects. While many of these efforts were private projects of the faculty involved, these individuals also were mindful that being involved in one project often created opportunities to come back to do a second project with the same partners, or to start projects with other community actors who were tangentially involved previously [35]. We became aware that "chaining" [10] allowed one project to lead to another. As we moved from one project to the next, our opportunities to work and be involved became richer, more complex, and capable of involving a larger number of university people.

Projects tend to be concentrated in specific geographical areas and, as time passed, faculty began to use the terminology of "field stations" to describe concentrations of work in different places. One of those places was the coal towns of Shamokin, Mount Carmel, and Mahanoy City, which, together, have made up our Coal Region Field Station. We work in a rural region of small towns that are separated by ten to fifteen miles of farmland, geographic features like rivers and mountain ranges, and the political boundaries of county lines. While the concept of field stations had begun to coalesce in our thinking, and our teaching and research projects corresponded to the distinctive problems of different communities and local areas, the concept remained informal at Bucknell.

Our faculty group began to gain institutional traction about three years before Father Marty began his efforts to develop the Mother Maria Kaupas Center. As part of Bucknell's Center for Sustainability and the Environment, a research group was formed to focus on humanities and the social sciences. The humanities group was particularly effective, focusing on the history of the Susquehanna River basin and on indigenous stories related to the region and its towns. Membership in the group gave 
the two social scientists a reason to join together. They recognized that they had used similar research strategies over their decades of work at Bucknell but had never worked together. Comparing notes and developing mutually supportive teaching and research projects, it became clear that each had long-standing involvements and commitments to specific towns. Further, the two were able to use contacts developed over years to support each other when they wanted to develop new projects [36].

The idea that we had enduring commitments to specific places, that we could help new participants avoid the difficulty of having to develop rapport and network contacts with local residents, and that projects could chain together, gave form to the idea that we had developed field stations. We knew about the field station concept from other disciplines like anthropology, where professors and students would build a long-term involvement in a place. New and different projects could develop in that place. The history of involvement and the commitment to integrating newcomers, whose work focus might be imperfectly developed upon their arrival, gave the field stations institutional endurance.

Two years into the humanities/social sciences partnership at the Center for Sustainability and the Environment, we were able to hire an advanced graduate student, Brandn Green, as a part-time employee. With a background in rural sociology, he quickly understood the logic of the field station idea and he felt comfortable traveling around the region meeting local people, helping to set up new projects, and providing an operational center students could use as a staging platform. The pace at which one project chained into another project picked up. Green also had the inclination, the time, and the institutional resources to advertise our work to other Bucknell faculty, and he began building a larger group of interested and involved people.

In the fall of 2014, Green and Father Marty began talking about our interest in creating formal field stations in different communities around the region. It is lost in the mists of history which of the two ideas-the Mother Maria Kaupas Service Learning Center sponsored by Divine Redeemer Catholic Church and the Coal Region Field Station sponsored by what is now was called the Place Studies Program at the Center for Sustainability and the Environment-came first. Both groups had a lot of internal organizing work to do at the beginning and the development of the organizational machinery was separate.

\section{The Structure of the Partnership}

What we have described so far is a partnership project that grew out of a happy accident, that initiatives within two institutions dovetailed with each other so that the whole initiative could move forward quickly and smoothly. The result is an innovation that is dramatic for both institutions. From the church side, the willingness of a secular liberal arts institution to partner with a religious organization in a respectful and energetic way represents an opportunity that other dioceses are likely to want to reproduce. It comes in the wake of decades of distrust expressed by secular social scientists, that goals, values, and projects originating within church contexts should be taken seriously as valid social change efforts. On the university side, the understanding and sophistication of the church partners allows community research, community-based learning, and social service opportunities to be shared among a wider group of faculty and staff than was possible in the past.

While these developments make for a nice story, they do not point out a puzzle or a problem that could motivate an academic paper. The puzzle comes because partners on the Catholic Church side of the equation were surprised that members of a secular liberal arts university would want to partner with a Catholic Church project. We, on the Bucknell side, did not expect to find a low-income community whose members would embrace and support university people working in their midst. Making sense of these reciprocal feelings of disbelief is the focus of the next section of this paper.

Understanding surprise on the part of one partner might not seem like the kind of robust issue or problem that could drive a sociological analysis. In this case, it helps us to recognize and interpret some complex changes, both in the Catholic Church and in the community experience of Catholics who live in isolated, low-income coal region towns. We might understand the word "surprise" just to mean pleasure that this venture worked out so well. It is better to understand the term as, "Wow, 
we had this wild idea that we never thought would work out and all of our speculative ideas turned out to be right! This is working better than we even imagined it could."

When Father Marty did a survey of the congregation shortly after he arrived, he learned about anger that the archives and icons of the historic local churches had been given away. He also learned about discouragement with the economic fortunes in the town. Bringing in grant money to support the Mother Maria Kaupas Center, using the funds to renovate buildings, and then being able to bring Bucknell and its resources in to help with town projects seems to have made town residents feel that the church was bringing positive change. Part of the reason town residents support the Mother Maria Kaupas Center, and welcome Bucknell students and staff (they might be rejecting since the town can be seen as insular), is that they seem to feel that the Diocese in Harrisburg is investing in the town and that the church is back.

While the Sisters of St Casimir have played a crucial role in bringing the Mother Maria Kaupas Center into existence, equally important are the personal historic ties Father Marty has to Bucknell University. Perhaps the most important thing, is that he understands how the university works and how community-based learning and service learning operates. Early in the process of his creation of the service learning center, several people from Bucknell approached him and asked for his support in creating a university-based "field station". It was striking to the university people that, from the beginning, Father Marty understood exactly what they were talking about. Since many colleagues at the university could not really understand what they were trying to do, it was a surprise to encounter Father Marty with his sophisticated understanding of how such a project might work.

Because of his long and successful tenure at Bucknell, Father Marty also had many ties to people at the university. He could imagine how the university might act to support his project and when he had the opportunity to meet with university people he could explain fully the relationship between his church and its service learning center and the university.

Development and progress at the Mother Maria Kaupas Center happened very quickly, and as the whole project was constituted and new, dynamic projects were launched over a period of eighteen months. It seems fast and unusually successful. However, from an ABCD framework, all that had to change was the perspective. The talents and raw materials had always been there. What had to change was that participants had to see the resources and use them. That is what happened when the Mother Maria Kaupas Center came into existence.

The establishment of the Mother Maria Kaupas Center was under serious consideration in November 2014. The Divine Redeemer Parish members had to agree to make this a formal ministry of the congregation and the Diocese of Harrisburg had to approve the project. Father Marty quickly moved to create a board, inviting individuals from the community, from among his Bucknell alumni friends, from the regional Catholic community, and from Bucknell staff members. Early on, there were efforts to produce documents like a policy manual, a business plan, and understandings about insurance liability, which were difficult to produce since the center and its programs were mostly theoretical at that stage. However, the project came together and gained enough official structure so that the Mother Maria Kaupas Center was formally dedicated in April 2015. A group of the Sisters of St. Casimir came out from Chicago to join sisters from one of their original sponsoring organizations at Marywood University.

Once the center was formally created, a next step was to create an explicit relationship with Bucknell University. In June 2015, a Memorandum of Understanding was signed between Bucknell and the Diocese of Harrisburg and Bucknell agreed to make a $\$ 6000$ payment to compensate for space used and for staff support. In a six-month period, the center had progressed from an idea to a formal organization with partnership programs

On the Bucknell side, two related centers had developed and efforts were made to widen the faculty governance group. The group had secured some funding that allowed us to give summer grants (for summer 2015) to two junior faculty members and three students to do research centered on 
the coal region. There also was one class and an independent student initiative that spent the spring term working in the coal region, producing videotapes on local themes.

Despite some administrative turmoil internal to the University, student and faculty interest and involvement in the region still evolved. Research projects developed and grew and classes continued to be focused on the coal region towns of Mount Carmel and Shamokin. In spring 2016, there were four classes working on different projects in the coal region and Bucknell students and staff were involved in planning and development of a Kaupas Camp for summer, 2016. Field Station leaders also sought permanent university funding for operational expenses of the program along with a more programmatic university financial contribution to the administrative costs of the Center.

\section{The Importance of Mother Kaupas as a Symbol}

Mother Kaupas was born in Lithuania, lived in a country that did not allow education for Catholics or for women, and had the opportunity to leave this situation when her brother, a priest in Scranton, PA invited her to serve as his housekeeper. She expressed her sense of calling to serve religiously. Her brother helped her return to Europe to complete her education. He then was able to link her with the sisters, Servants of the Immaculate Heart of Mary, in Scranton, PA (who were Irish) and who prepared her to found a religious order of women serving immigrant Lithuanians, and to a priest in Mount Carmel who helped her establish a teaching religious order whose first school, Holy Cross, was in Mount Carmel. Mother Kaupas then was asked to establish the center of her religious community in Chicago so she could serve its much larger Lithuanian community. This led to the development of the mission of the Sisters of St. Casimir and, its network of almost 500 sisters, to a number of Catholic elementary and high schools and number of hospitals [30,37].

Discovering Mother Kaupas certainly made a successful venture out of Father Marty's dutiful exploration of local people who were not formally appointed as church officials (as are priests), but who created or became part of philosophical and service initiatives (as is the case with an order of nuns). His discovery was not exactly a happy accident, however. It brought to the surface a simmering anger among members of the local Catholic population. The discovery gave him, as a new priest, a means to address this anger in a way that could help to heal wounds that had developed over the previous 25 years.

The Mother Maria Kaupas Center project became an action strategy by which the Diocese could serve the needs of the people in the coal region. While the reasons priests are given parish assignments are always somewhat obscure, one reason Father Marty may have been placed in Mount Carmel was to use his considerable entrepreneurial gifts, seeking a way for the Catholic Church to address and perhaps help reverse poverty in this isolated and discouraged town. Following the philosophy of Catholic social teachings, Father Marty wanted to use the church to build the community. In his philosophy, addressing poverty in ways that might have secular connections is a religious act that builds both the church and the town.

\section{Discussion}

As we said at the beginning of the paper, there is surprise at the rapid development and seeming success of the Mother Maria Kaupas Center. The surprise comes partly because the vision of using a church/university partnership to create development opportunities in the struggling low-income community of Mount Carmel seems to be working. Most apparent to outsiders (like to board members of the center who are not on the local scene), is that both academic projects and local development efforts are being created and are supported by residents and local institutions like the school system.

\subsection{Change in Perspective}

The more important reason for success has to do with the way historical dysfunctions have been resolved. Local culture and identity are very important features of coal region towns, and the Catholic Church is embedded in the grammatical logic of coal culture [5,24]. Residents may have felt betrayed 
by the Diocese as it closed and merged churches, and families may have left the church in anger and pain in the wake of child abuse scandals. However, it seems, in important respects, that with the Mother Maria Kaupas Center for Service Learning, the Church has returned to lead the community.

This is not to say that the participants were blind or unsophisticated at evaluating what was in front of them. There were real historical events related to prejudice and oppression. There were abuses and conflicts. There was a real collapse of the coal economy and an out-migration of talented young people from poor communities. There also was no easy or automatic way to know that the resources or movements of social support that have come into play at the center were there, lying fallow. It is valuable to understand, however, that sometimes the simple change in perspective represented by the $\mathrm{ABCD}$ approach, representing as it did the article of faith that Father Marty brought to his work in Mount Carmel and the possibility of this program becoming a reality, can make opportunities that were invisible, apparent, and dynamic.

While these are some contemporary events, it should also be appreciated how important historically the Catholic Church was as it grew in the 19th and early 20th centuries and served as a national, wealthy, anchor institution. It embodied a contrasting view to the perspective of struggle found in the labor movement [27] and the struggle against dominating Protestant institutions (like public schools [38] or institutions of higher education, like Bucknell University). It brought a perspective that was nurturing, that used its human resources so that educated and established immigrants would help newcomers, and where religious people from different ethnic groups supported and assisted each other. The church also brought an internal, formal organizational structure that conferred a style of hierarchy and the authority of office, while also being sponsoring and personally supportive.

The Mother Maria Kaupas Center project provides a vision of what the town might be and what it might achieve when the town has otherwise been discouraged and in decline. It is striking how much authority the Father has with town residents and how willing residents and leaders are to support him and to accept his suggestions. The partnership with Bucknell is important because some real resources, in the form of some material goods, in the form of professional leadership, and in the form of student energy and enthusiasm, have been brought to the town. Father Marty, for his own part, enjoys being welcomed back to an institution where he "grew up" and where he often felt rejected.

\subsection{Symbolism of Place}

Two symbols have been central to the success of the collaboration. They are of the same concept, Mount Carmel as a place. For the church, Mount Carmel is a symbol that elicits nostalgia. By identifying a central figure in Mount Carmel, Father Marty has connected revitalization of the Divine Redeemer Parish to a past that is uncritically accepted by residents as positive. Their town was created through the immigration of individuals like Mother Kaupas. For many, their family histories parallel that of the Sisters.

Three or four generations ago, many of the family members of those who attend Divine Redeemer Church arrived in the coal region to take advantage of the economic boom at the advent of the industrial revolution. This was a complicated and difficult lifestyle, but one that produced economic growth for the succeeding generations that benefited from the social infrastructure and wealth. The children of the second generation grew up in both the tail end of the economic growth generated through natural resource extraction in the region and the collapse of an economic system unable to compete in a globalized market. Father Marty has found a symbol that connects the church directly to this story of both growth and decline, and more importantly, to the period of growth. The attachment to the coal region identified by Marsh [25], is now being utilized by Fr. Marty to create hope for the future through reinvestment by the church and by those with ties to the coal region.

Bucknell is, like many universities, actively establishing programs and academic structures to engage undergraduate students in meaningful community-based learning opportunities [10]. The service learning movement during the 1990s expanded the self-conception of the university beyond 
the goal of simply providing services for students to include an ideal of being active members of the communities within which they were located. This rise of localism by universities parallels the way alternative, viable, economic drivers have abandoned small and medium sized regional towns and cities [39]. Forces of globalization have been negative for the residents of Mount Carmel. Meanwhile, Bucknell's goal to educate students to work more effectively with people from different cultural and socioeconomic backgrounds is driven by the need to prepare young people to succeed in a globalized environment. One might be concerned that a dynamic like this one has produced university-dependent communities across the country. At the same time, and in a positive way, universities have used their surplus labor toward the end of improving community life.

One can puzzle about why a university would want to do this. As an organization and as a collection of individuals, before beginning its program, there was little personal or emotional attachment to the coal region within prospective participants in the Coal Region Field Station. This lack of attachment requires the identification of separate and complementary value structures to which Bucknell students and faculty could connect. Mount Carmel, rather than being a place the university had a mission-based reason to serve and reinvigorate, is seen as a place in need that exemplifies the national crisis described by Robert Putnam [40] in his recent book, Our Kids, and by our colleague and Coal Region Field Station participant, Jennifer Silva [41] in her book, Coming Up Short. American society fails to provide viable economic, institutional, and existential resources to residents or working-class towns and neighborhoods across the country.

In the views of Putnam and Silva, this is a national crisis of the first order. Putnam also believes that the only way communities like Mount Carmel can be saved is if middle-class people and large wealthy institutions like the Catholic Church and Bucknell University contribute resources, expertise, and institutional assets to the project of making life more economically viable and personally meaningful for people in these working-class areas. ${ }^{1}$

So far, this effort has been working because there is great symbolic power for both Bucknell people and for leaders of the Catholic Diocese where the task of revitalizing the Mount Carmel community is concerned. This symbolism has drawn members of the two institutions together in what many consider an unlikely partnership. However, neither the University nor the Church can enter the community as saviors, even if this image is part of the symbolism that draws activists into the work. The point of this paper is that the community has valuable, indigenous assets that can be turned to the task of building community resilience. The church and the university, meanwhile, cannot help if they merely bestow their excess wealth on the town. Their presence only has value if they serve as catalysts, allowing residents to achieve successes that already exist in the town as potentialities.

\section{Conclusions}

While we can understand the surprise felt by parties to the Mother Kaupas Center, this does not change the fact that we are writing about a project that is in its infancy. It faces challenges that beset any new organization. It must become legally and institutionally established. It must develop a resource base that supports its current program and that can be sustainable over time. It must come up with projects that express felt needs in the community and it must assemble partners and resources that allow those projects to move forward to success. Doing these things means that the leaders must be creative about thinking up new ways to access resources and they must develop skills at things like writing grants and reaching out to elected officials, convincing them to support the self-help effort of this indigent community.

Success of the project also relies heavily on the Coal Region Field Station network and its capacity to convince the university to invest in the center and support it with legitimacy. Faculty must find

1 Robert Putnam stated this position in a speech at Bucknell University on 10 April 2016. The position supplements the argument of his book Our Kids [39]. 
value in the community and the center in terms of producing subjects of research and ways of building class projects around local experiences. The town of Mount Carmel is 35 miles from campus and both students and faculty have to be willing to travel to work in the place.

While there are practical challenges to moving this initiative forward, the upside of the project is symbolic. On the town side, we could say that the community is undervalued and that it has much to gain when participants recognize that there are underutilized assets that can make projects successful and improve the bleak situation of the community. On the university side, there is much to be gained if Bucknell sees its local region as a place with an exciting history. University leadership can play a role in transforming the local area from a discouraging locale with few opportunities into an exciting place where university activities can give meaning and energy in a way that fosters a positive vision of the place and its future.

Acknowledgments: We would like to thank our colleages at the Mother Maria Kaupus Center and Bucknell University for their helpful insights and valuable feedback. In addition, we would like to give a special acknowledgement to the Sisters of St. Casimir.

Author Contributions: $\mathrm{CM}$ and BG were equally responsible for the conception of the article. CM collected data and drafted the article. BG provided review, scientific writing, and editorial assistance.

Conflicts of Interest: The authors declare no conflict of interest.

\section{References}

1. Carl Milofsky, and Heather Feldhaus. "Teaching Sociology and Developing Community Assets through Collaborative Community-Based Research." Paper presented at meetings of the Eastern Sociological Society, New York, NY, USA, 23 February 2012.

2. Nick Acheson, and Carl Milofsky. "Derry Exceptionalism and an Organic Model of Sustained Dialog." In Public Deliberation and Sustained Dialoathergue: Pracademic Perspectives. Edited by R. Lohmann and J. Van Til. New York: Columbia University Press, 2011, pp. 167-85.

3. Albert Hunter. Symbolic Communities. The Persistence and Change of Chicago's Local Communities. Chicago: University of Chicago Press, 1974.

4. Gerald D. Suttles. The Social Construction of Community. Chicago: University of Chicago Press, 1972.

5. Harold Aurand. Coal Cracker Culture. Work and Values in Pennsylvania Anthracite, 1835-1935. Selinsgrove: Susquehanna University Press, 2013.

6. Herbert J. Gans. The Urban Villagers. Group and Class in the Life of Italian Americans. New York: Free Press, 1962.

7. Vicky Cattell. Poverty, Community, and Health. Basingstoke: Palgrave MacMillan, 2011.

8. Albert J. Hunter, and Gerald D. Suttles. "The expanding community of limited liability." In The Social Construction of Communities. Edited by Gerald D. Suttles. Chicago: University of Chicago Press, 1972, chap. 3, pp. 44-81.

9. Carl Milofsky. "Organization from Community. A Case Study of Congregational Renewal." Nonprofit and Voluntary Sector Quarterly 26 (1997): S139-60.

10. Carl Milofsky, and Brandn Q. Green. "Chaining and Virtual Organization in a Slow Sociological Project: The Brown Ridge School District Health Needs Assessment becomes the Central Susquehanna Affordable Care Act Project." Applied Sociology 9 (2015): 170-81.

11. Albert Hunter. "The Symbolic Ecology of Suburbia." In Neighborhood and Community Environments. Edited by Irwin Altman and Abraham Wandersman. New York: Plenum, 1987.

12. Rick Eckstein, and Kevin Delaney. "New Sports Stadiums, Community Self-Esteem, and Community Collective Conscience." Journal of Sport and Social Issues 26 (2002): 235-47. [CrossRef]

13. Terri Mannarini, Stefano Tartaglia, Angela Fedi, and Katiuscia Greganti. "Image of neighborhood, self-image and sense of community." Journal of Environmental Psychology 26 (2006): 202-14. [CrossRef]

14. Lee Cuba1, and David M. Hummon. "A Place to Call Home. Identification with Dwelling, Community, and Region." The Sociological Quarterly 34 (2005): 235-47. [CrossRef]

15. Eric Klinenberg. "Race, place, and vulnerability: Urban neighborhoods and the ecology of support." In Heat Wave. Chicago: University of Chicago Press, 2002, chap. 2, pp. 79-128.

16. Anne F. Young, Anne Russell, and Jennifer R. Powers. "The Sense of Belonging to a Neighbourhood: Can it Be Measured and Is it related to Health and Well Being in Older Women?" Social Science and Medicine 59 (2004): 2627-37. [CrossRef] [PubMed] 
17. Stefan Stürmefr, and Claudia Kampmeier. "Active Citizenship: The Role of Community Identification in Community Volunteerism and Local Participation." Psychologica Belgica 43 (2003): 103-22.

18. John P. Kretzmann, and John L. McKnight. "Introduction." In Building Communities from the Inside Out. A Path Toward Finding and Mobilizing a Community's Assets. Skokie: ACTA Publications, 1993.

19. John P. Kretzmann, and John L. McKnight. "Releasing Individual Capacities." In Building Communities from the Inside Out. A Path Toward Finding and Mobilizing a Community's Assets. Skokie: ACTA Publications, 1993.

20. Amnon Boehm. "Clients and Social Workers' Perceptions of Social Work: An Israeli Case Study." British Journal of Social Work 43 (2013): 964-86. [CrossRef]

21. Benzoin Cohen, and Eli Buchbinder, eds. "Intervention Using the Strengths Approach in Social Work." In Maximizing Capacities: Applications of the Strengths Perspective in Social Work. Tel Aviv: Ramot, 2005 (cited in Boehm 2013).

22. Carol T. Mowbray, Michael E. Woolley, Andrew Grogan-Kaylor, Larry M. Gant, Megan E. Gilster, and Trina R. Williams Shanks. "Neighborhood Research from a Spatially Oriented Strengths Perspective." Journal of Community Psychology 35 (2007): 667-80. [CrossRef]

23. Dennis Saleebey. The Strengths Perspective in Social Work Practice. Boston: Allyn \& Bacon, 1997.

24. Janet MacGaffey. Coal Dust on Your Feet: The Rise, Decline, and Restoration of an Anthracite Mining Town. Lewisburg: Bucknell University Press, 2013.

25. Ben Marsh. "Continuity and Decline in the Anthracite Towns of Pennsylvania." Annals of the American Association of Geographers 77 (1987): 337-52. [CrossRef]

26. USA.COM. "State Median Household Income and School District Rank." Available online: http:// www.usa.com/rank/Pennsylvania-state--median-household-income--school-district-rank.htm (accessed on 6 June 2016).

27. Philip Taft. Organized Labor in American History. New York: Harper \& Row, 1964.

28. Kevin Kenny. Making Sense of the Molly Maguires. New York: Oxford University Press, 1998.

29. Stewart Wolf, and John G. Bruhn Medical. The Power of the Clan. The Influence of Human Relationships on Heart Disease. New Brunswick: Transaction Publishers, 1998.

30. Sister M. Immaculata Wendt. Sisters of St. Casimir. A Journey in Faith. 100 Years 1907-2007. Dublin: Booklink, 2007.

31. Loren B. Mead. The Once and Future Church. Durham: Alban Institute, 1991.

32. Wikipedia. "Anti-Catholicism in the United States." 2016. Available online: https://en.wikipedia.org/ wiki/Anti-Catholicism_in_the_United_States\#Anti-Catholicism_in_the_entertainment_industry (accessed on 26 April 2016).

33. Andrew M. Greeley. An Ugly Little Secret: Anti-Catholicism in North American. Kansas City: Sheed, Andrews, and McMeel, 1977.

34. Andrew M. Greeley. "'An Ugly Little Secret' Revisited: An Analytic Reflection." U.S. Catholic Historian 21 (2003): 79-84.

35. Carl Milofsky. Smallville. The Institutionalization of Community in Twenty-First Century America. Hanover: University Presses of New England, 2008.

36. Carl Milofsky, Ben Marsh, and Brandn Green. "Social Assets Mapping as Data Collection and Community Organizing." Lewisburg: Place Studies Center, Center for Sustainability and the Environment, 2012. unpublished paper.

37. Sister Margaret Petcavage, SSC, and Sister Regina Dubickas, SSC, eds. Loving You, Mother Maria. Dublin: Booklink, 2012.

38. Abigail McCarthy. "Out of Small Town America." Atlantic 229 (1972): 74-84.

39. Ira Harkavy, and Matthew Hartley. "Pursuing Franklin's Dream: Philosophical and Historical Context of Service Learning." American Journal of Community Psychology 46 (2010): 418-27. [CrossRef] [PubMed]

40. Robert Putnam. Our Kids. New York: Simon \& Schuster, 2015

41. Jennifer M. Silva. Coming up Short. Working Class Adulthood in an Age of Uncertainty. New York: Oxford University Press, 2013.

(C) 2016 by the authors; licensee MDPI, Basel, Switzerland. This article is an open access article distributed under the terms and conditions of the Creative Commons Attribution (CC BY) license (http:/ / creativecommons.org/licenses/by/4.0/). 
Article

\title{
Small Faith-Related Organizations as Partners in Local Social Service Networks
}

\author{
David Campbell \\ Department of Human Ecology, University of California, Davis, One Shields Avenue, Davis, CA 95616, USA; \\ dave.c.campbell@ucdavis.edu; Tel.: +1-530-752-5451
}

Academic Editor: Robert Wineburg

Received: 15 February 2016; Accepted: 11 May 2016; Published: 20 May 2016

\begin{abstract}
Efforts to enlist small faith-related organizations as partners in public service delivery raise many questions. Using community social service networks as the unit of analysis, this paper asks one with broader relevance to nonprofit sector managers: What factors support and constrain effective integration of these organizations into a local service delivery network? The evidence and illustrations come from longitudinal case studies of five faith-related organizations who received their first government contract as part of a California faith-based initiative. By comparing the organizational development and network partnership trajectories of these organizations over more than a decade, the analysis identifies four key variables influencing partnership dynamics and outcomes: organizational niche within the local network; leadership connections and network legitimacy; faith-inspired commitments and persistence; and core organizational competencies and capacities. The evidence supports shifting the focus of faith-based initiatives to emphasize local planning and network development, taking into account how these four variables apply to specific organizations and their community context.
\end{abstract}

Keywords: faith; social services; organizational capacity; network; niche; community planning

\section{Introduction}

It has been two decades since federal welfare reform legislation cemented a shift in U.S. social policy away from cash assistance toward work-first programs designed to reinforce work incentives [1,2]. Charitable Choice provisions in the 1996 legislation sought to expand the role of faith-related organizations as government partners, with some viewing this as a way to shore up the safety net for poor citizens. Subsequently, community-level research has found that Charitable Choice did relatively little to alter pre-existing service delivery patterns, in part because congregations and other faith-related organizations were already integral parts of local social service networks, whether or not government policy or funding is involved [1,3-6]. This was true long before welfare reform and will no doubt persist, for two fundamental reasons. First, religious organizations have strong doctrinal and practical commitments to serve the poor and needy $[1,7,8]$. Second, in many poor neighborhoods and communities, churches and small faith-related nonprofits are among the few visible, viable (if not always thriving), and trusted institutions of any kind [9-14].

While students of social policy have much to gain by understanding the roles played by small, faith-related nonprofit organizations in local social service networks, these organizations pose a paradox as network partners. On the one hand, because they are often the only entity serving the most destitute clients and neighborhoods, faith-related organizations occupy a critical locational, cultural, and/or programmatic niche. On the other hand, their characteristic ways of working with program participants-marked by adaptive relationship-building that meets clients where they are rather than deployment of static, pre-set programs-fit uneasily into a social service world increasingly 
marked by bureaucratic norms, standardized programs, and rigid accountability metrics. While much attention has focused on how government can partner with these organizations within church-state legal restrictions $[15,16]$, the larger question posed is how to integrate these types of organizations into reciprocal network relationships governed by prevailing professional norms and standards. Many of the same issues are raised by partnerships with secular nonprofits of limited size and capacity, although they are not the focus of this analysis.

To explore this issue further, this paper asks: What primary considerations should inform local network leaders and the directors of small, faith-related organizations as they develop partnerships? The data come from unique access to five faith-related organizations which received their first-ever government contract during a California faith-based initiative. Using data points spanning more than a decade, we can describe and compare the organizational and network partnership trajectories of these five organizations. Using a combination of outcome and process analysis, the research isolates four key variables that distinguish more or less successful partnership outcomes: organizational niche within the local network; leadership connections and network legitimacy (i.e., being perceived as a good partner by existing network leaders, especially those in key organizations that can supply funding, referrals, or other resources); faith-inspired commitments and persistence; and core organizational competencies and capacities. The findings support recommendations for policy makers, local network leaders, and the directors of faith-related nonprofit organizations. Though the focus is on faith-related organizations, the insights have relevance to a broader class of smaller nonprofits engaged in human service delivery.

\section{A Local Network Perspective on Faith-Based Initiatives}

Two inter-related concerns about organizational approach and capacity have been raised in the literature on faith-based initiatives. The first is that small, faith-related organizations do not have the staff capacity needed to manage government funding and associated accountability and reporting requirements [17-19]. The corresponding concern is that developing this capacity will erode the distinctive characteristics that make these organizations valuable in the first place $[15,20]$. Indeed, much of the literature emphasizes the drawbacks of government funding for nonprofits including mission creep, bureaucratization, burdensome paperwork, diminishing support from volunteers, and a general loss of the organizational characteristics that make them a viable alternative to government [21-25]. Some research finds benefits, noting that government grants provide seed funding that fuels nonprofit initiative, confers organizational legitimacy and visibility, builds managerial capacity, and enables better quality services $[26,27]$.

Evidence suggests that government collaborations with faith-related organizations will require nuance and flexibility on both sides, attending both to the community context and to the specific nature and attributes of the faith-related organization [1,3]. The difficult work of supporting individuals in need requires pragmatic, locally-specific coordination to improve service integration and network governance $[28,29]$. Research shows that most clients receive social services from multiple agencies simultaneously $[6,30]$; that the services of faith-related organizations are intricately braided with those provided by publicly funded social service agencies [4,5]; and that there are few major differences between the efficacy of services provided by faith-related and secular organizations [3,31]. The challenge is less to find a single best provider according to pre-set criteria than to coordinate community assets to meet the specific needs of program participants and community partners. Thus, instead of comparing organizational effectiveness in isolation, researchers have begun to focus on a more compelling question: How do various local social service providers, both public and private, collaborate to create integrated systems of care? [1,32]. The work is practical and involves finding better ways to support information and resource sharing, cross training or co-location of staff, and other day-to-day coordination mechanisms that are essential to improve outcomes for client, organizations, and communities. 
Many local social service networks still operate as closed systems in which government generally partners only with a few, large nonprofits that mimic the culture and practices of government organizations [33]. Whether these established patterns can or should shift is an open question. A key issue raised by previous research is whether this effort will be driven by the self-serving needs of politicians and administrators for symbolic or token faith-based partners or by a genuine effort to forge partnerships that acknowledge the promise and limits of particular faith-related organizations $[5,34,35]$.

\section{Approach and Methods}

The author's engagement with these issues began during research on how local communities were implementing welfare reform [33] and continued during evaluation research examining the California Community and Faith-Based Initiative (CFBI). Backed by Governor Gray Davis, CFBI funded 40 community and faith-related organizations as partners in government workforce development efforts, primarily during the years 2002-2005. The goal was to harness the unique locational and cultural assets of these organizations to expand the reach of workforce development service to underserved populations, including ex-offenders, recovering addicts, and the homeless. As documented elsewhere $[30,32,36]$, the initiative succeeded in expanding the reach of workforce services, and demonstrated that a focused effort by a state agency could indeed increase the organizational capacity of non-profit partners, including both secular and faith-related organizations. But the evaluation and subsequent follow up research also called into question the staying power of the resulting partnerships. Mirroring the findings of related studies, a survey conducted in 2008, three years after the initiative ended, found that about a third of the faith-related organizations for whom the state grant was their first government contract had closed [32,37].

Building on the earlier work, this study traces the organizational and network partnership trajectories of five small, faith-related organizations that were involved in the California initiative. The five cases were purposively selected from a sample of 14 nonprofits which researchers studied using community network analysis during the CFBI evaluation [36]. The selection criterion was straightforward: the case histories represent the five faith-related organizations among the 14 for whom the funding was their first-ever government grant. Secular nonprofits (5) and faith-related organizations which did have previous contracting experience (4) were excluded. Table 1 presents basic information on the five organizations.

Table 1. Characteristics of the Sample Organizations.

\begin{tabular}{|c|c|c|c|c|c|c|}
\hline Organization & Location & Faith Category $^{a}$ & $\begin{array}{c}\text { Years Org } \\
\text { Established } \\
\text { Prior to } \\
\text { EDD Grant }\end{array}$ & $\begin{array}{c}\text { Approximate } \\
\text { Staff-Participant } \\
\text { Ratio }\end{array}$ & $\begin{array}{l}\text { \# of Orgs in } \\
\text { Organizational } \\
\text { Network }^{\mathbf{b}}\end{array}$ & $\begin{array}{c}\sim \% \text { ED Time } \\
\text { Spent on } \\
\text { External } \\
\text { Networking }\end{array}$ \\
\hline Zaferia Shalom & $\begin{array}{l}\text { Long } \\
\text { Beach }\end{array}$ & Faith-background & 10 & $1-12$ & 33 & $25 \%$ \\
\hline $\begin{array}{l}\text { Helping Hands } \\
\text { of Hope }\end{array}$ & Berkeley & Faith-background & 0 & $1-5$ & 35 & $15 \%$ \\
\hline $\begin{array}{c}\text { CHAMPIONS } \\
\text { Recovery }\end{array}$ & Hanford & Faith-centered & 2 & $1-15$ & 67 & $50 \%$ \\
\hline Tabitha's House & Bakersfield & Faith-centered & 10 & $1-7$ & NA & NA \\
\hline $\begin{array}{l}\text { Welcome Home } \\
\text { Ministries }\end{array}$ & San Diego & Faith-centered & 8 & $1-8$ & 81 & $90 \%$ \\
\hline
\end{tabular}

${ }^{a}$ Based on the categorization scheme developed by Sider and Unruh [16]; ${ }^{\mathrm{b}}$ Based on network mapping exercise conducted with organizations in 2005 (Tabitha's House did not participate); ${ }^{c}$ Based on interview question with executive directors in 2005 (Tabitha's House did not participate).

The data make it possible to track the ebb and flow of each organization's status and government funding partnerships from their founding until early 2016, over periods of time ranging from 14 to 24 years. Data sources include semi-structured interviews from the 2002-2005 evaluation revealing 
the experiences and perspectives of executive directors and staff, program participants, partner organizations, and leaders in the local service network. Two of the five organizations closed at or near the end of their CFBI grant. For the three organizations that outlived the grant, additional interviews were conducted with executive directors in 2008 and in 2016 to track post-grant developments. All told, there are approximately three dozen interviews for each of the organizations that remain open and 6-8 for the two now closed. Other methods informing the case histories include site visits, direction observation of programs, the creation of network-connection maps, and a review of relevant documents. The sample offers one of the few chances to track local partnership outcomes of faith-related organizations longitudinally.

\section{Outcome Analysis}

Table 2 summarizes the government partnership trajectories of the five organizations at five different points in time. All five at baseline had no government contracts or workforce development programs, and then developed those during the CFBI grant cycle. The CFBI evaluation found that all five successfully managed their contracts and met basic performance benchmarks and all were rated as "good" partners by EDD program managers. Even during the grant period, however, there were signs that they had different long-term potential as government partners. One of the five (Welcome Home) developed an active partnership with a One-Stop Center (the name given to local, government-run workforce development programs and services in California), grew in sophistication and community visibility, and successfully competed for a federal Department of Labor grant in 2004. Another one of the five organizations (Champions) developed loose connections with a One-Stop, experienced significant growth in administrative capacity and community visibility, and succeeded in receiving a large new contract from the Kings County Alcohol and Drug agency. Of the remaining three organizations, Helping Hands of Hope and Tabitha's House developed only very modest connections to the One-Stop, while Zaferia Shalom Zone Agency found their overtures to the One-Stop were not reciprocated. Of these three organizations, Tabitha's House secured new funding after CFBI as part of a coalition of local housing agencies serving the homeless, while the other two organizations were less visible locally and ceased all operations at or near the end of the CFBI grant.

As of our 2008 interviews, all three of the remaining organizations continued to receive some form of government contract, but none had a formal workforce development program. By 2016, one of the remaining three organizations (Champions) had grown substantially and become highly integrated into its local service delivery network, receiving numerous government contracts; one (Welcome Home) continued at roughly the same size and maintained an active partnership (though no contract) with local correctional officials; the other organization (Tabitha's House) now is back to its pre-CFBI initiative form as a small, personal ministry supported by volunteers and with no paid staff. 


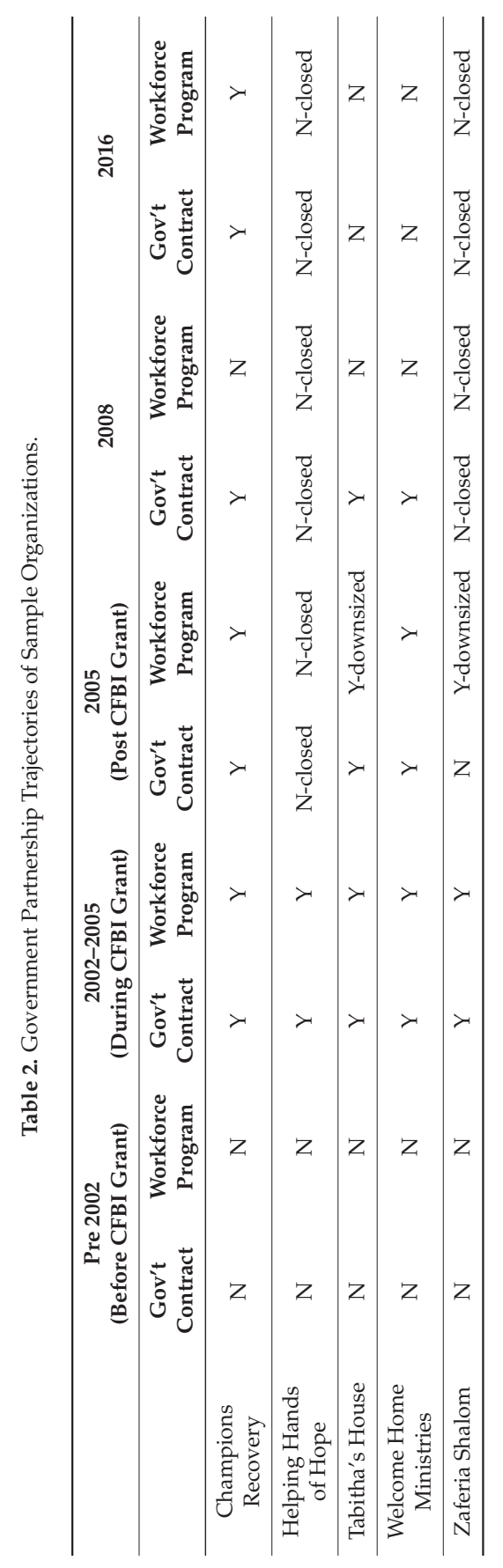




\section{Case Histories}

To put the outcome data in context and understand the dynamic factors leading to different partnership trajectories, brief case histories of the five organizations were constructed. The five shared a few general characteristics. All worked with substance abusers, ex-offenders, and the homeless, populations which some research finds faith-related organizations and programs are especially effective in serving $[9,31,34,38]$. Each served clients who are not well-served by government programs, often because they fear and distrust the government too much to use its services, or because performance targets make government providers reluctant to enroll them (creaming). Each organization deployed highly individualized programs that attempted to meet clients where they were, while also seeking to promote new attitudes, skills, and knowledge. Each deployed staff that shared affinities and life experiences with the clients they were serving. Against the background of these similarities, the condensed case histories we present are intended to bring into view differences in their histories, approach, and partnership trajectories. Three of the five were founded and directed by Christian women with an evangelical passion to serve "the least of these". These began as a personal ministry, incorporated and expanded using CFBI funds, and adapted when that funding ended. The other two organizations were spawned as community ministries by local congregations, but for different reasons closed at or near the end of the state initiative. These two will be considered first.

\subsection{Zaferia Shalom}

Zaferia began as a small, volunteer-driven ministry of a local United Methodist Church in Long Beach, part of their response to the riots that occurred after the Rodney King verdict in Los Angeles. The church, since closed, was situated in a low-income neighborhood where many individuals lacked cars and access to social services. Zaferia was the oldest of the five organizations studied. For 10 years prior to the CFBI grant, church volunteers provided walk-in services, such as a clothes closet. The workforce development grant provided $\$ 438,000$ over a three-year period, used to hire a full-time staff member and to provide resources to support job training activities including computer training, work clothes, resume assistance, interview skill development, as well as budgeting and other life skills. Housed in the social hall of the church, the program lacked dedicated space and was available only during set hours of 9-3 Monday through Friday and a couple of evenings during the week.

Zaferia's eventual closure was driven by an event beyond the program's control: the decision of the local Methodist officials to close its host congregation. Yet even prior to this event, there were signs that the nonprofit was having difficulty staking out a broader niche in the local social service network. Midway through the CFBI grant, another local nonprofit that had been referring clients to Zaferia got its own grant to do essentially the same work, causing the Zaferia caseload to dwindle dramatically. And despite a push from CFBI program managers to create better relationships between the CFBI-funded nonprofits and government run One-Stops, Zaferia reported being repeatedly rebuffed by local workforce officials when they reached out.

Since Zaferia's identity and organizational resources were inextricably linked to the local Methodist church, its closure was perhaps inevitable. On the other hand, many small non-profits do successfully spin off from a church and create independent organizations. One can imagine a scenario where the CFBI funding helped the organization expand and deepen its community partnerships, such that it became a valued resource and attracted funding from government or other entities. In this case, that is not what happened. Indeed, when we did a network mapping exercise with Zaferia's executive director in 2005, she reported the lowest total number of network connections of any of the organizations surveyed.

\subsection{Helping Hands of Hope}

Like Zaferia, Helping Hands began as an affiliated community ministry of a local congregation, in this case the Berkeley Mt. Zion Church. Unlike Zaferia, it incorporated just a few months before 
receiving CFBI funding in spring of 2002. Over three years, Helping Hands received $\$ 295,000$ in state EDD funds, using it to create a job training program featuring many of the same elements that Zaferia had emphasized: computer training, resume and interviewing assistance, and related life skills. Unlike the drop-in, individually paced Zaferia program, Helping Hands programs required participants to attend regularly scheduled computer skills training classes over a period of six or more weeks. Part of the idea was to mimic a work-like culture where regular attendance was the norm. Although they served others in need, the primary target of Helping Hands programs were individuals who were previously incarcerated and now trying to get their lives back on track by securing employment.

Helping Hands operated out of a small trailer in a closed school facility, set in the middle of a low-income neighborhood. The campus had a decidedly run down and unkempt feel, a result of not having been maintained by the city schools for some time. Still, the program was able to attract and graduate many students during the three years of the grant. Like Zaferia however, its executive director reported a low number of network connections and devoted the smallest percentage of time to external networking among those directors we surveyed.

By the time of our end-of-grant survey of participating CFBI organizations in 2005, Helping Hands had already closed its doors. Because we were unable to speak with an organizational representative at that time, we do not know the full story behind the decision to close, but the inability to secure new funding clearly played a role.

\subsection{Champions Recovery Alternative Programs, Inc.}

Champions was founded in May 2000 and occupied a graceful Victorian building in downtown Hanford, the county seat of rural and agricultural Kings County. The idea for the organization's substance abuse treatment program was incubated at the nearby Koinonia Christian Church by founding executive director Sue Braz. In addition to strong Christian beliefs, the director brought an extensive background in social services and Alcoholics Anonymous/Narcotics Anonymous (AA/NA) recovery programs, and was previously employed by county government.

Unlike other treatment programs in the community, Champions focused its initial programmatic effort on problems peculiar to the 14-25-year-old population, placing drug and alcohol treatment in the context of their lives and needs. Many clients were "court ordered." Champions set up outpatient treatment plans that incorporated 12-Step programs along with strict requirements for finding employment or continuing in education. Most staff members were in recovery themselves and thus had additional credibility in the eyes of their young clients. The director recognized the ongoing challenges associated with drug recovery work, and freely admitted that many of the young participants they serve stumble and relapse. But many returned to try again, and she had full trust that God had called her to the work and will provide what is needed to move forward, one day at a time.

Director Braz also brought to her work a strong motivation and goal of increasing the professionalism of the organization. Motivated by the opportunity to seek state faith-based funding, which required nonprofit status, the organization incorporated in January 2001. It was certified by the state Alcohol and Drug Program in September 2001. Funds received through the state CFBI grant (\$438,000 over a 3-year period from 2001 to 2004) were a vital source of organizational support throughout the start-up years, and the director credited Employment Development Department technical assistance during its state grant with helping Champions develop from a small grassroots group to a larger and more effective organization. The grant also provided an occasion to develop reciprocal relationships with the local One-Stop Career Center, to establish a best practices program model, and to generate hard data on participant outcomes. The visibility and legitimacy conferred by the grant has helped Champions secure a series of state and local government grants and contracts, including funds from the county welfare-to-work program, county Alcohol and Drug program, the state Substance Abuse Services Coordinating Agency, and a Strengthening Families grant for parents on methamphetamines. The major perceived drawback to the EDD grant concerned the volume of paperwork required. 
At the height of its state grant, Champions had 8.5 paid staff and 60 program participants. As of fall 2007, it had continued to grow, with 12 paid staff members, 5 contract staff, and 5 interns and approximately 100 program participants. A 2016 follow-up found Champions growing much larger while also having undergone a transition to a new executive director. Champions still receives multiple government contracts from local and federal agencies, and now has a total of 48 full-time or part-time staff and a large budget of approximately $\$ 1$ million per year.

The process of organizational growth was not without difficulties. Some inexperienced board members and staff committed serious errors that threatened contracting relationships, but the director typically was able to learn from mistakes, correct them, and move on. Interviews with local officials suggest that by 2005 Champions had already evolved from its image as "one of those church groups" ignored or sneered at in local meetings to a point where the organization was widely acknowledged as a key provider of drug and alcohol recovery in Kings County. Officials seemed less concerned with Champions being faith-based than with the possibility that it would be unable to continue its programs after state funding ended, a fear that proved to be unfounded.

In retrospect, Champions is the most successful of the five organizations in terms of growth and of becoming an established part of the local social services network. It serves youth that cannot receive similar services anywhere else in the county and has a track record of bringing new resources into the community. Its service portfolio has expanded significantly over the past decade, with two residential treatment facilities (one for men and one for women) in place and programs aimed at family recovery and unification. These meet a critical need, since in addition to gaining sobriety and employment, housing is the other big issue facing program participants, with many cases of relapse traced to the influences of living environments in which drugs are present.

\subsection{Tabitha's House}

Tabitha's House is a faith-based sober-living facility founded in Bakersfield in 1992 by Miss Benny Jacobs, an African-American and ordained minister (known affectionately by all simply as "Miss Benny"). Starting as a personal outreach ministry, Tabitha's House initially served five women in a single home, gradually expanding to occupy seventy-two units in an abandoned motel. Unique among area recovery facilities, Tabitha's House has provided housing for the spouses, partners, and children of their participants. The state grant in 2001 was Tabitha's first from a government source, and represented a major new infusion of resources $(\$ 357,000$ over three and one-half years). EDD funds allowed Tabitha's to add a new work readiness component called the Goals for Life program to its existing recovery program. Among our five organizations, Tabitha's was the one in which it was most difficult to discern if church-state boundaries were being strictly kept. While the staff took pains to wall off the Goals for Life program from religious elements, all Tabitha's residents were strongly encouraged to participate in Miss Benny's daily Bible studies. The director's expressed vision and everyday language and actions reflect her strong belief that without recognizing God's presence, it will be more difficult for individuals to gain and maintain sobriety.

State funding ceased at the end of January 2005, and resulted in a nearly complete elimination of workforce services on site. Before this time, Tabitha's House applied for and received a large $(\$ 408,500)$ HUD grant to provide transitional housing to the homeless population, as part of a collaboration of local service providers. A year later they were successful in winning an even larger HUD grant (over a million dollars). However, the success at getting grants revealed significant organizational shortcomings. The director and staff had difficulty navigating program rules requiring matching funds or other anticipated costs, creating a variety of financial and legal issues. As debt accumulated, Tabitha's hired a new contract administrator to put together a long-term plan for the organization's financial recovery, but the difficulties impacted both the viability of the organization as a partner in the eyes of public officials and the willingness of the executive director to continue seeking grants and contracts. 
As of fall 2007, Tabitha's House had 15 full time staff and 3 contract personnel, serving 100 clients at any given time, usually for extended periods. But by 2016, Tabitha's House had returned to something like its early form as a personal ministry. It still provided spiritual guidance and sober living services to families and singles, but "only by the grace of God" according to Miss Benny. It no longer receives government grants or contracts, nor does it employ paid staff, relying instead on four volunteers in addition to the director.

Tabitha's House presents something of a paradox. On the one hand, as the only residential treatment facility in the area that houses entire families, and with the director's reputation for welcoming even the most difficult program participants with unconditional love and genuine hope, it for a few years gained favor with such local agencies as the Department of Human Services, Department of Mental Health, the California Youth Authority, the Probation Department, Child Protective Services and others. But this move toward local network collaboration was not sustained for very long. The Director's strength—serving anyone who shows up with a whole heart-was offset by limited focus on building the organization's capacity to manage grants and contracts. Today, Tabitha's House is not a major partner in the local service delivery network, but continues to do work of value. Miss Benny devotes her life energies to the work, despite her advanced age (84) and significant personal obstacles. Tabitha's House sustains itself as a labor of love, operating for the most part off the radar screen of local network officials.

\subsection{Welcome Home Ministry}

In August 1994, experienced nurse Carmen Warner-Robbins began one-on-one visits with women in a San Diego county jail in her role as prison chaplain. Concerned with high rates of recidivism, she and her husband began working to help the women find jobs and reintegrate into society upon their release. Inspired by a message received during prayer, she began enlisting the women at the jail in designing and implementing a nonprofit organization called Welcome Home Ministry.

The model that evolved was built on the premise of peer-to-peer support. The post-release support begins by meeting each woman at the jail on the day of their release, providing them with toiletries and other basic essentials, finding them a place to live-usually in a treatment facility-and supporting their efforts to garner meaningful employment. The participants are invited into an ever-growing support network comprised of women who have faced similar situations and challenges. The Welcome Home "family", born when the first woman was picked up from jail in 1996, today consists of hundreds of women, many of whom meet for monthly potlucks that combine elements associated with support groups, twelve-step meetings, and church socials.

For its first few years Welcome Home operated as a personal outreach ministry, sustained primarily by private donations and the volunteer efforts of the director, her husband, and some of the original participants. In April 2000, the organization incorporated as a 501(c)(3) organization, and for many years received and successfully managed a series of sizable government grants, beginning with its state faith-based initiative grant (\$393,500 over 3 years). In subsequent years they received major grants totaling over $\$ 1$ million from the Substance Abuse and Mental Health Administration, and smaller grants from the Department of Labor, among others. Of note, the director's husband, a veteran of government social service programs, brought his expertise to bear in helping with the requirements of government contracting.

As of fall 2007, Welcome Home had 10 paid staff (several of them former clients) and connections with approximately 100 community volunteers, although the heart of its approach has always remained the peer support model. In general the organization weathered its early years as a nonprofit with fewer growing pains than might ordinarily be expected. Community leaders interviewed in 2004 expressed uniformly high regard for the organization. In addition to the organization's demonstrated ability to deliver services and partner with both prison officials and local employers, Welcome Home has the advantage of operating in a county that has been at the forefront of efforts to explore alternatives to 
government programs, having pioneered the idea of "managed competition" and developed active partnerships with the faith community during the early years of welfare reform [39].

Welcome Home recognizes the need to demonstrate program success. Two independent studies have found that the Welcome Home approach and services have substantially reduced the recidivism rate among those served, compared with prevailing norms [40,41]. The more rigorous of the two found that only $23 \%$ of Welcome Home participants enrolled in a study were rearrested 12-months following their release compared to an overall recidivism rate in California prisons of $66 \%$ [41]. The director's role in commissioning these outcome studies reflects her strong commitment to establishing the validity of the Welcome Home model, in hopes it will spread to other correctional facilities and communities.

A 2016 follow-up found that Welcome Home continues to provide a robust peer support network, operating in partnership with local prison officials and with various community partners. The organization itself no longer receives government grants, but its approach to prisoner re-entry has become a widely disseminated model that is shaping how public and private funding is being directed in prison systems. The Welcome Home narrative suggests another less expected way in which small, faith-related nonprofits can be sources of public value-by developing a model that can then inform a broader array of public and private efforts.

\section{Comparative Analysis}

The analysis of the organizational development and local partnership trajectories of these five organizations brings into view a number of important distinctions. In reviewing these, the focus is primarily on distinctions between the two organizations that have closed their doors and the three that are still operational, but additional consideration is given to more fine-grained distinctions between the latter three. Are there lessons from the comparisons that can help both nonprofit managers and their network partners better discern when and if to enter into collaborative partnerships, and to navigate the process of mutual assessment and adjustment that ensues? Four variables seem most relevant: organizational niche within the local network; leadership connections and network legitimacy; faith-inspired commitments and persistence, and core organizational competencies and capacities.

\subsection{Organizational Niche}

Understandably, the best network partners are those who bring to the table something different than what already exists. Both the now defunct organizations duplicated job training services that were also provided by the One-Stop Centers and/or by other nonprofits in the community. While they helped expand the reach of these services in their particular neighborhoods, they did less to distinguish themselves as adding unique value. By contrast, the three sustained organizations provided drug recovery and/or housing services that were unique in their communities. This made them more valuable as a place to refer individuals and as a portal into the workforce development network for individuals needing significant amounts of remedial care. Also of note, the three successful organizations had programs that featured strong peer/group support features among participants, and some form of 24/7 care and support, while the other two did not.

It is not particularly surprising that occupying a unique organizational or programmatic niche is a key factor correlated with successful nonprofit development. Less obvious is the manner in which a niche is defined in our three enduring cases. Research has focused on the ability of faith-based organizations to specialize in the services they provide, and/or on clients who are selected or self-select based in part of religious affinity [3,31]. By contrast, findings from this research suggest that the three successful organizations combined: (1) highly specialized niche clientele, defined primarily in terms of individuals with substance abuse related drug convictions and/or incarceration, and only secondarily in terms of possible religious affinity with the organization, which was often not the case; and (2) broad service portfolios, which attempted to meet a wide range of client needs from spiritual and emotional support, to system navigation and referrals, to material support resources for daily needs, as well as some form of mental health services. Specialists in one sense, the organizations are multi-task 
generalists in another, a reality that may be obscured by the use of the term "niche". Each combines drug recovery work with attention to housing, employment, and health care needs, but in distinct, locally-adapted fashions and with different combinations of emphasis. Importantly, each relies to a significant degree on referrals or partnership connections with public agencies.

The changes these organizations seek in client lives are complex and require action on multiple fronts over time. Clients may succeed in kicking their drug habit but fail to find employment. They may be on the road to recovery but be forced into housing choices that put them amidst the same destructive influences that led them to drugs in the first place. They may succeed on all three fronts-sobriety, employment, and housing-for years, only to relapse under the stress of some difficult personal crisis.

Operating in this type of environment brings a persistent organizational tension between providing the breadth of support services clients need, on the one hand, and focusing on what the organization is good at and can reasonably do, one the other. Although most acutely experienced by Tabitha's, we found all three organizations at risk of overextending their staff and resources-taking on more tasks and needs than a small organization can effectively manage [14,42]. This reality is tied to larger trends in how public policy supports, or fails to support, poor individuals and distressed communities $[5,43]$. It is one thing to fill a small niche or gap in the local network by providing for a limited set of participant needs, quite another to fill a gaping hole amidst a shredded safety net by serving multi-need clients that others in the network will not or cannot serve.

\subsection{Leadership Connections and Network Legitimacy}

Among this sample of faith-related organizations, executive directors who enjoyed and exceled at community networking had a decided edge over those who spent most of their time in direct service provision. The three more successful organizations were formed and sustained by strong, charismatic leaders who became highly visible in local networks and spent a good deal of their time on external networking; this was not the case in the other two organizations, which lacked a similarly recognizable and vocal champion.

Having executive directors with a deep sense of mission and purpose matters, but it must be matched by an ability to translate that zeal into effective networking. Making local connections increases organizational visibility and can also build partnerships that help clients navigate the network, securing needed services and supports. The need to build relationships with key actors and partners in a wide range of community organizations and service realms puts tremendous demands on nonprofit executive directors. The directors cope primarily by being willing to work long hours for their cause and by relying on core staff to handle many internal organizational functions.

Among the three still-functioning organizations, the executive directors brought a slightly different focus as they made network connections, with consequences for their long-term partnership trajectories. Sue Braz of Champions made it a point of emphasis to build the professional skills and capacity or her organization, with an explicit and largely successful goal of becoming an embedded fixture in the local social services network. Her vision for the organization involved tying together faith-inspired compassion and competent professional service. Welcome Home's director put less emphasis on professionalism per se than on building the organization's peer support network for participants while maintaining close partnerships with corrections officials. Her networking energy and focus also went toward spreading the Welcome Home model to other institutions and communities, including more recent work with a national prison ministry coalition. Finally, Miss Benny stayed true to her original vision of Tabitha's House as a ministry rooted in faith and committed to serving those who found their way to her door. She was less focused on how her organization fit into broader network structures, beyond being visible enough to attract client referrals from other agencies.

\subsection{Faith-Inspired Commitments and Persistence}

Faith-related organizations face a dual burden in establishing a reputation within local networks. They have to be convincing on the same terms as other nonprofits-seen as valuable, reliable, 
and cost-effective partners-but also must operate in a fashion that does not raise concerns about church-state issues. What counts as meeting these different standards can be a moving target, varying according to which funding source or to which specific network players the organization must relate at any given time. Using the terminology developed by Sider and Unruh [16], the two organizations that were not sustained were categorized by the CFBI evaluation as "faith-background" as opposed to the "faith-centered" approaches in the three more successful cases. All three of the sustained organizations insisted on staying true to their faith commitments as the essential grounding for their work and as essential to participant outcomes, even while abiding by the spirit of church-state restrictions that accompanied their state grant. By contrast, the two organizations that shut their doors went out of their way to present a more or less secular program.

Given the small sample of cases, it is hard to draw firm conclusions about the role these differences played in the eventual success or demise of the five organizations. What can be said is that faith commitments clearly played a significant role in explaining in the persistence of the three enduring organizations and the adaptive tenacity of their leaders. All three directors bring a deep sense of religious calling to their work, describing it as a faithful response to God's call to be in service to others. While the specific language the three leaders used to describe their faith commitments varied, the centrality of faith to their everyday pursuits was presumed. It manifested itself in many ways beyond the regular use of religious language, including resilience in the face of organizational adversity, a belief that all their participants are children of God deserving love and respect, willingness in one way or another to go the extra mile on behalf of those participants, and a hopeful outlook in the face of difficulties.

Since many of their program participants are among the hardest-to-serve, the organizations are not well suited to compare favorably with other service providers on traditional outcome measures $[36,44]$. Indeed, one of the key ways in which faith manifests itself in these organizations is in the form of resilience and hope- the belief that making the effort with each and every program participant is its own reward, regardless of the final outcome. Thus, a basic assumption of their programs often runs counter to prevailing notions of outcomes accountability, even while it may also help expand the reach of services to individuals otherwise not well served in the local network.

\subsection{Core Staff Competencies and Capacities}

The need of small faith-related organizations for relatively high levels of technical assistance in order to manage government contracts, at least initially, is supported by all the five cases $[3,42,44,45]$. However, it will be difficult for government or other intermediaries to plan and implement these efforts with broad brush approaches or uniform results. Reasons include variations in what executive directors and staff already know, in their capacity to absorb and integrate assistance, and in their access to alternative technical assistance resources. Organizational capacity is not a simple function of size or of any other variable that can be measured at a single point in time. All the organizations saw their capacity to manage grants shift and change over the years, not always in a linear, upward progression. Because the organizations began or remain relatively small, much depends on the inclinations, skills, and resilience of the director, staff, board, and other volunteers, as these may come and go. As in any organization, not all employees or volunteers work out, and some create real grant management problems.

One key variable linked to better success occurs when employees or key volunteers bring significant relevant experience in government or other organizations, rather than being selected simply due to their affinity with program participants or relationship with the executive director. Having internal management capacity and skills not only makes grant management go more smoothly, it can free executive directors to spend more time on local networking. Though it varied somewhat among the successful three, all had or gained access to individuals who could supplement the director's passion and vision with strong professional skills. 


\section{Conclusions and Recommendations}

Among this sample, the findings suggest that small, faith-related nonprofits are more likely to succeed as long-term government partners when they (1) occupy a unique and valuable programmatic niche in the community; (2) have executive directors who commit themselves to developing and deepening network connections; (3) operate within church-state guidelines while embodying faith commitments that inspire and inform an ethic of hope-filled service to participants and persistent resilience in the face of organizational challenges, and (4) are willing and able to develop an organizational culture that balances street-friendly service with basic bureaucratic competency. Clearly, much of what we have found is relevant to the broader set of smaller, less-established nonprofit organizations, but our focus in this paper has been on the small, faith-related organizations that have been the focus of recent social policy initiatives.

The case histories reveal persistent and perhaps unavoidable tensions as organizations move in these directions. Specializing in clients that others cannot or will not serve causes pressures to over-commit by providing too many different types of services [42]. Finding staff that can bridge the cultural worlds of hard core drug addicts and accountability-driven bureaucrats is not easy, yet the option of hiring some staff for each purpose is expensive and potentially divisive [45]. Time spent building network connections comes at a cost of attending to internal organizational concerns, and often draws executive directors away from the realm of compassionate one-on-one service that is their primary strength and motivation.

It will not be easy or straightforward for most small nonprofits to cope with these tensions. Indeed, even the three relatively successful cases in our sample provide cautionary evidence. We would be wise to temper claims that smaller nonprofits, faith-related or otherwise, can suddenly become a much more integral presence in the overall service delivery landscape, much less carry the full weight of restoring a safety net. On the other hand, failure to integrate these organizations into community networks forfeits the opportunity to harness the power and persistence of their work and to stake out an oasis of care for individuals otherwise left to fend for themselves against overwhelming odds.

As an element of federal policy, faith-based initiatives clearly have had important symbolic value to politicians on the right and the left, as evident in the last two Presidential administrations. By taking community planning and service delivery networks as the key unit of analysis, our work moves the discussion to a more grounded level, and suggests three overarching policy recommendations.

First, as is clear from this and earlier work, we need to be very careful in defining the objectives sought by faith-based initiatives. A shift in focus is needed, from how single organizations or programs serve the poor one at a time, to how we coordinate networks of providers in particular communities. The focus of faith-based initiatives should be on community planning and local network development, rather than simply on leveling the playing field or improving services within existing silos. This would require a very different emphasis in federal and state policy than has been true during the past two administrations $[1,4,5]$. Instead of piecemeal, short-term funding of one or two faith-related organizations in any given community, a better approach would support a more deliberate and comprehensive strategy of local network development and community planning, in which the assets and limitations of a wide range of local organizations are considered [32]. Along with this, we need to be more realistic about the levels of funding needed to support the comprehensive services required to address poverty at the local level $[4,5,43]$.

Second, we need to realize that developing network partnerships with smaller faith-related organization will require flexible approaches. These approaches need to vary depending on the assets and gaps in the local service delivery network, as these are compared to the niche roles, leadership vision, faith commitments, and organizational capacity of potential partner organizations. As the traditional wisdom has suggested, government will find it easier and more efficient to focus on partnering with nonprofits with some track record and evidence of organizational stability. At the same time, we have seen that small, new faith-related nonprofits can and sometimes do develop into important partners, particularly when they occupy a unique organizational or programmatic niche 
or otherwise function in ways that expand the reach of services [42,44]. The evidence also suggests that their evolution as government partners will likely take more time and investment than is often expected, and may proceed unevenly as the organizations' struggle to develop internal capacity and external legitimacy. For every organization that may evolve into an ongoing contractual partner, like Champions, there will be cases like Welcome Home where the nonprofit helps redirect funds and program priorities within existing public institutions, or like Tabitha's which is willing to accept as many referrals from public agencies as it can handle at a given point in time, but otherwise keeps to its own business of faith-based sobriety work.

Third, while church-state issues are important, they are not the core issue that partnerships with small faith-related organizations pose for government. The core issue is how the practices of these organizations-emphasizing flexible, individual treatment rather than pre-set programs, faithful service rather than short-term outcomes, etc. - can be meshed with the types of accountability requirements to which most social programs are now held by both government and private foundations. Perhaps one of the underappreciated values these organizations bring is to call into question accountability regimes which fail to reflect the actual street-level work and community coordination that is required to repair broken lives and neighborhoods [46]. At times awkwardly but often heroically, the community-based work continues, requiring our best efforts at understanding and support.

Acknowledgments: The author wishes to acknowledge with gratitude the willingness of directors, staff, participants, and partners of the faith-related organizations profiled in this article to share their experiences, good and not so good, with candor and insight. Thanks also to Cathy Lemp for her significant contributions to the research, analysis, and writing reflected in this paper. The research was supported in part by funds received from the California State Employment Development Department (EDD). The analysis, interpretations, and conclusions are the responsibility of the author and not EDD.

Conflicts of Interest: The author declares no conflict of interest.

\section{References}

1. Ram A. Cnaan, and Edward Newman. "The Safety Net and Faith-Based Services." Journal of Religion E Spirituality in Social Work: Social Thought 29 (2010): 321-36. [CrossRef]

2. Joe Soss, Richard C. Fording, and Sanford F. Schram. Disciplining the Poor: Neoliberal Paternalism and the Persistent Power of Race. Chicago: University of Chicago Press, 2011.

3. Wolfgang Bielefeld, and William Suhs Cleveland. "Faith-Based Organizations as Service Providers and Their Relationship to Government." Nonprofit and Voluntary Sector Quarterly 42 (2013): 468-94. [CrossRef]

4. Robert Wineburg. A Limited Partnership: The Politics of Religion, Welfare, and Social Service. New York: Columbia University Press, 2001.

5. Robert Wineburg. Faith-Based Inefficiency: The Follies of Bush's Initiatives. Westport: Praeger, 2007.

6. Robert Wuthnow. Saving America? Faith-Based Services and the Future of Civil Society. Princeton: Princeton University Press, 2004

7. Mark C. Falbo. "Community service and social transformation: The contribution of religious education to the health of the American polis." Religious Education 93 (1998): 143-55. [CrossRef]

8. Jo Anne Schneider. "Introduction to the Symposium: Faith-Based Organizations in Context." Nonprofit and Voluntary Sector Quarterly 42 (2013): 431-41. [CrossRef]

9. Ram A. Cnaan, Robert J. Wineburg, and Stephanie C. Boddie. The Newer Deal: Social Work and Religion in Partnership. New York: Columbia University Press, 2000.

10. Arthur E. Farnsley, II. “Can faith-based organizations compete? " Nonprofit and Voluntary Sector Quarterly 30 (2001): 99-111. [CrossRef]

11. Edwin I. Hernandez, and Neil Carlson. Gatherings of Hope: How Religious Congregations Contribute to the Quality of Life in Kent County. Grand Rapids: Calvin College, Center for Social Research, 2008.

12. Kevin P. Kearns. "Faith-based and secular social service agencies in Pittsburgh: Location, mission, and organizational capacity." Journal of Community Practice 14 (2007): 51-69. [CrossRef]

13. John B. Orr. Los Angeles Religion: A Civic Profile. Los Angeles: University of Southern California, Center for Religion and Civic Culture, 1998. 
14. David A. Reingold, Maureen Pirog, and David Brady. "Empirical evidence on faith-based organizations in an era of welfare reform." Social Service Review 81 (2007): 245-83. [CrossRef]

15. Charles L. Glenn. The Ambiguous Embrace. Princeton: Princeton University Press, 2000.

16. Ronald J. Sider, and Heidi Rolland Unruh. "Typology of Religious Characteristics of Social Service and Educational Organizations and Programs." Nonprofit and Voluntary Sector Quarterly 33 (2004): 109-34. [CrossRef]

17. David Campbell. "Faith-Related Social Services: A Blessing, Not a Miracle." Policy Report No. 27, Progressive Policy Institute, Washington, DC, USA, December 1997.

18. Margaret Gibelman, and Sheldon R. Gelman. "The promise of faith-based social services: Perception versus reality." Journal of Religion \& Spirituality in Social Work: Social Thought 22 (2003): 5-23. [CrossRef]

19. Tobi Jennifer Prin. "Faith-related Service Providers in the Nation's Capital: Can They Do More? " In Charting Civil Society, a Series by the Center on Nonprofits and Philanthropy. Washington: The Urban Institute, 1998.

20. Amy L. Sherman. "Will Conservative Welfare Reform Corrupt Religious Charities? " Policy Review 74 (1995): 58-63.

21. Paul J. DiMaggio, and Walter W. Powell. "The Iron Cage Revisited: Institutional Isomorphism and Collective Rationality." In The New Institutionalism in Organizational Analysis. Edited by Paul J. DiMaggio and Walter W. Powell. Chicago: University of Chicago Press, 1991.

22. Peter Frumkin, and Mark T. Kim. "The Effect of Government Funding on Nonprofit Administrative Efficiency: An Empirical Test." Ash Institute for Democratic Governance an Innovation, 2002. Available online: https://www.innovations.harvard.edu/effect-government-funding-nonprofit-administrativeefficiency-empirical-test (accessed on 14 May 2016).

23. Kristin A. Gronbjerg. Understanding Nonprofit Funding. San Francisco: Jossey-Bass, 1993.

24. Michael Krushinsky. "Management Implications of Government Funding of Nonprofit Organizations: Views from the United States and Canada." Nonprofit Management and Leadership 1 (1990): 39-53. [CrossRef]

25. Perri 6, and Jeremy Kendall, eds. The Contract Culture in Public Services. London: Ashgate Publishing Limited, 1997.

26. Ralph M. Kramer. Voluntary Agencies in the Welfare State. Berkeley: University of California Press, 1981.

27. Lester M. Salamon. Partners in Public Service. Baltimore: Johns Hopkins University Press, 1995.

28. Robert Agranoff. Managing Within Networks: Adding Value to Public Organizations. Washington: Georgetown University Press, 2007.

29. Eugene Bardach. Getting Agencies to Work Together: The Practice and Theory of Managerial Craftsmanship. Washington: Brookings Institution Press, 1998.

30. David Campbell, and Cathy Lemp. The Promise and Limits of Community and Faith-Related Organizations as Government Workforce Development Partners-Final Evaluation Report on the California Community and Faith-Based Initiative. Davis: California Communities Program, 2007.

31. Stephen V. Monsma, and J. Christopher Soper. Faith, Hope \& Jobs: Welfare-to-Work in Los Angeles. Washington: Georgetown University Press, 2006.

32. David Campbell. "Reconsidering the Implementation Strategy in Faith-based Policy Initiatives." Nonprofit and Voluntary Sector Quarterly 40 (2011): 130-48. [CrossRef]

33. David Campbell. "Beyond Charitable Choice: The Diverse Service Delivery Approaches of Local Faith-Related Organizations." Nonprofit and Voluntary Sector Quarterly 31 (2002): 207-30. [CrossRef]

34. John J. DiIulio. Godly Republic: A Centrist Blueprint for America's Faith-Based Future. Berkeley: University of California Press, 2007.

35. David Kuo. Tempting Faith: An Inside Story of Political Seduction. New York: Free Press, 2006.

36. David Campbell, and Eric Glunt. "Assessing the Effectiveness of Faith-based Programs: A Local Network Perspective." Journal of Religion and Spirituality in Social Work: Social Thought 25 (2006): 241-59. [CrossRef]

37. Fredrica D. Kramer, Kenneth Finegold, Carol J. De Vita, and Laura Wherry. "Federal Policy on the Ground: Faith-Based Organizations Delivering Local Services." In Assessing the New Federalism Discussion Paper. Washington: The Urban Institute, 2005.

38. Amy L. Solomon, and Caterina G. Roman. Summary of Focus Group with Ex-Prisoners: Ingredients for Successful Reintegration. Washington: The Urban Institute, 2001.

39. David Campbell. Community Welfare Reform Planning: Early Indications from Six California Counties. Davis: California Communities Program, 1997. 
40. Danise C. Miller. "Faith-Based Organization Welcomes Women Back Home into the Community." Family and Community Health 32 (2009): 298-308. [CrossRef] [PubMed]

41. Earl H. Goldstein, Carmen Warner-Robbins, and Richard Conklin. "A Peer-Driven Mentoring Case Management Community Reentry Model." Family and Community Health 32 (2009): 309-13. [CrossRef] [PubMed]

42. Jill Whitmer Sinha. "Examining Pros and Cons of Collaboration with Small to Midsized, Grassroots, and Strongly Faith-Based Partners." Journal of Leadership Studies 7 (2013): 61-69. [CrossRef]

43. Rebecca Sager. Faith, Politics, and Power. Oxford: Oxford University Press, 2012.

44. Jill Whitmer Sinha. "Unintended Consequence of the Faith-Based Initiative: Organizational Practices and Religious Identity within Faith-Based Human Services Organizations." Nonprofit and Voluntary Sector Quarterly 42 (2012): 563-83. [CrossRef]

45. Steven Rathgeb Smith. "The Challenge of Strengthening Nonprofits and Civil Society." Public Administration Review 68 (2008): S132-45. [CrossRef]

46. Lehn Benjamin, and David Campbell. "Nonprofit performance: Accounting for the agency of clients." In Nonprofit and Voluntary Sector Quarterly, 2014. Available online: http://nvs.sagepub.com/content/44/5/ 988.short (accessed on 14 May 2016).

(C) 2016 by the author; licensee MDPI, Basel, Switzerland. This article is an open access article distributed under the terms and conditions of the Creative Commons Attribution (CC BY) license (http:/ / creativecommons.org/licenses/by/4.0/). 


\title{
The Congregational Social Work Education Initiative: Toward a Vision for Community Health through Religious Tradition and Philanthropy
}

\author{
Jay Poole ${ }^{1, *}$, John Rife ${ }^{1,+}$, Wayne Moore ${ }^{2,+}$ and Fran Pearson ${ }^{1}$ \\ 1 Department of Social Work, University of North Carolina at Greensboro, PO Box 26170, Greensboro, \\ NC 27402, USA; jcrife@uncg.edu (J.R.); afpearso@uncg.edu (F.P.) \\ 2 Department of Sociology and Social Work, North Carolina Agricultural and Technical State University, \\ 1601 E, Market Street, Greensboro, NC 27411, USA; wmoore@ncat.edu \\ * Correspondence: kjpoole@uncg.edu; Tel.: +1-336-334-5147; Fax: +1-336-334-5210 \\ + These authors contributed equally to this work.
}

Academic Editor: Robert Wineberg

Received: 16 March 2016; Accepted: 18 May 2016; Published: 27 May 2016

\begin{abstract}
The relationship between social work field education, religiously affiliated organizations, and local philanthropic organizations is explored in this case study of a grant-funded project called the Congregational Social Work Education Initiative. Religiously affiliated organizations have traditionally been involved in the provision of social welfare services; yet, social work education has not embraced this tradition in ways that are intentional. Additionally, the impact of religion-based traditions on philanthropy is interesting and, here, this relationship is explored through tracing the history of a prominent family in the community of Greensboro, North Carolina. The unlikely collaboration between social work field education, religiously affiliated organizations, and a local philanthropic community health entity yields some interesting considerations for how communities can come together toward a vision of improved health.
\end{abstract}

Keywords: congregational social work; community health; parish nursing; philanthropy; health

\section{Introduction}

In 2007, the University of North Carolina at Greensboro in partnership with the Congregational Nurse Program (CNP), with generous funding from the Cone Health Foundation established the Congregational Social Work Education Initiative (CSWEI). At the time, there was no model that demonstrated a partnership between religiously affiliated nursing programs and schools or departments of social work. Certainly, there is a historic link between social work and religiously affiliated organizations (RAOs) but, as a small group of visionaries searched for exemplary models in an attempt to address the health concerns of the people of Greensboro, North Carolina, the pairing of parish-based nurses and social work students was not something that emerged in the literature. Approximately eight years earlier, the Cone Health Foundation had funded the Congregational Nurse Program, which is based on parish nursing as developed by Dr. Granger Westberg [1]. The central principle of parish nursing is that professional nurses work within and alongside congregations or RAOs addressing health and wellness concerns. The Congregational Nurse Program in Greensboro was very successful and by 2007 was working with over 50 congregations and religiously affiliated organizations. Several of the nurses identified feeling overwhelmed by the social and emotional needs of the people they were serving and asked the coordinator about the possibility of having social workers assist. Through a series of discussions both planned and accidental, an idea emerged to have social work students engage with congregational nurses in fulfillment of their field internship 
requirements, both at the undergraduate and graduate levels. A grant application was written to the Cone Health Foundation and, based on the successes of the Congregational Nurse Program, the Foundation granted a year of funding, renewable for two subsequent years, to the University of North Carolina at Greensboro Department of Social Work. Thus, the Congregational Social Work Education Initiative was launched with its first cohort of twelve students, six undergraduate and six graduate, who completed a $40 \mathrm{~h}$ pre-service training program before being placed with nurses in the field [2].

Reflecting on the project, some questions are raised: What historical contexts lead the Cone Health Foundation to take a risk by funding an effort that was not based on any evidenced-based model of care? Also, how did congregations and/or religiously affiliated organizations impact the formation and work of the Congregational Social Work Education Initiative? These are the questions that are addressed here. In order to begin to understand the link between congregations, religiously affiliated organizations and social work a review of the literature is conducted. Then, the Cone Health Foundation's history and connection to the Cone family is explored in an attempt to discover how religious traditions did or did not impact what would become the CSWEI. Lastly, by using the case of the Congregational Social Work Education Initiative as an exemplar, a discussion of how religion, religious tradition, religiously affiliated organizations, and social work education may come together to address local, regional, national, and global needs is presented.

\section{Literature Review}

Religious affiliated organizations (RAOs) such as The Salvation Army, and religious congregations such as churches and synagogues have long played a foundational role in the delivery of social services. Our beliefs about helping those in need have their roots in ancient spiritual teachings and these beliefs have influenced the development of American social welfare programs. As Garland notes, "Almost all modern social services can be traced back to roots in religious organizations" [3].

Through history, religious organizations and congregations have provided social services for members while also acting as a voice for the poor and oppressed [4]. Early Christians provided mutual aid and care to the needy. During the middle ages, religious organizations such as monasteries provided food, shelter, and clothing to individuals and families [5]. In the 19th century, groups such as the Methodist Settlement Movement "staffed outreach programs to the most marginalized inhabitants of the inner cities" [6]. Organizations such as the Baptist Training School Settlement provided services to the poor in the early 20th century [7]. In addition, religiously affiliated organizations throughout the United States, such as urban ministry and Salvation Army organizations, have and continue to play a central role in the delivery of social services.

The leadership by religiously affiliated organizations in providing care has influenced not only American social welfare but also the development of the social work profession. Indeed, professional social work's origins are found in the history of the rise and development of the Charitable Organization Society movement and the Settlement House movement at the turn of the 19th century, which were often affiliated or supported by churches [8,9]. Faith-based social service delivery has long been an important system of care [10] and the prominence of this delivery approach has received increased attention in the past twenty years as a result of Bush administration faith-based initiatives [11-13].

Garland defines church social work as bringing "the social work's profession's knowledge, values, and skills to the church as a resource" [1]. Despite the importance of religiously affiliated organizations in the history, development, and current delivery of social and health services, professional social work has often missed opportunities to join with these organizations in the delivery of services [14]. While social workers in medical settings have recognized the spiritual needs of patients and the importance of collaborating with clergy, social workers in child and family settings, mental health, and schools have been less active in this collaboration. As Manthey notes, during the modern development of the social work in the 20th century, there has been a drive for professionalization and a separation from volunteerism and religious-based service delivery [15]. This missed opportunity has been historically reinforced in social work education. Only in the past twenty years has the social 
work national accrediting agency, the Council on Social Work Education, required curricular content in spirituality as part of all Bachelor of Social Work and Master of Social Work programs. Despite the historical and current contributions religiously affiliated organizations have made to social work, recent research shows that building new partnerships can be challenging [16].

Research has shown that individuals and families often seek help from their pastor or church staff when facing unemployment, family dysfunction, and poverty [17]. However, church leaders may not always be skilled in recognizing or meeting the mental health needs of members. In addition, research has shown that church staff members rarely make referrals to mental health professionals [18]. Low levels of collaboration among professional social workers and religiously affiliated organizations and resulting low referral rates have expanded the professional distance between social work mental health professionals and clergy [19]. Social workers have been slow to embrace the importance of spirituality to many clients, while clergy do not always recognize the need for referral. Although there are exceptions opportunities for collaboration are being missed which result in low levels of service provision to people in need [20].

On the other hand, there are opportunities and needs for increased collaboration. Historically, social workers are taught in their educational programs to "start where the client is". Given the number of people who prefer seeking help in their religious organization, there are opportunities for social workers to more effectively meet health and mental health needs by reconnecting professionally with faith organizations [21,22].

Prior research has shown that clergy are concerned about the health needs of their members. Clergy support for specific programming such as health screenings, prevention interventions, health education, and health-related classes is strong [23]. This support provides opportunities for effective service delivery, student education, and interdisciplinary practice with congregants. Given the historical and current importance of religiously affiliated organizations in meeting the needs of people and the fact that the very roots of professional social work reflect a partnership with religious organizations and communities, social workers must work more diligently to embrace the historical importance of the religiously affiliated organizations and the significance that spirituality plays in peoples' lives [1,24]. In the current environment of sweeping changes in health and mental health delivery while continuing to face budget retrenchment, opportunities and potential benefits for collaboration are great [25]. Such collaborations require a mutual respect for the contributions of religiously affiliated organizations, the pressures faced in meeting congregant needs by pastors and other religious leaders, and a commitment by social workers to include the importance of spirituality and collaboration with religiously affiliated organizations in everyday social work practice.

In addition to the consideration and inclusion of spirituality, social workers and social work students must begin to understand and access the vast resources that may be a part of the ministries of many community congregations. For example, the Congregational Social Work Education Initiative students have become very aware that local churches will often help with the purchase of needed medications or assist with paying utility or grocery bills for the people being served. Social welfare assistance has never really left religiously affiliated organizations but many social workers have historically relied on secular social services agencies in accessing resources. Now, churches are often at the forefront of providing food, fiscal assistance, and shelter in some cases. As exemplified by the history of the Cone family below, religious traditions often emphasize acts of philanthropy and community service. It is very important for social workers and social work students to recognize the potential to access and enhance resources by building relationships with religiously affiliated organizations at the local and regional levels in particular. No longer can social welfare be regulated to departments of social services or secular charitable aid organizations. Congregational Social Work Education Initiative students are encouraged to work closely with religiously affiliated organizations in order to foster strong relationships so that the people served have access to resources. The fact that CSWEI has become a part of the effort to enhance the health and wellness of the community it serves reflects the principles of the Cone family and the Cone Health Foundation. The time has come 
to re-imagine possibilities and to explore partnerships between religiously affiliated organizations, social services, and social work education.

\section{The Cones: A Legacy of Care and Concern for Community}

The Cone Health Foundation's mission to support and develop activities, programs and organizations to improve the health of people in the greater Greensboro area is inextricably linked to the legacy of Moses H. Cone and Cesar Cone of Greensboro, NC. Both were visionary industrialists, establishing their leadership in textile manufacturing, international trade, finance, and philanthropy. Their American story is the story of a second-generation Jewish immigrant family's experience in the South. Through their father's values of hard work, love of family, and building relationships outside the Jewish community, Moses and Cesar Cone exemplified Jewish values and humanitarian ideals in business and civic dealings as they built their successful textile empire.

They drew upon their experiences as "drummers" or salesmen traveling across the South from Maryland to Alabama after the American Civil War for their father's wholesale grocery and dry goods business located in Baltimore. They called upon merchants and small mill operators who often had little cash to purchase goods; they bartered taking cloth as payment, in-turn selling it to other customers in their travels. After taking over their father's business in 1879, they recognized that with expanding railroad lines, merchants could re-stock their merchandise easier by rail; the elder bother Moses looked for other options. Moses Cone did not want to go into textile manufacturing but he seized the opportunity to reorganize textile manufacturing by assisting distressed small mill operators, many who had been former clients, by stabilizing textile prices and acting as an agent to sell their goods across the United States and overseas [26,27]. The Cone Export and Commission Company was founded in 1891 with offices in Greensboro and New York City, expanding with twelve offices in major American cities. When the mills could not provide enough finished textiles, especially denim, Moses Cone saw the opportunity to build their own mill to complete the full process from processing raw cotton to producing a finished product.

The Cone brothers had explored locating their mill in other locations but Greensboro's civic leaders appealed to the brothers to locate adjacent to their city in their desire to expand its economic base to build its reputation in the state and region. Greensboro had always been known as a tolerant and welcoming city. Authors attribute this to the early Quakers, Moravians, and Presbyterians, who settled the area prior to the American Revolution, and their experiences with discrimination and hostility toward their religious tenants and practices. These and other faith traditions had a positive respect for the small number of Jewish merchants in Greensboro and other small nearby towns [28-30]. The city leaders envisioned such a large mill could provide needed jobs for small farmers and tenant farmers and their families, many of whom were leaving rural areas seeking better living and work opportunities.

In 1895 Proximity Manufacturing Mill was opened for the production of denim. Greensboro offered multiple advantages-lower labor costs, affordable land for mills and housing, water for hydro-power, low freight costs with seven rail lines converging in the city; it was the ideal location where raw cotton could be shipped in and finished products shipped. They would open other mills to meet increasing demand for denim, flannel, and other finished textiles. Revolution Cotton Mill opened in 1899 and their largest, the White Oak Plant in 1902. Unfortunately Moses Cone died in 1908 at the age of 51; Cesar Cone carried on the work building Proximity Printworks in 1912 and entered into the lucrative long-term contract supplying blue denim to jean maker Levi Strauss in 1915. Younger Cone brothers would join and continue managing the family enterprises [31,32].

Lucius Wedge's assessment of Moses Cone's rise from merchant to industrialist to become America's "Denim King" noted his ability to adapt quickly to the ever-changing elements in textile manufacturing and maintaining his work force [33]. Most laborers in the early mills were illiterate, often tenant farmers, making attempts to escape rural poverty. Since mills were often built away from cities to take advantages of land and water resources, the brothers too developed separate "mill 
villages" to house workers, families, and provide a decent standard of living through efforts to enhance health, educational, religious, and social opportunities.

Historians and researchers have denounced many Southern mill towns, built by mill owners and operated by mill superintendents, as paternalistic and authoritarian models to exploit workers [29,31,34]. Overall these mill families faced grinding poverty with poor work and living conditions; they suffered from pellagra, poor sanitation, substandard street maintenance, lack of health care for infants, or assistance when sickness or injury occurred [31,34-36]. Mill owners hired ministers for church worship with sermons built around the themes of duty to the master, hard work, and acceptance of the social order [35,37].

Moses and Cesar Cone did take a paternal role in their villages; however, they believed the welfare of their workers and families was as important as volume and profits. In his examination of Jewish business, families, and civic engagement in the South, Eli Evans noted Moses and Cesar Cone "believed that a better community for everybody was a better community for the Jewish people." [28]. Balliett chronicled the expansion of the Cone business and how they attended to the physical, spiritual, health, education, and well-being of their workers and families [32]. Since building their first mill outside Greensboro in 1895, five self-sufficient villages were built to serve workers in its factories. At their peak, the villages covered 450 acres and housed 2675 workers in about 1500 houses. For African-American workers a separate mill village was built along with their school, church, and recreational center. Boarding houses for single men and family housing was constructed. Houses consisted of four to six rooms, for a nominal monthly rent of $\$ 1$ per room, this included electricity and sanitary water. Each village company store provided wood and coal at absolute costs; dairy, beef, pork, flour produced on company farms were offered at prices below those charged by local merchants along with other food staples, household goods, and clothing items at prices below town prices [32]. Each house sat on a large lot, with many residents having their own poultry house to supply eggs daily and chicken for the Sunday table. Canneries were provided in each village where residents could preserve fruit and vegetables raised in their home gardens. As the villages were incorporated into the city, by the late 1940s workers could buy their houses and join others in private homeownership [38].

An organized "welfare department" was built using the new professional disciplines of nursing and social work to provide services and programs to enhance family and community life. Classes for expectant mothers, well-baby clinics, dental clinics, physician visits were provided for sick or to attend work injuries. Social workers and nursing provided classes on sanitation, the domestic areas of cooking, sewing, canning, and food preparation. Cesar Cone was especially supportive of the Y.M.C.A. movement's ideals to develop personal character, leadership, and career aspirations for youth [27,32]. Two separate large facilities were erected for social, recreational, organized sports teams, and academic activities; women and girls could access the gymnasium and in-door pools for their organized games and clubs. Community wide activities were planned by village representatives along with Y.M.C.A., teachers, and staff from welfare department, with such activities as holiday celebrations, children summer camps, day trips to mountains, music or band concerts from their own glee club or the 18-20 piece Cone Memorial Band ensemble [32,39].

Both brothers believed in the importance of education, finding existing schools in the county to be inadequate in size, ill-equipped, and lacking competent teachers. They built schools in each village, hired and paid university trained teachers, instituted a nine-month school term, and encouraged workers to send their children to the schools and kindergartens. Night classes for adults offered reading, arithmetic, applied textile mechanics to encourage advancement plant and middle management positions. Women were encouraged to take classes in reading, writing, mathematics, and domestic sciences. New "departments" grew in the plants allowing new opportunities for men and women in such areas of technical writing, merchandising, shipping, secretarial work, and bookkeeping [26,31,39].

The brothers provided land to build six churches in the mill villages, constructing one for African American residents, and providing monies to an established congregation close to one village. The company provided major financing to erect these buildings; later provided lots and paid 
entirely for construction of their parsonages. Protestant faiths of Methodist, Baptist, and Presbyterian were represented and followed their denomination's practice of selecting ministers and governance. These churches continue to operate today $[32,40]$.

As noted, Moses H. Cone died at the age of 51 in 1908 without a will. He and his wife Bertha Landau Cone had no children. In settling his estate, his wife received 50 percent, and the remaining divided equally between his surviving brothers and sisters. Shortly after her husband's death, Bertha Cone's desire was to memorialize her husband by envisioning a modern hospital in Greensboro to serve its citizens, and to reflect the family's humanitarian ideal of service to others and the greater community [33,39]. This was written into the hospital's articles of incorporation dated 1911, "that no patient be refused admission nor discharged because of the inability to pay." Bertha Cone's gifts consisted of real and personal property, and her company shares with the proviso of reserving the income for her lifetime. She deeded 67 acres of land in Greensboro to locate the new hospital. Monies to construct and operate the hospital would come from using funds from her portion of the estate [39]. Their mountaintop estate, consisting of a manor house and 3600 acres near Blowing Rock, NC, also was deeded to the trust to be operated as a public park. During Moses Cone's lifetime, visitors could wander the landscaped paths, flower gardens and orchards. He had provided money for the Watauga Academy, which evolved into Appalachian College and served on its board of trustees. Bertha Cone would live another forty years. Upon her death in 1947, the available money for the construction of Moses H. Cone Memorial Hospital was reported at fifteen million dollars [33,39,41].

Moses H. Cone, a first generation Jewish American, followed the tenants of his faith along with the business practices of his father Herman Cone who had emigrated from Bavaria in 1846 at the age of 17. His oldest sister's husband Josef Rosengart wrote a letter to Herman before his departure for America, which remains one of the family's cherished possessions (Moses H. Cone Memorial Hospital Archives). In it his brother-in-law admonishes him to keep to the teachings and values of the Jewish faith, follow the commandments, continue prayers and to keep the Sabbath. It further directs, he be modest and polite to all, assist relatives and others, and "should you be lucky to become wealthy, do not let it make you proud and overbearing ... use it for doing good and for charity." Furthermore, it states "do not become known as a miser, be known as a philanthropist ... be particularly liberal toward the poor and charitable to the needy ... give assistance to the distressed."

Moses H. Cone, his siblings, and descendants have lived by the principles given by the family patriarch in 1846. His philanthropy and that of the family, past and present, contributed to the cultural and social growth of Greensboro. Their support can be seen on the names of school buildings, buildings on area colleges and university campuses, parks, support for museum, theatre and music events as well as their present representation on boards, committees, and civic groups serving the greater community. Additionally, the efforts of the Cone family to promote health and well-being were brought to fruition with the formation of the Cone Health Foundation, which seeks to be a "primary catalyst providing leadership for overcoming selected health barriers through investment and partnership" [42]. Founded in 1997 and following the traditions of community concern and philanthropy in the Cone family, the Cone Health Foundation is a key source for supporting the development of innovative efforts to address the Greater Greensboro community. Thus, the Jewish-based faith traditions practiced by the Cones are overarching in the work of the Cone Health Foundation, and these traditions directly impacted supporting the vision to engage in partnership with congregations, RAOs and congregationally-based nurses in order to educate future generations of social workers.

The religiously based traditions that influenced the Cone family of supporting well-being, community cohesion, creating opportunities for those in need, and promotion of healthy living are alive and well in the CSWEI and CNP programs. As each program weaves the services and supports they provide together in tandem with congregations and faith-based entities, it is quite evident that religious-based traditions are embedded in the foundations of the social services that are being delivered. The legacy of the Cones also is evident in the philanthropic efforts of the Cone Health Foundation and its focus on supporting a healthy community. While most would not acknowledge 
that religion-based values and beliefs are present in many social service delivery systems it appears that they indeed are often present and in the case of CSWEI and CNP, they are at the heart of who is served, why they are served, and how funding is garnered in order to serve. Perhaps it is important not to discount the impact of religion-based values, beliefs, and practices; rather, look for how they positively influence social services and how they can by embraced as we educate future human services professionals.

\section{Discussion}

In the recent past, social work education has not embraced religion, religion-based approaches to care, or religiously affiliated organizations as primary or even secondary locations for the delivery of social services despite the fact that students have a generally favorable view of religion and spiritually-based approaches [43]. While calls to join with RAOs in order to educate social workers and deliver social services have been heard, they are not always answered or embraced. Yet, we know from examining the history of social welfare that religion and RAOs have long been affiliated with efforts to address the health and well-being of people. Certainly, there are examples of RAOs, congregations, and religious traditions that seem to be antithetical to social welfare; however, at a foundational level, many religious denominations and traditions hold philanthropic and service efforts in high esteem. While attempts to engage social work students in considering the impact of religion and religiously based organizations on the lives of the people they will serve are positive, there is little to no evidence in the literature about how social work education has embraced RAOs as a serious partner in applied social work education. Tirrito and Cascio call for a comingling of social work and RAOs and give an example of how the Korean Church successfully developed a model of social service delivery for its congregants; yet, there is no evidence that their calls were headed by schools or departments of social work in terms of getting students directly involved with congregations [44]. Smith and Teasley, "...posit that the social work profession will stand as an instrumental link between the implementation of faith-based initiatives and the accountability of social service outcomes." [45]. Of course what remains to be seen is just how much social work education programs will entertain partnerships with RAOs in order to link professional development and evaluation to the social welfare efforts of congregations and faith-based entities. In their recent work, Garland and Yancey present a very comprehensive examination of the way social work is affiliated with congregations and they do point out that some social work education efforts use congregations that have a social work component as locations for field internships [46]. What is more common is that social workers practice in congregational settings and may take on student interns in their practices. Interestingly, Garland and Yancey interviewed CSWEI staff while writing their 2014 book and expressed that the model was unique in their research, particularly the close link to congregational nursing. This lead to an invitation for CSWEI and CNP staff to participate in the 2015 colloquium Congregational Social Work with Persons 55+ sponsored by Baylor University, where the model was presented to attendees. Certainly there is room for more exploration of how social work education might partner with congregations, RAOs and other faith-based entities in order to serve the community while educating the next generation of professional social workers. An example of such a partnership exists in the Congregational Social Work Education Initiative.

Originally, the conceptualization of CSWEI came from several conversations about how to better support the congregational nurses in Greensboro. The model reflected that of parish nursing, particularly with the notion that services would be embedded in congregational settings to enhance ease of access. We searched for and found a program director that was both a licensed clinical social worker and a registered nurse. She remains the program director to date. Once hired, her first task was to construct a pre-service training that focused on behavioral health and substance use topics. Students are required to complete $40 \mathrm{~h}$ of pre-service education before they are placed in the field. Students work closely with the congregational nurses from a holistic frame. Additionally, students and nurses interface with congregational leaders as well as community providers in order to deliver the best quality care. Now, in 2016, with continued funding from the Cone Health Foundation, the CSWEI/CNP 
model has achieved recognition as an innovative approach to social work field education as well as a unique community-based approach to address health and wellness [2]. Working closely with nurses, students are active in nearly 30 congregations and 3 faith-based organizations in Greensboro, NC. Over 100 students have successfully completed their internship requirements by participating in the Congregational Social Work Education Initiative. Since it first began in fall semester 2007, CSWEI students have made over 13,982 referrals to other provider agencies, served over 4452 individuals, and provided 8222 service hours. In fall 2012 formal mental health risk-assessments were tracked; the demand has grown from an initial 22 to 210 during the 2014-2015 academic year. Using 2015 North Carolina Medicaid rates, interns provided over $\$ 1,874,214$ in direct service, if these were reimbursed. Of those served over $40 \%$ were over the age of 50 and $63 \%$ were male while $36 \%$ were female. In terms of racial and ethnic identity, 62\% were African-American, 22\% were Caucasian, 3\% were Montagnard (Vietnamese), 3\% were Asian (other countries), 1.5\% were Latino/Latina, and 0.7\% were African. Income level averages include 54\% with incomes less than $\$ 499$ per month, 21\% between \$500-999 per month, and 13\% between \$1000-1499 per month. Since 2010 an increase for housing assistance was noted in the referral process: 192 people were served who were 50+ and reported having no permanent housing. The greatest needs reported by the people served included social service assistance, housing, food, medical concerns, and short-term mental health services. CSWEI emphasizes interdisciplinary, collaborative approaches to serving people in need. Currently, CSWEI is engaged in community efforts to enhance integrated care models and create new ones by partnering with medical and mental health organizations. Clearly, this project is serving people with great needs while working closely with local congregations, religiously affiliated organizations, medical and mental health clinics, and the Congregational Nurse Program. An additional grant from the Cone Health Foundation has expanded the focus of CSWEI with emphasis on people who have co-occurring mental health and substance use disorders. In this program, students work with a behavioral health nurse in conducting screenings and assessments as well as brief counseling and psychoeducation. Additionally, students create educational modules that are focused on mental wellness and health literacy. In order to ease barriers to access these modules are presented in community locations, including congregational settings. Through close work with nurses, clergy, congregants, and other staff of religiously affiliated organizations the students in CSWEI have a well-rounded experience, which is made possible through the support of the Cone Health Foundation.

\section{Conclusions}

This case study briefly explored the connection between congregations, religiously affiliated organizations and social services. Additionally, the history of a particular family in Greensboro, NC was presented to demonstrate how religious traditions impacted their commitment to the health of their community. Ultimately, the philanthropic efforts of the Cone family resulted in a local foundation that supported an innovative project, which aims to enhance access to care and address the health and mental health needs of vulnerable populations while educating social work students. The Cone brothers and their decedents probably did not imagine that the Jewish faith traditions that influenced them to be good stewards of their wealth, by building and supporting healthy communities, would result in a fusion of religiously affiliated organizations, congregational nursing, and social work education. In some ways, the work seems to have come full circle from religiously influenced giving, through secular education, back into religiously affiliated partnerships with social work education and community service. What connects these elements is a vision for a more healthy community and for the creation of services and supports that foster well-being and optimal quality of life. Perhaps social work education will continue to explore religion and religion-based entities as a location for teaching students while serving the needs of those in the community. Successful university and community partnerships to enhance social welfare will certainly depend on a vision for community health that is inclusive and innovative. 
Acknowledgments: The authors wish to thank the Cone Health Foundation for its innovative vision and continued support in building a healthier community.

Author Contributions: Jay Poole, John Rife and Wayne Moore contributed to the conceptualization of the paper. They co-wrote the paper and edited the revisions. Poole, the project principal investigator, identified this journal for submission. Fran Pearson, the director of the CSWEI project, provided information about the project and accomplishments/outcomes as well as assisting with revisions.

Conflicts of Interest: The authors declare no conflict of interest.

\section{References and Notes}

1. Granger Westberg. The Parish Nurse: Providing a Minister of Health for Your Congregation. Minneapolis: Augsburg Fortress, 1990, pp. 3-12.

2. Wayne Moore, Jay Poole, Fran Pearson, Lelia Moore, and John Rife. "Initiating New Community and Field Education Partnerships: The Congregational Social Work Education Initiative." Canadian Journal of Social Services 11 (2015): 1. Available online: http:/ / www.cscanada.net/index.php/css/article/view/6551 (accessed on 4 January 2016).

3. Diana Garland. "Church Social Work: An Introduction." In Church Social Work. Edited by Diana Garland. Botsford: NACSW, 1992, pp. 1-17.

4. Gaynor Yancey, and Diana Garland. "Congregational Social Work." In Encyclopedia of Social Work. Edited by Cynthia Franklin. Oxford: Oxford University Press, 2014.

5. Nicholas Placido, and David Cecil. Social Work and Church Collaboration: Assisting a Church's Development via Needs Assessment Strategies. St. Louis: NACSW Convention, 2012.

6. Sarah Kreutziger. "The Methodist Settlement Movement." In Christianity and Social Work, 3rd ed. Edited by Beryl Hugen and T. Laine Scales. Botsford: NACSW, 2008, pp. 81-92.

7. T. Laine Scales, and Michael Kelly. "To Give Christ to the Neighborhood: A Corrective Look at the Settlement Movement and Early Christian Workers." In Christianity and Social Work, 4th ed. Edited by T. Laine Scales and Michael Kelly. Botsford: NACSW, 2012, pp. 23-38.

8. Michael Sherr, and Hope Straughan. "Volunteerism, Social Work, and the Church: A Historic Overview and Look into the Future." Social Work \& Christianity 32 (2005): 97-115.

9. Phyllis Day. A New History of Social Welfare. Boston: Allyn and Bacon, 2006, pp. 30-35.

10. Ram A. Cnaan, Jill W. Sinha, and Charlene C. McGrew. "Congregations as Social Service Providers: Services, Capacity, Culture, and Organizational Behavior." Administration in Social Work 28 (2004): 47-68. [CrossRef]

11. Robert J. Wineburg. Faith-Based Inefficiency: The Follies of Bush's Initiatives. Westport: Praeger Publishers, 2007.

12. Ekkehard Hübschman. "Jewish Emigration from Bavaria to the Free States of America in the 19th Century." Paper presented at the 33rd IAJGS International Conference on Jewish Genealogy, Boston, MA, USA, 8 August 2013.

13. Nieli Langer. "Sectarian Organizations Serving Civic Purposes." In Religious Organizations in Community Services. Edited by Terry Tirrito and Toni Cascio. New York: Springfield Publishers, 2003, pp. 137-55.

14. Robert J. Wineburg. A Limited Partnership: The Politics of Religion, Welfare, and Social Service. New York: Columbia University Press, 2001.

15. Barbara Manthey. "Social Work, Religion and the Church: Policy Implications." Ph.D. Thesis, The University of Texas at Austin, Austin, TX, USA, 1989. p. 1175.

16. Diana Garland, and Gaynor Yancey. "Moving Mountains: Congregation as a Setting for Social Work Practice." In Christianity and Social Work, 4th ed. Edited by T. Laine Scales and Michael Kelly. Botsford: NACSW, 2012, pp. 311-36.

17. David Sherwood. "Churches as Contexts for Social Work Practice: Connecting With the Mission and Identity of Congregations." Social Work \& Christianity 30 (2003): 1-13.

18. Lauren Polson, and Robin K. Rogers. "Counseling and Mental Health Referral Practices of Church Staff." Social Work \& Christianity 34 (2007): 72-87. 
19. Jay Poole, John Rife, Fran Pearson, Lelia Moore, Antonia Reeves, and Wayne Moore. "Innovative Social Work Field Education in Congregational and Community-based Settings Serving Persons Fifty Five+: An Interdisciplinary Training Initiative for BSW and MSW Students." Social Work and Christianity 40 (2013): 404-21.

20. Robert J. Taylor, Christopher G. Ellison, Linda M. Chatters, Jeffrey S. Levin, and Karen D. Lincoln. "Mental Health Services in Faith Communities: The Role of Clergy in Black Churches." Social Work 45 (2000): $73-87$. [CrossRef] [PubMed]

21. Terry Tirrito, and Joan Spencer-Amado. “Older Adults' Willingness to Use Social Services in Places of Worship." Journal of Religious Gerontology 11 (2000): 29-42. [CrossRef]

22. Michael Sherr, and Terry Wolfer. "Preparing Social Work Students for Practice with Religious Congregations within the Context of Charitable Choice: The Grace House Ministry." Social Work E Christianity 30 (2003): 128-48.

23. W. Daniel Hale, and Richard G. Bennett. "Addressing Health Needs of an Aging Society through Medical Religious Partnerships: What Do Clergy and Laity Think? " The Gerontologist 43 (2003): 925-30. [CrossRef] [PubMed]

24. Sharon E. Moore, and Wanda Lott Collins. "A Model for Social Work Field Practicums in African American Churches." Journal of Teaching in Social Work 22 (2002): 171-88. [CrossRef]

25. Terry Tirrito, and Toni Cascio. Religious Organizations in Community Services: A Social Work Perspective. New York: Springer, 2003.

26. Lucius Wedge. "Moses Herman Cone (1856-1908)." In Immigrant Entrepreneurship: German-American Business Biographies: 1720 to the Present. Edited by Giles Hoyt. Washington: German Historical Institute, 2015.

27. Goldring/Woldenberg Institute of Southern Jewish Life. Encyclopedia of Southern Jewish Life—North Carolina. Jackson: Institute of Southern Jewish Life, 2014.

28. Eli Evans, Jr. The Provincials: A Personal History of Jews in the South. Chapel Hill: University of North Carolina Press, 1973.

29. William Powell. North Carolina through Four Centuries. Chapel Hill: University of North Carolina Press, 1989.

30. Leonard Rogoff. Down Home: Jewish Life in North Carolina. Chapel Hill: University of North Carolina Press, 2010.

31. Brent Glass. Textile History in North Carolina: A History. Raleigh: North Carolina Department Archives History, 1992.

32. Carl Balliett. Thirty Years of Progress 1895-1925. Greensboro: Proximity Manufacturing Company, 1925.

33. Indenture Note Bertha L. Cone to Moses H. Cone Hospital, Incorporated, Greensboro, NC, USA, 30 May 1911, Moses H. Cone Memorial Hospital Archives.

34. Jacquelyn Hall. Like a Family: The Making of a Southern Cotton Mill World. Chapel Hill: University of North Carolina Press, 2000.

35. Wilt Browning. Linthead: Growing up in a Carolina Cotton Mill Village. Asheboro: Downhome Press, 1990.

36. Linda Frankel. Women, Paternalism, and Protest in a Southern Textile Community: Henderson, NC 1900-1960. Ann Arbor: Bell and Howell Information Company, 1998.

37. Robert Veto. Looms and Weavers, Schools, and Teachers: Schooling in North Carolina Mill Towns, 1910-1940. Ann Arbor: Bell and Howell Information Co., 1989.

38. Howard Covington, Jr. Once upon a City: Greensboro, North Carolina's Second Century. Greensboro: Greensboro Historical Museum, Inc., 2008.

39. Philip Noblitt. Mansion in the Mountains: The Story of Moses and Bertha Cone and Their Blowing Rock Manor. Charlotte: Catawba Publishing Co., 1996.

40. Gayle Fripp. Images of Greensboro. Charlestown: Arcadia Publishing, 1997.

41. Adolph Rosenberg. "A Carolina's Community Hospital: A Special Edition." Southern Israelite Weekly Newspaper for Southern Jewry, 1951.

42. Cone Health Foundation. Available online: http://www.conehealthfoundation.com/foundation/about-us / (accessed on 20 February 2016).

43. Michael Sheridan, and Katherine Amato-von Hemert. "The Role of Religion and Spirituality in Social Work Education and Practice: A Survey of Student Views and Experiences." Journal of Social Work Education 35 (1999): 125-41. 
44. Terry Tirrito, and Toni Cascio. Religious Organizations in Community Services: A Social Work Perspective. New York: Springer, 2003.

45. Kenneth Scott Smith, and Martell Teasley. "Social Work Research on Faith-Based Programs: A Movement toward Evidence-Based Practice." Journal of Religion and Spirituality in Social Work: Social Thought 28 (2009): 306-27. [CrossRef]

46. Diana Garland, and Gaynor Yancey. Congregational Social Work: Christian Perspectives. Waco: North American Association of Christians in Social Work, 2014.

(C) 2016 by the authors; licensee MDPI, Basel, Switzerland. This article is an open access article distributed under the terms and conditions of the Creative Commons Attribution (CC BY) license (http:/ / creativecommons.org/licenses/by/4.0/). 


\title{
Article \\ Envisioning Religiously Diverse Partnership Systems among Government, Faith Communities and FBOs
}

\author{
Jo Anne Schneider ${ }^{1,2}$ \\ 1 Anthropology, George Washington University, Washington, DC 20052, USA; jschneid@email.gwu.edu or \\ joanne@chrysaliscollaborations.com; Tel.: +1-410-747-2644 \\ 2 Chrysalis Collaborations, Baltimore, MD 21229, USA
}

Academic Editor: Robert Wineburg

Received: 11 March 2016; Accepted: 21 July 2016; Published: 12 August 2016

\begin{abstract}
Recent U.S. policy regarding faith-based organizations (FBO) envisions "partnerships with government" that include both financial and non-financial relationships. This paper explores the current nature of a three-way partnership among faith communities, FBOs and government, proposing ways that government could more effectively partner with faith communities and their organizations. I use data from the Faith and Organizations Project and earlier studies of refugee resettlement and social welfare supports. The paper combines research and policy literature with research findings to describe how faith communities organize social services, education, health, senior services and community development through their FBOs, differences among religions and denominations and current forms of partnerships with government. Conclusions provide policy suggestions for U.S. systems.
\end{abstract}

Keywords: faith-based organizations; government partnerships

\section{Introduction}

Faith communities and their organizations have been central to the U.S. social welfare, health, human services and education systems from their beginnings, but White House initiatives starting in the Clinton and Bush presidencies highlighted faith community service provision. As discussed in several articles in this issue and elsewhere [1-3], the Clinton and Bush era faith-based initiatives encouraged small faith-based organizations (FBOs) and congregations to provide government-sponsored services through policy changes designed to provide support and make it easier for these types of organizations to participate in government contracting. The Obama administration's President's Advisory Council on Faith-Based and Neighborhood Initiatives re-envisioned the Faith-Based and Neighborhood Initiative (FBNI) as a partnership between government and faith communities to accomplish targeted objectives in a report published in 2010 [4]. The report highlights expanding beyond the Bush era strategy of providing technical assistance and grants to FBOs and congregations to an initiative that envisioned "partnerships with government" that included both financial and non-financial relationships to reduce poverty at home and abroad, promote inter-religious cooperation, address environmental issues and other related goals. The report stated that "The Government should highlight and develop these partnerships as much as partnerships involving financial collaboration." ([4], p. vi).

While some scholars have suggested that faith communities would rather partner with non-profits than work directly with government [1,5-7] and many others have documented faith community service provision [2,8-12], the idea of nonfinancial partnerships has not been explored in detail. Instead, organization scholars focus on the impact of government funding on FBOs [13-17] and the few churches that directly contract with government $[18,19]$. While some researchers explore the 
relationship between faith communities and FBOs [20-25], little is known about three-way service provision partnerships among faith communities, FBOs and government.

This article explores the current nature of three-way partnerships and proposes ways that government could more effectively partner with faith communities and their organizations in both funded and non-financial relationships. I use data from the Faith and Organizations Project [24] and earlier studies of refugee resettlement [26] and social welfare supports [7]. Research is combined with practical experience at NIH as an American Association for the Advancement of Science fellow (AAAS) and working as an agency administrator involved in both faith-based and secular coalitions to address poverty, welfare reform and training. I address three questions:

- How do faith communities currently work with government and non-profits?

- How do collaborations differ among various religions and denominations?

- Given current strategies, how could government best partner with faith communities and their organizations?

I start by looking at both the rhetoric and research background of current relationships between government and either faith communities or FBOs. The paper then uses key findings from the Faith and Organizations Project to describe how faith communities organize social services, education, health, senior services and community development through their FBOs, the differences among religions and denominations and current forms of partnerships with government. Case study examples from various research and practice experiences are used to illustrate concepts. A discussion of each key finding outlines key academic and policy literature related to the topic and offers policy suggestions related to that finding. Conclusions provide an additional overview of policy suggestions related to the FBNI as a whole.

\section{Data and Methods}

This article draws primarily on the findings of the Faith and Organizations Project, a national research/practice initiative started in 2001 by faith community and FBO leaders from several faiths in order to provide evidence-based tools and examples to FBOs, faith communities, policymakers and researchers. ${ }^{1}$ The overall plan for the project involved examining four aspects of the relationship among faith communities, FBOs, government and other stakeholders: (1) the relationship between faith communities and the FBOs they either founded or currently sponsor; (2) the ways that religious culture and values play out in the structure and programming of FBOs; (3) the role of FBOs in their sectors (interactions with government, other funders, other organizations providing similar services); and (4) relationships with people served by the organization. The pilot study (2004-2006) [23] provided preliminary data on all four topic areas while the Maintaining Vital Connections Between Faith Communities and their Organizations Study (2008-2010) [24], funded by Lilly Endowment Inc.) focused primarily on the first two questions.

The project included three types of comparisons: comparisons across religions and denominations, comparisons among organizations providing different kinds of services and observations regarding the role of organization size, age, funding sources and other organizational characteristics. The project design includes comparisons among Catholics, Mainline Protestants, Jews, Muslims, Evangelicals, Peace churches (Quakers, Mennonite, Brethren) and African American Christians. Our second study also included several organizations sponsored by interfaiths.

The project has consistently compared a wide range of agencies in four broad service areas: social services (from large multi-service organizations, like Catholic Charities, Jewish agencies and Lutheran Children and Family Services (LCFS) to local FBOs providing housing for people with disabilities or other social services, to congregation-sponsored blessing rooms), healthcare and

\footnotetext{
1 See www.faithandorganizations.umd.edu.
} 
senior services (hospital systems, retirement communities, clinics, congregation sponsored seniors programs), education (K-12 religious schools) and community development projects (community development corporations, emergency services, youth enrichment). ${ }^{2}$ With the exception of one Evangelical congregation's emergency services ministry, all organizations were either 501c3 nonprofits or congregation-sponsored entities with a separate bank account and advisory committee. They ranged in size and age from multi-million dollar organizations several hundred years old with multiple locations to congregation-sponsored ministries in existence for less than five years. We purposely did not include any congregation-based ministries run exclusively as projects of a pastor or committee.

The Maintaining Vital Connections Study [24] examined the relationship between 81 faith-based organizations located in the Northeast (from Philadelphia to Northern Virginia), Midwest (Ohio and Chicago) and South (South Carolina) and their sponsoring faith communities. An earlier pilot study of 11 faith-based organizations was conducted between 2004 and 2006 in Philadelphia and the greater Washington Metropolitan area. ${ }^{3}$ The project compared strategies used by the various denominations for guiding, supporting and maintaining connections with their nonprofit organizations. Depending on the religion or denomination, these guidance and support activities were carried out primarily by congregations, by higher level judicatories, like Jewish Federations, a Catholic diocese or a Quaker Yearly Meeting, by intermediary organizations, such as Friends Services for the Aging or a Catholic healthcare system, or by a combination of any of these institutions.

We focused on pairs of institutions, for example a congregation and the school that it had founded. In some cases, a single faith community founded several organizations. For example, a large, several hundred-year-old Quaker Meeting had founded a retirement community, a senior services organization and a school and was also a key member of an interfaith community development corporation. We also included several interfaith organizations that were sponsored by as many as 30 individual congregations. "Interfaith" in this context usually meant sponsorship from a variety of Mainline Protestant denominations, sometimes with one Catholic parish or Quaker Meeting added to the mix. However, several interfaith organizations had expanded to include Jews, Muslims and secular community groups as supporters, as well. In most cases, the practical theology and primary support system of the interfaiths came from a small number of particularly active Mainline Protestant congregations or a combination of Mainline Protestants and Catholics, so in these organizations, we concentrated on connections to the most active congregations.

Jewish and Catholic communities, through various umbrella institutions, such as the Federation, a religious order or a diocese, were responsible for a full range of organizations, and we chose two or three institutions under each of those denominational umbrellas for intensive study. Federations are regional centralized fundraising, planning and support institutions for Jewish non-profits providing a wide array of services $[27,28]$. To understand the nature of these relationships, we focused on how they were enacted at several different levels. For example, our research on order-sponsored Catholic hospitals included research on the regional office of one order, the national health system that oversaw all of its hospitals plus those of several other orders and a single hospital located under this umbrella in Baltimore. Jewish Federation research included a local Federation and several of its organizations, also looking at links to local synagogues and national umbrella organizations. The study looked at the faith community's understanding of its overall sponsorship role and the types of organizations it considered to be affiliated with it, as well as at the specific relationships between each faith community and selected organizations. Both studies combine several qualitative methods:

- Overview history of each faith community's support and guidance of its organizations and ministries, as well as a history of the relationship between the faith community and specific

2 A list of organizations in the second study is available at http://www.faithandorganizations.umd.edu/pdfs/MatrixComplete.pdf.

3 See Schneider et al. [23] for a complete description of this study. 
selected organizations: Histories were developed using existing histories of the organization or faith community, a review of documents related to stewardship (e.g., archived minutes of meetings, religious statements, statements of justice and charity activities or other documents relating to the guidance of the organizations) and interviews with people knowledgeable about the history of the faith community or the organization.

- In-depth interviews with current and former key individuals from both the faith communities and organizations regarding present-day relationships and organizational patterns.

- Participant observation in faith community oversight activities and selected organization events related to the relationship with the faith community: Project researchers attended numerous faith community and organization activities and sat in on meetings relevant to maintaining connections to the organization. These activities and meetings varied by faith tradition and included faith community committee meetings, presentations by selected organizations to the faith community, organization board meetings, annual meetings and events for the larger community. Other participant observation opportunities involved infrequent activities (e.g., an annual presentation at a Yearly Meeting or Synod conference, an annual Christmas party or an organization festival honoring volunteers), quarterly committee meetings or monthly board meetings. In addition to observing meetings and events, our staff participated in weatherization days, summer arts programs and other direct service volunteer activities where relevant. While observing, researchers also talked with participants about how they had learned of the organization or event, their thoughts on the organization and key faith-related reasons for being involved with the organization.

- Analysis of recent and ongoing written materials produced by the faith community and selected organizations: these included board and committee minutes, outreach and recruitment materials, theological materials related to charity and justice activities and other similar documents.

- Relationship self-assessment questionnaires: One of the products of the study was a combination qualitative and quantitative self-assessment tool for both faith communities and organizations to use. Toward the end of the study, this self-assessment instrument was tested in both selected organizations in the in-depth study and additional FBOs and faith communities in the South, Midwest and East Coast.

These various data were drawn together and used to: (1) develop comprehensive pictures of each organization/faith community relationship; and (2) provide comparative material for general analysis. We used several standard ethnographic analysis techniques to understand our findings [29], including creating keyword-based analysis runs using the DTsearch program (http://dtsearch.com/).

In addition to Faith and Organizations Project research, I draw on several of my earlier research/practice experiences. Between 1981 and 1988, multi-method ethnographic dissertation research on refugee resettlement for Soviet Jews and Poles in Philadelphia, focusing on refugees interactions with Catholic, Jewish, Mainline Protestant, Lutheran and one secular non-profit responsible for resettlement, as well as interactions with government and the faith/ethnic communities in which they were settled $[26,30]$. Practical experience running both a faith-based youth development program and serving as an administrator in a secular organization offering welfare to work and training in Philadelphia between 1992 and 1997 was combined with twelve studies conducted between 1992 and 2002 in Philadelphia, Kenosha and Milwaukee Wisconsin in order to analyze social welfare supports for families in Pennsylvania and Wisconsin [7]. The welfare and poverty research examined community responses to the needs of various populations, including multi-method ethnography of both faith and secular communities' interaction with government as well as non-profit and FBO activity. Finally, I briefly draw on experience working with the federal government as an AAAS fellow at the National Cancer Institute from 2003-2005. My primary project involved creating a model for federal government agencies and national non-profits to better connect with local faith communities, FBOs and secular community entities in order to improve healthcare too hard to reach populations. 


\section{The Rhetoric and Reality of Government Relationships to Faith Communities and FBOs}

While proponents of charitable choice provisions in the 1996 welfare reform law ${ }^{4}$ and the Bush-era faith-based initiative claim a renewed interest in faith communities providing supports in partnership with government, historians of social services in the U.S. note that faith communities and FBOs provided the bulk of social services in the U.S., often with government funding, from before the United States was formed [31-34]. In fact, faith communities were the primary support for the needy before passage of the Roosevelt New Deal programs in 1935 [3,31,32]. The government's role as the primary provider of income supports lasted only from the New Deal until passage of the Personal Responsibility and Work Opportunity Act (PRWOA) (often known as Temporary Assistance to Needy Families (TANF)) in 1996. Emergency services, ${ }^{5}$ training, medical care, support for at-risk children and many other social programs always included faith communities and their organizations as significant providers [3,31-34]. Wineburg et al. [3] date the devolution of services to faith-based and secular non-profits to the Reagan era, with significant increases in contracting out services previously offered directly by government following welfare reform in 1996. Other scholars date the proliferation of non-profits in the U.S., many funded through government contracts, to the 1960s [35,36].

The same pattern is true for healthcare and education. While most medical practitioners have always been for-profit, hospitals started out as community or religious institutions [37]. Government gradually began to play an increasing role in funding healthcare for the elderly, low income and those with special needs only after the passage of Medicaid and Medicare in 1965. Educational systems only gradually came under state control, with faith communities maintaining separate systems to this day.

While faith community involvement in social services, healthcare, senior services, emergency services and education has a strong legacy in the United States, religious involvement in service provision had different rationales for Jews, Catholics and Protestants. As Hall $[33,38]$ documents, Protestants dominated U.S. culture from the colonial era on in most communities, deliberately secularizing their non-profits by the end of the 19th century in an effort to maintain moral authority. Modern social work also evolved from two fundamentally religious movements of the late 19th and early 20th centuries, the Charitable Organization Societies and the social gospel movements [31,34]. The Jewish and Catholic systems, on the other hand, developed originally as alternative venues for their co-religionists to obtain services and education outside of the predominantly Protestant mainstream institutions [27,39-41]. However, by the 20th century, Catholic and Jewish institutions served everyone, and the Catholic school system had become an important alternative to public education for many non-Catholics in large urban school systems.

The legacy of this long history of religious involvement in social services, healthcare and education is evident in the significant presence of organizations founded by faith communities in U.S. social services. Ammerman ([20], p. 179) notes that Lutheran Social Services, Catholic Charities, the Jewish social service network and the Salvation Army comprise some of the largest providers of social services in the U.S. Catholics run the largest health systems in this country, as well as the largest independent school system [40,42,43]. Wineburg et al. ([3], p. 25) report that by 1981, the U.S. census reported that 47 percent of private U.S. social service expenditures went to FBOs. Established FBOs have also continued to receive the bulk of government funding. Scholars report that most funding for faith-based organizations goes to FBOs with a long history of government funding [6,14], and a U.S

4 Charitable Choice, Section 104 of the 1996 welfare reform act, allowed religious providers to offer services without having to remove outward signs of their religious identity. Government funding could not be used for sectarian activities, like bible study or worship.

5 Emergency services refers to providing food, clothing, emergency shelter and other relief to people in need. Holiday packages or meals for the needy also generally fall into this category. The literature on congregational service provision universally notes the provision of emergency services as the most prevalent social service provided by congregations [2,5,10]. Most of the organizations providing emergency services in U.S. communities have their roots in faith communities, including the various gospel missions and Salvation Army, as well as soup kitchens, food pantries and shelters sponsored by congregations, interfaith networks or a Catholic diocese. 
federal government report noted that 93 percent of the FBOs receiving funds from Housing and Urban Development and that 80 percent of FBOs funded by Health and Human Services had received government funding before [44].

\subsection{Charitable Choice, FBNI and the Role of Faith-Based Organizations}

A full discussion of the Clinton and Bush faith-based initiatives are beyond the scope of this paper. Readers interested in policy history will find other articles in this volume that discuss the Bush initiative in detail. While the Clinton Charitable Choice legislation and Bush Faith-Based and Neighborhood Initiative did not initiate faith-based involvement in the U.S. social welfare system or partnerships between government and faith communities, it did shift the focus and goals of involving faith communities in government-sponsored service provision. Prior to these two initiatives, government contracts stipulated that religiously-based non-profits could not use religious elements in government funded programs. This meant that, while agencies like Catholic Social Services and Jewish Employment and Vocational Services embedded their religious values in their social services, they could use no outward signs of religion or religious elements in their programming or facilities. Organizations providing services through congregations, like the congregations that resettled refugees for Lutheran Immigration and Refugee Services and Church World Service were enjoined to not proselytize to the families they hosted [26,30].

My research in the 1980s revealed that agencies managed this separation of church and state through their connections to their wider faith communities. For example, Catholic Poles resettled by Catholic Social Services were usually resettled in Polish Catholic neighborhoods and would generally receive a visit from the priest from the nearest parish to invite them to attend church and tell them about the school within a week after arrival. While religion was not mentioned at Catholic Social Services, I suspect the list of incoming refugees was quietly shared with the parishes. Likewise, Jewish agencies resettled Soviet Jews in largely Jewish neighborhoods, offering low cost or free memberships to the Jewish Community Center, Jewish child care centers, seniors programs and other more openly Jewish services available in that community. Synagogues were encouraged to offer low cost memberships to Soviet Jews by the local Federation [26,30].

Many scholars and policymakers alike presumed that organizations offering secularized services would become more secular over time [45]. Starting with a Reagan-era speech, these large, multi-service non-profits were equated with the uncaring, bureaucratic services of government ([3], p. 23). The faith-based initiative was designed to encourage congregations and smaller, more openly faith-based FBOs to compete for government contracts. Proponents of the new FBNI claimed that established FBOs like Catholic Charities, Jewish Children and Family Services and Episcopal Community Services were secular because they "did not preach or disseminate religious doctrines, hired professionally trained staff who were not necessarily from their faith tradition, did not celebrate religious holidays with clients, and mirrored their secular counterparts" ([46], p. 6).

In contrast, the ideal FBO would be grounded in a congregation, providing "holistic", caring services through volunteers and staff hired from the faith community, rely on free or less expensive resources from that faith community and transform the individual receiving services through religiously-based programming. While critics argued for separation of church and state through a variety of mechanisms, both scholars and policymakers attempted to identify the faith base in organizations, so that they could determine if openly religious providers were "better" than secular nonprofits or those that did not use religious elements in their programming. Numerous scholars and a policy committee created a series of scales, most relying on outward signs of religiosity, to identify the level of faith in an organization [15,45,47-49]. Generally, the scales included a number of gradations varying from secular to faith integrated, with the faith-integrated programs using prayer and other religious elements in their programming and generally suffusing religion throughout their programs. While each of these scales were careful to note that different organizations used religion in varying 
ways, the general impression they offered was that more visibly religious organizations were more faith based than others.

Scholars attempted to develop evaluation tools to measure the role of faith in service provision, one step in determining if faith-based or secular programs provided "better" services (for example, [50]). Many scholars noted that faith was often linked in the policy rhetoric with transformation, with proponents of the faith-based initiative assuming that FBOs would engender transformation in the individual through the faith elements. ${ }^{6}$ Measures of religious program effects often focused on levels of faith using one of the typologies identified above (for example, [51]), comparing organizations grouped by the type of religiosity on standard program outcomes, such as number and characteristics of job placements $[14,16,52,53]$. Most of the empirical studies comparing FBOs with various levels of faith to each other and secular organizations found evaluations difficult to do, faith hard to measure and complex results $[14,16,53,54]$.

As the policy rhetoric encouraged openly religious organizations and congregations to become involved in government-funded service provision, established FBOs worried that they would lose contracts as funds were targeted toward congregationally-based, supposedly holistic, small FBOs [6]. The scholarly literature documented this focus on congregation-sponsored programs and smaller FBOs through such initiatives as government outreach through faith-based liaisons and other mechanisms $[18,55]$ and technical assistance to new faith-based and community organizations through the Compassion Capital Fund and similar initiatives $[6,14]$. Larger, established FBOs responded by clarifying the religious roots of their organizations $[41,56,57]$.

Analysis of the focus on congregations, the descriptions of ideal FBOs and transformation suggest that these visions of the role of faith-based organizations in social services reflect Protestant and Evangelical approaches to social service. As discussed in detail elsewhere [58,59], our research found that these two denominations organize their social support activities through congregations or networks of people with a shared faith vision, often relying on congregations or networks for resources, volunteers and staff. Evangelicals are most likely to infuse faith through all elements of an FBO. Images of transformation could imply the impact of profound instances of faith found in most religious traditions, but it most resembles the process of being "born again" in Evangelical parlance. African American congregations are most likely to develop complex, government-funded service initiatives through a congregation [5,60]. African American Christians can follow either Mainline Protestant or Evangelical faith approaches, but FBOs and congregational projects tend to be clearly pastor led and closely tied to the congregation [60].

While the reliance on Evangelical and Protestant models is unsurprising given their predominance in U.S. culture and politics at the time, as well as the religious background of President Bush, they do privilege one model of organizing faith community service provision over others. Emphasis on Evangelical and Protestant models at the state level reflects the fact that the majority of the faith-based liaisons came from these traditions and that their activities reflected their religious approach and networks. Sager ([55], p. 106) notes that 17 of the 30 state faith-based liaisons she interviewed were conservative or liberal Protestant, five were Catholics and only two came from a non-Christian background. As discussed in more detail below, Protestant and Evangelical models are not shared by all religious traditions, particularly the Jewish and Catholic organizations that provide a significant proportion of services in this country. Policy suggestions will focus on expanding the vision of what constitutes a faith-based organization, the nature of the faith community and ways that faith communities relate to FBOs to include the range of religious traditions in the United States.

The scholarly consensus on the Bush faith-based initiative was that it brought in few new contractors, and many of the smaller or newer organizations interested in the faith-based initiative had trouble competing successfully for contracts $[14,16]$. Research on congregations showed that

6 See ([61], pp. 90-92), for a discussion of faith and transformation. 
while most congregations participate in some form of social outreach, these programs are usually low intensity initiatives and that most congregations would prefer to partner with FBOs or secular non-profits to provide more complex services [2,5]. Research on the impact of the faith-based initiative showed that while more congregations expressed interest in social welfare, only African American congregations and those already providing complex services likely to be funded by government sought government funds [1,9]. This clearly suggests that strengthening non-financial partnerships with faith communities was an appropriate direction for the Obama administration Faith-Based and Neighborhood Initiative.

\subsection{Government Partnerships with Faith Communities and FBOs}

How does government interact with FBOs and faith communities now? Both the literature and research experience suggest four types of interactions; first, government contracts with FBOs, faith community intermediaries or congregations to provide specific services. Examples of $\mathrm{FBO} /$ government contracts would include contracts with Catholic Charities to provide GED or foster care services, a subcontract between a quasi-governmental agency like a workforce development board and a faith-based training provider or city funding to an interfaith Community Development Corporation (CDC) using federal Community Development Block Grant (CDBG) monies to develop a low to moderate income housing project. Intermediary contracts also involve an incorporated entity, for example a Jewish Federation contract for refugee resettlement, which is used to fund programs by several Federation agencies to serve specific needs of refugees in that community. Congregation contracts also involve either a congregation or a congregation-affiliated FBO, like Head Start contracts with an African American church's non-profit entity or direct funding to a congregation to run a welfare to work program.

In each case, competitive contracts or grants connect a government entity with a single provider. The faith community supporting that incorporated agency is generally not part of the negotiation or implementation of the contract, although the contract may include an in-kind match of space, volunteers or other resources provided by the faith community. When matches are involved, the non-profit or congregation receiving the contracts works with its faith community to obtain matching resources; government is usually not a part of this interaction.

The second form of interaction involves government funding through some form of voucher, such as Medicare or Medicaid insurance payments to a hospital or clinic, public school vouchers to religious schools or a Workforce Investment grant ${ }^{7}$ given to an individual to obtain training from a program of his or her choice. In each case, FBOs receiving payment through a voucher are subject to government regulation related to those vouchers. For example, Catholic schools participating in Milwaukee's school choice program had to offer an alternative to religious instruction to students attending through the voucher program. Schools, hospitals, training programs and a variety of other entities are subject to various forms of government regulation regardless of whether or not they receive funding from government either directly or indirectly.

Government funding for FBOs in any form raises concerns regarding the impact of government funding on FBO or congregation autonomy. Monsma ([16], pp. 20-24) describes a statist approach to government/non-profit relations, which envisions government as the appropriate funder for services, but sees the agency receiving funds as responsible for providing services according to government guidelines. As such, the non-profit becomes an arm of government, leading to conformity among programs, lack of autonomy and loss of individuality [62-64]. Research shows that both congregations and $\mathrm{FBOs}$ report that fear of government intervention in religious elements of programs

7 The Workforce Investment Act (WIA) combined a series of federal programs offering training and employment-related services. The act replaced Private Industry Councils (PICs) with Workforce Investment Act boards that offered one stop shops of approved training programs. One stops theoretically provide information and referral for a range of programs related to employment and training. Eligible recipients receive vouchers for training that they can use at any eligible program. 
or organizations is a major reason not to seek government funding $[9,65]$. Despite this concern, some researchers show that FBOs and other non-profits are able to both conform to government dictates and maintain unique program elements that reflect their mission and religious traditions [7,24,36]. Research suggests that mixed sources of income enable freedom to add program elements beyond government dictates [16] and that even small amounts of funding from a faith community can powerfully shape program direction $[23,24]$.

The third form of government/faith community interaction involves government disseminating information through FBOs or faith communities. Examples include providing referral data on WIC, food stamps ${ }^{8}$ or welfare through faith-based homeless shelters. Another common strategy involves government or government funded programs to improve health and welfare, such as a National Cancer Institute/American Cancer Society (ACS) initiative to get African American churches to develop programs to promote fruit and vegetable consumption by their members. The program used government-/ACS-created materials and program guides disseminated through a combination of social marketing and contacts with national-level faith community leaders. Other examples include NIH-funded efforts to offer programs in churches to prevent diabetes or promote healthy behaviors [66,67]. Federal and local government attempting to coordinate faith-based responses to natural disasters, such as Katrina or Haiti, through information dissemination is another example.

In each case, government agencies either use known contacts or media to provide information through faith communities, presuming that they will have greater reach than government itself. Particularly with efforts to promote health or social programs, contacts are often with congregations or higher level adjudicators on the presumption that these entities are most able to reach target populations. Occasionally, the same strategy is used to recruit volunteers for mentoring, foster parents or other initiatives. However, these efforts are more likely to come from an FBO with a government contract than government directly.

The final form of interaction involves inviting faith community or FBO representatives to participate in government sponsored coalitions. The various task forces sponsored by the Obama administration that made recommendations related to this administrations Faith-Based and Neighborhood Partnerships is one example. All levels of government use task forces or coalitions for various initiatives, and some government-sponsored programs require community participation. The nature of these coalitions varies greatly depending on the level of government and collaborative goals.

In most cases, all four forms of collaboration involve contracts between government and an entity presumed to represent a larger faith community. Contracts and vouchers are the exception, as the relationship is usually exclusively between government and the FBO or the faith community entity receiving funding. Particularly with information dissemination efforts and some coalitions, government outreach to the faith community or FBO is expected to reach into a broader community. However, these initiatives may not understand the unique attributes of the faith community that shape appropriate approaches to collaboration and ways that faith communities and FBOs may respond to government goals. True partnership involves better understanding the nature of the three-way relationship among faith communities, FBOs and government. I now turn to the discussion of the key findings from the Faith and Organizations project that could enhance partnerships for government, faith communities and FBOs.

\section{Religious Social Support Systems and Their Potential Relationships with Government}

This brief description of government's current interactions with faith communities and FBOs suggests that government forms relationships with individual organizations for tangible purposes like providing a service or disseminating information on healthy behaviors. However, these organizations

8 The Women, Infant and Children's (WIC) and food stamp (now called the Supplemental Nutrition Assistance Program (SNAP)) programs are the two main federally-funded food and nutrition programs offered in the U.S. 
come out of multiple communities and interact with several constituencies. Figure 1 comes initially out of my work on social welfare support systems [7], illustrating local systems for service provision. Each of the large circles represents a community of citizens and institutions that creates non-profit, for-profit and faith-based organizations to provide services. The large circles, community-based, faith-based, government-contracted and ancillary services, indicates networks of individuals and organizations that come out of a specific social, religious or geographic community. The faith community circle would include the institutions and members of all of the denominations and religions in a particular locality, consisting of smaller circles for Jews, Catholics, Muslims, Mainline Protestants, etc. These smaller networks may be linked to each other through denominational conferences and to other religions or denominations through interfaiths or more informal inter-religious collaboration. The large community-based circle includes both geographic neighborhoods and communities of identity (race, ethnic, immigrant/refugee, sexual orientation, etc.). As with the faith community circle, it actually would contain many sub-circles whose members may or may not work with each other. The contracted government and ancillary services circles represent citizens and organizations that come together to address a specific need, such as educating children, providing healthcare or working with government to address poverty.

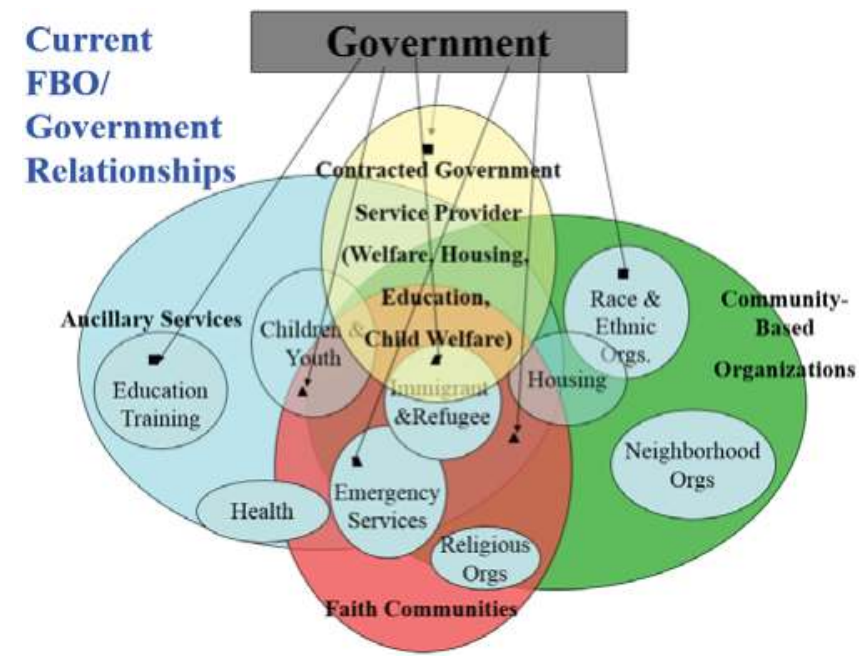

Figure 1. Current faith-based organization (FBO)/government relationships.

The smaller circles represent networks of organizations providing a specific service, like emergency services or housing, or providing venues for social activities, support and advocacy for people from a particular racial, ethnic, immigrant or religious group. As these small circles indicate, the organizations and people associated with them tend to know each other either as competitors or collaborators, but may not have ongoing relationships with organizations offering another kind of service. This siloing of services is typical in the U.S. and even occurs sometimes in multi-service organizations where the staff involved in childcare may not interact with people in their own agency offering housing services, but would be connected to staff at other organizations providing child care in a variety of information sharing and coalition activities ([7], pp. 239-62). Both the Faith and Organizations Project research [24] and other scholars have noted that agencies tend to work as part of networks, with faith-based organizations more often collaborating with other FBOs or faith communities [6,54]. 
While these networks focus on a specific need, their membership overlaps with faith communityand community-based networks. For instance, a retired lay leader in a Quaker Meeting worked as a lawyer specializing in housing for the poor and elderly. As a volunteer, he sat on the board of both faith-based and secular housing organizations, as well as serving as an active member of the local council for the elderly. Because of his known expertise in these areas, he provided advice to agencies developing housing for low income people and the elderly through government contracts and has served on local government advisory committees on these topics. Over time, he has developed trust-based relationships with many individuals and organizations in his faith community, as well as the work and volunteer arenas in which he is involved. As such, he has connections in faith-based, ancillary services and government-contracted circles. Those connections provide him with access to resources and information that he could share within any of these communities or with government.

Trust-based connections that can lead to resources are called social capital [68,69]. Both organizations and individuals develop social capital that they use to garner resources, advice and support $[7,70]$. While all individuals and organizations develop bonding social capital among people or organizations like themselves, some research and policy discussion suggest that the most successful develop connections outside of their core communities or bridging social capital [71]. Partnership with government also involves local organizations and communities fostering linking social capital [72] or trust-based relationships with institutions with unequal power relations, such as government and an agency receiving a government contract. My work suggests that bridging, bonding and linking social capital are equally important to meet goals $[7,70]$.

While individuals and organizations in each of these circles may have access to resources through their connections, the nature of those connections and the unspoken rules and behaviors necessary to access them come out of the culture of that particular community. People and organizations that have access to community resources have also developed cultural capital or the learned behaviors or symbols of identity that indicate membership in a group. Faith and Organizations Project research found that cultural capital, in the form of shared religious values and visible practices connected with that faith, was essential for FBOs to garner support from their faith communities. Faith communities expected their FBOs to reflect their practical theology: the formal and informal mechanisms a faith community uses to enact its theological teachings through its religious culture and structures. Faith communities saw their role in supporting or guiding FBOs they sponsored not simply as providing board members, funding, volunteers or other resources, but offering guidance and oversight to ensure that the organization reflected its religious base. FBOs and faith communities understood themselves as stewards of their FBOs, defining stewardship as overall administration and guidance for non-profits by the founding or supporting faith community [73]. Study results reveal that support structures for religious-based non-profit activities come from the practical theology of their founding religion, leading to the development of systems of stewardship based on religious values and practices. Further, communities support organizations that reflect their practical theology through publicity for the organization and tangible supports, like donations, volunteers and ongoing partnerships. FBOs that stray from the practical theology of their faith community become targets for community concern, facing reduced donations, trouble finding board members from the faith community and other indicators of diminishing support.

These findings have significant implications for government partnerships with FBOs. As illustrated in figure one, government may contract with an FBO or secular agency to offer a specific service. The arrows to squares represent contracts or dissemination relationships with secular non-profits while the arrows to triangles represent government collaborations with FBOs. The point of this chart is that, while government may understand that these individual organizations come out of communities, the relationship most often focuses on the concrete goals of that specific activity. As with the statist paradigm for government/FBO relations, government focuses on the agency's ability to successfully deliver a particular program as stated in an RFP or program outline created by government; for example, placing 50 percent of trainees in a welfare to work program in jobs 
offering $\$ 6.00$ per hour, with at least half of the jobs offering health insurance; or a church may be asked to present a nutrition program promoting eating nine servings of fruit and vegetables a day to 50 members, enrolling 25 in a pledge program to meet specific nutritional goals for 90 days. In each case, the goals are determined by government in a classic top down bureaucratic fashion [74]. If an agency uses additional resources or strategies from their faith tradition to meet the stated outcomes, so much the better, but the point is to meet program outcomes and account for those activities, not offer faith-based interventions.

The Bush-era faith-based initiatives emphasis on congregations and small FBOs presumed that working directly with a congregation or an FBO strongly tied to a faith community would automatically provide services that would have extra resources and new approaches from that faith community. However, the goals were government goals. Rather than develop relationships both with an FBO and the faith community that supported it, contracts were with the FBO only. Even though the faith community could be expected to provide resources like space, volunteers or in-kind contributions, they were generally not part of the contract negotiation or party to the contract. While both Charitable Choice and the language of the faith-based initiative allowed faith communities to use their religious background in their programming, implementation involved much confusion over the line between programming based on religious values and inherently sectarian activities, such as prayer or sharing faith [16].

Further, since faith-based programming was characterized using Protestant or Evangelical language, Jewish, Mainline Protestant and some Peace church, organizations that highly valued supporting freedom of religion as a religious value in their programs denied that they were faith based. For example, most of our Jewish programs categorically announced that they offered secular programming using professionals, but when asked, explained that the basis for this decision was the fundamental Jewish values of Tikun Olam (repairing the world) and that using professionals reflected Jewish values that the greatest Mitzvah (blessing/good deed) was to offer the highest quality services that would lead to the best results. Like these Jewish institutions, we found religion embedded in the structures, strategies and programming of most Mainline Protestant, Catholic and Peace church organizations, which the standard typologies would label as faith related or faith background. These findings suggest that government needs to more carefully understand the diversity among religions and denominations it hopes to partner with, as well as the nature of the social networks that provide non-financial resources to both government and FBOs. It means understanding partnerships as a three-way interaction among government, FBOs and faith communities rather than a one-to-one relationships with either an FBO or faith community. I next look carefully at some key aspects of these differences across religions and denominations.

4.1. Religion Is Embedded in the Structures and Practices of FBOs, and Maintaining that Religion's Values Is Critical to FBOs with Strong Ties to Their Faith

As outlined earlier, to date, the Bush faith-based initiative and supporting scholarship attempted to develop universal typologies of faith to identify faith-based organizations. While a full review of the various classification systems is beyond the scope of this paper, I review the general characteristics of the most popular scales here. ${ }^{9}$ Most scholars agree that the religiosity of an organization exists on a continuum and that several dimensions of the organization's structure and activities should be measured independently to understand the role of faith in organization practice. For example, Sider and Unruh [47] present a typology that measures the characteristics of both organizations and programs, stating that a particular program may present more or fewer religious attributes than the organization as a whole. Their typology categorizes organizations from most religious (faith permeated) to secular based on such visible signs of religiosity as: (1) religious environment (building

9 See [47] and [75] for review of various classification systems. 
name, religious symbols displayed); (2) religious program content; (3) religious background of senior management; (4) criteria for selecting other staff; (5) sources of financial support and other resources; (6) organized religious practice of personnel; (7) mission statement and other materials; (8) founding organization and purpose; (9) affiliation with religious entities; (10) selection criteria for the board; (11) integration of religious content with other program components; and (12) expected connection between religious content and expected outcomes ([47], pp. 112-15). The most religious organizations actively use religious background in choosing staff and board; religious statements permeate all aspects of the organization; and its programming and staff actively use religion (prayer, religious texts, etc.) when serving clients.

Both Monsma [14,76] and Ebaugh, Chafetz and Pipes [48,77] also use a series of visibly religious attributes to characterize dimensions of religiosity. Monsma used a list of ten religious attributes, identifying organizations and faith based/segmented and faith based/integrated based on the number and type of religious practices. The Ebaugh, Chafetz and Pipes ([48], p. 264) scales used a similar list of 18 elements that fall into several categories: (1) visible religious symbols; (2) preference for religious candidates in staffing; (3) religiously explicit mission statement and materials; (4) prayer or use of religious material in programming with clients and staff; (5) indicators of proselytizing; and (6) staff understandings that their work serves a religious purpose (for example, put religious principles into action, demonstrate God's love to clients). Through factor analysis, they identify three scales of service religiosity, staff religiosity and formal organization religiosity that behave independently. Most scales contain similar elements, and some scholars base religiosity on the numbers of religious staff involved in the organization and the pervasiveness of the founding religion in its programming and ethos (for example, [20]). All of these scales share an emphasis on outside signs of religiosity, such as mission statements and symbols in buildings; percentage of funding, staff and participants connected to the founding religion; and open, individual religious practice, such as prayer, proselytizing and the use of religious materials in programming or organization practice.

Other scholars view the relationship between religious background and organization structure as far more complicated than represented on these scales $[6,22,53,57,75,78]$. Some note the diversity of religious expression, but look for universal aspects found in all religions to identify an organization as faith based [79]. In contrast, the Faith and Organizations Project research demonstrates that religious culture and theology determine the way that religion is integrated into an organization, and religion is often embedded in the structure and culture of agency practices [23,24]. Further, as discussed elsewhere [5], these popular scales reflect understandings of religion more prevalent in Protestant denominations, particularly Evangelical faith traditions. As the vignette on the Jewish organizations indicates, FBOs relying on strong religious backgrounds can appear secular in these typologies and may not want to be identified as faith based using the criteria from these universal scales. As with other scholars who have attempted to apply universal scales in evaluation research [6,53], our research suggests that FBOs and their faith communities should be encouraged to clarify for themselves and their government partners how their faith plays out in their organizations. Understanding practical theology is key to discerning how religious values are reflected in the organization and its programming.

Outlining practical theology for each religion and denomination is beyond the scope of this paper, but is available in other publications from the project $[24,80]$. Since practical theology changes across time and place, respecting the diversity of religious practice is particularly important when developing partnerships among faith communities, FBOs, government and other stakeholders. This is particularly true with Mainline Protestant and Evangelical organizations, where great diversity exists both within and across denominations or independent faith communities.

Understanding the nature of practical theology and religious culture for faith communities and FBOs is essential for partnerships because these religious elements will determine the resource structure for each FBO, outreach strategies to a faith community and the types of activities an organization is willing to undertake. The legal language regarding faith-based organizations stipulates that government cannot interfere with religious practice, but how this clause is interpreted can become a 
deciding issue for FBO participation in government initiatives. Religious exemption clauses are the basis for allowing faith communities to hire co-religionists and set certain personnel, structural and programmatic policies that reflect their theology. However, the exact nature of the religious exemption clause is established by local government. One vignette from our study illustrates the importance of government respecting specific religious values in order to partner with a wide range of FBOs. ${ }^{10}$

In March 2010, the District of Columbia implemented a same sex marriage law, stipulating that any agency that received government funds to provide services must offer equal treatment to same sex couples as anyone else served by their programs. Agencies also were required to provide the same benefits to same sex couples as any other married employee.

This new law caused a major dilemma for Catholic Charities of Washington DC. The agency is a large, multi-service organization that began as the Catholic Home Bureau in 1898 offering home placements for orphans. It incorporated in 1922 as Associated Catholic Charities and merged with several other Catholic organizations in 2004 under the Catholic Charities name to become a multi-site organization offering a wide array of services to area residents regardless of race, nationality or religion. At the time this law was debated, 68 percent of the Catholic Charities budget came from government, approximately twenty-two million dollars according to the Catholic News Agency. ${ }^{11}$ The agency had government funding for foster care, independent living for older youth aging out of foster care, homeless services, services for people with persistent mental illness, people with developmental disabilities, families in crisis, immigrants and refugees. The agency was one of the top five in number, size and scope as a provider for foster care, accounting for 10 percent of private sector foster care in the area. While key leaders are Catholic, agency employees come from many different religious backgrounds. While Catholic values underlay program design and staff culture includes open religious activities, like requests for prayer on the email system behind the scenes, the services offered are deliberately secular or non-denominational.

Catholic Charities is described by its staff as "the social service arm of the Catholic church." As determined by structures established by the Catholic Church in the U.S. in the early 20th century, Catholic Charities/Catholic Social Services are directly under the diocese, with the local bishop as titular head of the board. The first meeting of the National Catholic Charities Conference in 1910 at Catholic University included in its statement of purpose: "The National Conference... aims to preserve the organic spiritual character of Catholic charity." Today, the Catholic values in Catholic Charities are supported through its strong ties to the local dioceses, as well as support from its National trade association, Catholic Charities USA. As such, local Catholic Charities must follow the teachings of the church, including "our religious teaching that marriage is between one man and one woman."12

Analysis of the proposed law by the agency determined that it would impact on foster care because they would be expected to place children with same sex couples as foster parents and on employee benefit packages that covered spouses, but would not impact on any other direct service program funded by government. Agency leadership began to work with the archdiocese to formulate a response when the bill was first proposed. Agency and church leadership testified at numerous hearings, as well as attempting to negotiate behind the scenes for several months, with little results. A key leader explained: "We argued that the narrow religious exemption [clause] threatened our partnership to provide services with government-was in violation of our religious tenets which we can not do." Describing the religious exemption clause in the law as "the narrowest in the country", agency and church leaders together determined that the agency would need to get out of foster care

10 This case is based on interviews with several key staff at Catholic Charities of DC between 2009 and 2010 , participant observation in the agency, informal conversations and a review of newspaper articles related to the incident.

11 Catholic News Agency Press Release 3 March 2010.

12 Interview with Catholic Charities leadership staff. All quotes in this vignette are from various conversations with the same staff person. 
altogether and change its spousal benefits so that they would provide equal treatment for all employees, but not cover same sex couples.

Once the decision was made, the agency worked with local government to find another agency with a similar philosophy to take over foster care. Ultimately, all staff and cases were transferred to a secular organization with Baptist roots, enabling complete continuity of care for children and families receiving foster care services, but ending over 100 years as a key provider of foster care in the DC area. Spousal benefits were changed so that anyone either joining the organization as new staff or marrying would not be offered health and other benefits for their spouse. While agency leaders were unhappy with these changes, they clearly stated that they had no choice as they could not allow DC government to "legislate the marriage policy of the Catholic church." When asked what the organization would have preferred, a key leader commented:

In a perfect world what would have happened differently was government's recognition of the public/private partnership with FBOs, allowing the organizations to operate within the teachings of their own religion. Providing the kind of religious exemption that allows church to be church and government to be government. Continue[ing] to provide foster care to couples that were of different genders. If all organizations said no [to allowing same sex couples to be foster parent], that would be an undue hardship on same sex couples. But they can get services elsewhere-we can be true to who we are.

This case demonstrates that even large, multi-service FBOs providing apparently secular services consider following their religious teachings paramount. Despite the loss of a key program, the agency clearly showed that government could not dictate internal policy. While the agency continues to partner with government, this incident necessarily changes and limits the nature of the relationship. This case also shows that FBOs are embedded in faith communities and respond to unique faith community structures. This discussion of role of religion in FBOs suggests three strategies for government initiatives partnering with FBOs:

- Ask FBOs and faith communities to clarify the role of their religious traditions in their organization and explain the unique resources and limitations their faith background creates in partnerships with government and other entities.

- Developing partnerships should involve working with both FBOs and faith communities, encouraging both to outline how they can best partner with government, what they expect from government and how they manage the relationship between FBOs and faith communities.

- Religious exemption clauses should not attempt to legislate practical theology, but search for ways that government can partner with a diverse range of religiously-based institutions and ensure that all citizens have access to high quality services. The policy debate on this issue notes that guaranteeing options for people served is easier in diverse cities than in rural or smaller communities.

4.2. Faith Community Systems Shape How Different Religions and Denominations Structure Social Justice and Charity Work; Understanding These Structures Is Important for Government Outreach Efforts

The Faith and Organizations Project found three systems for organizing efforts to address any number of issues from a faith perspective that tracked back to the practical theology of a given group of religions or denominations. A detailed discussion of these systems is available elsewhere $[24,80]$. Here, I briefly outline key features of these systems and which religions and denominations use each system. I then discuss implications for government partnerships.

The six religions in the Maintaining Connections study fell into three strategies for organizing stewardship. As discussed in a companion paper [80], these strategies reflected the practical theology of their founding religions, but also larger historical forces that influenced general strategies. 
As Wittberg ${ }^{13}$ commented, the older religions-Jews and Catholics-shared strategies that saw stewardship and providing for those in need as the responsibility of communities as a whole. This obligation may be conceived as applying either to members of that religion exclusively or to the whole world. Our pilot study suggests that Muslims share a similar ethos [23]. This expectation came from times when church and state were merged, with faith communities having primary responsibility for providing supports for their members. Even today, stewardship is organized through community-wide structures that reflect this history and a practical theology that asserts member responsibility as part of the community to take care of each other. We have labeled these systems institutionalized based on their reliance on centralized institutional structures. Catholic systems are integrated into either a diocese or religious order, sometimes via a local parish $[39,41]$. Jewish systems centralize all social and health services through Federations, with the synagogues remaining independent from the system $[27,28]$. While the formalization of community responsibility in 501c3 non-profits through the federation system is unique to the U.S., Jews in other countries view responsibility for community members in need communally and have developed a variety of structures with similar aims [81]. Major features of the institutionalized systems are:

- Centralized fundraising, volunteer recruitment, training and sometimes facilities management.

- Strong tradition of centralized planning for the community or its institutions as a whole.

- Centralized bodies occasionally encourage or force mergers or collaborations among organizations in the community for the greater good of the systems as a whole.

- Ability to share resources across the system.

- Strong networks of religiously-based, national umbrella associations, in addition to local centralized systems that also provide additional support and networks.

- Tendency for FBOs outside of the centralized umbrella nevertheless to develop ties with other organizations in the faith. Elementary schools are connected with the wider faith community and the centralized umbrella (Federation, order or diocese), but most are also under the direct sponsorship of a local congregation.

- The expectation that the faith community is responsible for the community as a whole, either envisioned as those of the same faith or all people.

Religions that came out of the Protestant Reformation instead stress the importance of individual action to support those in need. However, individuals are part of congregations, and these congregations are the central element in congregational systems. As Hall [33] documents, the congregational system is the foundation for much of the U.S. non-profit sector, and these organization's stewardship strategies often look similar to secular non-profits. Ministries or programs such as a church food pantry may begin as efforts within a congregation, but they usually become institutionalized as independent or semi-independent non-profits. Well-established FBOs maintain strong ties to congregations or at least retain vestiges of these congregational roots, through board appointments and other mechanisms. In this study, Mainline Protestants, some African American churches and "Peace churches", such as the Quakers and Mennonites, fell into the congregational system. Some Evangelical groups use this system, as well. The major features of congregational systems are:

- Ministries often formalize either as independent programs of their founding congregation(s) with independent advisory committees and separate accounting systems or as independent 501c3 organizations with limited ties to their original congregation. Some form as interfaith entities.

- Organizations maintain ties to one or more congregations through board appointments, appeals for resources, volunteers and in-kind supports. Often, FBO by-laws stipulate that a percentage of board members be from the founding faith or founding congregations.

13 Wittberg personal communication. 
- Most see volunteering as an important component of organizational activity and create volunteer opportunities for people from their congregation(s) because volunteering enables individuals to enact their faith or religious values.

- Congregational system FBOs from Mainline Protestant and Quaker traditions often embed their faith in more general values, with many specifically stating that they value theological diversity within a general spiritual or Christian context. On principle, they do not proselytize.

- Congregational system denominations create fewer umbrella organizations, such as professional associations for their FBOs, and the FBOs tend to belong to fewer umbrella groups.

Network systems are relatively new, although they harken back to the religious movements of the 19th century. Scholars note an increasing prevalence of these free standing, openly religious FBOs [16]. In these systems, social networks formed around specific non-profits are the key element supporting those non-profits. However, these networks are value driven, and an organization can quickly lose support if it does not reflect the beliefs and practices of its supporting network. While face to face networks are often important in supporting these organizations, networks are just as likely to be virtual, drawing from people with similar goals even internationally to support a specific ministry. Network-based FBOs may be connected with one or multiple congregations, but their decision-making and support systems reside outside the congregational system. FBOs in network systems differ from those in congregational systems in two important ways: (1) the program or organization is supported by a network of individuals focused on a specific ministry; and (2) the people who work in these FBOs, either as volunteers or paid staff, share the faith approach of the organization's founders and use this faith as a prime motivator in their work. In contrast, congregational organizations draw staff and volunteers who are interested in the service or ministry of the program, but who do not necessarily share similar approaches to faith or come from the religion of the founding congregation(s). The network-based FBOs in this study ranged from small emergency assistance programs founded by a single person to a multi-site pregnancy center working to prevent abortions and from a recently-founded evangelical Christian school to a nearly 200-year-old multi-service organization. Major features of network systems are:

- FBOs frequently become a faith community for their staff, active volunteers and sometimes program participants, transcending any particular congregation.

- Staff and volunteers share its founding faith and are primarily motivated by that faith.

- Resources come through networks of like-minded believers, and often, FBOs highlight their faith or trust in God as a source for resources for the organization.

- Since these FBOs are supported through personal networks, they are more likely to end when the pastor or founder moves on. In older, established FBOs, ministries can change as the leader's calling or gospel vision changes.

- One main subset of this group comprises evangelistic FBOs, for whom sharing their faith is a key element of the ministry.

Understanding which system a faith community or FBO uses influences how government or other partners can most effectively interact with FBOs and members of that faith. Non-financial partnerships often involve attempts to either disseminate information or generate civic engagement in the form of volunteers or other resources from a faith community for a government-sponsored or locality-wide initiative. Civic engagement refers to initiatives to work together for the common good $[38,71,82,83]$. As I discuss elsewhere [82], social capital often generates civic engagement, particularly for faith communities, but well-known institutions can also draw civic engagement through the web or other media based on reputation rather than trust-based networks.

While reaching out to congregations through interfaith organizations or personal networks would make sense for congregational systems, policymakers would be wise to contact the centralized community-wide entity in institutionalized systems. These systems are likely to have centralized volunteer banks. Likewise in both systems, while some synagogues and parishes may be involved 
in social service activities, culturally, most faith community members expect that large initiatives will run through the diocese or Federation. Reaching out to congregations has proven less effective, especially with Catholics [84]. At the other extreme, working through FBOs or the virtual networks that support them in order to reach people associated with network FBOs may be the most effective method of outreach.

Policymakers would also be wise to understand the differences among congregational denominations in developing outreach strategies. While working at NIH, I observed several initiatives that sought to reach African American churches through national denominational headquarters, presuming that information would be disseminated to local churches. This strategy made sense for denominations with hierarchical structures, like African Methodist Episcopal (AME), AME Zion or United Methodists, but proved unproductive in trying to reach loose confederations of Baptists and independent churches. The same differences appear among white, Latino and Asian Protestant denominations. In these cases, local-level social capital is far more effective than using national leaders to reach local faith communities. Further, understanding that congregational system FBOs may be the key contact point for people interested in working on a particular topic, it may make most sense to use the FBO to reach out to faith community members.

Differences between the three systems go beyond outreach strategies. As outlined above, each system has different strengths and weaknesses, as well as relying on very different understandings of religious obligations to provide for those in need or the role of religious expression in faith-based activities. For example, institutionalized systems' planning processes could prove a major asset for policymakers, while congregational systems may be a primary source for volunteers. Since variation exists within systems and at the local level, policymakers would do well to not only identify the generalized system a faith community uses, but its local attributes. These brief observations on systems suggest the following policy strategies:

- Understanding and identifying local faith community systems would facilitate outreach and partnership strategies for government and other stakeholders seeking to partner with faith communities.

- Since each system comes out of faith traditions, understanding the practical theology and history behind each system is important in order to tailor partnership initiatives to mesh with the belief systems and the organizational strategies of that system.

\subsection{Faith Community Umbrella Organizations Are an Important Underutilized Resource, but All Are Not the Same}

Umbrella organizations can provide important resources for both FBOs and faith communities, as well as serving as a conduit between government and faith communities. The Bush faith-based initiative contracted with intermediaries to provide technical assistance through the Compassion Capital Fund and similar initiatives. Government also has a history of contracting directly with faith-based intermediaries, such as refugee resettlement contracts with national organizations affiliated with Catholics, Jews and several Mainline Protestant religions or contracts with Jewish Federations to provide services for the elderly, immigrants and refugees or other specific populations through a network of organizations. In this second example, intermediaries hold primary responsibility for a contract, coordinating work through member organizations and faith communities.

The brief discussion of faith community systems above demonstrates that umbrellas function in different ways in each system. Institutionalized system faith communities have highly developed networks of umbrella organizations at several levels. At the national level, Jewish umbrella professional associations for Federations, the Jewish community centers, Jewish family and vocational services and communal service networks provide technical support, networking for employment and an array of information. Catholic umbrellas like the Catholic Health Association and Catholic Charities USA provide similar supports, as well as national policy on various issues. At the regional level, Jewish federations vary significantly among themselves, but generally offer centralized fundraising, 
planning, leadership development and other resources to their faith communities and member FBOs. Catholic Health Care systems serve as similar umbrellas for their member hospitals, usually offering a combination of policy setting, the ability to share resources, planning and initiatives to help administrators understand the faith behind their work. For Catholics, both national umbrellas for the church, such as the U.S. Conference of Bishops and the Order headquarters, and local-level adjudicators, such as an archdiocese, provide faith community policy and some administrative umbrella functions. Local Catholic Charities organizations are sometimes umbrellas themselves with several quasi-independent units providing services to different populations. Policymakers would do well to rely on the expertise and organizing power of these umbrellas to develop partnerships and reach faith communities affiliated with them.

Congregational system umbrellas fall into two general categories. On the one hand, national umbrellas focused on refugee resettlement, disaster relief, international poverty and related issues, such as the Lutheran Immigration and Refugee Service, the Mennonite Central Committee and the Church World Service, have highly developed systems that simultaneously work with national policymakers and effectively network with both FBOs and congregations at the local level. These umbrellas provide an important resource for partnerships to provide services, marshal faith community support in times of disaster or disseminate information. However, at the local level, umbrellas tend to be smaller, more localized or entity specific. For example, Quakers have developed professional organizations for retirement communities and schools that offer technical support, common purchasing, quality assurance and insurance pools, as well as advice on maintaining the faith base in organizations. Sometimes, these organizations partner with Mennonites and Brethren. As such, they would serve as effective intermediaries to reach FBOs providing particular services.

Mainline Protestants have fewer of these organizations. The other umbrella institution in congregational systems, local interfaiths, vary widely from functioning as social service agencies to simply gatherings where pastors can share common concerns. Higher level adjudicatory bodies also vary greatly among congregational denominations, with some loose conferences having limited ability to reach member congregations. Denominations with adjudicatory levels, like Episcopals, Methodists, Lutherans and Quakers' Yearly Meetings, vary greatly in their ability or willingness to create centralized programs or disseminate information at the local level. This great variation among congregational umbrellas suggests that policymakers would need to learn about the strengths and weaknesses of these local structures before asking them to serve as intermediaries to reach FBOs or faith communities or serve as partners in initiatives.

Umbrellas are fewer and looser among Evangelicals because of the fluid network nature of their institutions and the predominance of charismatic leaders among this faith tradition. Initiatives like Jim Wallis's Call for Renewal suggest one example and networks among crisis pregnancy centers another. Our study did not focus on political or advocacy coalitions and cannot comment on strategies for government to partner with those networks. In general, our limited knowledge of these intermediaries suggests that policymakers would do well to assess their abilities and reach before working with them. They may prove powerful partners, but in other cases, using neutral intermediaries with strong social capital ties into Evangelical networks may be more productive.

This brief discussion of umbrellas suggests several policy strategies:

- Policymakers would do well to identify existing faith community umbrella institutions and use them in partnerships or to provide intermediary services where appropriate.

- Assess the capabilities of existing faith-based umbrellas as potential intermediaries or partners, developing partnerships based on their strengths and weaknesses.

- Since umbrellas function differently in the three faith community systems, develop different strategies appropriate to their form, capacity, strengths and weaknesses. 


\subsection{Social Marketing Cannot Substitute for Developing Local Social Capital}

Any form of partnership comes out of connections between government agents and faith community or FBO representatives, either at the national, regional or local level. Both financial and non-financial partnerships rely on the same mechanisms: developing trust-based relationships with both parties bringing something to the partnership. In the case of government, government is often presumed to offer funding for programs, access to other kinds of resources (expertise, goods like surplus dairy goods, health services like immunizations) or information useful to faith community residents. Faith communities, FBOs and other non-profits have services, resources in the form of space, volunteers, in-kind goods or funding and communities that can disseminate information (for example [85]). However, these are only a few ways that government, faith communities, FBOs and other stakeholders can collaborate. Coalitions of government, faith community and faith-based leaders can work together to find solutions to a number of pressing issues. Faith communities have a long history of lobbying government on various forms of legislation and partnering on a variety of initiatives related to addressing human needs. This section focuses on problem solving at the local level, discussing both current strategies and potential ways they could be improved.

My experience with government collaborations at both the federal and local level reveals two main strategies for government to reach out to local communities. The first involves using media and dissemination of materials through local non-profits, FBOs and sometimes faith communities to share information or promote particular behaviors. Increasingly, these initiatives use sophisticated marketing techniques combined with connections through federal or regional intermediaries to reach a target audience, a technique known as social marketing. Examples include the billboards promoting marriage seen in many low income neighborhoods or the nutrition programs described earlier. While these marketing techniques have some impact, they do not have the long-term effects of developing local social capital, and the message comes top-down from government.

Government officials at all levels also use their connections to assemble coalitions, spread information on potential contracts and sponsor meetings of local community leaders to promote an initiative. The numerous state and local conferences to spread information on the faith-based initiatives are one example. As Sager ([55], p. 106) notes, government officials are most likely to rely on known actors in a community or their personal networks in order to invite people to these events. As such, pre-existing social capital becomes the way that communities partner with government, limiting the breadth of partnerships. My work on training and welfare suggests the same is true for contracting, with government contracting primarily with agencies who had previously had successful government contracting experiences in the past. Advocacy interactions between government and local communities also usually involve known actors from a series of pre-existing coalitions or activist groups, with the most effective advocacy activities relying on a combination of testimony and behind the scenes social capital [7]. Usually, interactions with government involve linking social capital, as government is generally in the more powerful position. The non-governmental coalitions that form to either work collaboratively with government or advocate for change draw members through a combination of bridging and bonding social capital. Government usually sets the agenda or establishes the rules for interaction with agency or community representatives asked to contribute to government goals.

In most cases, partnerships with government are not true collaborations. The one community where I have seen FBOs, non-profits, government and a wide array of faith community actors work together in a true partnership fashion is perhaps the family support system in Kenosha, Wisconsin, a small city of approximately 100,000 on the Illinois/Wisconsin border. Kenosha is particularly known for two reasons. First, it is the city that chose to "not be like Flint" when its auto-manufacturing employment base closed down through a series of innovative business development initiatives and efforts to forestall foreclosures and maintain quality of life for residents during hard economic times. Second, it developed an integrated welfare to work system that is one of the models for the 1996 U.S. Welfare Reform (TANF). For several years under visionary county government, the welfare to work system involved a for-profit, non-profit and government collaboration to provide services. 
While most activities focused on employment, the Kenosha County Job Center also sponsored an emergency services network that included all of the faith-based and secular non-profits providing emergency services (the homeless shelter, domestic violence agency, ethnic organizations) and relevant government offices (child welfare, school system, etc.) that would regularly meet to address the needs of at-risk families. Through a combination of formal and informal contacts, these quasi-governmental agency coalitions also brought in churches to assist when appropriate, and information sharing was often done informally at faith communities where both government and non-profit agency staff were members. Pastors at the larger churches who participated in the interfaith forums developed ties to churches serving the most at-risk residents so that these faith community leaders could work together to address the needs of the hardest to reach residents. As such, Kenosha relied on a combination of bridging and bonding social capital through the simultaneous efforts of agencies and individuals to ensure its citizens' needs were met. This was possible because Kenosha was a small community with a strong commitment to maintaining quality of life for its citizens $[7,86]$.

I have often wondered if the multiple forms of social capital that allowed Kenosha to so effectively meet community needs could be developed in larger cities. Figure 2 shows the same relationships as Figure 1, but government is portrayed as partnering with communities instead of specific entities. Creating this kind of partnership would involve the multiple social capital connections I saw in Kenosha. It would also involve government working to develop bridging social capital with faith and other types of communities instead of the unequal power relationships of most current government/community partnerships.

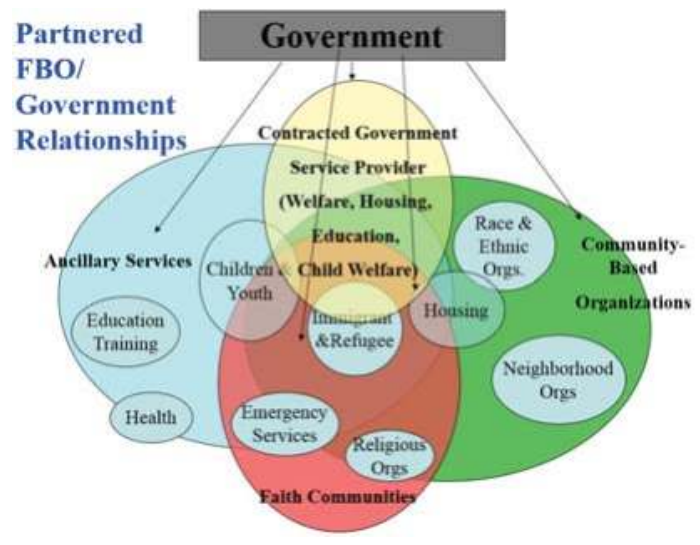

Figure 2. Partnered FBO/government relationships.

One vignette from Philadelphia suggests how this might be possible. In the mid-1990s, I participated in a series of coalitions to influence local implementation of TANF and its predecessor legislation and change state outcome measures for employment and training programs to allow for a broader, more long-term set of outcomes for program participants. Most of these coalitions were through my job and included representatives from a variety of training providers, legal services and representatives from several advocacy coalitions. We all interacted with the Private Industry Council, then a quasi-governmental entity, the local welfare department and several state offices granting contracts. While we had strong positive relationships with government, interactions largely reflected that government had a more powerful position. We would ask government to make changes or lobby through traditional mechanisms, like hearings, instead of working together in partnership. Faith communities played a small role in these activities, with religious leaders participating in hearings, but rarely the coalitions, which included a combination of secular agencies and FBOs. 
However, mid-way through the several years of these activities, the faith communities in the liberal, middle to upper middle class neighborhoods of the city (Germantown, Mt. Airy, Chestnut Hill) developed a coalition to address the same topics, inviting representatives from faith communities throughout the city whose residents lived in these neighborhoods to participate. Over half of the participants in this coalition were people known to each other through the work-based coalitions, but in this context, we were representing our churches, synagogues and Quaker Meetings. The head of the regional welfare department attended as the representative from his Baptist church. Additionally, a number of active lay people from local faith communities with no professional interest in these topics attended, as well.

This coalition was largely unproductive in creating a policy or programmatic agenda because of the diversity of views from the various participants. However, we noticed that the kinds of issues raised by faith community members as important to address poverty went well beyond the ways that those of us used to working in government-focused coalitions envisioned either the problem or possible solutions. The coalition did allow the development of stronger, more equal relationships between the FBO and non-profit organization staff and government workers, as well as developing bridging social capital among the various faith community participants. Looking back, I wonder if this kind of coalition could potentially form the basis for government, FBO and faith community partnerships. Could bridging social capital be harnessed to develop active partnerships to address specific issues?

Both the Kenosha and Philadelphia examples highlight two things about social capital in local communities. First, as the figures illustrate, significant overlap exists among individuals involved in faith communities, neighborhoods or communities of identity, and various types of secular communities formed to address particular social issues. Government representatives that live in these communities also participate in these multiple worlds. As such, potential exists to reach beyond the already established networks that work with government to reach across communities. This would involve a combination of bridging and bonding social capital. Just as in Kenosha, where African American pastors who worked with city-wide coalitions created partnerships with African American pastors that shunned involvement outside of their race-based communities, bridging individuals can extend networks over time.

Second, these vignettes illustrate that faith communities are not always isolated from the service provision world. Presently, a variety of governmental anti-poverty and other initiatives (prisoner reentry, etc.) targets churches in neighborhoods where people receiving services are likely to live. While some successful programs have come out of these initiatives, in many cases, local faith communities do not have the capacity or interest to develop government-sponsored programs; nor are they participating in clarifying the kinds of supports needed by targeted populations, like ex-prisoners or low income families, or designing programs to meet their needs. While many faith community members have little interaction with government or agencies providing specific services, sometimes, some members of those congregations do have these connections through work or as recipients of service. In addition, other faith communities participating in denominational, neighborhood or interfaith activities may have the capacity to partner with targeted faith communities to develop a service network for specific populations. Strategically using social capital through work and other social networks to develop partnerships across several faith communities, FBOs and government could be more effective than current efforts.

Taken together, this brief discussion of social capital suggests the following strategies for partnerships:

- Government and community members should emphasize creating three-way partnerships among government, FBOs/non-profits and faith communities that strategically use social capital across agency focus and various types of communities to expand partnership opportunities.

- Rather than top down partnerships initiated by government or coalitions lobbying government to meet a specific need, ideally, partnerships would involve bridging social capital with 
government and non-governmental representatives working together to set agendas, as well as meet specified goals.

- Outreach to hard to reach populations can be facilitated through using bridging organizations or individuals to reach into more isolated communities.

\section{Conclusions}

How could the U.S. partnership system be transformed to meet the vision set out in the President's advisory council recommendations? Our findings suggest several strategies that could contribute to this effort. Taken together, several principles underlay these suggestions:

- Partnerships should foster three-way relationships with government, FBOs and faith communities, drawing from the different resources and perspectives available from each.

- Government needs to understand that FBOs and congregations are embedded in larger religious communities and respect the differences inherent in the religious culture, structure and beliefs that undergird any initiative coming out of a faith community.

- Partnerships with government need to include both financial and non-financial partnerships. FBOs and secular non-profits rely on government funding for a number of initiatives. As the vast literature on private funding suggests, faith communities have limited capacity to sponsor complex services and cannot substitute for government. At the same time, both financial and in-kind resources from faith communities can expand the vision and capacity of services, enhancing any government-funded initiative.

In my view, an ideal partnership system would include two additional ingredients, one expanding from the task force recommendations and another coming from models from Germany. The task force focused on reforming the White House FBNI office recommended "convening and encouraging learning communities of social service programs and providers" ([4], p. 121). Learning communities would be an important way to share experiences and build relationships that could lead to expanded partnerships. However, simply including providers without also inviting researchers and local policymakers limits the kinds of new information that could be generated from these initiatives. The Bush White House office did initiate research and encourage a broad range of evaluations and more general studies of topics related to the faith-based initiative. Developing research initiatives beyond evaluation and using learning community models could be particularly effective in expanding our understanding of faith communities in partnership with government, as well as developing and disseminating partnership models that work.

Second, the U.S. domestic social welfare arena has either been characterized as a top down initiatives from government or as government shifting services back to the private sector. Perhaps the best way to partner with government would be to move toward systems based on the Catholic concept of subsidiarity as in Germany [87]. ${ }^{14}$ In the German system, government funds an array of social services through intermediary organizations, most of them religious in nature, but allows agencies to provide services according to their values and styles. Citizens choose which agency they want as a service provider. While strains in this system have been noted as Germany becomes more diverse, the system mirrors the ideal system the Catholic Charities of DC leader asked for "allowing the organizations to operate within the teachings of their own religion," providing services that meet general government-stipulated parameters for quality and offering choices so that everyone could find programs that are culturally appropriate. Monsma ([6], pp. 23-29) also calls for a pluralistic system along these lines. We already have vestiges of a system like this with contracted services today. Creating a true partnership would involve government working with the various faith-based

14 See [56] for discussion of Subsidiarity. 
and secular communities interested in a particular topic to develop program outlines and outcome measures that ensure equity, but also allow for different visions of appropriate service.

It is possible for government, faith communities and FBOs to work together in a true partnership relationship; in fact, all of the ingredients already exist. However, government would need to shift from its current approach to work more collaboratively with an expanded set of actors. Developing networks and partnerships would involve more strategic attention to network creation and outreach through multiple communities at several levels. Documenting efforts through research is a key component of any initiative and should not be ignored as new approaches are tried. Only through efforts that draw from a wide array of experiences and perspectives, documenting what does and does not work and why, can we begin to address the pressing needs of this country through partnership models.

Conflicts of Interest: The author declares no conflict of interest.

\section{References}

1. Chaves, Mark, and Bob Wineburg. "Did the Faith Based initiative Change Congregations?" Nonprofit and Voluntary Sector Quarterly 39 (2010): 343-55. [CrossRef]

2. Cnaan, Ram A., Stephanie Boddie, Femida Handy, Gaynor Yancey, and Richard Schneider. The Invisible Hand: American Congregations and the Provision of Welfare. New York: New York University Press, 2002.

3. Wineburg, Robert, Brian Coleman, Stephanie Boddie, and Ram Cnaan. "Leveling the Playing Field: Epitomizing Devolution through Faith Based Organizations." Journal of Sociology and Social Welfare 35 (2008): 17-42.

4. White House Office of Faith Based and Neighborhood Partnerships. "A New Era of Partnerships: Report of Recommendations to the President." March 2010. Available online: http:/ /www.whitehouse.gov/sites / default/files/microsites/ofbnp-council-final-report.pdf (accessed on 6 August 2016).

5. Chaves, Mark. Congregations in America. Cambridge and New York: Harvard University Press, 2004.

6. Kearns, Kevin, Chisung Park, and Linda Yankoski. "Comparing Faith-Based and Secular Community Service Corporations In Pittsburgh and Allegheny County, Pennsylvania." Nonprofit and Voluntary Sector Quarterly 34 (2005): 206-31. [CrossRef]

7. Schneider, Jo Anne. Social Capital and Welfare Reform: Organizations, Congregations and Communities. New York: Columbia University Press, 2006.

8. Demerath, N. Jay, III, Peter Dobkin Hall, Terry Schmitt, and Rhys H. Williams, eds. Sacred Companies: Organizational Aspects of Religion and Religious Aspects of Organizations. New York: Oxford University Press, 1998.

9. Owens, Michael. "Which Congregations will Take Advantage of Charitable Choice? Explaining the Pursuit of Public Funding by Congregations." Social Science Quarterly 87 (2006): 55-75. [CrossRef]

10. Grettenberger, Susan. Churches as a Community Resource and Source of Funding for Human Services. Aspen Institute Working Paper Series; Washington: Aspen Institute, 2001.

11. Unruh, Heidi, and Ron Sider. Saving Souls, Serving Society: Understanding the Faith Factor in Church-Based Ministry. New York: Oxford University Press, 2005.

12. Wuthnow, Robert. Saving America?:Faith-Based Services and the Future of Civil Society. Princeton: Princeton University Press, 2004.

13. Campbell, David. "Beyond Charitable Choice: The Diverse Service Delivery Approaches of Local Faith-related Organizations." Nonprofit and Voluntary Sector Quarterly 31 (2002): 207-30. [CrossRef]

14. Kennedy, Sheila Suess, and Wolfgang Bielefeld. Charitable Choice at Work: Evaluating Faith-Based Job Programs in the States. Washington: Georgetown University Press, 2006.

15. Monsma, Stephen. When Sacred and Secular Mix: Religious Nonprofit Organizations and Public Money. London: Rowman and Littlefield Publishers Inc., 1996.

16. Monsma, Stephen. Putting Faith in Partnership. Ann Arbor: University of Michigan Press, 2004.

17. Wittberg, Pattricia. From Piety to Professionalism-And Back? Transformations of Organized Religious Virtuosity. Lanham: Lexington Books, 2006. 
18. Wineburg, Bob. A Limited Partnership: The Politics of Religion, Welfare and Social Service. New York: Columbia University Press, 2001.

19. Sinha, Jill W. Cookman United Methodist Church and Transitional Journey: A Case Study in Charitable Choice. Baltimore: The Center for Public Justice Charitable Choice Tracking Project, 2000.

20. Ammerman, Nancy T. Pillars of Faith: American Congregations and Their Partners. Berkeley: University of California Press, 2005.

21. Foley, Michael, and Dean Hoge. Religion and the New Immigrants: How Faith Communities form our Newest Citizens. New York: Oxford University Press, 2007.

22. Jeavons, Thomas. When the Bottom Line is Faithfulness: Management of Christian Service Organizations. Bloomington: Indiana University Press, 1994.

23. Schneider, Jo Anne, Katie Day, and Gwynneth Anderson. Connections between Faith Communities and Their Non-Profits: Findings from the Faith and Organizations Project Pilot Study on the Role of Religious Culture and Theology on Social and Health Services. Washington: George Washington University, 2006.

24. Schneider, Jo Anne, Isaac Morrison, John Belcher, Patricia Wittberg, Wolfgang Bielefeld, Jill Witmer-Sinha, and Heidi Unruh. Maintaining Vital Connections Between Faith Communities and Their Organizations. Washington: The Lilly Endowment, Inc., 2010.

25. Wuthnow, Robert. Linkages between Churches and Faith-Based Nonprofits. Report to the Aspen Institute. Washington: Aspen Institute, 2000.

26. Schneider, Jo Anne. "In the Big Village: Economic Adjustment and Identity Formation for Eastern European Refugees in Philadelphia, PA." Ph.D. Dissertation, Anthropology Department, Temple University, Philadelphia, PA, USA, 1988.

27. Bernstein, Philip. To Dwell in Unity: The Jewish Federation Movement in America Since 1960. Philadelphia: The Jewish Publication Society, 1983.

28. Elazer, Daniel. Community and Polity: The Organizational Dynamics of American Jewry, rev. ed. Philadelphia: The Jewish Publications Society, 1995.

29. Schneider, Jo Anne. "Using multi-methods ethnography to promote quality service and understand interactions among organizations: Examples from the Kenosha social capital study and neighborhood settlement house needs assessment and evaluation." Nonprofit Management and Leadership 16 (2006): 411-28. [CrossRef]

30. Schneider, Jo Anne. "Lessons on Keeping the Faith in Faith Based Initiatives from the Refugee Resettlement Program." Paper presented at the 31st Annual Conference Association for Research on Nonprofit Organizations and Voluntary Action, Montreal, QC, Canada, 16 November 2002. (unpublished)

31. Trattner, Walter. From Poor Law to Welfare State. New York: The Free Press, 1994.

32. Oakley, Diedre. "The American Welfare State Decoded: Uncovering the Neglected History of Public Partnership." City and Community 5 (2006): 243-67. [CrossRef]

33. Hall, Peter Dobkin. "The History of Religious Philanthropy in America." In Faith and Philanthropy in America. Edited by Robert Wuthnow, Virginia Hodgkinson and Associates. San Francisco: Josey Bass, 1990, pp. 38-62.

34. Cnaan, Ram, Bob Wineberg, and Stephanie Boddie. The Newer Deal: Social Work and Religion in Partnership. New York: Columbia University Press, 1999.

35. Salamon, Lester. Partners in Public Service: Government, Non-Profit Relations in the Modern Welfare State. Baltimore and London: Johns Hopkins University Press, 1995.

36. Trudeau, Dan. "Junior Partner of Empowered Community? The Role of Non-Profit Social Service Providers amidst State Restructuring in the U.S." Urban Studies 45 (2008): 2805-27. [CrossRef]

37. Levin, Jeff. "Faith-Based Partnerships for Population Health: Challenges, Initiatives and Prospects." Public Health Reports 129 (2014): 127-29. [PubMed]

38. Hall, Peter Dobkin. "The Rise of Civic Engagement Tradition." In Taking Faith Seriously. Edited by Mary Jo Bane, Brent Coffin and Richard Higgins. Cambridge: Harvard University Press, 2005, pp. 21-60.

39. Hehir, J. Bryan. "The Legacy and Future of Catholic Charities: Challenges within the Church and Within Society." Paper presented at the Catholic University of America, Daughters of Isabella Lecture, Life Cycle Institute, Washington, DC, USA, 8 October 2002.

40. Cochran, Clarke E. "Institutional Identity; Sacramental Potential: Catholic Healthcare at Centuries End." Christian Bioethics 5 (1999): 26-43. [CrossRef] [PubMed] 
41. Curran, Charles. "The Catholic Identity of Catholic Institutions." Theological Studies 58 (1997): 90-108. [CrossRef]

42. Wittberg, Patricia. "Religious Orders and Higher Education." In The Handbook of Research on Catholic Higher Education. Edited by Thomas Hunt. Greenwich: Information Age Publishing, 2003, pp. 263-89.

43. Walch, Timothy. Parish School: American Catholic Parochial Education from Colonial Times to the Present. New York: Crossroad, 1996.

44. Hendon, David, and Jeremiah Russell. "Notes on Church-State Affairs." Journal of Church and State 47 (2005): 189-203. [CrossRef]

45. Smith, Stephen, and Michael Sosin. "The Varieties of Faith Related Agencies." Public Administration Review 61 (2001): 651-70. [CrossRef]

46. Boddie, Stephanie, and Ram Cnaan. "Setting the Context: Assessing the Effectiveness of Faith Based Social Services." Journal of Religion and Spirituality in Social Work 25 (2006): 5-18.

47. Sider, Ronald J., and Heidi Rolland Unruh. "Typology of Religious Characteristics of Social Service and Educational Organizations and Programs." Nonprofit and Voluntary Sector Quarterly 33 (2004): 109-34. [CrossRef]

48. Ebaugh, Helen Rose, Janet Saltzman Chafetz, and Paula Pipes. "Where's the Faith in Faith Based Organizations? Measures and Correlates of Religiosity in Faith Based Social Service Coalitions." Social Forces 84 (2006): 2259-72. [CrossRef]

49. Working Group on Human Needs and Faith Based and Community Initiatives. Finding Common Ground: 29 Recommendations of the Working Group on Human Needs and Faith Based and Community Initiatives. Washington: Search for Common Ground, 2002.

50. Boddie, Stephanie, and Ram Cnaan. "Faith Based Social Services: Measures, Assessments and Effectiveness." Journal of Religion and Spirituality in Social Work 25 (2006): 5-18.

51. Fischer, Robert, and Judson Stelter. "Testing Faith: Improving the Evidence Base on Faith Based Human Services." Journal of Religion and Spirituality in Social Work 25 (2006): 105-24. [CrossRef]

52. Graddy, Elizabeth. "How do they Fit? Assessing the Role of Faith-Based Organizations in Social Service Provision." Journal of Religion and Spirituality in Social Work 25 (2006): 129-50. [CrossRef]

53. Grettenberger, Susan, John Bartkowski, and Steven R. Smith. "Evaluating the Effectiveness of Faith Based Welfare to Work Agencies: Methodological Challenges and Possibilities." Journal of Religion and Spirituality in Social Work 25 (2006): 223-40. [CrossRef]

54. Campbell, David, and Eric Glunt. "Assessing the Effectiveness of Faith-Based Programs: A Local Network Perspective." Journal of Religion and Spirituality in Social Work 25 (2006): 241-60. [CrossRef]

55. Sager, Rebecca. "The Importance of State Faith Based Liaison." Sociology of Religion 68 (2007): 97-109. [CrossRef]

56. Hehir, J. Bryan. "Religious Ideas and Social Policy: Subsidiarity and Catholic Style of Ministry." In Who Will Provide: The Changing Role of Religion in American Social Welfare. Edited by Mary Jo Bane, Brent Coffin and Ronald Thieman. Boulder: Westview Press, 2000, pp. 97-120.

57. Thiemann, Ronald. "Lutheran Social Ministry in Transition: What's Faith Got to Do with It?" In Taking Faith Seriously. Edited by Mary Jo Bane, Brent Coffin and Richard Higgins. Cambridge: Harvard University Press, 2005, pp. 177-209.

58. Unruh, Heidi, Jill Sinha, and John Belcher. "Mainline Protestants and their Organizations." In Comparing Strategies to Maintain Connections Between Faith Communities and Organizations Across Religions. Edited by Jo Anne Schneider and Isaac Morrison. College Park: University of Maryland, 2010, pp. 13-28.

59. Unruh, Heidi, Jill Sinha, Isaac Morrison, and John Belcher. "Evangelicals and their Organizations." In Comparing Strategies to Maintain Connections Between Faith Communities and Organizations Across Religions. Edited by Jo Anne Schneider and Isaac Morrison. College Park: University of Maryland, 2010, pp. $29-45$.

60. Sinha, Jill W. "The Black Church and their Organizations." In Comparing Strategies to Maintain Connections Between Faith Communities and Organizations Across Religions. Edited by Jo Anne Schneider and Isaac Morrison. College Park: University of Maryland, 2010, pp. 46-57.

61. Zanis, David, and Ram Cnaan. "Social Service Research and Religion: Thoughts about how to Measure Intervention Based Impact." Journal of Religion and Spirituality in Social Work 25 (2006): 83-104. [CrossRef] 
62. Smith, Stephen, and Michael Lipsky. Nonprofits for Hire: The Welfare State in the Age of Contracting. Cambridge: Harvard University Press, 1993.

63. Kennedy, Sheila Suess, and Wolfgang Bielefeld. "Government Shekels without Government Shackles? The Administrative Challenges of Charitable Choice." Public Administration Review 62 (2002): 4-11. [CrossRef]

64. DiMagio, Paul, and Walter Powell. "The Iron Cage Revisited: Institutional Isomorphism and Collective Rationality in Organizational fields." In Community Organizations: Studies in Resource Mobilization and Exchange. Edited by Carl Milofsky. New York: Oxford University Press, 1988, pp. 77-99.

65. Ebaugh, Helen Rose, Janet Saltzman Chafetz, and Paula Pipes. "The Influence of Evangelicalism on Government Funding of Faith-Based Social Service Organizations." Review of Religious Research 47 (2006): 380-92.

66. Castro, F. G., J. Elder, K. Coe, H. M. Tafoya-Barraza, S. Moratto, N. Campbell, and G. Talavera. “Mobilizing Churches for Health Promotion in Latino Communities: Campaneros en la Salud." Journal of the National Cancer Institute Monograph 18 (1995): 127-35.

67. Boltri, J. M., Y. M. Davis-Smith, J. P. Seale, S. Shellenberger, I. S. Okosun, and M. E. Cornelius. “Diabetes Prevention in a faith based Setting: Results of Translational Research." Journal of Health Management Practice 14 (2008): 29-32. [CrossRef] [PubMed]

68. Bourdieu, Pierre. "The forms of capital." In Handbook of Theory and Research for the Sociology of Education. Edited by John G. Richardson. Translated by Richard Nice. New York: Greenwood Press, 1986.

69. Portes, Alejandro. "Social capital: Its origins and applications in modern sociology." Annual Review of Sociology 24 (1998): 1-24. [CrossRef]

70. Schneider, Jo Anne. "Organizational Social Capital and Nonprofits." Nonprofit and Voluntary Sector Quarterly 38 (2009): 643-62. [CrossRef]

71. Putnam, Robert, and Lewis Feldstein. Better Together: Restoring the American Community. New York: Simon and Schuster, 2003.

72. World Bank. "World Development Report 2000/2001." 2001. Available online: www.worldbank.org/ poverty/wdrpoverty/report (accessed on 6 August 2016).

73. Jeavons, Thomas. "Stewardship Revisited: Secular and Sacred Views of Governance and Management." Nonprofit and Voluntary Sector Quarterly 23 (1994): 107-22. [CrossRef]

74. Weber, Max. From Max Weber: Essays in Sociology. Translated by H. H. Gerth and C. Wright Mills. Edited by H. H. Gerth and C. Wright Mills. London: Routledge and Kegan Paul, 1948.

75. Lockhart, William. "Building Bridges and Bonds: Generating Social Capital in Secular and Faith Based Poverty to Work Programs." Sociology of Religion 66 (2005): 45-60. [CrossRef]

76. Monsma, Stephen. "Nonprofit and Faith-Based Welfare to Work Programs." Society 40 (2003): 13-18. [CrossRef]

77. Ebaugh, Helen Rose, Janet Saltzman Chafetz, and Paula Pipes. "Funding Good Works: Funding Sources for Faith Based Social Service Coalitions." Nonprofit and Voluntary Sector Quarterly 34 (2005): 448-72. [CrossRef]

78. Jeavons, Thomas. "Religious and Faith-Based Organizations Do We Know One When We See One?" Nonprofit and Voluntary Quarterly 33 (2004): 140-45. [CrossRef]

79. Netting, F. Ellen, Mary Katherine O'Connor, and Gaynor Yancey. "Belief Systems in Faith Based Human Services Programs." Journal of Religion and Spirituality in Social Work 25 (2006): 261-86. [CrossRef]

80. Schneider, Jo Anne, and Patricia Wittberg. "Comparing Practical Theology across Religions and Denominations." Journal of the Religious Research Association 52 (2011): 405-26.

81. Harris, Margaret, Romayne Hutchison, and Ben Cairns. "Community-Wide Planning for Faith Based Service Provision: Practical, Policy and Conceptual Challenges." Nonprofit and Voluntary Sector Quarterly 34 (2005): 88-109. [CrossRef]

82. Schneider, Jo Anne. "Connections and Disconnections between Civic Engagement and Social Capital in Community Based Non-profits." Nonprofit and Voluntary Sector Quarterly 36 (2007): 572-97. [CrossRef]

83. Skocpol, Theda, and Morris Fiorina, eds. Civic Engagement in American Democracy. Washington: Brookings Institution Press and Russell Sage Foundation, 1999.

84. Bane, Mary Jo. "The Catholic Puzzle: Parishes and Civic Life." In Taking Faith Seriously. Edited by Mary Jo Bane, Brent Coffin and Richard Higgins. Cambridge: Harvard University Press, 2005, pp. 63-93. 
85. Gazley, Beth, and Jeffrey L. Brudney. "The Purpose (and perils) of Government Nonprofit Partnership." Nonprofit and Voluntary Sector Quarterly 36 (2007): 389-415. [CrossRef]

86. Schneider, Jo Anne. Kenosha Social Capital Project Education Report: Churches, Non-profits and Community. Indiana County: Indiana University of Pennsylvania, 2001.

87. Becker, Thomas. "Religious Organizations as Providers of Social Services in Germany." In Religion and Public Policy: A German-American Comparison. Washington: American Institute for Contemporary German Studies, 2008, pp. 25-30.

(C) 2016 by the author; licensee MDPI, Basel, Switzerland. This article is an open access article distributed under the terms and conditions of the Creative Commons Attribution (CC BY) license (http:/ / creativecommons.org/licenses/by/4.0/). 


\title{
Maintaining the Connection: Strategic Approaches to Keeping the Link between Initiating Congregations and Their Social Service Off-Spring
}

\author{
Ian Bedford ${ }^{1,2}$ \\ 1 St Stephen's Uniting Church, PO Box 189, Wodonga, VIC 3689, Australia; ianjudybedford@iinet.net.au; \\ Tel.: +61-26-056-0524 \\ 2 Formerly faculty of Albury-Wodonoga Campus, Latrobe University, Melbourne, VIC 3086, Australia
}

Academic Editors: Peter Kaufman and Robert Wineburg

Received: 7 March 2016; Accepted: 19 August 2016; Published: 25 August 2016

\begin{abstract}
Whilst much research has established that religious congregations have a long history of initiating social services that address many and varied community welfare and health issues, little attention has been paid to the process involved in this congregationally-based response as well as little paid to the unique issues that arise such as the role of clergy in their development and operation. Some research has however identified examples of congregationally-initiated programs evolving to the point where their link to their initiating congregation becomes effectively severed. The research reported in this article is drawn from a larger research project that identified a framework for understanding the complex processes by which congregations initiate, operate, and modify their social services. However, it focuses in particular on the resources such congregations can bring to a wider community and the need for intentional strategies to address the risk that such resources may be lost if the link to the congregation is allowed to atrophy. Whilst the more comprehensive framework focuses on an integrated understanding, this article gives specific attention to those issues and strategies relevant to maintaining the link where that is the implicit expectation of the congregation rather than taking it for granted and being surprised when it is found to have gone.
\end{abstract}

Keywords: congregations; social service; ownership

\section{Introduction}

It was in the 1980s that Wineburg [1-3] began to notice a pattern occurring in his community as a response to the US Federal Government reduction in funding for community social services; this was one of steady growth in the participation of religious congregations in the local provision of social services. This pattern became a growing focus of significant US research on the extent and nature of these emerging (and pre-existing) congregationally-based social services, with some key researchers being Wineburg [4] in Greensboro NC, Dudley [5] in Chicago IL, Farnsley [6] in Indianapolis IN, Cnaan [7] in Philadelphia PA and Chaves [8]. In the United Kingdom (UK), Harris [9] in particular noted a similar involvement of religious congregations in what she termed the provision of "Quiet Care" to their local communities, whilst in Australia Kaldor and his colleagues [10,11] associated with their National Church Life Surveys of 1991 and 1996, began to document a similar response to community needs by church congregations.

Much of this research focused on documenting the extent to which congregations engaged in this type of social response, the nature and replacement dollar value of the resources they offered, and the type of services that were provided to the community by these means. However, almost as an aside to this focus, Harris commented in her work that: 
Paradoxically, the ultimate 'success' — of having a project adopted by an outside funder in the government or voluntary sector-was often regarded as a mixed blessing by congregations. Whilst they were glad to be relieved of constant anxiety about finding financial and human resources, they also resented their loss of control and were anxious about being pulled in to a more formal caring world...The affiliation brought essential contacts and expertise into the group but also created pressures to professionalization and formality. Additional...questions were raised about the extent to which [the activity] was still a congregational [italics in original] project ([12], p. 167)...Even though such sponsorship reflects project success and offers the possibility of expansion with less responsibility, it may take from the volunteers what they most value: the ability to control the project and run it according to their own preferences ([12], p. 169).

In like terms, Cnaan and colleagues included the following comment:

[P]eople in the congregational camp are worried about the impact that such collaboration with government may have on the congregation as a place of worship. It is possible congregations will be forced to apply practices that are not well accepted by members and that will impinge on their religious freedom and sense of being. The experience of transforming volunteer programs into professional and paid ones is often accompanied by increased bureaucratization....and stagnation...[T]he spirit of volunteerism and enthusiasm in congregations may subside when some members are paid for the work that others formerly provided voluntarily...tensions may build between paid staff and the traditional volunteers, and the volunteers may withdraw ([13], p. 7f).

Both researchers identified that, in regard to their case samples, "something" was at risk of being lost when congregationally-based social services begun as a response to their faith perspective become entwined with the processes of government and other external funding. That something, Harris suggests, is "control" whilst Cnaan suggests it is "the spirit of volunteerism".

My own practice experience as a social worker in two Australian States, Victoria and Queensland, led me to ask questions not so much about the nature and extent of this congregationally-based social service provision, but the intrinsic processes by which these services were developed and sustained. This stimulus for research led to a doctoral study [14]. The data obtained, provided a detailed overview of factors involved in Initiating, Operating, and Modifying congregational community services. Initiation included Congregational Culture, Key Persons and Catalysts coalescing to generate a Vision for social service. Operations included Programming, Staffing, Resourcing, Managing, Networking, Owning, and finally Modifying. The modifications examined social services, agency, and program development. Thus a need arose to examine Evaluations, Crucial Decisions, and Unexpected Events. The overall thrust of this deep internal process analysis, is remarkably consistent with the later research of Garland and her colleagues [15] when researching How 35 Congregations Launched and Sustained Community Ministries. However, their article focuses on the "factors" in congregational "support" for "community ministries." My research focused on the processes engaged in when developing and operating these social services.

The keys to my analysis are deciphering the processes by which congregations linked their social capital to the provision of social services, and coupling them to their wider community. Here I was able to decipher the patterns by which that linkage could be undermined. This analysis therefore was consistent with the concerns noted by Harris and Cnaan, as well as in many a history of the provision of social services initiated from congregational settings, for example as touched on in the article in this volume by Netting and $\mathrm{O}^{\prime}$ Connor [16]. As such this research suggests that the factor at risk of submergence is losing the emotional "Ownership" by a congregation of their social service activities.

This paralleled Harris' sense of the "control issue" (congregation or community) as well as Cnann's sense of the importance of maintaining volunteer spirit. Further, my analysis maintains that the loss of spirit can be prevented. It is the purpose of this article to outline the contribution 
congregations can bring to the provision of community services and keep them from losing their voluntary spirit. After reflecting from that, the article will elaborate on the strategic options that the research on the identified congregations used to maintain their linkage with the social services they spawned and thus kept in part their emotional and psychological "Ownership". It must be remembered that, being a first of its kind research, I was generalizing and will be generalizing to theory grounded in this analysis.

\section{Research Method}

This research was undertaken in Victoria, Australia, following a qualitative methodology and applying a "grounded theory" research design [17]. Data consisted of four datasets sequentially collected along the Theoretical Sampling approach of Grounded Theory. The first dataset consisted of 13 in-depth, unstructured interviews with social workers who had worked and volunteered in many and varied ways at the "local church—social service agency" interface. The second data set was obtained through similar in-depth, unstructured interviews with seven people from a congregation in a low-income, largely public housing area of a provincial city (Congregation A), whilst the third dataset was similarly obtained from eight people involved with the social service activities of a congregation located in a largely upper middle class suburb of a metropolitan city (Congregation B). The fourth dataset was obtained from 24 documents longitudinally generated over a 10 year period along with one in-depth interview with the congregation minister of a congregational social service located in a low-income, multicultural suburb of the same metropolitan city (Congregation C). All interviews were transcribed and provided back to interviewees for correction and final permission to use in a progressive thematic analysis as called for in the Grounded Theory approach to coding of data and the identification of "theoretical saturation" for emerging concepts. Coding was undertaken using the software QSR NVivo 1.3.

\section{Results}

One of the six dimensions identified for the way in which congregations operated their social service activities was labeled "Owning", the last dimension of operation to emerge from or be identified through the iterative data analysis process that is characteristic of the Grounded Theory approach. This dimension was identified through statements from respondents such as:

Well I really want [the congregational council] to own the decision where we go [with regard to the future of the Community Service activity]. I don't believe it's the [Parson's] decision to head off in a certain direction [such as separate Incorporation] because ultimately...the longer they've been here the closer they are to going somewhere else...I think the [congregational council] have to own the decision [about] which way we are going...what we've got to do to pay our bills and all those sorts of things...three people shouldn't be worrying themselves sick at night about everything [18].

In reality it is a fascinating thing, the issue of ownership...There's a core group who believe in [the community service]. The [congregation] has, as the year progresses, more and more accepted [it] as being a ministry within the congregation, there to stay [19].

I think unless [congregational community services] enlist the active support of lay-people who take ownership then these activities...[are] fragile organisations, or organisms, subject to the priorities and gifts and self-esteem of the incoming clergy [20]

It is important to help [the Community Centre] struggle with this issue [of ownership]...If [the congregation] does not "own" the program, it "disowns" the program...Within the [Congregation], ownership has two strong foci of expression - in the clergy and in the volunteers. The [congregation] and the [congregational council] have still to come to terms 
with its existence, and some still view the [Community Centre] as a "[partner Agency] intrusion" into their program [21].

This term "ownership" clearly was seen as important in the process of operation.

\subsection{The Social Capital Congregations Provide to Their Linked Social Services}

What was clearly evident was that congregants who developed social services linked to congregations were adept at using the inherent social capital, as they knew it. Schneider explored this kind of social capital regarding congregation and community, quite thoroughly [22]. The characteristics of this social capital, or how program developers connected with people, to access resources, related, for example to the use of buildings, or tapping a source for help with staffing. Their use of agency board members to help get access to funding kept the link with a supportive community strong. In capturing social capital this way, they could maintain a spiritual base or context from which to function, and still claim ownership. These ideas warrant further elaboration.

\subsubsection{Buildings}

The most obvious resource that congregations provide in their development of social services is the use of their space to operate programs at no cost. However, this resource provision was not found to be as simple as might first be presumed in that there was a rather consistent evolution of the way this space was provided for the social service work.

Congregations typically have facilities where they meet for worship and other faith-related activities. These are then made available, so it seemed, to any social service that a congregation developed; typically at no charge (unless a partner church agency was paying, as applied in one of the research congregations). Rarely was the space actually suitable for the social service purpose to which it was being put. A main reason was that the ideas for the facility were not co-linked to the ideas for the program. Thus typically, the available facility was on a "take it as you find it" basis, but the research identified that, commonly, over time two typical changes happened.

Firstly, congregations became concerned about the unsuitable accommodation being provided for their social services and began to find ways to access funds to renovate them. Funds might be gained from special building appeals for the purpose, bequests becoming available, and grants from central church property funding bodies. These funds were initially used to make "modest" alterations to the facilities to provide a social service space more consistent with the service being provided, e.g., a shed built in the church yard from which an Emergency Relief service can operate and where recipients can be congenially welcomed as well as food etc. stored. Gradual purpose-specific changes helped create an overall sense that the social service is valued within the congregation as well as the wider community and is "improving" the way that service is delivered.

However, the second development, which is much more evident in the research congregations than might be casually expected, given overall funding issues, (see Section 3.1.3 below), is the remodeling of the congregational facilities to co-locate both worship space and general community space, which included the social service. All congregations saw a clear statement in this more extensive and expensive remodeling that their social service involvement was an explicit component of their faith understanding and commitment and a deliberate expression of it. Worship and service were integrated aspects of their identity as a faith community, and there was legitimacy in any who come for the support of the social service being at least visually aware that this service was integral in this way. That so many congregations gradually and eventually made this adjustment so intentionally was one of the key insights that this research brought into focus. Finding sufficient funds for such activities is no mean feat. One of the three congregations in this study went into significant, and at times, worrisome debt. Blending service into their spiritual life took form in expansion of the facility. While sometimes such expansions may be missed in a research article, I saw much tenacity from congregational leaders. Such rebuilding projects do not happen quickly or easily. So, to keep "ownership", congregants expanded their social capital skills to meet capital need too. 


\subsubsection{Staff and Board}

Analysis of the datasets identified four key areas in which social service staff were potentially engaged from within a congregation and/or its network of links to the wider church. These included both trained and untrained staff able to operate as "support workers" who provided reception, administration, and basic contact roles e.g., serving in an "Opportunity Shop"1. However, congregants often had minimal if any training for the role, and were typically volunteers. Some were very poorly remunerated for the time put in e.g., paid a small honorarium. At times they were officially employed but they also contributed many "volunteer" hours to the service in addition to paid hours. Most of the time, these people would comment that they were both giving and receiving from their involvement. Personal gains cited were enhanced social contact, better organization for their own daily routine, gaining referral information needed for personal reasons, sometimes quite similar to other users of the service. Most important for this article was an expression that such giving brought depth to their own faith understanding.

Other staff had more defined roles that required some degree of specialized contact with social service recipients, but often these volunteer personnel were given little if any training for their role e.g., as Emergency Relief service interviewers, and likewise little support and supervision. At the time of the research, some efforts were being made within each of the research congregations to redress this "start up" oversight through, typically, in-house provision of some training sessions. Some of these contact volunteers also exhibited an initiative to privately seek training for their role in order to address their anxieties about undertaking these roles without proper training.

Further, at least two of the congregations exhibited an amazing capacity to attract qualified professional people in "good standing" with their professional bodies to provide highly specialized services as either direct contact workers who received no payment e.g., qualified grief and loss counsellors, or as supervisors and consultants either for no or very minimal payment. In addition, professional staff were employed under award conditions but typically worked many hours longer than their award provisions. Some of these paid staff were also active members of the congregation and saw an overlap between their paid work and their ministry as congregational members. Such an overlap was found to sometimes cause role confusion and burnout. Others did not have that congregational link but shared the faith link and saw their work as part of the wider church ministry. Some employees had no such identification with congregation or faith and viewed their role as their professional employment.

Finally, there were the clergy themselves. They often took on a range of roles within the social services. Sometimes they were the key contact person whose work and ministry were supported by the others from the congregation and community. One minister in the study undertook a self-appointed role as community caseworker for people with mental health issues.

Sometimes clergy took on the role of de facto Chief Executive Officer for the social service, overseeing its overall functioning and administration. They would combine that role with chair of any board or committee nominally responsible for overseeing the social service. In some situations, the clergy acted as community workers undertaking a variety of roles such as local school chaplain, but seeking affirmation and support in that role from their congregation. In all these settings, it appeared to be the clergy who either were operating according to their own sense of social service ministry but with varying degrees of congregational support, or who had brought a particular vision of social service to a congregation and gained their commitment to support and share in that social service ministry or ministries.

In contrast, some clergy recognized the social service concerns of congregational members, recognized the skills and interests of the congregation, and then worked to encourage and support the

1 A program of two congregations in the study which sells secondhand clothing and household items at very low cost affordable to low-income people. 
sense of social service ministry of these congregations. They might function as supervisors, it might be as limited back-up contact support, or it might be as an active member of the board or committee overseeing the social service. Two things were evident in regard to the clergy role. Firstly, where the motivation and or direction came from the clergy, there was an evident fragility about the longer term viability of the social services that developed for they were heavily dependent on the energy of these clergy. This friction came to be because the clergy may have been perceived as focusing more on the services than the congregation's needs. Secondly, the capacity of congregational members to sustain their individual and collective involvement was enhanced significantly when clergy were active permission givers and encouragers of congregational involvement as opposed to passive accepters or even "benign" neglecters of that involvement. This interdependence of congregational involvement and even initiative with clergy's active permission by giving and encouraging was another of the unexpected key insights arising from this research. The clergy member leading from behind seemed to be the healthiest leader for the whole congregation and community.

Congregations also often provided the people who had some sort of formal oversight of the congregational community services. This might be a responsibility of the overall congregational board or council, with a social service as but one area of their oversight e.g., the oversight of a congregation's community Opportunity Shop. This might be the "official" position, with little more than tacit attention paid to it, but with an informal cluster of congregational people who chat among themselves on an "as need" basis maintaining some oversight, or it might be a semi-formal "committee" that meets semi-regularly providing that oversight. Increasingly, congregations were discovering that informal ways of operating were likely to be legal risks.

Hence, some instituted formal incorporation as legally separate bodies but with boards made up of at least a majority of congregational members, if not fully of congregational members. Being legally independent did not necessarily break the nexus with the congregation, although the risk of that is a matter requiring consideration. The legal alternative was for the social service to be merged with a larger church social service established legally in other ways, but sharing with the congregation an agreement for mutual engagement in the congregation's geographical area. One of the research congregations had a formal agreement to that effect, with a condition that neither party could unilaterally withdraw from the arrangement but had to engage in a mutual negotiation to address any issue and respond as jointly agreed. In the event, this central church agency provided financial management and overall management support but left the congregationally based personnel to determine the exact social service programs on offer.

Leadership of board and social services was sometimes undertaken by the clergy. In fact, a unique feature of congregational community service development was the availability of clergy as lead personnel in a way other community-based social services could not expect to have, a special resource for effective social service development. However, at times the qualified personnel already identified with a congregation would take on these formal leadership roles, often contributing significant expertise including legal advisers, treasurers, program supervisors, and management consultants. In some settings it was recognized that congregations could support the formal training and professional development of needed leadership personnel and staff by intentionally calling members to these social service ministries and facilitating their development.

Overall, what was evident was a significant capacity of congregations to staff social services they began, albeit sometimes naively at first, but often with a high level of experience and competence as well. This may lead to some dubious "in house" appointments but, conversely, may also facilitate a shared commitment to the social services in question. Above all, however, this arrangement was clearly associated with a significantly less than "commercial" salary cost being needed to sustain the social service. Nonetheless, there were a range of risks associated with this arrangement including burnout, lack of adequate training, and lack of supervision. 


\subsubsection{Funding}

Because of the facilities and staffing options potentially available to congregations (i.e., facilities typically provided rent-free and staff either unpaid volunteers or paid only small honorariums), operating costs are likewise potentially lower than might otherwise be encountered when establishing and operating a social service based on a more typically professionalized basis. Indeed, two of the three congregations included in this research appeared to have relatively low costs for these reasons using mainly volunteers, including professionally accredited volunteers. The third congregation, even though facing higher costs in some areas of its social service due to employing a small number of key professional staff, was still the clear beneficiary of these unfunded contributions from their associated congregations (i.e., encountering low or no rental costs and other professional staff being volunteers as well as volunteer support staff).

Congregations have a culture of giving, in contrast to the philanthropic responses of Australians generally [23]. However, all three research congregations found that regular direct giving by congregational members to their social service activities was far short of what was needed, despite some concerted fundraising efforts being evident. Many costs were apparently "absorbed" into the general congregational operating budget (e.g., wage contribution of the clergy, utilities costs, office space nominal rental charges, photocopying) with no recognition whatsoever of this income forgone by the congregation, income needing to be "replaced" if the social service was to operate outside of a congregational setting. Nonetheless, there were direct congregational contributions such as the salary of a paid Director/Coordinator of a social service. These contributions were in fact never sufficient and the shortfall, where it existed, was addressed by a range of other means: applications for grants from wider church funds, applications for grants from community philanthropic sources, applications to larger central church agencies for funds, applications to local government for community funds, fundraising initiatives such as special social events and income producing Opportunity Shops or fee for service activities, and, significantly, contracts with government to deliver certain services.

This plethora of funding sources was found to have two serious dilemmas. Firstly, the largely ad hoc sources offered no guarantee of continuity, meaning the funding of these social services was always uncertain and unreliable. For example, philanthropic trusts might give a significant grant once, and then not consider the social service for another few years. Grants from Central Church sources were typically more predictable than that, but always uncertain and dependent on funding policies. In-house fundraising sources such as Opportunity Shops or, in one case, a Calendar publishing enterprise, were more reliable but still limited in their contributions. The second dilemma was the administrative detail and time required to seek grants from philanthropic bodies, and more especially government, combined with the commitment to operate any program so funded, but with an expectation that the funds provided would not fully meet operating costs. Those who went this path reported significant stress whilst undertaking the formalities involved. Government funding was also found to compromise the social service agendas of the churches and congregations concerned with service agendas becoming defined by personnel outside the actual service delivery contexts.

Overall, it was clear that congregations, to the extent that funding is needed for a social service, can access such funding from somewhat novel sources, but the pattern was clearly one that evidenced a perpetual inadequacy of funding to meet the developing needs of these social services, even when such funding is derived from government contract. If the "full cost" of operating these services was taken into account, then these social services may well never survive. With so many costs effectively covered by default by congregations, then the constant round of fundraising apparently has proved to be barely "sufficient" at least for a time, even if unpredictable and administratively demanding.

\subsubsection{A Community of Support}

The significant set of resources for the provision of social services clearly have their origins in that sense of caring and social concern that is characteristic of at least some religious congregations. Within these congregations, that concern extends beyond the mere provision of a social service. It is 
evidently expressed in all the research congregations (and many others reviewed beyond those formally researched) to be a community of care readily accessible by any who seek such personal support. It is a community that actively exists and is therefore, apparently, available to some degree when needed. It is a community that has a value or ethic that readily adds supportive care of outsiders to its formal purpose for existing. It is a community willing to put its resources to use to provide such care and involvement.

However, congregations are not only willing to directly provide such resources, formally and informally, to the wider community; they are also apparently willing to tap into wider community resources to enhance their capacity to undertake these responses. The research congregations were found to tap into other congregations and resources within their own religious denomination even from outside their immediate area, the resources of religious congregations linked to other denominations, especially those existing within their own geographical area, and also the resources of like-minded people who have no religious affiliation or even identification if they are willing to be an active part of the congregational social service. In this congregations become facilitators or catalysts for a wider and more integrated resource of care within a community.

Further, whilst many of the social services are formal programs such as Emergency Relief provision or Grief and Loss Counselling, what all the research congregations did was develop ways which help promote a less formal means of social inclusion and informal interpersonal care. This resource, then, was evidently a dimension of community care not readily accessible in social services that operate in formal and professionalized settings. It was also a natural and integrated setting, not a social group formed of people with a common social limitation.

These are achieved through Coffee and Chat activities, craft groups, as well as the general atmosphere of non-judgmental acceptance that typically accompanies these congregational social services. These informal strategies for accepting and supporting people in need, toward people who may have experienced some form of social alienation, are the therapeutic resource that a few of the social workers interviewed identified as a strength of congregational social services, their "magic" as one recently stated. For one respondent, it was a partnership possibility with the more formal and professional processes of a central church agency, whilst for another it was a natural outcome of the social service operating within the context of integration with a worshipping and caring community. The informal support sought was able to be obtained from a known community i.e., a community whose acceptance and caring response was a given and not something needing to be accessed without prior knowledge.

\subsubsection{A Spiritual Base}

Another, perhaps even more unique component of the resources a congregational social service can offer is a recognition of and response to the spiritual dimension of a service user's life and concerns. The discussion of spirituality in the helping professions and in social services is a potentially vexed issue and the debate around it is beyond this article. Rather, this study recognizes that for congregations, some understanding of their spiritual purpose in offering a social service is a component of what they offer. In some cases, this may involve an intentional strategy to share that spiritual perspective with those who make use of the service.

This approach is likely to raise many issues of concern which were grappled with in one of the research congregations, at least until congregants realized through their discussions that this was not really a core aspect of their purpose in providing the service. Rather, they joined the other congregations in seeking only that they operate in a manner consistent with their spiritual basis and be able to share that with service users should there be any who wish to engage with that aspect of their lives.

Within the social work profession, it has been recognized that spirituality is a potentially legitimate component of some people's lives and concerns $[24,25]$. Hence, it was recognized by some respondents that a congregational social service that was potentially willing and able to respond to that at some level 
was a valuable community resource not typically available in other settings. Such a congregational setting, by its very nature, would give clear permission for service users, concerned about that aspect of their life and concerns, to seek a response at the spiritual level. Such responses indeed had no place for being imposed on people any more than it was supportive to deny concerned people access to them. Congregational community services therefore provide a natural and accessible setting for this dimension of life to be incorporated as appropriate for any given service user.

Further, congregational community services also readily "undergird" their community service with their spiritual life. It perhaps is rather obvious to say that the very existence of a congregational social service reflects in some measure the activation of the spiritual resources of a congregation. However, in many congregations these more obvious and concrete resources are reinforced by further "quiet" spiritual resources such as praying for those who come into the facility, a readiness to engage in more spiritual processes should they be sought, as well as a potential willingness to advocate for issues of social concern and justice of which any particular service user's issue might be an example. These are the sort of value-added components that congregational social services can generate.

\subsection{An Observed Pattern of Development Potentially Leading to Disconnection}

This pattern in the analysis of congregations engaging in social service delivery in their community, whilst based on a small sample yet consistent with casual observation of past and present congregational activities, provides a good insight into key facets, and levels of detail not yet chronicled of congregations evolving into service providers. Whilst evidence from this study is emerging to point out that the processes are complex, some features reflect a basic volunteer mentality of "making do," whilst other aspects feature an increasingly formal and structured approach. However, this data also suggest that there are strengths in both. What is instructive is that the unexpected combinations of these two features are much more reflective of the processes involved.

Yet the data also suggests that, without an awareness of the intricacies of this process, there is an inherent risk that these social services tend to evolve towards what is labelled a default outcome. The loss of congregational connection and a growth of formality is something that most congregations cannot manage. Here in Australia, the history of development of congregationally initiated programs such as those listed in the Uniting Church report, Rejoining Word and Deed [26], suggests that most congregations that develop social services effectively lose their congregational connection in all but name, unless a deliberate strategy is adopted to ensure that links are maintained. Such is the case even as programs are improved to meet best practice requirements. The pattern for the operation emerging from this research identified not only what congregations offer the community by way of social service resources, but also an understanding of how to manage this evolution strategically.

The default pattern has been identified by a social work respondent as one which involves the appointment of people to key roles in a congregational social service such as a Chief Executive Officer or a Professional Social Worker. This pattern is identified as:

(1) In order to secure government funding and/or to meet formal funding requirements, congregational social services seek to appoint suitably qualified personnel who are either active members of the congregation or who are willing to move to the congregation's locality and become active members of the congregation;

(2) If such persons are not available, congregational social services seek to appoint suitably qualified persons who, whilst not living locally and/or not members of the congregation offering the social service, identify with the faith perspective of the congregation and endorse it;

(3) If such persons are not available, congregational social services then seek to appoint suitably qualified persons who agree to abide by the values and ethos of the congregational perspective and social service goals even though not personally engaging with the faith perspective that generates them. 
This process is, of course, not the totality of complex issues that can move a congregational social service from one in which the blend of creative, if sometimes naïve, volunteerism and a growth of professional formality can steadily move the social service away from its congregational intention to that of a professionalized and secularized church sponsored agency with little but an historical link to its founding congregation. However, in order to maximize the retention of those qualities that are indeed constructively available through the congregational setting whilst obviating aspects that risk the provision of a quality social service, a strategic approach that intentionally counter-balances volunteer features with professional features is called for. Within this approach there is a need to be strategic about maintaining the congregational link rather than taking it for granted as it in fact steadily dissipates with further developments occurring along the lines of the processes outlined above.

The remainder of this article outlines those strategies which were identified in the research as potentially contributing to a goal of retaining the strengths of the congregational link even as other developments occur. This can be summed up in the concept originally mentioned, referring to approaches that promote a retention of the congregation's sense of emotional and spiritual ownership.

\subsection{Strategies That Work to Maintain the Connection}

As congregationally linked social services developed, it was apparent that the link was typically taken for granted. What gave substance to that link was neither recognized nor sought. However, as presumed features of that link dissipated, congregational members would begin to express concerns that reflected their awareness that things were changing even if they could not quite name them specifically. Further analysis of comments in the datasets reflect this recognition. When examined further, I identified a range of actions which were seen to help promote a sense of "ownership" or linkage. Such actions were recognized through their decline or omission rather than as intentional ways to promote congregational social services. Once recognized, these become a list of potential strategies which could be intentionally implemented to build and sustain this congregational link.

These are:

- $\quad$ the emergence of a congregational vision that explicitly incorporates a specific social service as a component of congregational life and mission;

- formal structures of some sort between the congregation and the social service which indicate how the congregation will operate their social service whilst retaining the congregational link and responsibility;

- $\quad$ articipation by congregational members in the defined decision-making structures related to the social service as board/committee members;

- announcements about the social service activities, needs, and progress made during the congregational community notices and/or weekly information sheet as part of each worship service along with a promotion of the link through congregational teaching in sermons which maintain an awareness of and reinforce congregational engagement;

- financial contributions to and fundraising for the social service as a part of the congregational budget arrangements along with some involvement by the congregational administrative and/or mission personnel in the social service's own budgeting processes;

- a $\log o$ for the social service that explicitly articulates the congregational linkage with the social service included on all notice boards and church publications;

- $\quad$ provision of a pool of congregational volunteers to work within the social service as their ministry contribution to the congregational mission;

- $\quad$ staff for the social service being appointed from within the congregation as the ministry involvement of these qualified personnel;

- general congregational participation in the activities of the social service e.g., as participants in the craft group established for people with mental health issues or volunteers organized to provide the refreshments for a Coffee and Chat activity for users of the social service; 
- congregational provision of buildings that meet the need of the social service, especially ones that have been redesigned to address the social service focus;

- $\quad$ prayer support for the work of the social service to express the faith perspective that the social service is indeed a ministry of the congregation.

This is a formidable list of actions exhibiting this link between social service and congregation. How many are crucial for such links to be seen as strong was not clear. What was clear was that, when a lack of such linking activities was seen to be growing, the sense of ownership slipped, leading to a further decline in the key resources accessed through the congregation itself. Further, as ownership slipped, it was sometimes identified with the development of a more significant and formal professional culture of operation consistent with Cnaan's loss of a spirit of volunteerism as well as Harris's loss of control. Hence, this analysis identified that respondents saw a need to intentionally promote congregational ownership and linkage by being intentional about these expressions of that link.

\subsection{Deterrents to Congregational Ownership Retention}

Whilst the relevance of the previously mentioned actions to maintaining the linkage between a congregation and its social service may be a belated recognition born of their subsequent absence, a number of respondents also noted a series of concerns that impact congregational social services, typically undermine the retention of a link regardless of where a congregation may be on these previous actions. Such influences are as follows:

- $\quad$ The complexity of fundraising was identified as a significant deterrent for congregational social services. These matters included the diversity and conditions of government and philanthropic funding requirements and sources. Such funders require the need for the retention of detailed records for programmatic expenditure, and the accountability requirements for reporting accurately on the utilization of funds received;

- $\quad$ The scale and complexity of current program delivery approaches involving complex management procedures to monitor and evaluate such programs including health and safety as well as risk management;

- The limited capacity in skills and personnel of a congregation to resource these management aspects of modern day social service delivery;

- The excessive dependence of congregational social services on retirees, women, and the unemployed for the personnel to staff congregational social services;

- The difficulties in providing adequate supervision and support for the staff that are found, whether paid of voluntary;

- The potential for burnout by highly motivated and committed staff who experience difficulty in drawing a boundary between their social service involvement and their general involvement in congregational life and ministry;

- The commitments of congregational members elsewhere than in social service delivery, such as family life, other aspects of congregational life, and their own work commitments;

- Lack of personal support for volunteers from key congregational leaders including clergy especially at crucial times such as illness;

- The inherent slowness to develop a specific program because of the series of meetings involved with doing so, or conversely the speed with which some leaders such as clergy, implement programs that reflect their agenda rather than an agenda the congregation feel able to resource.

Nonetheless, other respondents saw that these apparently increasing deterrents were simply matters that congregations committed to social service delivery could develop strategic means to address. These responses were evident in all three of the research congregations. These strategies, built into the operating processes of the congregational social services, included: 
- Establishing specific supervision and mentoring relationships with older people experienced in relevant aspects of congregational social services;

- Negotiating working partnerships with larger, more fully professionalized central church agencies able to offer administrative support such as with financial management and reporting, as well as with staff supervision and training relevant to the programs on offer;

- Ensuring that clergy recognize and respond with the necessary permissions and encouragements to support lay involvement and that they maintain a capacity and accountability to congregations with regard to their program visions and support for the program visions of congregational members;

- Strategically identifying that when actions are taken, such as to employ professional staff, the decision is made with intentional issues in mind. A relevant strategic purpose might reflect the importance of an appointment being actively linked to the congregational life and faith, or the importance of a position being a relevant blend of the less formal volunteer qualities of congregational culture as well as the more formal features of quality social service delivery;

- Ensuring that a congregation intentionally calls lay-people to and supports their training in the range of skills needed for the congregational social services including the knowledge, skills and formal professional recognition of key social service accreditation bodies;

- Maintaining due process when developing new social services and proper accountability processes when operating them, including seeking feedback from service users, congregational members, related community service providers, as well as use of a variety of evaluation strategies that assist service planning and development.

These responses from respondents all suggest that congregations can develop strategies to address potential deterrents where they are committed to the social services they set out to offer their wider community. The issue is one of being aware of the necessity of understanding the diverse complexities of the environment within which congregational social services operate and therefore the need for being intentionally strategic when considering their operation, rather than operating in a manner that just assumes a congregational link will remain. Without that strategic thinking, the risk is that gradually elements of the resources that the congregational link brings, the social capital that it offers, will be lost to the social service, a loss that formal and professional processes cannot in all aspects overcome. For example, loss of an informal community of support and the inherent responsiveness of socially connected congregations cannot be easily overcome through professionally facilitated client-focused support groups.

\section{Contextual Changes in the Past Decade}

Without undertaking a close examination of policy and procedural changes of the past decade, I have encountered two key changes impacting on congregations within the delivery of community services within the Australian setting. Firstly, government has moved substantially towards a so-called "Public-Private Partnership" approach which prioritizes contractually-based funding arrangements with large community service providers, both not-for-profit and for-profit. Secondly, the main religious denominations have engaged in a process of "merging" their locality-based community service agencies into single, large services able to compete in this new competitive, contractual environment (see for example the comments to a recent Synod of the Uniting Church in Australia [27]).

These two substantial changes appear to threaten the viability of the smaller, localized congregational community service activities that have come to depend on significant government funding. Whilst the central church bodies flag establishing alternative congregational support systems [27], nothing that supports local congregational involvement has yet clearly emerged. What is risked in the overall delivery of community services through these changes is the provision of low cost, high social capital engagement with at-risk people as these services professionalize and diminish the important sense of emotional ownership that is their hallmark. However, attention to the features 
raised in this article provides clarity for strategies aimed at assisting effective partnerships between congregations and these larger agencies which strategically value and nurture these links rather than diminish them.

Congregations which seek to maintain their own community ministry in the face of these changes will recall that, in the early years of congregational ministry before the gradual evolution of community services away from their founding congregation, congregations undertook their early work without government support. Conviction that community service ministries remain a crucial part of congregational life can therefore potentially see new forms of community ministry emerging in response to the "gaps" inevitably arising with these new Public-Private Partnership contracts. Once again, awareness of the concerns identified in this article provides clear strategies to support any such new developments.

\section{Conclusions}

Congregations in many instances have a strong history of developing social services for their wider community. History suggests many lose these services as they progress through a process of professionalization, secularization, and separated operation. In doing so, the congregations lose their community ministry as an expression of their faith, and social services lose a diverse range of social capital that otherwise supports their work and development. Whilst there may be an argument that congregations may well be good catalysts for social services that ultimately need to be taken up by the wider community and government, the research on which this article is based did not find that as the intention of any congregation. Support from government and community is welcome, but the retention of some sense of emotional ownership is assumed, and the loss of it contrary to congregational expectations.

This research has clearly established that this loss, this disconnect, is neither inevitable nor necessary. The findings call for strategic awareness of congregational community service processes. This is a balance between the congregational operating culture and that of a formal social service, which is regularly reviewed and changed. The findings indicate that congregations have significant social capital for a wider community social service provision. No formal, professional agency can ever fully replace that spirit of connection. For this reason at least, the link between congregations providing social services and their social service off-spring is one that continues to need strategic attention instead of an acceptance of an ad hoc default evolution that separates the two, the more so as more recent changes continue to develop and impact smaller congregational services.

Acknowledgments: The author was in receipt of an Australian Government Post-Graduate Research Scholarship whilst undertaking the research on which this article is based. No funding has been received from any source to assist with the publication of this article.

Author Contributions: The author is entirely and solely responsible for the totality of the research on which this article is based.

Conflicts of Interest: The author declares no conflict of interest. The author has had over 30 years of involvement as a congregational member, as a volunteer, and as a professional social worker in congregationally-based community services in Australia as well as spending nine years undertaking this research.

\section{References}

1. Robert J. Wineburg. "Volunteers in Service to their Community: Congregational Commitment to Helping the Needy." Journal of Volunteer Administration 9 (1990): 35-47.

2. Robert J. Wineburg. "A Community Study of the Ways Religious Congregations Support Individuals and the Local Human Services Network." Journal of Applied Social Science 15 (1991): 51-74.

3. Robert J. Wineburg. "Local Human Services Provision by Religious Congregations: A Community Analysis." Nonprofit and Voluntary Sector Quarterly 21 (1992): 107-18. [CrossRef]

4. Robert J. Wineburg. "An Investigation of Religious Support of Public and Private Agencies in One Community in an Era of Retrenchment." Journal of Community Practice 3 (1996): 35-56. [CrossRef] 
5. Carl S. Dudley. Basic Steps towards Community Ministry: Guidelines and Models in Action. Washington: Alban Institute, 1991.

6. Arthur E. Farnsley, II. "Thinking of Congregations as Community Assets." Research Notes from the Project on Religion and Urban Culture 1 (1998): 1-5.

7. Ram A. Cnaan. Social and Community Involvement of Religious Congregations Housed in Historic Religious Properties: Findings from a Six-City Study. Philadelphia: School of Social Work, University of Pennsylvania, 1998.

8. Mark Chaves. Religious Organizations and Welfare Reform: Who Will Take Advantage of "Charitable Choice"? Washington: Aspen Institute, 1999.

9. Margaret Harris. "Quiet Care: Welfare Work and Religious Congregations." Journal of Social Policy 24 (1995): 53-71. [CrossRef]

10. Peter Kaldor, John Bellamy, and Sandra Moore. Mission under the Microscope: Keys to Effective and Sustainable Mission. Adelaide: Openbook Publishers, 1995.

11. Peter Kaldor, Robert Dixon, and Ruth Powell. Taking Stock: A Profile of Australian Church Attenders. Adelaide: Open Book Publishers, 1999.

12. Margaret Harris. Organizing God's Work: Challenges for Churches and Synagogues. London: Macmillan, 1998.

13. Ram A. Cnaan, Stephanie C. Boddie, Fermida Handy, Gaynor Yancey, and Richard Schneider. The Invisible Caring Hand: American Congregations and the Provision of Welfare. New York: New York University Press, 2002.

14. Ian A. Bedford. "Reaching Out Beyond Itself: A Framework for Understanding the Community Service Involvement of Local Church Congregations." Ph.D. Thesis, University of Melbourne, Parkville, Australia, 27 January 2004. Available online: https://minerva-access.unimelb.edu.au/handle/11343/38840 (accessed on 23 August 2016).

15. Diana R. Garland, Terry A. Wolfer, and Dennis M. Myers. "How 35 congregations launched and sustained community ministries." Social Work and Christianity 35 (2008): 229-57.

16. F. Ellen Netting, and Mary K. O'Connor. "The Intersectionality of Religion and Social Welfare: Historical Development of Richmond's Nonprofit Health \& Human Services." Religions 2016, forthcoming.

17. Barney G. Glaser, and Anselm L. Strauss. The Discovery of Grounded Theory: Strategies for Qualitative Research. Chicago: Aldine Publishing Co., 1967.

18. Parishioner D, Congregation A, interviewed by the author, 26 March 1999.

19. Parishioner C, Congregation B, interviewed by the author, 11 December 1999.

20. Counsellor C, Congregation B, interviewed by the author, 10 December 1999.

21. Document 2 Congregation $C$ as an internal report drafted February 1992 and provided to the author on 1 July 1999.

22. Jo Anne Schneider. The Kenosha Social Capital Study: Churches, Nonprofits, and Community. Indiana: Indiana University of Pennsylvania, 2001.

23. Mark Lyons, and Ian Nivison-Smith. "Religion and Giving in Australia." The Australian Journal of Social Issues 41 (2006): 419-36.

24. Frank M. Loewenberg. Religion and Social Work Practice in Contemporary American Society. New York: Columbia University Press, 1988.

25. Edward Canda. "Spirituality, Religious Diversity, and Social Work Practice." Social Casework 69 (1988): 238-47.

26. Paul Linossier. A Common Sense of Purpose: The Rejoining Word and Deed. Melbourne: Justice and Social Responsibility Unit, Commission for Mission, Uniting Church in Australia Synod of Victoria, 1994.

27. Uniting Church in Australia. "Uniting Care Network Project Control Group report to June 2016 Synod." Available online: https://www.victas.uca.org.au/aboutus/Synod_Meeting/Reports/C1.3\%20UnitingCare\% 20Network\%20PCG\%20report\%20to\%202016\%20Synod.pdf (accessed on 7 August 2016).

(c) 2016 by the author; licensee MDPI, Basel, Switzerland. This article is an open access article distributed under the terms and conditions of the Creative Commons Attribution (CC BY) license (http:/ / creativecommons.org/licenses/by/4.0/). 


\title{
The Dual Role a Buddhist Monk Played in the American South: The Balance between Heritage and Citizenship in the Refugee Community
}

\author{
Daniel Rhodes \\ Department of Social Work, University of North Carolina at Greensboro, 1400 Spring Garden Street Greensboro, \\ NC 27412, USA; dtrhodes@uncg.edu
}

Academic Editor: Robert Wineburg

Received: 13 March 2016; Accepted: 4 May 2016; Published: 7 May 2016

\begin{abstract}
Buddhist Monks in Vietnam struggle with cultural preservation differently from a monk in the U.S. where the forces of acculturation for new arrivals, often refugees, are extraordinarily overwhelming. The author provides a case study examining how Buddhist leaders engage in cultural preservation and community building in the American South. Fusing ideas of Engaged Buddhism and community building, the author will demonstrate how a Buddhist monk is able to navigate the broader American culture and assist Vietnamese immigrants and refugees to acculturate, while maintaining their own cultural heritage, beliefs and religious traditions; ultimately building a viable and sustainable Buddhist community that contributes greatly to its new host community.
\end{abstract}

Keywords: Engaged Buddhism; Vietnamese refugees; community building; social work

\section{Introduction}

A few days after taking a group of students from my community building class to visit the Vietnamese Buddhist temple, Chùa An Lạc, we were sitting together in the classroom reflecting on the experience. These were very bright students, attending a private liberal arts college ${ }^{1}$. Most were white and privileged, and were steeped in our attempts to teach about diversity and pluralism. One of the students raised her hand and posed the question, "does the temple have anything in its mission statement about social justice?"

I love teaching and do enjoy the conversations I have with students in the classroom, but I am sometimes stunned by their questions and comments. I had to pause for a moment and process her question. I have been connected with this Vietnamese Buddhist community for almost twenty years and have brought numerous friends, acquaintances and classes to the temple for visits. Having spent a good portion of the past twenty years studying Vietnamese Buddhism and tradition, I have to remind myself that people who are unfamiliar with the religion and culture come with a lot of curiosity and interest. This Buddhist community, especially the head monk Thích Thường Lực ${ }^{2}$, is always patient,

1 This story is from my time teaching at Guilford College, a small, Quaker liberal-arts college in Greensboro, NC. One of the courses I taught while there was Community Building and I would take this class to Chùa An Lạc as an experiential exercise in community building from an immigrant and refugee perspective.

2 When I give presentations or chatting with people about Vietnamese Buddhism, I will often ask them what they think, "Thích" means. Some Americans are familiar with it, especially with the writings of Thích Nhât Hanh, so their assumption is that Thích means, "master" (from the master pupil dynamic in Asian traditions) or teacher. Thích is actually a truncation of, Thích-Ca Mâu-Ni. Thích-Ca Mâu-Ni is the literal sounding translation of Śākyamuni to Vietnamese, Śākyamuni being the clan that the historical Buddha came from. When a Vietnamese becomes a Buddhist, they are assigned a Buddhist name; Thích Thường Lực Buddhist's name is Thường Lực. Monks who have been ordained will use Thích in front of their name, signifying that they have become a member of the historical Buddha's clan, the Śâkya clan. You see this in Vietnamese 
kind and generous. Buddhism often comes with an air of mystery in this country, and people are drawn to it without really questioning what attracts them, or the nuances of the tradition and culture it comes from. Americans will see figures such as His Holiness The Dalai Lama on television or the Internet, and will conflate all Buddhist ideas and cultures into that one caricature. Many Buddhist leaders from Asian countries have learned the language of Western liberalism and are able to use it effectively to communicate ideas and concepts that are, in reality, completely foreign to a Western frame of mind.

My initial reaction was to respond to this student about the ethnocentrism of applying the term "social justice" to a culture and religion that has transplanted to this country because of the great suffering inflicted upon its people by its government. These momentary pauses before reacting, my "mindful" moments, help me to gather my thoughts and be skilful in my tone and response. I informed the student that social justice is, in a lot of ways, a very Western concept ${ }^{3}$. This Vietnamese Buddhist community is guided by the Buddhist tradition that permeates its culture and beliefs, passed down for generations. There are codes of ethics that guide how Vietnamese Buddhists live their lives, but the term social justice is not something that comes up as a part of conversation when the Buddhist temple conducts its day-to-day activities. I could see the student was attempting to process my answer, unsure how to connect it to her frame of reference, where social justice is an important part of her developing identity.

The exchange reinforced for me the importance of attempting to help students navigate the complexities of working with diverse groups of people, especially when we are dealing with immigrant and refugee populations who come to this country, with their own set of values, norms, beliefs and religious traditions. Our concept of Buddhism that gets promulgated by the mainstream media often greatly misrepresents the reality of most non-Western Buddhists who live in this country.

The purpose of this paper is to reflect on my own personal experience of working with Vietnamese Buddhist immigrant and refugee populations who have migrated to a rural part of the Southeastern United States. This is, in essence, a case study, though not a formal case study, however. As a trained clinical social worker and academic, I will often follow specific guidelines in how I engage in community-based research. These guiding principles are important and will serve as the foundation of my research methodology. Often following the principles of Participatory Action Research (PAR) and critical ethnography [2,3], I approach most of my community-based work on these sets of ideas.

My experience with this particular immigrant and refugee community is very different, however. I will often use the term autoethnography when I am describing my work and experience with this particular community, but even this term becomes problematic. When we deconstruct autoethnography, it is ethnographic study that uses the author or researcher as the platform for disseminating information about a community group or culture that he or she is invested in. Or as Jones notes, autoethnography is a "blurred genre, it overlaps with, and is indebted to, research and writing practices in anthropology, sociology, psychology, literary criticism, journalism and communication" ([4], p. 765). But D. Soyini Madison considers autoethnography as more an autobiography, or what she calls, "travel writing, or memoir." (I don't completely agree with Madison's assessment on this). For Madison, she prefers to use the term, "critical ethnography" noting that it, "is always a meeting of multiple sides in an encounter with and among others, one in which there is negotiation and dialogue toward substantial and viable meanings that make a difference in others worlds" ([3], p. 10). Beyond the semantics of autoethnography versus critical ethnography, the ideas and concepts (i.e., my methodology) of which I

Buddhist names, Thích Nhất Hạnh, Thích Thiện Quãng, Thích Thường Lực. Vietnamese Buddhist nuns will be addressed as, Su Co (sister) and monks will be addressed as, Thầy, which means, "teacher" or "master." Thầy is the proper way to address Buddhist monks and nuns in the Vietnamese Buddhist tradition.

3 Peter Harvey expands on this idea more, "It is true that Buddhism does not usually talk in terms of 'rights', which is a term that arose from the Western philosophical tradition. That does not mean, however, that Buddhists cannot agree with the substance of what is expressed in 'human rights' language." ([1], p. 119). 
have approached my work with this Vietnamese Buddhist community clearly falls in the realm of what Madison would consider to be critical ethnography and what I consider to be PAR.

As noted, this comes from my eighteen years of connection with this Vietnamese Buddhist community. This has been more than a group of people that I have studied for research purposes. My agenda when I first connected with this group was not to do research or to be a casual, social science, "objective observer". I came to this community with a deep passion to learn about the culture, the community and the religious tradition. It has evolved out of my own personal interest in Buddhism. My experiences have not been to sit down and engage in ethnographic questions with community members. It has been to get to know this community intimately and to be a part of this community as much as I can, knowing that I am an outsider, that I am a Westerner learning about an immigrant and refugee community of which I would never truly know what their life experiences were and are. I was not a researcher or academic, I was a student, a student of Buddhism and a student of their culture. It is a community that has welcomed me with graciousness, and in reality this community has given me more than I can ever give back to them.

Through my time with this community I have seen rifts, fractures and amazing growth. I have followed two specific Buddhist teachers throughout the past eighteen years and they have been my guides and instructors in both a Buddhist tradition and the Vietnamese culture. I would spend days on end at the Buddhist temple, working, studying, eating, sharing and learning. Ernest Stringer in his book on PAR quipped about his community-based research, "I've heard such comments as 'All he does is sit around drinking coffee or tea with people'" ([2], p. 95) ${ }^{4}$.

After several years connected with this community, I traveled to Long Beach, California and spent a month at a Buddhist temple there, studying with the monastic brother of my first Buddhist teacher, Thích Thiện Quãng. After my month in California I traveled back to this area and spent a year as an AmeriCorps member at this Buddhist temple (For the rest of the paper I will refer to the Buddhist temple by its proper Vietnamese name, Chùa An Lạc. Chùa is Vietnamese for Temple or Pagoda, and An Lạc is the formal name of the Temple, which loosely means peace and tranquility, or happiness. An Lạc is a term taken from one of the Buddhist scriptures, or what is called Sütra).

AmeriCorps is like a domestic Peace Corps, where members serve in local communities. The University of North Carolina at Greensboro (UNCG) has an organization called The Center for New North Carolinians (CNNC) [5]. This center was initially developed in conjunction with the Department of Social Work at UNCG. The main mission of the CNNC is to serve newly arriving immigrant and refugee populations in the area. The former director of The Center for New North Carolinians, Raleigh Bailey noted, "In the early 1990s, North Carolina began to witness a dramatic influx of immigrants. The foreign-born population increased by 273.6 percent between 1990 and 2000, growing from 115,077 to 430,000 residents." North Carolina, especially in Greensboro where I reside, was designated as a refugee resettlement area, because of, "(1) a robust labor market", and "(2) a federally funded program that settled refugees in selected parts of the state" ([6], p. 57).

A component of the CNNC is an AmeriCorps program called the AmeriCorps ACCESS project (Accessing Cross-Cultural Education Service Systems) [7]. AmeriCorps ACCESS members are placed in community organizations who serve immigrant and refugee populations. I had connections with the CNNC ever since my time as an undergraduate social work student at UNCG. At this time, in 2000, the two main Buddhist teachers I followed, head monk Thích Thiện Quãng and his novice monk Thường Lực, were attempting to establish a new Vietnamese Buddhist temple in High Point, a small furniture town located in the central part of North Carolina. Knowing that being a part of the AmeriCorps ACCESS project would help connect the Vietnamese community to an organization which had a

4 Stringer elaborates more on the connection with people in PAR, "The process of action research, therefore, are enriched by researchers who contribute to the lives of the groups with whom they work. Researchers increase their effectiveness when they immerse themselves in the richness of group life, talking with people about general events and activities, sharing a birthday cake, participating in informal or leisure activities, telling jokes, and so on" ([2], p. 95). 
history of helping immigrant and refugee populations develop non-profit organizations, I decided to spend a year as an AmeriCorps member at Chùa An Lạc, helping with administrative duties that many organizations and religious based groups deal with when attempting to establish themselves. I also taught an English for Speakers of Other Languages (ESOL) class and a Citizenship Class.

My year as an AmeriCorps member at the temple was, in a small way, an attempt to give back to the community that had given me so much at that time. It also allowed me the opportunity to spend more time with the community than just visiting on the weekends, when people would come together for cultural events and community building. My AmeriCorps time also became the essence of the critical ethnographic approach of working with this community. I wanted to transcend this position of being a casual observer, to a more engaged dialogue with the community. As Madison continues to note about critical ethnography,

It is through dialogue and meeting with others that I am most fully myself. The wonderful paradox in the ethnographienc moment of dialogue and otherness is that communion with another brings the self more fully into being and, in doing so, opens you to know others more fully ([3], p. 11)

This year spent with this community as an AmeriCorps member also communicated to the community my investment into their culture and beliefs, and in their success in maintaining a viable and sustainable Buddhist temple, which also serves as a community and cultural center. As Stinger notes, "The process of action research, therefore, are enriched by researchers who contribute to the lives of the groups with whom they work" ([2], p. 95). All of this, I am fully aware, could have been done without me. But I could not have learned as much about the community and been a real part of it, unless I was willing to let go of my own "objective" biases and spend substantial time working directly with this community.

Even after my year as an AmeriCorps member was over I continued to maintain a strong, ongoing relationship with this Vietnamese Buddhist community and the members of the Chùa An Lac. As I have noted, this has been a part of my life for eighteen years now. My time and experience culminated to me eventually moving into Chùa An Lạc a little over a year ago, living and studying as a Buddhist monk for six months ${ }^{5}$.

Given this background, the main purpose of this paper is to educate the reader on the challenges of a Vietnamese Buddhist community attempting to establish itself in a rural part of the United States that is politically conservative, traditionally Christian (one of the first things local people will ask you upon meeting you is, "So, what church do you go to?") and has a long history of racial issues, which historically included apartheid laws and segregation that still hangs over the region and area.

As I mentioned earlier, many Westerners have caricatures in mind when they are thinking in terms of Asian cultures and religious traditions. As academics, we are not much better. In Healy's book International Social Work, she notes,

More than $90 \%$ of American professors surveyed express no need to read books or journals published outside their own country to keep up in their fields-a quite astounding finding of disinterest in their profession beyond national borders, and possibly indicative of ethnocentrism ([8], p. 6).

This is disturbing, given the fact that part of our obligation as teachers is to educate students on global issues; now so, more than ever, given the level of international migration we are experiencing all

5 I actually lived and studied as a novice monk. The process for ordination can take anywhere from two to several years, depending on the persons disposition, growth and understanding. Although studying as a novice monk, I was never ordained a full Buddhist monk. Many of the adults, some I have known for eighteen years, were pleased to see me attempt to deepen my own Buddhist practice and to dedicate a good portion of my time studying Vietnamese Buddhism and their culture. 
over the world. Before I can begin discussing my experience with the Vietnamese Buddhist community I have worked so much with over my life, I must give, at the very least, a background on Buddhism, its tradition and theories. Looking at how Buddhism spread throughout the world, into Vietnam and eventually to the United States. This is by no means an exhaustive history, and I would encourage readers more interested in this background to refer to my referenced sources.

\section{Buddhist History}

Buddhism has a long and complex history, dating back 2500 years and originating in India. The word Buddha is a Sanskrit/Pali 6 word and translates into "to awaken" or "to open up". The term actually is very ancient in the Sanskrit language and was originally used to describe a flower opening. The historical figure we know today to be the Buddha was actually a man born in the northeastern part of India, or what is known today as Nepal. The word Buddha was known during this time in India as an individual who is "awakened" or enlightened. Over time, especially for those of us in the West, we often now associate the word Buddha to mean the historical founder of the Buddhist religion. The man himself was known as Siddhārtha Guatama from the Shakya Clan, and this historical figure is often referred to as Sākyamuni Buddha (enlightened one from the Śākya Clan) $[9,10]$.

Guatama Buddha was born around 5th to 6th century B.C.E. and was originally a prince in the Sākya clan, until deciding later in his life to give up his princely duties and become an ascetic seeking spiritual enlightenment. Through his spiritual discipline, he was working towards finding a way to the elimination of suffering and to end the repeated cycle of birth and death, known as Samsāra. After many years of asceticism and Vipassana meditation practice (insight meditation [11]), Guatama eventually obtained the spiritual enlightenment he sought and became whom we now know as the Buddha ([9], pp. 7-8).

After his enlightenment, the Buddha traveled around the region teaching on his enlightenment and how he came to this point in his life. During his religious training, he attained many discoveries and would expound on them to people who would listen and follow him. The foundation of his teachings consisted of what is known as The Four Noble Truths and The Noble Eightfold Path. These were to become the ethical and moral ideas that guide all Buddhists throughout the world and influence Buddhists in their daily lives. The Four Noble Truths consist of:

1. Life is Suffering (Dukha)

2. he Arising of Dukha

3. The Cessation of Dukha

4. The Path Leading to the Cessation of Dukha ([10], p. 16)

These concepts, as with many things that we attempt to translate into English, become difficult for a lot of Westerners to comprehend. The first Nobel Truth, life is suffering, or Dukha, does not, from some scholar's account, literally mean that we are in a constant state of suffering. What some have translated it now to mean is more of this idea of dis-ease, that life is difficult and that we are quite often struggling. Walpola Rahula expands on this,

(Dukkha) includes deeper ideas such as "imperfection", "impermanence", "emptiness", "insubstantiality". It is difficult therefore to find one word to embrace the conception of the term dukkha as the First Noble Truth. It is better to leave Dukha untranslated, than to give an inadequate and wrong idea of it be conveniently translating it as "suffering" or "pain" ([10], p. 17).

6 Sanskrit and Pali are both languages used in ancient Buddhist texts. Sanskrit is often related to the Mahāyāna school of Buddhism, and Pali is related to the Theravada school. I will mainly be using Sanskrit and Vietnamese, though in some cases Pali will be used in referenced sources. 
The Second Nobel Truth, the arising of Dukha, the Buddha believed is often created within ourselves, through our attachments and desires. With the Third Nobel Truth the Buddha believed that there was a way to reduce the amount of Dukha in our lives. This leads us to the Fourth Nobel Truth, the path leading to the cessation of Dukha, or what the Buddha called the Nobel Eightfold Path ${ }^{7}$ ([12]):

1. Skillful Understanding

2. Skillful Thinking

3. Skillful Speech

4. Skillful Action

5. Skillful Livelihood

6. Skillful Effort

7. Skillful Mindfulness 8

8. Skillful Concentration [12]

Along with these Noble Truths and Eightfold Path, the Buddha also taught what is called the Five Precepts. After a student had listened to the Buddha's teachings and decided that he or she wanted to become a follower of the Buddha, they would take what is called "refuge". This refuge means that a person would dedicate his or her life to these teachings and agree to observe a moral and ethical code known as the Five Precepts. These Precepts were:

1. One shall not kill

2. One shall not steal

3. One shall not engage in false speech

4. One shall not engage in sexual misconduct

5. One shall not take in any intoxicants ([10], p. 80)

The Buddha believed that if one followed these moral and ethical guidelines, a person would greatly reduce the amount of suffering or Dukha in his or her life. As Rahula notes, "Practically the whole teaching of the Buddha, to which he devoted himself during 45 years, deals in some way or other with this Path" ([10], p. 45). These Four Noble Truths, Eightfold Path and Five Precepts have been the guiding principles for all Buddhist schools and traditions and have been handed down from the Buddha himself through subsequent generations.

Buddhist followers and adherents divided into different groups. A monastic tradition formed after the Buddha started teaching and those who wanted to devote themselves to this Path full time become Buddhist monks (Bhikșu) and nuns (Bhikșuñi) ([14], p. 115). This community of monks and nuns become known as the Sangha, and this is what Sangha initially meant, a community of just monks and nuns ([14], p. 768). Over the years, this term Sangha has evolved to mean an overall Buddhist community (though some traditions still recognize the Sangha as meaning just a group of monks or nuns). For the monastics, there were additional rules that one was to follow, but for the lay individual, he or she only needed to observe the Five Precepts and attempt to follow the Eightfold Path as closely as possible [15]. The monastic order was an important component in maintaining and spreading the teachings of the Buddha, and quickly become the leadership that formed for lay individuals to follow. This is really important to note, since this Buddhist leadership through the monastic training was

7 The Eightfold Path is often mistranslated as “Right” (ex. Right Understanding, Right Thinking, etc.). I prefer Bhante Henepola Gunaratana's translation of The Eightfold Path where he uses "Skillful" as opposed to "Right". Therefore eliminating the binary of "right" and "wrong" which can be antithetical to Buddhist practice.

8 From a clinical social work perspective, the very act of mindfulness and concentration has shown to have significant impact on people who are experiencing a breadth of mental health issues, ranging from anxiety and depression to posttraumatic stress disorder. Mindfulness practices (becoming ubiquitous in our Western lexicon) have also shown to have significant benefits in the application of pain management. All of this being the more "secular" notion of Buddhist practice, mindfulness, without including the other moral and ethical codes that the Buddha originally taught ([13], pp. 187-200). 
instrumental in maintaining the doctrine and ideas that were carried down through the generations and the monastics serve an essential role for Buddhist communities [16].

\section{Mahāyāna, Theravada and Buddhist Diaspora}

As with any religion there are fragmentations and schisms, and Buddhism was not immune to these divisions. Around 100 B.C.E. Buddhism divided into two main schools, Mahāyāna, which means great or large vehicle and, Hīnayāna, which means lesser vehicle. The terms themselves were used to describe the type of practice. Mahāyāna Buddhists believed in what were called the later teachings of the Buddha, while Hinnayāna Buddhists believed in what were the original teachings of the Buddha ([9] pp. 82-86). Both were working towards this notion of enlightenment, but Mahāyāna Buddhists became increasingly concerned about the suffering of others, and the need to help reduce or eliminate Dukha in all living beings. Mahāyāna Buddhists began to work towards this notion of the Bodhisattva ideal ${ }^{9}$ ([1], p. 87). A Bodhisattva is an individual who attains enlightenment, i.e., ends the cycle Samsāra for himself or herself, but continues to stay in this life to help others end their suffering ([14], p. 134). For the Hinnayāna Buddhist, the main goal was to obtain enlightenment and end the cycle of birth and death. Both traditions continued to put a heavy emphasis on compassion (Karuña) and non-violence (Ahimsā), but Mahāyāna Buddhists felt that it was a moral obligation to actively help end the suffering of others (hence the term great vehicle, a vehicle that can carry more than one person, and small vehicle, a vehicle for only one person). Over time, the term Hīnayāna became perceived as derogatory, meaning lesser than, so the term Theravada formed, which means School of the Elders. Eventually those in the Theravada tradition only recognized and observed the original teachings of the Buddha and did not recognize the later teachings of the Buddha, as the Mahāyāna Buddhists did ([9], p. 98).

Through this process of shifting and changing, Buddhism began to spread outward into the Asian world. The Theravada tradition moved south through India and easterly, moving into Sri Lanka, Burma (modern day Myanmar), Thailand, Laos and Cambodia. Mahāyāna Buddhism moved north and easterly into Tibet, Nepal, China, Korea, Japan and Vietnam ([1], pp. 6-7). Through this movement a synchronistic process happened where Buddhism would integrate the cultural norms and values, while still maintaining the foundation of the Buddhist teaching (Four Noble Truths, Eightfold Path, etc.). The monastic order helped to maintain the structure, while integrating traditional rituals and practices from each culture that Buddhism spread to. Given these two main schools of Buddhism, with the influence of each culture and tradition, we began to see a plethora of Buddhist traditions emerge (i.e., Chan, Zen, Pure Land). Each tradition became a unique form of Buddhism, fusing indigenous cultural values and practices, while maintaining the foundational teaching. Often, Buddhist monastics would become the cultural brokers, teaching on the Buddhist doctrine as it has been passed down, and integrating the local cultural customs and beliefs. We see this role continue even today, as we will reflect later in this paper, with Vietnamese Buddhist monks and nuns in this country ([9], pp. 117-20).

\section{Engaged Buddhism}

As noted, Buddhism has evolved over the past 2500 years based on the traditions, cultures and identities of those practicing it. The idea of "Engaged Buddhism" much like "social justice" is, in a lot of ways, a very Western concept ([1], p. 112). For Buddhists, especially Mahāyāna Buddhists, all Buddhism is an engagement, "in contemporary Asia (Buddhism) means energetic engagement with social and political issues and crises at least as much as it means monastic or meditative withdrawal" ([17], p. ix). The Mahāyāna Buddhists emphasis on the Bodhisattva ideal is an engagement with others with the intent of reducing suffering, or Dukha. A strong component of Buddhism, however, is based on this

9 In addition to the Five Precepts, some Buddhists in the Mahāyāna traditions would take additional precepts, such as Bodhisattva vows ([1], p. 87). 
notion of enlightenment, which is a solitary process. The foundation of Buddhist practice is meditation. Many in the Mahāyāna tradition believe that before one can even begin to help others, or reduce the amount of Dukha in the world, one has to become enlightened him/herself, which could take numerous lifetimes. This process of meditation can often be perceived as very solipsistic and detached from others. As Kraft notes, "Buddhism has been seen as passive, otherworldly, or escapist" ([18], p. 65).

It was the Vietnamese Buddhist monk, Thích Nhât Hạnh, who first coined the term, "Engaged Buddhism" and "introduced its implications to the West" ([17], p. 2). For Thích Nhãt Hạnh, Engaged Buddhism was a way to counter the notion that Buddhism was very passive and focused on self-enlightenment. Engaged Buddhism was a manifestation of the moral and ethical guidelines handed down from the Buddhist tradition, in direct response to the suffering caused by war. Having endured the French Indochina War as a young monk, Thích Nhât Hạnh continued to see his country divided by struggle, ultimately leading to the U.S. becoming involved in the civil strife. In the 1960s, as the conflict escalated and people were dying, Thích Nhât Hạnh believed that Buddhists did not have the luxury of helping others only after becoming a Bodhisattva, Buddhists must deal with suffering directly as it was occurring. Because of this, Thích Nhât Hạnh formed the School of Youth for Social Services in, "1964, which trained social workers to rebuild bombed villages" ([19], p. 357). This was Thích Nhât Hạnh's way of fusing Buddhist ideas (especially the moral and ethical codes) with social work and community work. This School of Youth for Social Services trained monks, nuns and lay people to be community and social workers and to "relieve the suffering caused by the war and to extend their work to all Vietnamese people regardless of political orientation" ([20], p. 38). These engaged Buddhists also helped to "rebuild bombed villages, teach children, set up medical stations, and organize agricultural cooperatives" ([21], p. vii).

We also need to be aware of the Engaged Buddhist social movement among Theravada Buddhist traditions. Often, we will equate Engaged Buddhism with the Vietnamese Buddhist monk, Thích Nhãt Hạnh, and Mahāyāna Buddhism, with its emphasis on the Bodhisattva ideal of reducing suffering among all living beings. Socially Engaged Buddhism was a "struggle of Third World Buddhists" ([22], p. 26). Engaged Buddhist ideas have a long and rich history in other Southeast Asian countries, and are not specifically led by monastics. Aung San Suu Kyi has led a struggle in Burma (Myanmar) for democracy and freedom for over thirty years, using Buddhist principles as her guide and eventually winning the Nobel Peace Prize in 1991 for her non-violent leadership [23].

Maha Ghosananda was a Cambodian Buddhist monk and often referred to as the Gandhi of Cambodia. Maha Ghosananda worked tirelessly in Cambodian refugee camps in Thailand in the late 1970s and 1980s, helping Cambodians attempting to escape from the brutal Khmer Rouge. Maha Ghosananda would travel "though the refugee camps, where Cambodians were physically starving and spiritually demoralized, and he constructed makeshift Wats and chanted the Buddha's Dhamma" ([24], p. 115). After the fall of the Khmer Rouge, Maha Ghosananda traveled back to Cambodia to help rebuild Buddhist temples and "led the movement to educate the monks and nuns in the skills of nonviolence and the monitoring of human rights" ([25], p. 20).

Bhikkhu Buddhadāsa was a Thai monk who advocated reform in the Thai Theravada Buddhist tradition. He worked towards removing the more superstitious elements of the Thai Buddhist tradition and attempted to bring the practice back to the basic principles that were first taught by the Buddha. Bhikkhu Buddhadāsa also wanted to reinforce the compassionate nature of Buddhist practice, writing an essay titled, Democratic Socialism where he equated Buddhism to social work and notes, "Social services is for the benefit of all humanity in the most basic sense: to overcome $d u k k h a$ or suffering...All true social work serves this ideal" ([26], p. 167).

These are just brief examples of Engaged Buddhists throughout Southeast Asia. As we reflect on the Engaged Buddhist practice of Vietnamese immigrant and refugees, especially as they migrate to the U.S., we should not forget that Engaged Buddhism is a Buddhist practice and is not unique to just Mahāyāna Buddhism. As Rick Fields noted about the struggles with the war in Vietnam, 
"Vietnam...became the only Asian country where Theravadins and Mahayanists worked in active collaboration" ([19], p. 354).

Though Thích Nhât Hạnh coined the term, Engaged Buddhism, and began the social services community that provided aid to those who were suffering from war, the ideas that influenced him to start this movement were already deeply rooted. It began with the Buddha's teachings of The Four Noble Truths, The Eightfold Path and The Five Precepts. It was expounded on and evolved through the Mahāyāna tradition of the Bodhisattva, a being whose purpose is to help alleviate suffering in the world, and is what all Mahāyāna Buddhists strive to become. It began with the notion of community, or Sangha, that was so essential in the Buddhist traditions and influence how Buddhist communities come together and practice. All of these were in place long before Thích Nhât Hạnh coined the term Engaged Buddhism. These ideas were in the cultural DNA of Vietnamese Buddhists. But as Jones notes, "Socially engaged Buddhism developed as a 'radical conservatism' out of the struggle of Third World Buddhists to develop a synthesis combining the best in their traditional cultures with the best of modernity" ([22], p. 26). This would be essential for Vietnamese Buddhists as they migrated to the United States and attempted to maintain their own cultural values and norms while becoming a part of modernity in the United States ${ }^{10}$.

\section{Vietnamese Migration to America and Acculturation versus Assimilation}

The Vietnamese War ended in 1975 resulting in the death of 1.1 million Vietnamese [27]. This does not include the suffering inflicted upon Vietnamese who worked with the Americans during the war, remaining in Vietnam and enduring persecution after the United State withdrew. According to Taylor:

Many Second Republic officials were killed and hundreds of people were sent to concentration camps, ostensibly to re-educate them to live in a socialist society. A system of registering the population was instituted to ensure that those whose families had supported the Second Republic were penalized by denial of employment, education, and food rations ([28], p. 614).

After the Vietnam War, countless Vietnamese started fleeing their country, with many coming to the U.S., leading to one of the largest mass migrations to this country in history ([29], p. 351).

As Hien Duc Do notes, "the American public's general attitude toward Vietnamese refugees at the end of the war (1975) were hostility" ([30], p. 81). As he continues, "A May 1975 Gallup Pole showed '54 percent of all Americans opposed to admitting Vietnamese refugees to live in the United States.'” Cited as, "One common concern was economic self-interest-a fear of having jobs taken away and needing to provide public assistance and welfare to the refugees" ([30], p. 81). For anyone who is keeping up with our current U.S. political discourse, these are the same "common concerns" echoed today, as well as potential terrorist activities, in wanting to refuse refugees fleeing war to come here.

By 1975, as Vietnamese started migrating to the U.S., the country was on the heels of social upheaval. Individuals in The Civil Rights movement had fought vigorously for equality, and the elimination of the Jim Crow and segregation laws were beginning to erode the apartheid system that had dominated the culture of the Southern U.S. Given all of this, the country was far from the equality and racial justice that many had struggled and died for. Laws had changed, however, and Vietnamese refugees were coming to this country during a time when legal structures were more supportive:

Before 1960, the National Origins system severely restricted immigration of Asians to America. The 1965 Immigration and Nationalities Act under President Johnson, with its new preference and quota system, allowed more Asians to be accepted into

10 In the mid-1960s, Thích Nhãt Hanh started touring globally, speaking of the suffering of the Vietnamese and calling for the end of the war. It was during this time he was "exiled" by the Vietnamese government. He eventually moved to France and started a monastery and helped Vietnamese refugees there ([17], pp. 323-34). 
the U.S. The American Civil Rights Movement (1955-1968) abolished much outright racial discrimination. The Vietnamese were lucky to arrive in the wake of these historical developments ([29], p. 353).

Starting in 1975, 130,000 Vietnamese began coming to the U.S., in the beginning these were mostly well-educated professionals. By the late 1970s and early 1980s, 500,000 “boat people" started arriving. These numbers only increased with time; by 2000, there were 1,122,528 Vietnamese in the United States, and by 2011 1,737,433 (0.5\% of the US population and a 38\% increase from 2000 to 2010) ([29], p. 349).

Many of these refugees struggled with their adjustment to their new country. Historically, newly arriving immigrant and refugee groups attempt to acculturate to a new way of life, hoping to maintain aspects of their indigenous customs while adopting the norms and values of the dominant culture. For those in the dominant culture, however, acculturation is not important. The dominant cultures expectation for many arriving to the U.S. is that groups are expected to assimilate.

Hien Duc Do notes with the Vietnamese immigration experience,

To minimize the social impact of this large influx of Vietnamese refugees, the U.S. government adopted a refugee dispersion policy that had four purposes: (1) to relocate refugees as quickly as possible so that they could achieve financial independence; (2) to ease the economic impact of a large influx of refugees on any given community; (3) to make it easier to find sponsors; and (4) to prevent the development of an ethnic ghetto. Given the U.S. political and social climate at the time, the factors leading to this policy were primarily political and financial, not social. The policy sought to encourage Vietnamese refugees to assimilate quickly into American society by finding work as soon as possible after leaving refugee camps ([30], p. 82).

There are, of course, very problematic aspects about this US government policy. But I want to draw your attention to two main points that speak volumes to the challenges that Vietnamese faced when coming to the country, the first being the "social climate" in this country after the end of the Vietnam War. The U.S. government created a policy that focused more on the overall climate of Americans' perceptions of Vietnamese refugees coming to this country, than they did about a group of traumatized people who were escaping for their lives. The trauma of Vietnamese refugees was not a consideration of the U.S. government.

The second issue is based on American's perception and pressure. Because of this the U.S. policy on Vietnamese refugee resettlement was based on, as noted, "the primarily political and financial, not social." That means that no consideration for the social and cultural identity was part of the U.S. policy in transitioning Vietnamese refugees to this county. As the quote above states, the U.S. policy was based on "assimilating" Vietnamese refugees to this country as quickly as possible. In other words, the U.S. Policy with regard to Vietnamese refugees, was not integration (i.e., "we will help you to integrate to our country and help you maintain your cultural identity.") The U.S. government wanted to assimilate Vietnamese refugees as quickly as possible. This left Vietnamese themselves to try and maintain as much of their cultural identity as they could.

\section{Chùa An Lạc and a Vietnamese Buddhist Community: A Critical Ethnographic Reflection}

I met Thích Thiện Quãng at the Vietnamese Buddhist temple, Chùa Quan Âm, in Greensboro, NC in 1998. At the time there were only two Buddhist temples in Guilford County serving immigrant and refugee populations ${ }^{11}$. The Greensboro Wat (Wat is Thai for temple or Pagoda) is a temple that has been around since the 1980s and primarily serves the Thai, Cambodian and Laotian communities

11 As of writing this paper, there are now seven Buddhist temples in Guilford County. The original, Wat Greensboro, serving Thai, Cambodian and Laotian communities. Three Vietnamese Buddhist temples, Two Laotian Buddhist Temples and a Burmese Buddhist temple. All serving Southeast Asian immigrant and refugee communities. 
(all who observe Theravada Buddhism). Chùa Quan Âm is a Vietnamese Buddhist temple serving the growing Vietnamese Buddhist population in the area and follows the Mahāyāna school of Buddhism. Thích Thiện Quãng was a quiet and unassuming monk who spoke little English, but was always welcoming and tried very hard to communicate to me as much as he could. He had just taken on a novice monk, Thường Lực, who was around twenty-three at the time and had come to this country at nineteen. Thường Lực's father had been one of the Vietnamese "boat people" who escaped Vietnam and spent time in a refugee camp in the Philippines before eventually relocating to the U.S. and bringing the rest of his family over.

I started spending time with Thích Thiện Quãng, Thường Lực and the members of Chùa Quan Âm, doing photo documentary work and trying to learn as much as I could about the community and Vietnamese Buddhism. The Vietnamese population continued to increase and in late 1999, Thích Thiện Quãng decided to branch out and start another Vietnamese Buddhist temple in the more rural area of High Point, a city right next to Greensboro. High Point is an old furniture factory town, and there were a number of Vietnamese migrating there to take advantage of the factory jobs. Followed by his novice monk, Thường Lực, they both moved into a small, two-bedroom apartment in a low-rent housing complex. These were interesting times, as several of us would meet in the tiny living room of this two-bedroom apartment to discuss the growth of the potentially new temple, and engage in the ceremonial Buddhist practices.

While living in the apartment, Thích Thiện Quãng and Thường Lực, along with a handful of Vietnamese followers, began searching for a suitable house to start the new temple. This is often how Vietnamese Buddhist temples initially form, especially in more rural areas where the community is lacking the resources to buy a building to convert into a temple. In these situations the community would just purchase a house. Purchasing a house was also a logistic consideration, since most monks or nuns actually lived in the Buddhist temple, so having a residential dwelling also served the needs of the monastics. In many cases, the community without a monk or nun present would purchase a house, convert into a temple and then the community would start searching for an ordained monk or nun to move in and become the head monastic. This was the developing of a Buddhist community that many Vietnamese engaged in during the earlier years of migration. This was the community forming the Sangha that was so essential in Buddhist practice.

After looking at several houses, the community, under the guidance of Thích Thiện Quãng, finally found a suitable, two-bedroom house, which had about an acre of land. The community pooled their resources and was able to make a down payment on the house. On January of 2000, Thích Thiện Quãng and his novice monk, Thường Lực moved into this house and began forming the Buddhist temple, Chùa An Lạc. It was also at this time that I started spending more time at Chùa An Lạc, helping the community convert this house into a viable Buddhist temple and learning more about the community and tradition. This was an amazing experience, and I really began to see first-hand the community building aspect of Vietnamese Buddhists, especially under the guidance of a Buddhist monk and his novice pupil.

Two very important Buddhist festivals were rapidly approaching, Têt Nguyên Đán (or simply knows as, Tết, Vietnamese New Year) and Phật Đản (Buddha's Birthday). The community was assiduously working to prepare the temple for these first two festivals. Têt was to fall on Feb. 6 of 2000 , so this did not give the community members much time to prepare. But the burgeoning community came together and managed to get the temple established enough for the important Vietnamese holiday. In the synchronistic fashion of Buddhist tradition, there becomes this fusion of the indigenous cultural heritage of the New Year's celebration, while simultaneously also becoming a Buddhist tradition and religious festival. Têt Nguyên Đán was now a cultural festival and a Buddhist holiday. On this cold evening in February many Vietnamese (Buddhists and non-Buddhists) crammed into this tiny, two-bedroom house to celebrate Chùa An Lạc's first Vietnamese festival.

The next big festival occurred in the spring of 2000. This was Buddha's birthday, or Phật Đản, a traditional Buddhist holiday. Once again, the temple community had to come together and prepare 
for a big cultural and religious event, while still establishing themselves as a viable Buddhist temple. What was truly amazing about these festivals was how these events mobilized the Vietnamese Buddhist community. Having to live in a dominant culture that is not Buddhist, and then having to live in a region of the country that is considered the "bible belt" (Southeast region of the U.S. this is heavily Christian and politically conservative, also not known for being open to other beliefs and faiths), it was difficult for Vietnamese Buddhists to express their religious beliefs openly. Chùa An Lac was forming into more than just a Buddhist temple; it was becoming a cultural and community center. With the monks living there, people were stopping by on a regular basis. People would come in during lunch to eat with the monks. Families would come by in the evening to bring dinner for the monks ${ }^{12}$. People would come by after work so they could do things around the house itself to help make it look more like a Buddhist temple on the inside. The community was developing into an actual Sangha, with the monks once again taking on the role of cultural brokers, much as monks have been doing for the past two thousand years. The temple became a "refuge" for Vietnamese Buddhists to help maintain their cultural identity, while acculturating to the broader American culture.

In the summer of 2000, I decided to travel to Long Beach, CA and visit the Dharma Brother of Thích Thiện Quãng, Thích Thiện Long. They both had studied at the same monastery in Vietnam before migrating to the U.S. Thích Thiện Long was the head monk of a Buddhist temple in CA, Chùa Phật Tổ. I traveled to this temple because I wanted to deepen my own practice in Buddhism, while learning about a Vietnamese Buddhist community that had become more established. The Vietnamese population in California was bigger than the rural community of High Point, NC, and Vietnamese in Long Beach were able to create their own pockets of communities around multiple temples that generally collaborated on events and provided for the Vietnamese community. It also became a valuable learning experience for me in connecting with Vietnamese Buddhists, and helped give me ideas to bring back to Chùa An Lạc when I returned a month later and become an AmeriCorps ACCESS member, working full time at Chùa An Lạc for the next year.

The subsequent years after 2000 showed growth with Chùa An Lac. Under the leadership of Thích Thiện Quãng, the temple's main mission was to focus on sustainability and viability, not growing too rapidly. Thích Thiện Quãng was always cognizant of the economic status of most of the temple's working class members, and never wanted to push members to take on more than they could financially. Tithing is antithetical to Buddhist tradition and most Buddhist communities and temples sustain themselves based on the generosity of temple members (Dāna). Giving to a temple helps to generate merit, which can lead to a favorable rebirth. Merit giving can come in the form of money, food, or labor. Most temple members would often come to the temple and do work as a form of Dāna, which literally led to the physical growth of the temple itself.

A couple of years after founding Chùa An Lạc, Thường Lực became a fully ordained monk and was now known as Thích Thường Lực. With both monks fully ordained, the temple was increasing in its leadership, with Thích Thường Lực taking on more managerial responsibilities as Thích Thiện Quãng, getting older, assumed more teaching responsibilities. Eventually, Thích Thiện Quãng appointed Thích Thường Lực as the head monk of the temple, passing on the leadership to his young student. Under the leadership of the new head monk of Chùa An Lạc, Thích Thường Lực, the temple members embarked on an expansion project with the house, doubling the size of the actual dwelling and creating a larger main hall that could hold the growing number of Vietnamese that started coming for regular Sunday services. A Vietnamese youth group, GĐPT Thiện Tài $[31]^{13}$, also migrated to the temple, especially

12 Another important component of Buddhism is this idea of Dāna. Dāna is this idea of "giving" or "charity" and helps generate merit for those who engage in it. This notion of giving is a guiding principle of Buddhists ([14], pp. 211-12).

13 GĐPT is a Vietnamese youth group, structured similarly to the Scouts here in the U.S. GĐPT is an abbreviation for, Gia Đình Phật Tử, which is literally translated as, group of Buddhists like a family, but generally means, Buddhist youth. Thiện Tài is the Vietnamese translation of Sudhana; a boy profiled in one of the Mahāyāna text, The Avatamsaka Sutra (Flower Ornament Scripture) and whose name means, "Great Wealth" ([31], p. 1173). The Gia Đình Phật Tử youth group mainly refers to themselves as GĐPT and much like Buddhist temples (ex. Chùa An Lạc, Chùa Phật Tổ), each GĐPT group will 
with the increasing size of the space. GĐPT Thiện Tài was a Vietnamese youth group that specifically worked with young Vietnamese (mostly school aged kids) to help them maintain their cultural identity and language. Both Thích Thiện Quãng and Thích Thường Lực were very supportive of the GĐPT Thiện Tài, and made sure they were an integral part of Chùa An Lạc's community.

Several years after purchasing the house, Chùa An Lac's community took advantage of the next-door neighbor putting their house up for sale. Although this temple had two established Buddhist monks, there were no nuns who were part of this community. The lack of female monastic leadership, such as nuns, created complications for doing community work, since there were cultural and religious considerations with monks accompanying women to medical appointments. The monks, especially the bi-lingual Thích Thường Lực, would often accompany lay individuals to various appointments to help interpret during interviews. Many newly arriving Vietnamese needed someone to interpret for medical appointments, social service visits, and other situations, which required someone who could understand both English and Vietnamese really well. The lack of female monastics led to a great void in the needs of women, since they would often feel uncomfortable with a monk interpreting with sensitive medical issues.

When I was staying at Chùa Phật Tổ in Long Beach, CA (a community with a considerably larger Vietnamese Buddhist population) there were nuns living at the temple and available for the community to access. It was not uncommon to see older Vietnamese women; many trained as nurses, retired and had decided to leave the family life to pursue ordination as a Bhikṣuni. These women would then dedicate their monastic lives continuing to serve the community as nurses. With the purchasing of the house next door by Chùa An Lac, women were able to move into that house and the monks could begin to train women who were interested in becoming Buddhist nuns. Up to this point there had been women in this area who were interested in monastic training, but would often have to move to other parts of the country where there were larger Vietnamese Buddhist communities and opportunities for women to train as Bhikșuñ. With the addition of this house, women where were interested could now train as nuns at Chùa An Lac.

\section{Conclusions}

Sixteen years has passed since the founding of Chùa An Lac. Kids have become adults, who now have kids of their own, who are growing up in the temple and attempting to maintain a cultural identity. Some communities now consist of second and third generation Vietnamese, born in the United States and growing up as Vietnamese Americans. They delicately attempt to straddle two very distinct cultural identities. I spent time with some of these young people and will often view them as typical American kids. Then I see them interact with their parents, grandparents or older temple members and this metamorphosis happens where they become traditionally Vietnamese. These younger people are able to navigate their cultural identities a lot easier than the first and second generations of Vietnamese who came to this country.

Because of political changes in Vietnam, and the reduction of persecution, Vietnamese now coming to the U.S. are considered immigrants not refugees. Whereas refugees migrate to another country because "they were persecuted or fear persecution due to race, religion, nationality, political opinion, or membership in a particular social group" [32], immigrants migrate for other reasons and are not recognized as having to flee their home country by the U.S. Government. Refugees are permanent residents, but immigrants initially do not have permanent statues and have a finite amount of time to work on obtaining citizenship or they will have to return to their home country. Vietnamese who are now immigrating to the U.S. struggle with the U.S Citizenship and Immigration Service

take on a Buddhist name to signify each group. The Avatamsaka Sutra goes into great detail about the auspiciousness of Thiện Tài's (Sudhana) birth and is therefore why his names means, metaphorically, "Great Wealth." In taking on the name of Thiện Tài, this GĐPT group is both honoring this Buddhist figure and wishing for great fortune for the youth as they grow. 
(USCIS), knowing they do not have the same privileges as refugees, and are working with a timeframe on becoming a U.S. citizen. They struggle with the language and cultural norms and will often find the temple a great source of refuge, where they can converse openly in their primary language and discuss their religious beliefs without being proselytized to by Americans who know nothing of the Buddhist religion or Vietnamese culture.

I have continued to maintain a connection with this temple and community over the years. Often cycling in and out depending on jobs and educational programs that $I$ had to attend to as part of my own personal life. Over these years I have brought many friends, acquaintances, and, at different times, classes to Chùa An Lạc. Thích Thường Lực is very engaging and does a wonderful job educating others on the community building aspect of the temple and how it serves as a cultural center. I often chide him for being a "social worker" monk, which he takes in his stride. The temple continues to hold regular festivals each year, which takes an enormous amount of time, planning and energy. For each festival (generally four each year) the temple members put up several huge, heavy-duty event tents.

Thích Thường Lực and I have talked about the amount of work that goes into these events and he is very reflective on it. Thích Thường Lực notes that he could always garner the resources to build a big building or other kind of structure that would alleviate all the work that goes into preparing for the festivals (often attracting 400 to 500 attendees for each event). But he attributes a lot of the success of the temple to the fact that it requires people to come together to prepare for these huge events. It is one thing for people to show up to a building, watch an event, eat then leave; but having to come together as a community, set up everything for the event, prepare food and serve it to guests, then clean up and take things down afterwards requires enormous planning and time-consuming execution. Regardless of conflicts and differences, everyone works together to make sure each festival is successful. This type of community building cannot be coordinated by chance; it requires the dedication of all community members coming together to make it work. It is what creates a true Sanigha, and Thích Thường Lực, much like his predecessors from the past two thousand years of Buddhist diaspora, has become the cultural broker of this Vietnamese Buddhist community.

Conflicts of Interest: The author declares no conflict of interest.

\section{References}

1. Peter Harvey. An Introduction to Buddhist Ethics. Cambridge: Oxford Press, 2000.

2. Ernest T. Stringer. Action Research, 4th ed. Los Angles: Sage Publishing, 2014.

3. D. Soyini Madison. Critical Ethnography: Methods, Ethics, and Performance, 2nd ed. Los Angles: Sage Publishing, 2012.

4. Stacy Holman Jones. "Autoethnography: Making the Personal Political." In The Sage Handbook of Qualitative Research, 3rd ed. Edited by Norman K. Denzin and Yvonna S. Lincoln. Thousand Oaks: Sage Publishing, 2005, pp. 763-820.

5. The Center for New North Carolinians. Available online: https://cnnc.uncg.edu/ (accessed on 13 March 2016).

6. Raleigh Bailey. "New Immigrant Communities in the North Carolina Piedmont Triad: Integration Issues and Challenges." In Beyond the Gateway: Immigrants in a Changing America (Program in Migration and Refugee Studies). Edited by Elzbieta M. Gozdziak and Susan F. Martin. Lanham: Lexington Books, 2005, pp. 57-86.

7. AmeriCorps ACCESS Project. Available online: https://cnnc.uncg.edu/americorps-access-project/ (accessed on 13 March 2016).

8. Lynne Healy. International Social Work: Professional Action in an Interdependent World, 2nd ed. New York: Oxford Press, 2008.

9. Richard H. Robinson, and Willard L. Johnson. The Buddhist Religion: A Historical Introduction, 4th ed. Belmont: Wadsworth Publishing, 1997.

10. Walpola Rahula. What the Buddha Taught. New York: Grove Press, 1974.

11. S. N. Goenka. Satipațthāna Sutta Discourses. Seattle: Vipassana Research Institute, 1998.

12. Bhante Henepola Gunaratana. Eight Mindfulness Steps to Happiness. Boston: Wisdom Publication, 2001. 
13. John Briere, and Catherine Scott. Principles of Trauma Therapy: A Guide to Symptoms, Evaluation and, Treatment, 2nd ed. Los Angles: Sage Publishers, 2013, pp. 187-200.

14. Robert E. Buswell, Jr., and Donald S. Lopez, Jr. The Princeton Dictionary of Buddhism. Princeton: Princeton Press, 2014.

15. Charles S. Prebish. Buddhist Monastic Discipline: The Sanskrit Prātimokșa Sūtras of the Mahāsāmghikas and Mūlasarvāstivādins. Delhi: Motilal Banarsidass Publishers, 1996.

16. Walpola Rahula. The Heritage of the Bhikkhu. New York: Grove Press, 1974.

17. Christopher S. Queen, and Sallie B. King, eds. Engaged Buddhism: Buddhist Liberation Movements in Asia. New York: SUNY Press, 1996.

18. Kenneth Kraft. "Engaged Buddhism." In Engaged Buddhist Reader. Edited by Arnold Kotler. Berkeley: Parallax Press, 1996, pp. 64-69.

19. Rick Fields. How the Swans Came to the Lake: A Narrative History of Buddhism in America. Boston: Shambhala, 1992.

20. Patricia Hunt-Perry, and Lyn Fine. "All Buddhism is Engaged: Thich Nhat Hanh and the Order of Interbeing." In Engaged Buddhism in the West. Edited by Christopher S. Queen. Boston: Wisdom Publication, 2000, pp. $35-66$.

21. Thích Nhãt Hạnh. The Miracle of Mindfulness: An Introduction to the Practice of Meditation. Boston: Beacon Press, 1975.

22. Ken Jones. The New Social Face of Buddhism: A Call to Action. Boston: Wisdom Publication, 2003.

23. Aung San Suu Kyi. Freedom from Fear. New York: Penguin Books, 1995.

24. Stephen T. Asma. The Gods Drink Whisky: Stumbling Toward Enlightenment in the Land of the Tattered Buddha. New York: Harper Press, 2005.

25. Maha Ghosananda. Step by Step: Meditations on Wisdom and Compassion. Berkeley: Parallax Press, 1992.

26. Bhikkhu Buddhadāsa. Me and Mine: Selected Essays of Bhikkhu Buddhadāsa. Delhi: Sri Satguru Publications, 1989.

27. Ronald H. Spector. "Vietnam War: 1954-1975." Encyclopedia Britannica. Available online: http://www. britannica.com/event/Vietnam-War (accessed on 13 March 2016).

28. K. W. Taylor. A History of the Vietnamese. Cambridge: Cambridge Press, 2013.

29. Hien V. Ho, and Chat V. Dang. Vietnam History: Stories Retold for a new Generation. Charleston: CreateSpace Press, 2016.

30. Hien Duc Do. "Reproducing Vietnam in America." In A Nation of Religions. Edited by Stephen Prothero. Chapel Hill: University of North Carolina Press, 2006.

31. Thomas Cleary. The Flower Ornament Scripture: A Translation of the Avatamsaka Sutra. Boston: Shambhala Press, 1993.

32. U.S. Citizenship and Immigration Service. "Refugees." Available online: https://www.uscis.gov/ humanitarian/refugees-asylum/refugees (accessed on 13 March 2016).

(C) 2016 by the author; licensee MDPI, Basel, Switzerland. This article is an open access article distributed under the terms and conditions of the Creative Commons Attribution (CC BY) license (http:/ / creativecommons.org/licenses/by/4.0/). 
Article

\title{
Social Work Field Education in and with Congregations and Religiously-Affiliated Organizations in a Christian Context
}

\author{
Helen Harris *, Gaynor Yancey and Dennis Myers \\ Garland School of Social Work, Baylor University, Waco, TX 76706, USA; Gaynor_Yancey@baylor.edu (G.Y.); \\ Dennis_Myers@baylor.edu (D.M.) \\ * Correspondence: Helen_Harris@baylor.edu; Tel.: +1-254-710-4431
}

Academic Editor: Robert Wineburg

Received: 13 March 2016; Accepted: 3 May 2016; Published: 9 May 2016

\begin{abstract}
Recent attention to human spirituality, research on congregationally-related practice, and growth in employment within religiously-based organizations energize the creation of educational initiatives to prepare future professionals for competent social work practice within these settings. Internship experiences with congregations and religiously-affiliated organizations (RAOs) play a pivotal role in delivering the competencies required by the social work accreditation body. Conceptual tools are needed for understanding congregationally-related practice, for navigating potential conflict between faith and professional practice, and for delivering effective internship experiences. This article, written from the faculty's perspective of a Christian, religiously affiliated social work degree program, offers a framework for conceptualizing social work with congregations and RAOs and a beginning discussion for sorting out dilemmas in the integration of faith and practice in these settings. Two models, individual placement and rotational model placement, for congregationally-related internship experiences are presented and evaluated. Recommendations for enriched internship learning and future research are offered.
\end{abstract}

Keywords: social work partnerships; congregations; RAOs; field education; faith and service

\section{Introduction}

The social work profession and social work education are increasingly recognizing the importance of faith, religion and spirituality in our clients and students. The National Association of Social Work Code of Ethics [1] and the Council on Social Work Education Accreditation Standards [2] each include religion as an area of diversity requiring cultural competence for practice. In 2002, the Council on Social Work Education (CSWE) published a case book which focused specifically on decision cases around spirituality and religion in social work practice. Concurrently, the church, which has historically been a foundational institution for responding to human needs, is increasingly acknowledging the importance of professionally trained social workers for delivering effective and efficient human services [3].

Religious traditions and congregations characteristically provide social services to meet the needs of humankind. consistent with the Examples of this involvement include Jewish Social and Community Services, Buddhist Global Relief, Islamic Social Services Association, and others.

This article focuses on the ways that Christian congregations contribute to this religion-based commitment to social provision. Ellor, Netting, and Thibault noted that "Jewish and Christian traditions have dominated the processes which have shaped values and guided social welfare policy in the United States" ([4], p. 15). One distinctive seems to be that social services organizations in faith traditions other than Christianity are more likely to have a secular focus than faith integration ([4], p. 166). The focus of this paper is on the predominantly Christian affiliated 
organizations in the United States that sponsor social service work, recognizing that the same principles can apply in other traditions.

The convergence of interest from the profession and from churches/congregations and religiously-affiliated organizations (RAOs) energizes recent attention to the role, impact, and appropriateness of social workers in this area of practice. Garland [5,6] wrote about the concept of church social work and social workers in congregations. Northern [7] followed with a study of social workers in congregational contexts, previously referred to as churches. Both wrote from a Christian congregation contextual experience. Garland and Yancey [8] document, in their seminal book on congregations as a context for social work practice, the prevalence and the practice of social workers in congregations.

Recognition that social workers are, in fact, practicing in these settings focuses attention on how social work education is preparing professionals for congregationally-related practice. More specifically, it is important for social work educators and practitioners to know how social work internship experiences inform preparation for work with congregations and RAOs. Building on definitions and conceptualization offered by Garland and Yancey [8], we critically examine the possibilities and issues involved in the design and delivery of congregationally-related internships and report findings and implications from an evaluation of a single congregational and a rotational field model of internship placements in congregations and RAOs.

\section{Field Education as Signature Pedagogy}

While the CSWE, the accrediting body for social work education programs, identified field education as the signature pedagogy for the profession, Holden, Barker, Rosenberg, Kuppen, and Ferrell [9] found little evidence in their meta-analysis that field education is uniformly situated at the core of the curriculum. Larrison and Korr [10] stated that the requirement for a signature pedagogy is that it prepares students to both think like and behave like a member of the profession. That suggests that field placement sites would consistently provide a context for the development of professional competencies and demonstrate a pattern of hiring social work graduates.

The signature pedagogy literature relies heavily on work by Lee Shulman in studying signature pedagogy in five professions: medicine, law, nursing, engineering, and clergy [10,11]. Shulman asserted that emotional investment in the field experience, even when it includes anxiety, is necessary to learning. This component is part of what elevates field education to critical importance, at least as significant as classroom education [11].

Copp [12] discussed the importance of field education noting that ministerial students are best prepared for reflective practice though internships, i.e., real life experience. Copp supports the importance of field education in congregations for those students who expect to work in social work roles in the church with some professional identity of minister. Further, some social work programs have added dual degree programs for social work students who specifically prepare for ministry and practice in congregational settings or RAOs as an extension of their faith.

Congregations can provide social workers with competency-friendly contexts regardless of the student's particular career interests. As is the case with other placements, interns participate in an orientation to the mission of the organization and preparation for the social work role and responsibilities in the congregational context. The distinctive of internship preparation in these religiously affiliated settings is that it is specific to the content of the congregation's unique mission and the social work roles in interaction with minister and clergy roles.

\section{Defining and Conceptualizing Social Work with Congregations and RAOs}

For the purposes of this article, we define a congregation as a religious community assembled, in most cases Christian, for the purpose of worship of a deity or deities, study and enactment of religiously prescribed beliefs and practices, and usually having a physical location. The term, church, is also used interchangeably with congregation. Jeavons and Netting [8] view the congregation as a generally 
more inclusive concept while church refers in this article exclusively to Christian-based religious communities. Because the preponderance of research on social work and religious communities is based on Christian institutions, we utilize, from time to time, church in references to Christian congregations. We recognize that these concepts are applicable to field internships in other religiously affiliated entities like Jewish, Buddhist, Muslim, and other affiliated agencies. Further, there is no implied requirement that the student be of the same religious persuasion of the agency in order for social services to be delivered effectively.

Garland and Yancey defined RAOs as those which "identify with a congregation, multiple congregations, a religious order, denomination or some other religious organization" ([13], p. 15). Some are affiliated historically and others "pursue a mission and espouse values described in religious language" ([13], p. 15). Prior to this, in 2011, the Ninth Circuit Court addressed Title XXX issues by defining religious organizations this way:

Although the court did not formulate any clear test, the two tests can be combined to determine what organizational requirements must be met. First, the hypothetical corporation must be organized for a religious purpose, and the purpose must be set forth in the articles of incorporation. Second, the actions of the corporation must be consistent with the religious purpose. Third, the corporation must hold itself out to the public to be a religious organization. Fourth, the corporation must be non-profit. Fifth, the corporation must offer products for free, or for a nominal amount [14].

Garland and Yancey [8] defined congregational social work as providing professional practice "in and through a religious congregation, whether the employer is the congregation itself or a social service or denominational agency working in collaboration with congregations" ([8], p. 1). Figure 1 illustrates the dimensions and variations that encompass the conceptualization of congregational social work.

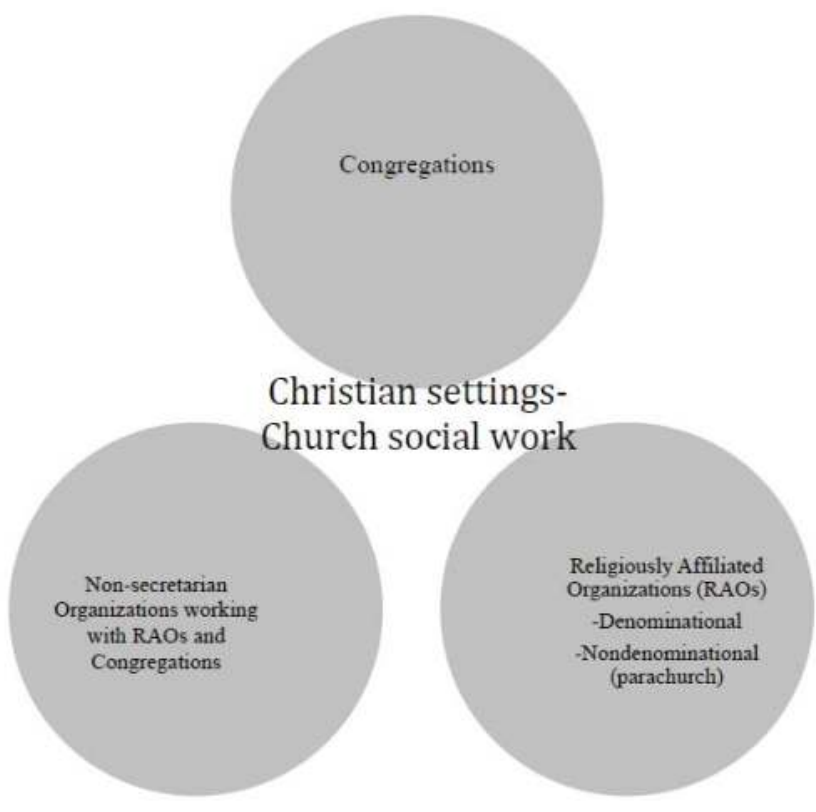

Figure 1. Christian Settings.

As is shown in Figure 1, this arena of practice includes relating to, with, and for congregations, RAOs, and non-sectarian settings. Importantly, these authors suggested that while social workers are able to work in congregations as the specific field of practice, they also are an important part of 
the web of relationships that is possible with other congregations, RAOs, and non-sectarian agencies, including government ([8], p. 17).

\section{Historic and Current Trends}

Much of the literature specific to RAOs and congregational social work is fairly recent. The roots of the profession include significant contributions by persons of faith, congregations and RAOs, all of which have been consistent providers of community services throughout social service history [3]. It should be noted that the involvement of the church as a context for social work practice was historically enacted through affiliations with denominational and adjudicatory agencies and associations. Garland [6] about the historical roots of social services in the church and observed that many, in some cases a third of referrals by workers in social service organizations, were made to the church, specifically for food, clothing, and financial assistance. They recommended that social workers both practice in the church and practice in collaboration with the church to meet the needs of the poor and oppressed. As early as 1930, Johnson detailed the "social work of the churches" in a National Federation of Churches report [15]. This report included the contributions of congregations by type of social service provision, with a strong emphasis on advocacy and social justice.

Beginning with the 1900s, the focus of the profession turned significantly to the scientific method and positivist models, even as the church continued to provide a safety net of social services, often for congregants and sometimes for communities as well [16] These authors recommended that the profession reconnect with those religious roots of the profession and find ways to partner with congregations.

In 1942, the National Conference of Catholic Charities began publishing a series of monographs entitled Certain Aspects of Case Work Practice in Catholic Social Work.

These monographs were focused on casework practice in Catholic social service agencies. This series was followed by the first publications in the early 1960s of congregational social work articles which were located in professional social work literature. The term "parish social work" was used by Martin Ferm [17] as a description of the context of practice for a social worker who is on the staff of a Lutheran congregation. Alice Taggart [18] reflected on her work as a "parish assistant" in a Unitarian congregation in New York.

Moore and Collins [19] wrote specifically about the importance of social work services in African-American churches and recommended that field placements in these settings would provide students with experience with diversity. Larson and Robertson [20] observed the experiences of three baccalaureate social work students placed in faith-based agencies and concluded that programs need to better prepare students for addressing issues of faith and practice. Child welfare services, for example, find a rich history in the work of the church through the development of orphanages, children's homes, and homes for "unwed mothers." Scales [21], for example, described the development of Buckner Orphan's Home in Dallas, Texas, a ministry that now has international outreach and services.

Garland and Yancey completed in-depth interviews with 51 social workers in churches and congregations and concluded that their practice in this setting can best be described as community ministry including activities like "benevolence, emergency assistance, and tutoring activities" ([8], p. 5). In some cases, community ministry involved offering the benevolence and caring ministries historically offered to congregants and to the larger community and neighborhoods. On the other hand, the interview findings from other respondents revealed that community ministry included supporting RAOs, which were sometimes also the ministries of specific Christian denominations.

While there is not much written about congregational social work, there is even less written about field placements in churches or congregational settings. Settings, or contexts of practice, are described, but there is a void in finding discussions about field placements in congregational settings. One exception is the study by Poole, Rife, Pearson, Moore, Reaves, and Moore [22] in which he reported on the Congregational Social Work Education Initiative's (CSWEI) work of seven years in developing a model of interdisciplinary teams including social work students under the supervision 
of congregational nurses and licensed social workers. The authors also acknowledged the importance of field placement opportunities including a rotational model in religiously-affiliated organizations and congregations.

The progressive and sustained attention to the role of social work practice in religious settings attests to the growth of investment in this area [23]. This trend continues today as does the role of religious denominations in providing areas including crisis and disaster response, hospitals and medical care, and family and child services. As we documented, current literature does not emphasize social work or social work field placements in congregations. The relevance of this topic is both about the need for professionals who know how to competently engage the church as a viable contributor to a community's web of services as well as the need for social workers who practice in congregations and religiously affiliated agencies. Further, social workers in RAOs or agencies need to be prepared to consult with congregations and other RAOS and secular non-profits. These settings provide an important context for preparation of social work students.

\section{The Use of RAOs in Field Education in CSWE Programs}

Organizations that participate in social work education by providing internships are also called field placements and are by definition "the settings in which students complete the required agency-based experience for their social work programs" ([24], p. xvii). Berg-Weger and Birkenmaier describe a diversity of settings in which social work falls on a continuum from primary to secondary service delivery providers. The field education literature, however, does not include a discussion of congregations as field practicum sites. Keith-Lucas [25] wrote about church children's homes in a series of essays that addressed the influence and support of the church. The author did not, however, address social work field education at that time. The tendency has been to identify large-system RAOs like Lutheran Social Services and Catholic Charities as the main context for social work involvement in religious settings.

Of the approximately 771 accredited social work programs in the United States, there are hundreds of religiously-affiliated programs. Further, fully a fourth of accredited baccalaureate social work programs in the United States are in faith affiliated accredited social work programs. Social work students who identify as Christians or "persons of faith" are not all at faith-affiliated schools. Significantly, many students in state, public social work education programs report faith affiliations and religious values that impact their social work practice. These students struggle with how to integrate their religious faith and may well work after graduation in faith-based organizations with no help or preparation for the integration of faith and practice from their educational programs. Since some students in both public and private programs are interested in social work practice in faith-based organizations, it makes sense to prepare them for the work in field internships in these settings. The recognition by professional social work educators of congregations as contexts for social work practice is essential to this preparation.

A search of web sites with CSWE accredited BSW and MSW programs and their field education programs and sites (2007) revealed that of the 675 schools listed, 154 (23\%) schools posted field placement options on their websites; it was difficult to ascertain which were faith based and which were not. Forty-eight public programs with field placements on websites included an average of 98 field placement sites with an average of seven faith based organizations. Faith-based organizations in public social work field education are significantly underutilized. The same is true of religiously affiliated schools with field education on their websites. Most include no faith-based organizations. Of the 32 websites examined, there was an average of 48 field placement sites per program with an average of only four faith- based organizations per program. The same trend was noted in MSW field education. There are both strengths and challenges to consider in using congregations and RAOs for social work field placements and social work employment. While it is true that many social work programs do not list their field placement sites on their websites making this a limited picture of 
field education, this glimpse suggests that congregational and religiously affiliated placements may be under-utilized.

In the field education program of the authors, 120 RAOs have served as approved field education sites in the years 1990-2016. Of those, 15 were in other states; five were in international sites. Additionally, the program approved 43 congregations as field sites for internships; seven in other states. Those congregations included Baptist, Methodist, Episcopalian, AME, Presbyterian, non-denominational, and Salvation Army sites [26].

\section{Strengths and Challenges of Congregational and RAO Field Placements}

As is true with all educational innovations, the strengths and challenges of placing students in congregations and RAOs need to be examined carefully for the unique field experiences that are possible in both.

\subsection{Strengths}

Congregations and RAOs are historically the settings of many social services in the United States including services like children's homes, hospitals and medical care, and community services for the homeless and the poor. A number of RAOs provide social services across the United States; examples include Lutheran Social Services and Catholic Charities and smaller organizations like children's homes affiliated with Baptist, Presbyterian, and Methodist denominations. Churches in a number of denominations provide counseling and therapy centers, food and shelter for persons who are homeless, and a response in times of crisis and disaster. Usually, many of these services are delivered by ministry staff and volunteers who do not have the benefit of social work knowledge, values, and skills [3]. There is tremendous opportunity and need for fully prepared social workers who know how to competently work with congregations and even function as employees of congregations and RAOs. Congregations of all sizes are located in communities of all sizes in rural, suburban, and urban contexts. Social work field internships in these sites provide the congregation or agency the opportunity to understand and see in action the social work role. In the authors' social work education program, congregational internship placements have led to the development of long-term compensated social work positions within these host settings. In cases like this, the congregation or RAO benefits from social work knowledge and skills. Where the integration of faith and practice is an accepted part of the work, the social work intern and/or employee benefit from the opportunity to work in this setting. This opportunity for the ethical integration of faith and practice is a value that adds credence to social work practice in a $(\mathrm{w})$ holistic way.

\subsection{Challenges}

The social work profession historically adheres to a set of professional values, including self-determination, for example, for clients. This value is juxtaposed against the concern that congregations and RAOs are committed to proselytizing and religious conversion. This value dilemma has resulted in concern that the social worker in a faith-based setting will use the position of influence in the helping process to impose the value of faith on clients. For a period of social work education and practice history, there was a prescriptive separation of the social worker's faith and practice. Social work students were taught that their faith experience and beliefs and those of the client were off limits in the helping process. Current research, however, helps us see a different perspective from the lens of social work clients. Oxhandler, Parrish, Torres, and Achenbaum [27] found that many clients would like for social workers to address clients' spiritual and religious values as a part of social work practice.

The clear separation between social work education and religious beliefs and practices remains a key tenet in many social work programs, although the recent emphasis on spirituality and the inclusion of religion as part of culture has begun to have on-going dialogue and new opportunities for social work educators to address this through competency based educational experiences. This historic segregation of spirituality and preparation for practice presents several challenges in creating and sustaining 
congregational and RAO internships. One challenge is that more experienced social workers may well not have been professionally prepared to address the ethical integration of religious faith and practice in congregations and RAOs. Consequently, enlisting qualified and willing supervisors for internships can be problematic. Second, these more non-traditional settings are often not accustomed to the role of social work and the contributions the profession can make to the mission of their organizations. The challenge for schools of social work is to address the concern around imposition of values and role definition with the opportunity that social work knowledge and skills offers in settings that routinely provide resources, counseling, and community development services. Programs can address this challenge with rigorous attention to providing social work supervision that clarifies role and purpose. A third challenge is that many students are in programs where they may not be prepared for the ethical integration of religious faith and professional practice. The opportunity and challenge is to conceptualize the integration of faith and practice through three lenses which we discuss here: (1) the faith of the client; (2) the faith of the social worker; and (3) the affiliation of the organizational context. The work of Garland and Yancey [8], Sherwood [28] and Chamiec-Case [29] provides literature to begin to address this challenge.

\section{Conceptualizing the Integration of Religious Faith and Practice}

The authors report on findings from congregational and RAO internship placements based on the three-component model for the ethical integration of religious faith and practice that includes the essential components. Organizing instruction and internship learning was adopted by respecting and valuing the faith lens of the client; the faith lens of the social worker; and the organizational context.

\section{Faith Lens of the Client}

Understanding the client's holistic experience includes assessment of relevant emotional, cognitive, physical, social, and spiritual variables. This includes religious faith for some as support and strength in times of crisis; for others, this is experienced as a challenge including the experience of marginalization in the church when dealing with social issues. Understanding these dynamics is important for social workers to help clients create their plans for change.

\section{Faith Lens of the Social Worker}

Self-awareness is a fundamental principle of good social work practice. All social workers have a world view that impacts how they make meaning out of the challenges they face and the challenges clients face. The social worker's religious faith matters because it provides part of that lens through which the social worker sees the world and in some cases provides the motivation for the work. For many social workers, religious faith is a highly regarded value that informs their social work practice. This value should be respected by social work professionals as much as the values of dignity and worth, self-determination, and social justice are in professional social work. It is not unethical for the social worker to experience or respond to a call or sense of vocation to social work. It would be unethical for the social worker not to be self-aware that that call is about the social worker, not about the client. It would be unethical to impose the social worker's call or beliefs on the client.

\section{Organizational Context}

Organizational context is shaped by the mission, funding, and affiliations of the organization. Policies operationalize the mission of the agency or congregation. Additionally, the application of the law around discrimination impacts agencies. The separation of church and state in state or federally funded agencies includes both the protection against the state imposing or prescribing religion and against the state prohibiting or proscribing religion. While the mission of RAOs and congregations may be to share their own religious faith perspectives, this cannot be the mission or activity of programming that is funded with public monies. Additionally, the concept of informed consent is an important consideration. There may be an "assumed informed consent" that services will include prayer or 
scripture or other religious practices in religiously affiliated agencies or contexts of practice. That assumption may or may not be accurate. It is important that the social worker make clear what practices are utilized in the services that are offered so clients may choose or not choose to participate.

For instance, in a faith-affiliated hospital, the patient/client may be asked to sign an informed consent that acknowledges awareness that hospital staff may include prayer with them as part of treatment services. In a faith-affiliated children's home, programming may include church service attendance by children in care. Some congregational settings providing counseling or other therapeutic services include signed informed consent that prayer, the use of religious texts and other religious services are part of the therapeutic package.

\section{Field in Congregations and RAOs at One School of Social Work}

The authors work in one of more than 700 social work education programs accredited by the Council on Social Work Education (CSWE). Their setting has included baccalaureate social work education since 1969 and graduate social work education since 1999, both programs continuously accredited by CSWE. The school's mission statement is "to prepare students in a Christian context for excellence in professional social work practice and leadership in diverse settings worldwide" [30] The program's curriculum is centered on the competencies and practice behaviors of the CSWE with an additional competency which states: "The ethical integration of faith and practice" which is operationalized on the field program contract and evaluation by three core practice behaviors (the three legged stool):

- $\quad$ Clients: Students will understand and work effectively with the religious, faith, and spirituality dimensions of persons and communities.

- $\quad$ Students: Students will examine their own religious and spiritual frameworks and know how these aspects of self may inform and conflict with their social work practice.

- $\quad$ Context: Students will understand and work effectively within the context of the practice setting in regard to faith and spirituality [30].

The faith and practice competency is taught in an infusion model throughout the curriculum and evaluated both in the classroom coursework and in the field education program including the final field evaluation. Students in the Baccalaureate in Social Work (BSW) program complete a minimum of $480 \mathrm{~h}$ over two semesters in the field; students in the Master of Social Work (MSW) program complete a minimum of $1000 \mathrm{~h}$, over two years (foundation and concentration) in the field. Internships are available in traditional and non-sectarian public settings and in congregations and religiously-affiliated organizations.

In 2008, the social work program identified more than 80 agencies in the local area for both BSW and MSW placements. In recent years with distance education, the program has expanded field internship sites across the United States and in some international settings. Criteria for field education sites include: provision of social services that meet the social work scope of service; provision directly or indirectly of supervision of students including social work supervision; and participation in field program training with respect to curriculum, internship roles and tasks, and supervision requirements.

Table 1 reveals that approximately 30\% of the BSSW internship placements are in faith-based (congregational and RAO) organizations within the BSW and MSW programs.

Table 1. Snapshot of Social Work Placements.

\begin{tabular}{cccc}
\hline \multicolumn{2}{c}{ BSW Field Placements } & \multicolumn{2}{c}{ MSW Field Placements } \\
\hline Type of Agency & Number (\%) & Type of Agency & Number (\%) \\
\hline Faith-based & $10(32 \%)$ & Faith-based & $35(53 \%)$ \\
Non faith-based & $21(68 \%)$ & Non faith-based & $31(47 \%)$ \\
\hline
\end{tabular}




\section{Two Congregationally-Related Field Models}

The program's curriculum structures the integration of religious faith and practice by instruction focusing on the 10th competency (faith and practice) and the related practice behaviors as well as intentional development of field internships in congregational and RAOs. This emphasis is not instead of traditional social work field education but is an additional area of social work practice and competence that returns to the roots of the profession. It is consistent with the mission of the program, and develops competency in professional social work practice in systems that benefit from students and supervisors in the field. As a result of the emphasis of the integration of religious faith and practice, increasing numbers of students are interested in field internships in RAOs. The program has worked to develop field education opportunities in RAOs and congregations through several models.

\section{One Congregation Model}

A number of baccalaureate and graduate students have completed field internships in a single congregation with task supervision provided by the clergy or one of the ministers and field instruction provided by a licensed social worker within the congregation. These internships have been both micro/direct practice and macro/organizational and community practice. Several students have worked specifically with benevolence ministries or with senior adult ministries. With no on-staff social worker to provide field supervision, the school's program approved a task supervisor for on-site supervisor with a contracted off-site social work field instructor.

There are numerous narratives of the significant ways the students in one of these placements impacted the congregation and community. For example, one student, in a generalist practice congregational placement, discovered in the benevolence ministry that the church had a \$300 a month budget for helping with identified financial needs which was spent the first day of each month, almost always on someone who had received help on multiple occasions over the year. The remaining days of the month were filled with requests, no resources, regrets, and frustration. Those who called for help expressed frustration that there was no money left. The church members expressed frustration that despite their benevolence, they felt taken advantage of and not appreciated. In the midst of this, the student, with the field instructor's help, developed and implemented a two pronged approach: (a) case management for every person who called in requesting financial assistance including a comprehensive assessment, strong referral network, and budget counseling, and (b) a church commitment to support one family a year with assessment, case management, family counseling, job training and placement, budget counseling and $\$ 300$ a month assistance for the year. The generalist practice internship in the congregation became both a more effective method for providing "benevolence" and a macro practice approach to systems resources. Since then, the congregation has used this approach primarily with families with children. Additionally, this particular congregation has been a field internship placement site for several MSW students.

Strengths. The possible models for social work in one congregational setting seem endless with the micro, mezzo, and macro work that is a part of most congregations. These opportunities present both strengths and challenges in a setting where much work is done by numerous people who are responding to their faith through opportunities of service and where the motivational models are often based in religious texts rather than codes of ethics. There is significant strength in social workers who have been educationally prepared for this work to provide professional expertise for the services the church is already providing. Social workers who are trained in assessment, intervention, and evaluation are an asset to a helping process that includes both services and referral. A strength is the potential increase in efficiency and effectiveness for social services in congregations. Further, social workers are prepared to evaluate the effectiveness of programming and make needed changes. Additionally, the social work commitment to valuing all persons and providing ethical practice facilitates congregational participation in social justice practices including both fair processes and community engagement.

Limitations. As a fairly new phenomenon in the current age, social workers hired in a congregation face the limitation of role definition, much like they have faced in other secondary service settings 
like schools and hospitals. This can be challenging for the "only social worker" in a practice setting. Congregational social workers work with those from the neighborhood, other congregations, social agencies and local government. When they work with congregants with whom they worship, they may experience a dual relationship requiring role clarification and use of supervision. This complexity is not unlike that of rural social workers in small communities.

\section{Rotational Model}

In addition to the one congregation internship model, the program also designed and implemented a rotational, multiple site model which included student internship experiences in multiple agencies including congregation(s) over the course of the internship. This innovation occurred as part of the school's advanced placement opportunities for MSW students interested in preparation for practice with older persons, offered with funding provided by the Hartford Foundation's initiative to support the preparation of geriatric social workers. Many congregations include an older adult ministry for seniors who are ill, homebound, and/or are in residential placement. Occasionally, this ministry extends to include grief support, facilitating senior trips and activities, and caregiver ministry. The challenges of exposing social work students to professional opportunities in congregations including grief counseling, support for caregiving responsibilities and social skills and relationships in older adulthood can be maximized through the implementation of a rotational internship model.

In this model, a cohort of students (8-10) is assigned to a primary social service agency setting with a rotation of several days in the other seven to nine agencies during the semester. Additionally, each student in a primary internship setting hosts each of his/her peers for several days and carves out learning and practice opportunities for them. For example, the student who is in an internship placement in the Area Agency for Aging facilitates peers' exposure to home visits, making referrals for adult day care or respite services while the student in a hospital setting on the geriatric unit facilitates peers' experiences with end of life conversations, discharge planning to skilled nursing facilities, and family conferences for care planning. The student in a skilled nursing facility (SNF) facilitates peers' experiences with family members through adjusting to visits in the SNF by including approaches like reminiscence therapy to enhance their visits. Conversely, the student in a congregational placement facilitates peers' experiences with home visits of homebound older adults, grief counseling, and organizing the Senior Adult annual banquet. All of these serve as examples of solid social work practice in these settings.

The rotational model includes significant collaboration among the agencies. The field education program assists the agencies in identifying common training needs, policies, and task preparation. The agencies participate with hosting training that includes intake/admission/assessment forms, tasks they share in common and those that are unique to their respective agencies. The training includes identifying possible tasks for students rotating through the agency and the educational experience which is available to the student who is facilitating their peers' experiences. Agency directors meet several times during the year to evaluate the collaboration and needs for communication and planning together for student experiences. One benefit to agencies and administrators is preparation of 8-10 students who are prepared to work in their agencies after graduation.

As students host their peers' by including arranging for their learning experiences, their depth of learning is significant and includes collegial consultation and supervision. They become the negotiator of internship duties. For example, one student was able to organize peers' facilitation of a psycho-educational group; a second student organized the home visits and assessments for in-home services which were done by peers; and a third student organized opportunities for peers to meet with older adults entering end of life care for end of life decision making conversations about living wills, medical power of attorneys, etc. These are just three examples. Students share an internship seminar which meets weekly to share the similar and disparate learning, the differences in policies across the 8-10 agency spectrum, and the impact of federal and state policies and reimbursement procedures. The rotational model provides one student with a deep experience in congregational social work with 
older adults and seven to nine others with a significant exposure to the possibilities in this new area of practice.

Strengths. The strengths of the rotational model are significant as students prepare for a variety of contexts of practice, enhance their resumes, and gain consultative experience. Agencies have a larger pool of trained, prepared interns to consider for employment openings and streamline referral processes for shared clients. The field education program gains field placement sites as agencies that are not able to provide some needed experiences are supplemented with rotational agencies. The challenges and opportunities around role and purpose and the integration of faith and practice became more evident and the discussions were both rich and productive.

Students in the program reported that the learning was rich, the collegial relationships lasted well beyond the internship experience, and the rotational model was a real benefit on their resume during the job search process. Agency personnel reported the benefits of developing streamlined referral processes among agencies, adapting policies to avoid the duplication of work, and the benefits of having a pool of trained social workers in the job pool when they were ready to hire a social worker. Congregational participants, including supervisors and pastors, responded to the rotational model with support for social work in the congregational setting. Students, supervisors, ministers, and congregants discovered, then, that the congregation was a legitimate and important context of practice for social workers, both those who shared the faith belief system of the congregation and those who did not. This model, operationalized over a period of three years, provides important information in the ongoing discussion around the use of congregations and other non-traditional settings for field internship and social work practice sites.

Limitations. Limitations to the rotational model include additional administrative time requirements, some fragmentation of the internship experience, and substantive concerns about the lack of depth in some of the rotational placement sites. Administrators of agencies, field instructors, and field program faculty spend significantly more time developing and sustaining the rotational model than is spent in the one student per agency model. The field liaison has the critical role of coordinating this learning experience. Students have a primary agency but are out of that agency at least one day a week for more than half of the block internship as they rotate through other agencies. The field education program has more work to do with educating the agencies about each other, finding common policy, training and tasks and negotiating the rotational experience.

\section{Implications and Recommendations}

The social work profession has strong roots in congregations, beginning with multiple persons of faith who cared about orphans, families, the mentally ill, and those who were economically poor in their communities. While the profession sought credibility and evidence for outcome based work, there was some disavowing of religious beliefs and institutions, partially based on the concern that faith-informed professionals might impose their religious values on clients and agencies and systems. Over time, the combination of concern around ethical violations and an emphasis on positivism led to fewer social workers in congregations and more secularization of faith based or religiously affiliated agencies. The loss to the profession included an important context of practice, avoidance of instruction on the intentional ethical integration of religious faith and practice, and an absence of models for work in RAOs. The loss to congregations and RAOs included less evidence-informed and effective practice, unavailability of professionally trained and prepared staff to respond to the psychosocial needs of hurting congregants and community members, and in-accessibility of community resources due to lack of awareness and/or trust in the capacity to deliver services.

Over the past 15 years or so, there has been a return to consideration of spirituality and religion in social work practice [23,31]. Concurrently, some religiously affiliated programs took on the challenge and opportunity of revitalizing the integration of religious faith and practice and social work internships in congregations and RAOs [3]. The profession has in the past 15 years begun an important conversation about religion and spirituality as part of each client's cultural experience and 
the importance of culturally competent practice with all persons [32]. Further, the recent revision of the Diagnostic and Statistical Manual [33] includes religion and spirituality as part of culture in the assessment of mental health in persons. Programs like this have engaged in intentional work to operationalize the integration of religious faith and practice in ways that are ethical and respectful both of the values of the profession and the values of the congregational or RAO context of practice.

Internships, both single congregational and rotational, provide the opportunity for research around effectiveness of practice and a growing role for social workers in congregations and RAOs. The work of Garland and Yancey [8] suggests that there are growing numbers of social workers in congregations, though their titles may be other than social worker. Continued study of both the prevalence of social workers in congregations and RAOs and their role and purpose will be important to understanding how best to equip these workers and how best to understand the potential and challenges of this trend. Social work educators, social work interns, and social workers who carve out this territory, new again to the profession, may work as the only social worker in a congregation or may work in rotational internships that allow experiences in a variety of settings including a congregation. They may work as case managers and therapists and counselors or they may work as program planners, community organizers, and policy advocates for the oppressed in communities. They may "minister" to congregants or to the ministers around them and to the people in the geographic community whose basic needs are being met through congregational social work practices. They are uniquely equipped to do this advanced generalist practice in ethical, evidence based responses that respect their context of practice.

\section{Future Research}

As more social work academic programs consider field internship placements in congregations and in religiously-affiliated organizations, there is opportunity to, with intentionality, evaluate the learning experience of students, the ethical issues and responses, and a variety of models and their effectiveness. In addition, the internship experience will be enriched by the findings of research aimed at understanding the role of social work across a variety of religions and faith perspectives.

We think that the three-component model for integration of religious faith and practice (faith of the client, faith/worldview of the social worker, and organizational context) provide a helpful theoretical basis for guiding the design and involvement of social workers within congregational and RAO settings. Placements in congregations and RAOs provide rich opportunities to test the efficacy of these formulations as well as identify best practices in these settings. Larson and Robertson), in a qualitative study of three BSW students in Christian based practicum settings, noted that "It is interesting that the students in the current study all identified a lack of fit between some theories and methods taught at the university and those practiced at the agencies" ([20], p. 255). These and other questions are the rich ground for research available in the future. We recognize that additional research is needed in the application of these possibilities in organizational contexts affiliated with other religious traditions.

\section{Summary and Conclusions}

Eun-Kyoung and Barrett stated: "In recent decades, 'increasing numbers of contemporary social work practitioners have expressed their needs to integrate their spirituality and religious faith into their professional activities'" ([29], p. 354). This call for integration requires guidance from an accurate theoretical accounting for the nature of congregationally-based social work practice and a clear conceptualization of how ethical integration of faith and practice can occur with the internship experience. We offer a report of one school's response to both of these conceptual and practical requirements. Whether faith and practice integration occurs in non-sectarian agencies or within RAOs and congregations, we anticipate that the urgency and relevance of this conversation will be increasing in concert with the growing recognition of religion and spirituality as cultural experiences and the expanding involvement of social workers in a variety of religious settings. With this in mind, the 
authors continue to explore approaches for internships in religious congregations and RAOs. These approaches are intended both to professionalize services in these settings, open new employment opportunities for social workers, enhance opportunities for social workers to integrate their religious faith and practice, and develop new models for this work.

Acknowledgments: Diana R. Garland, for her inspirational leadership in the integration of religious faith and social work practice and her belief in the role of congregations in meeting the needs of persons.

Author Contributions: Gaynor Yancey and Dennis Myers assisted with conceptualizing the paper and articulating the importance of field education in congregations including their experience with supervising field interns in their congregations. They co-wrote and edited revisions. Myers included the concept in a conference he directed. Yancey is the author on a number of the key references and identified this journal for submission. Helen Harris is the primary author doing the majority of the writing and providing the primary conceptualization around field education in congregations.

Conflicts of Interest: The authors declare no conflict of interest.

\section{References}

1. National Association of Social Workers. "Code of Ethics." 2008. Available online: http:/ /www.nasw.org/ (accessed on 9 May 2015).

2. Council on Social Work Education. "Educational Policies and Accreditation Standards." 2008. Available online: http:/ / www.cswe.org/ (accessed on 9 May 2015).

3. Gaynor I. Yancey, and Diana R. Garland. "Christian congregations as contexts for social work practice." Social Work \& Christianity 41 (2014): 279-307.

4. James Ellor, Ellen Netting, and Jane Thibault. Religious and Spiritual Aspects of Human Service Practice. Columbia: University of South Carolina Press, 1999.

5. Diana R. Garland. "Social Workers on Church Staff." 1987. Available online: http://www.nacsw.org/ Publications/GarlandD_SWChurchStafs1987.pdf (accessed on 12 February 2016).

6. Diana R. Garland. Church Social Work. St. Davids: The North American Association of Christians in Social Work, 1992.

7. Vicki Moore Northern. "Social workers in congregational contexts." Social Work \& Christianity 36 (2009): 265-85.

8. Diana R. Garland, and Gaynor I. Yancey. Congregational Social Work. Botsford: North American Association of Christians in Social Work, 2014.

9. Gary Holden, Kathleen Barker, Gary Rosenberg, Sofie Kuppens, and Laura W. Ferrell. “The signature pedagogy of social work: An investigation of the evidence." Research on Social Work Practice 21 (2011): 363-72. [CrossRef]

10. Tanra Earls Larrison, and Wynne S. Korr. "Does social work have a signature pedagogy." Journal of Social Work Education 49 (2013): 194-206.

11. Sharon C. Lyter. "Potentional for field education as signature pedagogy: The field director role." Journal of Social Work Education 48 (2012): 179-88. [CrossRef]

12. Vicki D. Copp. "Moving toward center: Where field education realizes the 'best of both'." Christian Education Journal 6 (2009): 38-50.

13. Diana R. Garland, and Gaynor I. Yancey. "Moving mountains: Congregations as settings for social work practice." In Christianity and Social Work: Readings on the Integration of Christian Faith and Social Work Practice. Edited by T. Laine Scales and Michael Stokely Kelly. Botsford: North American Association of Christians in Social Work, 2012, pp. 331-36.

14. Bryana Sack. "Ninth Circuit Expands Definition of 'Religious Organization' for Purposes of Permissible Religious Discrimination under Title VII." Available online: http://bodyfeltmount.com/news/2011/02/ ninth-circuit-expands-religious-organization-definition (accessed on 6 May 2015).

15. F. Ernest Johnson. "The social work of the churches: A handbook of information." Social Sciences Review 4 (1930): 508-9.

16. Michael Sherr, and Terry Wolfer. "Preparing social work students for practice with religious congregations within the context of charitable choice: The grace house ministry." Social Work \& Christianity 30 (2003): $128-48$. 
17. Martin E. Ferm. "Parish social work-A pilot project." Lutheran Social Welfare Quarterly 2 (1962): 1-8.

18. Alice D. Taggart. "The caseworker as parish assistant." Social Casework 43 (1962): 75-79.

19. Sharon E. Moore, and Wanda Lott Collins. "A model for social work field practicums in African American churches." Journal of Teaching in Social Work 22 (2002): 171-88. [CrossRef]

20. Grant Larson, and Jeanette Robertson. "Exploring the experiences of BSW students in Christian-Based practicum settings." Social Work \& Christianity 34 (2007): 244-58.

21. T. Laine Scales. "Accepting a Trust so Responsible: Christians Caring for Children at Buckner Orphan's Home, Dallas, Texas, 1879-1909." In Christianity and Social Work: Readings on the Integration of Christian Faith and Social Work Practice. Edited by T. Laine Scales and Michael Stokely Kelly. Botsford: North American Association of Christians in Social Work, 2012, pp. 53-70.

22. Jay Poole, John C. Rife, Fran Pearson, Lelia Moore, Antonia Monk Reaves, and Wayne Moore. "Innovative Social work field education in congregational and community-based settings serving persons fifty-five: An interdisciplinary training initiative for BSW and MSW students." Social Work \& Christianity 40 (2013): 404-21.

23. Mary Van Hook, Beryl Hugen, and Marian Angela Aguilar, eds. Spirituality within Religious Traditions in Social Work Practice. Pacific Grove: Brooks/Cole Thomson Learning, 2001.

24. Marla Berg-Weger, and Julie Birkenmaier. The Practicum Companion for Social Work: Integrating Class and Field Work, 2nd ed. New York: Pearson/Allyn \& Bacon, 2007.

25. Alan Keith-Lucas. The Church Children's Home in a Changing World, Enduring Edition ed. Charlotte: UNC Press, 1962.

26. Melody Zuniga (Field Education Director of the Garland School of Social Work, Waco, TX, USA). Personal communication, 2016.

27. Holly K. Oxhandler, Danielle E. Parrish, Luis R. Torres, and W. Andrew Achenbaum. "The integration of client's religion and spirituality in social work practice: A national survey." Social Work 60 (2015): 228-37. [CrossRef] [PubMed]

28. David A. Sherwood. "Ethics and evangelism in social work." In Christianity and Social Work: Readings on the Integration of Christian Faith and Social Work Practice. Edited by T. Laine Scales and Michael Stokely Kelly. Botsford: North American Association of Christians in Social Work, 2012, pp. 337-60.

29. Rick Case-Chamiec. "Ethically integrating faith and practice." In Christianity and Social Work: Readings on the Integration of Christian Faith and Social Work Practice. Edited by T. Laine Scales and Michael Stokely Kelly. Botsford: North American Association of Christians in Social Work, 2012, pp. 337-60.

30. Baylor University School of Social Work. Available online: http://www.baylor.edu/ (accessed on 12 February 2016).

31. Sonia Leib Abels, ed. Spirituality in Social Work Practice: Narratives for Professional Helping. Denver: Love Publishing Co., 2000.

32. NASW. "Cultural Standards." Available online: https://www.socialworkers.org/practice/standards/ NASWCultural (accessed on 13 January 2016).

33. American Psychiatric Association. Diagnostic and Statistical Manual of Mental Disorders, 5th ed. Washington: American Psychiatric Publishing, 2013.

(C) 2016 by the authors; licensee MDPI, Basel, Switzerland. This article is an open access article distributed under the terms and conditions of the Creative Commons Attribution (CC BY) license (http: / / creativecommons.org/licenses/by/4.0/). 
Article

\title{
Baby Boomers as Congregational Volunteers in Community Ministry
}

\author{
Terry A. Wolfer ${ }^{1, *}$, Dennis R. Myers ${ }^{2}$, Edward C. Polson ${ }^{2}$ and Betsy Bevis ${ }^{2}$ \\ 1 College of Social Work, University of South Carolina, Columbia, SC 29208, USA \\ 2 Diana R. Garland School of Social Work, Baylor University, One Bear Place, \#97320, Waco, TX 76798-7320, \\ USA; Dennis_Myers@baylor.edu (D.R.M.); Clay_Polson@baylor.edu (E.C.P.); Betsy_Bevis@baylor.edu (B.B.) \\ * Correspondence: terry.wolfer@sc.edu
}

Academic Editor: Robert Wineburg

Received: 26 November 2016; Accepted: 6 April 2017; Published: 13 April 2017

\begin{abstract}
Religious congregations are a significant setting for volunteerism in the United States, and increasing rates of volunteerism correlate with age. Because of their prolonged health and increased longevity, the large boomer generation represents a potentially significant volunteer resource for congregations. But current research on boomers and congregational life provides little information about this age cohort for engaging them in community ministry. Using a large purposive sample $(n=2883)$ drawn from Protestant congregations in four regions of the U.S., we explore differences between boomer volunteers and non-volunteers including self-reported motivations, barriers, and outcomes. Despite similarities in most demographics and barriers to volunteering, volunteers and non-volunteers report differing levels of motivation for and outcomes of volunteering. Using service-learning concepts to explore how characteristics of volunteer opportunities influence the faith of volunteers, we found that certain program characteristics indeed correlate with positive outcomes while other characteristics are generally absent. Based on these findings, we provide guidance for both congregation and community agency leaders to increase and enhance opportunities for boomer volunteers.
\end{abstract}

Keywords: religious congregation; community ministry; volunteerism; baby boomer

\section{Introduction}

The unprecedented number of potential volunteers among the baby boomer (boomer) generation offers religious congregations a unique resource for meaningful engagement with the human vulnerability of their communities. According to Culp ([1], p. 2), "boomers will retire earlier, stay healthier, be more physically active, and live longer than any previous generation. They have greater wealth and more expendable income than other generations . . . and exhibit greater independence, are more skilled, and have a higher level of education." Researchers have estimated that those ages 55 and older have already performed $\$ 44.3$ billion dollars' worth of work through formal volunteering, and $\$ 17.8$ billion dollars' worth of informal volunteering [2].

More people volunteer in religious settings than any other. This is true across age groups and especially for boomers (e.g., age $16-24=25 \%, 45-54=33 \%, 55-64=39 \%, 65+=43 \%$ ) [3]. A more nuanced understanding of this age cohort reveals, however, that boomers are, at best, an uncertain resource for community ministry by religious congregations. Generalizations that suggest that most boomers are prime candidates for community ministry overlook the realities of boomer volunteerism. The volunteer participation rate in the 45-54 and 55-64 age groups has declined over 5 years (2011-2015) by 2.6 and 3 percentage points, respectively [3]. While boomers make up a significant proportion of U.S. volunteers, data also indicate that a little more than a quarter of boomers actually engage in volunteer behavior at least one time each year. According to the Corporation for National and 
Community Service, $31 \%$ percent of boomers who volunteered the first year did not do so the second year [4]. Furthermore, there has often been a tendency to overlook intragroup age (older versus younger boomers), gender, and ethnicity differences in boomer volunteering as well as the economic necessity of continued employment, and the growth of encore careers.

Nevertheless, a significant number of boomers, particularly those in the 65-70 age range and recently retired, remain a potentially substantial community ministry volunteer resource for congregations. As we indicated, boomers are volunteering more than previous generations and researchers project that this number will continue to increase as the young baby boomers begin reaching retirement age [5-7].

Data on boomer volunteerism paints a complex picture and raises important questions about the role that this important generational cohort is likely to play in U.S. civic life over the next several decades. Moreover, current research on boomers and congregational life does not provide congregational leaders with evidence to help them move beyond generalizations about this age cohort or navigate the complexities of engaging them in community ministry. Comparison baseline data (e.g., age, gender, ethnicity, income and education level, and relationship status) on boomers who affiliate with religious congregations and do and do not volunteer as members are not readily available. Congregational leaders will benefit from having access to research findings that address questions such as: What motivates and sustains boomer involvement in congregationally-based volunteerism? What is the relationship between their religious faith and their involvement in community ministry? What benefits and barriers do they experience? What characteristics of the community ministry setting contribute and detract from their participation?

Based on a large purposive sample $(n=2883)$ drawn from Protestant congregations in four regions of the U.S., we address socio-demographic, personal, and relational differences between boomer volunteers and non-volunteers as well as questions related to motivation to serve, barriers to volunteering, and outcomes of service. Further, we apply service learning concepts to explore characteristics of volunteer opportunities and community ministry venues that benefit boomer volunteers while also examining how their involvement stimulates and transforms their religious faith. We then use these findings to provide guidance for both congregation leaders and community agency volunteer coordinators regarding the recruitment, design, and delivery of meaningful volunteer opportunities for boomer volunteers in congregations.

\subsection{Boomer Volunteers}

\subsubsection{Education}

The boomer generation is one of the most highly educated generations in American history-88.8\% of boomers have completed high school and $28.5 \%$ have a bachelor's degree or higher [8] —and individuals with higher levels of educational attainment engage in volunteer activities at higher rates than did those with less education [3].

\subsubsection{Ethnicity}

Some indication of boomer volunteerism among ethnic groups can be derived from data on all adult volunteers. Surveys of adult volunteers report that whites continue to volunteer at higher rates $(26.4 \%)$ than Blacks (19.3\%), Asians (17.9\%) and Hispanics (15.5\%) [3]. Although there were fewer volunteers in ethnic sub-groups, the median hours per month were similar across ethnicities and ranged from 48 to 52 [3]. While variation in ethnic volunteerism seems evident, Einolf [6] noted that race and ethnicity were not statistically significant in the amount of volunteering performed by boomers. 


\subsubsection{Gender}

Women continue to volunteer at higher rates than men among boomers, as they do across all age groups $[3,9]$. Their type of volunteering also differs. Men are more likely to engage in general labor, provide transportation to people, and coach or supervise sports teams while women are more likely to collect and serve food, and tutor or teach. Further, women perform more informal volunteering than men through services to the community rather than through formal organizations [10].

\subsection{Continuity and Role Theory}

As baby boomers begin the transition to retirement, continuity and role theories help explain volunteerism in this age cohort. Continuity theory posits the importance of maintaining established patterns of behavior throughout one's life and especially across important status transitions such as retirement to preserve a person's well-being through the life course [11]. According to this theory, adults prefer to maintain existing internal and external structures through volunteer work consistent with their past experiences and enjoyable activities [12]. Essentially, patterns of volunteering preretirement lend to higher probability to volunteering postretirement.

Role theory adopts the concept of role salience for understanding "how people adjust to a role transition such as retirement and how they determine what other roles will be maintained or modified" ([13], p. 58). As individuals grow older, they lose specific roles in life and need to take on new roles. Smith found that those who volunteer for organizations (e.g., nonprofit board membership) during preretirement generally continue to do so but often shorten their volunteer commitments after retirement [13]. This researcher also reported that out of a pool of 258 working respondents ages 50 to 64 , those who consider the volunteer role highly salient are much more likely to see volunteering as part of an ideal retirement lifestyle as are those who frequently attend religious services. In fact, Smith found that almost 6 in 10 midlife workers saw volunteering as part of an ideal retirement lifestyle (57.9\% of the 258 respondents) [13].

\subsection{Boomer Volunteering: Perceptions, Motivations, and Outcomes}

\subsubsection{Perceptions and Motivations}

Congregational and community leaders seeking to recruit, match, and retain volunteers need to understand how boomers' perceptions and motivations of volunteering affect their willingness to take part in volunteering after retirement. Aging baby boomers may have more time in retirement, but perceptions are crucial in whether or not they volunteer with the free time available to them. In general, McClelland, Atkinson, Clark, and Lowell observed volunteers are motivated by incentives related to affiliation, power, and achievement [14]. More specific to boomers, the AARP intergenerational volunteer survey found retiree attitudinal factors such as altruism, high expectation of intergenerational support and equity, and fairness are important for volunteering [15]. Elcott and Himmelfarb observe that "the search for meaning and the pursuit of values can motivate an entirely new perspective on one's career and work life-and a long-desired unity of purpose [between interior expectations and external involvement] can be achieved that might have been unattainable in prior years" ([16], p. 200). They are navigating multiple personal and family transitions such as family caregiving, individual health, parenting adult children, rightsizing their living environment, and economic challenges. Developmentally, most are renegotiating their own identities, intimate relationships, and the sense of significance $[8,17]$.

According to Smith and Gay, "leaving the workforce deprives people of the incidentals paid work generally provides: time structure, social contact, collective effort or purpose, social identity or status, and regular activity" ([18], p. 3). Related to these findings, Okun and Michel found that increasing volunteerism among boomers was related to engaging opportunities that reflect a concern for the community, benefitting the lives of those volunteering and the community members being served [19]. 


\subsubsection{Christian Faith}

Boomer congregational volunteers may also be motivated by faith [20]. Dykstra views theological faith as "primarily a response to a gift, an activity of recognizing and accepting God's grace, which gives rise to a way of life- a way of believing, trusting, committing, and orienting all one's thoughts and actions" ([21], p. 18). Faith maturity, according to Benson, Donahue, and Erickson is defined as "the degree to which a person embodies the priorities, commitments, and perspectives characteristics of vibrant and life-transforming faith" ([22], p. 3). Several studies have examined the relationships among Christian faith, faith maturity, and adolescent and adult congregational volunteers [23,24]. To date, no studies have explored these relationships among baby boomers in Protestant congregations.

\subsubsection{Outcomes of Service}

Volunteer service, especially which puts volunteers in relationship with persons in need, can transform volunteers personally and intellectually. Research indicates that volunteer service contributes to an improved sense of well-being and self-worth, satisfaction in helping others, and greater tolerance for human differences $[25,26]$. For religiously oriented volunteers, service may also provide opportunities to practice and strengthen their faith $[27,28]$. Indeed, there is a robust social scientific research literature demonstrating that religious participation is positively related to volunteering in the U.S. [29-31].

Based on research on the faith and service relationship among adult and adolescent congregational volunteers in community ministry, religious faith and community service have a mutual and synergistic relationship with both faith motivating service and service enriching faith $[23,24]$. These findings are particularly relevant for this study of the impact of community ministry involvement on boomer congregants. In an interesting frame on understanding religiously-oriented volunteers, Garland and Yancey do not refer to members of the church as volunteers, preferring to refer to volunteers as servants instead, because of the life that Christians are called to lead according to the Bible [32]. The center of a Christian congregation is intended to be its service to others, including the community. They note boomers in Protestant congregations share many similarities with their non-involved colleagues while also holding unique values and beliefs. Whereas boomer volunteers serve as an option, congregational boomers view service as expected and essential; boomer volunteers are altruistically motivated and congregational boomers are also faith motivated; boomer volunteers act out of humanitarian concerns whereas congregational boomers also act out of their obedience to God; and boomer volunteers tend to value affirmation for their service whereas congregational boomers also value a sense that God affirms their actions.

\subsection{The Context for Congregational Boomer Volunteerism}

As mentioned above, religious participation is consistently found to be a robust predictor of volunteering in the U.S. [29-31]. Further, congregations generate a significant amount of volunteerism in American communities [33]. Previous research indicates that these organizations are particularly effective in mobilizing volunteers. They provide important motivations for volunteering, and they also serve as significant contexts for the development of valuable social capital and social networks that contribute to volunteer recruitment and communication [34]. Often congregations provide members a variety of opportunities for volunteerism.

Congregants volunteer for educational and religious activities that are administered by the congregation and occur within the context of the congregation's physical space. These contributions directly support core functions such as religious education, worship rituals, and on-site benevolence services. Congregational boomer volunteers also express their religious commitments as well as the mission of the congregation to which they belong by serving community agencies that may or may not be formally aligned with the congregation. Boomers are therefore involved in these three contexts-volunteerism within the congregational context, volunteerism co-sponsored by the 
congregation with other organizations (e.g., other congregations, denominational organizations), and volunteerism in community service agencies independent of congregation administrative control. This study focuses on congregational boomer involvement in agencies not connected with the congregation.

Meaningful involvement in community ministry by boomers in congregations requires that volunteers perceive benefit to recipients while also realizing the kinds of role performance outcomes that enrich their lives and faith. When this kind of reciprocity is available, both recipient and volunteer are changed by the interaction. Service-learning provides a framework for prescribing how these kinds of encounters can be intentionally created and sustained. In an ideal arrangement, boomer service becomes a context for their own personal and faith development. In effect, the ministry changes both the recipient and the boomer. To illustrate this effect, Lewis found that "older adults who have the opportunity to reflect on their service during and afterwards will be able to critically examine their involvement, make improvements, and integrate the experience into their lives" ([35], p. 663). In the full expression of the service-learning model, the boomer volunteer is offered opportunities to reflect on the impact of the engaged learning on changes in their beliefs and practices [36].

The process through which service-learning transforms volunteers has been characterized as a hermeneutical cycle of learning $[20,28]$. Volunteers initially have presuppositions, values, and beliefs based on their life experiences. As they experience volunteer service, particularly through developing relationships with persons in radically different life circumstances than their own, they experience dissonance with their initial presuppositions, values, and beliefs. These differences prompt them to either confirm or alter previous ideas and behaviors. Revised beliefs and values then become part of the basis for interpreting future experiences as the hermeneutical cycle of learning continues.

Congregational and agency volunteer leaders need to be able to deliver volunteer contexts that offer opportunities for role enactment that stimulate critical reflection on values, personal and religious beliefs, motivations, and perceptions. In an early study, Eyler and Giles specified characteristics of service learning programs and explored the relationships between these characteristics and volunteer outcomes [37]. The program characteristics included: (1) Placement quality-amount of direct recipient contact; leadership support, and meaningfulness and challenge of the volunteers' tasks; (2) Application-linkages between classroom and community service; (3) Reflection (oral and written) - opportunities to thoughtfully imagine the significance of service for intellectual and personal change; (4) Diversity - exposure to persons of differing ethnicity, socioeconomic level, age, gender, or lifestyle; and (5) Community voice-participation of service recipients in planning the service.

They found that these program characteristics at least moderately predicted the likelihood that volunteers would be transformed by their service. Service-learning programs may challenge a person's prejudices and previous experiences and assumptions, create cognitive dissonance, and cause a re-examination of beliefs. In addition, placement quality, application, and written reflection were significant predictors of knowing oneself better, experiencing a personal reward for helping, and developing increased levels of spirituality. They concluded that service learning promotes an appreciation for diversity and reduces negative stereotypes [37].

The effects on volunteers do not occur automatically, however. For example, Cotton and Stanton observe that eager but unprepared volunteers may do more harm than good if they serve without understanding the culture and needs of the recipients [38]. Rather than broadening and increasing the volunteers' understanding of others' lives, the experiences may only reinforce stereotypes about persons who are economically poor and culturally different. For these reasons, it remains important for leaders to design service-learning programs so as to overcome these unintended effects and maximize beneficial outcomes.

\section{Methodology}

The current study seeks to clarify how congregational boomers involved in community ministry programs (volunteers) differ from congregational boomers not involved in such programs (non-volunteers) and how their personal and spiritual lives are affected by the volunteer experience. 
We compare volunteers and non-volunteers on socio-demographic variables, obstacles to volunteering, and motivations that may influence their decision to volunteer. Further, we explore the proposition that boomers who volunteer in congregational community ministries will report higher levels of faith practices than non-volunteers and that these differences will remain when controlling for potential mediating factors (e.g., socio-demographic variables, obstacles, and motivations). To address the study objectives, we utilize secondary data drawn from a survey of attenders in 35 Protestant congregations from across the U.S. and present results from descriptive, bivariate, and multivariate data analysis.

\subsection{Congregation and Boomer Sample}

In 2004, we conducted a survey of individual attenders in a purposive sample of 35 Protestant congregations drawn from six states across the U.S.: California, Louisiana, Michigan, New York, South Carolina, and Texas [39]). The sample focused on Protestant congregations located in urban or suburban communities and known to provide service programs within their communities. While the sample was restricted to Protestant congregations, it included denominations representing conservative Protestant, mainline Protestant, and Black Protestant traditions. Furthermore, the researchers sought to recruit an ethnically diverse set of congregations including some that were predominantly white $(n=18)$, black $(n=9)$, Latino $(n=5)$, and multi-ethnic (i.e., congregations having no dominant racial/ethnic group) $(n=3)$.

All attenders present in each congregation at the time of the survey were invited to participate resulting in a final sample of 7403 individuals. All participants gave their informed consent for inclusion before they participated in the study. The study was approved by the Institutional Review Board of Baylor University. For the current study, we analyze data drawn from a sub-sample of 2883 participants born between the years of 1946 and 1964 (boomers). The sub-sample includes 1398 self-identified volunteers and 1361 non-volunteers. There were 124 respondents who did not answer the question about volunteering for community ministry.

\subsection{Instrumentation}

\subsubsection{Congregational Survey}

In addition to a standard set of demographic items, the congregational survey included questions about both the volunteer behavior and the religious faith and practice of participants. The resultant data allow us to examine, more closely than previous studies have been able, the relationship between religion and volunteerism among Protestant boomers.

\section{Christian Faith Practices}

Of particular importance for this study, the survey included a Christian Faith Practices Scale (CFPS), comprising a set of 13 Likert-type items that asked respondents to indicate the frequency with which they participate in specific faith practices or behaviors (from "Never" = 1 to "Always" $=7$ ) $[39,40]$. Factor analysis of the CFPS items further revealed two underlying subscales: (a) a serving practices subscale, and $(\mathrm{b})$ a relating practices subscale. The serving practices subscale (alpha $=0.80)$ is composed of three items including providing hospitality to strangers, volunteering time to help others less fortunate, and participating in activities to promote social justice. And the relating practices subscale (alpha $=0.75)$ is composed of three items including confessing faults to others; forgiving and working on healing relationships; and encouraging others, especially in failure. Other CFPS items were excluded because factor analysis indicated they did not fit well in either subscale.

\section{Volunteerism}

The congregational survey asked participants to report whether they currently volunteer in any "community ministry," defined as "involvement in activities encouraged by your church that support the physical, material, emotional, and social well-being of people from your congregation, 
neighborhood, and community." Utilizing this survey item, we were able to sort survey participants into "volunteer" and "non-volunteer" categories for comparison. Subsequently, the original researchers asked respondents who reported community ministry involvement (volunteers) to complete a second in-depth survey about their volunteer experiences (see below). In the current study, we designate those who completed this second survey as the "Volunteer Subsample" in order to distinguish them from respondents who reported volunteer involvement on the congregational survey but did not complete the follow-up volunteer survey.

\section{Motivation to Serve}

Utilizing seven Likert-type survey items drawn from the Faith Maturity Scale, we created a Motivation to Serve scale (alpha $=0.83$ ) [22]. The items included in this scale were: In my free time, I help people who have problems or needs; I do things to help protect the environment; I am active in efforts to promote social justice; I feel a deep sense of responsibility for reducing pain and suffering in the world; I give significant portions of time and money to help other people; I speak out for equality of women and minorities; and I care a great deal about reducing poverty in the U. S. and throughout the world. Respondents were asked to report how true each statement was (i.e., from "Never true" $=1$ to "Always true" =7).

\section{Life Satisfaction}

We also created a Life Satisfaction measure from another item on the Faith Maturity Scale: My life is filled with meaning and purpose ("Never true" = 1 to "Always true" =7) [22].

\section{Control Variables}

For all multivariate analyses we include variables that are potentially associated with boomer volunteering as controls: gender, ethnicity, frequency of congregational attendance, access to transportation, family caregiving responsibilities, health problems, and work responsibilities.

\subsubsection{Volunteer Survey}

The follow-up volunteer survey obtained additional information about the experiences of self-identified volunteers. Open-ended questions solicited information about types of service; recipients; specific volunteer activities; and changes volunteers experienced in their faith, values, attitudes, and behaviors. Checklists solicited information regarding congregational support for volunteer activities, and the volunteer's relationships with service recipients, motivation to volunteer, satisfaction with the experience, and the perceived relationship between service and evangelism. The volunteer survey also operationalized several key characteristics of community ministry programs drawn from the service-learning literature. These include program quality, reflection, diversity, and community voice [37]. Additionally, the survey asked about potential conflict experienced within community ministry programs. Following previous research, conflict was operationalized as "the extent to which volunteers encounter dissonance while involved in community service and the extent to which their involvement negatively affects other aspects of life" [20]. Using a seven-point Likert scale ranging from "Never" = 1 to "Always" $=7$, respondents were asked to answer 16 survey items evaluating their community ministry program in these five areas (i.e., program quality, reflection, diversity, community voice, and conflict).

\section{Findings}

Our findings are based on data drawn from the full congregational survey and a follow up volunteer survey administered to respondents who indicated involvement with at least one community ministry program. These data allow us to compare the characteristics of Protestant boomer volunteers and non-volunteers in our sample. Further, our findings reveal important information about the 
service learning contexts in which boomer congregational volunteers serve as well as some of the ways that service involvement may impact their values, beliefs and religious faith.

\subsection{Demographic Characteristics of Boomer Volunteers}

Survey data reveal that while Protestant boomer volunteers and non-volunteers are similar in some ways, there are also important differences between these groups. Demographic characteristics of boomer non-volunteers, volunteers, and a subsample of volunteers who completed the follow up survey (i.e., Volunteer Subsample) are presented in Table 1 below. Further, independent samples $t$-test results reported in Table 1 indicate statistically significant differences in the demographic profile of volunteers and non-volunteers in our study.

Table 1. Demographic Characteristics of Protestant Boomers in Sample.

\begin{tabular}{|c|c|c|c|c|c|}
\hline \multirow[b]{2}{*}{ Variables } & \multirow[b]{2}{*}{ Description } & \multicolumn{4}{|c|}{ Mean/Percent } \\
\hline & & Non-Volunteers & Volunteers & Volunteer Subsample & $t$-Test \\
\hline Age & Average age in years & 47.3 & 47.5 & 47.6 & -1.221 \\
\hline Male & & 43.3 & 40.3 & 40.6 & 1.601 \\
\hline Female & & 56.7 & 59.7 & 59.4 & -1.601 \\
\hline Education & Highest level of education & & & & \\
\hline Some College & & 27.7 & 22.1 & 17.9 & $3.404 * * *$ \\
\hline College & & 33.1 & 35.1 & 33.9 & -1.288 \\
\hline Graduate Degree & & 15.7 & 27.4 & 36.0 & $-7.540 * * *$ \\
\hline Ethnicity & Racial/ethnic identity & & & & \\
\hline African American & & 18.7 & 23.8 & 15.5 & $-3.265^{* *}$ \\
\hline Latino & & 12.9 & 10.2 & 6.9 & $2.221^{*}$ \\
\hline Live with & Relational living situation & & & & \\
\hline Alone & & 11.0 & 11.7 & 10.0 & -0.587 \\
\hline Spouse & & 70.5 & 71.7 & 76.2 & -0.701 \\
\hline Children & & 50.6 & 52.5 & 55.0 & -1.030 \\
\hline Friend & & 2.3 & 2.4 & 1.7 & -0.144 \\
\hline Others & & 5.9 & 5.9 & 4.8 & 0.019 \\
\hline Years in Cong & Years in congregation & 10.6 & 12.3 & 12.3 & $-4.005^{* * *}$ \\
\hline Involvement & Frequency of involvement & & & & \\
\hline More than 1 /week & & 34.7 & 62.2 & 72.3 & $-14.817^{* * *}$ \\
\hline Weekly & & 48.5 & 30.4 & 21.0 & $9.758 * * *$ \\
\hline Every 2-3 weeks & & 8.4 & 4.7 & 4.3 & $3.955^{* * *}$ \\
\hline
\end{tabular}

Notes: Independent sample $t$-test results indicate differences between means for Non-Volunteers and Volunteers; ${ }^{*} p<0.05 ;{ }^{* *} p<0.01 ; * * * 0.001$.

Survey data reveal that both volunteers and non-volunteers are slightly more likely to be female than male (volunteer-59.7\%; $n=834$; non-volunteer-56.7\%; $n=771$ ). The average age for both volunteers and non-volunteers in our sample is approximately 47 years (volunteer-47.5; $\mathrm{SD}=5.5$; non-volunteer-47.3; SD = 5.3). When asked about their current living situation, a majority of both groups reported that they lived with a spouse (volunteer-71.7\%; $n=1002$; non-volunteer-70.5\%; $n=959)$. Protestant boomer volunteers and non-volunteers in our sample are also similar in racial and ethnic composition. The majority identify as white (volunteer-64.9\%; $n=908$; non-volunteer-65.0; $n=897$ ). Interestingly, among boomer respondents who volunteered, almost a quarter identified as African American (23.8\%; $n=333)$. Finally, the average weekly hours worked for pay was similar for both volunteers and non-volunteers (volunteer-34.8; SD = 17.0; non-volunteer-35.6; SD = 16.6). 
In contrast to the similarities between these groups, our data reveal that Protestant boomer volunteers and non-volunteers do tend to differ significantly in areas such as educational attainment and congregational involvement. Consistent with the findings of previous research on U.S. volunteers [3], Protestant boomer volunteers report having higher levels of education than non-volunteers. Approximately sixty-two percent $(62.5 \% ; n=873)$ of Boomer volunteers indicate having completed a bachelor's degree compared to only $48.8 \%(n=662)$ of non-volunteers. Boomer volunteers also report having attended their religious congregation for a longer period of time than non-volunteers. On average, boomer volunteers reported attending their congregations for 12.3 years $(\mathrm{SD}=10.8)$ compared to 10.6 years for non-volunteers $(\mathrm{SD}=10.4) ; t(2605)=-4.01, p<0.001$. And our data indicate that boomer volunteers are more frequently involved with their congregations than non-volunteers. Approximately $93 \%$ of volunteers $(92.6 \% ; n=1269)$ report involvement with their congregations at least once a week compared to $83 \%$ of non-volunteers $(83.2 \% ; n=1096)$. Taken together, these initial findings suggest that boomer volunteers and non-volunteers tend to share demographic characteristics such as gender, race, and age. However, boomer volunteers tend to be more highly educated and may be more involved in the life of their religious congregation than non-volunteers.

\subsection{Boomers' Life Satisfaction and Motivation to Serve}

Our survey data also allow us to examine whether boomer volunteers and non-volunteers differ significantly in regards to reported life satisfaction, motivation to serve, and participation in faith practices. Table 2 presents findings that shed light on these relationships. When asked whether their "life is filled with meaning and purpose," boomer volunteers reported a small but significantly higher level of life satisfaction $(\mathrm{M}=5.89 ; \mathrm{SD}=1.06)$ than did non-volunteers $(\mathrm{M}=5.49 ; \mathrm{SD}=1.25)$. This suggests that volunteering may be related to increases in levels of life satisfaction among boomers.

Table 2. Life Satisfaction and Motivation to Serve.

\begin{tabular}{ccccc}
\hline & & Mean & & \\
\hline Variable & Non-Volunteers & Volunteers & Volunteer Subsample & $t$-Test \\
\hline Life Satisfaction & $5.49(n=1342)$ & $5.89(n=1383)$ & $5.90(n=417)$ & $9.05 * * *$ \\
Motivation to Serve & $28.33(n=1259)$ & $33.56(n=1318)$ & $33.38(n=403)$ & $18.97 * * *$ \\
\hline Notes: Independent sample $t$-test results indicate differences between means for Non-Volunteers and Volunteers; \\
$* p<0.05 ; * * p<0.01 ; * * p<0.001$.
\end{tabular}

Similar to life satisfaction, boomer volunteers indicated a significantly higher motivation to serve $(\mathrm{M}=33.56 ; \mathrm{SD}=6.75)$ than their non-volunteer counterparts $(\mathrm{M}=28.33 ; \mathrm{SD}=7.25)$. Independent sample $t$-test results reported in Table 2 indicate that there is a statistically significant difference between the mean response provided by non-volunteers and volunteers on these two items.

\subsection{Obstacles to Volunteerism among Boomers}

In addition to the influence that demographic and religious characteristics have on boomers' decisions to serve, there are additional obstacles that could prevent some boomers from volunteering such as family and work commitments, transportation, and health. Analyses of our survey data suggest, however, that boomer volunteers and non-volunteers tend to experience similar challenges and obstacles to their involvement with community ministry programs (see Table 3). When asked what factors "always" or "almost always" prevent them from being more involved in community ministries, the most common factor indicated by both groups was work responsibility (volunteer-15.6\%; $n=208$; non-volunteer-27.6\%; $n=352$ ). This comports well with previous studies that have suggested that increases in hours worked may have some negative impact on volunteering. The next most commonly reported barrier for both volunteers and non-volunteers was family and dependent care responsibilities (volunteer-11.3\%; $n=150$; non-volunteer-18.8\%; $n=236$ ). Obstacles that were 
reported by smaller numbers of volunteers and non-volunteers were health (volunteer- $2.6 \% ; n=34$; non-volunteer-3.1\%; $n=38$ ), transportation (volunteer-3.2\%; $n=42$; non-volunteer-4.1\%; $n=51$ ), and other (volunteer-9.4\%;n=16; non-volunteer-19.8\%; $n=39$ ). Additionally, independent samples $t$-tests were run to determine whether there were any significant differences in the percent of volunteers and non-volunteers reporting each of these obstacles. The only significant difference is in the percent reporting that work is an obstacle. Non-volunteers $(\mathrm{M}=3.99, \mathrm{SD}=1.99)$ tended to rate work as a more significant obstacle than volunteers $(\mathrm{M}=3.74, \mathrm{SD}=1.76), t(2602)=3.48, p<0.001$.

Table 3. Obstacles to Volunteerism among Protestant Boomers.

\begin{tabular}{|c|c|c|c|c|c|c|}
\hline \multirow[b]{2}{*}{ Obstacle } & \multicolumn{2}{|c|}{ Non-Volunteers } & \multicolumn{2}{|c|}{ Volunteers } & \multicolumn{2}{|c|}{ Volunteer Subsample } \\
\hline & Mean (SD) & $\begin{array}{l}\text { Percent Always or } \\
\text { Almost Always ( } n)\end{array}$ & Mean (SD) & $\begin{array}{l}\text { Percent Always or } \\
\text { Almost Always ( } n \text { ) }\end{array}$ & Mean (SD) & $\begin{array}{l}\text { Percent Always or } \\
\text { Almost Always ( } n \text { ) }\end{array}$ \\
\hline $\begin{array}{c}\text { Family/Dependent } \\
\text { Care }\end{array}$ & $3.28(2.07)$ & $18.8(236)$ & $3.19(1.82)$ & $11.3(150)$ & $3.31(1.72)$ & $9.7(39)$ \\
\hline Other & $3.02(2.16)$ & $19.8(39)$ & $2.89(1.98)$ & $9.4(16)$ & $3.17(1.84)$ & $7.5(4)$ \\
\hline
\end{tabular}

\subsection{Effects of Volunteering on Volunteers' Faith Practices}

Table 4 presents results from a series of OLS regression models examining the effects of volunteering on the faith practices of boomers. All models also include controls for volunteer characteristics and common obstacles to volunteering. The dependent variables in each model represent volunteers' scores on a different dimension of the Faith Practices Scale.

Table 4. Standardized Coefficients for Regression of Volunteering on Faith Practice Dimensions.

\begin{tabular}{cccc}
\hline & \multicolumn{3}{c}{ Dependent Variables } \\
\hline Independent Variables & Serving CFPS $(n=\mathbf{2 2 4 1})$ & Relating CFPS $(n=2239)$ & Total CFPS $(n=2166)$ \\
\hline Male & -0.001 & $-0.127^{* * *}$ & $-0.057^{* * *}$ \\
Age & $-0.033^{*}$ & $-0.080^{* * *}$ & $-0.048^{* *}$ \\
Education & -0.009 & $-0.051^{* *}$ & $-0.046^{* *}$ \\
African American & $0.072^{* * *}$ & $0.047^{* *}$ & $0.055^{* * *}$ \\
Active in Congregation & 0.026 & 0.021 & $0.179^{* * *}$ \\
Life Satisfaction & 0.029 & $0.237^{* * *}$ & $0.206^{* * *}$ \\
Motivation to Serve & $0.622^{* * *}$ & $0.422^{* * *}$ & $0.517^{* * *}$ \\
Health & -0.006 & 0.018 & 0.020 \\
Family Caregiving & -0.017 & 0.012 & -0.004 \\
Access to Transportation & $0.053^{* *}$ & -0.036 & 0.026 \\
Work-Related & -0.029 & -0.009 & $-0.039^{* *}$ \\
Responsibilities & $0.199^{* * *}$ & -0.014 & $0.128^{* * *}$ \\
Volunteer & 0.58 & 0.37 & 0.60 \\
$\mathrm{R}^{2}$ & $N$ & $0<0.001$ &
\end{tabular}

Note: ${ }^{*} p<0.05 ;{ }^{* *} p<0.01 ;{ }^{* * *} p<0.001$.

Findings for the final model (Total CFPS) indicate that for Protestant boomers volunteering in a community ministry program tends to have a significant positive impact on their faith practices as measured by the Faith Practices Scale $(0.128 ; p<0.001)$. Boomer volunteers tend to report more frequent participation in various faith practices than their non-volunteer counterparts. For a clearer understanding of the relationship between volunteering and faith practice, however, we break the Faith Practices Scale down into two smaller dimensions (i.e., serving and relating) and examine whether volunteering positively effects some types of faith practices more than others.

Results from our first model illustrate the effects of volunteerism on the serving dimension of the Faith Practices scale. Boomers who volunteer more frequently engage in such faith practices as 
providing hospitality to strangers, volunteering to help those who are less fortunate, and promoting social justice than non-volunteers $(0.199 ; p<0.001)$. This finding is not surprising as the community ministries with which boomers in our sample volunteer are likely to provide opportunities to develop and engage in these specific types of faith practices.

Interestingly, our results indicate that boomer volunteers do not tend to engage more frequently in "relating" practices of faith than their non-volunteer counterparts. Volunteers do not more frequently engage in such activities as confessing faults to others, forgiving and working on healing relationships, and forgiving others. While volunteering for community ministries may significantly broaden the social network of participants and expose volunteers to new groups of people, the experience appears to have minimal impact on these specific practices.

\subsection{Changes in Values, Beliefs, and Faith}

Data provided by congregational volunteers who completed the follow-up volunteer survey also make it possible for us to explore some of the ways that boomer volunteers perceive their volunteer activity impacts their own religious lives. Specifically, the follow-up survey asked congregational volunteers to indicate whether they were aware of changes that had occurred in their values, behavior, or faith resulting from involvement with congregational community ministries. Table 5 presents the results of these analyses for boomers (39-57 years) as well as results for the age cohort before (21-38 years) and after (58-95 years).

Table 5. Perceived Effects of Service on Volunteers' Values, Behavior, and Faith.

\begin{tabular}{cccc}
\hline & \multicolumn{4}{c}{ Percent of Volunteer Subsample that Perceive a Change in } \\
\hline Cohort & Values & Behavior & Faith \\
\hline 21-38 years & $80.95(n=136)$ & $70.83(n=119)$ & $73.78(n=121)$ \\
39-57 years & $84.34(n=350)$ & $71.15(n=291)$ & $80.65(n=325)$ \\
58-95 years & $76.17^{* *}(n=227)$ & $59.25^{* *}(n=173)$ & $65.86^{* * *}(n=191)$ \\
\hline
\end{tabular}

Notes: Independent sample $t$-tests revealed significant differences between means for Boomers (39-57 years) and older adults (58-95 years); ${ }^{*} p<0.05 ;{ }^{* *} p<0.01 ;{ }^{* * *} p<0.001$.

Our results indicate that a significant majority of boomer volunteers feel that their values (84.3\%; $n=350)$, behavior $(71.2 \% ; n=291)$, and faith $(80.7 \% ; n=325)$ have changed as a result of their service activity. It is interesting to note that approximately $10 \%$ fewer boomers indicate changes to their behavior than values or faith. Furthermore, the results of independent sample $t$-tests comparing the responses of younger and older cohorts to those of boomers reveal that there is a significant difference between boomers and older volunteers on these items. Boomers were significantly more likely to indicate that volunteering brought about changes in these aspects of their religious life than older volunteers. There is no significant difference between the responses provided by boomers and the younger cohort.

\subsection{Service Learning Contexts}

Congregational volunteers completing the follow-up survey were also asked to respond to 16 items evaluating characteristics of the community ministries for which they volunteered. These 16 items allowed respondents to indicate the frequency with which the community ministries demonstrated qualities that are considered desirable from a service learning perspective. Factor analysis revealed that these 16 items can be organized into five larger categories representing important service learning program characteristics: program quality, reflection, diversity, community voice, and conflict $[20,37]$. All factors have a Cronbach's alpha score of 0.65 or higher.

Table 6 below presents the average responses provided by the volunteer subsample for each of the 16 service learning items as well as the percent of volunteers reporting that each item is "always" or "almost always" true of the community ministry for which they volunteer. 
Table 6. Service Learning Characteristics Reported by Volunteer Subsample.

\begin{tabular}{|c|c|c|}
\hline Service Learning Characteristics & Mean (SD) & $\begin{array}{l}\text { Percent Always or } \\
\text { Almost Always ( } n \text { ) }\end{array}$ \\
\hline \multicolumn{3}{|l|}{ Program Quality } \\
\hline I do meaningful work in my community. & $5.60(1.23)$ & $56.0(229)$ \\
\hline I have important responsibilities in my community ministry. & $5.47(1.45)$ & $53.9(217)$ \\
\hline My community ministry involves challenging tasks. & $5.15(1.48)$ & $44.6(182)$ \\
\hline I work face to face with people we are caring for. & $5.65(1.71)$ & $63.2(258)$ \\
\hline I receive support from ministry leaders. & $5.33(1.71)$ & $53.8(213)$ \\
\hline \multicolumn{3}{|l|}{ Reflection } \\
\hline $\begin{array}{l}\text { Before the community ministry began, leaders encouraged me to think about } \\
\text { and discuss my expectations about the work. }\end{array}$ & $3.38(1.88)$ & $16.2(63)$ \\
\hline $\begin{array}{c}\text { Those of us serving in the community ministry talk about our experiences } \\
\text { with one another. }\end{array}$ & $4.72(1.55)$ & $32.2(129)$ \\
\hline $\begin{array}{l}\text { Leaders encourage critical reflection that challenges me to think in new ways } \\
\text { about my ministry. }\end{array}$ & $3.83(1.73)$ & $17.7(70)$ \\
\hline $\begin{array}{l}\text { I have opportunities to discuss connections between my community ministry } \\
\text { and biblical and church teachings. }\end{array}$ & $4.18(1.69)$ & $23.1(94)$ \\
\hline Leaders provide me with both supporting and challenging feedback. & $4.38(1.69)$ & $25.1(99)$ \\
\hline \multicolumn{3}{|l|}{ Diversity } \\
\hline $\begin{array}{l}\text { My community ministry is in a neighborhood where I don't feel safe. } \\
\text { How frequently do you encounter the following kinds of differences in } \\
\text { carrying out your ministry? }\end{array}$ & $2.51(1.57)$ & $6.2(25)$ \\
\hline Race/ethnicity & $4.81(1.70)$ & $37.5(153)$ \\
\hline Income & $5.44(1.34)$ & $50.0(203)$ \\
\hline Education & $5.38(1.32)$ & 46.7 (189) \\
\hline Personal habits & $5.12(1.46)$ & $40.6(164)$ \\
\hline Physical/mental/emotional difficulties & $4.37(1.62)$ & $24.8(101)$ \\
\hline Religious beliefs & $4.41(1.56)$ & $24.2(95)$ \\
\hline Sexual orientation & $3.04(1.76)$ & $10.4(40)$ \\
\hline Political ideas & $3.97(1.70)$ & $16.2(61)$ \\
\hline \multicolumn{3}{|l|}{ Community Voice } \\
\hline $\begin{array}{l}\text { We plan and organize the community ministry together with those } \\
\text { receiving the ministry. }\end{array}$ & $3.60(1.86)$ & $17.9(70)$ \\
\hline $\begin{array}{l}\text { Ministry leaders provide me with information about the problem (s) of those } \\
\text { receiving the ministry. }\end{array}$ & $4.18(1.74)$ & $22.4(88)$ \\
\hline \multicolumn{3}{|l|}{ Conflict } \\
\hline My involvement in this ministry creates stress in other areas of my life. & $2.66(1.43)$ & $3.7(15)$ \\
\hline $\begin{array}{l}\text { There have been conflicts or disagreements to work through in my } \\
\text { community ministry. }\end{array}$ & $2.57(1.39)$ & $3.8(15)$ \\
\hline
\end{tabular}

\subsection{Program Quality}

Our data indicate that a majority of boomer volunteers serve in contexts where characteristics associated with high program quality are frequently exhibited. More than half of boomer volunteers feel that they always or almost always do meaningful work in their community $(56.0 \% ; n=229)$, have important responsibilities in their community ministry $(53.9 \%$; $n=217)$, work face to face with the people they are caring for $(63.2 \% ; n=258)$, and receive support from ministry leaders $(53.8 \%$; 213$)$. In contrast, slightly less than half of respondents indicate that their community ministry involves challenging tasks $(44.6 \% ; n=182)$. These positive findings suggest that a majority of respondents feel supported, adequately challenged, and that they are engaged in meaningful work through their volunteering. Nevertheless, we also note that a significant percentage of boomer volunteers indicate these characteristics are not often true of their service context.

\subsection{Reflection}

In contrast, our data reveal that few boomer volunteers report frequent opportunities to reflect critically on their work either before, during or after volunteering. Only $16.2 \%(n=63)$ of volunteers 
indicated that they had always or almost always been encouraged by leaders to think about and discuss their expectations about the volunteer work. And while approximately a third of volunteers reported always or almost always talking about their volunteer experience with other volunteers $(32.2 \% ; n=129)$, a much smaller number felt encouraged by their leaders to think critically about their work $(17.7 \% ; n=70)$. Likewise, only one quarter of respondents report always or almost always being given opportunities to make connections between their service and church teachings $(23.1 \% ; n=94)$ and being provided significant feedback from their leaders $(25.1 \% ; n=99)$. The majority of boomer volunteers indicate that such opportunities for reflection are not frequent within their service contexts. This is a particularly significant finding as opportunity for reflection has often been identified as a central component of the service learning process [37].

\subsection{Diversity}

Several items on the survey examined respondents' exposure to diverse populations and contexts as a result of their volunteer activity. Our data reveal that the most common types of differences encountered by boomer volunteers were related to income $(50.0 \% ; n=203)$, education $(46.7 \%$; $n=189)$, personal habits $(40.6 \% ; n=164)$, and race/ethnicity $(37.5 \% ; n=153)$. We note that even the most common differences encountered (i.e., income and education) were experienced by half or less of the boomer volunteers. Differences that were less often encountered by volunteers were physical/mental/emotional health difficulties $(24.8 \% ; n=101)$, religious beliefs $(24.2 \% ; n=95)$, sexual orientation $(10.4 \% ; n=40)$, and political ideas $(16.2 \% ; n=61)$. These findings suggest that community ministry most often brought volunteers into contact with individuals that they considered similar to themselves in many of these categories. Furthermore, our data indicate that only a small percentage of volunteers indicate that they frequently feel unsafe in their community ministry's neighborhood $(6.2 \% ; n=25)$.

\subsection{Community Voice}

Two items gauged the volunteers' perception of community ministries' responsiveness to the needs of service recipients. Our survey data reveal that less than a quarter of boomer volunteers indicate always or almost always receiving information about the problems experienced by those that they are helping $(22.4 \% ; n=88)$. An even smaller proportion report being involved in programs that include service recipients in planning and organizing $(17.9 \% ; n=70)$. Indeed, the majority of volunteers indicate that such measures to increase ministry responsiveness to service recipients are not often characteristic of the programs with which they are involved. A significant area of improvement for community ministry programs may be in this area.

\subsection{Conflict}

Finally, two items sought to assess the extent to which boomer volunteers experienced any dissonance or personal conflict while engaged in community service. Our data suggest that very few boomer volunteers feel that their service always or almost always creates stress in other areas of their lives $(3.7 \% ; n=15)$. Likewise, few reported always or almost always experiencing conflicts or disagreements in their community ministry involvement $(3.8 \% ; n=15)$. It appears that dissonance and personal conflict are not significant problems experienced by most boomer volunteers.

To further examine the impact that service learning contexts may have on volunteers' experience, we developed a series of regression models examining the relationship between the five broad service learning characteristics identified above and volunteers' life satisfaction, motivation to serve, and perceived change in values, behavior and faith. For these analyses, we created a composite measure for each of the five service learning characteristics (i.e., program quality, reflection, diversity, community voice, and conflict) by summing volunteers' responses to the questions included in that category. These composite measures represent volunteers' evaluation of these aspects of their service learning contexts. 
Table 7 below presents the results of each of our regression models exploring the impact of service learning characteristics.

Table 7. Standardized Coefficients for Regression of Service Learning Characteristics on Life Satisfaction, Motivation to Serve, and Values, Behavior and Faith.

\begin{tabular}{|c|c|c|c|c|c|}
\hline \multirow[b]{2}{*}{$\begin{array}{l}\text { Independent } \\
\text { Variables }\end{array}$} & \multicolumn{5}{|c|}{ Dependent Variables } \\
\hline & $\begin{array}{l}\text { Life Satisfaction } \\
\qquad(n=303)\end{array}$ & $\begin{array}{c}\text { Motivation to } \\
\text { Serve } \\
(n=294)\end{array}$ & $\begin{array}{c}\text { Change in } \\
\text { Values } \\
(n=303)\end{array}$ & $\begin{array}{c}\text { Change in } \\
\text { Behavior } \\
(n=302)\end{array}$ & $\begin{array}{c}\text { Change in } \\
\text { Faith } \\
(n=295)\end{array}$ \\
\hline Male & -0.021 & $-0.144^{* *}$ & 0.012 & 0.040 & 0.041 \\
\hline Age & -0.047 & 0.075 & -0.083 & -0.054 & -0.133 * \\
\hline Education & 0.029 & 0.104 * & -0.056 & -0.093 & -0.123 * \\
\hline $\begin{array}{c}\text { African } \\
\text { American }\end{array}$ & 0.037 & 0.059 & -0.099 & -0.065 & $-0.214^{* * *}$ \\
\hline $\begin{array}{c}\text { Active in } \\
\text { Congregation }\end{array}$ & 0.093 & -0.033 & $0.141^{*}$ & 0.025 & 0.038 \\
\hline $\begin{array}{l}\text { Program } \\
\text { Quality }\end{array}$ & 0.113 & 0.072 & 0.075 & -0.015 & 0.011 \\
\hline Reflection & 0.073 & $0.198^{* *}$ & 0.131 & $0.307^{* * *}$ & 0.145 \\
\hline Diversity & $0.197 * *$ & $0.332 * * *$ & 0.063 & 0.118 & $0.133 *$ \\
\hline $\begin{array}{l}\text { Community } \\
\text { Voice }\end{array}$ & -0.067 & -0.024 & 0.014 & -0.116 & 0.002 \\
\hline Conflict & 0.060 & $0.197^{* * *}$ & 0.149 * & $0.183^{* *}$ & 0.096 \\
\hline $\mathrm{R}^{2}$ & 0.11 & 0.35 & 0.11 & 0.14 & 0.12 \\
\hline
\end{tabular}

Results in the first model reveal a significant positive relationship between life satisfaction and the opportunity to interact with diverse individuals and groups within the context of a congregation's community ministry $(0.197 ; p<0.01)$. Results from our second model reveal that contexts where reflection on service is encouraged $(0.198 ; p<0.01)$, where volunteers are exposed to diverse individuals and groups $(0.332 ; p<0.001)$, and where volunteers have experienced dissonance or personal conflict $(0.197 ; p<0.001)$ are all positively related to an increased motivation to serve. The final three models reveal that opportunities for reflection and the experience of conflict are both related to perceived changes in the volunteers' spiritual lives. The experience of dissonance or conflict is positively related to perceived changes in values $(0.149 ; p<0.05)$ and behavior $(0.183 ; p<0.01)$ while the opportunity for reflection on service is positively related to perceived changes in behavior $(0.307 ; p<0.001)$. These findings provide additional support for the notion that the characteristics of service learning contexts make a significant difference in the experience that boomer volunteers have. Further, they demonstrate some of the unique ways that service learning characteristics shape the experience of Protestant boomers.

\section{How to Promote Boomer Recruitment, Retention, and Reflection}

Within the limitations of our study, our findings on the outcomes of boomer volunteering and the characteristics of the service context (placement quality, opportunities for reflection and application, recipient diversity, and recipient involvement in planning) provide a basis for recommendations in three key result areas-recruiting, retaining/recognizing, and reflecting. We offer evidence-informed guidance to social workers, agency leaders, and congregational leaders in activating and sustaining the involvement of Protestant boomer volunteers in ways that address community need, energize the mission of the agency, and deepen the religious faith of the boomer. 


\subsection{Recruiting}

Our boomer congregational volunteers reported that volunteering benefitted them by greater life satisfaction when compared with their non-volunteering counterparts as well as by changes in their values, faith, and behavior. These outcomes of their volunteering are rarely recognized or highlighted by leaders in congregations and community service organizations. Acknowledging and communicating the potential impact of the service on the server provides an important tool in recruitment and sustaining boomer volunteers. The reports of deeper life satisfaction and substantive changes in values, faith, and behavior are evident and reflect outcomes that resonate with an age cohort seeking meaningful engagement and opportunities to reset their trajectory for the second half of life. Opportunities to strengthen faith and engage new values and behaviors may be viewed as paths to finishing well.

Like most volunteers, religiously-affiliated boomers are seeking opportunities to do important, meaningful, and challenging work in the community [4]. Our respondents reported that they always or almost always experience these opportunities a little over $50 \%$ of the time while reporting that challenging work occurs less than $45 \%$ of the time. According to these boomers, there is considerable room for improvement in creating the kinds of volunteer venues that attract the boomers to community service. Invitations should clearly specify the facets of the volunteering that offer meaning, importance, and challenge.

Significant differences in barriers to volunteering between volunteers and non-volunteers were reported in areas such as family caregiving, health, and transportation. Agency leadership and their congregational colleagues should consider what resources could be applied to mitigating the effects of these barriers, thereby allowing more opportunity for boomers to benefit from community engagement.

\subsection{Retaining/Recognizing}

A commitment to delivery of substantive volunteer opportunities that attract congregational boomer volunteers also energizes retention. Community service volunteers will benefit from an intentional evaluation process that periodically assesses the meaningfulness, importance, and challenge of the volunteer assignment and improves assignments based on this continuous review and change process.

Our respondents also reported disturbingly low frequency levels of program characteristics associated with quality of the volunteering experience such as discovering the expectations for volunteering; offering information on recipients; and providing feedback. These findings provide specific ways that congregational boomer involvement can be sustained through careful matching of volunteer expectations with a very specific description of the assignment and information on the characteristics of recipients. Consistent feedback and "checking in" on service performance may further promote retention and provide recognition for their engagement.

Previous research highlights the benefits of reciprocal relations between religious volunteers and recipients including involving them in planning of service opportunities as well as the benefit of serving those who differ from the boomer volunteer in some important way [20]. Respondents reported rare occurrences of reciprocal relations. Many respondents reported frequent interaction with recipients who differed from them by income, education, or personal habits. Apart from these differences, however, our respondents tended to serve those with similar characteristics. To the extent that increased reciprocity and "out of comfort zone" experiences promote personal and spiritual change, agency and congregational leaders may find that paying attention to these service facets will yield greater attractiveness to the venue and improved rates of retention.

\subsection{Reflecting}

As previously mentioned, faith and service have an interactive relationship, each informing the other. Agency leaders who want to retain and sustain these volunteers should welcome opportunities 
for them to reflect on the meaning of the volunteering for their faith development. Unfortunately, our respondents reported low levels of opportunities to benefit from this interactive relationship, infrequently talking about their volunteering, engaging in critical reflection; and connecting their community ministry with their religious beliefs. Agency and congregation leaders that encourage congregations to provide venues for reflection will facilitate the spiritual and personal benefits of the service. In some cases, these reflection opportunities will also help the boomer volunteer process the opportunities and issues related to the implications of service for evangelism.

\section{Study Limitations and Conclusions}

The current study has several significant limitations that must be taken into consideration. The first is the age of the data itself. The initial survey was administered in 2003 when members of the boomer cohort were between the ages of 39 and 57. Thirteen years later, the oldest members of the boomer cohort are now 70 and many are nearing or have already reached retirement age. This is significant for the issue of volunteering because age and work status have been shown to impact the amount of time individuals have to invest in volunteer service. We might expect that as members of the boomer cohort enter retirement, average levels of involvement in volunteer service will increase. While the current data cannot speak to this directly, they do suggest important factors that are likely to impact boomers' volunteer experiences as they have more time to commit to volunteering in the future.

It should also be noted that our findings are not generalizable to the entire population of congregations and attenders in the U.S. Rather than using a random sample of national congregations, we rely on a purposive sample of 35 Protestant congregations that were actively engaged in community ministry at the time of the survey. Congregations were selected to include geographic, denominational, and racial/ethnic diversity. Furthermore, data was collected only from individuals who were in attendance at a congregation on the day the survey was conducted. In addition, the sample was limited to Protestant Christians and did not address the volunteer experience of boomers in the context of other faith traditions. It is imperative that future research address this population in other religious and spiritual contexts.

Therefore, it is not possible to determine with any precision how representative our sample may be of the membership of participating congregations or of congregations in the U.S. Because our survey data are cross-sectional it is also not possible to determine the causal direction of the relationships we have identified between volunteering and other aspects of volunteers' lives and religious experience (e.g., life satisfaction, motivation to serve, faith practices).

Finally, in the current study we have adapted the service-learning characteristics originally developed by Eyler and Giles [37]. However, we included an additional category and survey items that were intended to assess the extent to which volunteers have experienced any dissonance or personal conflict while engaged in community service. In doing so, we expected that exposure to situations and contexts where volunteers experienced such dissonance may promote personal reflection and growth. However, our finding that less than four percent of boomer volunteers indicated experiencing dissonance or conflict in their service contexts suggests to us that most respondents may have interpreted the survey items more negatively than intended. Future research on the effects of service learning contexts might benefit from a close examination of the ways that the experience of conflict and dissonance impact service learning and volunteering.

Despite the limitations of the current study, our findings provide important information on the relationship between volunteering and the religious lives of boomer volunteers. Consistent with continuity theory [11], these boomers continued their engagement with the congregation and with the community ministry as they transitioned to retirement at higher rates than their non-volunteering counterparts. Also, indicators such as life satisfaction and changes in behavior, values, and faith verified the significant salience of the congregationally-based volunteer role for the boomers we sampled [13]. Further, our findings contribute to a growing body of literature examining the effects that service learning contexts have on the experience of volunteers. Our data encourage leaders of 
congregational ministry programs to provide the types of supports that our findings suggest would encourage service. This information will be valuable to social workers, congregational leaders, and administrators in organizations which rely on the service of volunteers to provide programs and services. Indeed, as more members of the boomer cohort approach retirement age over the next decade and have additional time to volunteer in their communities and congregations, research programs like this one will inform religious and community leaders as they intentionally match the unique beliefs, assets, and motivations of this cohort with volunteer opportunities and organizational supports that activate and sustain the vital work they do.

Acknowledgments: The authors acknowledge contributions to the original research project by Diana R. Garland, Beryl Hugen, David Sherwood, and Paula Sheridan.

Author Contributions: Terry A. Wolfer was co-investigator on the original research project, including conceptualization and data collection; co-conceptualized the current manuscript, drafted literature review and methods sections, revised and edited entire paper. Dennis R. Myers was co-investigator on the original research project, including conceptualization and data collection; co-conceptualized the current manuscript, drafted literature review and discussion sections, revised and edited entire paper. Edward C. Polson conducted quantitative analyses, drafted results section, and constructed data tables, revised and edited entire paper. Betsy Bevis assisted with the literature review and references.

Conflicts of Interest: The authors declare no conflict of interest.

\section{References}

1. Culp, Ken. "Recruiting and engaging baby boomer volunteers." Journal of Extension 47 (2009): 1-8.

2. Rozario, Philip. A. "Volunteering among current cohorts of older adults and baby boomers." Generations 30 (2006): 31-36.

3. "Bureau of Labor Statistics. " Available online: http://www.bls.gov/news.release/volun.htm (accessed on 10 October 2016).

4. “Corporation for National and Community Service. " Available online: https://www.nationalservice.gov/ pdf/07_0307_boomer_report.pdf (accessed on 30 September 2016).

5. Berkshire, Jennifer C. "Tapping older volunteers." Chronicle of Philanthropy 17 (2005): 42-43.

6. Einolf, Christopher J. "Will the boomers volunteer during retirement? Comparing the baby boom, silent, and long civic cohorts." Nonprofit and Voluntary Sector Quarterly 38 (2009): 181-99. [CrossRef]

7. Gonyea, Judith G., and Bradley K. Googins. "Expanding the boundaries of corporate volunteerism: Tapping the skills, talent and energy of retirees." Generations 30 (2006-2007): 78-84.

8. MetLife Mature Market Institute." Available online: http:/ /www.civicventures.org/publications/articles/ boomers_by_the_numbers.cfm (accessed on 14 December 2011).

9. Bouvier, Leon F., and Carol J. De Vita. "The baby boom-Entering midlife." Population Bulletin 46 (1991): 2-30.

10. Slevin, Kathleen F. "Intergenerational and community responsibility: Race uplift work in the retirement activities of professional African American women." Journal of Aging Studies 19 (2005): 309-26. [CrossRef]

11. Atchley, Robert C. Continuity and Adaptation in Aging. Baltimore: Johns Hopkins University Press, 1999.

12. Atchley, Robert C. "A continuity theory of normal aging." The Gerontologist 29 (1989): 183-90. [CrossRef] [PubMed]

13. Smith, Deborah B. "Volunteering in retirement: Perceptions of midlife workers." Nonprofit and Voluntary Sector Quarterly 33 (2004): 55-73. [CrossRef]

14. McClelland, David C., John W. Atkinson, Russell A. Clark, and Edgar L. Lowell. The Achievement Motive. New York: Appleton-Century-Crofts, 1953.

15. "Harvard School of Public Health and MetLife Foundation." Available online: http://www.hsph.harvard. edu/chc/reinventingaging/Report.pdf (accessed on 12 October 2011).

16. Elcott, David, and Stuart Himmelfarb. "Service-learning and Jewish baby boomers: An emerging opportunity or a best-missed chance? " Journal of Jewish Communal Service 87 (2012): 198-206.

17. Stewart, Abigail J., and Cynthia M. Torges. "Social, historical, and developmental influences on the psychology of the baby boom at midlife." In The Baby Boomers Grow Up: Contemporary Perspectives on Midlife. Edited by S. K. Whitbourne and S. L. Willis. Mahwah: Lawrence Erlbaum, 2006, pp. 23-44. 
18. Smith, Justin Davis, and Pat Gay. Active Ageing in Active Communities: Volunteering and the Transition to Retirement. Bristol: Policy Press for the Joseph Rowntree Foundation, 2005.

19. Okun, Morris A., and Josef Michel. "Sense of community and being a volunteer among the young-old." Journal of Applied Gerontology 25 (2006): 173-88. [CrossRef]

20. Myers, Dennis R., Terry A. Wolfer, and Diana R. Garland. "Congregational service-learning characteristics and volunteer faith development." Religious Education 103 (2008): 369-86. [CrossRef]

21. Dykstra, Craig. Growing in the Life of Faith: Education and Christian Practices. Louisville: Westminster John Knox Press, 1999.

22. Benson, Peter L., Michael J. Donahue, and Joseph A. Erickson. “The Faith Maturity Scale: Conceptualization, measurement, and empirical validation." Research in the Social Scientific Study of Religion 5 (1993): 1-26.

23. Garland, Diana R., Dennis R. Myers, and Terry A. Wolfer. "Protestant Christian volunteers in community social service programs: What motivates, challenges, and sustains them." Administration in Social Work 33 (2009): 23-39. [CrossRef]

24. Sherr, Michael E., Diana R. Garland, and Terry A. Wolfer. "The role of community service in the faith development of adolescents." Journal of Youth Ministry 6 (2007): 43-54.

25. Boyer, Ernest L. "The scholarship of engagement." Journal of Public Service and Outreach 1 (1996): 11-20. [CrossRef]

26. Jacoby, Barbara, and Associates. Service-Learning in Higher Education: Concepts and Practices. San Francisco: Jossey-Bass, 1996.

27. Dudley, Carl S. Next Steps in Community Ministry. Washington: The Alban Institute, 1996.

28. Garland, Diana S. Sacred Stories of Ordinary Families. San Francisco: Jossey-Bass, 2003.

29. Forbes, Kevin F., and Ernest M. Zampelli. "Volunteerism: The influences of social, religious, and human capital." Nonprofit and Voluntary Sector Quarterly 43 (2014): 227-53. [CrossRef]

30. Johnston, Joseph B. "Religion and volunteering over the adult life course." Journal for the Scientific Study of Religion 52 (2013): 733-52. [CrossRef]

31. Wuthnow, Robert. "Mobilizing civic engagement: The changing impact of religious involvement." In Civic Engagement in American Democracy. Edited by T. Skocpol and M. P. Fiorina. Washington: Brookings Institution Press, 1999, pp. 331-63.

32. Garland, Diana S. Richmond, and Gaynor Yancey. Congregational Social Work: Christian Perspectives. Botsford: North American Association of Christians in Social Work, 2014.

33. Ammerman, Nancy Tatom. Pillars of Faith: American Congregations and Their Partners. Berkeley: University of California Press, 2005.

34. Becker, Penny Edgell, and Pawan H. Dhingra. "Religious involvement and volunteering: Implications for civil society." Sociology of Religion 62 (2001): 315-35. [CrossRef]

35. Lewis, Melinda. "Service learning and older adults." Educational Gerontology 28 (2002): 655-67. [CrossRef]

36. "Charity Channel." Available online: http:// charitychannel.com/baby-boomers-adult-service-learningand-transformative-volunteer-experiences-part-1/ (accessed on 3 October 2016).

37. Eyler, Janet, and Dwight E. Giles. Where's the Learning in Service-Learning? San Francisco: Jossey-Bass, 1999.

38. Cotton, Debbie, and Timothy K. Stanton. "Joining campus and community through service learning." New Directions for Student Services 50 (1990): 101-10. [CrossRef]

39. Hugen, Beryl, Terry A. Wolfer, Diana R. Garland, Dennis Myers, David Sherwood, and Paula Sheridan. "Reconceptualizing faith and its relation to community ministry: A model of Christian faith practices." Social Work \& Christianity 30 (2003): 234-55.

40. Sherr, Michael, James Stamey, and Diana R. Garland. "Empowering faith practices: A validation study of the Christian Faith Practices Scale." Journal of Family and Community Ministries 23 (2009): 27-36. 
Article

\title{
Congregations and Social Services: An Update from the Third Wave of the National Congregations Study
}

\author{
Mark Chaves * and Alison J. Eagle \\ Department of Sociology, Duke University, Box 90088, Durham, NC 27708-0088, USA; alison.eagle@duke.edu \\ * Correspondence: mac58@soc.duke.edu; Tel.: +1-919-660-5783
}

Academic Editor: Robert Wineburg

Received: 9 March 2016; Accepted: 12 May 2016; Published: 19 May 2016

\begin{abstract}
Congregations and other religious organizations are an important part of the social welfare system in the United States. This article uses data from the 2012 National Congregations Study to describe key features of congregational involvement in social service programs and projects. Most congregations ( $83 \%$ ), containing $92 \%$ of religious service attendees, engage in some social or human service activities intended to help people outside of their congregation. These programs are primarily oriented to food, health, clothing, and housing provision, with less involvement in some of the more intense and long-term interventions such as drug abuse recovery, prison programs, or immigrant services. The median congregation involved in social services spent $\$ 1500$ per year directly on these programs, and $17 \%$ had a staff member who worked on them at least a quarter of the time. Fewer than $2 \%$ of congregations received any government financial support of their social service programs and projects within the past year; only $5 \%$ had applied for such funding. The typical, and probably most important, way in which congregations pursue social service activity is by providing small groups of volunteers to engage in well-defined and bounded tasks on a periodic basis, most often in collaboration with other congregations and community organizations.
\end{abstract}

Keywords: religion; social services; congregations; government funding; human services; volunteers; National Congregations Study

\section{Introduction}

The most lasting and important legacy of the second Bush administration's Faith-Based Initiative is the large body of research it inspired about religious organizations' place in our social welfare system. The Faith-Based Initiative did not change much on the ground. Religious organizations, including congregations, were an important part of our social welfare system long before the initiative, and they still are. Religious organizations, including congregations, received public funding to support social service activities long before the initiative, and they still do. All in all, religion's contributions to our social welfare system have not changed much since before the Faith-Based Initiative but, thanks to the research inspired by the initiative, we know much more about these contributions than we did before [1-3].

In this article we focus on congregations' social service activities. Research and writing on this subject in the midst of the Faith-Based Initiative was shaped by the policy debate, with those sympathetic to the initiative emphasizing the extent of social services performed by congregations and how much more they might be capable of doing, while those unsympathetic to the initiative emphasized how little social services congregations did, and the limits of what they reasonably could be expected to do [4-8]. With the fading of the Faith-Based Initiative, it now is clear that the policy debate obscured a fair degree of consensus concerning the basic facts about the extent and limits of congregations' social service work. Here we use data from the 2012 National Congregations Study to describe several key features of congregations' contemporary social service activity. 


\section{Data and Methods}

\subsection{Data}

The National Congregations Study (NCS) is a survey of a nationally representative sample of religious congregations from across the religious spectrum, conducted in 1998, 2006, and 2012. In those years, the General Social Survey (GSS) - a well-known in-person survey of a nationally representative sample of non-institutionalized, English- or Spanish-speaking adults conducted by NORC at the University of Chicago [9] — asked respondents who said they attend religious services at least once a year where they worship. The congregations named by these people constitute a representative cross-section of American congregations. The NCS then contacted those congregations and interviewed someone, usually a clergyperson or other leader, about the congregation's people, programs, and characteristics. Between the three waves of the NCS we now know about the demographics, leadership situation, worship life, programming, surrounding neighborhood, and more, of 3815 congregations.

The 2012 NCS (NCS-III) gathered data from 1331 congregations. The cooperation rate-the percentage of contacted congregations who agreed to participate-was $87 \%$. The overall response rate, calculated in line with the RR3 response rate developed by the American Association for Public Opinion Research [10], but not taking account of the GSS's own response rate, is between 73\% and 78\%. We report a range because the exact response rate depends on assumptions about the congregations associated with GSS respondents who declined to nominate a congregation after stating that they attended more than once a year.

The probability that a congregation appears in the NCS-III sample is proportional to its size: larger congregations are more likely to be in the sample than smaller congregations. Using weights to retain or undo this over-representation of larger congregations corresponds to viewing the data either from the perspective of attendees at the average congregation or from the perspective of the average congregation, without respect to its size. More information about this and other NCS methodological details is available elsewhere [11-14].

\subsection{Variables}

The 2012 NCS asked congregational informants, "Has your congregation participated in or supported social service, community development, or neighborhood organizing projects of any sort within the past 12 months?" Respondents were instructed to exclude any "projects that use or rent space in your building but have no other connection to your congregation." Any numerical estimate of the extent of congregations' social service activity depends on the exact way questions are asked and the extent of probing, and we know that more informal social service activities remain underreported without additional probing. Recognizing this, respondents who said "no" to this initial social services question were also asked, "Within the past 12 months, has your congregation engaged in any human service projects, outreach ministries, or other activities intended to help people who are not members of your congregation?" Congregations responding "yes" to either of these questions are considered to be engaged in social service activity of some sort.

In 2012, respondents who said "yes" to either of these questions were asked how many programs they sponsored or participated in within the last year. If they said four or fewer, they were asked to describe each program in an open-ended way. If they said more than four, they were asked to describe their four most important programs. The median number of programs reported was two for all congregations and three for congregations reporting some social service activity, with $73 \%$ of the latter reporting four or fewer programs. Five percent of congregations reported 15 or more distinct social service programs.

Interviewers were instructed to probe for each mentioned program's purpose (up to four programs), and they recorded verbatim the descriptions offered by the respondent. These verbatim descriptions were coded into a set of non-mutually-exclusive variables, each one indicating a specified program characteristic or area. Substantively, these variables indicate congregational participation in a 
wide variety of arenas, including food, clothing, health, housing, disaster relief, domestic violence, prisons, employment, and immigration. Two coders independently coded each verbatim response, with disagreements resolved by a referee.

Congregations that mentioned social service activity were asked follow-up questions about how these activities were supported. For each program mentioned (up to four), informants were asked "whether it is a program or project completely run by your congregation, or whether it is a program that is run by or in collaboration with other groups or organizations." Additional questions were asked regarding all of a congregation's social service programs, not just its most important four: how much money was directly spent by the congregation on all of the programs, whether or not a staff person devoted at least $25 \%$ of his or her time in the past 12 months to these projects, whether the congregation received outside funds to support these activities, whether any outside funds came from government sources, and whether the congregation applied within the last two years for a government grant to support any of these activities. These items help us to assess the depth of congregational involvement in social services.

Two additional items in the NCS survey help assess congregational interest in social services: whether they have had a representative of a social service organization as a visiting speaker in the past year, and whether within the past year they had a group, meeting, class, or event to plan or conduct an assessment of community needs.

To assess differences across religious groups in social service activity, we use a modified version of a standard categorization [15] of congregations into five broad religious traditions: Roman Catholic, white liberal/mainline Protestant, white conservative/evangelical Protestant, black Protestant, and non-Christian congregations. These subgroups were constructed based primarily on denominational affiliations. Protestant congregations with at least $80 \%$ of the regularly participating adults of African or African American descent were placed in the black Protestant category, regardless of denomination. White Protestant congregations unaffiliated with any denomination were placed in the evangelical category.

\subsection{Assessing Change over Time}

Brad Fulton's article in this volume [16] examines stability and change in congregations' social service activity, so we will not say much about changes between 1998 and 2012. Still, we should mention two methodological details that are relevant for assessing change over time with these data.

First, the two-question strategy described above to identify congregations doing any social services is the same one used in the 2006 NCS, but different from the approach used in the 1998 NCS, when congregations were asked only the first of these questions. This means that assessing change since 1998 requires constructing 2006 and 2012 numbers that are comparable to 1998 numbers. This can be done by ignoring responses to the follow-up question and analytically treating the 2006 and 2012 congregations that said "no" to the initial question the same way they were treated in 1998.

Second, the 1998 and 2006 NCS surveys allowed congregations to name and describe all of their social service programs, with no limit. The 2012 NCS limited these descriptions to a congregation's most important four programs. As noted above, even in 2012, questions about funding and staff support were asked with all congregational programs in mind, not just the most important four, so responses to those questions are in principle comparable over time, although interpretive caution still is advised since the context in which those questions were asked was not identical. Even more caution should be used when interpreting results implying change over time that are produced with information that was gathered about every program in 1998 and 2006 but only about the most important four programs in 2012. This includes information about specific program areas and information about collaborators. If, for example, a congregation's fifth most important program was aimed at helping people get jobs, that congregation would be coded as having a jobs program in 1998 and 2006 but not in 2012. Researchers using these data to investigate change over time should keep these details in mind. 


\section{Results}

Congregations focus most of their time and resources on worship services, religious education, and pastoral care of their members. At the same time, however, almost all also serve the needy beyond their walls in some fashion. In 2012, the vast majority of congregations (83\%) reported some involvement in social or human services, community development, or other projects and activities intended to help people outside the congregation. Since larger congregations are more likely to engage in social service work, this means that virtually all Americans (92\%) who attend religious services attend a congregation that is somehow active in this way. Mainline Protestant, Roman Catholic, and Jewish congregations are somewhat more likely to report social service activity (approximately $90 \%$ in each group) than evangelical or black Protestant congregations (approximately 80\% in each group). This difference is statistically significant at $p<0.05$. Among Christian traditions, a regression analysis shows that this difference occurs because there are more small, rural, and less-wealthy churches in the latter two groups. Regardless of these characteristics, Jewish congregations were more likely to be involved in social service activity. In any event, the vast majority of congregations in each of these religious traditions engages in some sort of social service work.

Congregations participate in a great variety of social service activities, but some types of activities are much more common than others. Figure 1 shows the variation. The single most common kind of helping activity involves food assistance, with more than half (52\%) of all congregations-almost two-thirds (63\%) of congregations active in social service-mentioning feeding the hungry among their four most important social service programs. Addressing health needs (21\%), building or repairing homes $(18 \%)$, and providing clothing or blankets to people $(17 \%)$ also were among the more commonly mentioned activities, though they were much less common than food assistance. Even more rarely mentioned by congregations as one of their most important four social service projects are those requiring longer-term commitments and more intensive interaction with the needy. Programs aimed at helping prisoners, victims of domestic violence, the unemployed, substance abusers, and immigrants, for example, each are listed by fewer than $5 \%$ of congregations as one of their most important four programs, and only $11 \%$ of congregations place any one of these activities on their top-four list.

\section{Congregations mentioning program area among their most important four programs, $\%$ of total}

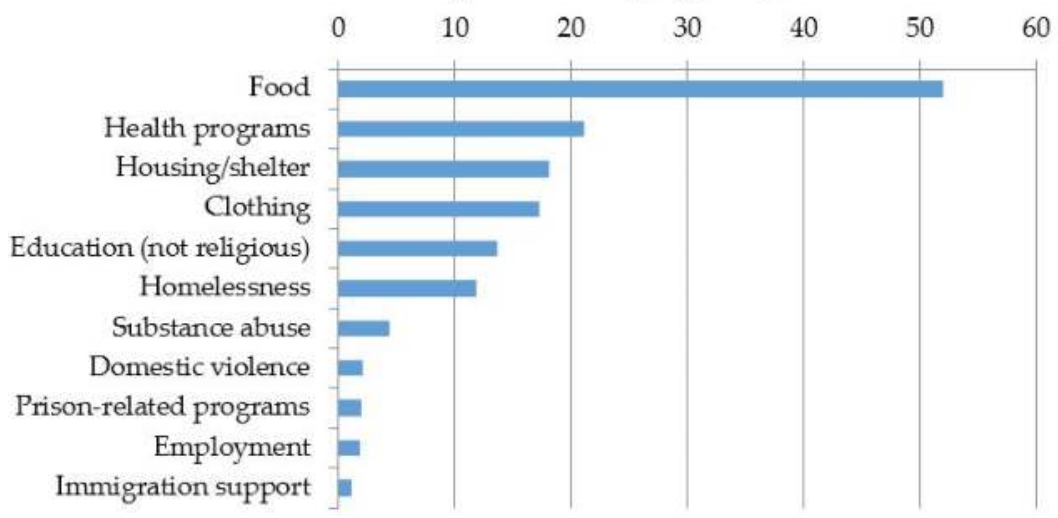

Figure 1. Congregational participation in selected social service program areas, 2012.

These results show that congregations are involved in an impressive range of activities, but categories like "food assistance" or "housing/shelter" encompass a great deal of variation both in the nature of the specific activity and in the intensity of congregational involvement in that arena. Food assistance, for example, includes donating money to a community food bank, participating 
in a Crop Walk fundraiser, supplying volunteers who serve dinner at a homeless shelter once a month, or operating a food pantry or soup kitchen. Congregations might address housing needs by organizing a team of volunteers to participate in a Habitat for Humanity project, or they might partner with city government to build affordable housing. Health assistance includes providing wheelchair ramps or home cleaning for disabled people, hosting health fairs or speakers on health-related issues, or supporting water projects in developing countries.

Table 1 helps us assess the depth of congregations' social service involvement. Its three panels provide information about the extent to which congregations are involved at all in social services, the extent to which they display an interest in social services that is serious enough to have had an outside speaker from a social service organization or a group that conducted a community needs assessment, and the extent to which they are more deeply involved in social services.

Table 1. Involvement in social services by religious congregations in the USA, 2012.

\begin{tabular}{|c|c|c|}
\hline Type of Involvement & All Congregations ${ }^{a}$ & Involved Congregations \\
\hline \multicolumn{3}{|l|}{ Expression of Interest } \\
\hline $\begin{array}{l}\text { Hosted a visiting speaker from local social service organization } \\
\text { in past year }\end{array}$ & $31.3 \%$ & $35.2 \%$ \\
\hline $\begin{array}{l}\text { Planned or conducted an assessment of community needs in } \\
\text { past year }\end{array}$ & $56.7 \%$ & $63.5 \%$ \\
\hline \multicolumn{3}{|l|}{ Deeper Involvement } \\
\hline Median \# of social service projects per congregation in past year & 2 & 3 \\
\hline $\begin{array}{l}\text { One or more paid staff spent more than } 25 \% \text { of time on social } \\
\text { service projects in past year }\end{array}$ & $14.0 \%$ & $16.9 \%$ \\
\hline $\begin{array}{l}\text { Median amount spent on social service projects per } \\
\text { congregation in past year }\end{array}$ & $\$ 700$ & $\$ 1500$ \\
\hline Applied for a government grant within past two years & $4.9 \%$ & $5.8 \%$ \\
\hline $\begin{array}{l}\text { Started a separate nonprofit organization for human service } \\
\text { projects or outreach in past two years }\end{array}$ & $8.9 \%$ & $10.1 \%$ \\
\hline
\end{tabular}

a The denominator in the first column is all congregations; the denominator in the second column is congregations that are involved in social services.

As we noted above, the vast majority of congregations- $83 \%$, containing $92 \%$ of religious service attendees-report some manner of social service involvement by saying "yes" to one of the NCS's two basic questions asking about such involvement. More than half (57\%) say that they conducted a community needs assessment in the last year, and almost one third (31\%) say that they had a visiting speaker in the last year who represented a social service organization. Although, as we noted earlier, we will not focus in this article on stability and change over time, it is worth noting that a larger percentage of congregations displayed interest in social services in 2012 than in 1998. In 1998, only $22 \%$ of congregations had a speaker from a social service agency and only $37 \%$ reported having done a community needs assessment in the last year. In 2006, the percentages were $31 \%$ and $48 \%$, respectively. Both of those increases are statistically significant. Congregations appeared to be somewhat more interested in social services and in government funding in 2012 than they were in 1998, perhaps reflecting the fact that the Faith-Based Initiative captured people's attention and, to some extent, their imaginations, even if it changed little, if anything, about the nature and extent of congregational involvement in social services. (See Brad Fulton's article in this volume [16] for a more detailed assessment of changes since 1998 in congregations' social service activities.)

The bottom panel of Table 1 shows that, despite nearly universal involvement in some sort of social service activity and relatively high levels of interest in the needs of their surrounding communities and the wider world of social service organizations, congregations' social service activities typically 
fall on the less intensive side of the range of activities mentioned above. Only $14 \%$ of congregations have at least one staff member devoting at least a quarter of their work time to social service projects. And, even excluding congregations who say that they do no social services, the median congregation in 2012 spent only $\$ 1500$ directly on its social service activities, which amounts to about $2 \%$ of the average congregation's budget.

Looking at other indicators of a deeper involvement in social services, $9 \%$ of congregations had at least one program supported with outside funding. Especially in light of all the media and research attention given the Faith-Based Initiative, congregational participation in government funding for social services seems strikingly low. Fewer than $2 \%$ of congregations had programs supported by a grant from a local, state, or national government agency, and only $5 \%$ had applied for a government grant within the last two years, while $9 \%$ of congregations reported starting a nonprofit organization focused on human services or outreach in that same time period. All of these numbers, not incidentally, are qualitatively similar to comparable NCS numbers from both 1998 and 2006, as Brad Fulton documents elsewhere in this volume [16]. The Faith-Based Initiative did not increase congregational receipt of public funds in support of their social service activity.

\section{Discussion}

Many of the numbers we report above might seem small, but they in fact represent a substantial amount of congregational contribution to community well-being. The $\$ 1500$ of direct congregational spending on their social service programs, for example, may not include special offerings congregations often gather for specific charitable purposes, the dollar value of their in-kind contributions to community organizations, or the dollar value of staff time in congregations where staff work on social service projects. Of course, congregations also support social service work through donations to denominational social service organizations like Catholic Charities, Lutheran Social Services, and Jewish Family Services.

Calculating the total monetary value of the material contributions congregations make to communities outside their own walls is very difficult. Jeff Biddle, drawing on data from a variety of sources, estimated that congregations spend $29 \%$ of their income on what he called "philanthropic activities" [17]. This estimate probably overstates congregations' spending beyond their own walls. Other calculations suggest that congregations spend only about $15 \%$ of their income on things other than running the local congregation $[18,19]$. But these low estimates assume that all of the money that congregations give to their denominations and other mission organizations is for charitable purposes, and conversely they assume that none of the money that congregations spend on their own operations benefits people beyond the membership. Neither of these assumptions is accurate. Some of the money that congregations send to their denominations supports organizational infrastructure and activities aimed mainly at members, such as seminary education for future leaders, regional and national offices of a denomination, or annual meetings of the denomination. On the other hand, some money spent on a congregation's local operations benefits people other than members, as when a clergyperson or other paid staff member spends time on a community project or when a community group uses a congregation's building for little or no charge. This accounting also misses other kinds of publicly beneficial action commonly taken by congregations, such as when they gather a special collection for an unbudgeted charitable purpose like disaster relief or organize members for volunteer work of various sorts. Another attempt to take more of this activity into account concluded that congregations spent $23 \%$ of their annual budgets on social and community service ([4], p. 88). The most prudent conclusion given the current state of knowledge is that between 15 and 30 percent of congregational income is spent in ways that benefit non-members.

Whatever the precise number, congregations clearly contribute a lot of material resources to their local communities and beyond. If we use the most conservative estimate mentioned in the previous paragraph — that beyond the $2 \%$ in direct cash outlays on social services, $15 \%$ of congregational income is spent in ways that benefit nonmembers - it would mean that about \$17 billion of the \$115 billion 
given to religious organizations in 2014 benefited non-members [20]. This estimate is too high since $\$ 115$ billion was given to all religious organizations, not just congregations. A more conservative estimate would take $15 \%$ of the $\$ 22.1$ billion contributed to congregations in a large but not complete subset of denominations in 2013 ([19], pp. 1, 17), yielding \$3.3 billion spent by congregations in ways that benefit nonmembers. This number probably is too low, since it is based on an estimate of total giving to congregations that does not include all congregations, but even by this conservative estimate, it is clear that congregations' financial contributions to their communities are substantial in absolute terms.

Several other numbers in Table 1 similarly represent substantial contributions. There are more than 300,000 congregations in the United States. If $14 \%$ of all congregations have a staff person devoting quarter time to social services, that means that more than 40,000 congregations are engaged in that way. If $9 \%$ started a nonprofit organization devoted to human services in the last two years, this means that congregations created more than 27,000 new social service organizations in the last two years. Since a small percentage of a large number equals a large number, the relatively small percentages of congregations that are more deeply engaged in social services still adds up to a substantial amount of activity.

A comparative perspective also provides helpful context for understanding the extent of congregations' contributions. The basic observation here is that congregations' level of social service involvement compares favorably to levels of effort observed in other organizations whose main purpose, like congregations, is something other than charity or social service. In what other set of organizations whose primary purpose is something other than charity or social service do the vast majority engage in at least some social service, however peripherally? In what other organizational population do as many as $52 \%$ somehow help to feed the hungry, $17 \%$ distribute clothing, $12 \%$ serve the homeless, or 14\% have staff devoting at least a quarter of their time to social service activities?

Burton Weisbrod's "collectiveness index" helps us compare congregations to other organizations in this regard [21]. This index measures the percentage of an organization's revenue that comes from contributions, gifts, and grants rather than from either sales or membership dues. The logic is that an organization is more publicly beneficial the more it benefits individuals beyond its own customers, members, or constituents, and that income from contributions, gifts, and grants measures that propensity. The estimates of congregations' philanthropic contributions described above can be understood as implying a "collectiveness" score for congregations of between 15 and 30 . That is, if $15 \%$ of congregations' income is spent trying to improve the well-being of nonmembers, we can say that $85 \%$ of member donations can be understood as "dues" and 15\% as a "gift" that supports congregations' publicly beneficial activities. Estimates of congregational spending beyond their walls that come out on the high side-closer to $30 \%$ - place congregations in the same vicinity as organizations primarily engaged in welfare (which score 43), advocacy (40), instruction and planning (37), and housing (31). Calculations that come out more on the low side still place congregations in the respectable company of Meals on Wheels (16), as well as organizations primarily engaged in legislative and political education (18), or general education (18).

Even the $2 \%$ of their income that congregations spend directly on social services looks impressive in comparative perspective. What other organizations whose primary purpose is something other than social service devote, on average, as much as $2 \%$ of their income to social services? To offer one comparison, corporations devote only about $1 \%$ of their pretax profits to charity. In absolute terms the $\$ 17.8$ billion in charitable donations given by corporations in 2014 [20] probably amounts to more than the total amount given by congregations, but, as a proportion of total income, congregations' public-serving activity compares well to the charitable activity of other organizations whose main purpose is neither charity nor social service.

All this said, the typical and probably most important way in which congregations pursue social service activity is not with direct financial contributions. It is by organizing small groups of volunteers to carry out well-defined tasks on a periodic basis. Examples abound: fifteen people spending several 
Saturdays renovating a house, five people cooking and serving dinner to the homeless one night a week, ten young people spending a summer week painting a school, ten people traveling to the sight of a natural disaster to provide assistance for a week, a couple of dozen people raising money in a Crop Walk, and so on. In this light, it is no accident that congregations are most active in areas like food assistance and home repair in which small groups of volunteers focused on a bounded task can be put to best use. Congregations are very good-perhaps uniquely good in American society-at mobilizing volunteers for this kind of work, work that usually is done, not incidentally, in collaboration with other congregations or service organizations rather than alone. In 2012, 75\% of congregations that reported any social service activity collaborated with other congregations or service organizations on at least one of their most important four programs.

Volunteer-based action has limits, of course, and attempts to push congregation-based volunteers beyond these limits (such as attempting to engage them in open-ended mentoring relationships with women transitioning from welfare to work) are fraught with difficulties [22], but congregations are and will continue to be valuable participants in our social welfare system, especially in collaboration with social service organizations able to use what congregations are best able to supply: small groups of volunteers charged with tasks that are well defined and bounded in scope and time.

\section{Conclusions}

All things considered, a fairly clear and stable picture has emerged about the extent, nature, and limits of congregations' social service activities. Most congregations focus primarily on their religious activities: worship services, religious education, and pastoral care for their own members. Virtually all also do something that can be considered social service, social ministry, or human service work. Some congregations do quite a lot of this, and a small percentage even receive government grants to support such work, but for the vast majority of congregations such activity remains a more peripheral, volunteer-driven part of what they do. Most congregational involvement in social service activity occurs in collaboration with other community organizations, and most activity is focused on meeting short-term, immediate needs, especially the need for food. The most typical, and important, form in which congregations engage in social services is by mobilizing small groups of volunteers to engage in well-defined and bounded tasks on a periodic basis.

Even though social service involvement is not their primary activity, congregations make impressive contributions in this arena. Few other organizations, aside from those whose express purpose is social service, conduct assessments of community needs and raise awareness of such to the same extent. The amount of time that paid staff and congregation-based volunteers devote to service outside the congregation itself are also significant contributions. This is the picture consistently painted by the NCS and by other research on congregations' social services. Freed from the need to discern this picture's implications for a politicized Faith-Based Initiative, we can more easily establish a common ground of knowledge and understanding about congregations' social service work.

Acknowledgments: The NCS was made possible by major grants from the Lilly Endowment, Inc. The 2012 NCS also was supported by grants from the Pew Research Center's Religion and Public Life Project, Louisville Institute, Center for the Study of Religion and American Culture at IUPUI, Rand Corporation, and Church Music Institute. The project also received generous support from Duke University and from the National Science Foundation via NSF support of the General Social Survey. Data were gathered by NORC at the University of Chicago. Shawna Anderson managed large portions of the project in the initial stages of data collection.

Author Contributions: Mark Chaves is the principal investigator for the National Congregations Study. Alison Eagle is the project manager. Alison Eagle analyzed the data. Both authors contributed to the writing.

Conflicts of Interest: The authors declare no conflict of interest. 


\section{Abbreviations}

The following abbreviations are used in this manuscript:

GSS General Social Survey

NCS National Congregations Study

\section{References}

1. Jo Anne Schneider. "Introduction to the Symposium: Faith-Based Organizations in Context." Nonprofit and Voluntary Sector Quarterly 42 (2013): 431-41. [CrossRef]

2. Wolfgang Bielefeld, and William Suhs Cleveland. "Defining Faith-Based Organizations and Understanding Them through Research." Nonprofit and Voluntary Sector Quarterly 42 (2013): 442-67. [CrossRef]

3. Mark Chaves, and Bob Wineburg. "Did the Faith-Based Initiative Change Congregations? " Nonprofit and Voluntary Sector Quarterly 39 (2010): 343-55. [CrossRef]

4. Ram A. Cnaan, Stephanie C. Boddie, Femida Handy, Gaynor Yancey, and Richard Schneider. The Invisible Caring Hand: American Congregations and the Provision of Welfare. New York: New York University Press, 2002.

5. Mark Chaves. Congregations in America. Cambridge: Harvard University Press, 2004, chap. 3.

6. Mark Chaves, and William Tsitsos. "Congregations and Social Services: What They Do, How They Do It, and with Whom." Nonprofit and Voluntary Sector Quarterly 30 (2001): 660-83. [CrossRef]

7. Bob Wineburg. A Limited Partnership: The Politics of Religion, Welfare, and Social Science. New York: Columbia University Press, 2001.

8. Bob Wineburg. Faith-Based Inefficiency: The Follies of Bush's Initiatives. Westport: Praeger, 2007.

9. Tom W. Smith, Peter V. Marsden, and Michael Hout. General Social Surveys, 1972-2012: Cumulative Codebook. Chicago: National Opinion Research Center, 2013.

10. The American Association for Public Opinion Research. Standard Definitions: Final Dispositions of Case Codes and Outcome Rates for Surveys, 5th ed. Lenexa: AAPOR, 2008, p. 35.

11. Mark Chaves, and Shawna L. Anderson. "Changing American Congregations: Findings from the Third Wave of the National Congregations Study." Journal for the Scientific Study of Religion 53 (2014): 676-86. [CrossRef]

12. Mark Chaves, and Shawna L. Anderson. "Continuity and Change in American Congregations: Introducing the Second Wave of the National Congregations Study." Sociology of Religion 69 (2008): 415-40. [CrossRef]

13. Mark Chaves, Mary Ellen Konieczny, Kraig Beyerlein, and Emily Barman. "The National Congregations Study: Background, Methods, and Selected Results." Journal for the Scientific Study of Religion 38 (1999): 458-76. [CrossRef]

14. Mark Chaves. "National Congregations Study." Available online: www.soc.duke.edu/natcong (accessed on 23 February 2016).

15. Brian Steensland, Jerry Z. Park, Mark D. Regnerus, Lynn D. Robinson, W. Bradford Wilcox, and Robert D. Woodberry. "The Measure of American Religion: Toward Improving the State of the Art." Social Forces 79 (2000): 291-318. [CrossRef]

16. Brad R. Fulton. "Trends in Addressing Social Needs: A Longitudinal Study of Congregation-Based Service Provision and Political Participation." Religions 7 (2016): article 51. [CrossRef]

17. Jeff E. Biddle. "Religious Organizations." In Who Benefits from the Nonprofit Sector. Edited by Charles T. Clotfelter. Chicago: University of Chicago Press, 1992, pp. 92-133.

18. Dean R. Hoge, Charles Zech, Patrick McNamara, and Michael J. Donahue. Money Matters: Personal Giving in American Churches. Louisville: Westminster John Knox Press, 1996, p. 34.

19. John L. Ronsvalle, and Sylvia Ronsvalle. The State of Church Giving through 2013: Crisis or Potential?. Champaign: Empty Tomb, Inc., 2015, p. 17.

20. Indiana University Lilly Family School of Philanthropy. Giving USA: The Annual Report on Philanthropy for the Year 2014. Chicago: Giving USA Foundation, 2015, pp. 16-17.

21. Burton A. Weisbrod. The Nonprofit Economy. Cambridge: Harvard University Press, 1988, pp. 76-78.

22. Paul Licherterman. Elusive Togetherness: Church Groups Trying to Bridge America's Divisions. Princeton: Princeton University Press, 2005, chap. 5. 
Article

\title{
Coopting the State: The Conservative Evangelical Movement and State-Level Institutionalization, Passage, and Diffusion of Faith-Based Initiatives
}

\author{
Rebecca Sager ${ }^{1, *}$ and Keith Bentele ${ }^{2}$ \\ 1 Department of Sociology, Loyola Marymount University, 1 LMU Dr., Los Angeles, CA 90045, USA \\ 2 Department of Sociology, University of Massachusetts Boston, 100 Morrissey Blvd., Boston, MA 02125-3393, \\ USA; Keith.Bentele@umb.edu \\ * Correspondence: rsager@lmu.edu; Tel.: +1-310-338-5967
}

Academic Editor: Robert Wineburg

Received: 23 February 2016; Accepted: 13 May 2016; Published: 7 June 2016

\begin{abstract}
In the following, we characterize the contemporary conservative Evangelical movement as an example of contentious politics, a movement that relies on both institutional and noninstitutional tactics to achieve political outcomes. Examining multiple institutional and legislative outcomes related to the Faith Based Initiative, we seek to understand why some states have established state faith-based bureaucracies and passed significantly more faith-based legislation. We find that the influence of elite movement actors within state Republican parties has been central to these policy achievements. Furthermore, we find that the presence of movement-inspired offices increase the rate of adoption of legislation, and the passage of symbolic policies increases the likelihood of passage of more substantive faith-based legislation. We argue that the examination of multiple outcomes over time is critical to capturing second order policy effects in which new institutions, the diffusion of legislation and institutions, and increasing policy legitimacy may shape subsequent legislative developments.
\end{abstract}

Keywords: faith-based; religion; state policy; social movements; conservative Evangelical

\section{Introduction}

Religious groups have long played a crucial role in the delivery of social services [1,2] From short term needs such as food pantries and soup kitchens, to more long term activities like drug treatment and job training [3], faith-based organizations have been a pillar of the social service sector [1-3]. While these groups have long done these activities on their own, in the mid-1990s there was a new push by some conservative Republicans to make these groups the default purveyors of social services and severely limit the role of government in these services [4,5]. This effort, known as the faith-based initiative, may have long fallen off the front page, but remains an important feature of the political landscape for many religious organizations.

Faith-based initiatives encompass a variety of laws and practices aimed at increasing the role of religion in government-funded social services [4]. A domestic policy priority for the Bush administration, during the Bush years, faith-based organizations received over two billion a year in grants on average [6]. Beyond the money, the faith-based initiatives created a new seat at the table of government agencies for religious groups and allowed them access to government officials in a way they had never had before [4], fundamentally altering how religious organizations and government interact.

Between 1996 and 2009, the most active years for the faith-based initiative, over 30 states created new faith-based liaison positions, state governments passed over 300 laws, and 11 federal government 
offices created faith-based offices. Conservative preferences for smaller government, a reduced welfare state, and privatization of public services have meshed nearly seamlessly with a genuine desire by many religious organizations to provide social services. In addition, this disposition has been supported aggressively by elements of the conservative Evangelical movement with an interest in fundamentally transforming the relationship between church and state. While less known than the battles over abortion or same sex marriage, we view these initiatives as extremely important developments in modern church/state relations.

In this paper, we trace the institutionalization and passage of faith-based initiatives at the state level from their inception in Texas under then Governor George Bush through his years as president during which the faith-based initiative was pursued with the most vigor at the state level. We examine multiple institutional and legislative outcomes related to faith-based initiatives, in order to better understand how Evangelical political elites and their allies have been so successful in creating faith-based institutions and uncover the drivers of the substantial variation in the volume of faith-based legislation passed within states over time. It is important to note that, while the Obama administration renamed the White House Office of Faith-Based Initiatives to include community and neighborhood partnerships, the office is intact, and all previously established federal faith-based government offices and liaisons have remained in place. Additionally, many states have maintained their faith-based bureaucracies even without the support of the Bush administration ${ }^{1}$. Thus, while the initiative certainly is not the domestic policy priority it once was, the supportive bureaucracies and policies remain largely in place.

To support the initiative, President Bush spent federal funds, created various federal level faith-based offices, and strongly encouraged states to follow his lead by enacting laws and policies in line with what he had done in Texas and at the federal level. Following the lead, 37 states created faith-based liaisons and enacted over 300 new laws that fundamentally reshaped how government interacts with religious groups [4]. This dramatic creation of a whole new area of public policy deserves our attention for several reasons. First, by examining the Faith-based Initiative, we begin to understand not just how faith-based policies became so popular over time, but also how and why other social policies can move to the forefront of a state's policy agenda. Our findings emphasize the importance of the utilization, by movement actors and allies, of political institutions and the elevation of activists to governing positions as a tactic for the creation of favorable policy. We find that the creation of movement-inspired bureaucracies and policy diffusion increases the likelihood of the subsequent passage of faith-based legislation. In addition, the passage of largely symbolic policies is found to increase the likelihood of more substantive legislative outcomes down the road. We view these dynamics as central to understanding the political successes of the conservative Evangelical movement in this policy area.

Second, we contribute to a broader understanding of policy successes by the contemporary conservative movement. In recent decades, the conservative Evangelical movement has become an increasingly salient feature of the political landscape throughout the United States [7,8]. Encompassing a variety of organizational actors ranging from religious organizations and interest groups to traditional social movement organizations, this movement strives to increase the presence of a particular brand of Christianity in public life through both cultural and political change. These varied efforts are often issue specific, including support for anti-abortion legislation, school prayer, and anti-evolution initiatives. We use the term movement here, but the development and expansion of the Faith-based

1 While the White House no longer tracks offices, the majority of states that created faith-based offices have maintained those offices or have maintained some level of faith based bureaucracy within the government. Twenty-three states currently with faith-based offices or liaisons in various agencies are: Alabama, Arizona, Arkansas, Connecticut, Delaware, Florida, Georgia, Indiana, Illinois, Georgia, Kentucky, Maryland, Michigan, Missouri, New Jersey, New York, North Dakota, Ohio, Oklahoma, Tennessee, Texas, Utah, and Virginia. There are very likely additional liaisons, however, without a singular agency tracking liaisons their identification is significantly more difficult. 
Initiative is not well described by a traditional social movement narrative. Rather the story is one of elite movement actors utilizing institutional tactics and existing political institutions to pursue movement goals. In essence, Evangelical movement actors and their allies have transformed the political opportunity structure and managed, through the creation of faith-based offices and liaisons, to literally incorporate movement goals into the bureaucratic fabric of the state. While this is distinct in many ways from the experience of a typical outsider social movement, we find this account to be consistent with, and even anticipated, by a broader contentious politics framework [9] as we detail below.

Finally, our approach underlines the utility of taking a multifaceted and longitudinal perspective on policy developments and the benefits of attention to the manner in which political gains, even symbolic ones, may transform future opportunities for success. Given that for many the Faith-based Initiative has receded into obscurity, it bears emphasizing that this policy initiative represents an important and consequential shift in governing philosophy and practice in regards to church-state separation, as well as a codification of the desire to move social services out of the government sector and into the religious sector [5]. Furthermore, the faith-based initiatives are of enduring significance as the victories for Evangelical activists in this policy area in many ways paved the way for, and shaped the strategies of, subsequent campaigns in a variety of policy arenas.

\subsection{Brief History of the Faith-Based Initiative}

The original implementation of the Faith-based Initiative, then known as Charitable Choice, passed as a component of the 1996 Welfare Reform Act [4]. There were two underlying goals of this legislation, increasing cooperation between religious groups and government agencies and increasing the amount of funding going to religious groups providing social services [10-12]. The passage of Charitable Choice and the subsequent Faith-based Initiative policies that followed in 2001 were the result of many years of lobbying by elite Evangelical movement activists who used their power within the Republican Party to promote these measures and create a new sustained state and federal level faith-based bureaucracy [4,13]. It cannot be overstated how central the efforts of conservative Evangelical actors were to early victories for the Faith-based Initiative at both the federal and state level. Unprecedented access was first gained in Texas under then-Governor George W. Bush who worked with Evangelical activists such as Marvin Olasky and Chuck Colson while creating these policies [4,14-16]. In 1996, Governor Bush created the first state faith-based liaisons and worked with state legislators to significantly alter state law regarding religion in the social service sector. Subsequently, other states, such as South Carolina, Oklahoma and New Jersey, followed suit with similar laws. Following the assumption of office by the Bush administration in 2001, significantly more states began to implement faith-based policies and practices in innovative ways, creating a wide variety of faith-based policies ranging from faith-based offices to special grant writing seminars, and even exclusive funding streams that were eventually declared unconstitutional [4].

Unlike some previous social policy changes, such as Civil Rights legislation or the Equal Rights Amendment, which had their roots in broad-based movement activism, the institutionalization of faith-based policies did not emerge from a groundswell of bottom-up movement support [16-19]. There were no marches in the street or petitions being signed in churches demanding change in state and federal policy. The political backers of the Faith-based Initiative have had to create a supportive constituency for their policy after it was already in place. This push from movement activists at all levels of government has resulted in the implementation of some type of faith-based policy or practice in nearly every state [20], with many states creating extensive faith-based bureaucratic structures that continue to exist long after initial efforts. 
Since 1996, 37 states have created a faith-based liaison position, and 24 of these states also created a faith-based office (see Figure 1$)^{2}$. In general, these offices have offered assistance and outreach to faith-based groups, as well as some help connecting with state organizations and navigating the federal government's grants systems [4]. Interviews with faith-based liaisons suggest that these offices and liaisons became either witting or unwitting insider movement activists [21] In one study, which involved interviews with 30 of 34 state faith-based liaisons between 2002 and 2005, all liaisons interviewed discussed reaching out to state legislators, state agencies, or working with governors to access funds directly or indirectly [4]. In addition to the proliferation of offices and liaison positions, the increase in state-level faith-based legislation was dramatic. Between 1996 and 2000, only 41 laws passed in a total of 10 states. Between 2001 and 2009 an additional 347 laws passed in 44 states (see Figure 2). During these years, the Faith-based Initiative became well established in the legal landscape of many states.

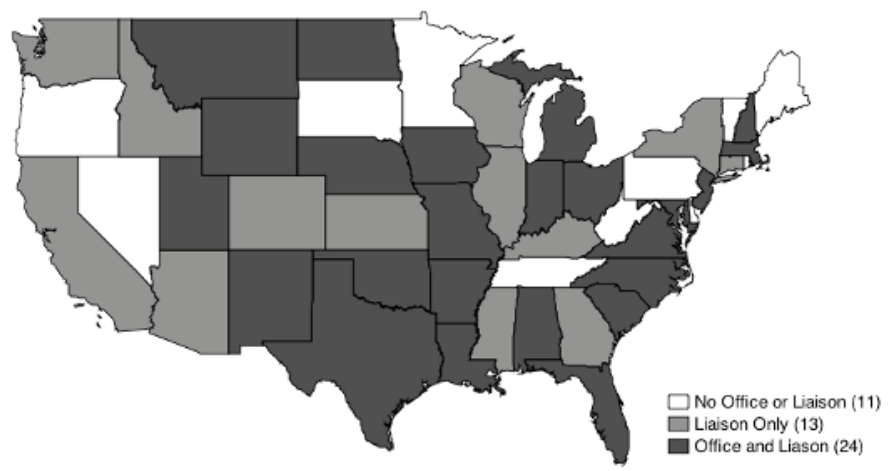

Both Alaska and Hawail created an office and a liaison position.

Figure 1. State creation of offices of faith-based and community initiatives and faith-based liaisons 1996-2009.

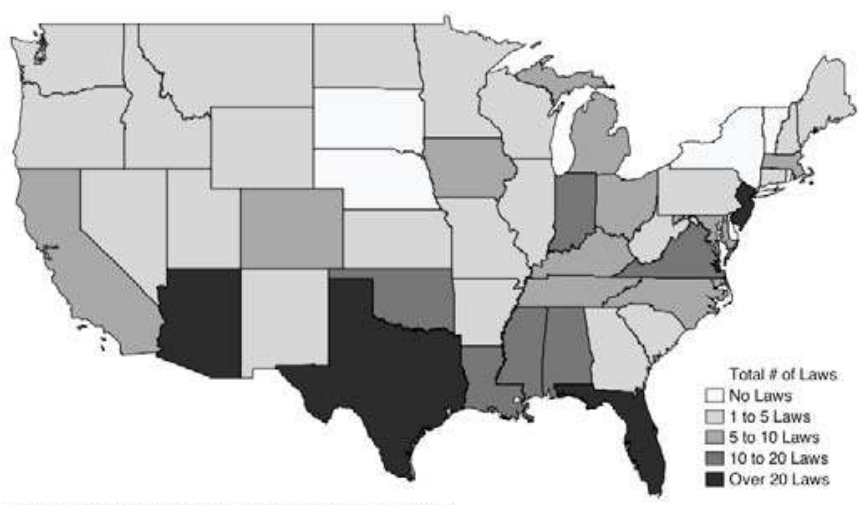

Alaska passed 6 pieces of legislation \& Hawail passed 2.

Figure 2. Faith-based legislation 1996-2009.

2 Currently, 23 of these states still have offices; however, it is unclear how many still have liaisons since many liaisons are in a variety of government offices, and the White House is no longer tracking which states have liaisons. 


\subsection{Literature Review}

\subsubsection{The Conservative Evangelical Movement and the Faith Based Initiative}

In implementing faith-based policies across state bureaucracies and legislative landscapes, the conservative Evangelical movement met the twin goals of creating social policy based on conservative Christian ideals and attempting to shift the burden of care away from the government and to religious groups $[4,5]$. To effectively implement policy and change government bureaucracy, the conservative Evangelical movement relied on a number of non-traditional movement tactics that sought to transform the character of government institutions in order to implement these policies [4]. While social movements are traditionally viewed as outsiders, in reality, social movements often use a wide range of both institutional and noninstitutional tactics. Public interest groups may engage on occasion in noninstitutional tactics (such as organizing protest events), and many movements have institutionalized over time into hybrid interest group/social movement organizations [22]. This latter type of organization may function more like a social movement during issue campaigns and more like a public interest group during periods of demobilization. Central to these phenomena are coordinated efforts by actors with shared interests to influence governments [22].

Tarrow [23] argues that the long history of American religious social movements is distinctly characterized by repeated entry into the realm of conventional politics, more so than any other category of social movement. From this perspective, the contemporary conservative Evangelical movement is not an anomaly, but directly in line with historical precedents. We view the conservative Evangelical "movement" as a complex phenomenon comprised of a diverse and ever-shifting range of organizations and issue campaigns. Traditional social movement organizations utilizing noninstitutional tactics do make up a portion of this social and political movement, but these are neither the elements nor tactics that have driven the development of the Faith-based Initiative. Thus, while there is a long rich history of populist evangelical movements and issue campaigns [24,25], we are focusing here on a specific effort and policy development that is particularly elite-driven and, we argue, better understood from a perspective that emphasizes the use of institutional and insider tactics.

\subsubsection{Conservative Evangelical Movement and Institutional Tactics}

It has been argued that a hallmark of recent conservative social movements is that they often do not utilize protest or disruption [7]. Rather, these movements rely more heavily on traditional institutional tactics (mobilizing voters, lawsuits, petitions, and lobbying) and efforts to transform the political culture and climate by electing their own members to public office [7,8,26-31].

This specific tactic of entry into institutional political arenas has been critical to the policy accomplishments of the conservative Evangelical movement, as it has provided access to elite political institutions $[7,8]$. Such access has long been conceptualized as key to movement influence and success [32]. For more traditional "outsider" movements, access to, and influence upon, political institutions may be sought through activities such as lobbying, protest, or attempts to shape public opinion [32]. For the movement actors involved in the promotion of the Faith-based Initiative, access has been cultivated by merging, in a sense, with political and state institutions through the election and appointment of movement actors to office and through the creation of new government institutions charged with the pursuit of movement goals [28,30,31].

Members of many social movements have pursued this specific approach of effecting social change and achieving movement goals by holding either political or bureaucratic positions within the state [33]. Santoro and McGuire [34] refer to such individuals as "institutional activists" who use their insider status to promote outsider goals and highlight the roles of such activists in influencing the content of policies pursued by the civil rights and women's movements. While not unique to the conservative Evangelical movement [33], we believe it fair to argue that this movement has been uniquely successful in the use of this particular tactic. Since at least the 1980s, many elite movement actors explicitly advocated entry into governing institutions as an effective route to achieving social and 
political change $[7,28,30,31]$. From school boards to state level elections, and finally to the presidential election in 2000, movement leaders focused on creating friendly political environments to achieve their goals by electing movement members as political leaders $[26,27,29,31]$. The role of evangelical influence on social policy is then better conceptualized as not about religion per se, but rather about how religion influences mediating mechanisms, such as political parties, into shifting public policy [35].

Entry by Evangelical movement actors into political institutions appears to have been the most successful and enduring at the level of state political parties, specifically Republican state parties. Orchestrated through a complex array of alliances and direct participation, religious conservatives have achieved increasing success and acceptance in the Republican Party [30,31]. A 1994 Campaign $\mathcal{E}$ Elections article suggested that the presence of movement-identified members and their allies was so substantial in some areas that the Christian Right "had a working majority in the principle state party organ" in eighteen states ([30], p. 118; [36]). In addition to using their individual positions to advance movement priorities, movement actors have been successful in many states in reshaping local party institutions and agendas to serve movement ambitions; movement activists became political actors and movement goals became items on party platforms.

\subsubsection{Faith-Based Initiatives and New Political Institutions}

When social movements are successful in gaining protections or new advantages, these gains are occasionally accompanied by the creation of new institutions tasked with monitoring or administering these protections. Two prominent examples include the creation of the National Labor Relations Board and the U.S. Commission on Civil Rights. Such institutions can provide new points of access for movements and, more broadly, may shift the balance of power between groups in conflict outside of the state. Scholars such as Burstein, Einwohner, and Hollander [37] characterize these types of outcomes as "structural" gains in which the degree of access available to movements is increased in a significant and enduring fashion. In the case of the Faith-based Initiative, the creation of state faith-based offices and liaison positions represents not just an additional point of access, but a set of long-standing and government funded positions, staffed in some cases by movement actors, charged with the pursuit of movement goals [4]. Once in place, these offices and positions create a durable link between state governments and religious organizations.

\subsubsection{Policy Diffusion as a Movement Outcome}

Scholars have long noted that neo-institutional theory may provide an especially fruitful framework for understanding social and political change [38,39]. Gross, Medvetz, and Russell assert specifically that neo-institutional theory is useful in that "it offers a theory of change qua the diffusion of practices across organizational fields" ([40], p. 338). In particular, they give the example of accounts of neoliberal policy reform that rely heavily on models of diffusion and isomorphism. We find these conceptual frames useful in the case of the Faith-based Initiative and suggest that while diffusion may occur somewhat "mechanically", it is also the case that diffusion may be an explicit movement strategy and goal. In a top-down fashion, the White House under President Bush was instrumental in the diffusion of the initiative using conferences, monthly conference calls, and letters to governors to specifically encourage states to create partnerships and relationships with each other in order to increase faith-based practices. Subsequently, as more states passed legislation related to the Faith-based Initiative and created faith-based offices and liaisons, this in and of itself increased the acceptance and legitimacy of such activities - creating legal and cultural changes that legitimated political developments originally argued to be illegitimate and unconstitutional [41,42].

\subsubsection{Movement Outcomes: Acceptance, Inclusion, and New Advantages}

Finally, in a classic formulation of movement outcomes, Gamson [43] identifies two major categories of successful movement outcomes: acceptance and new advantages. Subsequent scholars have extended and detailed the nature of these outcomes within a political and legislative context. 
Acceptance in this context "meant some basic acknowledgement by government officials that the challenger was legitimate" ([44], p. 463). New advantages include outcomes such as the passage of policies reflecting movement goals, the actual enforcement and implementation of legislated gains, or even just the entry of such legislation into the political agenda [44]. The outcome of acceptance is often viewed as a critical precursor to substantive legislative victories [22]. However, Amenta et al. [45] note that, because democratic governments usually recognize movements and interest groups as legitimate challengers, scholars have largely moved beyond viewing acceptance as a movement outcome, preferring instead to focus on "a modified version of Gamson's "inclusion", or challengers who gain state positions through election or appointment, which can lead to collective benefits" ([43], p. 291). As we noted above, the conservative Evangelical movement has been widely acknowledged as being exceptionally successful at both entering and developing an enduring bond with the GOP (Grand Old Party, or Republican Party) [46]. The movement has achieved an enviable degree of inclusion, but in the specific case of the faith-based initiative, we view the notion of "acceptance" as a movement outcome as pertinent because the basic premise of the initiative is one whose constitutionality was initially uncertain. The initiative gained a major boost in legitimacy when the Bush administration issued several executive orders that allowed states to pursue the creation of liaisons and offices in response to an official federal initiative [47,48].

In a related vein, we consider it significant that much of the legislative activity at the state-level has been largely symbolic. Since 1995, 132 individual state laws outlined provisions stating that state contracts and agencies should partner with, or include, faith-based organizations. It is important to note that these organizations had in fact partnered with state governments in all fifty states even before such laws were established [4]. These policies were created not of necessity, but out of a desire to symbolically establish the importance of faith-based social service organizations in the law. Such symbolic policies are consequential due to the signals they send to both those in power and the public [49-51]. In their research on congressional hearings, King et al. [52] find that attention to rights issues was enhanced by the cumulative number of previous hearings on such issues. They suggest that this is a function of increasing issue legitimacy, where issues or policies with analogous predecessors are more readily assumed to be within the scope of legitimate governmental authority [52,53]. In the case of policies related to the Faith-based Initiative, we believe that the aggregation of symbolic polices has contributed to establishing and increasing acceptance of religious organizations as legitimate, and in some cases preferred, recipients of government contracts and funds. In fact, many of these symbolic policies are explicitly and specifically concerned with exactly this issue: establishing the status of religious organizations as legitimate recipients or participants.

\section{Data and Methods}

To explore the determinants of various faith-based policy developments, we used multiple sources of data and statistical approaches. Data on faith-based policies were collected from two main sources. First, data on all legislation related to the Faith-based Initiative were gathered using the LexisNexis search engine. This is a standard tool used in legal research and contains data on all laws passed in every state between 1996 and 2009, including the content of each law passed, as well as its author and date of passage. Using search terms related to the faith-based initiative such as "faith-based" and "charitable choice", we have compiled a reasonably complete record of legislative implementation related to the Faith-based Initiative. Additional data on state faith-based liaisons was collected from LexisNexis, personal interviews, and the White House Office of Faith-Based and Community Initiatives. Data compiled from these three sources provide a comprehensive picture of both state faith-based liaison and office creation.

\subsection{Types of State Legislation}

In this section, we outline the various types of faith-based legislation that states have passed between 1996 and 2009. After detailed examination of over 300 laws, it was determined that the 
legislation could be divided into roughly nine different categories of laws (provided in Table 1). Broadly, the goal of this varied legislation was to create a new legal culture that would facilitate more openness to faith-based organizations (FBOs). This has been pursued through the passage of what we have categorized here as two types of legislation: symbolic and "concrete". The nine categories of laws were constructed so as to identify the primary impact of each law. The distinction between symbolic and concrete was made by assessing whether such laws would alter the allocation of resources for, or substantively change, existing policy practices in regards to FBOs. The first type, symbolic laws, are those that suggest states work with FBOs, use language that encourages participation, or create an atmosphere that suggests greater friendliness, without mandating extra participation. This category also includes laws that set up faith-friendly structures such as state administrative boards to work with FBOs. These are not laws that direct action, but rather suggest action.

Table 1. Type and number of Faith-based Initiative laws benefiting faith-based organizations.

\begin{tabular}{lc}
\hline Type of Law & $\begin{array}{c}\text { \# of } \\
\text { Laws }\end{array}$ \\
\hline "Symbolic" laws aimed at ensuring a friendly environment for FBOs (140 total) & 136 \\
\hline 1. Include language in legislation that encourages partnering and collaborating with faith-based \\
organizations, including incorporating Charitable Choice/faith-based language into state law \\
2. Create a faith-based advisory board \\
"Concrete" laws creating government access for FBOs (185 total) \\
3. Include members of the faith community on agency advisory boards \\
$\begin{array}{l}\text { 4. Make appropriations to faith-based offices/organizations } \\
\text { 5. Require government agencies to consider use of faith-based organizations for specific }\end{array}$ \\
government programs, such as drug rehabilitation, prison programs, or youth activities \\
6. Exempt faith-based organizations from standard regulations or licensing requirements \\
7. Assist with grant writing process (or assign extra points to application) \\
Other laws not categorized as either symbolic or concrete (22 total) \\
8. Create an Office of Faith-based Initiatives or FBL position * \\
9. Regulations on faith-based organizations and requiring religious groups to have their own \\
501(c)(3)s (non-profit organizations) & 45 \\
\hline \multicolumn{2}{l}{ Data was collected using LexisNexis database; Due to the collinearity that would be created by including these } \\
laws in the dependent variable while examining the impact of the presence of a faith-based office or liaison as \\
an independent variable, we have dropped these 11 laws from the dependent variable in the MMC (Multilevel \\
Model for Change) analyses.
\end{tabular}

On the other hand, concrete legislation is that which creates greater access for faith-based groups and expands faith-based practices by directing that specific actions be taken. While these laws do not necessarily create an advantage for faith-based groups (although some argue that they might), they do target FBOs for special help and explicit inclusion in the public sphere. These laws include creating funding streams geared toward the state Office of Faith-Based and Community Initiatives (OFBCI) or other "faith-based efforts", laws specifically requiring faith-based programs, or laws that require representatives from faith-based groups be appointed to state advisory boards. Table 1 lists the types of laws, the number of each, and whether we have categorized them as symbolic or concrete. In addition, there were a number of bills which were difficult to categorize (regulations regarding tax status) or that would present methodological complications if included in the analyses (those laws creating faith-based offices and liaison positions). The laws concerning tax status regulations are included in counts of total laws, but not those of symbolic or concrete legislation. The pieces of legislation creating faith-based offices and liaison positions are not included in any of the analyses of passed legislation below because the presence of these offices and positions is examined as an independent variable in those models (see Table 2). 
Table 2. State legislation by year. Number of faith-based laws passed by Year (1996-2009).

\begin{tabular}{|c|c|c|c|}
\hline Year & States & \#Laws & \#States \\
\hline 1996 & none & 0 & 0 \\
\hline 1997 & $\mathrm{AZ}(2), \mathrm{CA}(1), \mathrm{FL}(1), \mathrm{MI}(1), \mathrm{TX}(1)$ & 6 & 5 \\
\hline 1998 & FL (2), ID (1), KY(1), NJ (1) & 5 & 4 \\
\hline 1999 & $\mathrm{AZ}(2), \mathrm{CA}(1), \mathrm{FL}(1), \mathrm{LA}(1), \mathrm{MI}(1), \mathrm{NJ}(1), \mathrm{TX}(4)$ & 11 & 7 \\
\hline 2000 & $\mathrm{AZ}(3), \mathrm{CA}(2), \mathrm{CO}(3), \mathrm{FL}(7), \mathrm{KY}(1), \mathrm{MA}(1), \mathrm{MI}(1), \mathrm{NJ}(1)$ & 19 & 8 \\
\hline 2001 & $\begin{array}{c}\text { AK (1), AL (2), CA (1), FL (6), GA (1), IA (1), IN (1), LA (2), } \\
\text { MA (1), MD (1), MN (1), MT (1), NC (1), NJ (2), NV (2), } \\
\text { OH (2), OK (1), OR (2), TX (2), VA (1) }\end{array}$ & 32 & 20 \\
\hline 2002 & AZ (1), CO (1), FL (4), LA (1), MA (1), NJ (3), OK (3), PA (1), VA (2) & 17 & 9 \\
\hline 2003 & $\begin{array}{c}\text { AZ (2), CA (1), FL (3), IA (1), IL (1), IN (3), KS (1), LA (1), } \\
\text { MA (1), MD (2), MI (2), MN (1), MS (2), NJ (1), NM (3), } \\
\text { OH (1), OK (3), OR (2), TX (4), WI (1) }\end{array}$ & 36 & 20 \\
\hline 2004 & $\begin{array}{l}\text { AK (1), AL (1), AZ (3), CO (1), CT (1), FL (4), IA (1), } \\
\text { IN (1), KS (1), LA (2), MA (1), MD (1), MI (1), MO (1), MS (2), } \\
\text { NJ (2), OK (1), OR (1), VA (2), WY (1) }\end{array}$ & 29 & 20 \\
\hline 2005 & $\begin{array}{c}\mathrm{AL}(2), \mathrm{AR}(1), \mathrm{AZ}(4), \mathrm{CA}(1), \mathrm{CO}(2), \mathrm{FL}(3), \mathrm{IL}(1), \mathrm{IN}(2) \\
\mathrm{KY}(2), \mathrm{MD}(1), \mathrm{MN}(1), \mathrm{NC}(2), \mathrm{ND}(2), \mathrm{NJ}(2), \mathrm{NM}(1) \\
\mathrm{OH}(2), \mathrm{SC}(2), \mathrm{TN}(2), \mathrm{TX}(3), \mathrm{VA}(2), \mathrm{WV}(1)\end{array}$ & 39 & 21 \\
\hline 2006 & $\begin{array}{l}\text { AL (2), AZ (3), FL (1), GA (1), IN (1), KS (1), KY (1), } \\
\text { LA (3), MA (1), MD (2), MO (1), MS (2), NJ (2), OH (1), } \\
\text { SC (1), TN (2), VA (4), WA (3) }\end{array}$ & 32 & 18 \\
\hline 2007 & $\begin{array}{l}\text { AK (3), AL (2), AR (3), AZ (4), FL (3), HI (1), IL (1), IN (1), } \\
\text { MA (1), MD (2), MN (1), MO (1), MS (2), MT (1), ND (1), } \\
\mathrm{NH}(1), \mathrm{NJ}(1), \mathrm{OK}(5), \mathrm{SC}(1), \mathrm{TN}(1), \mathrm{TX}(6), \mathrm{VA}(2), \mathrm{WA}(1)\end{array}$ & 45 & 23 \\
\hline 2008 & $\begin{array}{c}\text { AK (1), AL (3), AZ (1), CA (1), FL (1), HI (1), IA (2), ID (1), } \\
\text { LA (2), MA (1), MO (1), MS (1), NC (2), NJ (1), NM (1), OK (2), } \\
\text { SC (1), TN (1), UT (1), VA (2) }\end{array}$ & 27 & 20 \\
\hline 2009 & $\begin{array}{c}\text { AL (1), AR (1), AZ (2), CA (1), IA (2), ID (1), IL (2), IN (4), } \\
\text { KS (1), KY (2), LA (2), ME (1), MI (1), MO (1), MS (3), } \\
\text { NC (1), ND (1), NJ (5), OH (1), OR (1), TN (2), TX (7), VA (2) }\end{array}$ & 43 & 23 \\
\hline & Total & 347 & 44 \\
\hline
\end{tabular}

\subsection{Statistical Models and Dependent Variables}

In the following, we employ two different statistical approaches on a variety of dependent variables related to implementation of the Faith-based Initiative. Each method allows the exploration of a different type of outcome and different specific research questions.

\subsubsection{Event History Analysis}

Our first set of analyses examine the factors associated with a greater likelihood of a state creating an OFBCI or a faith-based liaison position. We use discrete time event history analysis [54] to analyze longitudinal data on a dichotomous dependent variable indicating whether a state had created an OFBCI or appointed a faith-based liaison in a given year. Once a state had created an office or a liaison position, subsequent observations were removed from the analysis, as the state was no longer at risk of one of these events. Using a variety of techniques, we identified Alaska as an overly influential outlier on a number of variables. We have dropped Alaska from all analyses, resulting in models based on 531 state-year observations. 


\subsubsection{Multilevel Model for Change}

In our second set of analyses, we use a multilevel model for change (MMC), or hierarchical linear modeling for change [55], to explore the factors associated with increasing passage of legislation over time. The dependent variable in these analyses is the year-to-year cumulative count of faith-based legislation in each state. Each time a state passes another piece of legislation, the cumulative count increases; this creates a dependent variable that characterizes what can be thought of as trajectories of growth in faith-based legislation. As an illustration, Figure 3 displays trends in this dependent variable within four states: Texas, Connecticut, Florida and Indiana. In the cases of Texas and Florida, there is a clear pattern of consistent passage of new legislation over time. As this modeling strategy may be unfamiliar to some, we will explain the structure of the model in more detail below.

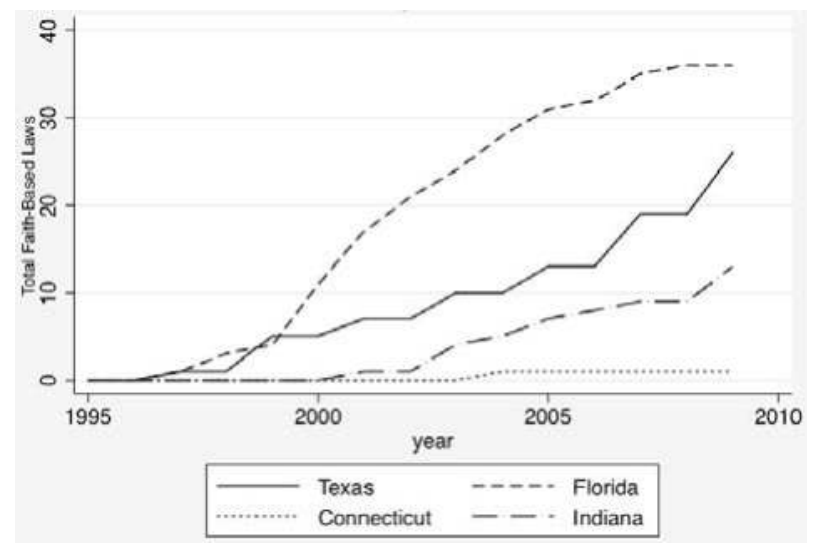

Figure 3. Cumulative count of faith-based legislation for selected states, 1995-2009.

\subsection{Independent Variables}

A number of factors may have influenced whether a state implemented particular aspects of the Faith-based Initiative. These include the size of a state's Evangelical constituency, the local strength of the conservative Evangelical social movement, a state's political environment, and policy diffusion.

\subsubsection{Indicators of Evangelical Social Movement Resources}

Measuring the strength of the Evangelical movement at the state level over time has proved to be an exceedingly difficult task. Within the movement, a number of different organizations (such as the Christian Coalition or Focus on the Family) have both risen and faded in influence and prominence over time. The challenges to constructing state-level estimates using membership or organizational data for such groups have proven insurmountable (and to our knowledge have not been overcome elsewhere). Consequently, we utilize a set of measures that do not measure the conservative Evangelical movement directly, but rather are indicators that previous research and social movement theory would lead us to expect to be strongly associated with movement strength: the percent of a state's population that identifies as Evangelical and the proportion of congregations in a state that are Evangelical.

These measures are drawn from data compiled by the Association of Religious Data Archives that draw upon the 1990, 2000, and 2010 waves of the Religious Congregations \& Membership in the United States survey (RCMS) published by the Glenmary Research Center [56-58]. These data provide the best subnational estimates of religious adherence by religious tradition currently available [19]. In addition to the estimated percentage of the state population that identifies as Evangelical, we construct a measure that identifies the proportion of all surveyed congregations that identify themselves as 
Evangelical. While these two factors are highly correlated, we expect that they might tap different important aspects of both potential movement resources and religious political culture within states. The annual values for these factors, used in the event history analyses, are estimated using a linear interpolation between survey wave years.

Two important limitations to these measures bear mentioning, one empirical and one theoretical. The empirical limitation is that the RCMS suffers from significant undercounts of particular denominations, especially historically African-American denominations [19]. As such, we consider our measures of Evangelical adherents and congregations throughout as primarily measures of white Evangelical adherents and congregations. The second limitation is that while we expect the number of adherents and congregations to be directly related to the resources upon which the Evangelical movement can and does draw, we cannot distinguish whether the political impact of, for example, a larger proportion of Evangelical state residents is a result of movement activity or political actors responding to, or reflecting, constituent preferences. As this is a rather serious limitation, we will return to this issue in the discussion.

\subsubsection{Political Opportunity Structure}

Politics-driven policy. We also examine multiple characteristics of the state political opportunity structure. First, we assess the impact of the overall political ideology of a state's legislature and governor using Berry et al.'s measure of state government ideology ${ }^{3}$ [59]. We expect states with more ideologically conservative governments will be more likely to implement legislation related to the Faith-based Initiative. Higher values on this measure indicate more ideologically liberal state governments.

Strength of the Evangelical movement within state Republican parties. It has been widely argued that, broadly speaking, entry into and influence within state Republican parties has been critical to legislative and political success for the conservative Evangelical movement. In order to investigate whether this is true in the specific case of the Faith-based Initiative, we use a variable characterizing the degree of influence and presence of the Evangelical movement within state Republican parties. This index of Evangelical movement influence was developed by Green and his colleagues [28,30]. Ranging from 1 (least influential) to 5 (most influential), the scale incorporates several measures derived from interviews and other data. In 1994, data were collected from a Campaigns and Elections study that relied upon two types of informants: state-level political insiders and Evangelical movement activists. This study was repeated in similar fashion in 2000. While not perfect, this work provides the only measure of this important aspect of Evangelical movement strength. We expect a stronger degree of influence in state Republican parties will be positively associated with both the institutionalization of, and a higher volume of legislation related to, the Faith-based Initiative.

Problem-driven policy. Advocates for faith-based initiatives are often driven by a genuine desire to facilitate the capacity of faith-based organizations to provide social services to their target populations, often the poor. As such, it is entirely possible that more extensive implementation of the Faith-based Initiative may develop, at least in part, as a response to the severity of poverty within a state. In order to assess this possibility, we include the Census Bureau's state poverty rates.

The Bush Administration. Finally, in our Event History analyses, we include a dummy variable indicating the years in which the Bush Administration was in office. The Bush administration used multiple approaches to encourage states to create their own faith-based institutions. We expect that this alone significantly increased the likelihood of any state taking such steps.

3 This measure was created using the roll call voting records of state legislators, the partisan divisions of the elected bodies, the outcomes of congressional elections, and the party of the state governor [59]. 


\subsubsection{Second Order Policy Effects}

Institutionalization. In our MMC analyses, we also examine the influence that institutionalization of the Faith-based Initiative at the state level may have on subsequent legislative developments. We include a dummy variable indicating whether a state has created a faith-based liaison position or faith-based office. As state liaisons have reported working with governors and state legislators to propose and pass faith-based initiatives, we expect the presence of offices and liaisons to increase the likelihood of adoption of faith-based legislation. In a small number of cases, pieces of legislation were primarily concerned with the creation of a faith-based office or liaison position (most offices and liaison positions were established by governors). In order to avoid artificially inflating the association between legislative passage and the presence of an office or liaison, we have removed these 11 laws from the cumulative count of total legislation ${ }^{4}$.

Institutional Duration. Furthermore, we expect that newer offices or liaisons may face a greater challenge in overcoming institutional inertia. Conversely, more established offices or liaisons may be more likely to have cultivated the connections, relationships, and institutional legitimacy necessary to get things done. In order to test this, we include a measure of institutional duration, which is the annual count of the number of years since the establishment of a faith-based office or liaison.

Policy Diffusion. The creation of faith-based offices or the passage of faith-based legislation in nearby states may increase the likelihood of a state adopting similar institutions and policies. In order to uncover evidence of state-level diffusion, we examine the impact of the count of contiguous states with faith-based offices or liaison positions within the Event History analyses. In the MMC analyses, we explore the impact of the count of faith-based legislation passed in contiguous states in the previous year on the passage of new legislation in a state.

Policy Legitimacy. Finally, in one set of MMC analyses, we examine whether the aggregation of symbolic legislation within a state increases the likelihood of the passage of more concrete legislation. This variable is operationalized as a state's cumulative count of symbolic faith-based legislation lagged by one year. Extending King at al.'s concept of issue legitimacy to policies themselves, it may be the case that recurrent passage of such legislation enhances the legitimacy of policy developments in this specific area and in doing so lays the groundwork for more substantive, if initially controversial, legislation. However, it may also be the case that symbolic legislation may be passed as a substitute for concrete action, as was suspected by some in the case of the Faith-based initiative [4,5,7].

\subsection{Control Variables}

In addition to these theoretically relevant variables, policy research suggests that particular socio-demographic and economic characteristics of states should be taken into account [60-62].

Economic. States with fewer economic resources may be less likely to appoint faith-based liaisons or create offices, as such innovations may be perceived as too costly [60]. This factor is included as a control in all models, in the form of real state revenue per capita. Revenue data are from the Statistical Abstract of the United States [63].

Religiosity. Second, we control for the overall level of religiosity in a state with a measure of estimated total religious adherents (to any religion) in a state relative to the state population. We expect that states with larger proportions of religious adherents may be more supportive of faith-based policies regardless of the efforts of Evangelical movement actors. In order to control for this possibility, we include this variable in all models. These data are also drawn from the Religious Congregations $\mathcal{E}$ Membership in the United States survey and are interpolated between survey wave years (1990, 2000, and 2010).

4 Our institutionalization dummy variable indicates the presence of an office or liaison in the year after the passage of such legislation. We also ran these analyses including these 11 laws and find that the results are identical in all substantive respects. 


\section{Results}

\subsection{Event History Analyses}

Institutional Impacts: The Creation of Faith-Based Offices and Liaisons

This first set of analyses examines the state-level factors associated with the creation of either a faith-based office or liaison position. Table 3 contains the results of six Event History models. The first four models are reduced models examining the impact of a variety of movement and political factors individually in models containing only control variables. Our full models 5 and 6 include all factors and introduce our two highly correlated measures of Evangelical movement resources separately. Within both of these full models, the following factors are significantly associated with an increased likelihood of state creation of an office or liaison: the variable characterizing the influence of the Christian Right in the state Republican Party, the Bush administration dummy variable, and our measure of policy diffusion. It is noteworthy that, controlling for other factors, neither the size of a state's Evangelical community in terms of adherents or organizational presence appear to be significantly related to whether a state established a faith-based office or liaison. Indeed, the only characteristic internal to states related to this outcome is the strength of movement actors within the state Republican Party. The two remaining factors, the Bush Administration dummy and the diffusion variable, both capture pressures and processes originating outside of states.

Table 3. Event History Analysis of State Creation of a Faith-Based Liaison Position and/or Office of Faith-Based Community Initiatives: 1998-2007 *.

\begin{tabular}{|c|c|c|c|c|c|c|}
\hline & Model 1 & Model 2 & Model 3 & Model 4 & Model 5 & Model 6 \\
\hline \multicolumn{7}{|l|}{ Evangelical Movement Resources } \\
\hline$\%$ White Evangelicals & $\begin{array}{c}1.02 \\
(0.024)\end{array}$ & & & & $\begin{array}{c}0.99 \\
(0.03)\end{array}$ & \\
\hline$\%$ Congregations Evangelical & & $\begin{array}{c}15.34 \\
(28.92)\end{array}$ & & & & $\begin{array}{l}1.28 \\
(2.23)\end{array}$ \\
\hline \multicolumn{7}{|l|}{ Political Opportunity Structure } \\
\hline $\begin{array}{c}\text { Republican Control of Both Houses } \\
\text { of the State Legislature }\end{array}$ & & & $2.01 *$ & & $1.95^{\wedge}$ & $1.92^{\wedge}$ \\
\hline & & & $(0.70)$ & & $(0.73)$ & $(0.73)$ \\
\hline Ideology of State Government (t-1) & & & $\begin{array}{l}0.97^{*} \\
(0.01)\end{array}$ & & $\begin{array}{l}0.97^{*} \\
(0.01)\end{array}$ & $\begin{array}{l}0.97^{*} \\
(0.02)\end{array}$ \\
\hline Evangelical Movement & & & $1.60 * *$ & & $1.78^{* * *}$ & $1.69 * *$ \\
\hline Influence in State Republican Party & & & $(0.22)$ & & $(0.28)$ & $(0.25)$ \\
\hline Bush Administration in Office & & & $\begin{array}{c}8.68^{* * *} \\
(6.92)\end{array}$ & & $\begin{array}{l}4.14 \\
(3.6)\end{array}$ & $\begin{array}{c}4.00 \\
(3.54)\end{array}$ \\
\hline Policy Diffusion & & & & & & \\
\hline $\begin{array}{l}\text { Number of Neighboring States } \\
\text { Faith-based Office }\end{array}$ & & & & $\begin{array}{l}1.56 * \\
(0.31)\end{array}$ & $\begin{array}{l}1.65 * \\
(0.34)\end{array}$ & $\begin{array}{l}1.66^{*} \\
(0.35)\end{array}$ \\
\hline Control Variables & & & & & & \\
\hline Per Capita State Revenue & $\begin{array}{c}0.99 \\
(0.12)\end{array}$ & $\begin{array}{l}1.10 \\
(0.10)\end{array}$ & $\begin{array}{l}1.11^{\wedge} \\
(0.07)\end{array}$ & $\begin{array}{c}0.97 \\
(0.14)\end{array}$ & $\begin{array}{l}1.12^{\wedge} \\
(0.07)\end{array}$ & $\begin{array}{l}1.12^{\wedge} \\
(0.06)\end{array}$ \\
\hline Poverty Rates & $\begin{array}{c}0.95 \\
(0.07)\end{array}$ & $\begin{array}{c}0.91 \\
(0.07)\end{array}$ & $\begin{array}{c}0.97 \\
(0.06)\end{array}$ & $\begin{array}{c}0.99 \\
(0.04)\end{array}$ & $\begin{array}{c}0.95 \\
(0.08)\end{array}$ & $\begin{array}{c}0.92 \\
(0.08)\end{array}$ \\
\hline$\%$ Religious Adherents & $\begin{array}{c}1.01 \\
(0.016)\end{array}$ & $\begin{array}{l}1.03 \\
(0.02)\end{array}$ & $\begin{array}{c}1.02 \\
(0.02)\end{array}$ & $\begin{array}{c}1.02 \\
(0.02)\end{array}$ & $\begin{array}{c}1.02 \\
(0.02)\end{array}$ & $\begin{array}{c}1.02 \\
(0.02)\end{array}$ \\
\hline $\begin{array}{c}\text { Log Pseudolikelihood } \\
N\end{array}$ & $\begin{array}{c}-100.15 \\
357\end{array}$ & $\begin{array}{c}-99.14 \\
357\end{array}$ & $\begin{array}{c}-90.69 \\
357\end{array}$ & $\begin{array}{c}-98.05 \\
357\end{array}$ & $\begin{array}{c}-87.54 \\
357\end{array}$ & $\begin{array}{c}-87.69 \\
357\end{array}$ \\
\hline
\end{tabular}

Notes: ${ }^{\wedge} p<0.1,{ }^{*} p<0.05,{ }^{* *} p<0.01,{ }^{* * *} p<0.001 ;{ }^{*}$ Exponentiated coefficients are presented so that a hazard ratio interpretation can be applied to the coefficients above. It should be noted that all models contain a set of year dummy variables for the years 2000-2001, 2002-2003, 2004-2005, 2006-2007 but are not presented above.

The Bush administration dummy variable is the single most influential factor in these analyses indicating that the odds of any state creating an office or liaison were nearly nine times higher following 
the 2000 election. The second most influential factor is the Christian Right influence variable, which ranges from 1 (weak influence) to 5 (great influence). The results of Model 6 indicate that states in which the Christian Right are characterized as having great influence on the state Republican Party have an estimated odds of creating an office or liaison that is three times larger than those in a state with weak Christian Right influence. Finally, the odds of a state creating an office or liaison when two neighboring states have done so are roughly $50 \%$ higher than a state with no such developments in contiguous states.

In summary, beyond the nationwide promotion of the creation of faith-based institutions by the Bush administration, the strength of the Christian Right within Republican state parties and policy diffusion appear to be the central drivers of state adoption of faith-based offices and liaison positions.

\subsection{Multilevel Model for Change Analyses}

\subsubsection{Legislative Impacts: The Passage of Faith-Based Legislation}

In the following set of analyses, we explore the factors influencing trajectories of change in the cumulative count of state faith-based legislation using a multilevel model for change. We find this approach both appropriate and highly useful for a number of reasons. First, this approach allows us to examine whether developments within states over time, such as the creation of faith-based institutions or shifts in the ideological composition of state governments, are associated with legislative outcomes. Simultaneously, we can assess whether relatively stable state characteristics, such as the proportion of Evangelicals in a state, drive substantially different overall trends of legislative activity between states. This is important, as we do not expect within-state variation in such factors to matter, that is, minor changes over time in the percent of Evangelical residents are not expected to drive trends. Rather, it is the influence of stable differences across states that are of interest. Such assessments are not possible in the context of either fixed-effects or first-differenced time series approaches, which are often used to examine legislative outcomes ${ }^{5}$.

In this two-level model, states are the larger, level II units and the cumulative counts of state legislation over time are the level I units. The level I model describes how states change over time, while the level II model describes how these changes vary across states [49]. The following is our level I model for cumulative faith-based legislation, $Y$, for each state $s$ at time $t$ :

$$
\mathrm{Y}_{\mathrm{ts}}=\pi_{01}+\pi_{1 \mathrm{~s}} \text { TIME }_{\mathrm{ts}}+\pi_{2 \mathrm{~s}} \text { OFFICEorLIAISON } \mathrm{ts}_{3 \mathrm{~s}}+\pi_{3 \mathrm{GOVIDEO}} \text { Gs }+\ldots \ldots \pi_{\mathrm{qs}} \mathrm{X}_{\mathrm{qts}}+\mathrm{e}_{\mathrm{ts}} .
$$

Annual state levels of cumulative legislation are a function of an intercept $\left(\pi_{01}\right.$, the grand mean of cumulative legislation across states when all predictors are set to mean values), TIME $\left(\pi_{1 \mathrm{~s}}\right)$, the presence of a state OFBCI or liaison (OFFICEorLIAISON) at time $t\left(\pi_{2 \mathrm{~s}}\right)$, while controlling for other variables included in the level I analysis $\left(\pi_{\mathrm{qs}}\right)$.

Using only time-varying independent variables, the level I analysis attempts to explain within-state year-to-year change in state faith-based legislation. Specifically, given the construction of the dependent variable as a cumulative count, the variable will either stay the same year-to-year, meaning no passage of legislation, or it can increase indicating the passage of legislation. The level II analysis, on the other hand, utilizes a set of time-invariant independent variables and examines the manner in which largely stable state characteristics predict the value of both the intercept and the slope of an individual state's

5 In addition, pooled cross-sectional analyses often raise serious problems in terms of high levels of autocorrelation and heteroscedasticity, both of which are present in these data. The error structure of the MMC model allows residuals to be both autocorrelated and heteroskedastic within the larger level II units (states, in this analysis), which allows more efficient use of the data [55]. Finally, one key assumption of the MMC is that unobserved panel level effects are not related with the variables in the analyses. Using a Hausman test, it was determined that that this assumption is satisfied in the dataset and the use of an MMC approach is appropriate. 
entire trajectory of change in cumulative legislation over the period examined. The outcome variables in the level II model are the $\pi$ parameters from the level I model:

$$
\begin{aligned}
& \pi_{01}=\beta_{00}+\beta_{01} \text { CRSTRENGTH }_{1 \mathrm{~s}}+\ldots \ldots+\beta_{0 \mathrm{q}} \mathrm{X}_{\mathrm{qs}}+\mathrm{r}_{0 \mathrm{~s}} \\
& \pi_{1 \mathrm{~s}}=\beta_{00}+\beta_{11} \text { CRSTRENGTH }_{1 \mathrm{~s}}+\ldots \ldots+\beta_{1 \mathrm{q}} \mathrm{X}_{\mathrm{qs}}+\mathrm{r}_{0 \mathrm{~s}} \\
& \pi_{2 \mathrm{~s}}=\beta_{00}+\mathrm{r}_{0 \mathrm{~s}}
\end{aligned}
$$

For example, we hypothesize that states with a stronger Christian Right influence in state Republican parties will experience more substantial increases in cumulative faith-based legislation over the entire 1996-2009 period.

The level II model assesses factors that impact initial values (the intercept) and rates of increase or decline in the dependent variable over the entire period examined (literally, the slopes in Figure 3). In 1996, no state had passed any faith-based legislation. As a consequence, the initial values, or the intercept for the MMC model, for all states is zero. As such, we will not be examining or discussing determinants of initial values in the following. The trajectory of change in total legislation for each state over the entire period examined is characterized in $\pi_{1 \mathrm{~s}}$ and is regressed upon a measure of Christian Right party influence (CRSTRENGTH) and a vector " $\mathrm{X}_{\mathrm{qs}}$ " of our other time-invariant predictors. The other time-invariant variables in the following analyses, all in the form of their average over the period studied, are \% white Evangelical, \% congregations Evangelical, and \% religious adherents.

\subsubsection{Determinants of Year-to-Year Change in Total Faith-Based Legislation}

Models 1-5 in Table 4 present our reduced models that contain all control variables and introduce each independent variable individually. Models 6 and 7 are our full models that contain all variables and introduce our correlated measures of Evangelical strength individually. First, we discuss the variables that are examined at level I of the models, those which predict change year-to-year in cumulative legislation.

Beginning with our measure of institutionalization, we find that annual change in legislation is strongly influenced by the presence of either a state OFBCI or the presence of a faith-based liaison. Based on an examination of the predicted values for Model $6^{6}$, a hypothetical state with average values on all variables and an office or liaison would pass roughly two more pieces of faith-based legislation every three years than an identical hypothetical state lacking an office or liaison. In addition, the likelihood of a state passing legislation increases substantially the longer a state has had a faith-based office or liaison. We can only speculate on the mechanisms driving this effect. This may represent some combination of faith-based liaisons deepening their relationships with legislators, finding ways to overcome institutional inertia, or a consequence of the increasing institutional legitimacy of more longstanding offices or liaisons. We should mention that these two measures, presence of an office or liaison and the number of years such offices or positions have existed, are unavoidably highly correlated. However, both factors consistently remain highly statistically significant $(p<0.000)$, and have nearly identical impacts, in the absence of one another in both full and reduced models.

Turning to one aspect of a state's political context, we find that states with more conservative state governments are more likely to pass legislation year-to-year. Finally, our diffusion variable (total faith-based legislation passed in contiguous states as of the previous year) is highly significant, indicating that states with neighbors that are actively pursuing a faith-based legislative agenda are more likely to pass such legislation themselves.

6 This is the full model with the best fit in these analyses. 


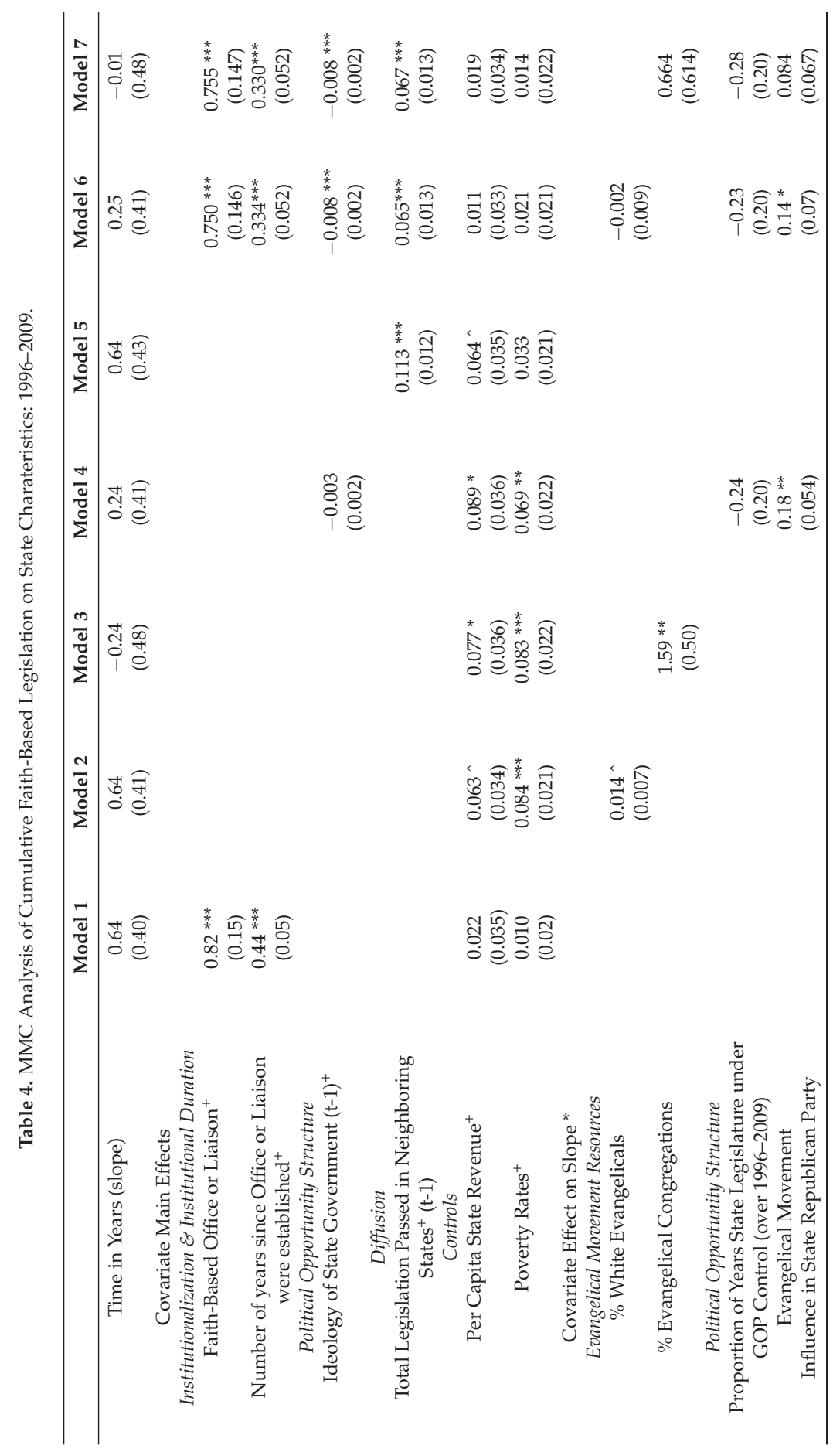


Religions 2016, 7, 71

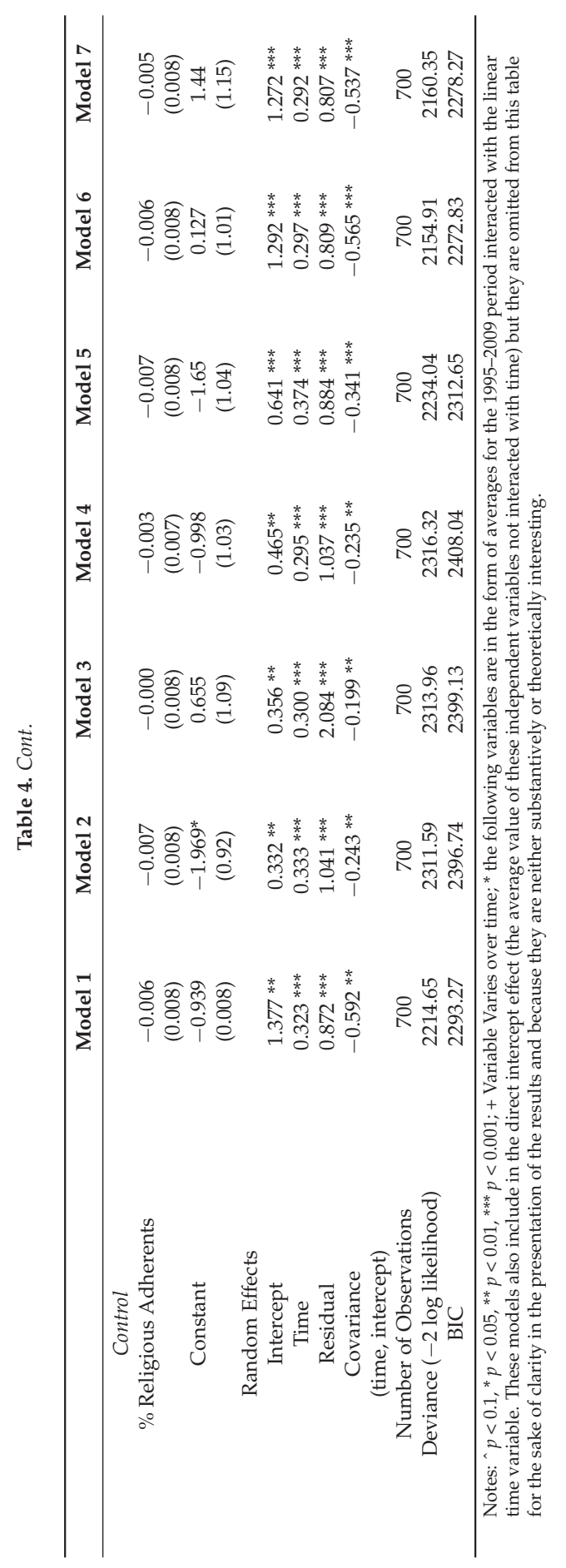




\subsubsection{Determinants of Overall Trends in Total Faith-Based Legislation}

Of the level II variables examined, only one factor emerges as significantly influential of overall trajectories of change in cumulative legislation consistently across models: the strength of the Christian Right within the state Republican Party. Using the coefficients from Model 6, Figure 4 displays the predicted values of cumulative legislation for three states where the Christian Right has very weak, moderate, and very strong influence within the state Republican Party (all other variables set to mean values). The magnitude of this effect suggests that this factor is one of the most influential in these analyses.

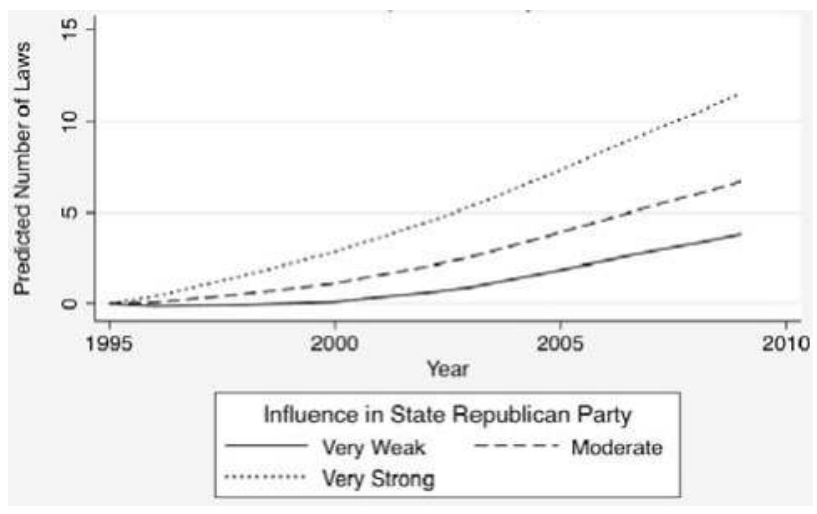

Figure 4. Predicted cumulative faith-based legislation for states containing Christian right social movements with weak, moderate, \& strong influence within the State Republican Party

The only other level II variable that is significant in any model is the percent of state congregations that are Evangelical (reduced Model 3). This suggests, as expected, that states with larger numbers of Evangelical congregations have passed more faith-based legislation. The proportion of Evangelical congregations is positively correlated with Christian Right influence in state Republican parties $(r=0.61)$. Not surprisingly, on average, the Christian Right has more influence in Republican parties in states where there is a larger Evangelical presence. In order to assess the extent to which this collinearity is impacting these estimates, models 6 and 7 were run omitting the Christian Right party influence variable (see Model 2, Table 5). These models indicate that, controlling for non-collinear factors, the measure of Evangelical congregations is highly significant and positively associated with a larger volume of faith-based legislation in the absence of the state Republican Party influence variable. Overall then, states with larger proportions of Evangelical congregations and more Evangelical influence in state Republican parties are more likely to pass legislation, and, in many cases, these are the same states ${ }^{7}$.

7 Given the high collinearity between these two variables, we cannot adjudicate between or assess the relative contributions of these two factors. However, across a wide range of models and while controlling for other indicators of Evangelical movement strength, the Evangelical party influence variable consistently emerges as a better predictor of faith-based legislative activity. 


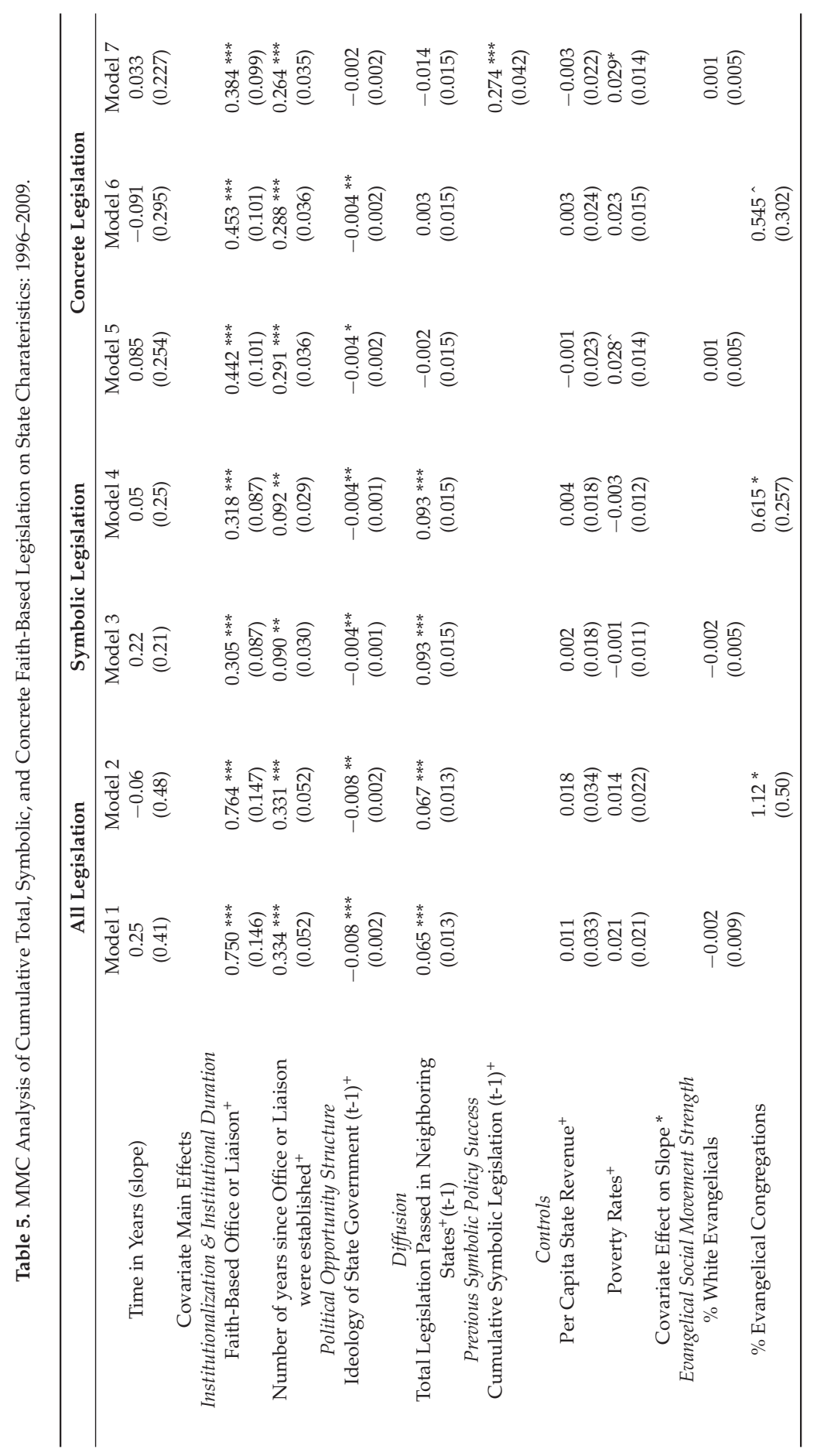




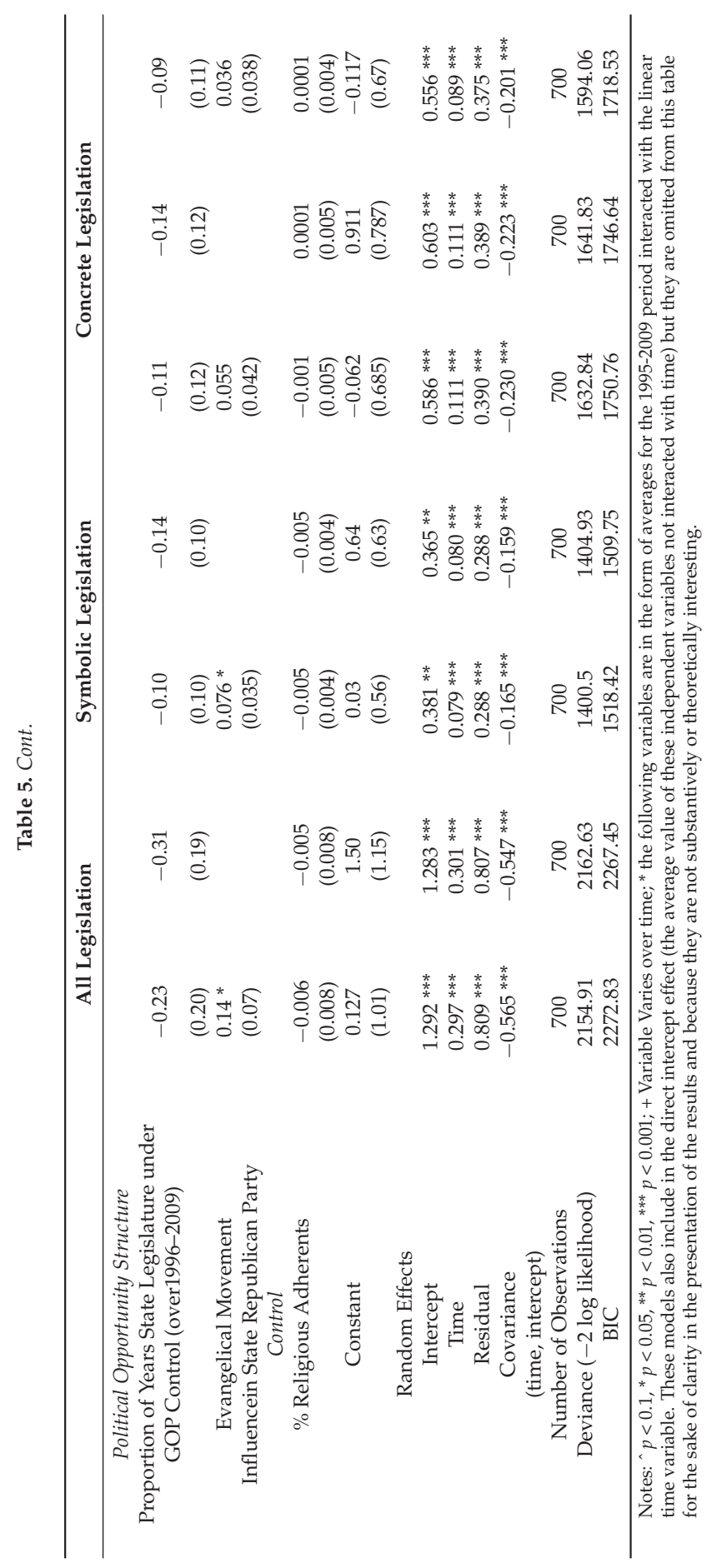




\subsubsection{Determinants of Trends in Total Symbolic and Concrete Faith-Based Legislation}

In our final set of analyses, we examine the determinants of two different dependent variables: total cumulative symbolic and total cumulative concrete faith-based legislation. Models 3-7 in Table 5 examine these dependent variables. Model 1 in Table 5 is Model 6 from Table 4 . Model 2 is Model 7 from Table 4 with the collinear Evangelical influence variable dropped, both provided for comparison. In all models, we find that the presence of an office or liaison is significantly associated with year-to-year increases in both symbolic and concrete legislation. Also consistent across models is the finding that the passage of faith-based legislation is more likely the longer an office or liaison has been established. Similarly, in all but Model 7, more ideologically conservative state governments are more likely to pass faith-based legislation of either type.

There are a number of noteworthy differences in the factors that are significantly associated with symbolic and concrete legislative outcomes. In the absence of one another, the measures of Evangelical congregations and Evangelical influence in Republican parties are significantly associated with a larger volume of both total and symbolic legislation, but not with concrete legislation (although \% Evangelical congregations is significant at the level of a one-tailed test in Model 6). Similarly, our measure of policy diffusion is significantly associated with a higher volume of symbolic, but not concrete legislation (in this case, the diffusion variable indicates whether the passage of symbolic legislation in neighboring states is associated with the passage of symbolic legislation within states, and the same for concrete legislation). This reveals that the significant effects of policy diffusion, Evangelical congregations, and Evangelical party influence on total legislation are primarily driven by patterns of adoption of more symbolic legislation. On the other hand, the adoption of more concrete legislation appears to be determined primarily by characteristics of state governments, specifically their ideological composition and the presence and longevity of faith-based institutions.

There may be multiple reasons for this. One interpretation is that symbolic policies offer a low-risk (and no cost) way for politicians to signal affiliations or support for particular constituencies. As such, the political calculus surrounding support for symbolic policies is likely distinct from that associated with more substantive legislation. In addition, it is often the case that more substantive legislation is more controversial and correspondingly more difficult to pass. The combination of political conditions necessary to pass such legislation do not necessarily line up neatly with state-level indicators of social movement strength or patterns of policy diffusion. Alternatively, these results are consistent with a scenario in which the efforts of faith-based liaisons, and their offices are the central driver of the passage of more concrete legislation, a task made easier in the context of more ideologically conservative governments.

Finally, in Model 7, one additional independent variable is added to these analyses: a state's cumulative count of symbolic faith-based legislation lagged by one year. We include this model to investigate a final question: does the passage of symbol legislation increase the likelihood of subsequent passage of concrete legislation? This variable is highly significant and positive indicating that year-to-year states that have previously passed more symbolic legislation are more likely to pass concrete legislation. We interpret this as an indication that the recurrent passage of symbolic legislation enhances the legitimacy of policy developments related to faith-based initiatives and consequently increases the likelihood of subsequent adoption of more substantive legislation.

\section{Discussion}

In the big picture, these results identify where and when states were more likely to pass measures that implemented the conservative Evangelical movement goals of reshaping church/state relationships and fostering the devolution of the welfare sector to religious groups. Our findings suggest that both institutional activism and the creation of movement-inspired state institutions have been extremely effective means of pursuing these outcomes. We find in these analyses a direct effect of elite movement actors on the passage of legislation. States where the Evangelical movement has made the biggest inroads into state Republican parties have passed a larger volume of faith-based legislation. 
These states are also more likely to create state faith-based offices and liaisons institutionalizing access and attention to a set of movement issues. In both sets of analyses, patterns of state creation of faith-based institutions and the passage of faith-based legislation are better predicted by the degree of influence held by movement actors within state Republican parties than the composition of states' religious communities. Once established, the presence of these liaisons and offices has resulted in an enduring increase in the likelihood of the subsequent passage of faith-based legislation. Transforming the political opportunity structure itself, this partial outsourcing of movement activity to the state results in second order policy effects that subsequently further movement goals.

We also find that another self-reinforcing dynamic, diffusion, has greatly aided the expansion of the Faith-based Initiative. In addition to the top-down diffusion process captured in the Bush administration's appeal to governors nationwide to create OFBCIs, states were more likely to both create office and liaison positions and pass symbolic faith-based legislation if their neighbors were doing so. In this context, we think it is reasonable to consider the diffusion of institutions and policies, in part, as a second-order policy outcome. Again, given the real concerns about the constitutionality of early legislative efforts related to the Faith-based Initiative, the existence of policies and institutions elsewhere provides assets, in terms of both practical models and policy legitimacy, to movement actors attempting to garner support for similar policies.

Finally, we find the previous passage of symbolic faith-based legislation is associated with a greater likelihood of subsequent passage of concrete policy outcomes. The passage of these initial unfunded, suggestive, and symbolic policies were viewed by many as low risk political pandering to the conservative religious base [7]. However, our findings suggest that these policies have had a very real impact, significantly reshaping political culture in regards to the legitimacy of church-state interactions in the domain of social services. In Gamson's [43] classic terms, symbolic policies have won increased acceptance of FBOs as legitimate potential recipients of funds and laid the groundwork for subsequent actual receipt of this new advantage. Perhaps most interesting is the fact that while indicators of Evangelical movement strength and influence are not directly associated with the adoption of more concrete legislation, they are strongly related to the creation of faith-based institutions and the passage of more symbolic legislation, both of which are among the very few factors which increase the likelihood of passage of more concrete legislation (see Figure 5). More substantive policy outcomes are then a second order outcome resulting from institutionalization of movement goals and actors and enhanced policy legitimacy via the recurrent passage of symbolic legislation.

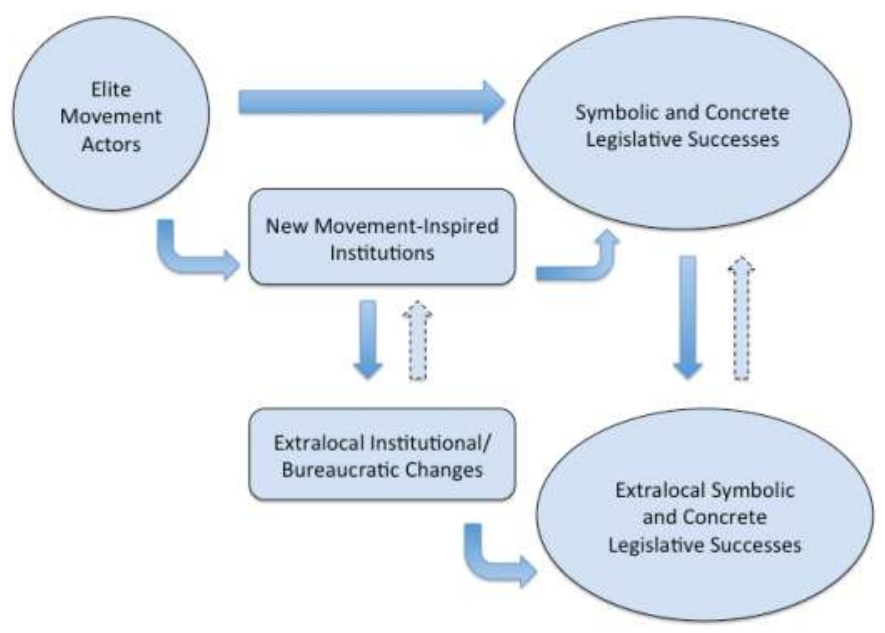

Figure 5. Model of long-term and second order policy impacts. 


\section{Conclusions}

While movement actors and allies were clearly successful in the years examined here, what is perhaps more surprising is how much of the initiative remains. At the national level, the renamed White House Office of Faith-Based and Neighborhood Partnerships has continued under the Obama administration to partner with faith-based groups in the hopes of expanding their social service work. While the name change highlighting the more formal inclusion of community groups has been viewed as a signal to Evangelicals that they no longer dominate the White House agenda, Obama has still not rescinded Bush's order on allowing religious groups to discriminate in hiring even when receiving federal funds (perhaps the most important legal decision impacting church/state relations from either president). Both of these actions suggest that the changes made to church/state relationships under Bush administration have not been fully diminished. Additionally, over twenty states still maintain state offices of faith-based initiatives that have pursued a variety of efforts to bring religious groups into greater partnership with government agencies, with two states, Delaware and Arizona, either creating or further codifying their offices after President Bush left office. While several states, such as Alaska and Minnesota, have closed their faith-based offices, the vast majority remains, and both the ideas and bureaucracy of the faith-based initiative have continued largely intact at the state and federal level.

The influence of the Evangelical movement has been widespread, impacting not only faith-based policy, but also a wide range of policy domains including education, marriage, health policy, and reproductive rights. These successes have been achieved through the use of a diverse set of both noninstitutional and institutional tactics, and, especially through effective utilization of an existing political institution, the Republican Party. The effectiveness of this institutional activism is rivaled only by the successes associated with the creation of new government institutions tasked with pursuing movement goals. While this tactic may have been utilized in an exceptionally consequential manner in the case of the Faith-based Initiative, access gained through new institutions is not unique to the Evangelical movement and is, in our opinion, an underdeveloped area in our understanding of long-term policy outcomes. Attention to the longer-term second order impacts of policy developments requires taking a perspective on policy outcomes that is both long-term and multifaceted. We expect such a perspective to be valuable for understanding developments in other policy arenas in which the Evangelical movement has focused its efforts and a broader set of policy achievements by the contemporary conservative movement writ large.

Author Contributions: Rebecca Sager and Keith Bentele contributed equally to the preparation and writing of this manuscript.

Conflicts of Interest: The authors declare no conflict of interest.

\section{References}

1. Mark Chaves. Congregations in America. Boston: Harvard University Press, 2004.

2. Robert Wuthnow. Saving America? Faith-Based Services and the Future of Civil Society. Princeton: Princeton University Press, 2006.

3. Mark Chaves. "Religious Congregations and Welfare Reform: Who Will Take Advantage of the Faith-Based Initiatives? " American Sociological Review 64 (1999): 836-46. [CrossRef]

4. Rebecca Sager. Faith, Politics and Power: The Politics of Faith-Based Initiatives. New York: Oxford University Press, 2010.

5. Robert Wineburgm, Brian Coleman, Stephanie Boddie, and Ram Cnaan. "Leveling the Playing Field: Epitomizing Devolution through Faith-Based Organizations." Journal of Sociology and Social Welfare 35 (2008): $17-42$.

6. Derek H. Davis. “George W. Bush and church-state partnerships to administer social service programs: Cautions and concerns." In Religion and Social Problems. Edited by Titus Hjelm. New York: Routledge, 2011. Available online: http:/ / site.ebrary.com/id/10447670 (accessed on 1 January 2015). 
7. Michael Lindsay. Faith in the Halls of Power: How Evangelicals Joined the American Elite. New York: Oxford University Press, 2006.

8. Michael Lindsay. "Evangelicals in the Power Elite: Elite Cohesion Advancing a Movement." American Sociological Review 73 (2008): 60-82. [CrossRef]

9. Sidney Tarrow. Power in Movement. New York: Cambridge University Press, 1998.

10. Charles Colson, and Nancy Pearcy. How Now Shall We Live? Carol Stream: Tyndale House, 1999.

11. Joseph Loconte. "Keeping the Faith." First Things 123 (2002): 14-16.

12. Marvin Olasky. Renewing American Compassion: How Compassion for the Needy Can Turn Ordinary Citizens into Heroes. New York: Free Press, 1996.

13. David Kuo. Tempting Faith: An Inside Story of Political Seduction. New York: Free Press, 2006.

14. Helen R. Ebaugh. The Faith-Based Initiative in Texas: A Case Study, Report of the Roundtable on Religion and Social Welfare Policy. Albany: Rockefeller Institute of Government, State University of New York, 2003.

15. Jo Renee Formicola, Mary C. Segers, and Paul Weber, eds. Faith-Based Initiatives and the Bush Administration: The Good, the Bad, and the Ugly. New York: Rowman \& Littlefield, 2003.

16. Robert Wineburg. A Limited Partnership: The Politics of Religion, Welfare, and Social Science. New York: Columbia University Press, 2001.

17. John Bartkowski, and Helen Regis. The Faith-Based Initiatives: Religion, Race, and Poverty in the Post-Welfare Era. New York: New York University Press, 2003.

18. John Bartkowski, and Helen Regis. "Religious Civility, Civil Society, and Charitable Choice: Faith-Based Poverty Relief in the Post-Welfare Era." In Faith, Morality, and Civil Society. Edited by Dale McConkey and Peter Lawler. Lexington: Lanham, Md., 2003, pp. 132-48.

19. Roger Finke, and Christopher Scheitle. "Accounting for the Uncounted: Computing Correctives for the 2000 RCMS Data." Revieww of Religious Research 47 (2005): 5-22. [CrossRef]

20. Mark Ragan, and David Wright. Scanning the Policy Environment of Faith-Based Social Services in the United States: What Has Changed Since 2002? Albany: Rockefeller Institute of Government, State University of New York, 2005.

21. Kenneth D. Wald, and Jeffrey C. Corey. "The Evangelical Movement and Public Policy: Social Movement Elites as Institutional Activists." State Politics and Policy Quarterly 2 (2002): 99-125. [CrossRef]

22. Charles Tilly, and Sidney Tarrow. Contentious Politics. Boulder: Paradigm Publishers, 2007.

23. Sidney Tarrow. "The Very Excess of Democracy': State Building and Contentious Politics in America." In Social Movements and American Political Institutions. Edited by Anne Costain and Andrew McFarland. New York: Rowman \& Littlefield, 1998, pp. 20-39.

24. Chip Berlet, and Matthew Lyons. Right-Wing Populism in America: Too Close for Comfort. New York: Guilford Press, 2000.

25. Robert D. Woodberry, and Christian S. Smith. "Fundamentalism et al.: Conservative Protestants in America." Annual Review of Sociology 24 (1998): 25-56. [CrossRef]

26. Kimberly Conger. A Matter of Context: Christian Right Influence in State Republican Parties. Ames: Iowa State University, 2008, Unpublished manuscript.

27. Kimberly Conger, email text "Moral Values Issues and Policy Party Organizations: Cycles of Conflict and Accommodation of the Christian Right in State-Level Republican Parties" to author, 2008.

28. Kimberly Conger, and John Green. "Spreading out and Digging in: Christian Conservatives and State Republican Parties." Campaigns and Elections Magazine, 28 February 2002.

29. David Domke, and Kevin Coe. The God Strategy: How Religion Became a Political Weapon in America. New York: Oxford University Press, 2007.

30. John C. Green, James L. Guth, and Clyde Wilcox. "Less Than Conquerors: The Christian Right in State Republican Parties." In Social Movements and American Political Institutions. Edited by Anne Costain and Andrew McFarland. New York: Rowman \& Littlefield, 1998, pp. 117-35.

31. John Green, Mark Rozell, and Clyde Wilcox. The Evangelical Movement in American Politics: Marching to the Millennium. Washington: Georgetown University Press, 2003.

32. Kenneth Andrews. "Social Movements and Policy Implementation: The Mississippi Civil Rights Movement and the War on Poverty, 1965 to 1971." American Sociological Review 66 (2001): 71-95. [CrossRef]

33. Timo Bohm. "Activists in Politics: The Influence of Embedded Activists on the Success of Social Movements." Social Problems 62 (2015): 477-98. [CrossRef] 
34. Wayne A. Santoro, and Gail M. McGuire. "Social Movement Insiders: The Impact of Institutional Activists on Affirmative Action and Comparable Worth Policies." Social Problems 44 (1997): 503-19. [CrossRef]

35. Christopher Scheitle, and Bryanna Hahn. "From the Pews to Policy: Specifying Evangelical Protestants Influence on States Sexual Orientation Policies." Social Forces 89 (2011): 913-35. [CrossRef]

36. John F. Persinos. "Has the Christian Right taken over the Republican Party? " Campaigns \& Elections 15 (1994): 20-24.

37. Paul Burstein, Rachel L. Einwohner, and Jocelyn A. Hollander. "The Success of Political Movements: A Bargaining Perspective." In The Politics of Social Protest. Edited by J. Craig Jenkins and Bert Klandermans. Minneapolis: University of Minnesota Press, 1995, pp. 275-95.

38. Sarah Soule. "The Student Divestment Movement in the United States and the Shantytown: Diffusion of a Protest Tactic." Social Forces 75 (1997): 855-83. [CrossRef]

39. Sarah Soule, and Yvonne Zylan. "Runaway Train? The Diffusion of State-Level Reform in ADC/AFDC Eligibility Requirements, 1950-1967." American Journal of Sociology 103 (1997): 733-62. [CrossRef]

40. Neil Gross, Thomas Medvetz, and Rupert Russell. "The Contemporary American Conservative Movement." Annual Review of Sociology 37 (2011): 325-54. [CrossRef]

41. Mark Chaves, and William Tsitsos. "Congregations and Social Services: What They Do, How They Do It, and with Whom." Non-Profit Voluntary Sector Quarterly 30 (2001): 660-83. [CrossRef]

42. Robert Wineburg. Faith-Based Inefficiency: The Follies of Bush's Initiatives. Westport: Greenwood, 2007.

43. William Gamson. The Strategy of Social Protest. Homewood: Dorsey, 1990.

44. Edwin Amenta, Neal Caren, Elizabeth Chiarello, and Yang Su. "The Political Consequences of Social Movements." Annual Review of Sociology 36 (2010): 287-307. [CrossRef]

45. Edwin Amenta, and Neal Caren. "The Legislative, Organizational, and Beneficiary Consequences of State-Oriented Challengers." In The Blackwell Companion to Social Movements. Edited by David Snow, Sarah Soule and Hanspeter Kriesi. Oxford: Blackwell, 2004, pp. 461-89.

46. John Micklethwait, and Adrian Wooldridge. The Right Nation: Conservative Power in America. New York: Penguin, 2005.

47. Amy Black, Douglas L. Koopman, and David K. Ryden. Of Little Faith: The Politics of George W. Bush's Faith-Based Initiatives. Washington: Georgetown University Press, 2006.

48. George W. Bush. “Executive Order 13199 of January 29, 2001: Establishment of White House Office of Faith-Based and Community Initiatives." Federal Register 66 (2001): 8499-50.

49. Murray Edeleman. The Symbolic Use of Politics. Urbana: University of Illinois Press, 1964.

50. Murray Edeleman. Politics as Symbolic Action. Chicago: Markham, 1971.

51. Deborah Stone. The Policy Paradox: The Art of Political Decision Making. New York: Norton, 1988.

52. Brayden King, Keith Bentele, and Sarah Soule. "Protest and Policymaking: Explaining Fluctuation in Congressional Attention to Rights Issues, 1960-1986." Social Forces 86 (2007): 137-61. [CrossRef]

53. Guy B. Peters. American Public Policy: Promise and Performance. London: Chatham House Publishers, 1999.

54. Paul Allison. Survival Analysis Using the SAS System: A Practical Guide. Cary: SAS Institute, 1995.

55. Judith Singer, and John Willett. Applied Longitudinal Data Analysis. New York: Oxford University Press, 2003.

56. Martin B. Bradley, Norman M. Green, Jr., Dale E. Jones, Mac Lynn, and Lou McNeil. Churches and Church Membership in the United States. Nashville: Glenmary Research Center, 1992.

57. Glenmary Research Center. Religious Congregations Membership Study 2000. Cincinnati: Glenmary Home Missioners, 2000.

58. Clifford Grammich, Kirk Hadaway, Richard Houseal, Dale E. Jones, Alexei Krindatch, Richie Stanley, and Richard H. Taylor. 2010 U.S. Religion Census: Religious Congregations E Membership Study. Nashville: Glenmary Research Center and the Association of Statisticians of American Religious Bodies (ASARB), 2012.

59. William D. Berry, Evan J. Ringquist, Richard C. Fording, and Russell L. Hanson. "Measuring Citizen and Government Ideology in the American States, 1960-93." American Journal of Political Science 42 (1998): 327-48. [CrossRef]

60. Colleen Grogan. "Political and Economic Factors Influencing State Medicaid Policy." Political Research Quarterly 47 (1994): 589-622. [CrossRef]

61. David Nice. Policy Innovation in State Government. Ames: Iowa State Press, 1994. 
62. "U.S. Census Bureau. 1993-2006. Statistical Abstracts." Available online: http://www.census.gov/prod/ www/abs/statab.html (accessed on 1 January 2011).

63. Sarah Soule, and Susan Olzak. "What Is the Role of Social Movements in Shaping Public Policy? The Case of the Equal Rights Amendment." American Sociological Review 69 (2004): 473-97. [CrossRef]

(c)

(C) 2016 by the authors; licensee MDPI, Basel, Switzerland. This article is an open access article distributed under the terms and conditions of the Creative Commons Attribution (CC BY) license (http:/ / creativecommons.org/licenses/by/4.0/). 
Article

\title{
Trends in Addressing Social Needs: A Longitudinal Study of Congregation-Based Service Provision and Political Participation
}

\author{
Brad R. Fulton \\ School of Public and Environmental Affairs, Indiana University, 1315 E. 10th St., Bloomington, IN 47405, USA; \\ fulton@indiana.edu; Tel.: +1-812-855-6948
}

Academic Editor: Robert Wineburg

Received: 15 March 2016; Accepted: 3 May 2016; Published: 7 May 2016

\begin{abstract}
When congregations seek to address social needs, they often pursue this goal through acts of service and political engagement. Over the past three decades, a tremendous amount of research has been dedicated to analyzing congregation-based service provision and political participation. However, little is known about how congregations' involvement in these arenas has changed during this period. To help fill this gap, this study analyzes three waves of data from a national survey of congregations to assess how congregations' participation patterns in service-related and political activities have been changing since the 1990s. It also examines trends among subpopulations of congregations grouped by their religious tradition, ethnoracial composition, and ideological orientation. Overall, this study finds that among most types of congregations, the percentage participating in service-related activities is substantial and increasing, while the percentage participating in political activities is less substantial and decreasing. This decline in political participation has implications for the role congregations play in addressing social needs. Relieving immediate needs through service provision without also pursuing long-term solutions through political participation can limit congregations' ability to comprehensively address social needs. Among the few types of congregations that have high and/or increasing participation rates in both service-related and political activities are Catholic, predominantly Hispanic, and politically liberal congregations.
\end{abstract}

Keywords: social services; political participation; congregations

\section{Introduction}

When congregations seek to address social needs, they often pursue this goal through acts of service and political engagement. Their service provision typically aims to provide short-term relief through meeting the immediate needs of individuals, whereas their political participation often aims to produce long-term solutions by advocating for policies to improve social conditions. Over the past three decades, a tremendous amount of research has been dedicated to analyzing congregation-based service provision and political participation. However, little is known about how congregations' involvement in these arenas has changed during this period ${ }^{1}$. To help fill this gap, this study analyzes three waves of data from a national survey of congregations to assess how congregations' participation patterns in service-related and political activities have been changing since the 1990s.

1 Chaves and Wineburg [1] and Todd and Houston [2] are among the few recent studies that assess changes in congregations' participation patterns in service-related and political activities. 
The analysis indicates that between 1998 and 2012 the percentage of congregations involved in service-related activities has been increasing, while the percentage of congregations participating in political activities has been decreasing. By 2012, twice as many congregations were participating in service-related activities than political activities. The analysis also examines participation trends among subpopulations of congregations grouped by their religious tradition, ethnoracial composition, and ideological orientation. With regard to general involvement in service-related activities, the participation rate among every type of congregation analyzed has either remained the same or increased since 1998. However, when involvement in specific types of service-related activities are analyzed, divergent participation trends among congregations are observed. With regard to general involvement in political activities, the participation rates among evangelical Protestant, predominantly white, and politically conservative congregations have exhibited the most substantial decreases. Meanwhile, the political participation rates among Catholic, predominantly Hispanic, and politically liberal congregations have been increasing. These divergent trends are even more pronounced when involvement in specific types of political activities are analyzed.

Overall, congregations continue to play a substantial role in addressing social needs; yet, their involvement is shifting to occur primarily through acts of service and less through political engagement. This shift has important implications for congregations' broader contribution to improving social conditions. Providing short-term relief of immediate needs through service provision without also pursuing long-term strategies to improve social conditions through political participation can limit congregations' ability to effectively and comprehensively address social needs.

\section{The Contemporary State of Congregation-Based Service Provision and Political Participation}

Over the past three decades scholars have conducted extensive research on congregation-based service provision [3-9]. These studies indicate that most congregations participate in some type of service-related activity, and the most common activities involve meeting people's immediate needs for food, healthcare, clothing, and shelter. A small percentage of congregations have paid staff members who devote a portion of their work time to service provision; however, most congregations rely solely on volunteers to provide services $[9,10]$. Because the resource requirements associated with offering social services often exceed a congregation's capacity, many congregations provide services in collaboration with other organizations [7,11-13]. A few congregations receive external funding to support their service provision and a very small percentage receive government funding [1,9]. As part of providing services, some congregations participate in activities such as assessing the needs of their community, promoting opportunities to provide volunteer service, and hosting representatives from social service agencies as guest speakers [10,14-16].

Additional research has examined how participation in service-related activities varies by congregations' religious tradition, ethnoracial composition, and theological orientation [3,4,17-20]. Most of these studies indicate that evangelical Protestant congregations are the least likely to participate in service-related activities, while theologically liberal congregations are the most likely to participate. Further, these studies indicate that the ethnoracial composition of a congregation is not a significant predictor of service provision. Studies that focus on specific types of service-related activities reveal additional variations in participation rates across the aforementioned congregational subpopulations [3,21-25].

Similarly, scholars have conducted extensive research on congregation-based political participation. Although a smaller percentage of congregations participate in political activity than in service-related activity, the political participation rates are nonetheless sizable, and congregations are involved in a wide variety of political activities $[2,10]$. Some activities focus on helping members become politically informed, such as facilitating group discussions on political topics, distributing voter guides, and hosting political leaders [26,27]. Other activities focus on mobilizing members for political action, such as sponsoring voter registration drives, partnering with community organizing coalitions, lobbying political officials, and participating in demonstrations $[28,29]$. 
Research has also examined how participation in political activities varies by congregations' religious tradition, ethnoracial composition, and political orientation [23,27,30,31]. Although participation in political activities occurs among all major types of congregations, most of these studies indicate that participation rates are highest among Catholic, predominantly black, and politically liberal congregations. Other studies that focus on specific types of political activities reveal additional variations in participation rates across the congregational subpopulations [32-38].

Collectively, these studies produce a detailed portrait of congregations' participation in service-related and political activities, revealing how their participation rates vary for particular types of activities and the extent participation rates vary by congregations' religious tradition, ethnoracial composition, and ideological orientation. Despite the trove of studies, however, research in this field is lacking a systematic national assessment of how congregations' participation patterns in service-related and political activities have changed over time. To begin to fill this gap, this study analyzes data that span three decades to assess how congregation-based service provision and political participation have been changing since the 1990s. This study also examines how congregations' involvement in specific types of activities has varied over this time period and whether the participation rates among major congregation types have varied as well.

\section{Methods}

\subsection{Data}

To examine trends in congregation-based service provision and political participation, this study analyzes three waves of data from the National Congregations Study (NCS) [39]. The NCS is a nationally representative, repeated cross-sectional survey of congregations in the United States. The survey gathered data on the congregations from key informants and its three waves of data collection occurred in 1998 ( $n=1234), 2006-2007(n=1506)$, and $2012(n=1331)$. See Mark Chaves and Alison Eagle's [9] article in this volume for a more detailed description of the NCS data.

\subsection{Variables}

The analysis uses the following NCS survey items to construct variables that measure a congregation's involvement in specific service-related activities. Each congregation was asked if it had participated in or supported social service projects of any sort within the past 12 months. Responses were used to construct the binary variable-provided formal social services ${ }^{2}$. Congregations that indicated providing social services were asked how much money they spent on the services (amount spent on social services), whether any of the services were supported by outside funds (received external funding), and whether they received funding from the government (received government funding). Congregations were also asked if they collaborated with outside organizations to provide these services and if any of their paid staff members devoted more than $25 \%$ of their work time to providing these services (employed staff for social service programs). In addition, every congregation was asked if it had a group that assesses community needs, if it hosted a social service representative as a visiting speaker, and whether it had promoted opportunities to provide assistance to people outside their congregation ${ }^{3}$. A final service-related variable was constructed to indicate whether a congregation had participated in at least one type of service-related activity asked about in the NCS.

The analysis uses the following NCS survey items to construct binary variables to indicate a congregation's participation in specific political activities. Each congregation was asked if it had a

2 In Waves II and III, if the respondent answered "no" to this question, the interviewer asked follow-up questions to probe into whether the congregation provided any type of social services. For consistency, in order to assess change over time related to this item, Wave II and III responses generated from the follow-up questions were not included in the analysis.

3 The survey item related to the variable-promoted opportunities to provide assistance - was only included in Waves II and III of the NCS. 
group that discusses politics, if it distributed voter guides, and if it hosted a political representative as a visiting speaker ${ }^{4}$. The analysis uses these variables to indicate a congregation's involvement in efforts to help its members become politically informed. Each congregation was also asked whether it had promoted opportunities to participate politically, helped people register to vote, lobbied elected officials, or participated in a demonstration or march. The analysis uses these variables to indicate a congregation's involvement in efforts to mobilize its members for political action. A final political participation variable was constructed to indicate whether a congregation had participated in at least one type of political activity asked about in the NCS.

In addition to assessing participation trends among the entire population of congregations, this study examines trends among the subpopulations of congregations based on their religious tradition, ethnoracial composition, and ideological orientation. The analysis focuses on the four most prevalent religious traditions in the U.S.: Catholic, black Protestant, mainline Protestant, and evangelical Protestant. The black Protestant category includes Protestant congregations affiliated with a historically black denomination as well as congregations in which at least $80 \%$ of the participants are black. The differentiation between mainline Protestant and evangelical Protestant is based on the Steensland et al. [40] classification scheme. The categories for the ethnoracial composition of a congregation are based on whether at least $80 \%$ of its regular participants are of the same race or ethnicity (i.e., predominantly white, predominantly black, or predominantly Hispanic). The ideological orientation of a congregation is measured on a conservative-liberal continuum along two dimensions - theological and political. In the NCS, respondents were asked, "Theologically speaking, would your congregation be considered more on the conservative side, more on the liberal side, or right in the middle?" A dummy variable was constructed for each response option (i.e., theologically conservative, theologically moderate, and theologically liberal). The NCS asked an identical question related to the congregation's political orientation and the response options were used to construct the following dummy variables: politically conservative, politically moderate, and politically liberal.

\section{Results}

Table 1 displays the percentage of congregations involved in service-related and political activities in 1998, 2006-2007, and 2012 ${ }^{5}$. The table also indicates whether there has been a significant change in the percentage of congregations participating in each type of activity between 1998 and 2012. The analysis indicates that the percentage of congregations involved in at least one type of service-related activity has been increasing since 1998, and for each specific activity the percentage of participating congregations has either remained the same or increased since 1998. However, the percentage of congregations participating in at least one type of political activity has been decreasing, and for each specific activity the percentage of participating congregations has either remained the same or decreased since 1998. Although most of the changes in participation rates are modest, the divergent trends are widening the gap between the percentage of congregations involved in service provision and the percentage involved in political participation. Between 1998 and 2012, the percentage of congregations participating in at least one type of service-related activity increased from $71 \%$ to $78 \%$, while the percentage of congregation participating in at least one type of political activity decreased from $43 \%$ to $35 \%$.

4 The variable-hosted a political representative as a visiting speaker-was constructed using two related NCS survey items. If a congregation indicated hosting either an elected government official or a political candidate as a visiting speaker, this variable was coded 1 . If not, it was coded as 0 .

5 For all of the analyses in this study, the data are weighted using the following congregation level weight-wt_all3_cong_dup — which treats each congregation as one unit regardless of its size. This is the appropriate weight to use when assessing trends among congregations because a congregation's likelihood of appearing in the NCS sample is proportional to its size and using the congregation level weight undoes the over-representation of larger congregations in the NCS [39]. 
Table 1. The percentage of congregations involved in service-related and political activities for each wave.

\begin{tabular}{|c|c|c|c|c|}
\hline Percentage of Congregations that ... & $\begin{array}{c}\text { Wave I } \\
1998\end{array}$ & $\begin{array}{l}\text { Wave II } \\
2006-7\end{array}$ & $\begin{array}{c}\text { Wave III } \\
2012\end{array}$ & $p$ value $^{\mathrm{a}}$ \\
\hline \multicolumn{5}{|l|}{ Service-related Activities } \\
\hline Participated in at least one type of service-related activity & 70.8 & 72.8 & 78.2 & 0.050 \\
\hline Provided formal social services & 58.4 & 45.4 & 60.4 & 0.614 \\
\hline Amount spent on social services (median) $\times \$ 100^{b, c}$ & 17.6 & 22.8 & 20.0 & - \\
\hline Received external funding $b$ & 18.4 & 17.7 & 12.4 & 0.102 \\
\hline Received government funding $\mathrm{b}$ & 4.6 & 3.5 & 1.6 & 0.076 \\
\hline Collaborated with outside organizations ${ }^{b}$ & 81.4 & 75.8 & 81.2 & 0.961 \\
\hline Employed staff for social service programs & 6.4 & 6.9 & 11.5 & 0.026 \\
\hline Had a group that assesses community needs & 36.9 & 48.4 & 56.7 & 0.000 \\
\hline Hosted a social service representative as a visiting speaker & 22.1 & 30.6 & 31.3 & 0.003 \\
\hline Promoted opportunities to provide assistance ${ }^{\mathrm{d}}$ & - & 93.6 & 91.8 & - \\
\hline \multicolumn{5}{|l|}{ Political Activities } \\
\hline Participated in at least one type of political activity & 43.0 & 44.3 & 34.9 & 0.026 \\
\hline Had a group that discusses politics & 6.3 & 6.3 & 5.8 & 0.666 \\
\hline Distributed voter guides & 17.0 & 17.2 & 12.9 & 0.057 \\
\hline Hosted a political representative as a visiting speaker & 8.7 & 10.2 & 8.1 & 0.740 \\
\hline Promoted opportunities to participate politically & 26.2 & 21.4 & 14.5 & 0.000 \\
\hline Helped people register to vote & 8.3 & 17.8 & 11.1 & 0.178 \\
\hline Lobbied elected officials & 4.4 & 7.9 & 6.6 & 0.131 \\
\hline Participated in a demonstration or march & 9.2 & 8.3 & 12.5 & 0.123 \\
\hline
\end{tabular}

The diverging participation patterns are even more pronounced when the participation rates for similar types of service-related and political activities are compared. In 2012, 57\% of congregations had a group that assesses community needs, which is a $54 \%$ increase since 1998 . In comparison, the percentage of congregations that had a group that discusses politics remained at approximately $6 \%$. Similarly, in 2012, 31\% of congregations hosted a representative from a social service agency as a visiting speaker, which is a $50 \%$ increase since 1998. Meanwhile, the percentage of congregations that hosted a political representative as a visiting speaker remained at approximately $9 \%$. In 2012, more than $90 \%$ of congregations promoted opportunities to provide assistance to people outside their congregation. In comparison, only $15 \%$ of congregations promoted opportunities to participate in political activities, which is a $45 \%$ decrease since 1998 . These divergent trends provide further evidence for congregations' dampening interest in political participation contrasting with a growing interest in service provision.

As the percentage of congregations involved in service-related activities has been increasing, a few noteworthy shifts have also occurred with congregations' funding sources for providing formal social services. In 2012 , only $12 \%$ of congregations received external funding to support their social service programs, which is a $33 \%$ decrease since 1998. Furthermore, the percentage of congregations that receive government funding to support their programs has been decreasing. In 2012, less than $2 \%$ of all congregations that provided formal social services received government funding, which is a $65 \%$ decrease since 1998. At the same time, however, the median amount of money that congregations spend on social service programs has increased. In addition, the percentage of congregations with staff members who devote more than $25 \%$ of their work time to social service programs has nearly doubled since 1998. These trends indicate that even though a decreasing percentage of congregations have been relying on external funding to support their social services, the amount of money and resources congregations are allocating to social service provision has been increasing.

The second analysis examines subpopulations of congregations grouped by their religious tradition, ethnoracial composition, and ideological orientation, and it assesses differences in their 
participation patterns for specific types of service-related and political activities. This analysis helps to identify sources of the general upward trend in congregation-based service provision and general downward trend in political participation. It also identifies the types of congregations that diverge from the participation trends exhibited by the majority of congregations. Table 2 displays the percentage of congregations by religious tradition, ethnoracial composition, and ideological orientation in 1998, 2006-2007, and 2012. The table also indicates whether there has been a significant change in the percentage of congregations within these subpopulations between 1998 and 2012.

Table 2. The percentage of congregations by religious tradition, ethnoracial composition, and ideological orientation for each wave.

\begin{tabular}{|c|c|c|c|c|}
\hline Percentage of Congregations that Are ... & Wave I 1998 & Wave II 2006-7 & Wave III 2012 & $p$ value $^{a}$ \\
\hline \multicolumn{5}{|l|}{ Religious Tradition } \\
\hline Evangelical Protestant & 45.7 & 47.8 & 46.1 & 0.904 \\
\hline Mainline Protestant & 26.3 & 19.6 & 20.3 & 0.053 \\
\hline Black Protestant & 15.8 & 23.4 & 21.4 & 0.088 \\
\hline Catholic & 7.3 & 6.1 & 5.5 & 0.161 \\
\hline \multicolumn{5}{|l|}{ Ethnoracial Composition } \\
\hline Predominantly white & 72.8 & 63.0 & 58.4 & 0.000 \\
\hline Predominantly black & 17.2 & 24.4 & 21.2 & 0.234 \\
\hline Predominantly Hispanic & 1.3 & 2.2 & 5.9 & 0.003 \\
\hline \multicolumn{5}{|l|}{ Theological Orientation } \\
\hline Theologically conservative & 59.8 & 62.8 & 62.8 & 0.441 \\
\hline Theologically moderate & 29.9 & 29.5 & 25.0 & 0.166 \\
\hline Theologically liberal & 10.3 & 7.7 & 12.2 & 0.448 \\
\hline \multicolumn{5}{|l|}{ Political Orientation } \\
\hline Politically conservative & 62.0 & 58.0 & 54.8 & 0.068 \\
\hline Politically moderate & 30.6 & 34.6 & 33.7 & 0.406 \\
\hline Politically liberal & 7.4 & 7.4 & 11.5 & 0.072 \\
\hline
\end{tabular}

Source: National Congregations Study [39]; ${ }^{a} p$ value for mean difference test comparing Wave I and Wave III values.

The analysis indicates that between 1998 and 2012 the percentages of mainline Protestant and Catholic congregations have been decreasing and the percentage of black Protestant congregations has been increasing, while the percentage of evangelical Protestant congregations has remained at nearly $50 \%$. During this same period, the percentage of predominantly white congregations decreased from $73 \%$ to $58 \%$ and the percentage of predominantly Hispanic congregations increased from $1 \%$ to $6 \%$, while the percentage of predominantly black congregations remained at approximately $20 \%$. The distribution of congregations based on their self-described theological orientation has remained relatively unchanged between 1998 and 2012. During this same period, the percentages of politically liberal and politically moderate congregations have been increasing; yet, over $50 \%$ of congregations continue to identify as politically conservative. Overall, the prevalence of evangelical Protestant and theologically conservative congregations has remained stable, while the prevalence of predominantly white and politically conservative congregations has been decreasing. Although assessing changes in the population of U.S. congregations is not the focus of this study, these changes have implications for the overall contribution of congregations to service provision and political participation.

Analyzing the service provision participation patterns among subpopulations of congregations reveals sources of the general upward trend and identifies the types of congregations that deviate from this trend. Figure 1 displays the percentage of congregations by subpopulation involved in at least one type of service-related activity in 1998, 2006-2007, and 2012. The figure illustrates that the service provision participation rate among every type of congregation analyzed has either remained the same or increased since 1998. This finding provides strong evidence that the substantial and increasing 
involvement in service-related activities among congregations is not isolated to a select few types of congregations; rather, participation is prevalent among most types of congregations.

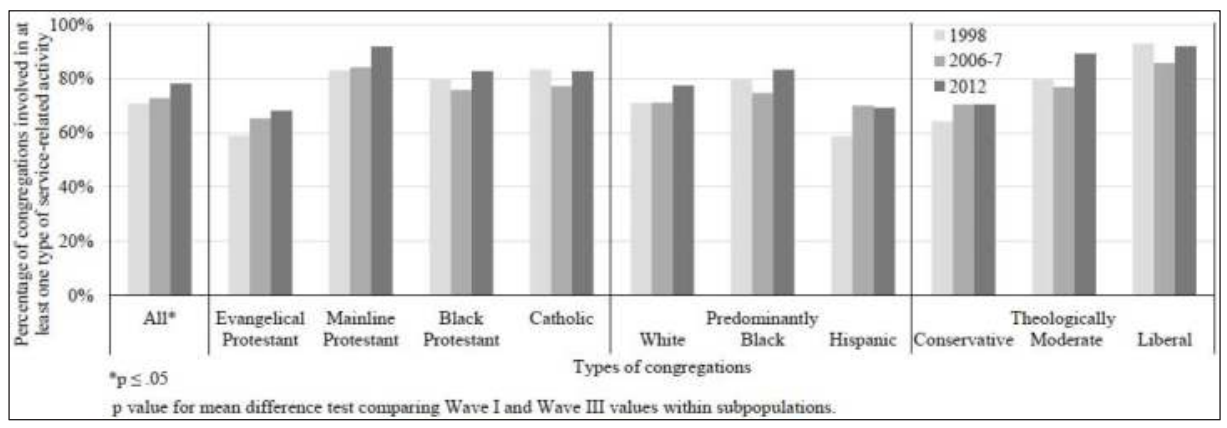

Figure 1. The percentage of congregations by subpopulation involved in at least one type of service-related activity by wave.

Differences in service provision participation patterns among congregations become evident, however, when specific types of service-related activities are analyzed. Figure 2 displays the percentage of congregations by subpopulation with a group that assesses the needs of its surrounding community. Between 1998 and 2012, the participation rate among Catholic congregations for this activity has remained steady at approximately 50\%, while the rate among each major type of Protestant congregation has been increasing. Evangelical congregations had the largest increase (from 28\% to 52\%) and black Protestant congregations had the highest participation rate in 2012 (66\%). In 1998, predominantly black and Hispanic congregations were significantly more likely than predominantly white congregations to have a group that assesses community needs; however, since then, the participation rate for this activity among predominantly white congregations has increased $73 \%$ - making their participation rate nearly equal to that of predominantly black and Hispanic congregations. A similarly substantial increase in needs-assessment participation occurred among theologically conservative congregations as well. These results indicate that much of the increase in community needs assessments derives from increasing participation rates among evangelical Protestant, predominantly white, and theologically conservative congregations, which represent the largest subpopulations of congregations and until recently, had the lowest participation rates. These upward trends are consistent with recent research that observes increasing levels of evangelical social engagement on a broad range of issues [41].

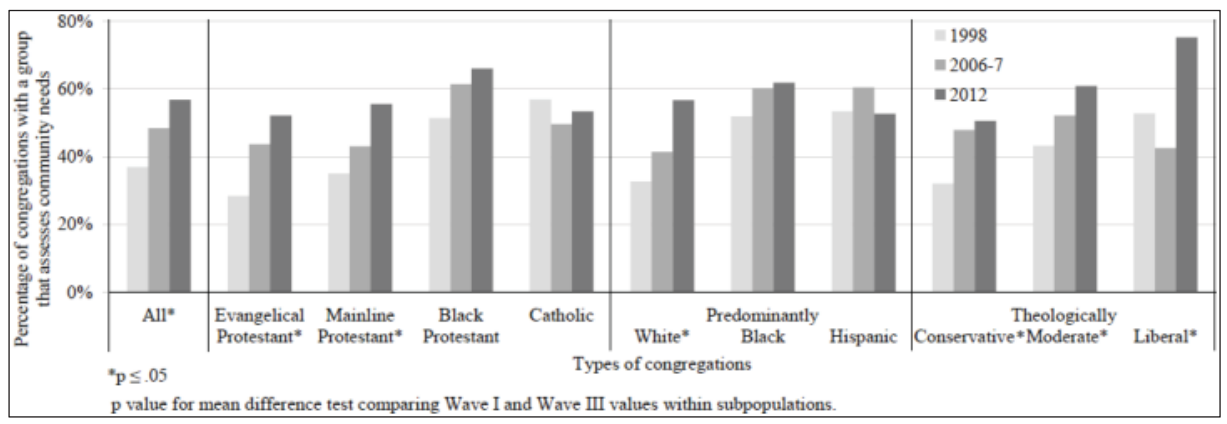

Figure 2. The percentage of congregations by subpopulation with a group that assesses community needs by wave. 
Figure 3 displays the percentage of congregations by subpopulation with staff members who devote at least 25\% of their work time to social service programs. Between 1998 and 2012, the percentages of Catholic congregations with staff for social services has been decreasing, while the percentages among mainline Protestant and black Protestant congregations have more than doubled. During this same period, a modest upward trend in congregations employing staff for social services occurred among predominantly white and Hispanic congregations as well as among theologically conservative and liberal congregations. The largest increase occurred among theologically liberal congregations, whose participation increased more than six-fold from 3\% to $19 \%$. Although this study does not assess the depth of congregations' involvement in service-related activities, this particular activity-allocating staff time to providing social services—certainly signals substantial involvement in service provision ${ }^{6}$.

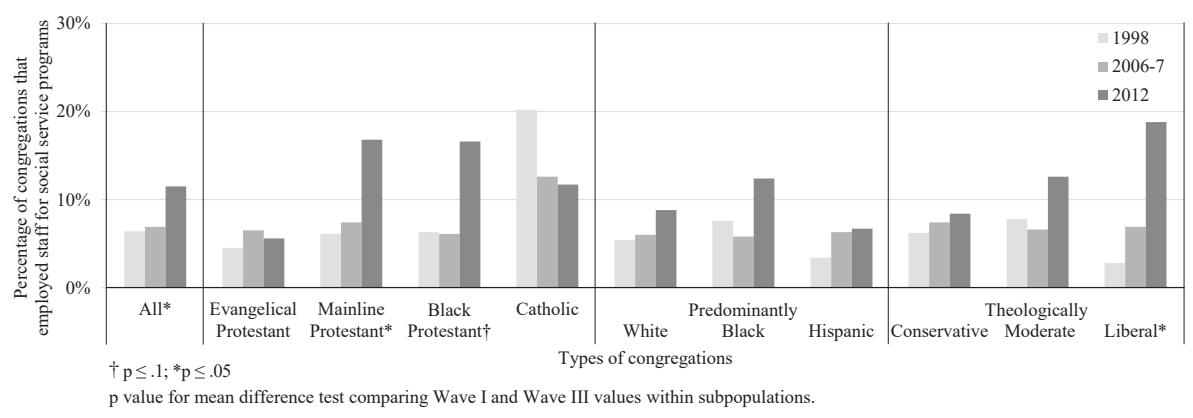

Figure 3. The percentage of congregations by subpopulation that employed staff for social service programs by wave.

Analyzing the political activity participation patterns among subpopulations of congregations reveals sources of the general downward trend and identifies the types of congregations that deviate from this trend. Figure 4 displays the percentage of congregations by subpopulation involved in at least one type of political activity in 1998, 2006-2007, and 2012. The figure illustrates that the political participation rate among each major type of Protestant congregation has been decreasing since 1998. The largest decrease occurred among evangelical congregations, whose participation dropped from $38 \%$ to $24 \%$ - the lowest participation rate among the religious traditions analyzed. During this same period, however, the participation rate among Catholic congregations has been increasing. By 2012, 75\% of Catholic congregations were participating in at least one type of political activity. Additionally, the participation rate has been decreasing among politically conservative congregations and increasing among politically liberal congregations. In 1998, liberal congregations were 1.4 times more likely than conservative congregations to participate in political activities; since then, they have become 2.8 times more likely to participate. This analysis indicates that much of the decrease in congregation-based political activities derives from decreasing participation rates among evangelical Protestant, predominantly white, and politically conservative congregations. Offsetting this decrease are the political activities of Catholic and politically liberal congregations, whose participation rates have been substantial and increasing since 1998 .

6 For a detailed description of the breadth and depth of congregation-based service provision see Chaves and Eagle's [9] article in this volume. 


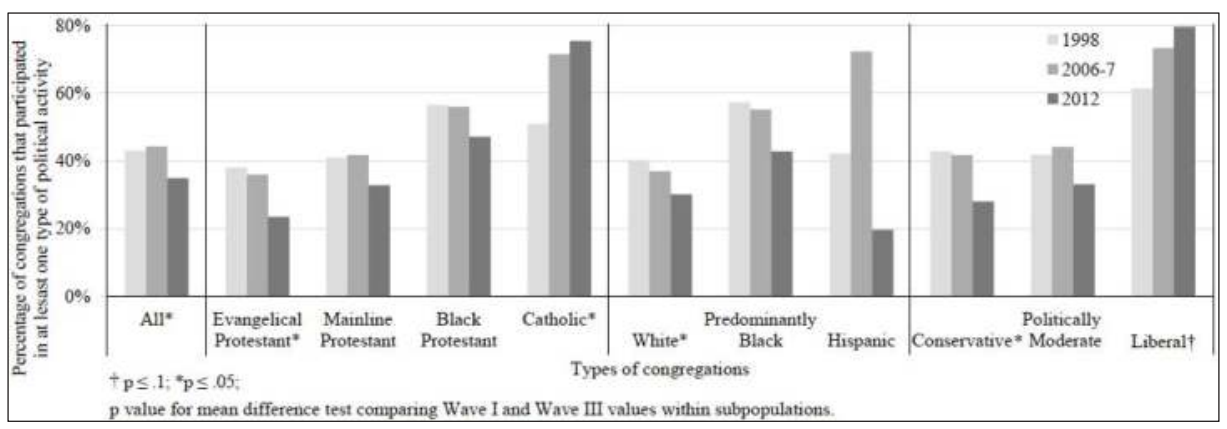

Figure 4 . The percentage of congregations by subpopulation that participated in at least one type of political activity by wave.

Differences in political participation patterns among congregations become more pronounced when specific types of political activities are analyzed. Figure 5 displays the percentage of congregations by subpopulation that distributed voter guides. In 1998, participation rates for this activity were highest among black Protestant and evangelical Protestant congregations (23\% and $19 \%$ respectively); however, in 2012, the percentage of evangelical Protestant congregations that distributed voter guides decreased to $11 \%$. Meanwhile, the percentage of Catholic congregations distributing voter guides has more than doubled since 1998-increasing from $14 \%$ to $39 \%$-which surpasses the participation rate among each major type of Protestant congregation by a wide margin. Similar to the divergent trend among Catholic congregations is an increase in the participation rate among predominantly Hispanic congregations. Between 1998 and 2012, the percentage of predominantly Hispanic congregations distributing voter guides increased from less than $1 \%$ to $13 \%$. During this same period, the percentage of predominantly white congregations distributing voter guides halved to $9 \%$ and the participation rate among black congregations remained steady at approximately $17 \%$. Similar trends are observed among the other activities that focus on helping members become politically informed (results not displayed). The percentage of black Protestant congregations participating in these types of activities remained relatively unchanged, while the participation rates increased among Catholic and Hispanic congregations and decreased among evangelical and white congregations.

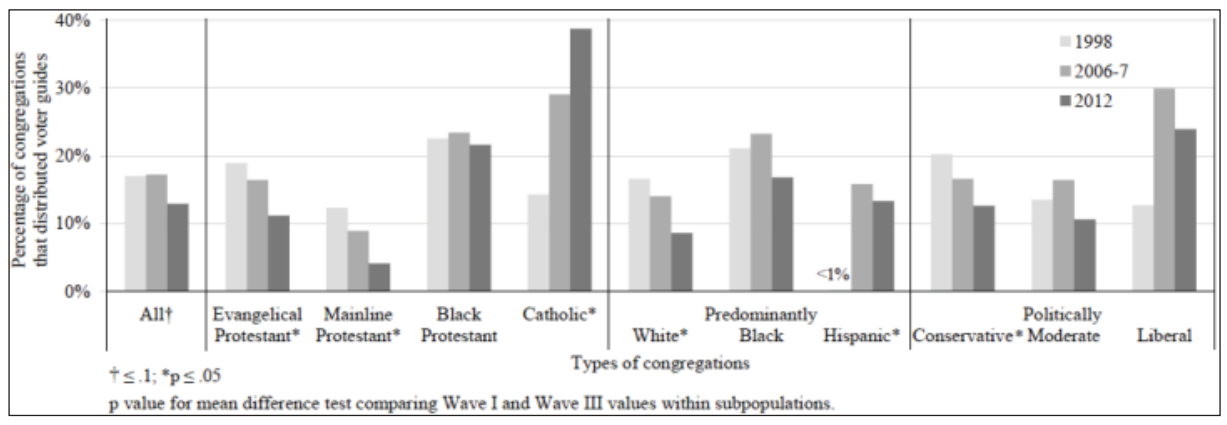

Figure 5. The percentage of congregations by subpopulation that distributed voter guides by wave.

Similar trends are also observed for activities that focus on mobilizing members for political action. Figure 6 displays the percentage of congregations by subpopulation that promoted opportunities for their members to participate politically. Between 1998 and 2012, the participation rate among Catholic congregations for this activity remained at approximately $33 \%$, while the rate among each 
major type of Protestant congregation has been decreasing. Black Protestant congregations had the largest decrease (from $36 \%$ to $16 \%$ ) and evangelical congregations had the lowest participation rate in $2012(7 \%)$. During this same period, the percentage of predominantly white and black congregations that promoted opportunities to participate politically decreased significantly, while the percentage of predominantly Hispanic congregations that promoted such opportunities increased marginally.

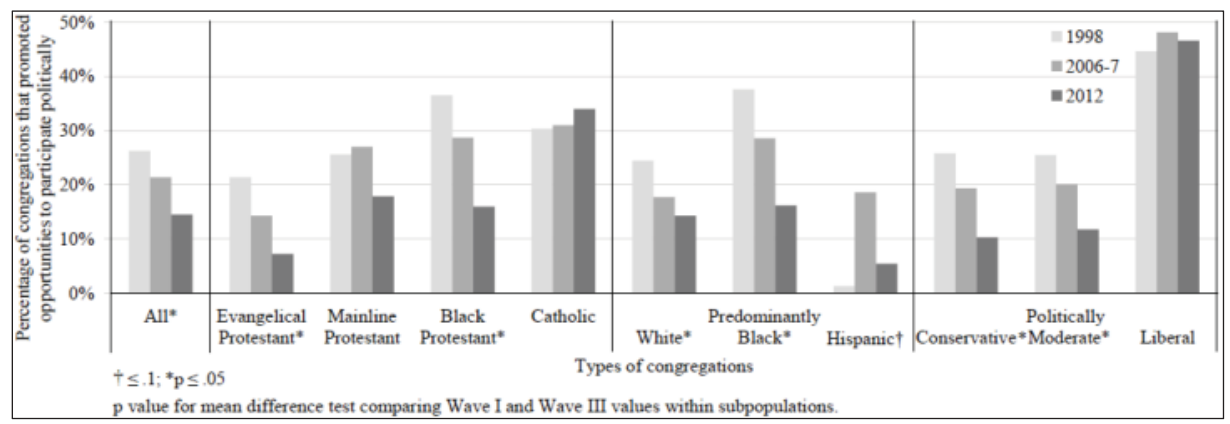

Figure 6. The percentage of congregations by subpopulation that promoted opportunities to participate politically by wave.

Figure 7 displays the percentage of congregations by subpopulation that participated in a demonstration or march. In 1998, Catholic congregations were at least two times more likely than each major type of Protestant congregations to participate in a demonstration or march. Since then, the percentage of Catholic congregations involved in this activity has more than doubled, while the participation rates among the Protestant congregations have remained the same. In 2012, more than half of all Catholic congregations had participated in a demonstration or march, which makes their participation rate for this activity four times greater than those observed among the Protestant congregations. Similarly, the percentage of Catholic congregations that had lobbied an elected official doubled between 1998 and 2012, increasing from 12\% to 24\%. Similar to the divergent trend among Catholic congregations is an increase in the participation rate among predominantly Hispanic congregations. Between 1998 and 2012, the percentage of predominantly Hispanic congregations that participated in a demonstration or march increased from less than $1 \%$ to $17 \%$. Over this same period, the participation rate among predominantly white and black congregations remained at approximately $10 \%$.

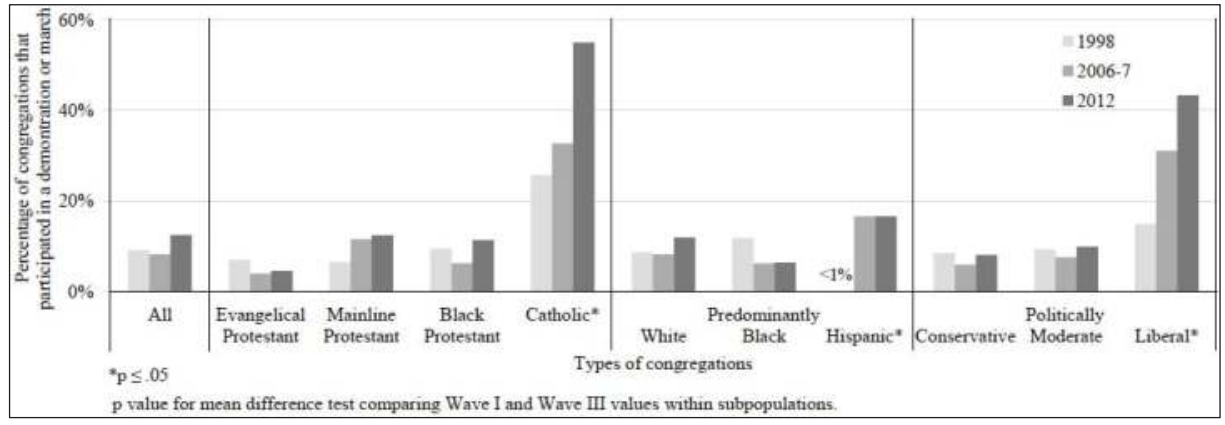

Figure 7. The percentage of congregations by subpopulation that participated in a demonstration or march by wave. 
Divergent trends were also observed among congregations with different political orientations. For every political activity analyzed, the participation rates among politically conservative congregations have either remained the same or decreased since 1998, while the participation rates among politically liberal congregations have either remained the same or increased. Between 1998 and 2012, the percentage of politically conservative congregations that distributed voter guides decreased from $20 \%$ to $13 \%$. Meanwhile, the percentage of politically liberal congregations that distributed voter guides increased marginally from $13 \%$ to $24 \%$. Similarly, the percentage of politically conservative congregations that promoted opportunities to participate politically decreased from $26 \%$ to $10 \%$, while the percentage of politically liberal congregations that promoted such opportunities remained steady at approximately $45 \%$. During this same period, the percentage of politically conservative congregations that participated in a demonstration or march remained steady at approximately $8 \%$, while the percentage of politically liberal congregations that participated in a demonstration or march almost tripled, increasing from $15 \%$ to $43 \%$.

\section{Discussion}

Despite the few divergent trends, the substantial and generally increasing participation rates in service-related activities among most types of congregations supports the view that service provision is an institutionalized and nearly universal practice of congregations. Congregational political participation, however, appears to be becoming a niche practice. While many types of congregations exhibit less substantial and generally decreasing political participation rates, participation rates are relatively high among Catholic and politically liberal congregations and increasing substantially among predominantly Hispanic congregations. The following paragraphs discuss contours of the divergent trends in political participation exhibited among Catholic, politically liberal, and predominantly Hispanic congregations.

The high percentage of Catholic congregations involved in political activities is not a new finding; however, it is noteworthy that their participation rates have increased, while the rates among each major type of Protestant congregation have either remained the same or decreased. Furthermore, Beyerlein and Chaves [27] observed that in 1998 the primary differences in congregations across religious traditions were not in the rates of participation, but rather in the types of political participation. Each religious tradition engaged in politics in distinct ways. While this observation remains true among the major types of Protestant congregations, substantial shifts have taken place such that the rate of participation has become a primary difference between Catholic congregations and Protestant congregations. By 2012, Catholic congregations had the highest participation rate for every political activity analyzed except for hosting a political representative as a visiting speaker.

The trend of fewer politically conservative congregations and more politically liberal congregations participating in political activities runs counter to popular perceptions [42]. These perceptions are fueled by media outlets and political pundits, whose coverage of religion and politics tends to focus almost exclusively on the religious right and rarely even mentions religious progressives [43]. Although the overall number of politically-engaged conservative congregations remains greater than the number of politically-engaged liberal congregations, the gap is shrinking and the difference in public attention each group's political activity receives is of greater magnitude than the difference in their actual levels of engagement [44]. The persistent perceived prominence of the religious right and relative absence of religious progressives in the political arena is partly attributable to three related factors. First, the general rightward shift of American political culture since the 1980s has resulted in the policy positions of religious progressives receiving less of a public hearing [45]. Second, the religious right has mobilized so effectively for a media-oriented political culture that its representatives have crowded out religious voices advocating for progressive policies [46]. Third, secular voices—sometimes simply non-religious voices and sometimes clearly anti-religious ones-increasingly dominate progressive policy discourse [47]. 
Another complex element of the findings is the seemingly contradictory evidence that the percentage of predominantly Hispanic congregations participating in specific types of political activities has been increasing, while the overall percentage of Hispanic congregations participating in at least one type of political activity has been decreasing. Although Figure 4 illustrates a substantial drop in the percentage of Hispanic congregations that participated in at least one type of political activity, this statistic can be misleading. Additional analyses indicate that the initially substantial and increasing participation rate among Hispanic congregations between 1998 and 2006-2007, and the subsequent major decrease in participation in 2012, were produced primarily by changes in the participation rate for one type of activity-helping people register to vote, which increased from $41 \%$ to $66 \%$ between 1998 and 2006-2007, and then dropped to 11\% in 2012. These substantial swings in participation rates correspond to changes in voter registration laws that significantly impacted congregations'—especially Hispanic congregations'-ability to help people register to vote.

In particular, the 1993 National Voter Registration Act made it much easier for community-based organizations to conduct voter registration drives, and which in turn contributed to burgeoning voter registration rolls for the next 15 years [48,49]. However, following the 2008 elections, which had the highest turnout rate since 1960 and the largest turnout of Hispanic and black voters in U.S. history, several states began introducing and enacting more stringent election regulations [50]. Particularly relevant was legislation that imposed burdensome requirements on organizations seeking to help people register to vote [51]. The most restrictive measures were passed in Southern states that have substantial Hispanic populations [50,52]. These laws led several civic engagement organizations to discontinue their voter registration activities; many of which had focused on registering racial and ethnic minorities, since minority citizens disproportionately register through voter registration drives [50,51].

Analyzing data from Wave I and Wave II of the National Congregations Study indicates that a significant number of Hispanic congregations were among the organizations that began participating in voter registration activities during the 15 years following the 1993 National Voter Registration Act. Analyzing the Wave III data indicates that between 2006-2007 and 2012 the percentage of Hispanic congregations involved in voter registration activities decreased significantly ${ }^{7}$. This finding suggests that the major drop in participation may have been at least partly in response to the stricter regulations following the 2008 elections.

The large percentage of Hispanic congregations involved in voter registration activities in 1998 and 2006-2007 account for a substantial portion of the Hispanic congregations participating in at least one type of political activity. Consequently, when a significant percentage of Hispanic congregations had discontinued this activity by 2012, it led to the assessment that the general involvement in political activity among Hispanic congregations had decreased since 1998. Additional analyses, however, indicate that the participation rates among Hispanic congregations for all of the other political activities analyzed have either remained the same or increased since 1998. Based on these analyses, a more accurate assessment is that apart from the aberrations caused by changes in voter registration laws that disproportionately affected Hispanic congregations, the participation rate among Hispanic congregations involved in political activities has increased since 1998.

\section{Conclusions}

Although this study provides a detailed analysis of congregations' involvement in service provision and political participation over the past three decades, it has limitations. First, the analysis is based on a limited number of service-related and political activities; other participation patterns could be observed if a wider variety of activities were analyzed. In addition, the data on congregations' involvement in these activities were collected with minimal probing, and studies have demonstrated

7 Similar but dampened patterns are observed among predominantly white and black congregations. 
that additional probing results in a larger percentage of congregations reporting involvement $[4,10]$. Furthermore, other methodological differences, such as using narrow or broad definitions of congregation-based service provision and political participation as well as giving respondents a list of activities to select from versus asking them to recall activities from memory, can influence a congregation's likelihood of reporting involvement in such activities and may have produced differences in the reported participation rates across studies $[4,10]$. In order to ensure that the longitudinal analyses in this study are unaffected by such methodological differences, this study relies on the three waves of data collected by the NCS, which used consistent methods across each of its three waves.

Second, this study does not analyze the extent of congregations' involvement in service-related and political activities. Although it is important to understand differences between congregations with no involvement and those with at least some involvement, scholars and practitioners could benefit from understanding changes among congregations in the volume and scope of their service provision and political participation. In addition, with regard to congregation-based political activities, it would be beneficial to understand changes in the issues congregations are addressing as well as changes in the positions they are taking on those issues. Other studies have examined how the number, type, and content of activities congregations participate in have changed over time $[1,2,53]$, but these studies are limited to analyzing only two waves of data.

Third, this study does not examine how the size of a congregation is associated with its participation in service-related and political activities. Although the correlation between congregational size and participation in such activities is known to be significant and stable over time, one point is worth noting. Because this study conducted its analysis at the congregation level and did not differentiate between the size of congregations, this study underrepresents the percentage of church attenders in congregations that provide services and participate politically. Since it is also important to know the number of people exposed to congregation-based service-related and political activities, future studies could conduct similar change-over-time analyses at the attendee level.

Fourth, the analysis of participation patterns among congregational subpopulations does not include non-Christian congregations nor ethnoracially diverse congregations ${ }^{8}$. The relatively small percentages of non-Christian congregations in the U.S., and subsequently in the NCS, inhibits analytical precision, and combining all of the congregations from non-Christian traditions into one category would obscure any differences that exist between those traditions. Future research could collect sufficiently large samples of congregations within these less prevalent traditions and conduct similar longitudinal analyses going forward. In contrast, the NCS does contain a sufficiently large number of ethnoracially diverse congregations; however, these congregations were not included in the analysis for important methodological reasons ${ }^{9}$. Within the subset of ethnoracially diverse congregations, there is substantial variation in ethnoracial composition. Some have one ethnoracial group that represents a large majority of its members, others are split 50/50 across two ethnoracial groups, and some have equal representation across multiple ethnoracial groups. Thus, combining each type of ethnoracially diverse congregation into one category would make it difficult to specify the source of variation in outcomes. This limitation is not unique to congregational studies; it pertains to any study attempting to analyze outcomes associated with ethnoracial diversity. Rather than treating ethnoracially diverse groups as having similar composition, researchers could use more refined methods that capture the variation in composition that exists among ethnoracially diverse groups. Finally, future research could enhance understanding of congregational activities by analyzing how congregation-based service

8 Based on the operationalization used in this study, a congregation is considered to be ethnoracially diverse if no single ethnoracial group represents $80 \%$ or more of its members.

9 The analysis of congregational subpopulations does not include predominantly Asian and Native American congregations because of their insufficient representation in the NCS. 
provision and political participation are associated with the interaction between a congregation's religious tradition and ethnoracial composition.

Despite these limitations, this study fills a critical need by providing the first longitudinal analysis to assess how congregations' involvement in service provision and political participation has changed over the past three decades. Overall, this study finds that among most types of congregations, the percentage participating in service-related activities is substantial and increasing, while the percentage participating in political activities is less substantial and decreasing. This decline in political participation has implications for congregations' ability to effectively address social needs. Congregations can address social needs more comprehensively when they combine acts of service with political engagement. In doing so, they can relieve immediate needs while at the same time advocate for long-term solutions. Among the few types of congregations that have high and/or increasing participation rates in both service-related and political activities are Catholic, predominantly Hispanic, and politically liberal congregations. Although their representation among the total population of congregations in U.S. is relatively small, Catholic congregations are among the largest congregations and predominantly Hispanic and politically liberal congregations are among the fastest growing. While it is likely that a high percentage of congregations will remain involved in service provision, the future trajectory of congregation-based political participation remains uncertain.

Acknowledgments: Ruodan Zhang provided valuable research assistance with the analytical portions of this article.

Conflicts of Interest: The author declares no conflict of interest.

\section{Abbreviations}

NCS National Congregations Study

\section{References}

1. Mark Chaves, and Bob Wineburg. "Did the faith-based initiative change congregations?" Nonprofit and Voluntary Sector Quarterly 39 (2010): 343-55. [CrossRef]

2. Nathan R. Todd, and Jaclyn D. Houston. "Examining patterns of political, social service, and collaborative involvement of religious congregations: A latent class and transition analysis." American Journal of Community Psychology 51 (2013): 442-38. [CrossRef] [PubMed]

3. Mark Chaves, and William Tsitsos. "Congregations and social services: What they do, how they do it, and with whom." Nonprofit and Voluntary Sector Quarterly 60 (2001): 660-83. [CrossRef]

4. Ram Cnaan. The Invisible Caring Hand: American Congregations and the Provision of Welfare. New York: New York University Press, 2002.

5. Robert Wuthnow. Saving America?: Faith-Based Services and the Future of Civil Society. Princeton: Princeton University Press, 2004.

6. Richard M. Clerkin, and Kirsten A. Grønbjerg. "The capacities and challenges of faith-based human service organizations." Public Administration Review 67 (2007): 115-26. [CrossRef]

7. Robert J. Wineburg. A Limited Partnership: The Politics of Religion, Welfare, and Social Service. New York: Columbia University Press, 2001.

8. Robert J. Wineburg. "A longitudinal case study of religious congregations in local human services." Nonprofit and Voluntary Sector Quarterly 23 (1994): 159-69. [CrossRef]

9. Mark Chaves, and Alison Eagle. "Congregations and social services: An update from the third wave of the National Congregations Study." Religions 2016, submitted.

10. Mark Chaves. Congregations in America. Cambridge: Harvard University Press, 2004.

11. Nancy T. Ammerman. Pillars of Faith: American Congregations and Their Partners. Berkeley: University of California Press, 2005.

12. Ram Cnaan, Stephanie C. Boddie, Charlene C. McGrew, and Jennifer Kang. The Other Philadelphia Story: How Local Congregations Support Quality of Life in Urban America. Philadelphia: University of Pennsylvania Press, 2006. 
13. M. Lori Thomas. "Faith and collaboration: A qualitative analysis of faith-based social service programs in organizational relationships." Administration in Social Work 33 (2009): 40-60. [CrossRef]

14. Omar M. McRoberts. Streets of Glory: Church and Community in a Black Urban Neighborhood. Chicago: University of Chicago, 2003.

15. Nancy T. Ammerman, and Arthur E. Farnsley. Congregation and Community. New Brunswick: Rutgers University Press, 1997.

16. Jo Anne Schneider. Social Capital and Welfare Reform: Organizations, Congregations, and Communities. New York: Columbia University Press., 2006.

17. Mark Chaves, and Lynn M. Higgins. "Comparing the community involvement of black and white congregations." Journal for the Scientific Study of Religion 31 (1992): 425-40. [CrossRef]

18. Mark Chaves, Helen Giesel, and William Tsitsos. "Religious variation in public presence." In The Quiet Hand of God: Faith-Based Activism and the Public Role of Mainline Protestantism. Edited by Robert Wuthnow and John H. Evans. Berkeley: University of California Press, 2002, pp. 108-28.

19. William Tsitsos. "Race differences in congregational social service activity." Journal for the Scientific Study of Religion 42 (2003): 205-15. [CrossRef]

20. Edward C. Polson. "Social diversity and civic engagement: The effects of ethnic and social heterogeneity on the community involvement of American congregations." Nonprofit and Voluntary Sector Quarterly 44 (2015): 968-87. [CrossRef]

21. Sandra Barnes. "Priestly and prophetic influences on black church social services." Social Problems 51 (2004): 202-21. [CrossRef]

22. Khari Brown. "Racial/Ethnic differences in religious congregation-based social service delivery efforts." Journal of Sociology and Social Welfare 35 (2008): 95-113.

23. James C. Cavendish. "Church-based community activism: A comparison of black and white catholic congregations." Journal for the Scientific Study of Religion 39 (2000): 371-84. [CrossRef]

24. Malcolm V. Williams, Ann Haas, Beth Ann Griffin, Brad R. Fulton, David E. Kanouse, Laura M. Bogart, and Kathryn Pitkin Derose. "Predictors of the existence of congregational hiv programs: Similarities and differences compared with other health programs." American Journal of Health Promotion 29 (2015): 225-35. [CrossRef] [PubMed]

25. Brad R. Fulton. "Black churches and HIV/AIDS: Factors influencing congregations' responsiveness to social issues." Journal for the Scientific Study of Religion 50 (2011): 617-30. [CrossRef] [PubMed]

26. Robert Wuthnow. Red State Religion: Faith and Politics in America's Heartland. Princeton: Princeton University Press, 2012.

27. Kraig Beyerlein, and Mark Chaves. "The political activities of religious congregations in the United States." Journal for the Scientific Study of Religion 42 (2003): 229-46. [CrossRef]

28. Richard L. Wood, and Brad R. Fulton. A Shared Future: Faith-Based Community Organizing for Racial Equity and Ethical Democracy. Chicago: University of Chicago Press, 2015.

29. Robert D. Putnam, and David E. Campbell. American Grace: How Religion Divides and Unites Us. New York: Simon and Schuster, 2010.

30. Brad R. Fulton, and Richard L. Wood. "Interfaith community organizing: Emerging theological and organizational challenges." International Journal of Public Theology 6 (2012): 398-420. [CrossRef]

31. David E. Campbell. "Acts of faith: Churches and political engagement." Political Behavior 26 (2004): 155-80. [CrossRef]

32. Robert Wuthnow, and John Evans. The Quiet Hand of God: Faith-Based Activism and the Public Role of Mainline Protestantism. Berkeley: University of California Press, 2002.

33. Khari Brown. "Racial differences in congregation-based political activism." Social Forces 84 (2006): 1581-604. [CrossRef]

34. Khari Brown. "Racial/ethnic differences in the political behavior of American religious congregations." Sociological Spectrum 29 (2009): 227-48. [CrossRef]

35. Kenneth D. Wald, and Allison Calhoun-Brown. Religion and Politics in the United States. Lanham: Rowman \& Littlefield, 2014.

36. Paul Lichterman, and C. Brady Potts. The Civic Life of American Religion. Stanford: Stanford University Press, 2009. 
37. Heidi Swarts. "Drawing new symbolic boundaries over old social boundaries: Forging social movement unity in congregation-based community organizing." Sociological Perspectives 54 (2011): 453-77. [CrossRef]

38. Brad R. Fulton, and Richard L. Wood. "Pragmatic progressives: Achieving and leveraging social diversity through faith-based organizing." In Religion and Progressive Activism in the United States. Edited by Ruth Braunstein, Todd N. Fuist and Rhys H. Williams. New York: New York University Press, 2017, forthcoming.

39. Mark Chaves, Shawna Anderson, and Alison Eagle. National Congregations Study: Cumulative Datafile and Codebook. Durham: Department of Sociology, Duke University, 2014.

40. Brian Steensland, Jerry Z. Park, Mark D. Regnerus, Lynn D. Robinson, W. Bradford Wilcox, and Robert D. Woodberry. "The measure of American religion: Toward improving the state of the art." Social Forces 79 (2000): 291-318. [CrossRef]

41. Brian Steensland, and Philip Goff. The New Evangelical Social Engagement. New York: Oxford University Press, 2014.

42. Ruth Braunstein, Todd N. Fuist, and Rhys H. Williams. Religion and Progressive Activism in the United States. New York: New York University Press, 2017, forthcoming.

43. The Economist. "The religious left: Even evangelical Christians are not uniformly right-wing." 2016. Available online: http:/ / www.economist.com/news/united-states/21693555-politics-american-christiansmore-nuanced-sometimes-assumed-not-all (accessed on 1 March 2016).

44. Amy Sullivan. The Party Faithful: How and Why Democrats Are Closing the God Gap. New York: Simon and Schuster, 2008.

45. E.J. Dionne, Jr. Souled Out: Reclaiming Faith and Politics after the Religious Right. Princeton: Princeton University Press, 2009.

46. Heather Hendershot. Shaking the World for Jesus: Media and Conservative Evangelical Culture. Chicago: University of Chicago Press, 2010.

47. Ryan L. Claassen. Godless Democrats and Pious Republicans?: Party Activists, Party Capture, and the 'God Gap'. Cambridge: Cambridge University Press, 2015.

48. John Mark Hansen. "Mobilization, participation, and political change." Party Politics 22 (2016): 149-57. [CrossRef]

49. Stephen Mortellaro, and Michelle Kanter Cohen. "Restricting voter registration drives." Project Vote, 2014. Available online: http:/ /www.projectvote.org/wp-content/uploads/2015/06/RESTRICTING-VR-DRIVESPOLICY-PAPER-SEPT-2014.pdf (accessed on 1 March 2016).

50. Jessica A. González. "New state voting laws: A barrier to the Latino vote?" 2012. Available online: http:/ / papers.ssrn.com/sol3/papers.cfm?abstract_id=2060460 (accessed on 1 March 2016).

51. Justin Levitt. "Election deform: The pursuit of unwarranted electoral regulation." Election Law Journal 11 (2012): 97-117.

52. Wendy R. Weiser, and Diana Kasdan. "Voting law changes: Election update." 2012. Available online: http:/ / www.brennancenter.org/publication/voting-law-changes-election-update (accessed on 1 March 2016).

53. Brad R. Fulton. "Network ties and organizational action: Explaining variation in social service provision patterns." Management and Organizational Studies 2016, forthcoming.

(C) 2016 by the author; licensee MDPI, Basel, Switzerland. This article is an open access article distributed under the terms and conditions of the Creative Commons Attribution (CC BY) license (http:/ / creativecommons.org/licenses/by/4.0/). 
Article

\title{
Faith-Based International Development Work: A Review
}

\author{
Dan Heist ${ }^{1}$ and Ram A. Cnaan ${ }^{2, *}$ \\ 1 School of Social Policy and Practice, University of Pennsylvania, 3815 Walnut St., Philadelphia, \\ PA 19104-6214, USA; heist@sp2.upenn.edu \\ 2 School of Social Policy and Practice, University of Pennsylvania, 3701 Locust Walk, Caster Building, \\ Room D-20, Philadelphia, PA 19104-6214, USA \\ * Correspondence: cnaan@sp2.upenn.edu; Tel.: +1-215-898-5523 \\ Academic Editor: Robert Wineburg \\ Received: 10 December 2015; Accepted: 15 February 2016; Published: 25 February 2016
}

\begin{abstract}
In the wake of the Faith-Based Initiative in the USA, substantial research has resulted in an increased awareness of religious congregations and faith-based organizations as welfare service providers. The next frontier appears to be the role of religious organizations in international social and economic development, a topic that only recently started to attract academic interest. In this paper, we review available literature on the role that religious, or faith-based, organizations play in international social and economic development. We also provide results from our own study of USA international $\mathrm{NGOs}^{1}$ that are faith-based. We divide the paper into the positive contributions of faith-based international NGOs and the drawbacks of these NGOs. We find that faith-based nonprofits constitute almost 60 percent of USA-based international development organizations, and their contribution to international social development is quite considerable. We conclude with a call for further research and nuanced understanding of the role religion plays in international development.
\end{abstract}

Keywords: international development; international social and economic development; religious community; faith based organizations; faith-based NGOs; humanitarian work

\section{Introduction}

Some scholars look at the Faith Based Initiative of the George W. Bush administration as a failure. They conclude that too few congregations joined the ranks of social service providers and, as such, it was much ado about nothing [1]. It is our contention that the errant expectation for congregations and other faith-based organizations to do more welfare provision came from a misunderstanding of the level of welfare service provision from the faith-based community before the initiative took place. The gloomy review of the faith-based initiative failed to account for the already impressive engagement of the faith community in social services provision [2]. In the USA context, the faith community provides more welfare services to more people than any other group of nonprofit organizations. There are numerous congregations as well as faith-based organizations caring for the welfare of Americans even though this is not their primary raison d'être.

Starting with this perspective, we aim to recognize one area of welfare activity that is also poorly understood-faith-based international social and economic development. This is an important field of

1 In this paper we use the terms nonprofit organizations and NGOs interchangeably. We use these terms as close as possible to the sources we use, acknowledging that, in the US, it is more common to use the term nonprofit, while in many other countries NGO is the more common term. 
social practice in which people and organizations in rich countries, with or without their government, support people and communities in less prosperous countries. In general, the term international development applies broadly to a variety of international activities. In this paper we focus on the efforts of voluntary associations, such as nonprofits and NGOs, specifically those considered faith-based or religious. We attempt to review the historical context and existing literature, discuss some strengths and some weaknesses of faith-based organizations in international social and economic development, as well as carry out a modest empirical investigation on the scope and the role of USA faith-based international development organizations. We identified as many resources as we could find from as many locales as possible though a large share of our findings came from USA-based literature.

\section{Literature Review}

Religion is a wide term that reflects many worldviews. Carole Rakodi contended that "'religion' and the English words used to talk about it, such as faith or belief, do not always translate directly into other religious traditions and languages" ([3], p. 640). While this may be linguistically the case, Muslim and Hindu faith-based development organizations are deeply aware that they originate from and represent a specific faith tradition. In this respect we distinguish between the "substantive" and "functional" definitions of religion [3-5]. We do not follow a substantive definition that is focused on how religion is carried out such as "the sacred", rather we apply the functionalist definition that focuses on "what religion does" for society or a group ([3], p. 638). In this paper, we do not explore the various theological and hermeneutical aspects of religion, but rather how religion or more precisely faith organizations operate in comparison to secular organizations.

International social and economic development is a wide field that focuses on improving basic conditions and the quality of life of people living in developing countries. It can start with country-to-country support, but it is also commonly understood as the activity of private (usually nonprofit) organizations that bring skills, resources, expertise, and goods from a rich environment to a foreign country where it is most needed. In this respect, we do not cover in-country organizations that strive for social and economic development such as local churches or local denominations. There are, however, many schools of thought and understanding concerning the exact definition and characteristics of international social development. This field of activity includes, but is not limited to, economic development, literacy, vocational education, higher education, human rights, political freedom, reduced poverty, secure housing, sustainable development, social infrastructure, health promotion, and quality of life or subjective well-being [6-8]. As is common in the literature, we do not imply that these organizations enhance national or regional development. We assume that they strive to improve quality of life in a sustainable manner that in some cases lead to meaningful development.

Just as international social and economic development is a comprehensive and hard to define concept, so is religion. Some scholars argue that the study of international development in its historical and anthropological context is inseparable from the study of religion [9]. Our focus is not on the religiosity of people and workers but on the organizations that carry out international development work. For the past twenty years, there has been considerable debate over what a faith-based organization is and what a faith-based development organization is [10-12]. In most instances, we opted to go with the definitions used by the sources we reviewed as well as with the organizations we studied. This makes our work easier but it introduces the risk of drawing conclusions from studies that defined faith-based development organizations in different ways.

Dicklitch and Rice proposed that "FBNs [Faith-based NGOs] can be defined as non-state actors that have a central religious or faith core to their philosophy, membership, or programmatic approach, although they are not simply missionaries" ([13], p. 662). An inclusive framework is put forth by Carole Rakodi, whose work demonstrates that "religion and development are not separate spheres of life-they are intertwined and each influences the other" ([3], p. 635). Tara Hefferan, Laurie Occhipinti and Julie Adkins modified a typology put forth by Sider and Unruh-a typology focused on the US context-to consider what role "faith" plays in FBOs working in Latin America and the Caribbean. 
By identifying several key areas for examining faith, the typology allows researchers to consider how "faith and religion are manifested in goals, mission, programming, and funding" along six different faith axes, ranging from "secular" to "faith-saturated" ([14], p. 9). We are far from being able to accurately theorize or even describe the behavior of faith-based organizations. What this study seeks to add is a more comprehensive review of the scope and impact of faith-based development organizations based on extant literature and a modest independent study.

At the G20 Interfaith Summit Meeting 2015 in Istanbul, Peter Howard attempted to elicit what is required of an NGO to be defined as a faith-based organization. First is the notion of the sacredness of life: Faith-based NGOs value the life of everyone. Workers of faith-based NGOs understand people as created in the image of God with transcendent sacredness so that workers can engage with greater honor. Instead of thinking of rights in terms of minimum standards of asylum, food, or education, they think of rights in terms of inclusion, abundance and community. Second, faith-based NGOs have long-term and consistent presence in areas with great needs. This international presence brings with it faith assets such as people, networks, leaders, infrastructure, buildings, and donations. These assets can be mobilized faster, more comprehensively, and wherever needed when compared with public agencies or secular NGOs. Third, faith-based NGOs apply and obey their conscience: Using religious doctrines they advocate for the needy and serve as a voice of conscience. Fourth, faith-based NGOs operate from the standpoint of faith. All world religious traditions emphasize that their faith is an important tool for coping and resiliency. Fifth, faith-based NGOs uphold the theology of mercy and forgiveness. Merciful people and organizations care for and are appreciated by their beneficiaries. Finally, faith-based NGOs emphasize charity. Charity in this context is the willingness to give time, attention, and resources in abundance. Clearly, an empirical investigation will show that not every faith-based NGO fully adheres to all six requisites. In fact, many likely fall short of meeting all six. However, on average faith-based international development organizations may be characterized by these six requisites and often aspire to actualize them. Organizations that follow all six criteria offered by Howard tend to follow their mission with corresponding programs rather than alter programs to pursue funding opportunities [15].

Since the dawn of the 19th century, American Protestant denominations have sent volunteers and paid missionaries to spread their teachings worldwide, including places that were considered unsafe such as Africa, Asia, and Latin America [16]. Many Catholic missionaries and organizations brought technology and knowledge to remote parts of the world for hundreds of years. Numerous religious employees and volunteers took to the road and journeyed long distances spending years trying to evangelize the natives. These missionaries, in addition to spreading their respective religious messages, provided social and healthcare services that formed the foundation of many countries' health and human services infrastructure $[17,18]$. In many countries, the basic universities, hospitals, and other major institutions started with these religious missions. Today, many faith-based international social and economic development organizations provide care and establish civic infrastructure with, or often without, an eye towards proselytization. As Hefferan et al. rightly contended, faith-based development organizations are very diverse and understudied. They noted enormous variation in organizations that fall within the category of faith-based organizations. They suggested that most faith-based development organizations are Christian, however others are Muslim, Jewish, "spiritual" or multi faith, and Buddhist, with a few that are Baha'i, Hindu, or Jain [14].

Unfortunately, there is very little data regarding the role of religion in mainstream social and economic development studies and policy [3,19,20]. Kurt Alan ver Beek argued that within the context of international social and economic development, spirituality is taboo. ver Beek searched the three leading development studies journals; Journal of Development Studies, World Development, and the Journal of Developing Areas, for any mentioning of religion or spirituality. He covered the years 1982 to 1998 and found almost no hits. For example, in the Journal of Development Studies there were 46 hits for "gender", 38 for "population", 19 for "environment", one for "religion", and none for "spirituality". 
Most telling is the fact that in all three journals between 1982 and 1998 there was not one article in which religion was a major theme [21]. ver Beek concluded that:

Given the apparently integral link between spirituality and issues central to development, it would seem reasonable that spirituality would occupy a relatively prominent place in development theory and practice. However, the subject is conspicuously under-represented in development literature and in the policies and programmes of development organisations ([21], p. 36).

Ten years after ver Beek's study was published, more publications regarding the nexus between religion and international development were published. However, as Jones and Petersen noted, the majority of these publications suffered from being instrumental in their approach, narrowly focusing on specific faith-based organizations, and were frequently based on normative assumptions rather than empirical assessments. These authors explained "that, in chronological terms, the interest in religion came more from the development industry, particularly the big multilateral and bilateral donors, than from universities and research organisations" ([22], p. 1292). Jones and Petersen acknowledged that more had been written on religion and international social and economic development in the last ten to twenty years. However, despite this, the additional literature was not written systematically, and did not enable full assessment of the role of religion and faith in international development [22]. In studying faith-based development organizations, authors often demonstrate a bias. They either dismiss or wholly support faith-based organizations. While we aim to highlight the unique contributions of faith-based development organizations, we apply a more balanced approach.

Furthermore, it is important to keep in mind the debate over the effectiveness of humanitarian aid in achieving international development goals. Faith-based organizations provide humanitarian services and welfare services designed to reduce suffering and improve living conditions. There is significant debate in development literature about whether humanitarian aid actually helps with development of countries [23]. For the purpose of this paper, we assume the term international development to include the humanitarian and welfare activities of faith-based organizations. We follow the USA's National Taxonomy of Exempt Entities which includes humanitarian organizations in their "International Relief and Development" category [24].

\section{Strengths and Weaknesses}

We begin our investigation with a discussion of suggested strengths and contributions of faith-based international NGOs to international social and economic development. Next, we devote a section to their asserted criticism and review potential weaknesses of faith-based international NGOs. On the strengths and contributions side, we begin with trust in faith-based organizations by the people who are being helped. This is followed by sections on faith networks, religious volunteers for international social and economic development organizations, and funding of international work and the share of the faith community. We then move to an independent study we carried out to compare scope and scale of secular versus faith-based international development nonprofit organizations. We then discuss the impact of faith-based international organizations on the life of their service recipients.

On the side of drawbacks of faith-based international development, we start with issues of proselytization by these faith-based NGOs. This is followed by a discussion on the faith-based NGOs' inclination to work alone and to avoid partnerships and coalitions. The last section of drawbacks deals with religion as a source or contributor to armed conflicts, genocide, terrorism, and other human atrocities. We conclude with a summary as well as suggestions for future research. 


\section{Trust of People Being Helped}

When helping people locally or internationally, forming trust relationships is essential. People that trust the helpers, and do not suspect their motives, are more likely to be transformed and adapt to change. A variety of studies show that faith-based international organizations enjoy strong popular support and trust among the poorest and neediest populations. These organizations and their workers reach people at the grassroots level, speak their language and respect their sentiments and culture. For example, Jones and Petersen reported that "a 2008 Gallup poll showed that $82 \%$ of people in sub-Saharan Africa claimed that they trusted religious organisations more than other societal institutions" ([22], p. 1305). Rick James, based on the World Bank set of studies, concluded that faith-based development organizations are better at reaching out to client population in development than workers of secular organizations [12]. Similarly, Erica Bornstein studied Protestant NGOs in Zimbabwe with a focus on the World Vision national office in Harare as well as in the field. She found that for staff members in the field, faith serves to create bonds of community [25].

Clarke and Jennings contended:

...the language of faith, the religious idiom, frequently better reflects the cultural norms in which the poor and marginalised operate. They are better able to draw such individuals and communities into global discourses of social justice, rights and development, without recourse to the often distancing language of secular development discourse ([26], p. 16).

The problem with these contentions is that few of them were empirically tested. With the exception of the Gallup findings, referenced above, all other sources seem to rely on anecdotal information, and to some extent, on ideological preferences [22]. However, there are very few reports suggesting that religious development workers deterred locals or caused them to distrust the service organizations.

Bruno De Cordier studied Western Muslim FBOs, primarily from the United Kingdom and their work in Central Asia, Iraq, and Pakistan. Some of the studied organizations were large scale and include such organizations as the Islamic Relief Worldwide and Muslim Aid. De Cordier found that Muslim FBOs were more effective in these countries because of their religious beliefs and affiliations. The locals distrusted Western relief organizations and saw them as agents of the corrupt West. Muslim NGOs, alternatively, are viewed as authentic and people are willing to accept help from them [27]. These findings support Jonathon Benthall's assertion that "It is well established that international Christian NGOs can work effectively in Christian parts of Africa through local church networks, and there is surely considerable potential for international Islamic charities to work in a similar way among Muslims" ([28], p. 7).

Robert Leurs reports that, Christian and secular organizations find it difficult to function in Muslim-dominated Kano State. Local residents prefer working with organizations that shared their own religious heritage [29]. Put differently, people on the ground often prefer faith-based providers to secular ones, and if possible those of a faith that locals can relate to.

Deryke Belshaw found in humanitarian work in Africa five advantages FBOs have over secular providers. They can have: (1) the long-term commitment to their memberships as they have served the community for a long time; (2) the majority of the FBO's members are likely to consist of the poorest and most marginalized in developing countries; (3) links to sister organizations that possibly provide funding and expertise; (4) emphasis on the "golden rule" (i.e., treat others as you yourself wish to be treated) as a guide to social relationships; and (5) spiritual and relational experiences that can raise the self-regard and confidence of marginalized people and help them benefit from new opportunities. While not all FBOs live by these standards, they more often describe FBOs as compared with secular ones [30]. Alkire noted the reason why many governments and world financial organizations financially support faith-based development organizations is that these organizations are vital and effective partners in international efforts to reduce poverty. Their perceived closeness to poor communities and their highly motivated staff and volunteers prove them indispensable [31]. 
Just as people on the ground trust religious social and economic development organizations, so do many big funders. In the context of Africa, Paul Gifford noted that "Agencies of official Western aid, reluctant to give to governments they considered corrupt, sought out more reliable local partners, often churches with their extensive networks, grassroots membership, and established structures" ([32], p. 94).

\section{Faith Networks}

It seems that in the past two decades more forces within international social and economic development look to religion to be part of the solution. Possibly the first initiative was the Development Dialogue on Values and Ethics, established in 1998 by James Wolfensohn, then president of the World Bank, and George Carey, then Archbishop of Canterbury. The initiative sought a wide-ranging international and national dialogue among faith and development institutions, with the effort to combat world poverty as the central focus and it evolved into the World Faiths Development Dialogue [33]. The participants realized that the role that faith-based organizations and people played in international social and economic development identified them as important partners in care and that their contributions were unique and significant.

In a related report published by the World Bank in 2000, researchers found that in many developing countries, faith-based organizations develop pervasive networks that often supersede those of local government or other social service providers. It cited examples from Benin to Panama and from Vietnam to Georgia, of religious organizations serving as the dominant care providers and offering services without regard to ethnicity, nationality or religion [34].

Perhaps the most salient example of faith-based networks is the collaborations formed to sustain a prolonged response to the global refugee crisis. According to a report from the United Nations in 2012, there is a great need for more support from international faith-based organizations in response to refugee crises. UN High Commissioner for Refugees António Guterres reported that faith-based relief agencies "can help prevent conflict and address the root causes of displacement, assist refugees in making informed choices in exile, and play a central role in making solutions sustainable by helping refugees integrate in their new communities" [35]. In her qualitative research among Syrian refugees, and the role of religion in their experience, Estella Carpi found that "secular humanitarian responses fail to address the potentialities that lie within engagement with the faiths of displaced groups." She concluded that religious observance among refugees does more than provide a source of community [36].

Many humanitarian efforts involved faith-based organizations working in tandem to address overwhelming issues. This sentiment was officially reported by the United Nations. The World Conference on Religion and Peace (aka the "UN of religions") officially concluded that

Religious communities are, without question, the largest and best-organized civil institutions in the world today, claiming the allegiance of billions of believers and bridging the divides of race, class and nationality. They are uniquely equipped to meet the challenges of our time: resolving conflicts, caring for the sick and needy, promoting peaceful co-existence among all peoples ([37]).

Berger noted that faith-based NGOs are embedded in extensive networks of both faith-based organizations and secular NGOs that allowed them to be successful in various important campaigns such as the 2000 jubilee year. This massive campaign started as a movement to advocate for international debt relief. The organizers used the biblical term of debt relief (jubilee) to gain support, predicting that in the year 2000 most poor countries would be free of their debt. According to Berger, they were successful and received support from all across the political map. In 1996, the International Monetary Fund (IMF) and World Bank announced a new initiative with the aim of ensuring that no poor country faced a debt burden it could not manage. Berger concluded that "Religious nongovernmental organizations were also active in the Nobel Prize winning International Campaign to Ban Landmines 
and are actively involved in the 1000-plus member NGO Coalition working for the advancement of the International Criminal Court" ([19], p. 20). Similarly, although our focus is not on within-country development efforts, many faith-based international NGOs have the advantage of local congregations that they can mobilize in their development and welfare services. Having supporting allies on the ground is a strategic advantage that many secular NGOs lack.

\section{Volunteers for International Social and Economic Development}

The number of international nonprofit and social agencies relying on the help of volunteers has grown enormously in recent decades. International volunteering utilizes volunteers who are not citizens of the country in which they are working. In the past fifty years, the number of international religious volunteers and service providers has dramatically increased. In the last half century missionary work did not plateau but expanded. Micklethwait and Wooldridge suggested that missionary work expanded with reduced cost of travel as new opportunities arose. Several geopolitical events (such as the end of colonialism, the fall of most communist regimes, and the spread of democracy that has weakened the control of state-sponsored religions) opened many countries to the presence of religious volunteers. However, not all religious groups are equally involved in international work [38]. Hanson and Xiang noted "the US is the largest single exporter of Protestant Christianity" ([39], p. 6). Similarly, Brouwer, Gifford and Rose discovered that Protestant denominations with the most restrictive religious doctrines and distinctive worship practices often engage more volunteers worldwide and also have enjoyed the most membership growth [40].

Rieffel and Zalud estimated that, in 2006, out of 43,000 Americans engaged in long-term international volunteering, 8000 were affiliated with specific faith-based organizations such as Habitat for Humanity, Catholic Relief Services, and the Presbyterian Hunger Program [41]. However, this estimate excludes missionaries whose primary goal is to propagate the religion of the sending agency such as the thousands of missionaries sent annually by The Church of Jesus Christ and Latter-day Saints (LDS Church) or the Assemblies of God. Moreau, Corwin, and McGee reported that in 2001 alone, an estimated 350,000 Americans travelled abroad with Protestant missionary agencies for periods that may range from a week to over a year [42]. Furthermore, these estimates did not take into account the many religiously-motivated international volunteers who are serving in secular organizations [43]. Sadly, there are no equivalent statistics regarding religious international volunteering from European countries.

Benjamin Lough studied international volunteers from the USA and determined that young adults aged 15-24 years were those most likely to engage in unpaid service abroad, followed by those approaching traditional retirement age (55-64 years). This was likely the result of the time and cost required from international volunteers. Similarly, two-thirds of international volunteers were living in higher earning households ( $\$ 100,000$ or more). Lough also found that almost half $(45 \%)$ of those volunteering abroad were "associated with a religious organization", a higher rate of religious affiliation than domestic volunteers (estimated at around 35\%) [44].

When discussing international volunteering, there are three key types to consider. One type is known as "volunteer tourism". McGehee and Santos defined volunteer tourism as "utilizing discretionary time and income to travel out of the sphere of regular activity to assist others in need" ([45], p. 760). Those who can afford the time and cost fly to a remote community and provide a needed service such as building a structure, monitoring an election, providing medical care, digging a well or paving a path in a rain forest. A second type of international volunteering has to do with responding to a natural disaster or other emerging crises. Many faith-based and social organizations are ready to respond to any humanitarian crisis. This type of volunteering usually involves civil professionals (from construction experts to medical workers) who are trained in relief work and who are willing to be mobilized on short notice [46,47].

The third archetype of international volunteering may be called long-term deployment. Long-term volunteers commit to a relatively long period of service (ranging from a few months to many years) 
and relocate to a place where they are needed. In the secular world, one of the most commonly known types of long-term volunteering is the Peace Corps. In 2006, for example, there were 7800 Peace Corps volunteers who spent lengthy periods of time outside of the USA [41]. Many faith-based organizations also send volunteers for long periods of time to help meet local needs and/or for proselytizing. As noted above, their numbers are significant and if we include missionaries they are the majority of long-term deployed volunteers.

Lough found out that when looking at the type of main organizations for volunteers who spent all or almost all of their time volunteering internationally from 2007 to 2012, 45.4\% were religious organizations. The next most common type of international organization were social and community service organization (10.8\%) [44].

\section{Funding for Faith-Based International Development}

According to the National Center for Charitable Statistics, organizations categorized by the National Taxonomy of Exempt Entities (NTEE) Code Q, international affairs, reported a total of $\$ 40.1$ billion in gross receipts in 2014 [24]. Much of this came from government grants, and investments. Giving USA 2015 reported that $\$ 15.1$ billion of this funding came from private donations [48]. The four international development organizations with the largest amount of private support in 2013 were all faith-based organizations: Food for the Poor with $\$ 891.4$ million (mostly from donations in kind), World Vision with \$826.9 million, Feed the Children with \$613.7 million, and Compassion International with $\$ 596.1$ million. These four organizations account for $20 \%$ of the total donations given to international affairs. As a trend, giving to the international NGOs declined gradually over the last seven years from its peak in 2008 at $\$ 22.26$ billion. This trend is a result of the impact of the recession on charitable giving [49].

Elizabeth Ferris suggested that in the early 2000s "the church related agencies associated with the World Council of Churches mobilized over US \$1 billion per year for relief and development and the members of the Caritas Internationalis family, in 162 countries, mobilized at least that amount" ([50], p. 313). These sums do not include locally raised funds, the many religious groups that not affiliated with these two large organizations, and religious donations to secular organizations. This amount is similar to the sum reported by Dicklitch and Rice who estimated that combined the major faith-based international social and economic development organizations spend about two billion dollars a year [13].

One source of private funding for international development comes from collective donations. It is not uncommon for congregants in various faith traditions to be asked during a worship service to make a financial donation to an international relief effort sponsored by or associated with that place of worship. The National Congregations Study (NCS), drawn from a representative sample of U.S. places of worship, found in 2006 that nearly half (41.6\%) of religious congregations held gatherings to consider "travel to another country to provide assistance to people in need" [51]. Moreau, Corwin, and McGee reported that donations to Protestant missionary agencies totaled $\$ 3.75$ billion, a $44 \%$ increase in five years [42].

Smillie and Minear noted that while both secular and faith-based international social and economic development organizations receive money from governments, faith-based organizations limit this source of income to keep their independence while secular organizations are almost fully dependent on government support and can be viewed as an arm of government. These authors suggested that, for example, $70 \%$ of funds for Action Contre la Faim in France came from official sources, while World Vision USA received only $23 \%$ of its income from the government in 2001. Oxfam GB received 28\% from the government and the Lutheran World Federation just 20\% [52].

International development attracts larger donors as well. Sixty percent of corporate donors look overseas to make a difference, indeed $57 \%$ of the Fortune 500 companies gave to internationally based charitable organizations [49]. While corporations can be lucrative sources of philanthropy, it is also 
important to recognize that corporate giving strategies often focus on improving conditions in regions where the firm hopes to develop markets as well.

As an example of the resources that one faith-based organization can garner, Paul Gifford reported that in 2008, Caritas international (the Catholic international development organizing body) alone employed 440,000 paid staff and 650,000 volunteers, and had a combined estimated worth of US $\$ 5.5$ billion. He also noted many smaller Catholic organizations that support international development such as the British MIVA (Missionary Vehicle Association) that purchased and distributed some 3000 ambulances, special cars, boats and so forth). He concluded that "It is not necessary to list more. The list is virtually endless, and the extent of Western funding is virtually impossible to discover, because so much is invisible as it is personal" ([32], p. 93).

\section{The Scope of Religious vs. Secular International Development Organizations}

We made the case that people in the developing countries often prefer faith-based NGOs especially if they match their own faith. We also documented the impressive volume of volunteers and funding that comes from and through religious international development. We noted that most of the very large international social and economic development organizations are faith-based ones. The one thing we did not yet document is the ratio of faith-based vs. secular international development organizations. In this case, we decided to carry out our own investigation.

Our aim was to identify faith-based international development within a larger pool of organizations associated with international social and the economic development. Unfortunately, data were only available for USA-based international organizations. Using data from the National Center on Charitable Statistics, we looked at those organizations that fall under the NTEE category of Q3 International Development organizations [24]. With the help of NCCS and Jon Durnford at DataLake Nonprofit Research, we found that 59\% (3505) of international development organizations were faith-based organizations. Although constituting a majority of the number of organizations, faith-based nonprofits only accounted for an estimated $40 \%(\$ 12,493,572,141)$ of gross revenues, and $30 \%(\$ 9,702,649,428)$ of the total assets of Q3 organizations that filed a form 990 (annual tax report for nonprofits organizations) with the Internal Revenue Service. The prevalence of religiously affiliated organizations in international development emphasizes the need for further research in this field.

In order to get an idea of the kinds of services being provided by international NGOs, we took a small sample of organizations, based on their self-identification, divided them into religious or secular and collected information provided on their websites. We recognize that information on organization websites is provided for publicity purposes and can be exaggerated. Considering the dearth of empirical data on faith-based organizations in international development and the limited scope of this article, we felt that this would be one feasible starting point. Using a random sample of Q3 organizations from the NCCS and Guidestar websites, we went to the organizations' websites reviewing their mission statements and mining for information [24,53]. If we found terms related to religion like "faith", "Christian", "Jewish", or "God", we categorized them as faith-based organizations. We took a quota sample of 21 faith-based organizations, as well as a similar sample of secular organizations. Even this small sample of organizations covered a wide range of services. Almost every organization was involved in more than one activity. The types of services included, but were not limited to: food provision, clean water, clothing, refugee services, education, medical, orphanages, microfinance, infrastructure, advocacy, and technology. As we compared the kinds of activities that each type of organization was involved in, we found that faith-based organizations on average provided significantly more kinds of services ( 4.2 types of services per organization) compared to the secular organizations (2.6 types per organization, $p<0.05$ ). As such, faith-based international organizations were covering wider range of services while secular ones tend to specialize in limited number of service areas. The implications for this finding are unclear, further research may consider how providing more types of services per organization relates to levels of collaboration. 
As we compared what kinds of services were provided by faith-based and secular organizations, there were no significant differences. In other words, faith-based organizations were not predominant providers of one type of service like clean water or clothing. We also compared the locations of services provided by each type of organization, but the websites provided this information in inconsistent formats, some reporting work in "Africa" and others focusing on specific cities or villages. Even after attempting to compare by country or region, no clear patterns emerged from the data. Overall, a comparison of websites of international NGOs suggests that the differences between faith-based and secular NGOs are not readily distinguishable online.

\section{Impact on the Ground}

Maybe the most difficult task is to assess the "on the ground" impact of faith-based international social and economic development organizations. In this respect, we rely on and quote from Narayan et al. These authors reviewed all the available World Bank country reports and came up with the following summary:

In some regions NGOs with the strongest presence are religiously affiliated. This is the case, for instance, in Benin, where these organizations function as one of the most visible and widely distributed institutional safety nets for the poor. The majority of the orphanages are run by Catholic sisters, the only country-wide nutritional program is managed by Cathwell (Catholic Relief Services), and nuns and priests have set up several programs to assist the sick, the abandoned, and the destitute. In Cotonou, the Catholic Church is arguably the strongest presence helping the most vulnerable (Benin 1994). In Panama (1998) over half the communities acknowledge churches and schools for their support. In Vietnam (1999) poor Catholic households in need of support turn to the church. In Georgia, the Russian Orthodox Church and the International Orthodox Churches Charities run soup kitchens for the elderly and disabled and distribute food and medicines (Georgia 1997). These efforts were praised by local people who noted that "although local Armenian and Georgian priests had organized the distribution, they did not reject any minority, including Jews, Greeks or Russians" (Georgia 1997). In Pakistan (1993) the PPA reports "a deeply entrenched tradition of private charity and welfare reinforced by Islamic religious obligation." Mosques and shrines are valued as sites of charity. Ashrams are mentioned in some places in India as places of refuge for the poor ([34], p. 134).

Narayan et al. also searched for negative examples of the work of faith-based international social and economic development organizations. They managed to find some examples but they were all related to small highly evangelical groups whose overall share of international social and economic development was marginal. These evangelical groups often put proselytization ahead of service provision and, as such, agitated local communities and their traditions. We will discuss this issue in greater detail below. It is important to note the negative side of faith-based international social and economic development, however, we should keep in mind that its magnitude is dwarfed in comparison with the size of faith-based international social and economic development support. This is what Narayan and colleagues reported:

While faith-based groups are often mentioned as sources of help, in Panama "discussions revealed that Christian sects have occasionally had a divisive effect among indigenous communities. In one Kuna island community, for example, part of the community refuses to recognize the Asambleas de Dios, with their congress not wanting any more churches because the proliferation of churches is seen as fragmenting the community into small units ... If the community is divided, those divisions are reflected in church organizations" (Panama 1998)...Georgians expressed mixed sentiments toward the role of religious organizations that required them to switch faiths. The report notes, "This issue perplexed an Azerbaijani family, who finally decided to accept aid from Jehovah's 
Witnesses, despite initial reluctance to accept a pacifist faith whose tenets they might have to violate if members were called to serve in the Georgian army. They compromised by deciding the 'less important' family members-mother and sister-would use the aid" (Georgia 1997) ([34], p. 140).

In many parts of the world, faith-based organizations are the major source of care in developing areas. For example, Bennell, Harding, and Rogers-Wright reported that in Sierra Leone, about 75\% of primary schools are owned and managed by FBOs [54]. Daun reported that in Africa, Christian (Catholic and Protestant alike) missionaries brought the concept and practice of formal education and the establishment of educational institutions [55]. Later, the spread of Islam led to the provision of education throughout the continent. These key world religious influences are the foundation of educational facilities and institutions throughout Africa. The late Nelson Mandela told the audience in the World Council of churches in 1998 "My generation is the product of missionary education. Without (that) I would not be here today. I will never have sufficient words to thank the missionaries for what they did for us" [56].

Gifford reported that in Africa "Historically, churches were far more involved in education than colonial governments" ([32], p. 85). Indeed, according to Hastings in 1945, in the areas of tropical Africa that were ruled by Great Britain, $96.4 \%$ of the school-attending children did so through a mission school [57]. Gifford found that "In Africa in 2009 there were claimed to be over 12,000 Catholic infant schools, 33,000 primary schools, and almost 10,000 secondary schools, plus about twenty universities" ([32], p. 86). The qualification in the above sentence refers to the fact that many of these schools are currently financed by African governments. Gifford also demonstrated that among university students the majority graduated from Christian schools, and where there are national tests, students from religious schools pass at a significantly higher rate [32].

Gifford assessed that "In Africa, in 2010, the Catholic Church operated 16,178 health centers, 1074 hospitals, 5373 out-patient clinics, 186 leper colonies, 753 homes for the elderly and the physically and mentally disabled, 979 orphanages, and 2947 educational and rehabilitation centers" ([30], p. 90). He also reported that half of all AIDS-related organizations in Africa are provided by Catholic organizations. Gifford concluded that in health "As with schools, the church led the way, long before governments" ([32], p. 91).

At least in one occasion, in 1947, the Nobel Peace Prize was awarded to two Quaker organizations - the Friends Service Committee in London and the American Friends Service Committee in Philadelphia - for humanitarian service and dedication to peace and nonviolence. Other religious leaders such as the Dali Lama, Mother Teresa, and Bishop Desmond Tutu also received the Nobel Peace Prize.

There are very few empirical studies of effectiveness comparing religious and secular development organizations. One related study compared Christian and secular micro-finance organizations. Mersland, D'Espallier and Supphellen reported that "Christian MFIs have significantly lower funding costs and consistently underperform in terms of financial profit indicators. Contrary to our hypotheses, Christian MFIs are as efficient in assuring loan repayment and their average loan sizes are on par with those of their secular peers" ([58], p. 145). It is not our contention that faith-based international development organizations should be considered superior to their secular counterparts. The mere fact that they add international development services that otherwise would not have been provided is an important contribution that needed to be assessed and better understood.

\section{The Issue of Proselytization}

In a previous paragraph, we noted that corporate support for international development is often a means to capture markets and obtain gains. The same is often said about faith-based international development which is often perceived as a means for converting locals and gaining new supporters. It is no secret that many evangelical development organizations are hoping for converts and may even try to convert local service recipients. Two points should be made in this respect. 
First, both secular and faith-based organizations are engaged in some form of conversion. They both try to increase the education of locals, make them more capable to handle complex issues, and think more like people in the West. Some faith-based organizations add a faith element while others do not. However, all organizations aim to transform the way people in developing countries think and operate. In this respect, Berger noted:

From the start, NGOs have been a moral entity. They have challenged the "Wrong" in favor of the "Right" and sought to alter inequitable distributions of power and resources in favor of the disenfranchised. Religious NGOs, however, recognize the religious rather than purely "reasoned" origin of the values, which they seek to realize. The Golden Rule "Love thy neighbor", underpinning all religious traditions, exhorts believers to be concerned with the condition of others, thereby bringing religious practice into the public sphere ([19], p. 19).

Second, data from numerous sources suggests that most faith-based development organizations focus on service delivery rather than on proselytization. For example, Barr, Fafchamps, and Owens reported that in Uganda "The activities of surveyed NGOs and the methods they use to spread their messages (workshops, open air speeches, and door-to-door visits) appear similar to the traditional charitable works performed by churches. However, there is very little evidence to suggest that the surveyed NGOs are, in fact, 'churches in disguise': only $30 \%$ of surveyed NGOs are faith based, and the content of their messages is highly varied" ([59], p. 664).

Similarly, Dicklitch and Rice study FBOs in Africa highlighting the Mennonite Central Committee (MCC) which operates in twenty African countries. The authors argued that "the MCC successfully contributes to development initiatives in 20 African countries because of its philosophical and programmatic approach, which focuses squarely on accountability, a holistic approach to basic human rights, and a listen and learn approach that encourages self-help initiatives and empowerment rather than a culture of dependency" ([13], p. 661). These authors also contend that workers of the MCC explicitly avoided acts of proselytization, allowing their care and actions to speak for them. The authors reported that "Although it is an FBN, the MCC is not a traditional missionary organization. It does not seek to proselytise, although it works with mainly local faith-based organizations such as Presbyterians, Lutherans, and United Methodists" ([13], p. 668).

An interesting perspective on proselytization is offered by Robert Woodberry. He studied a large number of countries in which missionaries were actively proselytizing in the 19th and early 20th century versus countries in the same developing world where missionary work was prohibited. Woodberry found that the missionary movement had strong, positive influence on liberal democratization. Countries open to missionaries ended up upholding democratic principles and experienced democratic government significantly more so that countries not exposed to missionaries [60]. In another perspective on proselytization, Dena Freeman explains how the Pentecostal movement in Africa seeks to transform individual converts, helping them to break away from traditional cultural norms, thereby liberating themselves to pursue wealth and personal progression [61]. The issue of proselytization must be recognized when discussing religion and international development, though an understanding of its scope and consequences should be further studied.

\section{Coordination and Isolation}

In addition to proselytization, faith-based international NGOs are often accused of acting alone and refusing to collaborate with other organizations from different faith traditions, secular NGOs, and public agencies. The logic of this criticism is that resources are limited, and if more coordination and collaboration were to take place, NGOs could maximize their beneficial impact, minimize waste and overlap, and more people could be served at lower cost. While there are no studies that comprehensively address this topic, it seems like a given in many public discussions. Benedetti suggested that the less fundamentalist faith-based NGOs are more willingly participate in partnerships and coalitions, while the more religiously fundamentalist NGOs are less likely to collaborate [62]. 
Ghandour for example, reported a case in which moderate Islamic NGOs actively collaborated with secular and moderate Christian NGOs. However, again, there are not enough empirical data to substantiate this assertion [63].

It should be noted that coordination and collaboration are very complex and problematic issues among all types of international NGOs, not only religious [64,65]. NGOs fear full partnership as it may mean downsizing, inability to claim success, loss in donor support, and possible mission drift. In a report for Congressional Research Services, Marion Lawson noted that "several aid officials have suggested that aid workers are too busy to devote time and attention to coordination, a task that most are not evaluated on as part of their individual performance reviews" ([66], p. 17). Lawson's report provides a long list of the benefits and barriers to international development collaboration and assesses that it is problematic to the sector as a whole and not to one sub-sector or another.

Clearly there is a need to develop new and nuanced models to guide intra and cross- sectoral partnerships and collaborations to avoid pitfalls and better serve those in need. It is however, a joint challenge to faith-based NGOs and the other organizations in the field of international social and economic development.

\section{Religious Groups and Their Contribution to Tension and Terrorism}

The final criticism levied against faith-based NGOs in the international development context is that they contribute to tensions and conflicts. The current terrorist activities taken by ISIS, for example, are seen as the result of people's adherence and blind commitment to one faith tradition. Hasenclever and Rittberger noted "Often the political resurgence of religious communities is accompanied by violent clashes in and between nations. Take, for example, the bloody conflicts in Algeria, Bosnia, East-Timor, Kashmir, Nigeria, Palestine, and Sri Lanka, to name but a few" ([67], p. 641).

Terrorism is often affiliated with religious groups [68]. However, contending that world conflicts and military harm is the outcome of religious fanaticism is to ignore the fact that such conflicts are complex phenomena involving motives that are rooted in political, economic, territorial, cultural, and psychological in nature. Religion is a force that can galvanize and unified people to the point of extremism [69]. Hasenclever and Rittberger, who above listed many religious-based conflicts also argued that "although differences in religious creed are hardly ever a genuine source of violent clashes, under certain conditions, they have the potential to escalate conflict behavior" ([67], p. 642).

In the context of international social and economic development, the faith-based organizations are countering the impact of extremist groups. There are many ways by which people can actualize their faith. Hatred and terrorism is one way; serving people in need is another way. The faith-based international development organizations are emphasizing the latter.

\section{Discussion and Conclusions}

International social and economic development is an important field of care in which people and organizations in rich countries, with or without their government, support people and communities in less prosperous countries. The great divide between developed and developing countries, also known as the North-South division, calls on people in the rich parts of the world to assist those in poorer areas. Unfortunately, international social and economic development is not a high priority for most people and financial support for this noble aim has declined since the last recession of 2008.

In the realm of international affairs, religion has often been seen as a divisive influence, creating conflict between once peaceful neighbors, leading to war between nations and peoples. Critics suggest that religion gives a license and even encouragement to kill all that are different, as is currently highlighted in mass media with regards to ISIS (Islamic State of Iraq and Syria). For many in the public the only purpose of faith-based international development is to gain new members and become more influential. The distrust of religious people and organizations is partially based on past transgressions and modern day focus on extreme groups. Advocates of international development in contrast claim long-standing traditions of social improvement and unique advantages to address the most pressing 
social problems. Government officials and diplomats often ask, "What value does faith bring to the realm of international development" [70]? This paper is an attempt to elucidate the various elements that should be considered in answering that question.

Following ver Beek, we started this article by stating that the involvement of the faith community in international social and economic development is underreported and understudied [21]. In this article, we documented some of the involvement of faith-based organizations in the field of international social and economic development. Until the year 2000, there were no studies that focused on the role of the faith community in contributing to international social and economic development. Since 2000, more studies were focusing on faith-based involvement in international social and economic development, but most of them were case-studies, anecdotal accounts, and authors' reflections. Still, a picture had emerged. We now know that in many parts of the world, the key international social and economic development organizations are religious. In the United States, the four largest development organizations are faith-based and these organizations alone account for $20 \%$ of all funds devoted to US-originated international social and economic development. We also know that a large number of volunteers who constitute the majority of international development workers are working in a faith-based organization or are being motivated by religious conviction. Findings from Europe, though not as encompassing as the data from the USA are, suggest similar trends.

We divided most of the article into two unequal parts. The first views at faith-based international development organizations favorably and reports their strengths and importance. We also discussed in this section some sources that disagree with the rosy picture of the faith-based international development organizations. The second part looks at the drawbacks of these organizations and discusses the criticism directed at faith-based international development organizations. Here again, we also cite sources contending against the criticism.

Our own empirical investigation found out that of all organizations that are categorized as international development $59 \%$ can also be defined as faith-based. This empirical investigation definitely indicates the importance of faith-based factors in international social and economic development.

At this stage, more focused investigation should be conducted to assess real impact of these organizations on the ground, including the financial and employee/volunteer contribution. Our findings, so far, suggest that faith-based international social and economic development is similar to welfare services provided by congregations in the USA. Faith-based NGOs are heavily involved in direct relief and development, the majority of them are not on the ground for proselytization purposes, and they go unnoticed and underappreciated. The faith-based international development field is taken for granted and rarely documented. Ultimately, faith-based organizations, like their secular counterparts, are attempting to alleviate the negative life conditions of people in the communities they are serving.

Deneulin and Rakodi reviewed the field of faith-based international development 30 years after the publication of a special issue of World Development on "Religion and Development". They noted that much is still unknown. They suggested two broad implications. "First, the assumptions of secularization and secularism that supposedly define the relationships between religion, society, and politics have to be revisited. Second, development studies must recognize that religion is dynamic and heterogeneous" ([4], p. 45). After reviewing the literature and conducting our study, we concur. Faith plays a key role in international development work, some of which is clearly recognizable and some very latent. Clearly, further study of this field is warranted.

It was surprising that there is no one comprehensive source about the scope and magnitude of faith-based international social and economic development. Most accounts we found were limited to one country or one region and even these were limited to one faith tradition or one sub-set of activities such as hunger relief or health prevention. On the flip-side, it was also surprising that there are few sources that attempted to reflect the wide diversity among faith-based international development organizations. Those NGOs affiliated with a distinct faith tradition may differ from the unaffiliated, 
and those that are focused on one country may differ from the more globally focused ones. We hope that we brought some clarity and insight, but acknowledge that much work is still ahead.

Author Contributions: The authors worked together on all parts of the paper, and both equally contributed to the content and writing.

Conflicts of Interest: The authors declare no conflict of interest.

\section{References}

1. Mark Chaves, and Bob Wineburg. "Did the faith-based initiative change congregations?" Nonprofit and Voluntary Sector Quarterly 39 (2010): 343-55. [CrossRef]

2. Ram A. Cnaan, and Daniel W. Curtis. "Religious congregations as voluntary associations: An overview." Nonprofit \& Voluntary Sector Quarterly 42 (2013): 7-33. [CrossRef]

3. Carole Rakodi. "A framework for analysing the links between religion and development." Development in Practice 22 (2012): 634-50. [CrossRef]

4. Séverine Deneulin, and Carole Rakodi. "Revisiting religion and development: 30 Years on." World Development 39 (2011): 45-54. [CrossRef]

5. Emma Tomalin. Religions and Development. London: Routledge, 2013.

6. Richard J. Estes. "Developmental social work: A new paradigm for a new century." Paper presented at the 10th International Symposium of the Inter-University Consortium for International Social Development, Cairo, Egypt, 28 June-2 July 1998.

7. Mark Lusk. "International social development and counter-development." Journal of Comparative Social Welfare 26 (2010): 165-76. [CrossRef]

8. Brij Mohan. Fallacies of Development: Crises of Human and Social Development. New Delhi: Atlantic, 2007.

9. Philip Quarles van Ufford, and Matthew Schoffeleers, eds. Religion and Development: Towards an Integrated Approach. Amsterdam: Free University Press, 1988.

10. Heidi Rolland Unruh, and Ronald J. Sider. Saving Souls, Serving Society. New York: Oxford University Press, 2005.

11. Matthew Clarke. Development and Religion: Theology and Practice. Cheltenham: Edward Elgar, 2011.

12. James R. Rick. "What is distinctive about FBOs? How European FBOs define and operationalise their faith." Praxis Paper 22, INTRAC, 2009. Available online: http://www.intrac.org/data/files/resources/ 482/Praxis-Paper-22-What-is-Distinctive-About-FBOs.pdf (accessed on 27 October 2015).

13. Susan Dicklitch, and Heather Rice. "The Mennonite Central Committee (MCC) and faith-based NGO aid to Africa." Development in Practice 14 (2004): 660-72. [CrossRef]

14. Tara Hefferan, Laurie Occhipinti, and Julie Adkins. "Faith-based organizations, neoliberalism, and development: An introduction." In Bridging the Gaps: Faith-Based Organizations, Neoliberalism, and Development. Edited by Tara Hefferan, Julie Adkins and Laurie Occhipinti. Lanham: Lexington Books, 2009, pp. 1-34.

15. Peter Howard. "Humanitarian aid organizations and sustainable development." Paper presented at the G20 Interfaith Summit Meeting, Istanbul, Turkey, 18-20 November 2015.

16. Robert D. Woodberry, and Timothy S. Shah. "The pioneering Protestants." Journal of Democracy 15 (2004): 47-61. [CrossRef]

17. Philip G. Altbach, and Toru Umakoshi. Asian Universities: Historical Perspectives and Contemporary Challenges. Baltimore: Johns Hopkins University Press, 2004.

18. Morton H. Fried. "Reflections on Christianity in China." American Ethnologist 14 (2009): 94-106. [CrossRef]

19. Julia Berger. "Religious nongovernmental organizations: An exploratory analysis." Voluntas 14 (2003): 15-39. [CrossRef]

20. Gerrie Ter Haar, and Stephen Ellis. "The role of religion in development: Towards a new relationship between the European Union and Africa." The European Journal of Development Research 18 (2006): 351-67. [CrossRef]

21. Kurt Alan ver Beek. "Spirituality: A development taboo." Development in Practice 10 (2000): 31-43. [CrossRef]

22. Ben Jones, and Marie Juul Petersen. "Instrumental, narrow, normative? Reviewing recent work on religion and development." Third World Quarterly 32 (2011): 1291-306. [CrossRef]

23. Henrik Hansen, and Finn Tarp. "Aid effectiveness disputed." Journal of International Development 12 (2000): 375-98. [CrossRef] 
24. National Center for Charitable Statistics. "Public Charities: NTEE = Q3 (International Development, including NTEE subcategories)." NCCS.org. Available online: http://nccsweb.urban.org/PubApps/show OrgsByCategory.php?close=1\&ntee=Q3 (accessed on 27 October 2015).

25. Erica Bornstein. The Spirit of Development: Protestant NGOs, Morality, and Economics in Zimbabwe. Stanford: Stanford University Press, 2003.

26. Gerard Clarke, and Michael Jennings, eds. Development, Civil Society and Faith-based Organizations. London: Palgrave Macmillan, 2008.

27. Bruno De Cordier. "Faith-based aid, globalization and the humanitarian frontline: An analysis of Western-based Muslim aid organisations." Disasters 33 (2009): 608-28. [CrossRef] [PubMed]

28. Jonathon Benthall. "The overreaction against Islamic charities." ISIM Bulletin 20, Institute for the Study of Islam in the Modern World, Leiden, The Netherlands, 2007. Available online: https://openaccess. leidenuniv.nl/bitstream/1887/12453/1/Review_20.pdf (accessed on 27 October 2015).

29. Robert Leurs. "Are faith based organisations distinctive? Comparing religious and secular NGOs in Nigeria." Development in Practice 22 (2013): 704-20. [CrossRef]

30. Deryke Belshaw. "Enhancing the development capability of civil society organisations, with particular reference to Christian faith-based organisations (FBOs)." June 2005. Available online: http:/ /www.sarpn. org/documents/d0002355/CFBOS_Belshaw_June2005.pdf (accessed on 27 October 2015).

31. Sabina Alkire. "Religion and development." In The Elgar Companion to Development Studies. Edited by David A. Clarke. Cheltenham: Edward Elgar, 2006, pp. 502-9.

32. Paul Gifford. Christianity, Development and Modernity in Africa. London: Hurst, 2015.

33. Katherine Marshall. "Development and religion: A different lens on development debates." Peabody Journal of Education 76 (2001): 339-75. [CrossRef]

34. Deepa Narayan, Raj Patel, Kai Schafft, Anne Rademacher, and Sarah Koch-Schulte. Voices of the Poor: Can Anyone Hear Us? Washington: World Bank Publications, 1999. Available online: http://siteresources. worldbank.org/INTPOVERTY/Resources/335642-1124115102975/1555199-1124115187705/vol1.pdf (accessed on 27 October 2015).

35. António Guterres. "UNHCR, faith-based organizations agree to expand cooperation on world's displaced." United Nations High Commission for Refugees, 14 December 2012. Available online: http://www.unhcr. org /cgibin/texis/vtx/search?page=search\&docid=50cadf419\&query=dialogue\%20faith (accessed on 27 October 2015).

36. Estella Carpi. "The political and the humanitarian in Lebanon: Social responsiveness to emergency crisis from the 2006 war to the Syrian refugee influx." Oriente Moderno 94 (2014): 402-27. [CrossRef]

37. Lori-Anne Corkum, and Katie Hunt. "Imagining Our Future Together: Changing the Social Imaginary through Hope." Journal of Religion and Culture: Conference Proceedings 1 (2011): 41-58.

38. John Micklethwait, and Adrian Wooldridge. God is Back: How the Global Revival of Faith is Changing the World. New York: Penguin, 2009.

39. Gordon H. Hanson, and Chong Xiang. "Exporting Christianity: Governance and doctrine in the globalization of US denominations." National Bureau of Economic Research, April 2010. Available online: http:/ / www.nber.org/papers/w16964 (accessed on 27 October 2015).

40. Steve Brouwer, Paul Gifford, and Susan D. Rose. Exporting the American Gospel: Global Christian Fundamentalism. New York: Routledge, 1996.

41. Lex Rieffel, and Sarah Zalud. "International Volunteering: Smart Power." Policy Brief \#155, Brookings Institute Policy, June 2006. Available online: http://reliefweb.int/sites/reliefweb.int/files/resources/ 11B04DF19242BE108525719B0056F19F-br-volunteer-jun2006.pdf (accessed on 27 October 2015).

42. A. Scott Moreau, Gary R. Corwin, and Gary B. McGee, eds. Introducing World Missions: A Biblical, Historical and Practical Survey. Grand Rapids: Baker Academic, 2004.

43. Rachel Hutchins-Viroux. "International NGOs and national attachment in the global age: The evolution of community sentiment in the United States." Studies in Ethnicity and Nationalism 10 (2010): 19-37. [CrossRef]

44. Benjamin J. Lough. International Volunteering from the United States between 2004 and 2012. St. Louis: Center for Social Development, Washington University, 2010.

45. Nancy Gard McGehee, and Carla Almeida Santos. "Social change, discourse and volunteer tourism." Annals of Tourism Research 32 (2005): 760-79. [CrossRef]

46. Damon P. Coppola. Introduction to International Disaster Relief Management. Oxford: Elsevier, 2007. 
47. Patricia J. Owens, Anthony Forgione Jr., and Susan Briggs. "Challenges of international disaster relief: Use of a deployable rapid assembly shelter and surgical hospital." Disaster Management Response 3 (2005): 11-16. [CrossRef] [PubMed]

48. Giving USA: The Annual Report on Philanthropy for the Year 2014. Chicago: Giving USA Foundation, 2015.

49. Giving USA: The Annual Report on Philanthropy for the Year 2013. Chicago: Giving USA Foundation, 2014.

50. Elizabeth Ferris. "Faith-based and secular humanitarian organizations." International Review 87 (2005): 311-25. [CrossRef]

51. Mark Chaves, and Shawna L. Anderson. "Continuity and change in American congregations: Introducing the second wave of the national congregations study." Sociology of Religion 69 (2008): 415-40. [CrossRef]

52. Ian Smillie, and Larry Minear. Charity of Nations. Bloomfield: Kumarian, 2004.

53. Guidestar Advanced Search. Available online: http://www.guidestar.org/SearchResults.aspx (accessed on 8 December 2015).

54. Paul Bennell, Jeanne Harding, and Shirley Rogers-Wright. PRSP Education Sector Review. Freetown: British Council Sierra Leone, 2004.

55. Holger Daun. "Primary education in Sub-Saharan Africa-A moral issue, an economic matter, or both?" Comparative Education 36 (2000): 37-53. [CrossRef]

56. Nelson Mandela. "Together on the way." Address by President Nelson Mandela to the WCC on the occasion of its 50th anniversary, Harare, Zimbabwe, 13 December 1998.

57. Hastings. The Church in Africa, 1495-1950. Oxford: Oxford University Press, 1994.

58. Roy Mersland, Bert D'Espallier, and Magne Supphellen. "The effects of religion on development efforts: Evidence from the microfinance industry and a research agenda." World Development 41 (2013): 145-56. [CrossRef]

59. Abigail Barr, Marcel Fafchamps, and Trudy Owens. "The governance of non-governmental organizations in Uganda." World Development 33 (2005): 657-79. [CrossRef]

60. Robert D. Woodberry. "The missionary roots of liberal democracy." American Political Science Review 106 (2012): 244-74. [CrossRef]

61. Dena Freeman. "Pentecostalism and Economic Development in Sub-Saharan Africa." In The Routledge Handbook of Religions and Global Development. Edited by Emma Tomlin. Oxford: Taylor \& Francis, 2015. Available online: https://www.routledgehandbooks.com/doi/10.4324/9780203694442.ch8 (accessed on 21 January 2016).

62. Carlo Benedetti. "Islamic and Christian inspired relief NGOs: Between tactical collaboration and strategic diffidence?" Journal of International Development 18 (2006): 849-59. [CrossRef]

63. Abdel-Rahman Ghandour. "Humanitarianism, Islam and the West: Contest or cooperation?" Humanitarian Exchange 25 (2003): 14-17.

64. Jon Bennet. Meeting Needs: NGO Coordination in Practice. London: Earthscan, 1995.

65. A. Strand. "Bridging the Gap between Islamic and Western NGOs Working in Conflict Areas." Master's degree Dissertation, University of York, York, UK, 1998.

66. Marian Leonardo Lawson. "Foreign aid: International donor coordination of development assistance." 5 February 2013. Available online: http:/ / fpc.state.gov/documents/organization/205216.pdf (accessed on 27 October 2015).

67. Andreas Hasenclever, and Volker Rittberger. "Does religion make a difference? Theoretical approaches to the impact of faith on political conflict." Millennium: Journal of International Studies 29 (2000): 641-74. [CrossRef]

68. Eli Berman, and David D. Laitin. "Religion, terrorism and public goods: Testing the club model." Journal of Public Economics 92 (2008): 1942-67. [CrossRef]

69. Sudhis Kakar. The Color of Violence: Cultural, Identities, Religion, and Conflict. Chicago: University of Chicago Press, 1996.

70. Jeffrey Haynes. Faith-based Organizations at the United Nations. New York: Palgrave Macmillan, 2014.

(C) 2016 by the authors; licensee MDPI, Basel, Switzerland. This article is an open access article distributed under the terms and conditions of the Creative Commons Attribution (CC BY) license (http:/ / creativecommons.org/licenses/by/4.0/). 
Article

\title{
Unpacking Donor Retention: Individual Monetary Giving to U.S.-Based Christian Faith-Related, International Nongovernmental Organizations
}

\author{
Ramya Ramanath \\ School of Public Service, DePaul University, Chicago, IL 60604, USA; rramanat@depaul.edu; \\ Tel.: +1-312-362-7708
}

Academic Editor: Robert Wineburg

Received: 14 July 2016; Accepted: 31 October 2016; Published: 8 November 2016

\begin{abstract}
This article examines an important but relatively overlooked aspect in the field of international giving in the U.S.-individual monetary donations to Christian faith-related international nongovernmental organizations (INGOs)-and outlines the cognitive process influencing donors who choose to keep up their financial support to Christian faith-related INGOs. The propositions forwarded in this article draw on existing literature on Christian giving to international causes, INGO management, donor retention and finally, the logic of self-perception to highlight how existing donors might evaluate their repeat giving decision. The more existing donors of Christian faith-related INGOs can identify themselves with the INGO's identity-comprising its beliefs and values, its claims to legitimacy, and performance-the more likely it is for donors to be satisfied and decide to maintain a stable relationship with the specific INGO.
\end{abstract}

Keywords: donor retention; faith-related organizations; Christian; international NGOs; INGOs

\section{Introduction}

Financial donations from private individuals play a vital role in maintaining select types of international nongovernmental organizations (INGOs) ${ }^{1}$. Retaining such donors, however, remains a challenge for all kinds of NGOs. Sargeant and Woodliffe ([2], p. 2) note that half of all first-time donors to an NGO do not donate a second time; among repeat donors, loss rates as great as 30\% annually are very common. Despite the persistence of this fundamental problem facing many NGOs, there is surprisingly little research about the mental process of evaluation of individuals who maintain long-term monetary relationships with an NGO. Of particular interest in this article are the judgement, perception and reasoning of existing donors of INGOs that combine Christianity and humanitarian service, also referred to as Christian faith-related INGOs. This type of INGO is motivated by its Christian doctrinal roots, but its operations are difficult to distinguish from those of secular INGOs.

1 In this article, I view INGOs as a sub-set of NGOs i.e., NGOs that are based in and receive funds from high-income countries, located primarily in the global North but are working to address the needs of those in one or more low-income countries, largely in the global South. NGOs can be defined in a variety of ways, but are often defined by what they are not (i.e., not government or business) rather than what they are. The question of what NGOs are, is widely debated. Lewis ([1], p. 327) argues that there are two ways in which NGOs are distinct-their identity as a subset of third sector organizations that do not make a profit and derive their authority independent of a political process and also that they engage in emergency relief, service delivery and/or policy and rights advocacy. I use the term nongovernmental organization instead of the more US-specific term for this same breed of organizations, namely nonprofit organization (NPO). I do so in order to avoid an overload of terms and abbreviations in this article. I recognize that US-based NGOs, whether international in their scope of activities or not, are referred to as nonprofit organizations. When I am certain that the concerned author is referring to an NGO that is headquartered in a global North country but focuses its operations on the needs-be it emergency relief, service delivery and/or rights-based and advocacy interventions-in the global South, then I use the term INGO. 
Their mission and their working culture reflect the Christian faith and life of their "Christ above Culture theological foundation" ([3], p. 339). Examples include INGOs such as Catholic Relief Services, Catholic Agency for Overseas Development (CAFOD), Church World Service, American Friends Service Committee, Lutheran World Services and Mennonite Central Committee-all of which appeal for funding to both Christian religious and secular sources.

Historically, individuals have accounted for more than half of all U.S. international giving. Herzer and Nunnenkamp ([4], p. 2) state that individual donations, both in cash and in-kind, constitute the most important revenue source for U.S.-based INGOs engaged in international development cooperation $^{2}$. Individual giving to international causes however suffered a considerable setback following the 2008 financial crises. According to Giving USA [5], it was in 2015 that individual giving to international affairs recorded an upward trend for the first time since the 2008 financial meltdown ${ }^{3,4}$. Despite a slow climb towards pre-2008 levels, the extent of individual giving to international affairs is yet to return to its pre-recession levels and INGOs are finding fundraising increasingly problematic [8]. This, presumably, has created a highly competitive environment among INGOs fundraising in the U.S. More knowledge therefore of how (and why) existing donors to international causes-be it in emergency relief, service delivery and/or advocacy and rights-based interventions-stay committed to their respective INGOs may help explicate the donor base of Christian faith-related INGOs and offer insight into how to reverse the decline of individual contributions to international causes.

While religious motivations were once primary in the establishment of international relief and development NGOs, the arrival of modernity is said to mark a shift in the operating philosophy from an "ethic of [Christian] duty" to an "ethic of results" among INGOs ([9], p. 205). While the former concentrates on the motivations and values that drive organizational actions, the latter type of ethic accords primary importance to measurable consequences of those actions. Although not mutually exclusive, the two philosophies, some argue, can be at odds with one another, requiring Christian agencies to consciously maintain a sense of the sacred and faith alongside the secular ([9], p. 229). Several U.S.- and faith-based INGOs, for instance, are engaging with a more secular identity, attributable to the convention of church-state separation, media distaste for participation in public policy by overtly religious organizations, and an emphasis on greater sensitivity toward increasingly multicultural and multi-faith societies ([10], p. 2; [9]). However, beyond recognition of an organizational shift from chiefly religious to secular values, little is known about how the individual donor base of these agencies evaluates its giving intentions. In particular, this article seeks to address the following: How do individual donors of Christian faith-related INGOs based in the U.S. judge and evaluate their intention to sustain their financial commitment to the INGO?

This article begins with a brief overview of the long-standing relationship between Christianity and international giving in the US. It finds that, over the years, Christian giving to international causes has evolved from one dominated by missionary activities to a gradual expansion into the realm of

2 In Herzer and Nunnenkamp's [4] study, these NGOs (referred to as Private Voluntary Organizations) are those registered with the US Agency for International Development (USAID) and do not therefore include the full sample of US-based NGOs engaged in international affairs (see footnote 3). To qualify for registration with USAID, NGOs are required to fulfil a list of several conditions including the following: have to be US-based, solicit cash contributions from the US general public, conduct overseas program activities consistent with the general purposes of the US Foreign Assistance Act and/or Public Law 480, exempt from federal income taxes under section 501(c)(3) of the Internal Revenue Code, incorporated for no less than 18 months and provide financial statements to the public upon request. This registration is necessary to compete for specific funding categories such as development and humanitarian assistance grants.

3 Giving USA's [5] estimate of giving to the international affairs subsectors includes giving to organizations working in international aid, development, or relief; those that promote international understanding; and organizations working on international peace and security issues. It also includes research institutes devoted to foreign policy and analysis, as well as organizations working in the domain of international human rights.

4 Giving USA [6] attributed the decline in individual giving to international affairs to the non-occurrence of any major international natural disaster in 2014. In 2013, Global Impact [7] ascribed a decline in individual giving to international causes to economic troubles in the US and domestic natural disasters that caused individual donors to lessen their contributions to the international sector. 
development [11]. This expansion paralleled the onset of the Progressive Era during which Christian organizations of a wide variety emerged. Of particular interest to this research are the breed of INGOs that fall in the center of a continuum of religiosity (between faith-embedded on one end and secular agencies on the other) and are referred to as Christian faith-related INGOs. Although there is an abundance of literature on how these Christian faith-related INGOs balance their religious and secular identities, there is comparatively less known about the cognitions that influence the commitment of individual donors of these agencies. This article then reviews factors known in literature to influence donor retention; factors gathered from the perspective of NGOs and to a far lesser extent, from an evaluation of the thought processes of donors themselves. In an effort to therefore begin the process of filling a gap in the literature, this article forwards four propositions on the mental process of knowing, including aspects such as judgment, perception, and reasoning that influence the repeat giving decision of individual donors of Christian faith-related INGOs.

\section{Review of the Literature}

\subsection{Christianity and International Giving in the U.S.}

In reviewing popular U.S. literature of the 19th century, Wuthnow [12] finds no apparent link between Christianity and giving. Not until the 1880s did church leaders explicitly emphasize tithing, the designation of one-tenth of a Christian's income for church or charitable giving. Charity implied several acts including "love in general to helping the poor, and it did not always connote connections with religion" or even money ([12], p. 9). However, most references to charity included discussions on Christian charity, a phrase made popular by a sermon by Massachusetts Bay Colony Governor John Winthrop delivered while aboard his flagship, the Arbella, in 1630. Winthrop voiced his hopes that Christian charity would inspire the behavior of the settlers of the New World toward each other: "We ought to account ourselves knit together by this bond of love, and live in the exercise of it, if we would have the comfort of our being in Christ" [13]. Winthrop thus set forth Christian charity as a key element of American identity. This identity was embedded in a host of organizations, both state and non-state, that bridged religion (mostly Christianity) and individual giving of time, talent and treasure $[12,14,15]$. Christian charity of the 19th century was a lifestyle, a way of behaving that fell between "a purely ideal general concept of love and something as narrowly conceived as giving money to the church or to some other good cause" ([12], p. 13). This ideal permeated international giving to individual missionaries and missionary organizations, the precursors of cross-border assistance mediated by modern INGOs.

If 19th century missionary work belonged to Christian Protestant missionaries from Britain, then the 20th was dominated by Protestant missionaries from North America ([16], p. 37). Starting in the early 1920s, North Americans have comprised the largest segment of Protestant missionaries overseas, totaling one-half to two-thirds of the world's missionary force [16]. These Christian missions mobilized committed groups of volunteers who were (and continue to be) motivated by religious precepts and the belief that they were doing God's work $[17,18]$. At about the same time period, many missionary organizations expanded their strictly religious focus to include developmental activities. Some entered into a formal relationship with the United Nations, and others began orienting their mission to serve the general public. Religious denominations and organizations began establishing NGO offices to organize their service delivery. This evolution reflected a time when missionaries began efforts to address poverty and suffering brought on by "rapid industrialization, the legacy of slavery, and the First World War and the belief in improvement characteristic of the Progressive era" ([19], p. 87). Nielssen, Okkenhaug and Skeie ([20], p. 19) note that following World War I, "missions had to be justified in secular terms because support simply for evangelisation did not generate funding." Berger ([21], p. 20) and McClearly and Barro [22] similarly note that the need for resources from a broader base of adherents led many religious organizations to seek formal recognition as NGOs. Casanova [23] traces the evolution of organized religion from a sole emphasis on the private sphere 
of moral and spiritual regulation of individual conduct to a more recent attentiveness on shaping the conduct of public life. This reinvented breed of Christian NGOs "did not think of themselves as surrendering to secular and political influences, but as making the ancient religion more relevant to modern society" ([18], p. 534).

\subsection{Christian Faith-Related NGOs, Managing Identities}

Post-World War II saw a dramatic rise in the number and diversity of Christian NGOs, particularly those referred to variously as faith-related, faith-inspired or secular-Christian NGOs. Like their secular counterparts, they comprise agencies that are engaged in three broad types of activities, namely emergency relief, service delivery, and policy and rights advocacy [24]. Benedetti [25] describes faith-related Christian NGOs as those whose identity, membership, funding, mission and services are indistinguishable from their secular counterparts, who use language similar to that of secular NGOs, but whose mission nonetheless uses Christianity as a point of reference and ideology. Scheitle ([26], p. 3) refers to them as parachurch organizations and "the religious market's other supplier". Berger ([21], p. 31) describes them as organizations that venture "beyond notions of social responsibility to assertions of 'Rights' and 'Wrongs', 'Truths' and 'Untruths'”. These NGOs justify their actions as being inspired and guided by the teachings and principles of Christianity or from a particular interpretation or school of thought within Christianity ([27], p. 1). In essence, Christian faith-related NGOs are those [28,29] in which:

(1) Christianity is explicit in their origins or history, but may not be explicit currently;

(2) staff are not required to affirm Christianity, but senior staff often do;

(3) programs and services are not entirely Christian, but Christian content may be available if desired; and,

(4) there is a mix of private and secular funding.

By choosing to classify themselves as NGOs, these religiously-based organizations have taken on "a political identity and inject their uniquely religious voices into a predominantly secular discourse about the nature of the new world order" ([21], p. 19). Some scholars refer to INGOs as essentially "fund-raising institutions, which then either partner with, or subcontract to, non-governmental organizations or community-based organizations [CBOs] in the recipient country" ([30], p. 22). Most INGOs, including Christian faith-related INGOs, adopt a multi-unit organizational structure with local, national, and international components. INGO governance (of such aspects as mission, strategies, and accountabilities) assumes a variety of forms. Some INGOs are centrally controlled, others may have a central secretariat that mobilizes members around shared values but exercises little direct control, and numerous other INGOs fall in between the two extremes of governance arrangements [31]. Generally stated, the central secretariat is headquartered in a global North country and is responsible for executing global actions, controlling service quality, protecting the shared ideological brand, and providing support services such as fundraising, IT, and administration. According to Brown, Ebrahim and Batliwala ([32], p. 1099), a key challenge for INGOs is balancing centralized coordination of aspects such as brand and service quality with less centralized aspects such as local information, capacity, customization, and innovation.

Although Christian faith-related INGOs may not necessarily consider their foundations in Christian conviction to conflict with their global operations, existing literature highlights that managing the two is a continual balancing act. Religiosity is reflected in a number of different components including in the INGO's mission statement, culture, affiliation to a religious denomination, staffing policies, choice in implementing partners, and sources of financial support, to name a few. Ebaugh et al. [33] conclude that a faith-related NGO publicly expresses its religious identity in its name, its mission statement or the use of religious symbolism. It can also be expressed through its design and implementation methods, the organization's culture and practices, staffing and funding. World Vision International, one of the world's largest Christian faith-related INGOs, partners with secular agencies to 
deliver services and maintain its dual organizational identity. Its field offices, notes Stoddard ([34], p. 27), work in partnership with both secular and religious local organizations of all faiths, and it integrates faith into its activities in varying degrees of religiosity depending on the country where it is operating. Chen ([35], p. 111) cites the case of Habitat for Humanity's reconstruction work in Sri Lanka post-Tsunami. The INGO's commitment to tackling issues of housing and homelessness draws upon international best practices which in turn allows the INGO "to reduce, if not avoid, negative stigmatism associated with being a Christian NGO." Downplaying its Christian associations in the course of doing its work in primarily Buddhist Sri Lanka allowed Sri Lankan stakeholders to identify more with Habitat's professional, pragmatic and technical aspects as a housing provider. In managing their identities, some other faith-related NGOs utilize their faith in a more humanistic than religious fashion by referring to the general, unspecified faith of their target population. Thaut ([3], p. 334) describes the reliance on this humanistic approach through the example of one NGO's mission statement that reads: "founded on the belief in the brotherhood and sisterhood of all of humankind, and in the faith and goodwill that people have toward each other, regardless of their religious creed." NGOs can use multiple means to communicate their religious orientation to the public.

Ebaugh et al. [33] identify a range of religious expressions. While some faith-related agencies may require volunteers or staff to pray with clients, others might only display their religiosity by introducing religious principles into discussions of lifestyle or behavioral issues. Staffing policies and practices are yet another window into both understanding and managing organizational expression of religiosity. In its work in Afghanistan, for instance, World Vision's national office consists of a mostly Muslim staff, and its programs are indistinguishable from those of secular agencies. McGregor ([36], p. 738) notes how some Christian NGOs acknowledge a shared interest in broader spiritual concerns by providing prayer mats and creating Muslim prayer spaces within their offices. Like secular agencies, a faith-related NGO might also consciously limit "how much government funding it may accept without compromising the goals of the organization" ([3], p. 334). Christian Aid restricts government funding to 30\% of its total income in order to maintain its independence (though, notably, not to protect its religious goals [3], p. 335). Vanderwoerd [37] argues that even though government funding might alter NGO religiosity, government funding is not the cause of adaptations in NGO structures and processes. Other scholars reinforce this notion in observing that religious NGOs, unlike secular ones, are in fact better placed to avoid the mission creep problem because they can appeal to a religious base for monetary support ([34], p. 29).

Thus, even though we have considerable understanding of the strategic approaches that Christian faith-related INGOs use to manage their service delivery, we know far less about the characteristics-be it attitudinal, behavioral, geographic or demographic - of their individual donor base. Of particular concern to this article are the cognitions or psychological evaluations of donors that continue their financial support to the INGO.

\subsection{Donor Retention as One Expression of Loyalty to an NGO}

Scholarship on donor retention is perplexing. It tends to confuse the notion of retention with loyalty. Referring to this prevalent misinterpretation, Wymer and Rundle-Thiele ([38], pp. 173-74) write that "an examination of the context in which the term loyalty is used and examining the way in which loyalty is measured often makes it clear that retention (not loyalty) is the true focal construct being investigated." In focusing on donor retention (as an outcome) this article recognizes that donor loyalty/commitment (an antecedent) can and does manifest itself in a variety of ways besides through a donor's sustained monetary contributions to one or more NGOs [39]. Scholars have documented how donors express loyalty through attitudes and behaviors such as proximity-seeking and long tenure [40,41], positive affect [42], motivation and involvement [43], and behaviors such as performance and obedience to organizational policies [44]. Thus, although donor loyalty has been variously used to encompass antecedents and consequences of attachment, for the purposes of this paper, donor retention is conceived of as a consequence of one's loyalty to an NGO, a loyalty expressed 
by keeping up financial support of an NGO over time ([45], p. 154). Duration as a measurement of loyalty differs among researchers. Sargeant [46] and Bennett and Ali-Choudhary [47] define a committed giver as one who has made monetary contributions to the NGO in the preceding 18 months. Naskrent and Siebelt [48] define retention by identifying two types of donors: committed givers and cash donors. Committed donors are active donors with ongoing direct debits and cash donors are those who have given two or more cash gifts to the NGO, including one within the preceding 24 months. This article considers both types of donations made within the preceding 24 months in examining donor retention.

Attention to donor retention remains a challenge and a failing within the NGO sector. One chief reason for this lack of consideration is a poor record in relationship-building. Sargeant and Shang ([49], p. 7) fault the sector for being "content simply to refill an increasingly leaky bucket and ignoring opportunities to build meaningful relationships with supporters over time." They argue that this process demands implementation of a significantly better "business model" for fundraising. Many other scholars and fundraising associations ([50], p. 157; [51-54]) recommend adopting the repurchasing perspective of commercial customer retention. Willingness to give again (or donate a larger amount or recommend the NGO to family and friends) is an expression of a donor's loyalty to the NGO [1]. According to Sargeant ([55], p. 1), even small improvements in the level of donor attrition can have profound impacts on the "profitability" of fund-raising.

Arnett, German and Hunt ([56], p. 90) borrow from business-consumer marketing literature to develop an identity salience model of relationship marketing success between NGOs and individual donors5. They recommend that NGO managers focus on increasing the salience of their donors' NGO-related identity and on developing such identities in potential donors. This is reflected in the suggestion forwarded by Choi and DiNitto ([57], p. 111) who urge service delivery NGOs to identify and target existing and potential donors on religious grounds or to partner with faith-based organizations, particularly if their donor base has given only or predominantly to religious organizations. Arnett, German and Hunt [56] further recommend that NGOs encourage their existing and potential donors to become more actively involved in NGO-related activities while also maintaining and, when possible, improving organizational prestige. In the context of donors for whom religiosity is salient, changes in religious giving is directly related to attendance in religious services or in other words, sustained (and higher mounts of) giving is found to be positively related to frequent attendance in religious activities $[58,59]$. This is found to be true for secular givers as well i.e., the same people who commit the most time to an organization also give the most money to it ([60], p. 172). Activities that increase involvement and attachment are known to increase identity salience ${ }^{5}$, which in turn encourages donors to promote (and donate to) the NGO in the future [61]. Treating individual donors like customers dedicated to patronizing a specific store requires NGOs to focus on attracting and maintaining a rapport with their donor-customers. Here, NGOs can draw on extensive research on which factors foster the development and maintenance of relationships, including trust, commitment, mutual control, satisfaction, compliance, internalization and identification, to name a few. Although there is no consensus on which factor is most influential in retaining individual donors, researchers seem to agree that the NGO must offer donors, like a retail store would its customer, a good reason to repurchase [62].

5 Identity salience is a concept grounded in identity theory. According to Arnett, German \& Hunt ([56], p. 89), identity salience posits that people have several "identities," that is, self-conceptions or self-definitions in their lives. These identities are arranged hierarchically and salient identities, according to identity theory, are more likely to affect behavior than those that are less important. Therefore, increasing the salience of NGO-related identity refers to increasing the importance of the NGO in defining the identity of the donor. 


\subsection{Repeat Donor Intention as Expressed by the Donors Themselves}

The limited amount of literature on the psychological evaluations of individuals may be explained partly by the general scholarly consensus that philanthropic individuals, by giving large or frequent gifts, exercise undue influence over NGO activities [63,64]. Fundraising campaigns, notes Kelly [65], are anchored by a few lead donors who usually restrict the use of their major gifts. As such, there is greater scholarly interest in understanding motivations of a few, well-heeled donors rather than stretching the net wide to uncover interests of several, smaller donors. Furthermore, many faith-based organizations, especially very large ones such as Catholic Charities, depend heavily on external funding sources, often including the government. Very few can survive or count on individual donors to sustain them [66].

Thus, detailed information on the mental process of evaluation that drives individual donor commitment (which in due course sustains commitment) to an NGO receives less than needed attention in the academic community. Some notable exceptions include the works of Nathan and Hallam [67] who studied both committed donors and lapsers of eleven different NGOs from the vantage point of recruitment, communications, tipping points and decisions to lapse. They concluded that NGOs were not meeting the needs of their donors, with most lapsers of a given NGO reporting that "they had never really had any loyalty to it [the NGO] in the first place" ([67], p. 317). The lack of understanding and respect for needs was found to run both ways. Naskrent and Siebelt [48] drew similar conclusions when they studied donor retention in Germany from the donor's point of view. They found that NGOs must communicate both qualitatively and emotionally about how the donor has contributed to the prior success and activities of the NGO if they want to foster repeat giving.

Ciconte and Jacob ([68], p. 117) refer to it as the "care and feeding" approach which begins with informing and educating donors about the NGO and how their contributions will make a difference. This approach is echoed in the findings of Khodakarami, Petersen and Venkatesan [69] who analyzed donation data gathered over two decades in a public university. They draw a distinction between intrinsic and extrinsic motivators and find that the latter, more so than the former, influenced repeat giving by donors. Intrinsic motivators are those that are an endogenous part of a person's engagement in an activity. For example, a donor may choose to give to an NGO because they can inherently relate to it or have personal experience with that very NGO and/or believe that they will benefit from the cause that the NGO is engaged in. Extrinsic motivators on the other hand originate outside the person and encourage them to achieve a desired outcome. These may include the NGO's communication and relationship building efforts, the NGO's marketing efforts or a sense that the NGO is responsive to the donor's concerns. As the donor's relationship with the university evolved, Kodhakarami et al. [69] found donors to have learned more about new initiatives that were worth supporting and these were less related to their intrinsic motivators. It was the donors who felt appreciated and/or whose concerns were addressed by the university that were significantly more willing to donate repeatedly. Beldad, Snip and van Hoof [70] are another set of scholars to conduct a survey among residents of two cities in the Netherlands to determine the factors influencing repeat donation intention. Like Kodhakarami et al. [69] they found that repeat donations were predicated on donors' positive experience with the NGO. This positive experience meant that the "transaction" between the donor and the organization proceeded without any problem and that the donation act did not cause difficulty and inconvenience for the donor. However, unlike Kodhakarami et al. [69], the authors Beldad et al. [70] find repeat donation intention to be positively influenced by such intrinsic motivators as a donor's affinity with the cause, trust in the NGO and the NGO's positive reputation. Surprisingly, donor intention to repeatedly donate was not found to be influenced by a moral obligation to help others. Beldad et al.'s [70] survey instrument, however, did not did not ask respondents their religious affiliation nor the extent of their religiosity.

As the sustainability of many Christian INGOs and their projects depends largely on regular monetary donations, it is important to understand not only why people donate but also to know the mental process of judgment, perception and reasoning that governs repeat donations. Although the 
factors influencing first-time donations might influence repeat donations as well, the intent of the propositions forwarded in the next section is to utilize the logic of self-perception from the discipline of social psychology to identify how repeat donors of Christian faith-related INGOs are likely to rationalize their commitment to monetary giving.

\section{Proposition Development: Christian Faith-Related INGOs and Individual Donors' Evaluation of Retention}

Hou, Zhang and King [71] utilized the logic of self-perception developed by Bem [72] to examine how donors make sense of a breach of trust and the decision-making behavior deployed by donors to restore their violated trust. This logic is particularly useful in understanding donor retention behavior for it posits that rather than determining whether an INGO is worthy of continual trust (exercised, for instance, through repeat monetary giving), donors come to view themselves as a trusting or a trustworthy person. Donors have "virtually no knowledge" a priori of their internal states and about which stimuli or cues influenced their repeat giving behavior to the INGO in question ([72], p. 6). Individual donors have therefore to be "explicitly trained" and this occurs when they come to "know their own attitudes, emotions, and other internal states partially by inferring them from observations of their own overt behavior and/or the circumstances under which the behavior occurs" [72].

Self-perception of generalized trust and trustworthiness-the belief, for example that a few providing assistance to the multitude of the world's poor is basically good-is traced to socialization that occurs through early parenting [73,74], moral education [75], and/or religious upbringing [76]. These beliefs and attitudes are intrinsic motivators that, according to the theory of self-perception, are cues drawn from the individual's own overt actions. Such internal cues can, as was reviewed earlier, be reinforced through INGO-led efforts that include repeat trust interactions between the INGO and the donor ([77], enabling a donor's "emotional buzz" of feeling good, elated, and energized from interactions with INGO staff, leadership, other donors, and/or beneficiaries [78], or recognition and approval of those in their network [79]. But according to the theory of self-perception, since donors draw on their own past behaviors to gather evidence for their existing beliefs and attitudes, it is critical that such external reinforcements from the INGO remain "subtle or less discriminable" and do not discount any intrinsic motives that the donor may hold ([72], p. 9). Thus, the logic of self-perception emphasizes that following the first donation, an INGO's subsequent appeals for funds should not be so strong or excessive that it is construed as a "hard sell" because the donor is more likely to give again if his or her repeat giving decision is seen by him or her as freely chosen ([2], p. 282). The theory therefore builds on the idea that a donor's trust and trustworthiness can be developed through a process of gradual exposure to the INGO; a process of induced self-perception change where the donor comes to trust the specific INGO and complies (i.e., gives) again (or gives higher sums) out of a desire to maintain the instilled self-view.

This is depicted in Figure 1 as a mental process comprising confirmation, perceived validity and satisfaction. A high level of confirmation is formed when INGO performance is evaluated by a donor to be greater than or equal to donor expectation; a low level of confirmation (or disconfirmation) is formed in the opposite case. Perceived validity or legitimacy is the comparison between the actual performance and the expectation post-giving. Perceived validity has a positive effect on the satisfaction of individual donors donating to a specific INGO. When first-time individual donors accumulate some giving experiences and improve levels of confirmation, perceived validity increases. Improved levels of confirmation lowers perceived risk (enhances perceived benefits), thus creating conditions that increase the chances of continued giving to the specific INGO. The process is developed into four propositions elaborated below. 


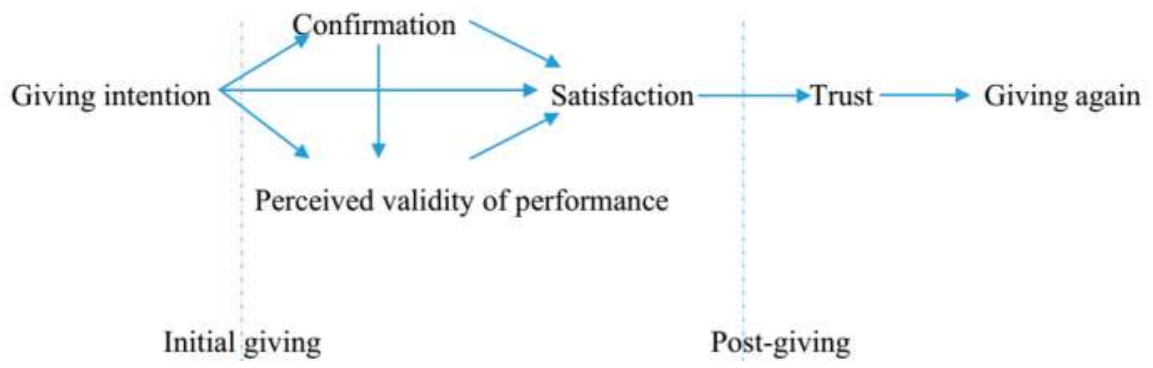

Figure 1. Repeat giving decision of an individual INGO Donor. Source: Adapted (with permission) from ([71], p. 9).

\section{Level of Donor Confirmation and Satisfaction}

Proposition 1. Confirmation from existing donors has a positive influence on donor satisfaction and the resulting repeat giving decision to the INGO.

Confirmation is the comparison between INGO performance as perceived by an existing individual donor and their expectations prior to making their financial donation. If the performance of the INGO is perceived to be greater than or equal to the expectation prior to giving, then the INGO donor is satisfied and is more likely to trust the INGO with his or her money in the future. That donors have expectations on how they will be treated after making a contribution is well known. But the problem for INGOs, quite like for any NGO, is in recognizing what those expectations might be. This is made more difficult because, often, donors themselves are unaware of their expectations.

Given this obscurity, it is reasonable to draw on existing research that points out that donors expect quality service that fulfils some key fundamentals, namely: (a) that the act of making the first (and subsequent) donation is easy and trouble-free; (b) that the INGO meets the promise/s it makes at the time of soliciting funds; (c) that it gives priority to their interests on an ongoing basis; and (d) the overall donation experience remains a positive one. For an INGO donor who has made his or her first donation, the intent to give again lies in the INGO meeting these minimum expectations applicable to donors of a variety of NGOs. Of particular interest to this research are the expectations that may be specific to the donor of a Christian faith-related INGO. There are no absolutes with respect to what each INGO donor might expect and what could be done to satisfy his or her need for confirmation but Bennett and Barkensjo [80] suggest the adoption of "relationship fundraising" wherein every effort is made to segment the donor base and to develop a uniquely tailored service, and a carefully researched understanding of the "quality of service" for each of the identified segments. Unlike the more prevalent a priori segmentation method (where the number and types of segments are determined in advance by the fundraiser) a post-hoc segmentation model could be utilized where the number of segments and segment characteristics is inferred from data collected via questions and feedback from existing donors of Christian faith-related INGOs. Such inferences are drawn from statistical techniques (like K-means clustering) and is deployed in the works of Wedel and Kamakura [81], and Durango-Cohen, Torres, and Durango-Cohen [82]. Such post-hoc segmentation could be useful because the traits of donors of Christian faith-related INGOs are not known. What we do know from existing research is that one likely segment characteristic is the religiosity of their donor base. A Christian faith-related INGO attracts a donor base similar to that of a secular INGO and will therefore recruit some that are deeply religious or strongly affiliated to the Christian church and others that are less so. A deeply religious donor may therefore expect the INGO to meet its stated promise of serving a Christian mission. For instance, Catholic Relief Services (CRS), on its webpage, declares its commitment "to the Church and its teaching" and highlights that it does so by putting its "faith into action to help 
the world's poorest create lasting change" [83]. The governance of the agency is tied to the Catholic Church and to bishops who comprise its board of directors, a board that is "selected by the National Council of Bishops and is staffed by men and women committed to the Catholic Church's apostolate of helping those in need" [84]. While a deeply religious Catholic donor may seek confirmation from the aforementioned details presented in the INGO website, those less religious donors may draw on the same expectation-conformation process or may seek it from other organizational attributes such as the INGO's ability to fulfil promises made at the time of soliciting funds.

A donor may, for instance, expect CRS to live up to its stated promise of devoting its resources "where it's needed most" [83]. Donors may have been socialized by their parents who instilled in them trust in kith and kin by letting them learn through experience that they can rely on others $[73,74]$. If an INGO such as CRS were to breach this long-instilled generalized expectation, then the INGO could hurt its ability to retain this donor. In their research of eleven different UK charities, Nathan and Hallam ([67], p. 322) found that donors were often offended by spending that they found to be unnecessary, such as on highly paid staff. The realization that their case NGO had "made the Sunday papers where one of the directors was living in Hampstead with a six bedroom house and three bathrooms" had influenced this research participant's sense of pride, resulting in him suspending his donations to the NGO ([67], p. 322). Some INGO donors may expect the INGO to use the donated sum to fulfil its stated purpose and this propensity to trust may have its origins in one's religious beliefs or in early childhood experiences. When this generalized expectation-that the INGO mirror their religiosity or that media coverage favorably portray INGO's use of public donations-is not confirmed then it is likely to hurt the donor's positive sense of self. This is rendered worse when the INGO fails to explain itself to the donors.

As such, the expectations and the source/s of expectation-confirmation that trigger repeat giving may be different for different clusters of donors. But evidence on how different levels of religiosity or how different aspects of an individual's intrinsic characteristics influence repeat giving intentions is yet to be studied. Donor expectations that are confirmed by the INGO may directly lead to satisfaction, trust, and consequent repeat giving or may be preceded by a validity-check i.e., a procedure of determining the credibility or the soundness of the INGO's appeals for more funds (see Figure 1). This is addressed in propositions 2 and 3 below.

Proposition 2. The perceived validity of donors has a positive influence on donor satisfaction and their repeat giving decision to the INGO.

Proposition 3. Confirmation from existing donors has a positive influence on perceived validity and the said donor's repeat giving decision to the INGO.

If confirmation is the reassurance of one's already held beliefs about INGO performance, then validity is interpreted in this article to refer to the verification of these beliefs by an external entity. For an INGO, questions about the validity of its performance, are questions primarily of perceived legitimacy. INGO legitimacy, writes Vestergaard ([85], p. 98) depends on the "perceived validity of each of the three actors in the humanitarian exchange-the benefactor, the beneficiary and the donor." Although INGOs base their legitimacy largely on the premise that they are accountable to the populations they serve i.e., its beneficiaries, they are accountable to a host of different stakeholders from the local to the transnational level. The list typically includes donors (private, public, and/or corporate), government from the donor country (in the case of this article, the US government), host national government (i.e., the country where the INGO's beneficiaries reside), host local government, the INGO board, leaders, staff, and volunteers, and partner agencies (such as Southern NGOs and $\mathrm{CBOs})$, licensing and accrediting bodies, and other INGOs. Each one of them influences organizational performance and the overall perceived legitimacy of the INGO. As a result, there is little scholarly agreement on the precise set of measures to help evaluate INGO performance but existing approaches broadly fall under "reputation" and the "hybrid multi-dimensional" categories ([86], p. 440). 
Reputation measures are particularly important since they influence the INGO's ability to both recruit and retain donors. Forman and Stoddard [87] write that northern donors have expressed a clear preference for donating to high performance, and, by implication, highly reputed NGOs. Reputation plays a critical role for INGOs because, as Meijer ([88], p. 36) argues, "not only is the service intangible, the donors also do not consume it. ... In view of the fact that the charity [in this case, the INGO] does not directly deliver a product to the donor and that it is often difficult for the donor to check on the output of the charity, reputation becomes an important issue." Donating to a high performance INGO helps donors develop self-continuity, self-distinctiveness, and self-esteem [89]. Some scholars such as Breeze ([90], p. 14) find that an existing donor's need for self-worth may translate into the donor feeling unable to alter his or her previous giving decision and this, in turn, enables donor retention.

But other scholars argue that in a highly competitive funding environment where potential and existing donors are increasingly aware of the accountability deficits of INGOs, leaving retention to a donor's continual need for self-worth may not be sufficient. Donors can be won over by another INGO, perhaps because the INGO is perceived to be performing better and/or because it offers better incentives to induce repeat giving by its donors [91]. Furthermore, not all Christian faith-related INGOs have the resources necessary to build the reputation and image that the few large, high-profile INGOs enjoy. The perceived validity of performance of INGOs (regardless of size and public profile) could be nurtured among existing donors through adoption of a hybrid multidimensional approach, mentioned earlier. This approach measures INGO reputation but also considers the INGO's goals and resources. Several watchdog groups, such as Charity Navigator, adopt such an approach. They host financial data on aspects such as overhead ratios (i.e., all of an INGO's expenses other than those spent on programs and services it delivers), together with information on accountability, transparency and outcomes.

However, in keeping with the logic of self-perception which recommends the adoption of means that make sense to each donor, unless the information is made relevant and is simplified, donors will resist consuming it to make decisions on repeat giving. As a source of validation, an INGO could offer its existing donors, irrespective of the size of their existing donation/s, with a 'behind-the-scenes' tour of the INGO's facility where they get to meet other donors, raise concerns, offer feedback and engage with members of the board of the INGO, leaders and staff that administer the INGO's programs and members of partner organizations from developing countries who may be visiting the INGO headquarters. Such face-to-face interactions provide donors access to at least some of the people, products and processes that make up the overhead costs and more importantly, support achievement of INGO mission. It also provides INGOs direct access to qualitatively and emotionally communicate to the visiting donors about how they have contributed to the prior activities of the INGO. This, in turn, has the potential to generate self-attribution (rather than attribution by an external entity such as a watchdog group), a process where donors get to formulate their own perception of INGO performance, even considering involvement in areas where the INGO might need their skills and expertise. By dedicating more time to donor relations, Worth ([92], p. 242) says that these efforts can yield "more over time than the occasional foundation gift."

Proposition 4. An existing donor's satisfaction with the service quality can have a positive effect on trust and increase the likelihood of the INGO retaining the donor.

This proposition draws on the previous three to suggest that the quality of INGO service must meet or surpass donor expectations in order to enable retention. A number of scholars suggest that from a donor's perspective, INGOs are better served in addressing issues of service value than of cause value $[62,93]$. Cause value is the primary work of the INGO such as providing relief to victims of war or natural disasters, improving access to clean water or fighting global poverty and injustice. Service value, on the other hand, are the things that an INGO does specifically for the donor, such as showing appreciation and acting on donor complaints and feedback. If individual donors are satisfied with 
the quality of the service, then they are likely to trust the INGO and this trust may create a behavioral response i.e., a donor's decision to continue to donate.

In the INGO context, the amount of cause value that an INGO delivers depends on how well it accomplishes its work, which could be measured as how much change the INGO brings about for every donated dollar spent. But the notion of change can be hard to quantify because its meaning varies depending on the type of work being measured, its aims and the capacity of the INGO in question. For an INGO that is providing earthquake relief in Haiti, change is relatively easily measured by counting the delivery of emergency supplies and the number of people assisted. As Ebrahim and Rangan ([94], p. 19) write, even though providing emergency relief in the immediate aftermath of a disaster "is a complex activity, requiring highly sophisticated coordination and supply chain management capabilities," it focuses on meeting survival needs rather than longer-term changes and is therefore possible to quantify the change that such an INGO delivers. Similarly, if an INGO engages in post-emergency community development in Haiti and provides services such as access to education and health care to all children below the age of five, then defining, tracking and reporting on progress to donors, although resource intensive, is doable. However, for a Christian faith-related INGO that aims to implement longer-term changes such as ending gender violence, it is nearly impossible to attribute changes solely to its interventions. Eradicating gender violence in Haiti or any given geography would require analysis and interventions at multiple levels including individual, interpersonal, community, and societal. It would furthermore involve several organizations, institutions, and coalitions, both governmental and nongovernmental.

Because it is hard for all INGOs to collect and share objective measures on all aspects of their performance, scholars such as McGrath [62] recommend implementing donor satisfaction by working towards improving service value. This is an aspect related to what the INGO does for its donors. In the general NGO context, Sargeant and Lee [95] have demonstrated that satisfaction and involvement do not directly engender retention but that their impact is mediated by commitment. Commitment, according to Allen and Meyer ([96], p. 3), is of the normative, continuance and affective kind. Normative commitment refers to commitment that donors feel if they think about giving as a behavior that they must engage in. Continuance commitment is what they feel they need to do, and affective commitment is what they want to do. It is one or any combination of the three types of commitment that "provide a means to increase donor satisfaction so that donors will want to give again" ([61], p. 129).

Christian faith-related INGOs, like other NGOs working internationally, are known for their ability to represent, through imagery, the distant others as a cause of public action. The imagery as part of fundraising appeals are utilized by INGOs to generate a "shock effect" or a "positive image" - both of which generate normative commitment among potential and existing donors. The former type of normative appeal, writes Chouliaraki ([97], p. 10), is meant to invoke guilt and indignation but runs "the risk of fatigue and apathy". The latter, although a positively framed appeal for donations, "glosses over asymmetries of power and runs the risk of denying the need for action on the grounds that it may be unnecessary or, even, unreal" [97]. Continuance commitment is based on calculations of the costs that an individual thinks he or she may incur upon terminating donations to the INGO. It is a commitment derived from cost-benefit analysis undertaken to fulfil a financial need (for instance the possibility of losing on tax savings) but is predominantly a commitment realized from the donor's psychological need for gratification, the type of satisfaction identified earlier as the "emotional buzz" of feeling good about oneself. The final type of commitment is the affective kind and translates as the sense of identification and affiliation that the donor feels with the achievements (and struggles) of the INGO. Given that commitment is the most directly influencing variable of retention, donor retention is best achieved when the INGO cultivates all three types of commitment. Naskrent and Siebelt ([48], p. 772) find that information shared with donors on how they have contributed to the success and recognition of the INGO has potential to strengthen all three types of commitment, and hence the service value of donor contributions. 
But if the logic of self-perception is to be applied to increasing service value of a donor's contribution, then all such INGO communications may be more effective if the appeals are subtle and do not overuse emotions (of guilt, shame, pity or anger). Chouliaraki [97] refers to communications devoid of emotions as the "post-humanitarian" nature of appeals where the focus is not on the moral question of 'why give' (or 'why give again'), but rather on an introspection of donors themselves. Madianou ([98], pp. 255-57) cites the case of the US-based INGO WaterForward that works on clean water projects in developing countries. She finds that the webpage does not share a single image or story of the people being helped through the INGO. There is not even any context of the specific projects funded nor the national contexts. The emphasis, instead, is on the network of users because the site is designed as a digital photo album where users can invite their friends (via existing accounts on Facebook or Twitter) but at a price. Users buy space for their friends' portraits for $\$ 10$ each and collected funds are used for clean water projects. But doing so, Madianou [98] points out, can render donor action [of initial and continued giving] hollow, and even meaningless.

In citing Madianous' [98] example of the aforementioned INGO, I do not intend to highlight that service value is best created by de-emotionalizing INGO appeals for more funds but instead, that donor retention may require a better balance between the emotional and moral appeals common among strongly Christian INGOs at one extreme, with the technocratic, aesthecized appeal of INGOs such as WaterForward, at the other. To achieve this balance, a more strategic approach to donor segmentation may be required. The INGO may consider, for example, a branding strategy that is viable for both those who are strongly affiliated to Christian doctrines and others who are more skeptical of emotional and moral funding appeals.

\section{Conclusions}

This article examines an important but relatively overlooked aspect in the field of international giving in the US-individual monetary donations to Christian faith-related INGOs-and outlines the cognitive process influencing donors who choose to keep up their financial support to Christian faith-related INGOs. Since the era of World War II, these INGOs have grown in prominence as representatives of their local donor publics. Today, they deliver services such as health care, disaster relief and education, influence policy and build capacity of people and their organizations across various parts of globe. Differing from congregational and denominational structures, which tend to focus on the development of their membership, the Christian faith-related INGOs addressed in this article seek to fulfil explicitly public missions. The extent to which they emphasize their religious or spiritual foundations varies considerably, as does their financing. That said, many are privately funded with a substantial portion of their financial resources coming from a large number of smaller donors.

Despite the critical role of individuals in helping sustain funding of Christian faith-related INGOs, there is surprisingly little research on how individual donors personally evaluate their repeat purchase decision. This article does not examine the demographic characteristics such as age, gender, level of education, income levels, race or ethnicity of those that sustain their giving intentions to an INGO. Instead, it relies on the logic of self-perception which postulates that individuals more easily focus on, process, recognize and retrieve self-relevant rather than self-irrelevant information. As institutions that identify themselves as mediators acting on behalf of US public's concern for the well-being of distant others, INGOs can and do influence donor intent to continue giving. The propositions forwarded in this article highlight that the more existing donors can identify themselves with the INGO's identity - comprising INGO's beliefs and values (proposition 1), its claims to legitimacy (propositions 2 and 3) and performance (proposition 4) - the more likely it is for them to be satisfied and decide to maintain a stable relationship with the specific INGO.

Given the paucity of a priori information on the characteristics (attitudinal, behavioral, geographic and demographic) of the donor base of a US-based Christian faith-related INGO, this breed of organizations may benefit from post-hoc segmentation. Such a donor segmentation strategy relies on no pre-judgment about the segment bases of the donors. Instead, the segmentation places existing 
donors of Christian faith-related INGOs into groups with others who have similar views/responses to questions asked and feedback received. The segments so created are likely to be more understandable to this breed of INGOs and offer an opportunity to each such INGO to communicate its beliefs and values, its claims to legitimacy and its performance more effectively and in doing so, increase the likelihood of retaining its individual donor base.

Conflicts of Interest: The author declares no conflict of interest.

\section{References}

1. David Lewis. "Theorising the organisation and management of non-governmental development organisations: Towards a composite approach." Public Management Review 5 (2003): 325-44. [CrossRef]

2. Adrian Sargeant, and Lucy Woodliffe. "Building donor loyalty: The antecedents and role of commitment in the context of charity giving." Journal of Nonprofit \& Public Sector Marketing 18 (2007): 47-68. [CrossRef]

3. Laura C. Thaut. "The role of faith in Christian faith-based humanitarian agencies: Constructing the taxonomy." Voluntas: International Journal of Voluntary and Nonprofit Organizations 20 (2009): 319-50. [CrossRef]

4. Dierk Herzer, and Peter Nunnenkamp. "Private Donations, Government Grants, Commercial Activities, and Fundraising: Cointegration and Causality for NGOs in International Development Cooperation." Kiel Working Papers 46 (2013): 1-30. [CrossRef]

5. Giving USA. “Giving USA 2016: The Annual Report on Philanthropy for the Year 2015." Available online: https:/ / givingusa.org/product/2016-digital-package/ (accessed on 10 October 2016).

6. Giving USA. "Giving USA 2015: The Annual Report on Philanthropy for the Year 2014." Available online: https: / givingusa.org/product/giving-usa-2015-the-annual-report-on-philanthropy-for-the-year2014-digital-package-pre-sale/ (accessed on 10 October 2016).

7. Global Impact. "Assessment of U.S. Giving to International Causes." Available online: http:/ / charity.org/sites/default/files/userfiles/pdfs / Assessment\%20of\%20US\%20Giving\%20to\% 20International\%20Causes\%20FINAL.pdf (accessed on 14 July 2016).

8. Amy F. Butcher. "Giving Report Shows Growth, But Not for Everyone." Nonprofit Quarterly, 2016.

9. Michael Barnett, and Janice Stein. Sacred Aid: Faith and Humanitarianism. Oxford: Oxford University Press, 2012.

10. Gerard Clarke. "Faith matters: Faith-based organisations, civil society and international development." Journal of International Development 18 (2006): 835-48. [CrossRef]

11. Firoze Manji, and Carl O'Coill. "The missionary position: NGOs and development in Africa." International Affairs 78 (2002): 567-83. [CrossRef]

12. Robert Wuthnow. Saving America?: Faith-based Services and the Future of Civil Society. Princeton: Princeton University Press, 2004.

13. The Winthrop Society. "A Model of of Christian Charity: By Governor John Winthrop, 1630." Available online: http:/ / winthropsociety.com/doc_charity.php (accessed on 3 June 2016).

14. Kathleen D. McCarthy. American Creed: Philanthropy and the Rise of Civil Society, 1700-1865. Chicago: University of Chicago Press, 2003.

15. Samuel P. Huntington. Who Are We?: The Challenges to America's National Identity. New York, London, Toronto and Sydney: Simon and Schuster, 2004.

16. Julie Hearn. "The 'invisible' NGO: US evangelical missions in Kenya." Journal of Religion in Africa 32 (2002): 32-60. [CrossRef]

17. Margaret Harris. Organizing God's Work: Challenges for Churches and Synagogues. New York: St. Martin's Press, 1999.

18. James Leiby. "Charity organization reconsidered." Social Service Review 58 (1984): 523-38. [CrossRef]

19. Cecelia Lynch. "Acting on belief: Christian perspectives on suffering and violence." Ethics and International Affairs 14 (2000): 83-97. [CrossRef]

20. Hilde Nielssen, Inger Marie Okkenhaug, and Karina Hestad-Skeie. "Introduction." In Protestant Missions and Local Encounters in the Nineteenth and Twentieth Centuries: Unto the Ends of the World. Leiden and Boston: Brill, 2011, pp. 1-22. 
21. Julia Berger. "Religious nongovernmental organizations: An exploratory analysis." Voluntas: International Journal of Voluntary and Nonprofit Organizations 14 (2003): 15-39. [CrossRef]

22. Rachel M. McCleary, and Robert J. Barro. "Private voluntary organizations engaged in international assistance, 1939-2004." Nonprofit and Voluntary Sector Quarterly 37 (2008): 512-36. [CrossRef]

23. José Casanova. Public Religion in the Modern World. Chicago: University of Chicago Press, 1994.

24. Adil Najam. "NGO accountability: A conceptual framework." Development Policy Review 14 (1996): 339-54. [CrossRef]

25. Carlo Benedetti. "Islamic and Christian inspired relief NGOs: Between tactical collaboration and strategic diffidence? " Journal of International Development 18 (2006): 849-59. [CrossRef]

26. Christopher P. Scheitle. Beyond the Congregation: The World of Christian Nonprofits. Oxford: Oxford University Press, 2010.

27. Gerard Clarke, and Michael Jennings. "Introduction." In Development, Civil Society and Faith-Based Organizations: Bridging the Sacred and the Secular. Edited by Gerald D. Clarke and Michael D. Jennings. Basingstoke: Palgrave Macmillan, 2007, pp. 1-16.

28. Ramya Ramanath. "Capacity for public service delivery: A cross-case analysis of ten small faith-related non-profit organisations." Voluntary Sector Review 5 (2014): 3-27. [CrossRef]

29. Ronald J. Sider, and Heidi Rolland Unruh. "Typology of religious characteristics of social service and educational organizations and programs." Nonprofit and Voluntary Sector Quarterly 33 (2004): 109-34. [CrossRef]

30. Eric Werker, and Faisal Z. Ahmed. "What do nongovernmental organizations do? " The Journal of Economic Perspectives 22 (2008): 73-92. [CrossRef]

31. Marc Lindenberg, and Coralie Bryant. Going Global: Transforming Relief and Development NGOs. Bloomfield: Kumarian Press, 2001.

32. David L. Brown, Alnoor Ebrahim, and Srilatha Batliwala. "Governing international advocacy NGOs." World Development 40 (2012): 1098-1108. [CrossRef]

33. Helen Rose Ebaugh, Paula F. Pipes., Janet Saltzman Chafetz, and Martha Daniels. "Where's the religion? Distinguishing faith-based from secular social service agencies." Journal for the Scientific Study of Religion 42 (2003): 411-26. [CrossRef]

34. Abby Stoddard. "Humanitarian NGOs: Challenges and trends." London: Humanitarian Policy Group, Overseas Development Institute, 2003, Available online: https://www.odi.org/resources/docs/349.pdf (accessed on 1 May 2016).

35. Ted Yu Shen Chen. "Habitat for Humanity's post-tsunami housing reconstruction approaches in Sri Lanka." International Journal of Mass Emergencies \& Disasters 33 (2015): 96-116.

36. Andrew McGregor. "Geographies of religion and development: Rebuilding sacred spaces in Aceh, Indonesia, after the tsunami." Environment and Planning A 42 (2010): 729-46. [CrossRef]

37. James R. Vanderwoerd. "How faith-based social service organizations manage secular pressures associated with government funding." Nonprofit Management \& Leadership 14 (2004): 239-62. [CrossRef]

38. Water Wymer, and Sharyn Rundle-Thiele. "Supporter loyalty conceptualization, measurement, and outcomes." Nonprofit and Voluntary Sector Quarterly 45 (2016): 172-91. [CrossRef]

39. Norm O'Reilly, Steven Ayer, Ann Pegoraro, Bridget Leonard, and Sharyn Rundle-Thiele. "Toward an understanding of donor loyalty: Demographics, personality, persuasion, and revenue." Journal of Nonprofit $\mathcal{E}$ Public Sector Marketing 24 (2012): 65-81. [CrossRef]

40. Caryl E. Rusbult, and Daniel Farrell. "A longitudinal test of the investment model." Journal of Applied Psychology 68 (1983): 429-38. [CrossRef]

41. James D. Werbel, and Sam Gould. "A comparison of the relationship of commitment to turnover in recent hires and tenured employees." Journal of Applied Psychology 69 (1984): 687-90. [CrossRef]

42. Charles A. O'Reilly, and David F. Caldwell. "Job choice: The impact of intrinsic and extrinsic factors on subsequent satisfaction and commitment." Journal of Applied Psychology 65 (1980): 559-65. [CrossRef]

43. Richard T Mowday, Lyman M. Porter, and Richard M. Steers. Organizational Linkage: The Psychology of Commitment, Absenteeism and Turnover. New York: Academic Press, 1982.

44. Harold L. Angle, and James L. Perry. "An empirical assessment of organizational commitment and organizational effectiveness." Administrative Science Quarterly 26 (1981): 1-14. [CrossRef] 
45. Helen Bussell, and Deborah Forbes. "Developing relationship marketing in the voluntary sector." Journal of Nonprofit \& Public Sector Marketing 15 (2006): 151-74. [CrossRef]

46. Adrian Sargeant. "Relationship fundraising: How to keep donors loyal." Nonprofit Management and Leadership 12 (2001): 177-92. [CrossRef]

47. Roger Bennett, and Rehnuma Ali-Choudhury. "Internationalisation of British fundraising charities: A two-phase empirical study." International Journal of Nonprofit and Voluntary Sector Marketing 15 (2010): 28-51. [CrossRef]

48. Julia Naskrent, and Philipp Siebelt. "The influence of commitment, trust, satisfaction, and involvement on donor retention." Voluntas: International Journal of Voluntary and Nonprofit Organizations 22 (2011): 757-78. [CrossRef]

49. Adrian Sargeant, and Shang Jen. "Growing Philanthropy in the United States: A Report on the June 2011 Washington, D.C. Growing Philanthropy Summit." 2011. Available online: http:/ /www.simonejoyaux.com/ downloads/growingphilanthropyreport_final.pdf (accessed on 5 February 2016).

50. Ken Burnett. Relationship Fundraising: A Donor Based Approach to the Business of Raising Money. San Francisco: Jossey Bass, 2002.

51. Yi-Hui Huang. "OPRA: A cross-cultural, multiple-item scale for measuring organisation-public relationships." Journal of Public Relations Research 13 (2001): 61-90. [CrossRef]

52. Chun-ju Flora Hung. "Toward a normative theory of relationship management." Available online: http: //www.instituteforpr.org/normative-theory-relationship-management/ (accessed on 3 January 2016).

53. Sally Shaw, and Justine B. Allen. "We Actually Trust the Community: Examining the dynamics of a nonprofit funding relationship in New Zealand." Voluntas: International Journal of Voluntary and Nonprofit Organizations 17 (2006): 211-20. [CrossRef]

54. Association of Fundraising Professionals. "Fundraising Effectiveness Survey Report." 2012. Available online: http:/ / www.afpnet.org/files/ContentDocuments/FEP2012Report.pdf (accessed on 13 December 2015).

55. Adrian Sargeant. "Donor retention: What do we know and what can we do about it? " 2008. Available online: https:/ /afpidaho.afpnet.org/files /ContentDocuments /Donor_Retention_What_Do_We_Know.pdf (accessed on 6 July 2015).

56. Dennis B. Arnett, Steve D. German., and Shelby D. Hunt. "The identity salience model of relationship marketing success: The case of nonprofit marketing." Journal of Marketing 67 (2003): 89-105. [CrossRef]

57. Namkee G. Choi, and Diana M. DiNitto. "Predictors of time volunteering, religious giving, and secular giving: Implications for nonprofit organizations." Journal of Sociology and Social Welfare 39 (2012): 93-120.

58. Mark Chaves. "Financing American religion." In Financing American Religion. Edited by Mark Chaves. Walnut Cree: AltaMira Press, 1999, pp. 169-88.

59. Mark Chaves, and Sharon L. Miller, eds. Financing American Religion. Walnut Creek: AltaMira Press, 1999.

60. John M. Mulder. "Faith and money: Theological reflections on financial American religion." In Financing American Religion. Edited by Mark Chaves. Walnut Cree: AltaMIra Press, 1999, pp. 157-68.

61. Debra A. Laverie, and Dennis B. Arnett. "Factors affecting fan attendance: The influence of identity salience and satisfaction." Journal of Leisure Research 32 (2000): 225-46.

62. Simon McGrath. "Giving donors good reason to give again." Journal of Nonprofit and Voluntary Sector Marketing 2 (1997): 125-35. [CrossRef]

63. Monica Langley. "Mr. Rose gives away millions in donations, not a cent of control." Wall Street Journal, 1998, A1-10.

64. Howard P. Tuckman. "Competition, commercialization, and the evolution of nonprofit organizational structures." Journal of Policy Analysis and Management 17 (1998): 175-94. [CrossRef]

65. Kathleen S. Kelly. Fund Raising and Public Relations: A Critical Analysis. Mahwah: Lawrence Erlbaum, 1991.

66. Thomas H. Jeavons. "The vitality and independence of religious organizations." Society 40 (2003): 27-36. [CrossRef]

67. Amber Nathan, and Leslie Hallam. "A qualitative investigation into the donor lapsing experience." International Journal of Nonprofit and Voluntary Sector Marketing 14 (2009): 317-31. [CrossRef]

68. Barbara L. Ciconte, and Jeanne Jacob. Fundraising Basics: A Complete Guide, 3rd ed. Boston: Jones \& Bartlett Publishers, 2011.

69. Farnoosh Khodakarami, Andrew J. Peterson, and Rajkumar Venkatesan. "Developing donor relationships: The role of the breadth of giving." Journal of Marketing 79 (2015): 77-93. [CrossRef] 
70. Ardion Beldad, Babiche Snip, and Joris van Hoof. "Generosity the second time around: Determinants of individuals' repeat donation intention." Nonprofit and Voluntary Sector Quarterly 43 (2014): 144-63. [CrossRef]

71. Jundong Hou, Chi Zhang, and Robert Allen King. "Understanding the dynamics of the individual donor's trust damage in the philanthropic sector." Voluntas: International Journal of Voluntary and Nonprofit Organizations, 2016. [CrossRef]

72. Daryl J. Bem. "Self-perception theory." Advances in Experimental Social Psychology 6 (1972): 1-62.

73. Ken J. Rotenberg. "The socialisation of trust: Parents' and children's interpersonal trust." International Journal of Behavioral Development 18 (1995): 713-26. [CrossRef]

74. Roger C. Mayer, James H. Davis, and F. David Schoorman. "An integrative model of organizational trust." Academy of Management Review 20 (1995): 709-34.

75. Sander Van der Linden. "Charitable intent: A moral or social construct? A revised theory of planned behavior model." Current Psychology 30 (2011): 355-74. [CrossRef]

76. Christopher J. Einolf. "The link between religion and helping others: The role of values, ideas, and language." Sociology of Religion 72 (2011): 435-55. [CrossRef]

77. Karen S. Cook, and Russell Hardin. Norms of Cooperativeness and Networks of Trust. New York: Russell Sage Foundation, 2001.

78. Edward J. Lawler, and Jeong Koo Yoon. "Power and the emergence of commitment behavior in negotiated exchange." American Sociological Review 58 (1993): 465-81. [CrossRef]

79. Debra Z. Basil, Nancy M. Ridgway, and Michael D. Basil. "Guilt appeals: The mediating effect of responsibility." Psychology \& Marketing 23 (2006): 1035-54. [CrossRef]

80. Roger Bennett, and Anna Barkensjo. "Relationship quality, relationship marketing, and client perceptions of the levels of service quality of charitable organisations." International Journal of Service Industry Management 16 (2005): 81-106. [CrossRef]

81. Michel Wedel, and Wagner A. Kamakura. Market Segmentation: Conceptual and Methodological Foundations. Norwell: Kluwer Academic Publishers, 2000.

82. Elizabeth J. Durango-Cohen, Ramón L. Torres, and Pablo L. Durango-Cohen. "Donor Segmentation: When Summary Statistics Don't Tell the Whole Story." Journal of Interactive Marketing 27 (2013): 172-84. [CrossRef]

83. Catholic Relief Services. "About Catholic Relief Services." 2016. Available online: http:/ /www.crs.org/about (accessed on 3 June 2016).

84. Catholic Relief Services. "Catholic Relief Services: United States Conference of Catholic Bishops." 2004. Available online: http:/ / www.crs.org/sites/default/files/2005_financials.pdf (accessed on 15 May 2016).

85. Anne Vestergaard. "Distance and Suffering: Humanitarian Discourse in the age of Mediatization." Ph.D. Thesis, Copenhagen Business School, Frederiksberg, Denmark, 4 July 2016. Available online: http://www.lse.ac.uk/media@lse/study/pdf/ChouliarakiLSEPublicLectureDistantSuffering.pdf (accessed on 1 July 2016).

86. Jesse D. Lecy, Hans Peter Schmitz, and Haley Swedlund. "Non-Governmental and not-for-profit organizational effectiveness: A modern synthesis." Voluntas: International Journal of Voluntary and Nonprofit Organizations 23 (2011): 434-57. [CrossRef]

87. Shepard Forman, and Abby Stoddard. "International assistance." In The State of Nonprofit America. Edited by Lester M. Salomon. Washington: Brookings Institution Press, 2002, pp. 240-74.

88. May-May Meijer. "The effects of charity reputation on charitable giving." Corporate Reputation Review 12 (2009): 33-42. [CrossRef]

89. Jane E. Dutton, Janet M. Dukerich, and Celia V. Harquail. "Organizational images and member identification." Administrative Science Quarterly 39 (1994): 239-63. [CrossRef]

90. Beth Breeze. "How donors choose charities: The role of personal taste and experiences in giving decisions." Voluntary Sector Review 4 (2013): 165-83. [CrossRef]

91. Lisa Austen Jones. "Incentives: Making the most of incentives budgets-Market trends are determining how firms are rewarding staff." Marketing 107 (2002): 29-31.

92. Michael J. Worth. New Strategies for Educational Fund Raising. Westport: Praeger Publishers, 2002.

93. Altaf Merchant, John B. Ford, and Adrian Sargeant. "'Don't forget to say thank you': The effect of an acknowledgement on donor relationships." Journal of Marketing Management 26 (2010): 593-611. [CrossRef] 
94. Alnoor S. Ebrahim, and V. Kasturi Rangan. "The limits of nonprofit impact: A contingency framework for measuring social performance." Harvard Business School, General Management Unit Working Paper No. 10-099, Boston, MA, USA: Harvard Business School, 2010.

95. Adrian Sargeant, and Stephen Lee. "Trust and relationship commitment in the United Kingdom voluntary sector: Determinants of donor behavior." Psychology \& Marketing 21 (2004): 613-35. [CrossRef]

96. Natalie J. Allen, and John P. Meyer. "The measurement and antecedents of affective, continuance and normative commitment to the organization." Journal of Occupational Psychology 63 (1990): 1-18. [CrossRef]

97. Lilie Chouliaraki. "Post-humanitarianism Humanitarian communication beyond a politics of pity." International Journal of Cultural Studies 13 (2010): 107-26. [CrossRef]

98. Mirca Madianou. "Humanitarian campaigns in social media: Network architectures and polymedia events." Journalism Studies 14 (2013): 249-66. [CrossRef]

(C) 2016 by the author; licensee MDPI, Basel, Switzerland. This article is an open access article distributed under the terms and conditions of the Creative Commons Attribution (CC BY) license (http:/ / creativecommons.org/licenses/by/4.0/). 


\title{
Postscript of Special Issue "Religion, Welfare and Social Service Provision: Common Ground"
}

\author{
Jay Poole \\ Department of Social Work, University of North Carolina at Greensboro, PO Box 26170, \\ Greensboro, NC 27402, USA; kjpoole@uncg.edu
}

Received: 19 February 2019; Accepted: 25 February 2019; Published: 26 February 2019

The roots of social work and other helping professions run deep in community-based connections, and joining with local faith-based entities to explore strengths and challenges is essential to good organization and planning.

Far too often, however, resources in the community go unnoticed, only revealing themselves to social work scholars and professionals when they immerse themselves among those they are trying to help. As the preceding pages demonstrate, local religious institutions have a long tradition of emphasizing and promoting community development and communal assistance. And these entities are usually best placed to serve those most in need-right in the communities where they live, work and pray.

By and large, faith-based entities are more than eager to partner with local scholars and professionals. The Congregational Nurse Program in Greensboro, NC, where I teach, is a telling example of how, in many cases, religion-based organizations welcome help in attending to their congregations' needs.

A decade ago the Greensboro nurse program was well established and doing great work in the community. But until a chance encounter between a nurse in the program and a social work professor at a local university, the Congregational Nurse Program was not on the radar of any of the area's campuses. The program's coordinator had reached out to local universities to explore how students could study social work by working alongside nurses to meet the needs of the community's most vulnerable, but nothing came of the effort.

It took that chance encounter a decade ago for the collaboration to come to fruition. Together with the Congregational Nurse Program, our social work department at the University of North Carolina Greensboro created a field education unit that paired social work students with congregational nurses. Our collaboration, in turn, resulted in a far deeper effort: Two university social work programs, together with a local philanthropic organization with faith-based roots and an established group of nurses in the community, working to provide an array of services to people whose needs were not being met by traditional providers.

Through this action research project, today we have a well-coordinated team of social work students, nurses and community health workers stationed in more than 50 locations around Greensboro. Much of the effort is located in churches and synagogues, as well as in faith-affiliated shelters for those experiencing homelessness.

What we have discovered is that coming to church to see that nice nurse or social worker holds far less stigma than, say, going into a mental health clinic, or even a doctor's office. At our locations we can screen for health problems, assess mental wellness and identify needs-all without anyone else knowing anything, except that someone went to church.

The same can be said for shelters for those experiencing homelessness. By embedding ourselves in the shelters, we have become part of the service array, and can be where those in need are. Our initial collaboration with the Congregational Nurse Program eventually led to funding for an integrated 
health clinic in the local day shelter. Today, our students are an integral part of the clinic, which addresses medical and behavioral health needs, and are involved in a wide range of activities.

Of course, not all faith-based organizations are interested in these types of partnerships. But many are.

Relationship building is invaluable in the helping professions, allowing for a melding of missions among often fundamentally different institutions. My university's partnership with the Congregational Nurse Program and a local philanthropic organization, the Cone Health Foundation, exemplifies how relationship building can overcome the financial and organizational hurdles that often stymie efforts to help those in need.

Because we locate ourselves in local churches, synagogues and shelters, there is little to no overhead cost to our program. We do not have to rent an office, pay for utilities, or buy expensive equipment. We rely on the resources generously provided by entities in the community. And they, in turn, have come to rely on our knowledge and our students' engaged labor.

The partnerships we have established in Greensboro are rich with opportunities to address unmet needs, all while educating the next generation of professional social workers through immersion in the community. Such joining of forces, as the articles in this volume illustrate, best leverage the respective skills and resources that different institutions bring to the table. It is our hope that the insights in these pages will inspire others to take a deeper look at religiously affiliated helping and the many possibilities it holds for effective cooperation.

Conflicts of Interest: The author declares no conflict of interest.

(C) 2019 by the author. Licensee MDPI, Basel, Switzerland. This article is an open access article distributed under the terms and conditions of the Creative Commons Attribution (CC BY) license (http:/ / creativecommons.org/licenses/by/4.0/). 
MDPI

St. Alban-Anlage 66

4052 Basel

Switzerland

Tel. +41616837734

Fax +41 613028918

www.mdpi.com

Religions Editorial Office

E-mail: religions@mdpi.com

www.mdpi.com/journal/religions

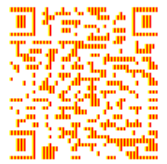



MDPI

St. Alban-Anlage 66

4052 Basel

Switzerland

Tel: +41 616837734

Fax: +41 613028918

www.mdpi.com 